[Francisco José Rodrigo Luelmo, Andrés Sánchez Padilla, Miguel İ. Campos, David Del Castillo Jiménez, David Díaz Sánchez, Cristina Luz García Gutiérrez, Imanol Herreros Chandro, David Manzano Cosano, David Mota Zurdo, Zorann Petrovici, Alberto Sevillano Sánchez, Lidia Fernández Fonfría, María Gajate Bajo, Irene González González, Mariam Gracia Mechbal, Eva Touboul Tardieu, Olga Glondys, Noemi de Haro García, Jesús Ferrer Cayón, Magdalena Garrido Caballero, Luiza lordache Cârstea, María del Pilar Loranca de Castro, Antonio Muñoz Sánchez, Eva Nieto McAvoy, Francisco Javier Rodríguez Jiménez, David Alegre Lorenz, Miguel Alonso Ibarra, Nelly Álvarez González, Pablo Gómez Nogales, Florian Grafl, Torben Ibs, María del Pilar Loranca de Castro, Ximena Machado, Miguel Ángel Melero Vargas, David Veiga Chousa, María Eloísa Zamorano Rodríguez, Hernán Rodríguez Velasco, Aritz Ipiña Bidaurrazaga, Sergio Cañas Díez, Alejandro Muñoz Rumbero, Germán Ruiz Llano, Víctor Sánchez Martín, Julián Paniagua López]
RELACIONES EN CONFLICTO. NUEVAS PERSPECTIVAS SOBRE RELACIONES INTERNACIONALES DESDE LA HISTORIA

Enrique Bengochea Tirado, Elena Monzón Pertejo y David G. Pérez Sarmiento (coord.) 

[Francisco José Rodrigo Luelmo, Andrés Sánchez Padilla, Miguel Í. Campos, David Del Castillo

Jiménez, David Díaz Sánchez, Cristina Luz García Gutiérrez, Imanol Herreros Chandro, David Manzano Cosano, David Mota Zurdo, Zorann Petrovici, Alberto Sevillano Sánchez, Lidia Fernández Fonfría, María Gajate Bajo, Irene González González, Mariam Gracia Mechbal, Eva Touboul Tardieu, Olga Glondys, Noemi de Haro García, Jesús Ferrer Cayón, Magdalena Garrido Caballero, Luiza lordache Cârstea, María del Pilar Loranca de Castro, Antonio Muñoz Sánchez, Eva Nieto McAvoy, Francisco Javier Rodríguez Jiménez, David Alegre Lorenz, Miguel Alonso lbarra, Nelly Álvarez González, Pablo Gómez Nogales, Florian Grafl, Torben Ibs, María del Pilar Loranca de Castro, Ximena Machado, Miguel Ángel Melero Vargas, David Veiga Chousa, María Eloísa Zamorano

Rodríguez, Hernán Rodríguez Velasco, Aritz Ipiña Bidaurrazaga, Sergio Cañas Díez, Alejandro Muñoz Rumbero, Germán Ruiz Llano, Víctor Sánchez Martín, Julián Paniagua López]

\section{RELACIONES EN CONFLICTO. NUEVAS PERSPECTIVAS SOBRE RELACIONES INTERNACIONALES DESDE LA HISTORIA}

Enrique Bengochea Tirado, Elena Monzón Pertejo y David G. Pérez Sarmiento (coord.) 
"Relaciones en conflicto. Nuevas perspectivas sobre relaciones internacionales desde la historia"

\section{ISBN: 978-84-606-5873-3}

DOI: $10.7203 / 10550.42835$

Coordina: Enrique Bengochea Tirado, Elena Monzón Pertejo y David G. Pérez Sarmiento

Edita: Universitat de València. Valencia, 2015

Asociación de Historia Contemporánea

Diseño y maquetación: Carles Rodrigo Monzó

(www.carlesrodrigo.es)

Autores: Francisco José Rodrigo Luelmo, Andrés Sánchez Padilla,

Miguel İ. Campos, David Del Castillo Jiménez, David Díaz Sánchez,

Cristina Luz García Gutiérrez, Imanol Herreros Chandro, David

Manzano Cosano, David Mota Zurdo, Zorann Petrovici, Alberto

Sevillano Sánchez, Lidia Fernández Fonfría, María Gajate Bajo,

Irene González González, Mariam Gracia Mechbal, Eva Touboul

Tardieu, Olga Glondys, Noemi de Haro García, Jesús Ferrer

Cayón, Magdalena Garrido Caballero, Luiza lordache Cârstea,

María del Pilar Loranca de Castro, Antonio Muñoz Sánchez, Eva

Nieto McAvoy, Francisco Javier Rodríguez Jiménez, David Alegre

Lorenz, Miguel Alonso Ibarra, Nelly Álvarez González, Pablo

Gómez Nogales, Florian Grafl, Torben Ibs, María del Pilar Loranca de Castro, Ximena Machado, Miguel Ángel Melero Vargas,

David Veiga Chousa, María Eloísa Zamorano Rodríguez, Hernán Rodríguez Velasco, Aritz Ipiña Bidaurrazaga, Sergio Cañas Díez, Alejandro Muñoz Rumbero, Germán Ruiz Llano, Víctor Sánchez

Martín, Julián Paniagua López. 
1. Historia de las relaciones internacionales: nuevos actores, nuevas fronteras geográficas y cronológicas

Francisco José Rodrigo Luelmo y Andrés Sánchez Padilla - La historia de las relaciones internacionales: nuevos actores, nuevas fronteras geográficas y cronológicas.

Miguel I. Campos - Francia ante la guerra civil española: del compromiso de ayuda oficial a la no intervención relâchée.

David del Castillo Jiménez - España entre EEUU y Japón durante la II Guerra Mundial: problemática de una relación a tres bandas.

David Díaz Sánchez - España en el exterior. El papel del ejército español en las misiones internacionales.

Cristina Luz García Gutiérrez - Relaciones económicas de España con las dictaduras chilena y argentina (1973-1983).

Imanol Herreros Chandro - El camino hacia Berna: España en el proceso de internacionalización de las leyes de propiedad intelectual.

David Manzano Cosano - El Pacífico y la colonización del mundo "occidental". David Mota Zurdo - El PNV de la II Guerra Mundial a la Guerra Fría (1945-1950) Antón Irala y la doctrina política de "burujabetza".

Zorann Petrovici - La corona española: promotora de la comunidad

iberoamericana de naciones.

Alberto Sevillano Sánchez - Una aproximación al mundo nórdico-báltico:

algunas notas sobre su concepción y su utilidad para el estudio de España a finales del siglo XIX.

\section{España-Marruecos: pasado, presente y futuro de las relaciones bilaterales}

Lidia Fernández Fonfría - Políticas religiosas oficiales de Marruecos dirigidas a la población emigrada.

María Gajate Bajo - El establecimiento del Protectorado hispano-francés en

Marruecos. Una visión local.

Irene González González - Escuela y colonización: el caso del Protectorado

español en Marruecos (1912-1956).

Mariam Gracias Mechbal - Instituciones científicas durante el Protectorado:

La Escuela de Estudios Árabes (CSIC).

Eva Touboul Tardieu - Los judíos sefardíes, ¿una herramienta para la

colonización? Filosefardismo en los principios del Protectorado.

\section{España y la Guerra Fría cultura}

Olga Glondys - España y la Guerra Fría cultural.

Noemi de Haro García - La imagen de España en la Guerra Fría: arte,

oficialidad y disidencia.

Jesús Ferrer Cayón - Del Hollywood Bowl a los Festivales de España: José

Iturbi o Bienvenido Mister Marshall.

Magdalena Garrido Caballero - La propaganda soviética en el exterior.

Luiza lordache Cârstea - Los repatriados españoles de la URSS en el marco

de la Guerra Fría (1954-1960).

María del Pilar Loranca de Castro - España y la Guerra Fría cultural: la influencia

estadounidense en el cómic durante el franquismo.

Antonio Muñoz Sánchez - Dos no bailan si uno no quiere. La socialdemocracia alemana y el socialismo español en los años sesenta.

Eva Nieto McAvoy - Arturo Barea, ¿un bevanista en la BBC? Exilio y tercerismo

07 en la guerra fría.

Francisco Javier Rodríguez Jiménez - "iotro tentáculo más del imperio?"

12 Sindicatos estadounidenses y españoles durante el franquismo.

17 4. Los teatros de lo bélico

Miguel Alonso Ibarra y David Alegre Loren - Reflexiones en torno a los teatros de lo bélico. Una disección del estado actual de los estudios de historia militar. Nelly Álvarez González - El teatro como arma de combate durante la Guerra Civil en la España sublevada (Valladolid, 1936-1939).

Pablo Gómez Nogales - España en lucha contra la revolución.

33 Florián Graf-A new approach to the Pistolerismo? The influence of Wars on

38 'experts of violence' in 1920 s Barcelona.

Torben lbs - Remembering the Völkerschlacht (battle of the nations) 1813 an its monument from 1913 in the 21th century. The Leipzig commemoration activities in 2013.

47 María del Pilar Loranca de Castro - La imagen de la Guerra de Independencia española durante el franquismo.

Ximena Machado - ¿Cómo ovejas al matadero? Formas de resistencia pasiva de los judíos en los guetos de Varsovia y de Lodz (1939-1942).

Miguel Ángel Melero Vargas - "Tomando la palabra... y empuñando el fusil: la participación ciudadana en la guerra civil. La ocupación sublevada y la represión. Un caso andaluz, Antequera".

David Veiga Chousa - La Hermandad Provincial de la División Azul de Alicante: un análisis a través de su boletín Blau Division.

66 Eloísa Zamorano - Imagen y castigo. Documentos gráficos de Nicolás II.

Lo que el cine grabó y el viento no se llevó.
Olvidado 1937-1945.

Germán Ruíz Llano - La Milicia alavesa de Acción Popular durante la

.

Victor Sánchez Martín - De rebeldes derrotados y revoluciones triunfantes.

La sublevación del Ejército Expedicionario en 1820: del fracaso militar

al éxito político.

Julián Paniagua - El contrabando de armas durante la guerra del Rif, 1921-1927. 
Parte 1.

HISTORIA DE LAS RELACIONES

INTERNACIONALES: NUEVOS ACTORES, NUEVAS

FRONTERAS GEOGRÁFICAS Y CRONOLÓGICAS 


\section{LA HISTORIA DE LAS RELACIONES INTERNACIONALES: NUEVOS ACTORES, NUEVAS FRONTERAS GEOGRÁFICAS Y CRONOLÓGICAS}

Francisco José Rodrigo Luelmo

Andrés Sánchez Padilla

Universidad Complutense de Madrid

Juan Carlos Pereira definió hace años a la Historia de las Relaciones Internacionales como el "estudio científico y global de las relaciones históricas que se han desarrollado entre los hombres, los Estados y las colectividades supranacionales en el seno de la sociedad internacional".' Sin embargo, los estudios internacionales han sufrido tantos cambios en los últimos años que se ha hecho muy difícil establecer una definición consensuada para nuestra especialidad historiográfica. Esta indefinición refleja, entre otras cosas, la creciente diversidad que caracteriza a los estudios históricos que analizan las interacciones entre grupos humanos separados por fronteras.

Esta pluralidad de enfoques analíticos es una muestra de vitalidad, sin duda, pero también refleja una larga crisis de identidad. Tradicionalmente, lo que se ha conocido en España como "Historia de las Relaciones Internacionales" se ha desarrollado de manera independiente en los países de habla inglesa y en la Europa continental. Sin embargo, hasta fechas muy recientes, en España sobre todo han ejercido influencia las escuelas francesa e italiana y apenas se han conocido las aportaciones del mundo anglosajón o alemán. La escuela francesa de las relaciones internacionales, fundada por Pierre Renouvin y Jean-Baptiste Duroselle en los años cincuenta del siglo XX, trató de modernizar la vieja historia diplomática francesa desarrollada desde el siglo XIX incorporando, bajo influencia de la escuela de Annales, factores explicativos de larga duración (geografía, economía, demografía, etc.) al estudio de la política exterior. ${ }^{2}$ Pero la verdadera importancia de esta escuela ha residido en su dilatada influencia en otros países. Sin embargo, hoy en día su proyección es cada vez menor, como testimonian las comunicaciones de esta mesa.

Por su parte, en los países de habla inglesa, la historia diplomática o internacional se desarrolló sin prestar atención a los debates académicos del continente. Los historiadores diplomáticos británicos, salvo excepciones, ${ }^{3}$ tampoco se interesaron demasiado en la teoría de las relaciones internacionales. ${ }^{4}$ En Estados Unidos, en cambio, se ha llevado a cabo un vivo debate

1 Juan Carlos PEREIRA: "Introducción. La historia de las relaciones internacionales en España. Respuestas, propuestas y conclusiones", en VV.AA.: La Historia de las Relaciones Internacionales: una visión desde España, Madrid, CEHRI, 1996, p. 5 .

2 Jean-Pierre AGUET: “Un 'Combat pour l'histoire': Lucien Fevbre et l'histoire diplomatique”, en Saul FRIEDLÄNDER, Harish KAPUR y André RESZLER (eds.): L'historien et les relations internationales: recueil d'études en hommage à Jacques Freymond, Genève, Institute Universitaire de Haute Études Internationales, 1981; René GIRAULT: "L'école française d'histoire des relations internationales", Balkan Studies, 29, 1 (1988), pp. 181-189; Pierre RENOUVIN y Jean-Baptiste DUROSELLE: Introduction à l'histoire des relations internationales, Paris, Librairie A. Colin, 1964.

3 Edward H CARR: The Twenty Years' Crisis, 1919-1939: An Introduction to the Study of International Relations, London, MacMillan, 1974.

4 Anthony ADAMTHWAITE: "L'état de la recherche dans le domaine de l'histoire des relations internationales en Grande-Bretagne", Relations Internationales, 42 (1985), pp. 165-168; Richard LANGHORNE: "International History in Britain", en VVAA : L Historia de las Relaciones Internacionales. Una visión desde España, CEHRI, 1996, pp. 97-105 desde hace varias décadas sobre la viabilidad de la historia diplomática provocado por las críticas desde otras especialidades hacia la obsolescencia metodológica de este área. ${ }^{5}$

¿Y qué es de España? A día de hoy podemos afirmar que la Historia de las Relaciones Internacionales es un área de estudio plenamente consolidada en la historiografía española. Su auge, desarrollo y consolidación ha coincidido con el profundo cambio que ha experimentado la política exterior de España desde 1975, que ha traído consigo la integración de España en la OTAN y la CEE y el afianzamiento de la democracia ${ }^{6}$ en un país considerado - de acuerdo con los parámetros de la sociología de las relaciones internacionales- como una "potencia media" situada en la periferia meridional europea y con una acción exterior tradicionalmente focalizada en tres áreas (Europa, Mediterráneo/mundo árabe e lberoamérica), aunque con una amplitud mayor de miras en la aldea global en la que actualmente residimos, aspecto que ha incidido en el surgimiento de nuevas áreas a estudiar en nuestra disciplina.

La Historia de las Relaciones Internacionales, pese a las dificultades a las que luego aludiremos, goza de una relativa buena salud en España. En primer lugar, está profundamente arraigada en el ámbito académico y en los planes de estudios: lo demuestran el número de publicaciones científicas, de trabajos de fin de Máster y de tesis doctorales. Asimismo, en los últimos años el número de profesores e investigadores que se han especializado en los estudios internacionales ha ido en constante aumento. Con una disciplina ya plenamente consolidada en la historiografía española, ésta ha experimentado una dinámica de creciente renovación gracias en buena medida a los contactos con centros de enseñanza superior e investigación extranjeros por parte de jóvenes investigadores pre y posdoctorales. En definitiva, se ha hecho un gran esfuerzo de convergencia con las corrientes internacionales; sin embargo, todavía queda mucho trabajo por hacer.

Pasando a cuestiones concretas, en primer lugar, se han creado y consolidado grupos como: el GHistRI, "Grupo de Investigación en Historia de las Relaciones Internacionales", de carácter interuniversitario y dirigido por el profesor Juan Carlos Pereira (UCM); ${ }^{7}$ el Grupo de Historia Actual, con epicentro en la Universidad de Cádiz; ${ }^{8}$ el Eurasian Hub, con base en la Universidad Autónoma de Barcelona, centrado en el estudio de la zona euroasiática y que reúne un amplio elenco interdisciplinar; ${ }^{9}$ y multitud de grupos en el Instituto de Historia del Consejo Superior de Investigaciones Científicas (CSIC), como los dirigidos por María Dolores Elizalde o Lorenzo Delgado. También hay que destacar centros de investigación como el CIDOB de Barcelona con su publicación Afers Internacionals por bandera-y el auge de asociaciones que reúnen entre a sus miembros a investigadores de este ámbito como la Comisión Española de Historia

5 Charles R. MAIER: "Marking Time: The Historiography of International Relations", en Michael KAMMEN (ed.): The Past before Us: Contemporary Historical Writing in the United States, Ithaca, NY Cornell University Press, 1980; Sally MARKS: “The World According to Washington", Diplomatic History, 11,3 (1987), pp. 265-282.

6 Para conocer el punto de partida y la evolución de la historiografía española de las relaciones internacionales, entre otros, vid. Lorenzo DELGADO: "Las relaciones internacionales del régimen de Franco: una reflexión", Arbor, 163, 642 (1999), pp. 153-178; Francisco OUINTANA: "La Historia de las Relaciones Internacionales en España: apuntes para un balance historiográfico", en VV.AA.: La Historia de las Relaciones Internacionales: una visión desde España, Madrid, CEHRI, 1996; más recientemente, Antonio MORENO JUSTE: "La Historia de las Relaciones Internacionales y de la política exterior española”, Ayer, 42 (2001), pp. 71-96; y Juan Carlos PEREIRA: "Los Estudios Internacionales en España: la política exterior. Un estado de la cuestión" en ÍD. (coord.): La política exterior de España. De 1800 hasta hoy, Barcelona, Ariel, 2010, pp. 61-91.

7 Para visitar su página web: http://www.ucm.es/info/ghistri.

8 Para visitar su página web: http://hum315.uca.es.

9 Para visitar su página web: http://eurasianhub.com. 
de las Relaciones Internacionales (CEHRI), que cuenta con más de 130 socios. ${ }^{10}$ Igualmente, promueven actividades sobre este área la Asociación de Historia Actual, ${ }^{1}$ la Asociación de Historiadores del Tiempo Presente ${ }^{12}$ o la Asociación de Estudios Asiáticos, entre otros.

Asimismo, es reseñable la presencia cada vez más importante que han tenido las cuestiones internacionales en los últimos congresos de la Asociación de Historia Contemporánea (AHC). Por ejemplo, las mesas específicas de Historia de las Relaciones Internacionales en Murcia (2008) y Santander (2010) contaron con veinticinco y treinta y cuatro comunicaciones, respectivamente; ello, sin contar a otras mesas de índole temática similar. Un amplio éxito que se vio confirmado en el III Encuentro de Jóvenes Investigadores de la AHC, celebrado en Vitoria en 2011, y que contó con treinta propuestas finalmente presentadas. Mientras, en el XI Congreso de la AHC, celebrado en Granada en 2012, las cuestiones internacionales estuvieron representadas por la mesa-taller "Historia transnacional, Historia global. Enfoques convergentes", que contó con diez comunicaciones defendidas. ${ }^{13}$

Por tanto, ante todos los retos planteados por esta disciplina, ¿cuáles eran las pretensiones de esta mesa-taller? Abarcar todas las inquietudes teóricas y metodológicas anteriormente citadas, pero también una aspiración muy concreta: ir más allá de las áreas, actores y cronologías tradicionalmente estudiadas por la historiografía española de las relaciones internacionales. Así, pretendiamos abarcar nuevas áreas geográficas de investigación más allá de España y sus vecinos; nuevas épocas más allá del siglo XX y, sobre todo, del tiempo presente; y nuevos actores más allá de los Estados. Además, no sólo aspirábamos a superar el marco convencional de análisis y estudio de la política exterior de España y sus áreas tradicionales de acción, sino que también pretendíamos seguir la línea marcada por congresos como el de Granada de 2012, en el que las cuestiones internacionales fueron incluidas en una mesa centrada en la historia transnacional y la global history.

De este IV Encuentro de Jóvenes Investigadores en Historia Contemporánea, que se celebró en Valencia en septiembre de 2013, tampoco podemos obviar un aspecto netamente positivo: la interdisciplinariedad y pluralidad de áreas, materias y cronologías que se ha podido ver en el mismo, pues la presencia de temas internacionales no se acabó en la mesa-taller que aquí presentamos, de carácter amplio y generalista. Así, las relaciones internacionales, en sus distintos vectores temáticos, también aparecieron en mesas como "España y la Guerra Fría cultural", "Movimientos migratorios desde una perspectiva global y comparada", "Historia militar" $y$ "España-Marruecos: pasado, presente y futuro de las relaciones bilaterales"; igualmente, aunque de forma más tangencial, fueron tratadas en otros talleres como "Los teatros de lo bélico" y "Los procesos de Transición democrática a debate".

Por otra parte, esta mesa-taller también es reflejo de cómo a nivel internacional -y progresivamente, en el mundo académico español- se pueden distinguir tres grandes cambios en la Historia de las Relaciones Internacionales como resultado del largo debate intelectual que acabamos de narrar y que todavía parece no haber terminado ${ }^{14}$. En primer lugar, el estudio de la acción exterior del Estado ha perdido la centralidad que tenía previamente y ha dejado de ser la seña de identidad de la especialidad. Los trabajos de las últimas décadas enfatizan sobre todo

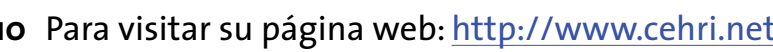

1 Para visitar su página web: http://www.historia-actual.org.

12 Para visitar su página web: http://historiadelpresente.blogspot.com.

13 A este respecto, http://www.ahistcon.org.

14 Jeffrey A. ENGEL: "Diplomatic History's III-Deserved Reputation and Bright Future", Perspectives on History, 50,9 (2012), Recuperado de internet (http://www.historians.org/publications-and-directories/perspectives-on-history/december-2012/the-future-of-the-discipline/diplomatic-hisBandwagon: A State of the Field", Journal of American History, 95, 4 (2009), pp. 1.053-1.073. que las relaciones internacionales no se limitan a las relaciones interestatales y que otros actores, como las empresas multinacionales, las organizaciones no gubernamentales, los partidos, los sindicatos o los emigrantes, juegan un papel crucial en el sistema internacional. Aunque en po se ha materializado con la misma intensidad, esta mesa proporciona un buen ejemplo con la comunicación de Alberto Sevillano, que se aproxima al interés de los intelectuales españoles del Ochocientos en la región europea que rodea al Mar del Norte. Igualmente, la comunicación de David Mota analiza la posición europeísta del PNV desde el final de la Segunda Guerra Mundial hasta el estallido de la Guerra Fría.

El segundo gran cambio es el aumento de la interdisciplinariedad. Tradicionalmente, los historiadores internacionalistas habían tenido poco contacto con otras ciencias sociales, ex ceptuando la ciencia política. Pero incluso el papel de esta se había reducido a proporcionar teorías normativas sobre las relaciones internacionales que se podían elegir o desechar en función de su utilidad. Sin embargo, en las últimas décadas los historiadores internacionalistas se encuentran cada vez más cómodos dialogando con otras disciplinas, como el derecho, la sociología, la economía o la antropología. A su vez, otras especialidades historiográficas, como la historia económica o la historia cultural, también han empezado a interesarse por la influencia de las relaciones internacionales en sus objetos de estudio. Los resultados de estos mestizajes, si continúan profundizándose, prometen ser muy interesantes. Un buen ejemplo de ello son las comunicaciones de Cristina Luz García e Imanol Herreros. García ha estudiado las negociaciones económicas entre los gobiernos españoles de la Transición y las dictaduras de Chile y Argentina, mientras que Herreros ha analizado económicamente el proceso de internacionalización de las leyes de propiedad intelectual en el siglo XIX.

Pero quizá el cambio más significativo de las últimas décadas es la influencia del giro cultural en la Historia de las Relaciones Internacionales. ${ }^{15}$ Aunque su presencia en España todavía sea muy escasa, el enfoque cultural de las relaciones internacionales es cada vez más influyente en los países de historiografía puntera, como Estados Unidos. En realidad, el giro cultural no es un enfoque único, sino que agrupa diversas aproximaciones. Por un lado, se ha desarrollado una historiografía más tradicional dedicada a analizar la acción cultural de los Estados y el ro de los intermediarios culturales en la política exterior que ha producido resultados muy sólidos. ${ }^{16}$ Por otro lado, se han intentado analizar de manera más ambiciosa, pero también más imprecisa, las circulaciones y transferencias culturales entre diferentes sociedades, aunque este enfoque todavía no ha producido resultados igual de consistentes. ${ }^{7}$ Hasta cierto punto, la comunicación de Alberto Sevillano también se podría incluir dentro de esa oleada cultural. Finalmente, se ha ido desarrollando un tercer enfoque que pretende reinterpretar globalmente las relaciones internacionales de acuerdo con un paradigma cultural. Su determinismo cultural, sin embargo, ha obtenido mucha menos aceptación dentro de la especialidad. ${ }^{8}$

Quizá la última innovación a tener en cuenta surgida en el seno de la especialidad es la llamada new diplomatic history. Su principal impulsor, Kenneth Weisbrode, ha defendido que la nueva historia diplomática debe ocuparse del estudio de todas las prácticas diplomáticas

15 Lorenzo DELGADO: "El factor cultural en las relaciones internacionales: una aproximación a su análisis histórico", Hispania, 54, 186 (1994), pp. 257-278; Jessica C.E. GIENOW-HECHT y Frank SCHUMACHER (eds.): Culture and International History, New York, Berghahn Books, 2003.

16 Antonio NIÑO: "Uso y abuso de las relaciones culturales en la política internacional", Ayer, 75 (2009), pp. 25-61.

17 Antonio NIÑO: "Relaciones y transferencias culturales internacionales", en Benoît PELLISTRANDI y Jean-François SIRINELLI (eds.): L'histoire culturelle en France et en Espagne, Madrid, Casa de Velázquez, 2008

18 Volker DEPKAT: “Cultural Approaches to International Relations - A Challenge?", en Jessica C.E. GIENOW-HECHT y Frank SCHUMACHER (eds.): Culture and International History, New York, Berghahn Books, 2003 
(tanto formales como informales) a escala micro y olvidar el antiguo énfasis en el proceso de toma de decisiones dentro de cada Estado. Aunque este nuevo enfoque ya cuenta con poderosas plataformas de difusión, todavía es demasiado pronto para evaluar sus aportaciones. ${ }^{19}$

No obstante, a pesar del impacto de estos cambios, la mayoría de los trabajos en Historia de las Relaciones Internacionales siguen centrando su atención en las relaciones entre Estados, si bien los objetos de estudio se han diversificado considerablemente. Un factor importante detrás de ello es la ingente magnitud de documentación diplomática que se desclasifica periódicamente en los países occidentales - con la excepción de España-, que también ha incentivado el desplazamiento de la atención hacia períodos cada vez más cercanos a la actualidad, como ejemplifican las comunicaciones de Zorann Petrovici y David Díaz. Petrovici ha subrayado la importancia del rol del rey Juan Carlos I en la construcción de la Comunidad Iberoamericana de Naciones, mientras que David Díaz ha intentado evaluar los resultados de las misiones internacionales en las que se han involucrado las Fuerzas Armadas españolas en las últimas dos décadas.

No obstante, períodos más clásicos con fuentes primarias que no han sido suficientemente exploradas siguen despertando la atención de los historiadores, como es el caso de las comunicaciones de Miguel í. Campos y David del Castillo. Campos estudia el suministro de armas a la República española por parte de Francia durante la Guerra Civil española, mientras que de Castillo se centra en la protección de los intereses de Japón en Estados Unidos por parte de España durante la Segunda Guerra Mundial.

Por tanto, si algo podemos destacar es la gran variedad de temas presentados en esta mesa-taller. Sigue Ilamando la atención que España sea el objeto primordial de análisis, al menos en el caso que nos ocupa: cinco de las nueve comunicaciones analizan su acción exterior o tienen a este país como protagonista, en diferentes épocas y áreas ${ }^{20}$. Por su parte, los trabajos de Imanol Herreros, David Manzano y Alberto Sevillano son los únicos que trascienden el ámbito español; en el caso del primero, si bien no deja de lado a España, cobran protagonismo las relaciones económicas internacionales — dimensión que también aborda la comunicación de Cristina Luz García. Mientras, en el caso de David del Castillo, David Manzano y Alberto Sevillano, se tratan dos áreas escasamente analizadas por la historiografía española: Asia y los países nórdicos y bálticos.

Fuera del ángulo bilateral, David Díaz también analiza actores multilaterales como la ONU, la OTAN, la OSCE, etc, mientras que Imanol Herreros emplea un prisma multilateral a la hora de analizar las negociaciones para la internacionalización de las leyes de propiedad intelectual. Igualmente, Herreros, Manzano y Sevillano son los únicos que apuestan por un siglo tradicionalmente "abandonado" como el XIX. Asimismo, cabe señalar que siguen pesando fuertemente los períodos cronológicos tradicionales: la Guerra Civil (Miguel I. Campos), la dictadura franquista, la Segunda Guerra Mundial y la Guerra Fría (David del Castillo y David Mota). Sólo dos comunicaciones estudian el período democrático (David Díaz y Zorann Petrovici), mientras que la de Cristina Luz García está "a caballo" entre la dictadura franquista y la democracia.

19 Kenneth WEISBRODE: "An Open Letter to the Membership of SHAFR", Passport (2008), Recuperado de internet (http://www Shafrors/passport/2008/december/Weisbrode pdf) También se puede de internet (http://www.shafr.org/passport/2008/december/Weisbrode.pdf). Tambièn se puede twork-for-the-new-diplomatic-history.

. Campos, David Díaz, Cristina Luz García, David del Castillo Z Zann Petrovici. Eso si, pese a que España es el "punto comin cian Luz Gacia, David del Cos ex ex "punto común de convergencia", existe tores no estatales (empresas multinacionales); David Díaz analiza las Fuerzas Armadas; y Zorann torrovici, a
Llegados a este punto, se puede afirmar que la Historia de las Relaciones Internacionales ha mejorado relativamente su situación en las últimas tres décadas. La especialidad parece haber superado fortalecida la crisis existencial que sufrió en los años ochenta. La diversidad de enfoques y la interdisciplinariedad con otras especialidades a la que aludiamos anteriormente demuestran su vitalidad intelectual y el aumento de su impacto. Sin embargo, se pueden detectar varias tareas pendientes que requieren ser abordadas en un futuro próximo.

En primer lugar, la Historia de las Relaciones Internacionales sigue sufriendo una gran indefinición teórica. El eclecticismo de las últimas décadas ha sido positivo y útil, pero para avanzar en el diálogo con otras ciencias sociales quizá sería conveniente empezar a clarificar algunos conceptos y categorías. Dentro de la teoría de las relaciones internacionales, uno de los grandes debates es como casar los modelos sobre el comportamiento del sistema internacional con aquellos sobre la política exterior de los Estados. Hasta la fecha, los historiadores han estado generalmente ausentes de esa clase de debates. Sin embargo, un mayo conocimiento de los conceptos que manejan los teóricos de las relaciones internacionales habría ampliado enormemente el alcance de trabajos como la comunicación de David Manzano, en la que ha tratado de reinterpretar la expansión de las potencias occidentales en el Pacífico durante el siglo XIX.

En segundo lugar, la internacionalización de la especialidad, a pesar de su propio nombre y objeto de estudio, sigue siendo precaria. Los debates en los países de habla inglesa tardan mucho en llegar al continente europeo, mientras que las contribuciones de las historiografías continentales no suelen generar ningún impacto en el mundo anglosajón. Hasta que no se construya un debate académico verdaderamente internacional, los avances en la Historia de las Relaciones Internacionales seguirán siendo más lentos que en otras ciencias sociales con un grado de internacionalización superior.

Finalmente, la pérdida de identidad de la Historia de las Relaciones Internacionales plantea un desafío para establecer una colaboración fructífera con otras especialidades historiográficas que estudian los contactos a través de las fronteras y que rompen barreras académicas tradicionales. Porque lo que tienen en común estas especialidades es precisamente la reducción de las relaciones internacionales tradicionalmente entendidas a un papel secundario. Surgida al calor de la globalización, la llamada historia global — que se puede llegar a confundir con la historia transnacional - trata de analizar la historia de la humanidad centrándose en objetos de estudio globales que trascienden toda clase de fronteras, desde el terrorismo al medio am biente. Hasta el momento, esta especialidad oscila entre convertirse en una mera historia de la globalización o tratar de reinterpretar la historia del mundo moderno a una escala que los historiadores del pasado no concebían posible. ${ }^{21}$ La ruptura de barreras académicas se ha llevado más lejos todavía en el caso de la historia transnacional, que ha centrado su atención en los movimientos y flujos de personas e ideas a través de las fronteras. Si bien su planteamiento no es enteramente novedoso, ha alcanzado una visibilidad extraordinaria en los últimos tiempos. Todavía no está muy claro cuáles pueden ser las relaciones entre la Historia de las Relaciones Internacionales y la historia transnacional, pero las oportunidades de colaboración deberían dar resultados fructíferos una vez se clarifiquen los objetos de estudio transnacionales. ${ }^{22}$

21 Bruce MAZLISH y Akira IRIYE (eds.): The Global History Reader, New York, Routledge, 2005; Bruce MAZLISH: The New Global History, New York, Routledge, 2006.

22 Gunilla BUDDE, Sebastian CONRAD y Oliver JANZ (eds.): Transnationale Geschichte: Themen, TendenGunilla BUDDE, Sebastian CONRAD y Oliver JANZ (eds.): Transnationale Geschichte: Themen, Tendenzen und Theorien, Gottingen, [s.n.], 2006; Jose Maria FARALDO: "Màs allá de las relaciones internacionales. Nuevas tendencias centroeuropeas en historia transnacional y comparativismo", en Encarna NICOLAS y Carmen GONZALEZ (eds.): Mundos de ayer, Murcia, EDI History", Contemporary European de Murcia, 2009 (publicacion digital); Akira IRIYE: "Transnational History", Contemporary European Transnational History. From the Mid-19th Century to the Present Day, Basingstoke, Palgrave Macmi- 
La historiografía española internacionalista ha experimentado, como dijimos antes, un notable avance y está ya plenamente consolidada; incluso se puede argumentar que vive el momento más pujante de su existencia, gracias al "derribo" de barreras académicas. Pero la disciplina no es ajena a la crisis económica global y, en particular, a los duros ajustes que viene sufriendo el sector de la educación superior y de la investigación en España desde hace casi un lustro; recortes que ponen en riesgo los avances producidos en los últimos años y el importante esfuerzo de convergencia con el resto del mundo e internacionalización de la academia española.

Sin embargo, amén de las dificultades económicas inherentes a la situación que atraviesa nuestro país, el obstáculo más grave y decisivo al que se enfrenta nuestra especialidad es, lisa y llanamente, la imposibilidad de acceso a las fuentes documentales para el estudio de las relaciones exteriores de España. Meses después del estallido del "caso Wikileaks", y a propuesta del entonces ministro de Asuntos Exteriores y Cooperación, Miguel Ángel Moratinos, el Consejo de Ministros adoptaba el 15 de octubre de 2010 un acuerdo secreto -y que, por ende, no fue publicado en el Boletín Oficial del Estado- por el cual se decidía clasificar como secreta - y por tanto, sujeta a la imposibilidad de ser consultada - la práctica totalidad de la documentación diplomática española posterior al año 1968 y gran parte de la anterior a esa fecha. Después de verse afectados como consecuencia de este acuerdo secreto, el profesor Carlos Sanz Díaz y el investigador Álvaro Jimena, ambos del Departamento de Historia Contemporánea de la Universidad Complutense de Madrid, procedieron a denunciar estos hechos, que trascendieron a la opinión pública en junio de 2012, tras publicarlos el diario El País. ${ }^{23}$

El actual ministro de Asuntos Exteriores y Cooperación, José Manuel García-Margallo, afirmó entonces que "desconocía" la decisión propuesta por Moratinos y prometió resolver dicho "veto" a la documentación diplomática. ${ }^{24}$ Sin embargo, unos meses después, la decisión fue en el sentido justamente contrario: el Palacio de Santa Cruz ordenó en septiembre de 2012 el cierre del Archivo General del Ministerio y su bifurcación en dos secciones independientes: la anterior a 1931 sería remitida al Archivo Histórico Nacional y la posterior a dicha fecha, al Archivo General de la Administración. La falta de recursos humanos y materiales hace que, en el momento de redactar estas líneas, no sea accesible la documentación diplomática española $n$ en un archivo ni en otro, con la consiguiente paralización de tesis doctorales e investigaciones. Al mismo tiempo, el Ministerio de Defensa también ha decidido suspender sine die la decisión adoptada por el anterior equipo ministerial de desclasificar diez mil documentos pertenecientes al período comprendido entre el final de la Guerra Civil y el año 1968. Ante esta situación, los historiadores hemos llevado a cabo distintas denuncias en diferentes medios de comunicación de alcance nacional y una constante interlocución con los distintos grupos parlamentarios representados en las Cortes Generales. Todo ello se ha visto plasmado en varias pregun-

Ilan, 2009; Lisa A. LINDSAY: “The Appeal of Transnational History”, Perspectives on History, 50, 9 (2012), december-2012/the-future-of-the-discipline/the-appeal-of-transnational-history; Mae M. NGAl: "Promises and Perils of Transnational History", Perspectives on History, 50, 9 (2012), disponible en: (http://www.historians.org/publications-and-directories/perspectives-on-history/december-2012/ the-future-of-the-discipline/promises-and-perils-of-transnational-history); Kiran Klaus PATEL: Nach der Nationalfixiertheit. Perkspectiven einer transnationalen geschichte (Öffentliche Vorlesungen der Humboldt Universtät zu Berlin, 128), Berlin, [s.n.], 2004; İ.: “Transnational History”, European History Online (2010), disponible en http://www.ieg-ego.eu/patelk-2010-en; Thomas RISSE-KAPPEN (ed.): Bringing Transnational Relations Back In: Non-State Actors, Domestic Structures and International Institutions, Cambridge, Cambridge University Press, 1995.

23 "Exteriores blinda todos sus documentos", El Pais, 3 de junio de 2012. Disponible en: http://politica. elpais.com/politica/2012/06/03/actualidad/1338750887 077908.htm

24 "Exteriores revisará el acuerdo que declara secretos todos sus documentos", El Pais, 5 de junio de 2012. Disponible en: http:// politica.elpais.com/politica/2012/06/05/actualidad/1338903319 488877.html tas formuladas al Gobierno por parte de los grupos políticos; y, sobre todo, en un manifiesto lanzado en julio de 2013 por la plataforma $\mathrm{H}$-Spain - perteneciente al portal $\mathrm{H}$-Net-, que ha sido apoyado por más de trescientos profesores e investigadores de España y del extranjero, así como por personalidades de la sociedad civil.25

Por tanto, para estudiar la historia de la política exterior de España, actualmente los investigadores tenemos que acudir a los archivos franceses, británicos o alemanes, no para contrastar fuentes - como era habitual hasta ahora- sino por ser los únicos depositarios de evidencia empírica para el desarrollo de investigaciones sobre España. Aprovechamos, pues, estas líneas para denunciar, una vez más, la situación surrealista en la nos encontramos en la actualidad los historiadores de las relaciones internacionales en España. De esta forma, exhortamos a Ministerio de Educación, Cultura y Deporte a que dé celeridad al proceso de descripción y acceso a la documentación transferida a sus archivos; y al Ministerio de Asuntos Exteriores y Cooperación para que, en virtud de las promesas del actual titular de dicho departamento, se levante el "veto" de 2010 en aplicación de la Ley de Transparencia recientemente aprobada; y, en tercer lugar, reclamamos que se regrese al statu quo anterior a la decisión del Ministerio de Defensa de frenar en seco la desclasificación de fuentes documentales hasta 1968. No sólo nos jugamos un mayor conocimiento, análisis y estudio de las relaciones internacionales de España, sino también un compromiso de transparencia, libertad de información y de investigación acordes a los cánones de un país democrático.

A todo ello hay que unir el hecho de que España, salvo raras excepciones, tampoco ha realizado una política clara y decidida de promoción de "colecciones de documentos diplomáticos", ampliamente consolidadas en países de nuestro entorno como Francia, Reino Unido, Italia Alemania o Portugal, así como en Estados Unidos. Sólo existen algunas publicaciones oficiales de temática internacional en revistas militares.

Dicho esto, seguimos teniendo preguntas abiertas, como se pudo comprobar en el coloquio final de esta mesa-taller. Por ejemplo, en tiempos de turbulencias económicas como los que actualmente vivimos, ¿cómo hacer ver a la sociedad la "utilidad" de esta disciplina? ¿Cómo realizar la necesaria "transferencia del conocimiento" a esa sociedad que, al fin y al cabo, es la que vía impuestos o mecenazgo financia los estudios de nuestra área? ¿Cuáles son nuestros reto y perspectivas de futuro, tanto laborales como académicas? ¿Hacia qué áreas, actores o épocas debe dirigirse la historiografía española de las relaciones internacionales? ¿Debemos los historiadores de las relaciones internacionales - porque el contexto actual y nuestra metodología así lo propician - tender a la interdisciplinariedad y trabajar conjuntamente en grandes proyectos investigación con politólogos, sociólogos, economistas, etc? ¿Qué nuevas perspectivas teóricas y metodológicas emplear? ¿Debemos tender a la "historia transnacional", a la global history o persistir en el eclecticismo actual? ¿Tenemos motivos para ser optimistas de cara al futuro?

Juan Carlos Pereira ya afirmó hace dos décadas que la falta de apoyo oficial que sufre nuestra especialidad era "incomprensible en un país que cuenta con uno de los pasados históricos internacionales más rico y complicado de estudiar, sin cuyo conocimiento en muchos casos es difícil adoptar las decisiones o establecer los objetivos más convenientes en la elaboración de la política exterior actual". ${ }^{26}$ Dos décadas después, como señala este mismo autor, los estudios internacionales están plenamente consolidados en España; sin embargo, queda mucho por hacer en tres ámbitos: un "mayor apoyo" de la Administración a la labor realizada por parte de las instituciones académicas, historiadores y grupos de investigación; un "mayor reconoci

25 El Manifiesto lanzado por H-Spain está disponible en: http://h-net.msu.edu/cgi-bin/logbrowse. pl?trx $=v x \&$ list $=H-$ Spain\&month $=1306 \&$ week $=a \& m s g=/ K c i k o R W J 7 x z 2 U O M S 4 B H a A$.

26 Juan Carlos PEREIRA: "De la Historia Diplomática a la Historia de las Relaciones Internacionales:

algo más que un cambio de término", Historia Contemporánea, 7 (1992), p. 171. 
miento social" a estos trabajos y a las aportaciones científicas que traen consigo; y "una mayor consideración" de lo realizado hasta ahora en el ámbito institucional a la hora de decidir y ejecutar la política exterior de España. ${ }^{27}$

Tras un vivo debate entre todos los presentes en el que se plantearon estas y otras cuestiones como la ya citada polémica sobre los archivos diplomáticos y militares, queremos mostrar nuestro más profundo agradecimiento a los nueve comunicantes que presentaron sus propuestas a la mesa-taller "La Historia de las Relaciones Internacionales: nuevos actores, nuevas fronteras geográficas y cronológicas"; queremos igualmente felicitar a la organización del IV Encuentro de Jóvenes Investigadores de la Asociación de Historia Contemporánea por el impecable desarrollo de unas jornadas de alto nivel científico en la Universidad de Valencia. Nos despedimos con un mensaje de esperanza que como historiadores debemos guardar en lo más profundo de nosotros mismos, para dar también una nota de optimismo a todos los jóvenes que se inician y que continúan esta larga y difícil, pero a la vez apasionada, aventura de la investigación. Porque como decía el escritor libanés Khalil Gibran, "por muy larga que sea la tormenta, el sol siempre vuelve a brillar entre las nubes". 
FRANCIA ANTE LA GUERRA CIVIL ESPAÑOLA:

DEL COMPROMISO DE AYUDA OFICIAL

A LA NO INTERVENCIÓN RELÂCHÉE

Miguel İ. Campos

Becario FPU Universidad Complutense de Madrid

Con la presente comunicación se pretende hacer una puesta al día historiográfica en cuanto al conocimiento del papel que jugó el país vecino en los meses clave de la guerra civil: julio-diciembre de 1936. Por otro lado, también se pretende arrojar nueva luz sobre las tensiones que se produjeron entre el Gobierno republicano y la Société Générale d'Etudes et Entreprises, empresa a la cual se cedió el monopolio de la adquisición del armamento y un balance de los aviones adquiridos en Francia, muchos menos de los difundidos por la historiografía franquista como ya matizó Gerald Howson, con nuevas fuentes primarias localizadas en diversos archivos nacionales y particulares ubicados en España.'

\section{La importancia de Francia}

Lo que ocurrió en el país vecino en los siguientes seis meses tras producirse el golpe de Estado entendemos que fue la clave esencial para entender cómo un golpe de Estado acabó convirtiéndose una guerra civil, junto a otros factores como las posturas de Gran Bretaña y Estados Unidos en la línea de la francesa y la decisión de apoyar a los sublevados de Hitler y Mussolini. La decisión posterior de Stalin de apoyar militar a la República también se mostró crucial.

El tablero francés refleja a escala lo que ocurrió a nivel general en varios aspectos. Por un lado, se observa el abandono a su suerte de un régimen homólogo debido a dos tipos de presiones que sufrió el Ejecutivo galo: las propias tensiones internas de la sociedad francesa a las que hay que sumar las presiones británicas en el sentido de inhibirse de los sucesos españoles para preservar una alianza que en aquellos momentos, ante el expansionismo nazi, era irrenunciable para Francia.

Otras similitudes que se detectan con lo ocurrido en otros países son, en primer lugar, la deserción de gran parte de los integrantes del cuerpo diplomático, muchos de los cuales mostraron una actitud ambigua durante cierto tiempo y obstaculizaron hasta donde les fue posible la adquisición de material bélico al Gobierno republicano, trasmitiendo puntualmente la información a los sublevados. En segundo lugar,y derivado de lo anterior, la República recurrió al empleo de eminentes intelectuales prorrepublicanos con prestigio internacional con un doble objetivo: por un lado mostrar a las potencias democráticas que en España no se pretendía instaurar ningún soviet y por otro tratar de conseguir material de guerra con el que detener el avance de los sublevados, a pesar de no ser ninguno de ellos experto en pertrechos bélicos y mucho menos en

1. Para tener una visión lo más completa debemos consultar la documentación francesa. Para paliar esta carencia hemos programado una estancia de investigación en los archivos franceses de Enterprises consultar en Paris donde se consiguió armamentoy que tengamos noticia ningún historiador ha abordado el tema con profundidad. el mercado negro. En el caso francés se envió, entre otros, a Fernando de los Ríos (quien luego sería embajador en Washington); Pablo de Azcárate, a la sazón subsecretario general de la Sociedad de Naciones (posteriormente fue embajador en Londres), Luis Jiménez de Asúa, abogado criminalista, experto en derecho penal de fama mundial y Luis de Araquistáin.

Otra analogía que observamos son las traiciones bancarias que sufrió la República por parte de diversos bancos franceses, más disimuladas que las sufridas en el Reino Unido. Estos bancos, al estar conectados con grupos impresores de diarios, aireaban todas las transacciones que hacían o intentaban hacer los emisarios republicanos. Como cuarta semejanza, en Francia se observa la predisposición de México de ayudar a España a adquirir pertrechos de guerra a través de sus legaciones europeas, pero debido a la intercepción por parte del MI6 británico de dichos planes y a la autopublicidad mexicana de la ayuda se tradujo en una ayuda más moral que efectiva, aunque la legación mexicana en París tuvo un papel relevante.

Una quinta afinidad con lo que sucedió en otros países fue el papel jugado por la no intervención, que "se aplicó sobre una premisa que resultó falsa: la esperanza de que las potencias fascistas se inhibirían al igual que lo harían las democracias". Esto obligó a la República trata de abastecerse en el mercado negro de armamento, con lo que ello significa y que virase hacia la Unión Soviética, cuyo primer paso se produjo precisamente en París. ${ }^{3}$

La República también mostró en Francia dos carencias propias que se repitieron en otros países. Una fue la falta de un plan nacional de adquisiciones fruto, en parte, de verse obligada a tratar de adquirir el armamento en el mercado negro. Otra fue la falta de control sobre los individuos que fueron enviados comisionados por diversas regiones de España o partidos políticos, los cuales sólo lograron encarecer los precios haciéndose la competencia entre ellos retornando a España con las manos vacías.

Finalmente Francia también jugó un papel importante para la adquisición de armamentos para República en una doble vertiente: por un lado como país productor de una cierta industria armamentística y por otro, gracias a su frontera compartida con España, la cual funcionó de manera permeable a la entrada o no de material bélico, fundamentalmente soviético.

\section{La petición inicial de ayuda}

Se ha reproducido en la historiografía en numerosas ocasiones la petición inicial de ayuda enviada por el Gobierno republicano a través de José Giral, a la sazón presidente del Gobierno, en la misma noche del 18 de julio, a través de un telegrama urgente a Leon Blum, su homólogo francés. ${ }^{4}$ Lo que parece que no queda muy claro en algunos autores es que esta petición inicial de suministro de armamento no implicaba una intervención de facto del Gobierno galo en España.

Pese a la rápida predisposición favorable de Blum de atender la petición española, enseguida se inició la división del Gobierno francés entre partidarios y detractores de ayudar a

2 Ángel VIÑAS: Las armas y el oro. Palancas de la guerra, mitos del franquismo, Pasado\&Presente, Barcelona, 2013, p.31.

3 El 25 de julio se produjo la petición republicana de ayuda al embajador soviético en París. "El telegrama no era muy específico ni precisaba las necesidades. Simplemente indicaba que la República se veía obligada a aprovisionar a sus fuerzas armadas con armamento moderno": ÁngelVIÑAS: La soledad de la República. El abandono de las democracias y el viraje hacia la Unión Soviética, Critica, Barcelona, 2006, p.85.

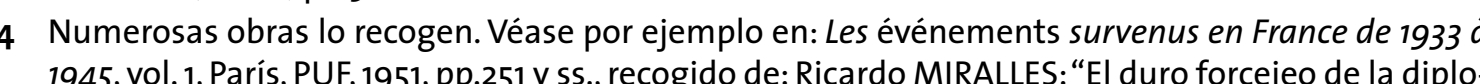
1945, vol. 1, Paris, PUF, 1951, pp.251 y sS., recogido de: Ricardo MIRALLES: "EI duro forcejeo de la diplola República. Diplomáticos y guerra civil, Marcial Pons, Madrid, 2010, 123 . Por otro lado sel volumen de armamento y munición solicitado era escaso (2o bombarderos Potez 54 con sus pilotos, 1.000 fusiles Lebel un millón de cartuchos y ocho cañones de $75 \mathrm{~mm}$ con sus municiones), pero de ha- 
Gobierno de Madrid. Además, y esto, es nuevo en la literatura sobre el tema, el 19 de julio se adquirieron 100.000 litros de gasolina etilada a la Sociedad Berre, pero surgieron problemas: esta empresa telegrafió a la CAMPSA si estaban conformes con que se cargasen los 1.000 hectólitros en el vapor Hermia, a lo que la compañía española dio su conformidad. Sin embargo, el vapor se negó a cargar más de 205 bidones, equivalentes a 49 hectólitros, por lo que la Berre solicitó a la CAMPSA que retirase con urgencia el resto de la gasolina, declinando toda responsabilidad y señalando que todos los gastos resultantes correrían de cuenta del comprador. ${ }^{5}$

\section{La traición del cuerpo diplomático}

Quien también jugó un papel importante para que la República no se pudiera proveer de armamento fue su propio embajador en París, Juan de Cárdenas Rodríguez de Rivas. ${ }^{6}$ El día 20 en su reunión con Blum, Cárdenas intentó ganar tiempo aconsejando al primer ministro francés que no hiciera nada hasta que Madrid no enviara más detalles sobre las armas y aviones concretos que necesitaba. Además, se encargó de que no se enviara el telegrama a Madrid pidiendo dichos detalles hasta bien entrada la noche.

El día 24 de julio estalló en la prensa francesa ${ }^{7}$ un gran escándalo, motivado porque Cristóbal del Castillo, a la sazón ministro consejero de la embajada, había filtrado la petición del armamento a la vez que presentó su dimisión.

\section{La división del Gobierno francés: del sí incondicional a la "no intervención"}

En el Consejo de Ministros el día 25 de julio la división del Gobierno galo ya empezó a hacerse patente. Dicho Consejo de Ministros decidió prohibir la exportación de material bélico con destino a España, a la vez que propuso un acuerdo a las potencias para no intervenir en el conflicto español en socorro de ningún bando, pero a los cuatro días se comprobó que la Italia de Mussolini ya había comenzado a enviar a los sublevados aviones, lo que hizo que el Gobierno francés volviera a disponer de libertad de acción, permitiendo la venta de aviones a Madrid por parte de la industria privada, pero sin armamento. ${ }^{8}$

A las 21:30 horas el día 25 de los Ríos tuvo una nueva reunión con miembros del Gobierno galo. El forcejeo fue duro y en la discusión jugó un gran papel una cláusula secreta conocida por casualidad por de los Ríos: el acuerdo firmado en diciembre de 1935 por Martínez Velasco, contenía una cláusula secreta que obligaba a España a comprar a Francia 20 millones de francos en armas y municiones. 9 Otro problema al que tuvo que hacer frente de los Ríos fue el de

5 La gasolina restante no debió de salir pues el 10 de septiembre el Banco de Bilbao informó a la CAMPSA que había recibido un radio de su sucursal en París manifestándole que se le reclamaban en concepto de almacenaje 2.000 francos. El desenlace aún nos es desconocido.

6 Varias semanas antes del golpe de Estado el Gobierno había decidido sustituirlo por Álvaro de Albornoz. Cárdenas era un aristócrata promonárquico. El relevo estaba planeado para el 15 de agosto.

7 En la prensa conservadora y de extrema derecha, especialmente Le Jour, L'Action Française, Le Figaro o L'Echo de Paris, se defendió la necesidad de eludir toda ayuda material al Gobierno de Madrid por parte de Francia.

8 Esa misma tarde de los Ríos se entrevistó con Blum y un ministro "en casa de un tercero". Blum se derrumbó y señaló que su "alma está destrozada", pero mantendría su "posición cueste lo que cueste y a cualquier riesgo [...] hay que ayudar a la España amiga. -¿Cómo? -Ya veremos".

9 De los Ríos supo de su existencia gracias a la conversación que tuvo la noche previa con el ministro de la Guerra, quien le preguntó si estaba enterado de esto y Fernando de los Ríos le respondió que sí, pues en "la intimidad de la embajada el Sr. [del] Castillo me habia dicho algo a medias palabras que me puso sobre la pista". Tras ello, de los Ríos pidió el expediente del tratado y encontró a cuar no le había hablado ninguno de los ministros franceses. Por otro lado, el ión de Estado perosioblį no disponer de estatuto diplomático para cursar un pedido de armamento de manera oficial, por lo que hubo que esperar a la llegada del nuevo embajador, Álvaro Sánchez de Albornoz, quien llegó el día 27 de julio.

Paralelamente y entre bastidores, las autoridades galas habían comunicado a de los Ríos y a Asúa que las dificultades terminarían si se encontraba un tercer país que hiciera las compras como si fueran para él. Rápidamente se logró el apoyo de México encabezado por su propio presidente, Lázaro Cárdenas, quien autorizó a su representante en París para que acompañase a los republicanos a cursar el pedido de armamento como si fuera para ellos. Sin embargo, e número de armas solicitado pareció excesivo a las autoridades francesas y empezaron nuevamente los problemas y las dificultades, principalmente en los funcionarios subalternos.

El 1 de agosto en un nuevo Consejo de Ministros se anuló el acuerdo del 25 de julio y se prepararon envíos de aviación. Por la noche, el Gobierno francés anunció el envío de telegramas tanto a Gran Bretaña como a Italia para que tomasen parte en un acuerdo junto a resto de potencias mediterráneas para no exportar armas ni al Gobierno legítimo de Madrid ni a los sublevados, con el pretexto de evitar que los disturbios españoles llevasen a Europa entera a una guerra de carácter general. ${ }^{10}$

Finalmente, en la sesión del Consejo de Ministros del 8 de agosto se tomó la decisión de declarar de manera unilateral la no intervención en la cuestión española con el voto a favor de cinco ministros socialistas y cuatro radicales, con Cot a la cabeza y seis socialistas en contra, con Blum a la cabeza y cuatro radicales." Sin embargo, pese a todos estos reveses, las gestiones políticas no se interrumpieron y la aduana francesa a lo largo del mes de agosto permitió que pasara material español desde la frontera catalana a la vasca e impidieron, gracias a gestiones realizadas con el Ministerio del Interior, que algunos aviones y barcos consignados a los rebeldes llegasen a su destino.

\section{El primer intento de mediación}

En una fecha sin determinar, ${ }^{12}$ Araquistáin escribió que la mediación acordada entre Francia e Inglaterra el día 4 de diciembre de 1936 en la guerra de España no había surgido de manera espontánea ni por inspiración de Herriot, quien era el aparente autor del proyecto. El origen lo situó a principios de octubre, a los pocos días de su llegada a París como embajador. En esa fecha Blum le llamó para comunicarle que Ivon Delbos había tenido "la demencia" de pensa proponer al Gobierno británico una proposición de paz a la República, pero el propio Blum no quiso dar este paso sin saber previamente si tal iniciativa sería bien recibida por parte de las autoridades españolas. Araquistáin le contestó, a título personal, que su impresión era que el

apareció en la reunión del día 24, de los Ríos señaló que podía servir de justificación legal para enviar la ayuda, a lo que Blum se mostró de acuerdo: Gerald HOWSON: Armas para España..., p.45.

10 Pese a este anuncio, todavía en esta fecha el Quai d' Orsay no se consideraba obligado por la propuesta que hacía de no suministrar armas al Gobierno español, postura adoptada como resultado de que "otras potencias extranjeras hayan suministrado armas a los insurrectos": Archivo del Ministerio de Asuntos Exteriores (AMAE), Archivo de Barcelona, RE. 135, carp.25, pl.2. Ese mismo día 1 por la mañana la embajada francesa en Londres hizo gestiones cerca del Gobierno británico sobre la declaración de no intervención.

11 Ricardo MIRALLES: “El duro...”, pp.124-125. Ante este acuerdo del Gobierno frentepopulista francés, el embajador español presentó una protesta y Fernando de los Ríos y Asúa dijeron a Blum que jurídicamente era un disparate ya que no se enfrentaban dos beligerantes, sino un Gobierno regular y unos militares rebeldes.

12 La propuesta franco-británica de mediación en la guerra de España por Luis de Araquistáin, Archivo Histórico Nacional (AHN), Fondos Contemporánes. Diversos. Archivo Particular de Luis de Araquistáin. Legajo 76 , documento 10 . 
Gobierno no aceptaría una mediación de ese tipo, pero que, de todas maneras, la comunicaría y en cuanto tuviese respuesta, se la haría llegar a Blum.

Tal y como auguraba Araquistáin, el Gobierno republicano le comunicó que no aceptaba ningún tipo de mediación que no implicase el sometimiento de los rebeldes y "mientras el gobierno legitimo tuviese un palmo de terreno nacional donde seguir combatiendo hasta la victoria definitiva". Ante tal respuesta, el Gobierno francés desistió de proseguir las negociaciones proyectadas con su homólogo británico, lo cual no implicaba que las negociaciones cesasen en absoluto.

\section{El contrato con la Société Europenne d'Etudes et Enterprises}

Mientras todo esto ocurría, desde prácticamente el inicio de la sublevación militar, sobre la embajada española en París apareció una nube de aventureros internacionales, gente de una moral mucho más que dudosa, a los que fue preciso en muchos casos darles beligerancia por haberse cerrado todas las demás posibilidades y vías "normales" para la adquisición de material bélico y reinar en dicha embajada el imperio de las angustiosas circunstancias de esos momentos, en donde aparecieron algunos escándalos tras lograr algunas operaciones con éxito o al conato de otras que fracasaron.

A este desbarajuste hay que añadir que Álvaro de Albornoz, el nuevo embajador en París, sabía todavía menos de finanzas o armamentos que de los Ríos, Asúa o Azcárate y se decidió ponerle remedio delegando la parte más ingrata del trabajo, el regateo con los comerciantes de armas en los pasillos y antesalas, en una organización de profesionales: la Société Européenne d'Etudes et d'Entreprises. ${ }^{13}$

En el contrato que el 8 de agosto de 1936 firmó el embajador en París, en nombre del Gobierno republicano, con dicha Société, se otorgaba a ésta el derecho de exclusividad para la compra de armamento y de todas las mercancías que fueran necesarias, bien en Francia o en terceros países. Además, centralizaría todas las compras en las mejores condiciones a los precios más bajos, recibiendo por ello un $7,5 \%$ del valor del contrato. También figuraba una cláusula por la cual se creaba un sistema de arbitraje por el cual, en el caso de que el Gobierno republicano omitiese designar su árbitro dentro del plazo de quince días, a contar desde el requerimiento que al efecto recibiese, se haría la designación por la Cámara de Comercio internacional de Bruselas, ${ }^{14}$ a la que también se le atribuía la designación del tercer árbitro. ${ }^{15}$

José Giral, y su ministro de exteriores, Augusto Barcia, hablaron de este contrato al menor número de personas posible, tanto de su propio Gobierno como del de Largo Caballero, que le sucedió el 4 de septiembre. Por eso, cuando Luis Araquistáin llegó a París para sustituir a Albornoz el 24 de septiembre, nadie le habló del contrato antes de partir ni supo de su existencia hasta una semana o dos después de su llegada. ${ }^{16}$

13 Compañía fundada en 1930 con el objeto de construir un ferrocarril en Yugoslavia. Trabajaba en asociación con la compañía británica Gas, Ligth y Coke, y entre sus accionistas de renombre figuraban Schneider-Creusot, el gigante de la venta de armas, el Imperial ottoman Bank, Worms et Cie., banco comercial propietario de una cadena de hoteles, entre los que figuraba el famoso Crillon de París, y el Comité des Forges. El presidente de la Société era Jean Reveillard, y su director administrativo el Dr. Simon Marcovici-Kleja, ex cónsul de Rumanía en Lille y un personaje un tanto siniestro.

14 Antonio Lara informó a Araquistáin de las averiguaciones que Ossorio y Gallardo había realizado en Bruselas y de las cuales resultó que no existía la citada Cámara Internacional de Comercio, si bien era cierto que en la Cámara de Comercio de Bruselas existía, aunque no tenía carácter internacional, una especie de Corte o Colegio arbitral o algo semejante.

15 Carta de Luis Araquistáin a Ossorio y Gallardo (12 abril 1937), AHN, Fondos Contemporáneos. Diversos. Archivo Particular de Luis de Araquistáin. Legajo 35, documento O41. y en AHN, Fondos Contemporáneos. Diversos. Archivo Particular de Luis de Araquistáin. Legajo 73, documento 13. Carta de Luis Araquistáin a Ossorio y Gallardo. 12 abril 1937.

16 Sin embargo la prensa francesa estaba al corriente del contrato: el 7 de septiembre fue descubier-
Araquistáin consideró el contrato como intolerablemente lesivo para los intereses republicanos, por lo que desde su cargo de embajador se limitó a ignorarlo, tanto en su condición de monopolio (era un contrato virtualmente nulo desde el punto de vista de la legislación republicana ya que todo monopolio, y el contrato con la Société lo era, exigía una ley del Parlamento) como en el pago de la comisión por operaciones independientes de ella. Ante esto, los representantes de la Société habían ido de manera reiterada y en variado tono a reclamar al embajador el cumplimiento del contrato y Araquistáin les manifestaba la imposibilidad material ante la que se encontraba de hacerlo debido a que el Gobierno enviaba constantemente delegaciones de compras a distintos lugares de Europa y América, sin que la embajada en París tuviese en muchas ocasiones conocimiento de esto, por lo que no podía controlar las adquisiciones realizadas de este modo.

Araquistáin temía que la Société acabase exigiendo el cumplimiento del contrato por la vía que en el mismo se señalaba. Esto indujo a Araquistáin a pensar en la conveniencia de proponer a la citada sociedad la rescisión total para conocer su actitud y en qué condiciones lo harían, pero hasta el mes de diciembre se había contenido por un doble temor: que se hiciese la situación más tirante aún con la Société o que se molestaran las personalidades políticas de que los representantes de la sociedad se decían protegidos. Lo que era indudable era que pronto había que tomar una decisión y Araquistáin se decantaba porque fuese el Gobierno quien se la enviase.

Como señala Howson, no está del todo claro cómo se resolvió el problema del contrato con la Société aunque algunas referencias que él vio indican que en la época en que las relaciones quedaron definitivamente interrumpidas, a comienzos de 1937, a la Société se le habían abonado 100 millones de francos por facturas que ésta no podía justificar y otros 64 millones en concepto de comisiones por unas compras con las que no tenía nada que ver, e incluso estaba tratando de obtener otros 28 millones de francos más que, según pretendía, aún se le adeudaban."

Creemos que podemos aportar algo de luz sobre el tema con nueva documentación localizada en archivos españoles: también existía otro contrato entre la Société y la legación de México en París, cuyos detalles ignoraba Araquistáin a la altura de mediados de diciembre de $1936 .{ }^{18}$ Tanto del contrato general como del otro contrato de dicha empresa con la embajada mexicana, firmados ambos en la misma fecha, sólo tuvo Araquistáin conocimiento por la propia Société.

En realidad el contrato con la legación mexicana era el único que tenía validez ya que todo lo comprado por la Société se había hecho en nombre de México y casi nada a nombre de España, debido al pacto de no intervención que imposibilitaba las ventas directas al Gobierno republicano. En resumen, la Société le había entregado una copia de ese supuesto contrato con la legación mexicana al mismo tiempo que le dio conocimiento del existente entre ella y la embajada española en París, pero ocultándole una cláusula clave del contrato mexicano: existía un límite fijado en 100 millones de francos. ${ }^{19}$

El tope de los 100 millones de francos se lo reveló un día a Araquistáin, de manera casual, el embajador de México en el transcurso de una conversación en la cual Araquistáin hizo alusión

to por I'Action Française: Gerald HOWSON: Armas para España..., p. 117.

17 lbid., p. 149

18 Carta de Luis de Araquistáin a Manuel de Irujo (11 enero 1937), AHN, Fondos Contemporáneos. Diversos. Archivo Particular de Luis de Araquistáin. Legajo 31, documento 195. Fue la primera noticia que tuvo Araquistáin de dichos contratos ya que nadie en la embajada le informó de su existencia, ni en los papeles que encontró en la embajada halló documentación que se refiriese a tales obligaciones, aunque sí borradores, copias de contratos sin la firma de Albornoz y algunos firmados por él, pero sólo para productos farmacéuticos. 19 La forma en que estaba redactado no hacía suponer (al menos a Araquistáin) que en el contrato hubiese un limite en la cuantía. En realidad, lo que la Societe entregó a Araquistain no fue una no fue el definitivo. 
a la Société y al abusivo de ambos contratos, creyendo el embajador español que, en esencia, ambos contratos eran idénticos. ${ }^{20} \mathrm{El}$ conocimiento de este contrato con México, el único que jurídicamente había sido operante, fortaleció la posición del Gobierno republicano hasta tal punto que la Société, la cual había exigido un arbitraje el día 29 de diciembre en virtud de una cláusula del contrato cuando aún se ignoraba la existencia del límite de los cien millones. El día 11 de enero la Société escribió a Araquistáin anunciándole que suspendía, por el momento, la demanda de arbitraje.

Por otro lado, en un Consejo de Ministros celebrado a comienzos de enero de 1937 se acordó la formación de una comisión interministerial integrada por el Julio Álvarez del Vayo, Juan Negrín y Manuel de Irujo, abogado y político del PNV y ministro sin cartera, para el estudio, informe y propuesta de la resolución que procediese en relación al funcionamiento de la Comisión de Compras de París y, para lo que aquí interesa, el contrato de la embajada y la Société,y para otras cuestiones. ${ }^{21}$

El día 19 de marzo de 1937 Araquistáin recibió un requerimiento de la Société para nombrar un árbitro que representase al Gobierno al cual Araquistáin contestó con el silencio por respuesta. ${ }^{22}$ En su opinión, la realización de tal arbitraje no significaba en la práctica un daño irreparable si se atendía a la real e insuperable dificultad que representaría la ejecución de un fallo, que dictado sin consentimiento de las autoridades republicanas al trámite sería seguramente en su contra. A pesar de todo, por motivos políticos y de otra índole, si el procedimiento se iniciaba y terminaba les crearía una situación desagradable, por lo que debía evitarse.

Como el plazo de los quince días venció, ${ }^{23}$ Araquistáin solicitó a Ossorio y Gallardo que averiguase si se había realizado alguna gestión en la Cámara de Comercio de Bruselas por parte de la Société respecto al arbitraje y, en caso afirmativo, hicieran saber de un modo formal que el Gobierno republicano, en consideración a que como representante del Estado no podía dimitir la inmunidad de que éste gozaba para solventar todas sus cuestiones litigiosas más que ante sus propios tribunales, por lo que rehusaba y declinaba esa jurisdicción arbitral y de ninguna manera podía reconocer ningún valor jurídico a ningún procedimiento ni decisión que en esa vía se siguiese o dictase.

Finalmente, el día 21 de abril Araquistáin escribió a Adalberto de Tejada,24 a la sazón embajador de México en Francia, para informarle de que Antonio Lara y Martí Estévez le habían

20 Este hecho ponía de manifiesto, una vez más, la picaresca que tuvo la Société con el Gobierno republicano.

21 Manuel Irujo entendía que lo primero que necesitaban era conocer el valor jurídico, la eficacia y la subsistencia del convenio celebrado entre la embajada y la Société y a tal efecto, ya que Álvarez del Vayo poseia una copia del contrato y de la carta de Araquistain que orientaba su criterio, le solicitó que las pasase al estudio y dictamen de su asesoria juridica para que esta dictaminase sobre los siguientes extremos: $1^{\circ}$ valor jurídico del contrato; $2^{\circ}$ medio adecuado para obtener su revisión o novación en las condiciones favorables para el Gobierno republicano y $3^{\circ}$ responsabilidades que del mismo pudieran derivarse: Carta de Manuel de Irujo a Julio Alvarez del Vayo (7 enero 1937), AHN, Fondos Contemporáneos. Diversos. Archivo Particular de Luis de Araquistáin. Legajo 31, documento I 99.

22 Araquistáin sospechaba, a tenor de las nuevas incidencias surgidas con dicha sociedad, que ésta, incluso contrariando su interés general, el cual le aconsejaba no provocar el trámite de arbitraje debido a la publicidad que representaba, impulsada por el despecho de sus administradores, insistiese en el camino del arbitraje, que hasta ese momento había parecido esgrimir más como un bluf que con el propósito verdadero de llevarlo a la práctica.

23 Véase más arriba la cláusula del contrato firmado entre Albornoz y la Société. Carta de Luis Araquistáin a Ossorio y Gallardo (12 abril 1937), AHN, Fondos Contemporáneos. Diversos. Archivo Particular de Luis de Araquistáin. Legajo 35, documento O41; y en Carta de Luis Araquistáin a Ossorio y Gallardo (12 abril 1937), AHN, Fondos Contemporáneos. Diversos. Archivo Particular de Luis de Araquistáin. Legajo 73 , documento 13.

24 Carta de Luis Araquistáin a Adalberto de Tejada (21 abril 1937), AHN, Fondos Contemporáneos. Diversos. Archivo Particular de Luis de Araquistáin. Legajo 40, documento T11. comunicado que en muy pocos días se reunirían con los representantes de la Société para ver si encontraban una solución amistosa. Para ello les era preciso reunir todos los datos necesarios a base de la documentación entregada por la Société a la legación de México, por lo que le solicitó su consulta nuevamente. ${ }^{25} \mathrm{~A}$ pesar de todo, aún no nos es posible determinar la fecha exacta del fin del contrato por la Société, aunque las razones parecen razonablemente aclaradas.

A las dificultades expuestas de manera resumida en el plano político con las autoridades galas y con la Société, también se encontraron los representantes de la República con muchas otras para la adquisición de material aéreo, tanto de aparatos como de repuestos e incluso de combustible. Por cuestiones de espacio daremos unas pequeñas pistas de lo que ocurrió y expondremos un balance de aviones adquiridos.

Que se tenga constancia documental, los únicos aviones que cruzaron la frontera entre el 18 de julio y el 8 de agosto fueron los Douglas DC-2 de la LAPE que transportaron el oro a París los días 25, 26 y 30 de julio, los solitarios aviones postales franceses entre Toulouse y Barcelona, y cuatro o cinco viejos aeroplanos Latécoère de 28 pasajeros sacados del depósito con objeto de evacuar de Barcelona y Alicante a ciudadanos franceses, a partir del 28 de julio. Sin embargo ya en la época

tomó cuerpo el bulo de que entre veinte y cincuenta "aviones militares" franceses se habían entregado a los republicanos antes del 8 de agosto de 1938 [sic]. Bulo que siguió apareciendo en las historias y artículos sobre la Guerra Civil española durante el medio siglo siguiente. ${ }^{26}$

Entre el 8 de agosto se enviaron 14 Dewoitine, de los cuales uno capotó en Francia y tres lo hicieron en Barcelona, ${ }^{27}$ logrando salvar 10 cazas y 6 bombarderos Potez. ${ }^{28} \mathrm{El} 26$ de agosto dos bombarderos desarmados más volaron hacia Barcelona. Entre el 5 y el 7 de septiembre se enviaron dos cazas más, también desarmados. Hasta el 19 ó 20 de octubre no se envió ningún contingente. En esa fecha se enviaron siete Potez 542 y dos Dewoitine $371 .^{29}$ En el mismo periodo los sublevados habían recibido de Alemania e Italia 141 militares (73 y 46 respectivamente) perfectamente adecuados para entrar en combate y con su tripulación. ${ }^{30}$

25 Por otro lado, también le informó que el Gobierno español le había pedido a él, como embaja dor español, que elaborase un informe que recopilase toda la actuación de la Société en relación a la República, para conocer el problema en todos los términos y pormenores y decidir lo que procediese con dicha entidad si los esfuerzos conciliatorios fracasaran. Para ello también le sería imprescindible a Araquistain tener una información exacta de lo actuado, obtenida de los documentos explicativos y justificantes de las operaciones realizadas. Dos semanas antes de enviar la carta, Araquistáin, acompañado de Lara y Esteve, acudieron a la legación mexicana y le pidieron que pusiera a disposición de los dos españoles la documentación citada.

26 Gerald HOWSON: Armas para España..., p.57.

27 Uno en el campo de Air France y dos en el terreno militar de El Prat. La embajada norteamericana en Madrid informó inmediatamente a Washington el 12 de agosto que se trataba, probablemente, de una veintena de aviones: Ángel VIÑAS: La soledad..., p.56, nota al pie 4.

28 Los aviones se enviaron desarmados ya que no podían circular por territorio francés armados, independientemente de que las fábricas no poseían y, por lo tanto, no podían vender aviones armados: Informe de Aboal (6 de septiembre 1936) p.1, FIP, carpeta: París. Comisión de Compras. Comisión Técnica. Subcarpeta: Comisión de Compras.

29 Gerald HOWSON: "Los armamentos: asuntos ocultos a tratar" en Paul PRESTON: La República asediada: hostilidad internacional y conflictos internos durante la Guerra Civil, Barcelona, Península, 1999, pp.239-264.

30 Isidoro MONJE GIL: Francia ante el estallido de la guerra civil española, Badajoz, Diputación de Badajoz, 2012, pp. 292-293. 
Con otros dos problemas tuvieron que lidiar en su labor los enviados republicanos: por un lado el agotamiento del número de aparatos para su compra y, por otro y en especial, la acentuación que sufrió la política de neutralidad por parte de las autoridades francesas. Otra labor importante realizada por Corpus Barga, encargado de adquirir aparatos en Francia, y su equipo estribó en luchar con los compradores enviados por los sublevados. También se realizaron otras gestiones: se compraron piezas de repuesto y se contrataron mecánicos y pilotos. ${ }^{31}$

Aboal, a la sazón técnico en aviación enviado a Francia, señaló en su informe que no se pudieron obtener más aviones de guerra debido a dos inconvenientes: no haber más existencias de aviones de guerra y por las dificultades encontradas tanto en algunos constructores, como por ejemplo Amiat, como en el gobierno francés debido a que sus ideas políticas eran contrarias a la República española. Por todo ello se hubo de recurrir a la adquisición de aviones civiles de características determinadas pero también sin elección por parte española ya que el mercado de aviones por su especial naturaleza no era abundante en disponibilidades eficientes.

Finalmente exponer el número de aparatos enviados por Aboal, de acuerdo a su testimonio:

\begin{tabular}{|c|c|}
\hline \multicolumn{2}{|c|}{ Relación de aviones adquiridos y enviados a España por Aboal hasta el 17 de octubre $36^{32}$} \\
\hline $\begin{array}{c}\text { Aviones militares: } \\
\text { 14 Dewoitine } 372 \\
6 \text { Potez } 54 \\
\text { 1 Potez "Comunne de París" } \\
\text { 1 Bloch } 210 \\
5 \text { Loire } 46\end{array}$ & $\begin{array}{c}\text { Aviones civiles: } \\
3 \text { Monopar S.T } 25 \text { Jubilee } \\
1 \text { Miles Hawk } \\
1 \text { Miles Falcon } \\
1 \text { Caudron Aiglon } \\
6 \text { Havilland bimotores } \\
3 \text { Airspeed Envoy } \\
1 \text { Airspeed Viceroy } \\
1 \text { Farman } 430\end{array}$ \\
\hline $\begin{array}{l}\text { Aviones sanitarios: } \\
1 \text { Farman } 192 \\
1 \text { Farman } 193 \\
1 \text { Farman } 190 \\
1 \text { Farman } 401 \\
1 \text { Farman } 402 \\
1 \text { Caudron "Pelican" }\end{array}$ & $\begin{array}{l}\text { Aviones escuelas: } \\
6 \text { Caudron Aiglon } \\
12 \text { Farman } 480\end{array}$ \\
\hline
\end{tabular}

A modo de conclusiones de esta comunicación, debe recordarse que la actitud de las autoridades francesas, más preocupadas en mantener el apoyo británico en el ámbito internacional y de evitar una fractura social interna que de ayudar a un Gobierno democrático y amigo enfrentado a una sublevación militar, fue derivando desde una postura oficial de ayuda a una no intervención "relajada", la cual consistió en afirmar de manera oficial que Francia no se inmiscuiría en los asuntos españoles a la vez que permitió a los enviados republicanos obtene un escaso volumen de material bélico, fundamentalmente en el mercado negro y cerrando los ojos ante el paso por la frontera. Esta situación se convirtió en un dogal que fue estrangulando lentamente a la República paralelamente Hitler y Mussolini equipaban con materia moderno y hombres a los sublevados.
Ante esta situación, a la que hay que sumar la defección de gran parte del cuerpo diplomático y su sustitución por intelectuales prorrepublicanos de prestigio internacional que nada sabían sobre armamento y mucho menos sobre el funcionamiento del mercado negro, el embajador republicano cometió un grave error al otorgar a la Société Générale d'Etudes et Enterprises la gestión de la compra de armamento. Error que costó a la República mucho tiempo y dinero solucionar.

Finalmente conviene recordar a pesar de lo sostenido por la historiografía franquista hasta la más reciente actualidad que la República no pudo adquirir un gran número de aviones militares en Francia y los aparatos que consiguió fueron fundamentalmente civiles y costó su tiempo adaptarlos para que entrasen en combate, mientras que los enviados por Hitler y Mussolini, además de ser más modernos, iban listos para utilizarse.

La actitud francesa, a la que hay que sumar la británica y la norteamericana, de no permiti a la República comprar material de guerra en sus fronteras, conjugado con el rápido apoyo de Hitler y Mussolini a Franco, provocó que la República virase hacia la Unión Soviética en busca de ayuda si quería, al menos, poder enfrentarse a los sublevados.

31 Se han conservado cartas escritas entre agosto y octubre por Hispano Aviación, la rama aeronáutica de Hispano-Suiza con sede en Guadalajara, y por CASA (Construcciones Aéreas SA), a no se solicitó, en vano, la urgente entrega de recambios, desde moitine y Loire-Nieuport, en las que ruedas de los trenes de aterrizaje.

32 Relación de aviones adquiridos y enviados a España enviado por Aboal el 17 de octubre 36, FIP, carpeta: París. Comisión de Compras. Comisión Técnica. Subcarpeta: Comisión de Compras. 


\section{ESPAÑA ENTRE EEUU Y JAPÓN DURANTE \\ LA II GUERRA MUNDIAL: PROBLEMÁTICA \\ DE UNA RELACIÓN A TRES BANDAS}

David Del Castillo Jiménez

Doctorando, Universidad Complutense de Madrid

Como es sabido, en diciembre de 1941 se produjo el ataque japonés contra las flota de los Estados Unidos en Pearl Harbor. Esta acción no sólo conllevó la entrada del país americano en la II Guerra Mundial, sino que también provocó el internamiento en campos de concentración de los residentes japoneses en territorio continental estadounidense. España, como potencia a la que Tokio confió (por una serie de circunstancias que intentaré aclarar) la representación de sus intereses diplomáticos ante Washington,' se vio convertida en uno de los actores de este proceso de reclusión masiva, dentro de una compleja dinámica a tres bandas que todavía está poco estudiada. Sobre esta esta realidad, el autor de este texto espera poder arrojar algo de luz a través del estudio (entre otras fuentes) de las fuentes diplomáticas españolas, que en general no han sido muy tenidas en cuenta por los estudiosos del tema.

\section{La situación de los japoneses americanos}

A la altura de 1940, había 126.947 personas de origen japonés o nikkei en el territorio continental de Estados Unidos (sin contar Alaska), así como otras 157.905 en Hawái. Dentro de este conjunto podían distinguirse varios grupos: los issei, o japoneses de Primera Generación, todos ellos nacidos fuera de Estados Unidos (aproximadamente un tercio de los japoneses estadounidenses continentales); los nisei o japoneses de Segunda Generación (unos dos tercios de los japoneses continentales, 79.642 individuos); y los sansei, hijos de nisei y por tanto japoneses de Tercera Generación (5.965 en 1942). Aparte de estos términos, también se empleaba el de kibei, referido a los nisei que habían pasado parte de su infancia en Japón antes de la II Guerra Mundial. ${ }^{2}$ En el plano jurídico, sólo los nikkei nacidos en Estados Unidos (es decir, nisei, sansei y kibei) poseían plenos derecho de ciudadanía, en tanto que los issei mantuvieron únicamente la ciudadanía japonesa (siendo, así, responsabilidad del gobierno de Tokio en última instancia); ${ }^{3}$ asî mismo, algunos nisei contaban con ambas ciudadanías. ${ }^{4}$

1 Florentino RODAO: Franco y el imperio japonés. Imágenes y propaganda en tiempos de guerra, Barcelona, Plaza \& Janés, 2002, pp. 286-290

2 Tetsuden KASHIMA: Judgment without Trial. Japanese American Imprisonment during World War II, Seattle, University of Washington Press, 2003, pp. 9-10

3 En 1922, tras el proceso "Ozawa contra los EEUU", el Tribunal Supremo estadounidense denegó oficialmente a los issei el derecho a la naturalización, lbid pp 14-15. Hasta el Acta de Naturalización de 1952, los issei no pudieron ser elegidos ciudadanos estadounidenses. Véase Natsu Taylor SAITO: "Crossing the Border: The Interdependence of Foreign Policy and Racial Justice in the United States", Yale Human Rights \& Development L.J., 1 (1998), p. 8.

4 Hasta 1916, el gobierno de Tokio aplicó el principio de jus sanguinis a los nacidos fuera de su territorio, de modo que cualquier hijo de padre japonés pasaba a ser automáticamente japonés. A partir de ese año Jón permitió renunciar a esa ciudpani retroactivanente, y a patir de 1924 un niseisólo era reconocido comojaponés sisus padres lo solicitaban en un plazo de 14 dís desde
Estos nikkei, como suele ocurrir con toda minoría étnica de origen inmigrante, tuvieron que enfrentarse al rechazo de ciertos sectores de la población del país de acogida. Por ejemplo, e el caso de California (Estado donde se concentraba el grueso de la población de origen japonés de los Estados Unidos continentales), 5 las medidas de corte xenófobo promovidas entre 1905 y 1920 por campañas como la "Keep California White!" generaron tal malestar en Tokio que se llegó a plantear la guerra con Estados Unidos (o, al menos, con el Estado californiano). ${ }^{6}$ Lo excepcional de la situación fue que, en el caso de la comunidad de japoneses estadounidenses, estas tensiones raciales que ya se habían producido en otros momentos en relación con otras minorías étnicas ${ }^{7}$ acabaron por trasladarse al ámbito de la Seguridad Nacional, con el internamiento en campos de concentración como consecuencia última de esto.

En rigor, este proceso de mutación de un conflicto interno en un problema de seguridad del Estado (lo que algunos especialistas en relaciones internacionales llaman "securitización") ${ }^{8}$ se habia empezado a producir antes de Pearl Harbor. Ya en 1936 el general Patton había propuesto un plan para arrestar e internar a ciertos individuos de origen japonés para usarlos como rehenes de cara a un hipotético conflicto. ${ }^{9}$ Así mismo, la administración Roosevelt encargó entre 1940 y 1941 dos informes sobre la posición que tomarían los nikkei en caso de conflicto: el primero, comenzado en julio del $40,^{10}$ fue elaborado por el teniente comandante de la Marina Kenneth D. Ringle ("informe Ringle")" y remitido a las autoridades militares hacia enero-febrero del $42^{12}$; el segundo, de octubre-noviembre del 41 , tuvo por autor a Curtis B. Munson ("infor-

su nacimiento. Véase Eric L. MULLER: American Inquisition. The Hunt for the Japanese American Disloyalty in World War II, The University of North Carolina Press, 2007, pp. 11-12.

5 Según los registros de 1942, al menos 91.025 expedientes de internados en campos de concentración de origen japonés pertenecían a residentes en California. Datos extraídos de los National Archives and Record Administration [NARA], Department of Justice. Civil Rights Division (12/09/1957
-... [DOJ. CRD], Record Group 210: Records of the War Relocation Authority [RG 210], Records About -...) [DOJ.CRD], Record Group 210: Records of the War Relocation Authority [RG 210], Records About 1942-1946 [Japanese-American Internee File]. Los datos al respecto pueden consultarse online en 1942-1946 [Japanese-American Internee File]. Los datos al respecto pueden consultarse online
la dirección web http://aad.archives.gov/aad/series-description.jsp?s=623\&cat=all\&bc=sl,fd

6 Kevin STARR: Embattled Dreams. California in War and Peace, 1940-1950, Nueva York, Oxford University, 2002, p. 49

7 Por ejemplo, en el caso sumamente similar (sólo que unas décadas antes) de los inmigrantes chinos en el siglo XIX. Ver Roger DANIELS: Asian America. Chinese and Japanese in the United States since 1850, University of Washington Press, Seattle, 1995, pp. 29-66.

8 Sobre este concepto véase Harald MÜLLER: "Security Cooperation", en Walter CARLSNAES, Thoma RISSE y Beth A. SIMMONS (eds.): Handbook of International Relations, Londres, SAGE, 2002, pp. 382-383, y sobre todo Barry BUZAN, Ole WAEVER y Jaap de WILDE: Security, a New Framework for Analysis, Boulder, Colorado, Lynne Rienner, 1998, p. 21.

9 Michi Nishiura WEGLYN: Years of Infamy. The Untold Story of America's Concentration Camps, Seattle, University of Washington, 1996, p. 182.

10 Según Tetsuden KASHIMA: Judgment without Trial..., pp. 36-37. No se ha encontrado referencia en otras fuentes al momento en que se encarga el informe, y su publicación efectiva resulta ser bastante posterior; además, la datación exacta del informe Ringle es problemática. Véase Nota 12 más abajo.

11 Kenneth D. RINGLE: “Japanese Question, Report on (The Ringle Report), Unpublished Report for the Chief of Naval Operations via The Commandant Eleventh Naval District", Navy Department Library [NAVLIB], Referencia D753.8.R3 1942. También puede consultarse en edición digital en http://www history.navy.mil/library/online/jap\%2ointern htm y en la Colección Asiática Digital de la Universidad de Oregón, en http://libweb.uoregon.edu/ec/e-asia/read/ringle.pdf.

12 Existe más de una copia en los archivos estadounidenses del "informe Ringle", alguna de ellas sin feExa "Report Teniente Comandante KD. Ringle, Eleventh inava cha (Ver "Report, Teniente Comandante K.D. Ringle, Eleventh Naval District, del Comandante al Chief of Naval Operations [CNO], sin fecha, copia en ASW 014.311 EAWC", referido en Stetson CONN, Rose C of Military History, United States Army, 2000 ( $1^{\mathrm{a}}$ Impresión 1964), P. 127, nota 41); esto, sumado a he 
me Munson")' ${ }^{13}$, hombre de negocios y agente personal de Roosvelt. Significativamente, aunque ambos informes señalaban que no existía un "problema japonés", esta conclusión no fue tenida en cuenta a la hora de planear el internamiento masivo en campos de concentración.

\section{El internamiento en campos de concentración}

Como se ha podido ver, entonces, cuando se produjo el ataque japonés contra las fuerzas de los Estados Unidos, en este último país existía una situación que auguraba duros tiempos para los nikkei. En un primer momento esto no se notó demasiado; durante las semanas inmediatamente posteriores a la declaración de guerra al Eje Berlín-Roma-Tokio, el gobierno de Washington estableció controles semejantes para todos los nacionales de los países enemigos. De esta forma, durante ese tiempo se arrestó a modo de prevención a unos 31.275 individuos; de estos, 17.477 eran japoneses o estadounidenses de origen japonés, en tanto que el resto eran alemanes e italianos. ${ }^{14}$ En todos los casos, la lista de individuos "sospechosos" quedó en manos del Inmigration and Naturalization Service de los Estados Unidos (INS), dependiente de Departamento de Justicia. ${ }^{15}$ Unos meses más tarde la diferencia de trato hacia unos y otros se hizo más clara, cuando el presidente Roosevelt firmó la Orden Ejecutiva 9066 el 19 de febrero de 1942. Por ella, unos 120.000 nikkei, en su mayoría procedentes de la Costa Oeste de los Estados Unidos, acabaron internados en campos de concentración.

Tras la firma de esta Orden presidencial, todos los residentes nikkei que no se encontraban bajo el control del Inmigration and Naturalization Service de los Estados Unidos (INS) pasaron a estar bajo la jurisdicción de la Wartime Civil Control Administration (WCCA), ${ }^{16}$ la rama de control de la actividad civil del Mando de Defensa Occidental (WDC), una de las cuatro agencias territoriales que el Departamento de Guerra había creado en marzo de 1941 y que, a la sazón estaba bajo la autoridad del general John L. DeWitt. ${ }^{7}$ De este modo, la práctica totalidad de los japoneses de la Costa Oeste acabaron internados en una quincena de centros de reunión temporales. A estos, llegado el caso, se sumaron progresivamente aquellos prisioneros del INS que iban quedando libres o en libertad condicional. Los prisioneros de origen alemán e italiano, estadounidenses y extranjeros, por el contrario (y esto es importante, en tanto en cuanto marca la diferencia de trato) no fueron internados masivamente en estos campos. En su lugar, fueron detenidos sólo en casos concretos, siguiendo el Programa de Exclusión Individual que se había creado ex profeso para ellos. ${ }^{10}$

Finalmente, el proceso de internamiento se culminó con la creación, a través de la Orden Ejecutiva 9102 de marzo de 1942, de la War Relocation Agency (WRA). Tras su creación, esta agencia seleccionó 10 territorios, la mayoría en zonas desérticas en Arkansas, Colorado y Wyoming, donde se edificaron los Ilamados "Centros de Realojamiento de Guerra". Su estructura les asemejaba a primitivas prisiones, con alambradas, cercas, torres de vigilancia y guardas

cho de que el informe fuese publicado anónimamente en la Harper's Magazine de Octubre de 1942 (Ver Mortin GRODZINS. Americans Betrayed: Politics and the Japanese Evacuation, Chicago The Uni(Ver Mor CroD Prins: versity of Chicago Press, 1949, p. 146, nota 46) dificulta saber exactamente cuándo comenzo a circular Enero de 1942 a a Enero de 1942, aunque podría haberse elaborado el 30 de Diciembre del 41. En cualquier caso, habría

13 Curtis B. MUNSON: "Japanese on the West Coast" (7 de Nov. de 1941), Franklin D. Roosvelt Presidential Library [FDR Library], President's Secretary Files [PSF], Department Files: War Department [WD], Stimson, Henry L., 1942, caja 84.

14 Tetsuden KASHIMA: Judgment without Trial..., p. 4.

15 lbid., p. 34.

16 Ibid., p. 6.

17 Stetson CONN: Guarding the United States... pp. 28; 33-34.

18 Tetsuden KASHIMA: Judgment without Trial..., pp. 127; 137. militares dependientes del WDC. Su duración estaría marcada por el final de la guerra, sin más concreción, y de las 120.313 personas de las que se hizo cargo la WRA, 118.803 acabaron allí (la inmensa mayoría, nikkei). ${ }^{19} \mathrm{~A}$ todos estos se sumaron unos 2000 nikkei que, por acuerdos de Estados Unidos con determinados países latinoamericanos, fueron también encarcelados en los Campos de Realojamiento; ${ }^{20}$ la mayoría de ellos eran peruanos (1.771 de 2.253), y al acabar la guerra quedarían en una situación legal tremendamente comprometida al no ser aceptados ni por Washington ni por Lima. ${ }^{21}$

Fuera del proceso quedaron los nikkei hawaianos, pues suponían una minoría demasiado grande como para ser encerrados en campos (suponían unos 157.905 habitantes, un 37,4\% de la población del archipiélago), ${ }^{22}$ además de ser inviable prescindir de una masa de trabajadores tan grande en un territorio que necesitaba nuevas infraestructuras de defensa. ${ }^{23} \mathrm{Así} \mathrm{mis-}$ mo se prestó poca atención a la pequeña comunidad japonesa de Alaska, donde el tamaño de territorio y la gran dispersión de la población favorecieron que no se realizase control alguno. ${ }^{24}$

\section{La protección de los nikkei}

Como se ha visto en el breve bosquejo presentado, la situación de los nikkei de Estados Unidos ya entrados en 1942 tenía bastante de excepcional; después de todo, fue el único grupo de población en América al que, durante la II Guerra Mundial, se le presupuso deslealtad hacia su país de nacimiento (o adopción), actuándose en consecuencia. ${ }^{25}$ En este marco, todos los miembros de la comunidad quedaron gravemente mermados en sus derechos: por un lado, los nisei y los sansei se vieron en la incómoda tesitura de que, aunque eran ciudadanos estadounidenses, no se les trataba como tales; por el otro, los issei ni siquiera tenían eso, pues como ciudadanos japoneses dependían de un Estado que había retirado a sus representantes del país a consecuencia de la guerra.

En estas circunstancias, todos los issei, así como los nisei que contaban con la doble nacionalidad japonesa y estadounidense (Véase Nota 4) se encontraron dependiendo exclusivamente de la asistencia que pudieran recibir a través de la llamada "protección delegada". Esta práctica está reconocida en el Derecho Internacional, y basándose en ella un Estado asume en tiempos de guerra la protección de los intereses de uno de los beligerantes en el territorio del otro contendiente. En ocasiones, también se emplea en circunstancias de paz cuando se solicita a los responsables consulares o diplomáticos de un país que extiendan hasta cierto punto su protección a los intereses de un país extranjero en una tercera potencia. ${ }^{26}$ Esto último puede deberse a variadas circunstancias, como la inexistencia de relaciones oficiales entre las naciones respecto a las cuales se ejerce la protección, o quizás la presencia de un número tan pequeño de ciudadanos del país representado en el tercer Estado que el primero carezca de diplomáticos permanentes en este último. ${ }^{27}$

19 Ibid., pp. 134-136.

20 Natsu Taylor SAITO: “Crossing the Border...”, p. 67

21 Tetsuden KASHIMA: Judgment without Trial..., p. 99; 102.

22 Ibid., p. 67

23 David D. LOWMAN: Magic: the Untold Story of U.S. Intelligence and the Evacuation of Japanese Residents from the West Coast during WWII, EEUU, Athena Press, 2000, p. 18

24 Tetsuden KASHIMA: Judgment without Trial..., p. 4.

25 Eric L. MULLER: American Inquisition..., pp. 19-20.

26 William McHenry FRANKLIN: Protecction of Foreign Interests. A Study in Diplomatic and Consula Practice, Washington D.C., United States Government, 1947, p. 2.

27 Edwin M. BORCHARD: The Diplomatic Protection of Citizens Abroad or The Law of International

Claims, Nueva York, The Banks Law, 1916, pp. 472-473. 
Dentro de la lógica de una guerra de la magnitud de la II Guerra Mundial, Japón se encontró con graves problemas para poner en marcha este mecanismo de sustitución en la representación de sus intereses. Después de todo, sus principales aliados (Alemania e Italia) estaban también en guerra con Estados Unidos ( $y$, por tanto, con el mismo problema); los antiguos aliados, como el Reino Unido, se habían convertido también en enemigos; en cuanto a los países latinoamericanos, quedaron descartados cuando la mayoría de ellos decidieron declarar la Guerra al Eje tras la cumbre de Río de Janeiro de $1942 . .^{2}$ En resumidas cuentas, no había muchos neutrales en el mundo que se encontrasen suficientemente cerca de la esfera diplomática de las potencias Eje. Es entonces, en este contexto, en el que la posición de España, un "neutral" (o, al menos, un "no beligerante") con una estructura diplomática relativamente solvente en América, ${ }^{29}$ adquirió una importancia significativa para las cancillerías de Berlín, Roma y Tokio. ${ }^{30}$

\section{España en la esfera diplomática del Eje}

En este punto, un planteamiento fundamental que debe quedar claro es que en los años previos a la II Guerra Mundial, Berlín y Roma potenciaron su intención de subvertir la orden internacional surgida en Versalles a través de la creación de una "esfera diplomática" focalizada en torno a ellos. El núcleo duro de dicha "esfera" era el Eje en sí, y una de sus maneras de captación de colaboradores se produjo a través del Pacto Anti-Komintern. ${ }^{31} \mathrm{Al}$ hablar, por tanto, de la cuestión de la representación de los intereses diplomáticos de estas potencias, debe tenerse en cuenta cómo encajaba España en ese "marco de cooperación" que había ido configurando (sobre todo, aunque no exclusivamente) el Tercer Reich, y en el que Japón ocupaba un lugar destacado.

En un primer momento, esta inclusión de la España de Franco en la órbita del Eje se había producido condicionada por las necesidades de la Guerra Civil Española del 36-39. Así, mientras que los países del Eje, y particularmente Italia, ${ }^{32}$ buscaron siempre el mayor nivel de compromiso posible por parte de su aliado español, desde Burgos siempre se anduvo con muchísimo cuidado. La mejor prueba de ello es que la entrada de la España de Franco en el Pacto Anti-Komintern ( 27 de marzo de 1939) 33 y la firma del Tratado de Amistad con el Reich ( 31 de

28 A pesar, entre otras cosas, de los esfuerzos diplomáticos españoles. Véase Javier TUSELL: Franco, España y la ll Guerra Mundial. Entre el Eje y la Neutralidad, Madrid, Temas de Hoy, 1995, pp. 258-259.

29 Es conveniente poner énfasis en el "relativamente". El servicio exterior que el franquismo heredó de la II República había estado lastrado por las estrecheces presupuestarias, y a pesar de los intentos reformistas republicanos no se habían logrado erradicar vicios como el exceso de personalismo en la gestión de los embajadores o la planificación sobre la marcha de las políticas. Véase José Luis NEILA: “El proyecto internacional de la República: Democracia, Paz y Neutralidad (1931-1936)", en Juan Carlos PEREIRA, (coord.): La política exterior de España, 1800-2003, Barcelona, Ariel, 2003, pp. 469; 472.

30 Para una lista completa de los países en los que España asumió la representación de los intereses de los países del Eje y sus aliados, véase William McHenry FRANKLIN: Protection of Foreign Interests..., p. 277.

31 De una manera semejante lo entendió el embajador español en Alemania en 1939, al escribir al conde de Jordana respecto a la entrada de España en el Pacto que "tanto Alemania como Italia buscan tener a su lado el mayor número de naciones (el subrayado es mío) y tratan de comprendernos en ese, más o menos hipotético, cortejo. En ese sentido, lejos de disgustarles la desconfianza que sienten hacia nosotros Francia e Inglaterra, tratan de fomentarla". Carta de Antonio Magaz al conde de Jordana, 20 de mayo de 1939. AMAE, leg. R-832/10, citado en Manuel ROS AGUDO: La guerra secreta de Franco (1939-1945), Barcelona, Crítica, 2003, p. 33.

32 No obstante, es muy posible que Mussolini hubiese preferido fortalecer lazos con España a través de algo más directo como un tratado bilateral (Véase Javier TUSELL: Franco, España y la II Guerra Mundial..., pp. 25-26).

33 Manuel ESPADAS BURGOS: Franquismo y política exterior, Madrid, Rialp, 1987, p. 137; Montserrat HUGUET: “La política exterior del franquismo (1939-1975)", en Juan Carlos PEREIRA (coord.): La política exterior de España, 1800-2003, Barcelona, Ariel, 2003, p. 495 marzo) se hicieron en el más absoluto secreto. ${ }^{34}$ El temor a Francia y Reino Unido, sin duda, fue el que aconsejó que este acercamiento al Eje fuese tan prudente, amén de la propia voluntad de independencia de la diplomacia española en aquel momento.

El segundo paso en esta implicación de España con las potencias fascistas hubiese sido, por lógica, la entrada en el Eje. Aunque oficialmente el gobierno franquista nunca llegó a dar este paso sabemos, por el llamado Protocolo de Hendaya (de octubre del año 40) que se estuvo a punto de ingresar en dicho pacto. Aunque el documento original no se conserva, sí que se conoce un acta de la reunión publicada por Estados Unidos en 1960, la cual coincide, según Espadas Burgos, con la versión que de ella da Ramón Serrano Súñer (Ministro de la Gobernación y cuñado del dictador Francisco Franco) en uno de sus libros de memorias (si bien no especifica en cuál). ${ }^{35}$ Es cierto que, finalmente, España no entró en el pacto tripartito, pero eso no impidió que actuase como un miembro no declarado del Eje; así, si estudiamos la bibliografía especializada, encontraremos un buen número de ejemplos de esta "ayuda encubierta" de España a las potencias del Eje. En el ámbito militar, dejando a un lado el envío de la División Azul a la URSS, el servicio más importante que hizo Franco al Eje fue permitir la disponibilidad del territorio español como base de acciones contra los aliados, sobre todo como punto de reabastecimiento y plataforma para las acciones de sabotaje de alemanes e italianos contra e tráfico comercial aliado, que se prolongaron hasta 1944 (si bien mitigadas tras el comienzo de la "Operación Torch" en el Norte de África). ${ }^{36}$

A nivel diplomático, se constata que los representantes españoles actuaron en múltiples ocasiones como agentes de inteligencia del Eje. Así, a lo largo de la primavera y del verano de 1940 , los medios diplomáticos españoles estuvieron compartiendo (a menudo por propia iniciativa) información militar con italianos y alemanes. ${ }^{37}$ De la misma forma, durante la batalla de Inglaterra se solicitó al embajador español, el duque de Alba, informes detallados sobre los efectos de los bombardeos alemanes, la moral del país y el ambiente político. ${ }^{88}$ Serrano, incluso, llego a poner en la capital inglesa a Ángel Alcázar de Velasco, uno de sus agentes de confianza, en calidad de agregado de prensa y espía. ${ }^{39}$ En el caso de Tánger, que España había ocupado al comienzo de la guerra, esta cooperación se manifestó permitiendo hasta 1944 la existencia de un consulado alemán desde el que se dio cobijo a los espías alemanes y se organizaron toda clase de actos contra los intereses de los Aliados en la ciudad $4^{\circ}$

Dentro ya de la legalidad internacional, España prestó también una valiosa asistencia diplomática al Eje. Aparte de asumir la representación de sus intereses en la mayor parte del continente americano desde febrero del $42,{ }^{41}$ el gobierno español hizo el infructuoso intento de utilizar el Consejo de la Hispanidad (creado en 1940) como herramienta para contrapesar la influencia estadounidense sobre las repúblicas latinoamericanas. ${ }^{42}$ En esa misma línea estuvo el fallido plan de Himmler (negociado durante su visita oficial a España en octubre de 1940) para crear un servicio de información conjunto hispano-alemán. ${ }^{43}$ De igual manera, conviene recordar la mediación española para el armisticio francés, así como el hecho de que Hitler y

34 Manuel ROS AGUDO: La guerra secreta de Franco..., pp. 29-30. 35 Manuel ESPADAS BURGOS: Franquismo y política exterior..., pp. 117-118. 36 Javier TUSELL: Franco, España y la II Guerra Mundial..., pp. 227-228. 37 Manuel ROS AGUDO: La guerra secreta de Franco..., pp. 141

38 lbid., pp. 144-145; p. 153

38 lbid., pp. $144-14$

40 Javier TUSELL: Franco, España y la II Guerra Mundial...., pp. 111-112.

41 Manuel ROS AGUDO: La guerra secreta de Franco..., p. 281.

42 Montserrat HUGUET: “La política exterior del franquismo...”, p. 498.

43 Manuel ROS AGUDO: La guerra secreta de Franco..., p. 187. 
Mussolini acordasen que fuese España la encargada de la neutralización de la flota francesa. ${ }^{44}$ Tampoco se puede despreciar la ayuda que prestó la diplomacia española a Berlín tanto antes de la "no-beligerancia" como cuando la abandonó para volver a la neutralidad. Finalmente todos los movimientos de España en favor de la "paz" (intentar localizar el conflicto en Polonia buscar una paz de Alemania con Occidente a través del "Plan D" de Doussinague...), buscaron favorecer los esfuerzos bélicos de sus aliados. 45

\section{La colaboración española con Japón}

Sin entrar en detalles excesivos, se puede afirmar que todo lo antedicho sobre la relación entre el régimen franquista y el Eje en su conjunto puede aplicarse para explicar la relación entre España y Japón. Al igual que con Berlín y Roma, Madrid colaboró con Tokio durante la Guerra Mundial porque ambos formaban parte de un mismo bando, existían simpatías mutuas y había ciertos intereses que españoles y japoneses pretendían satisfacer apoyando al otro. Además, tanto el gobierno español como el nipón tenían una gran carencia de apoyos internacionales, de modo que prácticamente se necesitaban para legitimarse. Esto, de hecho, fue lo que ocurrió literalmente cuando, en diciembre de 1937, el gobierno de Burgos fuese reconocido por Tokio a cambio de que España reconociese al Estado-títere del Manchukuo (en ambos casos, incidiéndose mucho en la común sintonía ideológica que implicaba el anticomunismo de los dos gobiernos implicados). $4^{46}$

Ya en plena II Guerra Mundial, este buen entendimiento entre los dos países se manifestó en diversas actuaciones. En el plano económico, destacaron hechos como la instalación en junio de 1940 de una misión económica japonesa en España. ${ }^{47}$ En el terreno diplomático, hubo gestos como el telegrama que Serrano Suñer (convertido ya en ministro de Asuntos Exteriores) cursó felicitando a los japoneses por el éxito del ataque a Pearl Harbor, $4^{8}$ o el otro que el sucesor de Serrano, Jordana, mandaría felicitando por su nombramiento al presidente filipino José Laurel, puesto en el poder por los japoneses. ${ }^{49}$ En el ámbito más oscuro, pero igualmente valioso, de la inteligencia, estuvo la creación de la llamada "red Tô", una red de espionaje contra Estados Unidos financiada por los nipones, amparada por la embajada española en Washington, y organizada por el ya citado agente de Serrano Suñer, el falangista Ángel Alcázar de Velasco. ${ }^{50}$

Dentro de toda esta cooperación destaca, naturalmente, la ya nombrada representación de intereses. Esta, que no era una experiencia nueva para los implicados (Madrid ya había representado los intereses de Tokio durante la I Guerra Mundial) ${ }^{51}$, se circunscribió a los Estados Unidos continentales (España carecía de representación consular en el archipiélago hawaiano por lo que la representación en este territorio correspondió a Suiza) $)^{52}$ y, por ende, implicó tra-

44 Ibid., p. 145

45 lbid. p. 329

46 Yasuhiro FUKAZAWA: “La Guerra Civil Española y la Guerra Chino-Japonesa”, en Revista Española del Pacífico, 5 (1995), p. 199.

47 Florentino RODAO: Franco y el Imperio japonés..., p. 153.

48 Luis SUÁREZ FERNÁNDEZ: España, Franco y la Segunda Guerra Mundial. Desde 1939 hasta 1945, Madrid, Actas, 1997, p. 350.

49 Para más información sobre el "incidente Laurel" véase Florentino PORTERO y Rosa PARDO: "La política exterior", en Raymond CARR et al.: Historia de España Menéndez Pidal. Tomo XLI. La época de Franco (1939-1975). Vol. 1, Política, Ejército, Iglesia, Economía y Administración, Madrid, Espasa Calpe, 1998, p. 208; Javier TUSELL: Franco, España y la II Guerra Mundial..., pp. 451-452, y Luis SUÁREZ FERNÁNDEZ: España, Franco y la Segunda Guerra Mundial..., p. 552.

50 Florentino RODAO: Franco y el imperio japonés..., p. 269.

51 Gerhard KREBS: "Japanese-Spanish Relations, 1936-1945", en The Transactions of the Asiatic Society of Japan, 3-IV (1988), p. 30.

52 Tetsuden KASHIMA: Judgement without Trial..., p. 39. bajo adicional en cuanto se comenzó la reclusión masiva de los nikkei. Para este fin, el ministerio de Asuntos Exteriores español puso en marcha una Oficina Central de Protecciones a fines de enero de 1942, tras lo cual los diplomáticos españoles empezaron a visitar los campos de internamiento y a señalar todas aquellas deficiencias y abusos que pudieran detectar. ${ }^{53}$

\section{El ejercicio de la representación de intereses}

Respecto a la actividad española de cara a los campos de internamiento, hay que señalar que hubo dos condicionantes que dificultaron notablemente la acción de la diplomacia de Madrid. El primero de ellos, de orden interno, fue la confusa maraña burocrática en la que pronto se convirtió todo el proceso de realojamiento, con conflictos interdepartamentales y continuos cambios de jurisdicciones (por ejemplo, en marzo del 42, cuando apenas si había comenzado la reclusión, el Departamento de Guerra devolvió precipitadamente a Justicia la responsabilidad sobre los prisioneros civiles) ${ }^{54}$. El segundo, externo, fue la propia actitud de Tokio, que no perdió la oportunidad de usar la situación de los nikkei como arma propagandística, llegando incluso a negarse a negociar la entrega de prisioneros estadounidenses escudándose en el maltrato que sufrían los nipones en América. ${ }^{55}$

A pesar de todo lo dicho, y de la propia debilidad de la posición diplomática de España, lo cierto es que la bibliografía disponible muestra algunos casos interesantes en los que la defensa de los intereses diplomáticos japoneses se ejerció eficazmente. Por ejemplo, en junio de 1942 los issei del centro de Fort Missoula (administrado por el INS), protestaron ante los diplomáticos españoles por la mala calidad de la alimentación (a la que atribuían tres muertes) y la falta de medicinas..$^{66}$ Aunque los archivos del Gobierno no dejan claro si se mejoraron las condiciones en el centro, sí que parece que hubo una notificación formal al Departamento de Estado. En otro caso, ya en enero del 44, sabemos que fue el cónsul español en San Francisco, Fernando de Amat, el que transmitió a la embajada en Washington (y de ahí, a Tokio), el malestar existente en el campo para prisioneros “problemáticos" de Tule Lake. En este centro, apenas dos meses antes (noviembre del 43) se habían producido intensas protestas de los internados ante su situación, lo que había provocado la intervención directa de las tropas estadounidenses para sofocarla. ${ }^{57}$ En conjunto, por lo que sabemos, todas estas actuaciones no tuvieron un gran impacto sobre el gobierno de los Estados Unidos, pero es sumamente probable que contribuyeran en algo a mejorar la situación de los nikkei, aunque sólo fuera por la necesidad de evitar unos malos informes que se tradujeran en peores condiciones para los prisioneros estadounidense en manos de Japón. ${ }^{58}$

\section{Valoración de la representación de intereses}

Aunque el gobierno español, a la postre, no llegó hasta el final en todo el proceso de internamiento de los nikkei (España dejó de representar los intereses de Japón el 22 de marzo de 1945) ${ }^{59}$, es innegable que su actuación lo convierte en el principal agente internacional implicado en el proceso (aparte, claro, de los propios EEUU y Japón). Como consecuencia de ello nos queda configurada una problemática internacional sumamente interesante, pues frente a la tradicional cuestión de una relación bilateral, aquí se nos queda configurada una a tres bandas. Esto,

53 Florentino RODAO: Franco y el imperio japonés..., p. 287.

54 Tetsuden KASHIMA: Judgement without Trial..., p. 117.

54 Tetsuden KASHIMA: Judgement without Trial..., p. 117.

56 Tetsuden KASHIMA: Judgement without Trial..., pp. $185-186$.

57 Michi Nishiura WEGLYN: Years of Infamy..., pp. 162-165; 168-173.

58 Tetsuden KASHIMA: Judgement without Trial..., p. 39

59 Florentino RODAO: Franco y el imperio japonés..., pp. 490. 
naturalmente, implica ciertas dificultades a la hora de elegir un marco teórico para el análisis, pero también ofrece nuevas y excitantes oportunidades para el investigador. Después de todo hasta ahora toda la cuestión de los campos de realojamiento sólo se había planteado desde la óptica de la política interna estadounidense, desde las relaciones bilaterales Washington-Tokio o, de manera algo más colateral, desde el estudio de los contactos entre España y Japón. La documentación española sobre el tema ha sido por ello, como señalaba en la introducción, muy poco tratada, dejando un agujero historiográfico que espero poder llenar en el futuro.

Aparte de esto, toda la cuestión presentada plantea un segundo nivel de análisis. Después de todo, la problemática implica interesantes cuestiones de tipo ético, pues por ironías de la Historia nos encontramos ante una situación en la que los papeles están invertidos. Así, en este caso, el país responsable de la creación de campos de concentración donde se vulneraron masivamente los derechos de miles de ciudadanos fue la democracia liberal, en tanto que la "protectora" de los derechos de la minoría oprimida resultó ser la dictadura pretoriana. Desde luego que, con esto, no se pretende insinuar que el régimen franquista fuese un vocacional "benefactor humanitario". Lo único que esto significa es que la realidad es mucho más compleja de lo que solemos pensar, y que en la mayor parte de los casos históricos la línea que inconscientemente solemos trazar entre "buenos" y "malos" está tremendamente difuminada. Es algo que, como historiadores, nunca nos podemos permitir olvidar. 


\section{ESPAÑA EN EL EXTERIOR. EL PAPEL DEL EJÉRCITO}

\section{ESPAÑOL EN LAS MISIONES INTERNACIONALES}

David Díaz Sánchez

Doctorando UAM

\section{Introducción}

España, en especial sus Fuerzas Armadas, han sido un ejército con vocación claramente hacia el interior, ya que antes de la democracia, España estuvo en una dictadura de más de 40 años en los que en gran parte se vivió aislado internacionalmente. Aunque el ejército estuvo presente en las colonias, la pérdida del Protectorado Marroquí por su independencia en 1956 junto con la colonia de Sidi-Ifni también por esas fechas, hizo que el único objetivo de las Fuerzas Armadas sea la defensa del territorio patrio.

No va a ser hasta la llegada de la transición española y la consolidación de la democracia, cuando los demás países acepten a España como un país participante en las Ilamadas "misiones de paz".' Aunque hay que destacar que ya España realizó misiones con sus fuerzas armadas al final del franquismo, que aunque no fueran en contexto de ser misiones de paz, sí que tenían una voluntad humanitaria. Destacan varios casos, como los dados en Túnez, Vietnam, o Guinea Ecuatorial.

A partir de ese momento, España, realizará misiones en el exterior en un marco jurídico de legalidad internacional, con otras naciones y bajo banderas de organismos internacionales. Es por ello, que las fuerzas armadas no sólo van a ser un instrumento de los estados para sus intereses, si no que se van a convertir con su labor, en actores internacionales.

\section{El Ejército como Poder Blando}

Joseph Nye en su libro "La paradoja del poder americano", defiende la existencia de un poder duro y un poder blando dentro de un Estado. El poder duro sería aquel compuesto por la presión política, la fuerza económica y las capacidades militares de un estado. El poder blando sería el resto de indicadores como por ejemplo el poder de comercialización de las películas de un estado, la capacidad de expansión de sus empresas, el volumen de productos que exporta, etc. Son indicadores que no necesita de una presión, sino que lo que muestra es cómo un país tiene una forma de ser y las demás personas del resto de países la demanda en menor o mayor medida dependiendo de si están de acuerdo con sus tesis o no.

Según Nye, el Estado que en un futuro sea capaz de proyectar una política, una cultura y una opinión marcada por unos ideales ${ }^{3}$ o principios que sean usados en los asuntos de po-

1 Los militares no hablan de misiones de paz, sino que eso es más un "invento político" para no mostrar a la sociedad que los militares van a misiones de guerra, pero ellos señalan que cuando van a una de esas misiones es porque precisamente falta la paz.

En su trabajo expone el poder duro y el poder blando del caso americano, pero se puede extrapolar a otros Estados.

El texto va contra la administración Bush que sólo busca utilizar la coacción y el poder duro para luchar contra el terrorismo. lítica interior e internacional de manera coherente, puede ver aumentado su credibilidad y cosechar un éxito internacional, además de ser un modelo a seguir. ${ }^{4}$

Pero a pesar de esta diferenciación, el poder duro y el poder blando, no son compartimientos estancos claramente separados. Pueden intercambiarse de lado dependiendo de su utilización. Esto viene a señalar la utilización de las fuerzas armadas en la actualidad. No tienen que significar la utilización del poder duro por parte de los estados, ya que en la enmarcación actual de las misiones de paz en las que intervienen los ejércitos no tiene nada que ver con las operaciones anteriores de guerra. Así las fuerzas armadas en estas misiones pueden mostra la bondad y la ayuda de los más poderosos a los más necesitados. De este modo, cambia la finalidad del ejército que ya no es sólo guardián de la patria sino que además es un actor de la proyección exterior de los países.

\section{España en las organizaciones internacionales}

España pertenece a la ONU (Organización de Naciones Unidas) desde 1955 y estaba dentro del Comité Especial de Operaciones de Mantenimiento de Paz de ONU, pero dicha actividad no fue activa hasta la democracia. Por eso, desde 1955 hubo misiones de la ONU en las que España no participó. Pero no sería hasta 1988, cuando se produzca la solicitud del Secretario General de ONU, Pérez de Cuellar, para que España participase en una misión de la ONU en Angola en 1989

España ingresó en las OSCE el 25 de junio de 1973 aportando un 4\% del presupuesto, que fue aumentado en 2003 siendo gran parte de esa aportación para misiones y proyectos a desarrollar en el exterior. Además de aportar dinero, España ha aportado observadores en diferentes misiones, sobre todo en territorio europeo.

El proceso de integración en la OTAN empieza el 2 de diciembre de 1981 con la notificación de España a la Alianza, su intención de incorporarse a la organización. El 10 de diciembre de 1981 se firmó en Bruselas el Protocolo de Adhesión de España en la OTAN y la entrada oficial el 20 de Mayo de 1982. Esta unión no es completa. La entrada en la estructura militar se va a ver frenada con la entrada del PSOE en el gobierno y el desarrollo del referéndum a la población para seguir en la OTAN en 1986. El resultado fue permanecer. Por ello, la participación de España quedaría reglada mediante la firma de los Acuerdos de Cooperación Militar.

En 1993, España se compromete a participar en misiones de paz bajo bandera de la OTAN.

Más tarde, en 1996 el Gobierno propuso a votación en el Parlamento la entrada de España en la Estructura Militar. El Parlamento apoyó la negociación y la entrada se cumplió el 1 de Enero de 1999. Desde esta fecha la participación de España en la OTAN ha ido a más.

España se adhirió a la CEE oficialmente el 1 de enero de 1986. A partir de ese momento, España inició otro proceso de entrada en la Unión Europea Occidental (UEO), una organización de seguridad europea que participaba en colaboración con la OTAN en 1990, y que se ha disuelto recientemente, en 2011.

Es a partir de la unión a estas organizaciones internacionales, unidas a la estabilización de la democracia en España, cuando se inicien diferentes misiones internacionales.

\section{La política de defensa nacional como justificación de la acción exterio}

La ley Orgánica de Defensa de 1980 define el Concepto de Defensa Nacional como "[...] la disposición, integración y acción coordinada de todas las energías y fuerzas morales y materiales de la Nación ante cualquier forma de agresión, debiendo todos los españoles participar

4 No todo el mundo piensa igual. N. Ferguson y S. Huntington señalan la importancia del poder militar y económico como los factores más importantes a la hora de provocar seducción en los demás. 
en el logro de tal fin". ${ }^{5}$ Cuando el Teniente General Muñoz Grandes destaca esto en una ponencia sobre la "Proyección Internacional de las Fuerzas Armadas" señala la importancia de la palabra "agresiones". Las agresiones, como menciona en dicha ponencia, tiene tres vertientes, pero sólo nos vale la última:

Las que atacan los valores de la civilización en que estamos integrados y, entre ellos y fundamental, la DIGNIDAD DEL SER HUMANO. De ello, intuimos ya la necesidad de tener una capacidad de DISUASION CREIBLE, que va unida a la capacidad de proyectar fuerzas a donde sea necesario $[. . .]^{6}$

Este punto justifica la acción exterior, sobre todo cuando hablamos de misiones de paz o misiones internacionales. Esto se verá reflejado, en el caso español, en el preámbulo de la directiva de Defensa Nacional 1/1996 que señala que:

[...] España se encuentra plenamente comprometida en la consecución de un orden más internacional más estable y seguro, basado en la convivencia pacífica, en la defensa de la democracia y de los derechos humanos y en el respeto a las normas del derecho internacional. Este compromiso se hace evidente con nuestra presencia y decidida participación en operaciones de paz. ${ }^{7}$

Además, uno de los objetivos básicos de esta directiva es la de "consolidar la presencia de España en las organizaciones internacionales de seguridad y defensa, asumiendo plenamente las responsabilidades y compromisos derivados de su participación en ellas". ${ }^{8}$ Como se ve reflejado en el "Libro Blanco de la Defensa" del año 2000 "España ha adoptado [...] un giro copernicano en relación con nuestros planteamientos defensivos tradicionales, cierra un ciclo histórico caracterizado por el aislamiento y la autarquía y ratifica nuestra plena incorporación a la comunidad occidental". 9 Lo que muestra que España, de este modo, ya no es un ente apartado del mundo, sino un actor internacional.

\section{Las misiones internacionales y/o misiones de paz ${ }^{10}$}

Las características generales de la participación de España en misiones internacionales han sido: - Desmovilización de unidades.

- Formación de nuevas unidades.

- Asesoramiento militar.

- Supervisión de elecciones.

- Control de resoluciones del Consejo de Seguridad de ONU.

- Control de alto el fuego. 5 Teniente General Agustín MUÑOZ GRANDES: “La proyección exterior de las fuerzas armadas es-
pañolas". Curso de Verano URJC: Organismos Internacionales y nuevo orden mundial (2012). Repañolas". Curso de Verano URJC: Organismos Internacionales y nuevo orden mundial (2012). Re-
cuperado de internet (http://www.funciva.org/uploads/ficheros documentos/1284377842 mucuperado de inter
noz grandes.pdf)

$$
6 \text { lbid. }
$$

7 DIRECTIVA NACIONAL DE DEFENSA 1/1996. http://www.defensa.gob.es/Galerias/ politica/seguridad-defensa/ficheros/DGL-DDN-1-1996.pdf

8 Ibid.

9 MINISTERIO DE DEFENSA: Libro Blanco de la Defensa, Madrid, Ed. Centro de Publicaciones, 2000, p.59.

- Para consultar todo el historial de misiones en las que ha participado España se puede mis.

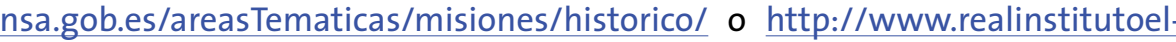
cano org/wps/ portal/rielcano/MisionesDePaz
- Control de embargos y vigilancia de fronteras terrestres marítimas y fluviales.

- Control de espacios aéreos.

- Desarme de unidades y de grupos armados civiles.

- Interposición entre unidades contrarias.

- Desminado.

- Evacuación de residentes.

- Construcción de centros de refugiados.

- Reconstrucción de infraestructuras (puentes, carreteras, hospitales, escuelas...)

- Asistencia sanitaria.

- Distribución de ayuda humanitaria."

\section{África}

La primera de las misiones de ONU en la que España aceptó participar fue el Grupo de Asistencia a la Transición de Namibia (UNTAG). Esta misión empieza su proceso en agosto de 1982, cuando el ministro de AAEE español, Pérez Llorca recibe una carta del Secretario General de la ONU para preguntarle si España podría contribuir con efectivos militares en una misión en Namibia, para garantizar su independencia en virtud de la Resolución 435/78 del Consejo de Seguridad de la ONU. La operación se inició en marzo de 1989 y finalizó al año siguiente.

Además, España colaboró en la Misión Diplomática de Observación cuyo cometido era "proporcionar información sobre el proceso de independencia de Namibia y sus primeras elecciones".12 Esta misión también tuvo que velar por los intereses de España en el territorio, ya que muchos de los buques pesqueros españoles atracaban por la zona dado que es un gran caladero del mundo.

La siguiente misión es en Angola, en el Grupo de Verificación de las Naciones Unidas en Angola (UNAVEM). En esta misión sí hay una participación de las tropas militares españolas, como observadores. La ONU quería comprobar la salida de tropas cubanas que estaban en el país apoyando al líder de Angola y ayudar en la transición del país evitando el choque entre las tres facciones: UNITA, MPLA, FNLA. Además se comprobaría que Sudáfrica no atacaría ni se posicionaría para atacar Angola violando sus fronteras.

Hubo dos UNAVEM. La I que finalizó en octubre de 1991 es la ya comentada anteriormente. La II tenía como objetivo cumplir con el Protocolo de paz firmado entre Portugal y la guerrilla UNITA, para dar inicio de un gobierno angoleño. Asi se quería verificar como actuaban las fuerzas del orden y el poder angoleño en el alto el fuego efectuado. La misión fue la de inspeccionar los diferentes campamentos paramilitares angoleños, para comprobar que no se utilizaban, además de observar que se iban desmilitarizando la población y los grupos paramilitares. Fue de octubre de 1991 a diciembre del 1993.

Otras misiones en África fueron la de 1994 como producto del genocidio que se dio en Ruanda. España participó en esta misión de la ONU Ilamada UNAMIR con motivo de la resolución 912/1994 con 20 efectivos del ejército del aire y aviones de transporte de ayuda humanitaria tanto para las organizaciones gubernamentales como las no gubernamentales.

En 1999 se produjo la misión de ONU para el Referéndum de Sahara Occidental (MINURSO) de muy corta duración, 20 días. Acudieron 2 oficiales con experiencia en el terreno y de la población, para asistir como observadores y participar en la elaboración del censo electoral.

La misión más reciente es la Operación Atalanta. El inicio de esta operación es producto de los actos de piratería que se producen en el Cuerno de África (Somalia) desde inicio del 2008 contra

11 Isidro SEPÚLVEDA: “España en las operaciones internacionales de pacificación”, en ÍD (ed.): III Congreso Internacional de Historia de la Defensa, Madrid, IUGM, 2009, pp. 112-113.

12 Francisco A. MARÍN: Martínez se va a la guerra: intervenciones militares de España en el extranjero,

Barcelona, Ed. Inédita, 2005, p. 290. 
barcos pesqueros de distintos países. Esta misión para España tiene dos objetivos uno participar con fuerzas multinacionales (participa con otros países de la UE) para asegurar el tráfico marítimo por la zona y por otro asegurar la seguridad de los pesqueros españoles que pescan por la zona.

La Operación Atalanta empezó en el año 2009 y tiene previsto finalizar en 2014. Dependerá en gran parte de los dirigentes somalíes sean o no capaces de evitar los actos de piratería en su zona.

\section{América}

En 1989 España participaba en el Grupo de Observadores de ONU en Centroamérica (ONUCA). Tercera misión española de paz bajo ONU, pero esta es la primera en la que un General español ocupaba el cargo de Jefatura de la Operación. El objetivo de esta misión consistía en verificar el cese de ayuda a las fuerzas insurrectas y eliminar el uso de un Estado para agredir a otro. La misión duró hasta 1991, ya que sufrió dos ampliaciones de tiempo. Lo importante de esta misión es el hito que constituye el que a España, desde fechas tempranas, se la considere acta para dirigir operaciones de $\mathrm{ONU}$, aunque estaba promovida por la capacidad de la comunicación lingüística más que por las actitudes militares.

En 1999 las Fuerzas Armadas españolas intervinieron en Centroamérica con motivo del huracán Mitch. La operación se denominó como ALFA-CHARLIE y su despliegue tenía carácter de ayuda humanitaria. Entre las misiones encomendadas estaban distribuir bienes de primea necesidad y la reconstrucción de infraestructuras de comunicación entre las zonas afectadas.

España estuvo desde octubre del 2004 hasta marzo del 2006 en la Misión de Estabilización de Naciones Unidas en Haití. La misión era controlar las luchas entre facciones y grupos del país provocando inseguridad entre los ciudadanos. Para España esta misión era importante porque tropas marroquís se unieron al contingente español, lo que ayudaba a mejorar las relaciones internacionales y de cooperación entre ambos países.

En enero del 2010, el buque Castilla, en misión humanitaria de la ONU, llegó a Haití con motivo del terrible terremoto que asoló el país. Su misión era desescombrar las zonas en ruinas, reparar vías de comunicación, preparar un sistema capaz de producir y distribuir agua potable, y, ayudar y asistir a los heridos. La misión terminó en mayo del mismo año y se denominó Operación Hispaniola.

Europa

La intervención de las fuerzas armadas españolas en Europa, viene marcada sobre todo por el conflicto yugoslavo en la década de los 90 . Una de las primeras misiones en las que participó España fue la iniciada por la Unión Europea para buscar una solución al conflicto. Se llamó Misión de Monitorización de la Comunidad Europea en la ex-Yugoslavia con 4 observadores militares. Pero el conflicto fue a peor en Bosnia-Herzegovina, lo que hizo mediar al Consejo de Seguridad de la ONU aprobando la resolución 743/1992 iniciando una misión que facilitara el alto el fuego entre croatas y serbios, escoltar la ayuda humanitaria que se iba enviando a la zona y protegiendo a los detenidos liberados hasta llegar a una zona segura.

España en 1993 contribuyó con 420 efectivos y dos fragatas a la Agrupación Naval de la UEO y a la Standing Naval Force Mediterranean de la OTAN para inspeccionar los barcos que iban a la Antigua Yugoslavia y controlar así el embargo del Consejo de Seguridad de la ONU contra Serbia (resolución 820/1993). La misión se denominó Sharp Guard.

España con la OTAN ha participado en las Operaciones en Macedonia dentro de las operaciones Essential Harvest, Amber Fox y Allied Harmony que van desde 1999-2003. Su objetivo era comprobar el desarme de la guerrilla, cumplimiento de los acuerdos entre la guerrilla y el gobierno. Aquí participaron 58 efectivos.

Cuando se acaba la guerra de Bosnia-Herzegovina el 5 de Octubre de 1995, la UNPROFOR es sustituida por la Fuerza de Implementación de la OTAN (IFOR) con una Brigada Española de 1200 efectivos para que se cumplan los acuerdos de Dayton. El 20 de diciembre de 1996 la IFOR es sustituida por la Fuerza de Estabilización de la OTAN (SFOR) con los mismos miembros españoles pero integrados en la División Multinacional del Sudeste, liderados por Francia. Más tarde, el contingente español se redujo a 550 miembros. En diciembre del 2004 la misión de la OTAN es pasada a la UE (EUFOR ALTHEA).

Después de bosnia llegó Kosovo, primero con 10 observadores militares en la Misión de Verificación de la OSCE, pero sobre todo con la OTAN en las Fuerzas de Protección (KFOR). Al principio con 1250 integrantes y luego se redujeron a 800 miembros dentro de la Brigada Multinacional Italiana y que concluyó en 2009. La misión en Kosovo ha durado 10 años y han participado 22.000 soldados cuya actuación fue la de facilitar el regreso de los refugiados, garantizar la paz, facilitar los movimientos de la población de la zona y proteger a las minorías étnicas de la región. También ha desactivado miles de minas, ha repartido ayuda humanitaria y ha ayudado en la construcción de escuelas, hospitales, carreteras, tendido eléctrico y canalización de agua.

Asia

La Guerra del Golfo de 1990 a 1991, fue una guerra en la que España participó en distintas intervenciones. Fue un gran hito para España, supuso un enorme trabajo llevarlo a cabo y un éxito, ya que representaba la primera vez que fuerzas militares terrestres españolas actuaban en una guerra fuera de España en un país extranjero, que no fuera colonia, pero todo bajo amparo de la ONU.

El 2 de agosto, Sadam Hussein invadió Kuwait con 100.000 hombres, anexionándoselo. Esto trajo la resolución 660 de la ONU que condenaba los hechos y la 661 declaraba el embargó económico y militar de Irak y Kuwait, y la CEE congeló las cuentas de Irak en sus países miembros.

Como esto no sirvió, la UEO, decidió enviar buques de guerra a la zona para efectuar un bloqueo y que no pudieran llegar o salir suministros de Irak y Kuwait.

España participó con una fuerza armada denominada "BRAVO", participar en dicho bloqueo con una fragata y una corbeta. La fragata estaría en el Estrecho de Ormuz velando por ese bloqueo y la corbeta en la zona de Tirán, al norte del mar Rojo. Bajo mandato de la ONU podían investigar cualquier barco que fuera hacia o saliera de los países mencionados para inspeccionar que llevaban a bordo y negarles el paso. La gran efectividad con la que trabajaron hizo que se ganaran el apodo dado por las otras naciones de "hormigas atómicas".

El embargo fue eficaz, sin embargo, no fue suficiente para hacer torcer el brazo a Sadam. Así se llegó a la resolución 678 de la ONU en que se apoyaba el uso de "todos los medios necesarios para hacer valer y llevar a la práctica la resolución 660".13 La UEO determinó que los buques dejaran un poco apartado el bloqueo y ayudaran en esas labores de conflicto. Los buques españoles ayudaron a proteger a buques de logística o de transporte de suministros para evitar que fueran atacadas.

Finalizada la Guerra del Golfo, la posición de Sadam estuvo muy débil, lo que quería ser aprovechado por los chíies al sur, los sunis en el centro y los kurdos al norte del país, para exigir sus reclamaciones con una serie de revueltas. El ejército fiel a Sadam, acabaron con la revuelta del sur en primer lugar y luego fueron al norte donde utilizaron gases tóxicos en la ciudad de $\mathrm{Ha}$ Ilabja con el resultado de 5000 muertos, provocando un éxodo del pueblo kurdo a las montañas donde lucharon contra el frío, las enfermedades y la falta de alimento, para huir a Turquía e Irán.

El Consejo de Seguridad ONU en la resolución 688 expresa la preocupación por los atentados contra la población kurda y la preocupación de su migración a otras zonas por lo que puede provocar de inestabilidad en otras regiones. Por ello se hace un llamamiento humanitario a todas las naciones y organizaciones para auxiliar a estas personas.

13 Ibid., pp. 311-312 
Así se produce la operación "Provide Comfort", en España operación "Alfa-Kilo" (ayuda a Kurdistán), es la primera de las misiones humanitarias en las que España envió unidades regulares del Ejército como respuesta a la demanda de la ONU.

El principal objetivo de la misión fue la de "proteger la vida de los kurdos y garantizarles el regreso a su patria en condiciones de dignidad".14 Para ello se realizaron la construcción de campos de refugiados con capacidad para 10.000 personas y auxiliar a cerca de 500.000 kurdos. Establecer un hospital de campaña y proporcionar seguridad a los que estuvieran allí. Después de ello hacer volver a la población kurda a su país, una tarea difícil porque no quería volver.

En 1998, el gobierno de Turquía, debido al terremoto que sufrieron algunas zonas del país pidió ayuda internacional porque se veía incapaz de resolver esa situación por sí solo y atender todas las necesidades de la gente. España acudió en su ayuda, como otros países, en una misión Ilamada Tango Tango, con 27 efectivos que durante 2 meses instalaron un hospital de campaña para atender a diversos heridos.

Con motivo de los atentados del 11 de Septiembre del 2001, unido a la lucha contra el terrorismo internacional para evitar futuros ataques. España participa en el contingente internacional de Fuerzas Armadas.

Las Fuerzas Armadas españolas engrosaron con 548 efectivos el número de militares que participaron dentro de la Operación Libertad Duradera, aunque el contingente de militares se Ilamó Fuerza Internacional de Asistencia en Afganistán (ISAF). Duró desde diciembre del 2001 hasta escribir este artículo.

El principal cometido de los militares españoles fue vigilar el espacio aéreo y terrestre de Afganistán y el Océano Índico, ayudar y apoyar al gobierno provisional afgano en el desarrollo de sus funciones como dirigentes del país, para que éste pueda valerse por sí sólo en un futuro.

Después de esto, viene la Guerra de Irak. No era una misión de paz, sino una misión de ocupación de un país, con motivo de la existencia de unas "supuestas" armas de destrucción masiva que tenía guardadas el líder iraquí Sadam Hussein y que iba a utilizar contra los países occidentales. España contribuyó con 1300 soldados en su mayoría de la brigada Plus Ultra, aunque también ayudó en los ataques perpetrados antes de la ocupación por los estadounidenses con apoyo logístico.

España ayudó en la misión de la ONU de ampliar la Fuerza Interina de Naciones Unidas en el Líbano (FINUL). España aporta 1100 efectivos, tiene al mando una brigada multinacional y contribuye con un batallón mecanizado, una unidad de comunicaciones y sistema de información. Hay una doble objetivo en esta misión, por un lado, al estar en medio del conflicto árabe-israelí, debe velar este contingente por que no se vulneren las fronteras del Líbano, por otro lado, verificar que el grupo terrorista Hezbolá esté controlado y desarmarlo.

En 2005 las Fuerzas Armadas españolas han participado en las operaciones de Respuesta Solidaria en Indonesia con motivo del tsunami que produjo una de las peores catástrofes naturales de la historia, España, contribuyó con 594 efectivos entre navales y terrestres, entre los que destacan el buque-hospital Galicia y una unidad de ingenieros para poder llevar a cabo ayuda a enfermos, heridos, etc. y ayudar a la reconstrucción de una isla que quedó asolada.

En 2005 en Respuesta Solidaria II en Pakistán con motivo del terremoto del 8 de octubre. España aportó 370 soldados pertenecientes a la Fuerza de Reacción Rápida de la OTAN, la cual lideró en esta misión.

\section{En España}

Si observamos los datos 15 que nos refleja el Centro de Investigaciones Sociológicas, en el que preguntan sobre si está justificada la labor de España en misiones internacionales de paz, la población muestra un gran apoyo que ha ido evolucionando desde los años 90 hasta la actualidad, pero que siempre se ha mantenido por encima del $80 \%$, lo que denota que la sociedad española está a favor de que las Fuerzas Armadas participen en este tipo de misiones. Pero a pesar de ello, las misiones de paz, como se ha visto anteriormente son muy variadas, pero la respuesta no es siempre la misma.

La sociedad española, a la que se ha encuestado, valora mucho que el ejército pueda participar en misiones por causa de crisis humanitaria, genocidios o por catástrofes naturales, pero sin embargo no ve tan justificada, o no la valora tanto, el intervenir en caso de guerra civil en algún lugar.

Además de esto, hay que mencionar que los españoles, cuando se les preguntan si entienden el objetivo de las misiones, los entienden y están de acuerdo con ellos, pero en ciertos casos la opinión pública ha ido variando desde el inicio de algunas misiones hasta el final de las mismas, o que están en la actualidad. En este caso podemos destacar el caso de Afganistán, que cuanto más dura la misión, más está evolucionando la opinión para que se produzca una retirada de las tropas españolas. Esto también tiene que ver con el peligro de ciertas misiones. Cuando los objetivos son más allá de una cuestión humanitaria, en las que hay un peligro porque están en una zona de guerra, mayor es el pensamiento social en contra, sobre todo porque se producen fallecimientos de soldados españoles y un peligro constante para ellos, lo que no gusta dentro de la población española.

\section{En el exterior}

En el exterior, en los lugares dónde España ha estado participando con sus Fuerzas Armadas, la población de estos lugares ha visto muy bien la labor española y contamos con algunos ejemplos del agradecimiento de su labor. Uno de esos ejemplos es por la Operación, denominada en España, Alfa-Kilo, en la que la población kurda quiso demostrar que la participación española fue muy buena mediante una carta:

Al gobierno español:

En nombre de las tribus kurdas de Duhok y Zakho en el Kurdistán de Irak, les agradecemos sus esfuerzos humanitarios apoyando a nuestro pueblo kurdo en su desastrosa y misera situación.

Nunca olvidaremos la gran defensa que han hecho de nosotros y la historia la escribirá con letras de oro.

Esperamos que continúen ayudando a los pobres y humildes de todo el mundo. Agradecemos la justicia de España y su buena reputación quedará en nuestros corazones.

Nuestros mejores deseos para ustedes. Victoria y vida para el pueblo español. ${ }^{16}$

También podemos destacar otros ejemplos como la entrega de la bandera de Bosnia a España en representación por los servicios ofrecidos y la ayuda al país ${ }^{77}$ o el reconocimiento de la

15 Javier NOYA: "La opinión pública española y las misiones de las fuerzas armadas en el exterior", 12 (2007). Recuperado de internet (http://www.realinstitutoelcano.org/wps/portal/rielcano/contenido?WCM_GLOBAL_CONTEXT=/elcano/elcano_es/zonas_es/imagen+de+espana/ari+121-2007)

16 Francisco A. MARÍN: Martínez se va a la guerra:... pp. 325

$17 \mathrm{http}: / /$ www.abc.es/20110127/espana/rc-bosnia-entrega-bandera-espana-201101271334.htm/ 
El éxito de la participación española en la I Guerra del Golfo fue reconocida por la UEO como por el Secretario General de la ONU. Además en Nueva York, por la Ouinta Avenida desfiló una representación de la fragata Descubierta por su labor desempeñada.

\section{Conclusión}

Una conclusión muy importante es que el ejército español ha sido capaz de desplazarse a diferentes lugares del planeta, para desarrollar todo tipo de misiones internacionales. Eso ha sido gracias a la gran labor de los militares para llevar a cabo todo lo necesario, logísticamente hablando, para poder realizarlas con éxito. Además el participar en tantas misiones es sintoma, también, que España cumple con sus deberes dentro de las organizaciones internacionales a las que pertenece, que es un país comprometido y serio, lo que hace a su vez, que éstas organizaciones reclamen su presencia.

El objetivo de la mayoría de las misiones internacionales de España han sido labores de ayuda humanitaria: de asistencia sanitaria, de llevar alimentos, agua, etc. Eso o hacer cumplir la paz para que no se produzcan incidentes militares. Esto encaja perfectamente con los valores que están en el preámbulo de la constitución española, con los valores de un país occidental del s. XXI y con una sociedad internacional que ya no busca conquistas militares.

Las Fuerzas Armadas españolas han ejercido su poder blando o duro, indistintamente. Cuando ha sido necesario, han ejercido su fuerza para enfrentarse a enemigos, pero cuando han acudido de manera humanitaria han mostrado su poder blando con el único objetivo de ayudar a los que más lo necesitan, como se ha podido ver en el punto 6.5. Esto muestra a España como un país generoso, con un objetivo de ayudar a los demás de una manera desinteresada, con el único anhelo de ayudar.

En España, la opinión pública, sigue ampliamente apoyando las misiones de paz, lo que muestra a las Fuerzas Armadas como una institución que está bien vista por los españoles y, que sus acciones son bien vistas y apoyadas. 
RELACIONES ECONÓMICAS DE ESPAÑA

CON LAS DICTADURAS CHILENA Y

ARGENTINA (1973-1983)

Cristina Luz García Gutiérrez

Universidad Autónoma de Madrid

Los años que analizamos en las relaciones de España con las dictaduras chilena y argentina están influenciados por su intercambio económico y por los intereses mutuos que en este momento tenían los tres países.'Podremos comprobar cómo la denuncia por las violaciones de los Derechos Humanos cometidas por ambos países, a pesar de estar de telón de fondo en muchas de las reuniones políticas y sobre todo en las presiones ciudadanas y los medios de comunicación, no fue suficiente para que cesase las relaciones económicas entre España y el cono sur. Muy al contrario podemos afirmar que incluso se intensificó gracias a la política neolibera impuesta por ambos regímenes que abrió los mercados internos a la inversión extranjera.

Tanto la Argentina del Ministro Martínez de la Hoz como el Chile de los Chicago Boys ${ }^{2}$ fueron alternativos a los modelos de desarrollo económico que se habían implementado anteriormente como fue la Industrialización por Sustitución de Importaciones (ISI). En el nuevo modelo se pretendía a partir de la llamada subsidiaridad del Estado, adelgazarlo a su mínima expresión derivando a la iniciativa privada sectores hasta el momento administrados por el Estado. Eso también llevo aparejado una degradación en los derechos laborales y un aumento en la desigualdad de estas sociedades. Los cambios eran tan fuertes que los mismos testigos de la realidad de estos países afirmaban que hubiese sido imposible aplicarlos en un contexto democrático. Joaquín Estefanía escribía a la altura de enero de 1982 sobre las economías de Argentina y Chile:

1 Como nos encontramos en un periodo de encabalgamiento entre el tardofranquismo y la transición a la democracia, mucho de los estudios llegan hasta el final del franquismo o comienzan en el año 1976. Lo que planteamos en este trabajo son las líneas de continuidad que existieron al menos en el aspecto económico con referencia a Chile y Argentina y que explican la evolución posterior que se dio de las inversiones españolas. La última obra de referencia de las relaciones posterior que se dio de las inversiones españolas. La última obra de referencia de las relaciones entre España e Iberoamérica es el libro de Celestino DEL ARENAL: Politica exterior de España y
relaciones con América Latina, Madrid, Siglo XXI, 2011. Anterior al mismo podemos destacar el relaciones con America Latina, Madrid, Siglo XXI, 2011. Anterior al mismo podemos destacar el prre, 1992. Sobre las relaciones económicas hay un gran vacio historiográfico. Los estudios que prre, 1992. Sobre las relaciones económicas hay un gran vacío historiográfico. Los estudios que
se han editado principalmente escritos por politólogos o economistas se suelen centrar en las se han editado principalmente escritos por politólogos o economistas se suelen centrar en las
relaciones económicas desde los años noventa, o la llamada "segunda colonización" hasta hoy relaciones economicas desde los años noventa, o la llamada "segunda colonización" hasta hoy sin atender a estos años iníciales. Este trabajo forma parte de la investigación de mi tesis doctoral: Españoles en el infierno: españoles detenidos, desaparecidos y ejecutados en las dictaduras de Chile y Argentina, que realizo gracias a una beca FPU-MEC. 2 Los Chicago Boys fueron un grupo de tecnócratas que participaron en la creación de la política sidad Pontificia Católica de Chile y la Universidad de Chicago donde impartía clases Milton Friedman padre del neoliberalismo económico.
Este modelo no podía haberse aplicado en un marco institucional democrático, porque es condición imprescindible para ponerlo en práctica la represión sindical que conlleva una paz social forzada para aumentar el paro y reducir la capacidad adquisitiva de los trabajadores. ${ }^{3}$ Los intereses económicos que se generaron en esos años en la economía española sobre estos países contrastaban con el aumento de la denuncia pública por las violaciones de los Derechos Humanos que se cometían en su territorio. Esto explica cómo en los momentos de presión por parte del Estado español ante la situación de los españoles que sufrieron la represión, las gestiones realizadas al más alto nivel tuviesen que tener especial cuidado de no entorpecer los intereses economicos que tenian las grandes empresas estatales, los empresarios particulares e incluso el sistema financiero español.

\section{Los asuntos pendientes en materia económica: el caso PEGASO}

Antes de nada, debemos especificar que tratamos con dos países que tradicionalmente tuvieron un nivel de intercambio muy diferente con España. Si Argentina fue uno de los países principales en la exportación de granos, sobre todo en los momentos de mayor aislamiento económico de la dictadura franquista, en el caso de Chile el intercambio era menor, y se vinculó sobre todo hasta los años 60 a la importación de nitrato.

Si nos referimos al momento anterior al golpe de Estado, mientras que en Argentina lo que se intentaba discutir era la mejora de la entrada de carnes a España, ya que en los años setenta se había perdido la condición de abastecedor regular del mercado español de carnes vacunas, en el caso chileno el tema económico que estructuró las conversaciones tanto antes como después del golpe fue el asunto PEGASO.

Durante la Unidad Popular de Allende la Empresa Nacional de Autocamiones (ENASA) ganó dos licitaciones de construcción de una planta de camiones y autobuses y otra para la fábrica de motores diesel. En marzo de 1973 se firmaron los contratos correspondientes y en relación a este magno proyecto se firmó el Convenio de Cooperación Financiera en virtud del cual e Gobierno español puso a disposición de Chile la cifra de 2.578.948.0oo pesetas para la adquisición de bienes de equipo. 4 Una vez producido el golpe de Estado las autoridades españolas se mantuvieron alerta con el asunto PEGASO y su intuición no estuvo desacertada porque finalmente el gran proyecto que marcaba un antes y un después en las relaciones bilaterales de los dos países iba a terminar en un estruendoso fracaso por parte española.

El embajador chileno en Madrid sufría las presiones del gobierno de España en la materia. Asi explicaba al Ministerio de Relaciones Exteriores en Chile su interpretación de lo que había sido para él un convenio "antinatura":

Cuando el gobierno del ex Presidente Allende necesitando ayuda exterior en forma apremiante, planteó a España la posibilidad de que extendiera un crédito, la sola idea en un principio pareció difícil por el mal ambiente que un país como España cabía esperar en cuanto ayuda efectiva a un país cuyos postulados eran de contenido marxista. En ese momento es cuando coinciden dos intereses: el del Gobierno de Chile (que necesita ser ayudado principalmente para adquirir alimentos) y el de España (que viendo cerradas las puertas de Europa, necesitaba de nuevas perspectivas para colocar algunos productos industriales que le daban su creciente desarrollo). La fórmula española para darle reali-

3 Joaquín ESTEFANIÁ: "El ultraliberalismo económico y la represión política arruinan a Argentina", El Pais, 3 de enero de 1982 y "Pinochet intenta legitimar su régimen a través de la Economía", El País, 8 de enero de 1982.

4 Memorandum sobre la situación PEGASO. Carta del Ministerio de Asuntos Exteriores de España al Embajador de Chile en España (o de noviembre de 1973). Archivo del Ministerio de Relaciones Exteriores de Chile (AMRECH). 
dad al crédito se llamó PEGASO. ${ }^{5} \mathrm{~A}$ pesar de las presiones, la Corporación de Fomento a la Producción (CORFO) ${ }^{6}$ en mayo de 1974 anunció la decisión de no continuar adelante con el proyecto PEGASO. Según el organismo encargado de evaluar el proyecto, la decisión se basaba meramente en cuestiones técnicas. A partir de ese momento se inició un intercambio epistolar entre ENASA y CORFO en la que la empresa española argumentaba como el camión de marca PEGASO cumplía con las cuestiones técnicas y que las demás empresas europeas que podían fabricar el producto se encontraban en la misma situación que España, refiriéndose a la crisis económica.

En noviembre de 1974 viajó a Madrid el Director Ejecutivo de la Comisión Automotriz, Don Alfredo Ovalle, a fin de tomar contacto con las autoridades españolas en el asunto PEGASO. En el mismo viaje el señor Ovalle llevaba la proposición de un convenio de adquisición de camiones del modelo CKD PEGASO, como fórmula para superar el problema planteado entre CORFO y ENASA. A pesar de que la solución alivió en parte las tensiones, el asunto PEGASO fue el pecado original de las relaciones económicas entre la dictadura chilena y la transición española. Un asunto que las autoridades españolas no podrían olvidar fácilmente y la posibilidad de haber introducido a una empresa española del rubro automotriz en suelo chileno. A pesar de ello, las conversaciones económicas siguieron su curso y fueron otros sectores los que acapararon la atención a partir de ese momento.

\section{Los nuevos marcos de negociación: El Acuerdo de Cooperación Económica con Argentina y las} Comisiones Mixtas Hispano-chilenas

Después de los primeros momentos de expectación por parte de las autoridades españolas ante los nuevos gobiernos se empezó a gestar un nuevo modelo de relación bilateral a parti de convenios específicos. En el caso de Chile fue la creación de las llamadas Comisiones Mixtas Hispano-Chilenas que pretendían celebrarse una vez al año a partir de la primera en junio de 1974 y en el caso de Argentina el marco legal fue definido por el Acuerdo de Cooperación Económica aprobado el 10 de mayo de 1977.

Mientras que las Comisiones Mixtas era la creación de un foro anual de debate en donde se reunían diferentes subcomisiones: científico-técnica, comercial o cultural en el caso del Acuerdo de Cooperación con Argentina lo que llevó fue a otorgar desde su emisión ventajas impositivas a exportaciones e importaciones mutuas así como la posibilidad de crear las llamadas empresas mixtas de capital hispano-argentino que tendría en el sector pesquero su mayor beneficiario

Si hacemos una evaluación de ambos procedimientos para abordar las relaciones económicas de la Transición con ambas dictaduras veremos cómo mientras que la vía argentina fue la que dio mayores beneficios a corto plazo, en el caso de las relaciones con Chile si bien los resultados tardaron en aparecer se construyeron unas sólidas bases de lo que más adelante serían la entrada de grandes capitales españoles sobre todo en la última época de la dictadura y ya en democracia.

Una de las respuestas por la que las Comisiones Mixtas Hispano-Chilenas no fueron de tanta ayuda se debió a que la necesidad de convocarlas año tras año, con un anuncio oficial de las mismas se hizo cada vez más complicado, debido al interés por parte de la administración Suárez, Calvo Sotelo y González de otorgar la mínima publicidad en sus relaciones con la dictadura de Pinochet.

5 Despacho del Embajador de Chile en España al Ministro de Relaciones Exteriores de Chile (29 de marzo de 1974), AMRECH.

6 CORFO es la agencia del Gobierno de Chile para el fomento del emprendimiento, la innovación y la competitividad en el país.
Por lo mismo si nos atenemos a los años de estudio se celebraron sólo cinco reuniones de la Comisión en nueve años. La primera y la segunda tuvieron como tema más importante la creación de un Acuerdo de Cooperación Pesquera. Los intereses de España de generar una mejora bilateral con ambos países en materia pesquera provenían de la situación de pérdida de caladeros tradicionales de la flota pesquera española debido a la ampliación a 200 millas jurisdiccionales de aguas con exclusividad económica. ${ }^{7}$ El primer borrador de Acuerdo con Chile tenía dos puntos fundamentales: la cooperación científica y técnica entre ambos países y las licencias de pesca. En realidad pretendía ser por parte española un pago de una por la otra, conseguir acceso fácil a caladeros de merluza, krill y atún a cambio de una trasfusión de conocimiento del sector pesquero español a Chile, país que a esa altura a pesar de sus grandes recursos naturales pesqueros los tenía infrautilizados.

Pero una vez redactado el Acuerdo el Presidente de la República, Augusto Pinochet escribió al Ministro de Relaciones Exteriores para que se modificases tres artículos que se consideraban perjudiciales para el interés nacional de Chile. ${ }^{8}$ Los mismos eran los siguientes:

$5^{\circ}$ ) En aguas comprendidas al sur del paralelo $37^{\circ}$ se concederán licencias para captura cualquier especie y sin limitación en a cuanto a su destino. $6^{\circ}$ ) Al norte del paralelo $37^{\circ}$ se concederán licencias de pesca de merluza. $7^{\circ}$ ) Se concederán licencias por el Gobierno chileno para la prospección y pesca de túnido en todas las aguas bajo jurisdicción chilena. ${ }^{9}$ Esto llevó a la redacción de un texto por parte chilena que en definitiva aceptaba la cooperación técnica pero limitaba las licencias de pesca a los barcos españoles. Es decir, España perdía la contrapartida que estaba buscando. Las conversaciones siguieron abiertas durante esos años hasta que en torno a la IV Comisión Hispano Chilena, España planteó que no estaría en ese momento dispuesta a negociar una cooperación en este sector sin obtener ventajas de algún tipo, ya que de otra manera bastaba con acogerse a

la legislación general chilena sobre la materia. ${ }^{10} \mathrm{Y}$ así se hizo, las negociaciones no dieron su fruto y el convenio no llegó a firmarse.

Muy diferente fue en este aspecto las gestiones realizadas entre Argentina y España en materia de pesca. Las licitaciones de empresas privadas para la explotación pesquera del mar epicontinental argentino al sur del paralelo $40^{\circ}$ y la creación de empresas mixtas hispano-argentinas fue sin duda uno de los mayores triunfos de las relaciones bilaterales entre la dictadura argentina y los gobiernos de transición en España. Ello alivió parte de la crisis que vivía el sector pesquero español y también llevó a invertir en barcos de gran tonelaje y a la restructuración de la flota, que en su mayor parte era de bajura. Empresas como PESCANOVA o

7 La demanda de las 200 millas jurisdiccionales comenzó en los países americanos durante la Segunda Guerra Mundial en un principio de protección a su soberanía y posible injerencia de su espacio en tiempos de guerra. Más adelante se generó todo un corpus jurídico propio que quería mantener las 12 millas como mar territorial pero ampliar a 200 millas jurisdiccionales como zona de exclusividad económica de cada país. Chile en concreto fue el primer país en introducirlo en su legislación por las explotaciones abusivas de otras potencias y por carecer de una plataforma continental extensa. España lo aprobó el 11 de enero de 1978 decisión que salió al encuentro de las medidas adoptadas por los paises de la Comunidad Económica Europea y de Marruecos. "España extiende a 200 millas sus aguas jurisdiccionales", El Pais, 12 de enero de 1978.

8 Carta del Presidente de la República al Ministro de Relaciones Exteriores (4 de noviembre de 1976), AMRECH.

9 Acuerdo de Cooperación Pesquera entre el Gobierno de Chile y el Gobierno de España. Reservados (1977), AMRECH.

10 Carta del encargado de negocios al Ministro de Relaciones Exteriores (30 de noviembre de 1979), AMRCH. 
FRUDESA invirtieron en esos años gracias a la legislación vigente que permitía ingresar la casi totalidad de los productos del mar provenientes de Argentina libre de derechos, bajo el régimen preferencial que había sido emitido en el Acuerdo de Cooperación Económica.

Esto junto con la construcción de carreteras y autovías y la inversión en la industria química y minera llevó a que Argentina se convirtiese en el primer receptor de inversiones directas españolas entre 1978 y 1980. España era el cuarto país aportador de capital en Argentina por detrás de Estados Unidos, Francia y Suiza. En oportunidad a la visita en 1978 de los Reyes de España al país, además de tratar el tema de los desaparecidos españoles, también se aprovechó para suscribir distintos acuerdos a través de los cuales Argentina colocó importantes lotes de carne vacuna y obtuvo líneas de crédito para la ejecución de proyectos a desarrollar por consorcios hispano-argentinos."

Este cuadro nos muestra el intercambio comercial argentino español en millones de dólares, que demuestra el superávit argentino en la balanza comercial sólo revertido por España en 1980.

\begin{tabular}{|c|c|c|c|}
\hline AÑO & $\begin{array}{c}\text { IMPORTACIONES } \\
\text { ESPAÑOLAS DE } \\
\text { ARGENTINA }\end{array}$ & $\begin{array}{c}\text { EXPORTACIONES } \\
\text { ESPAÑOLAS A } \\
\text { ARGENTINA }\end{array}$ & $\begin{array}{c}\text { SALDO PARA } \\
\text { ESPAÑA }\end{array}$ \\
\hline 1974 & 254,8 & 64,1 & $-190,7$ \\
\hline 1975 & 186,6 & 53,5 & $-133,1$ \\
\hline 1976 & 179,6 & 29,9 & $-149,7$ \\
\hline 1977 & 321,6 & 128,3 & $-193,3$ \\
\hline 1978 & 434,1 & 166,9 & $-267,2$ \\
\hline 1979 & 555,2 & 409,5 & $-145,7$ \\
\hline 1980 & 244,4 & 373,4 & +129 \\
\hline
\end{tabular}

Cuad. 01 Importaciones y Exportaciones españolas a Argentina (1974-1980). Fuente: Datos de la consejería económica de la Embajada Argentina en Madrid en base a la Dirección General de Aduanas de España. Elaboración propia.

En el año 1981 las relaciones comerciales entre Argentina y España aumentaron con respecto a 1980 y el déficit argentino se atenuó. Pero podemos comprobar ya un cambio en las inversiones españolas. Mientras que entre 1978 a 1980 Argentina era el mercado donde acudía el mayor flujo de inversión directa, ya en 1981 es Chile el que toma la delantera con el 13,1\% de las inversiones totales por delante de México (12,7\%), Estados Unidos (10\%), Argentina (9,8\%) o Brasil $(6,3 \%)$

Esta tendencia la vamos a encontrar hasta el final de la Junta Militar. El deterioro de la economía argentina con la devaluación del peso y el agotamiento de importantes contratos de suministro llevo a que las expectativas del empresariado español fuesen disminuyendo, retrocediendo Argentina en solo tres años del primer puesto al $13^{\circ}$ en posición de inversiones españolas. El modelo económico implantado por Martínez de la Hoz parecía que había dado réditos a corto plazo pero fue una burbuja de poca vida. ${ }^{12}$

Esto se incrementó con la entrada del gobierno socialista en el poder en España, como apuntaba el embajador en un despacho al Ministro:

11 Exposición del Consejero económico de la Embajada a la reunión de Roma de los consejos económicos argentinos en el exterior (23 de agosto de 1983). Archivo del Ministerio de Relaciones Exteriores y Culto de la República Argentina (AMRECRA).

12 Los informes económicos argentinos incidian en explicar como causa principal del deterioro del intercames economicos argentinos incidian en explicar como causa priscipal del deterioro del al embargo puesto por Estados Unidos junto con el problema de la refinanciación de la deuda.
Las relaciones bilaterales estuvieron por debajo de su nivel tradicional. La razón no ha sido otra que el único punto de fricción que sensibilizó al Gobierno y a la opinión pública española: la situación de ciudadanos denominados: "desaparecidos" o detenidos sin proceso. La importancia dada por España a este problema, dio lugar a una serie de políticas y posiciones determinantes con respecto- exclusivamente- a algunos países de América Latina. ${ }^{13} \mathrm{~A}$ pesar de ello, España no suscribió la denominada "Declaración de los diez" que supuso el embargo económico de la CEE a Argentina en solidaridad con Reino Unido durante la Guerra de las Malvinas. Pero es interesante subrayar cómo fue debido a una guerra sobre territorios geoestratégicos y no por la denuncia de los crímenes cometidos durante la dictadura argentina, que a la altura de 1982 eran totalmente notorios, por lo que países europeos decidieron embargar económicamente a Argentina.

La democratización del país haría que se recondujesen las relaciones bilaterales entre España y Argentina. Las palabras de Felipe González a Alfonsín en su investidura prometían cooperación al máximo de su gobierno dentro de las posibilidades de España a los problemas argentinos. La realidad fue que el intercambio económico de los primeros años de restructuración económica del plan Martínez de la Hoz no se superaron hasta pasar mucho tiempo. La crisis de deuda de los países latinoamericanos estaba en auge y España era uno de los mayores afectados. ${ }^{14}$

Las relaciones económicas entre ambos países en los años analizados tuvo sólo un beneficiario según las autoridades argentinas: España, que con el Acuerdo de Cooperación Económica consiguió:

Un excelente negocio para que ha sabido aprovechar a lo largo de los últimos años y que tiene tres facetas destacables:

1. El suministro de barcos, dragas, equipos telefónicos y ferroviarios etc...que permitió multiplicar las exportaciones españolas a nuestro país.

2. La intensa participación de consorcios españoles en obras que les fueron adjudicadas sin contrapartidas y - a veces- en perjuicio de las propias empresas argentinas.

3. La formación de las empresas pesqueras conjuntas que permitió a la flota española desembarazarse de numerosas unidades- muchas obsoletas- que habían quedado inactivas por la reducción drástica de los caladeros españoles.

Mirando en perspectiva, nos encontramos frente a una España que pelea milimetro a milímetro cada una de sus concesiones, que no regala nada y que ha desarrollado hábilmente su poder negociador con la gimnasia que supone el regateo constante para el ingreso a la Comunidad Económica Europea. Además la imagen desteñida que ofrece hoy en día la Argentina, por su quiebra financiera, su derrota en las Malvinas y sus avatares políticos, posterga el interés español de incrementar las relaciones y debilita la capacidad negociadora de nuestro país. ${ }^{15}$

13 Memoria de la Embajada de Argentina en España de 1983. Archivo del Ministerio de Relaciones Exteriores y Culto de la República Argentina. AMRECRA.

14 A la altura de 1983 el riesgo asumido por España en los 19 mayores países de la zona superaba los 7.700 millones de dólares, sin contar con la deuda comercial no asegurada, que suponía otros 6.000 millones de dólares. Los países donde se encontraba el mayor número de deuda eran los siguientes: México: 2.022, Argentina: 1.181, Venezuela: 855, Brasil: 827, Chile: 567, Perú: 509, Cuba: 502. El único país sin obligaciones pendientes con España fue Bolivia. Despacho del Embajador de Argentina en pais sin obligaciones pendientes con España fue Bolivia. Despacho del Embajador de Argentina en
Madrid al Subsecretario de Relaciones Económicas Internacionales. 23 de agosto de 1983. AMRECRA.

15 Informe del Consejero Económico de la Embajada en Madrid al Ministro de Relaciones Exteriores (Enero de 1983), AMRECRA. 
Por parte chilena, las relaciones seguían la línea de las Comisiones Mixtas y durante los primeros años se intentó por parte de la embajada ir diversificando los productos a importar desde Chile. Uno de los bienes más importados sobre todo hasta 1960 era el Ilamado Nitrato de Chile. La sociedad Nitrato de Chile S.A. era una corporación cuyo accionista único era Sociedad Química y Minera Chilena (SOQUIMICH), dependiente del Ministerio de Minería. La misma sociedad tenía a su cargo la promoción y venta del salitre chileno en España. Fue fundada en 1927 y todo el accionariado era chileno aunque el directorio estaba compuesto por cuatro españoles y un chileno. Para hacernos una idea de la importancia de la sociedad Nitrato de Chile debemos apuntar que España entre los años 1930 y 1950 llegó a ser la segunda consumidora mundial de salitre chileno después de Estados Unidos, con una importación media en esos años de 150.000 toneladas anuales.

El alza del precio del salitre y la competencia de los fertilizantes sintéticos, especialmente noruegos, asestaron duros golpes a Nitrato de Chile S.A. que al cerrar el año 1975 sólo había vendido 22.881 toneladas. ${ }^{16}$ Desde la Embajada chilena en Madrid se empieza a generar un plan de reconversión de las oficinas y el personal que trabajaba para la sociedad Nitrato de Chile en una Oficina Comercial de Promoción y Venta de Productos Chilenos en España. La misma asumiría también la centralización de compras de productos españoles para Chile y podría operar como una Central de Comercio Internacional para Europa.

El interés por el cobre chileno le tomó ventaja al nitrato, ya que la suministradora monopolística española cuprífera, la compañía Río Tinto Patiño producía una media de 100.000 toneladas anuales para una demanda que se preveía para principios de los años 80 de 250.000 toneladas anuales. En este sentido se preparó la visita del Ministro de Minería chileno, Enrique Valenzuela Blanquier a España en febrero de 1976. En la misma visita también se trató la exportación de carbón chileno que supliría parte de la necesidad de las nuevas termoeléctricas que estaban en construcción, el intercambio se procedería por bienes de equipo españoles ${ }^{17} \mathrm{La}$ celebración a la altura de 1978 de la III Comisión Mixta Hispano Chilena fue un logro de la diplomacia chilena en España. La reunión debía acometerse en Santiago de Chile y fue salvada de una postergación sin fecha gracias a la habilidad del Embajador y a sus buenas relaciones con Miguel Solano Aza, el cual en palabras del Ministro:

Ha sido una garantía para Chile de que muchas presiones políticas adversas a nuestro gobierno, no hayan encontrado camino y hayan sido neutralizadas con éxito, gracias a la constante ayuda prestada por la Subsecretaría que él dirige".18

Junto con Miguel Solano Aza viajó a Santiago en el mes de marzo de 1976 el Director General de Iberoamérica: Salvador Bermúdez de Castro. Según la opinión del encargado de negocios de la Embajada las relaciones económicas eran las únicas relaciones posibles entre los dos países para mejorar el "enturbiado fondo político de nuestras relaciones con España, debido al proceso de democratización interior del país". 19 Por parte de la Embajada en Madrid estaban seguros que el lenguaje que iban a utilizar los políticos españoles que viajasen a Chile iba a ser

16 Las cifras de precios ofrecidas a la altura de 1975 demostraban que el salitre chileno no era competitivo en el mercado español. Una tonelada de salitre chileno costaba a la sociedad Nitrato de Chile S.A. 145 dólares y la vendía a 180, mientras que el fertilizante más caro de la competencia se vendía a 130 dólares y el más barato a 90 dólares. Informe del encargado de negocios de la Embajada en Madrid, Mario Barrios V. al Ministerio de Relaciones Exteriores (14 de mayo de 1975), AMRECH.

17 Despacho del embajador chileno en Madrid al Ministro de Relaciones Exteriores (27 de febrero de 1976), AMRECH.

18 Carta del encargado de Negocios de la Embajada en Madrid al Ministerio de Relaciones Exteriores (16 de marzo de 1978), AMRECH.

19 Ibid. "mucho menos cohibido que el que suelen usar acá, apremiados por una atmósfera política verdaderamente pesada y que en general no nos es favorable"..$^{20}$ Uno de los puntos que más se trabajó fue las relaciones con entidades financieras españolas, entre ellos el Banco Santander, Banco Exterior, Banco Vizcaya, Banco Central, Banco Urquijo, Banesto y el grupo March. Don íñigo de Oriol y Urquijo, que era presidente de la Cámara de Comercio Oficial de España y de la Asociación Iberoamericana de Cámaras de Comercio en entrevista con el encargado de negocios de la embajada chilena le planteaba que:

"Una de las fórmulas más eficaces para estimular la corriente comercial de Chile a España era la radicación en Chile de Bancos españoles o Agencias de dichas instituciones con la suficiente amplitud de facultades para poder negociar en todos los terrenos con resultados concretos".2.

En este sentido se desplazó en marzo de 1977 el presidente del Banco Santander junto con sus hijos para "auscultar la situación económica chilena y estudiar posibilidades de inversión". El mismo se reunió con el presidente de la República, Augusto Pinochet y manifestó como "uno de los principales objetivos del Banco Santander desde su fundación en 1857 a partir del Consulado del Mar, ha sido el de promocionar y favorecer el intercambio comercial con América".

Los intereses de las financieras españolas en introducirse en Chile chocaban con una ley financiera perjudicial para sus intereses, las presiones en este sentido hicieron modificar la misma, de este modo en 1978 se publicó en Chile el decreto ley que introducía distintas modificaciones a la legislación bancaria y financiera para que de esa forma quedase solucionado e problema que presentaba la legislación chilena precedente que impedía que una persona jurídica tuviera más del $3 \%$ de las acciones de un banco comercial. Nada más se publicó desde el Ministerio de Relaciones Exteriores de Chile se informaba a la embajada en Madrid para que:

Ponga estos antecedentes en conocimiento de los ejecutivos del Banco Santander, Banco Vizcaya y Banco de Coca, quienes en entrevista con el Ministerio de Hacienda manifestaron interés en comprar bancos en Chile ${ }^{22}$

Sin estos contactos previos no puede entenderse la facilidad que tuvo el Banco Santander juntos con otros bancos para hacerse con bancos chilenos en el momento de la crisis de la deuda. La nacionalización de gran parte de la banca chilena en 1981, contradiciendo todos los preceptos neoliberales en los que estaba levantada la economía chilena tuvo como desencadenante la actuación de una auditoria del Banco Santander a uno de los bancos que le interesaba comprar. Ante el interés del Banco Santander de la compra del Banco Español-Chile envió a Santiago a veinte de sus mejores funcionarios para que estimasen y evaluasen el valor del banco. Así lo relataba el embajador de España en Chile, Salvador Bermúdez de Castro al Director General de Relaciones Económicas Internacionales del Palacio de Santa Cruz:

A lo largo de estas últimas semanas, los equipos ejecutivos y contables del Santander se enfrascaron en una ardua y detalladísima auditoría del Banco Español-Chile, en el curso de la cual fueron saliendo a la luz una serie de operaciones abusivas y fraudulentas realizadas por el grupo propietario mayoritario Sahli-Tassara. Puestos los antecedentes en co-

20 Ibid.

21 Carta del Encargado de Negocios de la Embajada de Chile en Madrid al Ministerio de Relaciones Exteriores (7 de abril de 1978), AMRECH.

22 Carta del Director Económico del Ministerio de Relaciones Exteriores al Embajador de Chile en Madrid (17 de enero de 1978), AMRECH. 
nocimiento del Banco Central de Chile y del Ministerio de Hacienda, dada la envergadura del nominal afectado- al parecer, más de 400 millones de dólares- y su entrelazamiento con varios de los restantes Bancos y Financieras ahora intervenidos, la decisión oficial se hizo impostergable. ${ }^{23}$

La nacionalización de la banca chilena era sólo circunstancial, la vuelta a manos privadas tenía ya interesados previstos en su compra:

La intención de estas Autoridades, según me lo ha expuesto personalmente el Vicepresidente Errázurriz, es la de sanear rápidamente los bancos intervenidos, devolviéndolos en breves al sector privado, mediante adjudicación o licitación. Errázurriz me dijo que deseaban que el Banco Español- Chile quedara en manos del Santander; lo que me consta coincide con los deseos de este último. En principio, el Banco Exterior estaría también interesado en otro de los Bancos intervenidos: posiblemente el Talca, que posee 34 sucursales a lo largo del país. ${ }^{24}$

La semana anterior al hecho de la nacionalización de los bancos chilenos, el Banco Urquijo y el Banco Central había abierto sendas oficinas en Santiago de Chile. La política del Santande y del Banco Exterior de comprar directamente bancos chilenos hacia que estuviesen a salvo de un eventual cambio en la política financiera que hiciese cerrar sucursales extranjeras. La reacción de la opinión pública española no se dejó esperar, el Diario de Barcelona titulaba un artículo a toda página: "La Banca española ayuda al General Pinochet", en donde se exigía a los medios financieros el respeto de la ética que suponía la Declaración de los Derechos Humanos. Cerrando el artículo con la denuncia de la falta de una política clara por parte de Gobierno y de los sectores económicos españoles ante la dictadura en Chile:

Al tiempo que la política exterior de Madrid con respecto a los regímenes dictatoriales latinoamericanos sigue siendo uno de los mayores "puntos débiles" de una política exterior mediocre, la exportación de capitales resulta también muy poco edificante 25

Es interesante comprobar cómo la introducción de la banca española en Chile junto con la política neoliberal de bajos aranceles al exterior hizo que a la altura de finales de los años setenta importantes empresas y empresarios empezasen a ver en Chile un lugar con intereses a corto y medio plazo. Mientras que la iniciativa política se hacía cada vez más difícil entre los dos países, los contactos con empresas y con las cámaras de comercio eran cada vez más constantes. En 1979 comenzaron las gestiones para la financiación española de un magno proyecto hidroeléctrico de ENDESA en Colbún, que sería el primero de la presencia de la hidroeléctrica en el país andino. Sobre el particular el Embajador en Madrid comentaba al Ministro:

Las autoridades que mejor pueden evaluar a Chile y su economía, estiman que no sólo es un país en donde no ven problemas para realizar operaciones de este tipo, sino que además es solvente e incluso atractivo para España. ${ }^{26}$

23 Carta del Embajador de España en Chile al Director General de Relaciones Económicas Internacionales (9 de noviembre de 1981) Secreto, Archivo del Ministerio de Asuntos Exteriores de España (AMAE). 4 lbid.

25 Diario de Barcelona, 28 de febrero de 1982

26 Despacho del Embajador de Chile al Ministro de Relaciones Exteriores de Chile 30 de marzo de 1979), AMRECH.
En el mismo año comentaba cómo las relaciones económicas eran el único sobrepeso a la desmejora de las relaciones políticas por el tema de las violaciones a los Derechos Humanos:

El incremento de las relaciones económicas, comerciales y financieras con España, se presenta en estos momentos como uno de los medios más efectivos para reafirmar una vinculación más estrecha entre los dos países que permita contrarrestar las acciones que intentan desvirtuar la realidad chilena o perturbar las relaciones a nivel Gobierno. ${ }^{27}$

La diferencia entre el discurso político y las relaciones económicas entre los dos países podría resumirse en las palabras del encargado de negocios de la embajada de Chile en Madrid:

Existen poderosos sectores que en los últimos años han venido desplegando intensa actividad, con el fin de enturbiar las relaciones hispano-chilenas. Estos grupos de oposición al Gobierno chileno controlan, entre otros sectores de poder, los medios de comunicación social, las instituciones intermedias, partidos políticos y demás instituciones sociales, actuando coordinadamente entre sí. Sin embargo a pesar de su intensa actividad, la cooperación bilateral entre Chile y España ha ido creciendo día tras día..$^{28}$

Y si nos atenemos a las cifras podemos comprobar cómo una vez pasadas las diferencias entre la operación PEGASO y la falta de entendimiento en el acuerdo pesquero las políticas neoliberales aplicadas por los Chicago Boys en Chile empezaron a ser un incentivo a la inversión española y al intercambio comercial entre ambos países. En este cuadro podemos comprobar el aumento del intercambio comercial entre ambos países en millones de pesetas:

\begin{tabular}{|c|c|c|c|c|}
\hline AÑO & $\begin{array}{c}\text { EXPORTACIÓN } \\
\text { CHILE A ESPAÑA }\end{array}$ & $\begin{array}{c}\text { IMPORTACIÓN } \\
\text { ESPAÑA A CHILE }\end{array}$ & $\begin{array}{c}\text { BALANZA } \\
\text { COMERCIAL }\end{array}$ & $\begin{array}{c}\text { INTERCAMBIO } \\
\text { COMERCIAL }\end{array}$ \\
\hline 1978 & 52.806 & 81.966 & -29.160 & 134.772 \\
\hline 1979 & 79.800 & 114.828 & -35.028 & 194.628 \\
\hline 1980 & 106.153 & 171.872 & -65.719 & 278.025 \\
\hline 1981 & 79.142 & 252.883 & -173.741 & 332.025 \\
\hline
\end{tabular}

Cuad. 02 Exportación e Importación españolas a Chile (1978-1981). Fuente: Datos de la consejería económica de la Embajada de Chile en Madrid.29

El cobre fue durante todo el periodo el producto más exportado de Chile a España seguido de pescados y moluscos. A la altura de 1982 en el sector pesquero se podía comprobar la diferencia entre lo que había supuesto la política argentina en creación de empresas mixtas hispano-argentinas en contra de la política chilena de conserva de sus aguas jurisdiccionales, mientras que de Argentina se extraían 39.000 Toneladas Registro Bruto (TRB) de Chile sólo se extraían 4.600 TRB. ${ }^{\circ}$ Lo cierto es que los inversionistas veían con mejores ojos la evolución de la economía chilena que la argentina a pesar de haberse implantado sistemas económicos parejos y de esta sufriendo ambos países a la altura de 1982 una fuerte crisis de deuda. Argentina bajaba en in-

27 Despacho del Embajador de Chile en Madrid al Ministro de Relaciones Exteriores de Chile (8 de febrero de 1979), AMRECH.

28 Carta del encargado de negocios de la embajada de Chile en Madrid al Ministerio de Relaciones Exteriores de Chile (25 de abril de 1980), AMRECH.

29 Despacho del Embajador de Chile en España al Ministro de Relaciones Exteriores (22 de diciembre de 1982), AMRECH.

30 lbid. 
terés dentro de los círculos empresariales a la misma velocidad que Chile subía. No sólo era una preferencia española sino que incluso un organismo dependiente de la ONU, la misma que por otro lado denunciaba la situación de violación de derechos humanos cometidas en suelo chileno, organizó en octubre de 1982 en Santiago de Chile un Foro de inversionistas auspiciado por el gobierno de Chile y la Organización de las Naciones Unidas para el Desarrollo Industrial (UNIDO). 3'Justo después de la victoria socialista en España, el biministro de Economía y Hacienda chileno, Rolf Lüders viajó a Madrid para reunirse con diferentes grupos empresariales españoles. Ante las preguntas sobre su perspectiva ante la entrada de un gobierno que ya en la oposición había demostrado su rechazo frontal con la dictadura chilena, expuso que la idea que había extraído de la visita era que la orientación del gobierno iba a ser socialdemócrata y que dadas las condiciones de recesión internacional, la situación daba poco margen de maniobra para que el PSOE intentase un programa más radical que el de su programa electoral..$^{32}$ Lo cierto es que si las reuniones de la Comisión Mixta Hispano-Chilena había sido difícil organizarlas periódicamente debido al interés del gobierno de darle un bajo perfil a las relaciones con la dictadura de Pinochet, con la nueva administración socialista parecía que se iba a convertir en misión imposible. Ante la fecha expuesta por la embajada de Chile en Madrid de celebrar la VI Comisión Mixta Hispano-Chilena en noviembre de 1983 , la administración socialista contestaba que estaban muy alcanzados en el tiempo por las actividades que se estaban desarrollando en esos momentos e incluso les advertía que el formato de las Comisiones Mixtas no funcionaba bien y que sería mejor cambiarlo por subcomisiones según los intereses y no esperar a reunirlas a todas. Esta opción sin duda daba menos solemnidad a las reuniones y por parte del gobierno se intentaba no terminar con las relaciones económicas con Chile, pero sí que se mostrasen lo menos posible a nivel institucional. La opinión del embajador era que las nueva llegada de los socialistas afectaría más de lo que se pensaba, en sus palabras al Ministro de Relaciones Exteriores claudicaba: "queda de manifiesto que las decisiones económicas y comerciales del Gobierno Socialista hacia nuestro país están nítidamente influenciadas por su posición política".33Esta contradicción entre los intereses económicos y el discurso político que si bien ya existía en la administración UCD se siguió dando con el gobierno socialista. En el año 1979 Felipe González en la reunión anual de la Federación Mundial de Trabajadores de Industrias Metalúrgicas promovió que se firmase un texto de condena a lo que estaba sucediendo con la falta de libertad sindical en Argentina y en Chile y declaraba que:

Creo conveniente que España no debe vender ni suministrar armamento a aquellos países con regímenes militares, sobre todo aquellos que han sido acusados por organismos internacionales y en especial las Naciones Unidas, como es el caso concreto de los países de Hispanoamérica. ${ }^{34}$

A pesar de estas declaraciones la operación de venta de los aviones CASA para el programa FALES de la Fuerza Aérea Chilena se mantuvo después de la victoria socialista. ${ }^{55}$ Gracias a la fiscalización por parte del Parlamento en España, sabemos que no fue hasta agosto de 1986

El foro se celebró en Santiago de Chile del 25 al 27 de octubre de 1982. Despacho del Embajador de Chile en Madrid al Ministro de Relaciones Exteriores de Chile (15 de septiembre de 1982), AMRECH. 32 Despacho del Embajador de Chile en España al Ministro de Relaciones Exteriores de Chile (30 de noviembre de 1982), AMRECH.

33 Despacho del Embajador de Chile en Madrid al Ministro de Relaciones Exteriores de Chile (28 de julio de 1983).

34 Despacho del Embajador de Chile en España al Ministro de Relaciones Exteriores de Chile 5 de abril de 1979), AMRECH.

35 Despacho del Embajador de Chile en España al Ministro de Relaciones Exteriores de Chile (22 de noviembre de 1982), AMRECH. cuando cesaron las autorizaciones de exportación de armas de guerra a Chile, ${ }^{36}$ es decir durante toda la primera legislatura socialista se siguió la venta de las mismas. Y todo ello a pesar de las acciones en contra del gobierno chileno por las violaciones de los derechos humanos, como fue la Comisión de Desaparecidos Españoles que generó el Senado español.

\section{Conclusiones}

Como hemos podido comprobar los años que comprendieron las dictaduras de Chile y Argentina fueron clave para la inserción económica de capitales españoles en ambos países. Era necesario aprovechar el momento ya que muchos capitales extranjeros habían decidido retirar sus inversiones después de los golpes de Estado. La administración española del tardofranquismo y de la transición a la democracia se movió por intereses realistas. Mientras la calle y el discurso público estaba plagado de denuncias contras las dictaduras que violaban sistemáticamente los derechos humanos, las relaciones económicas se iban intensificando. Así lo exponía el embajador de España en Chile al Ministro de Asuntos Exteriores a la altura de 1980 cuando se estaba analizando la pertinencia del viaje del Rey a Chile:

Tenemos que considerar que, o aprovechamos este tipo de coyunturas, en que la competencia este reducida en el número de países de procedencia por razones políticas, para instalarnos firmemente en ciertos sectores industriales del mercado local, o nos será mucho más difícil- por no decir casi imposible- penetrar en profundidad y con permanencia en un país que, en breve, volverá a ser muy atractivo como inversión. En este sentido, los indicadores han empezado ya a activarse y el tiempo urge. ${ }^{37}$

La semiclandestinidad en la que se hicieron estas grandes transacciones intentaba evita la denuncia pública de un país que quería mostrarse internacionalmente con un discurso modernizador y democrático. Que había pasado de ser el denunciado por crímenes contra la humanidad al denunciante de los mismos delitos en el contexto internacional.

Es interesante reflexionar cómo en el imaginario colectivo las inversiones españolas en el cono sur se vinculan a los años noventa y la llamada "segunda colonización", sin atender a los orígenes de la posición favorable de la que partía España en estos países y que puede explicar la ventaja comparativa que, a día de hoy, sigue dando tan buenos resultados.

36 Boletín oficial de las Cortes Generales. Congreso de los diputados (24 de febrero de 1987), p. 2238 y ss.

37 Despacho del Embajador de España en Chile, Salvador Bermúdez de Castro al Ministro de Asuntos Exteriores, Marcelino Oreja Aguirre. Urgente. Muy Secreta (20 de marzo de 1980), AMAE. 


\section{EL CAMINO HACIA BERNA: ESPAÑA \\ EN EL PROCESO DE INTERNACIONALIZACIÓN \\ DE LAS LEYES DE PROPIEDAD INTELECTUAL.}

Imanol Herreros Chandro

Doctorando en Historia Contemporánea por la UAM

\section{La naturaleza peculiar de la Propiedad Intelectual}

La propiedad intelectual tiene que ver con las creaciones de la mente: las invenciones, las obras literarias y artísticas, los símbolos, los nombres, las imágenes y los dibujos y modelos utilizados en el comercio [...] Al equilibrar el interés de los innovadores y el interés público, el sistema de P.I. procura fomentar un entorno propicio para que prosperen la creatividad y la innovación.'

Bajo el concepto Leyes de Propiedad Intelectual se abarca los sistemas jurídicos destinados a proteger los derechos derivados de las diferentes producciones intelectuales humanas. Se trata de las leyes de Propiedad Industrial y de los Derechos de Autor. Aunque ambos corpus legislativos defiendan este tipo de producciones intelectuales, los términos, plazos y condiciones en los que se establece los diferentes grados de protección son muy diferentes dependiendo de si se trata de propiedad industrial o derechos de autor.

Aunque el concepto de autoría surge en un momento histórico muy temprano, no es hasta finales del siglo XVIII y principios del siglo XIX, al calor de las revoluciones liberales europeas y en pleno proceso de modificación radical de los regímenes de propiedad, cuando comienza a plantearse la naturaleza peculiar de las obras producto del genio e intelecto del autor. Este proceso de reflexión, comenzará primeramente en el entorno anglosajón, para hacerlo de manera algo posterior en la Europa mediterránea, resultando en la creación de dos filosofías jurídicas diferentes acerca del objeto de protección. Ambas girarán esencialmente en torno a si los derechos de propiedad intelectual deben ser entendidos como un contrato entre agentes económicos o en una concepción de derechos morales. ${ }^{2}$ Aunque la diferencia en la concepción filosófica del modo de protección creará sistemas con algunas divergencias, ambos comparten varios problemas comunes: ¿Cómo regular la protección de estos bienes intangibles? ¿Cómo regular una propiedad que por su naturaleza y su objetivo final va a pasar a ser propiedad singular (del autor) y a la vez va a tener múltiples usuarios? La respuesta dada en ambos casos son las leyes de propiedad intelectual (en la Europa continental primero denominadas de Propiedad Literaria).

El carácter de bien intangible, está en la base de los problemas y los debates que se produjeron en torno a la elaboración de las leyes de propiedad intelectual. Tal y como expone Juana Marco Molina, los legisladores liberales que desarrollaron la primera Ley de Propiedad Litera-

1 http://www.wipo.int/about-ip/es/ [Consultado el 12 de septiembre de 2012]. Aunque esta es la definición oficial de la WIPO es la definición anglosajona, donde bajo el concepto de Propiedad Intelectual se recoge tanto derechos de autor como patentes y marcas.

2 Zorina KHAN and Kenneth L. SOKOLOFF: “The Early Development of Intellectual Property Institu-

tions in the United States", Journal of Economic Perspectives, vol. 15 (3) (2001), p. 237. ria española (1847) no fueron capaces de abstraer debidamente los derechos que el autor tiene sobre la obra, como creación inmaterial, de los derechos ordinarios que existen sobre el objeto físico sobre el que esta se presenta. ${ }^{3}$ De esta confusión derivará el progresivo endurecimiento de la legislación decimonónica sobre propiedad intelectual.

En general, las distintas leyes de propiedad intelectual apenas definen la manera en que se produce la apropiación de los bienes intangibles. La cuestión no gravita tanto en torno a quién detenta los derechos en el momento de producción de la obra como en cuanto a qué ocurre con ellos cuando salen a la luz, cuando pasan del autor a la sociedad. Esto ocurre porque los bienes susceptibles a ser sometidos a protección por parte de las leyes de defensa de la propiedad intelectual tienen características de bienes públicos puros. ${ }^{4}$ La información sólo necesita ser protegida en el momento en el que entra en contacto con el público ya que es en ese momento cuando se genera la posibilidad de que otros la utilicen. Si la información no se da a conocer no existe como bien. Este tipo de bienes se caracterizan por la no rivalidad y no exclusión, esto es, para que el bien pase del creador al usuario este primero no debe deshacerse de él. ${ }^{5}$ La información se difunde, no se intercambia de manos.

Esta cuestión se planteó desde los primeros momentos de la concepción de la legislación de protección de la propiedad intelectual. En el momento de salir al público, reconoce Bretón de los Herreros, la obra deja de ser privativa del autor para pasar a pertenecer en cierto modo a la sociedad. Esto es, desde el momento en el que la obra sale a conocimiento del público, de manera inevitable ésta pasa a ser parte del acerbo cultural del mismo. Tal y como Thomas de manera inevitable ésta pas
Jefferson reconoce en 1813 :

Si la naturaleza ha creado alguna cosa menos susceptible que las demás de ser objeto de propiedad exclusiva, esa es la acción del poder del pensamiento que llamamos idea, algo que un individuo puede poseer de manera exclusiva mientras la tenga guardada. Sin embargo, en el momento que se divulga, se fuerza a si misma a convertirse en posesión de todos, y su receptor no puede desposeerse de ella. ${ }^{6}$

Así, por tanto, estos bienes inmateriales no pueden ser enajenados nunca totalmente. Es cierto que puede evitarse su reproducción, pero incluso esto es solo hasta cierto punto. Se puede evitar que se reproduzcan la disposición de las palabras, las construcciones concretas de las frases, etc. pero no se puede evitar la reproducción de la idea e incluso de las escenas de la obra, es decir, la propiedad intelectual defiende la forma concreta en la que se expresa una determinada producción cultural, científica o artística, no la idea misma que subyace tras dicha expresión. ${ }^{7}$

Muy relacionado con el tema de la apropiabilidad, está la cuestión de la originalidad y autoría de la obra, la dicotomía entre la concepción de la obra como producto del genio individual o como producto de la sociedad. La obra del intelecto humano está sujeta a protección porque los legisladores comprendieron en determinado momento histórico que el hecho de que un

3 Juana MARCO MOLINA: La propiedad intelectual en la legislación española, Madrid, Marcial Pons, 1995. p. 22.

4 Esto es, por más que la consumamos (la información) nunca disminuye su utilidad. Patricio SÁlZ GONZÁLEZ: “Diseño y propiedad", en J. Capella y R. Ubeda (Coord.): Cocos, copias y coincidencias, Barcelona, Electa-Mondadori, 2003, p. 73.

5 Zorina Khan: "La Piratería de derechos de autor y el desarrollo: Evidencias de los EE.UU. en el S.XIX" Revista de Economía Institucional, vol. 9, $n^{\circ}$ 17, (segundo semestre 2007). p. 22.

6 Carta de Thomas Jefferson a Isaac McPherson, 13 de agosto de 1813.Antonio FERNÁNDEZ MORENO: "La propiedad intelectual: pasado, presente y... juturo?", en Contribuciones a las Ciencias Sociales, Octubre 2012. Recuperado de internet (www.eumed.net/rev/cccss/22/)

7 Christopher MAY: "Thinking, Buying, Selling: Intelectual Property Rights in Political Economy", New Political Economy, nº 3 (1998). p. 68. 
individuo fuese capaz de crear una obra original era mérito exclusivamente suyo. Es decir, los legisladores entendieron que el acto de creación es en sí mismo un acto personal de producción de un determinado bien. Tal y como Víctor Hugo definía la propiedad intelectual esta no es "una transmisión, ni una adquisición, es una creación".

Esto es, se asume que todo el bagaje cultural anterior del creador como una inversión personal, obviando que en realidad no es sino una exacción de una serie de conocimientos públicos patrimonio de la sociedad en la que el autor se ha formado. Este particular ya fue debatido largamente en los diferentes países occidentales a medida que se comenzaban a desarrollar los diferentes reglamentos y leyes de propiedad intelectual.

Al margen de la intangibilidad del bien, y de las dificultosas condiciones para determinar la propiedad del mismo, hay en la concepción de la propiedad intelectual un elemento que de nuevo vuelve a diferenciarla de la propiedad ordinaria. Este elemento entra en el ámbito de derecho moral. Simplificando, la propiedad intelectual se compone de dos elementos básicos. Por un lado, está la parte sujeta a derecho patrimonial, aquella de la que en última instancia se devengan los réditos económicos del bien sujeto a la protección de las leyes de propiedad intelectual. Esta es la parte que puede ser enajenada, legada en herencia y que finalmente, una vez extintos los plazos temporales prescritos por la ley, pasa a ser de dominio público. Se refiere a lo que es en sí la obra concreta: la novela, el cuadro, la composición dramática, el estudio científico, etc. Por otro lado, están los derechos morales sobra la obra, los cuales son inalienables. Esto es, el concepto de autoría. La novela, los resultados del ensayo clínico, el poema, la escultura, etc. se puede vender o se puede autorizar su duplicación y copia, pero la autoría no. Por muchas manos por las que pase un bien sujeto a la defensa de las leyes de propiedad intelectual, la autoría pertenecerá al autor o creador.

Este último componente de la propiedad intelectual es clave en la generación de un tipo de capital que si bien no es privativo de las creaciones científicas, artísticas o culturales, si es inherente a ellas; el capital simbólico o prestigio. Este tipo de capital es un elemento cuyo origen es anterior a la aparición de los derechos de autor y la propiedad intelectual. En el tiempo histórico previo a la regularización legal de la obra del intelecto humano, mucho antes de que el autor siquiera pudiese plantearse la posibilidad de ser el dueño de su obra, existía ya este tipo de capital asociado a la creación intelectual. Una de estas muestras nos la brinda Aristófanes, quien, en cierto concurso literario premió al autor menos aclamado por ser no obstante el más original: "Aristófanes demostró que las obras de todos los otros atletas eran copias serviles de obras preexistentes $[. .] "$..9 Con este bagaje de indefinición y prisioneros de una serie de trayectorias y decisiones históricas previas, arranca el proceso de creación de las leyes de propiedad intelectual.

Legislando lo inmaterial: los dos modelos de legislación

El primer paso para el desarrollo de una legislación orientada a proteger los derechos de autor pasó en la Europa continental por un arduo debate en torno a la conveniencia o incluso moralidad de someter a protección dichos bienes. Una vez que los diferentes legisladores asumieron que la propiedad intelectual merecía la consideración de propiedad y que por tanto debía ser protegida, surgió un problema de base legal y de trayectoria histórica.

8 Ana FERNÁNDEZ MORENO: La singularidad del procomún y los museos, Trabajo de fin de master, Universidad de Granada, 2010 p. 175. Recuperado de internet: (http.//digibug ugres/bitster, Universidad de Granada, 2010. p. 175. Recuperado de internet: (http://digibug.ugr.es/bitsMUSEOS.pdf)

9 Marie-Claude DOCK:"Génesis y evolución de la noción de propiedad literaria”, Revue Internationale du Droit D'Auteur, número especial: Histoire internationale du droit d'auteur, des origines á nos jours, Paris Association Française pour la diffusion du Droit d'Auteur National et Internationa (enero de 1974).p. 130.
En el mundo anglosajón la base jurídica sobre la que se asienta el copyright es el Common Law y la naturaleza de la propiedad intelectual se entiende en un sentido estrictamente mercantilista. Para el legislador anglosajón, la propiedad intelectual era y es esencialmente eso, una propiedad y por tanto hay una primacía de los derechos patrimoniales frente a los morales. Cierto es que, debido a sus particulares características, ésta debe ser un tipo de propiedad especial sujeta a caducidad. No obstante más allá de esto, en la legislación anglosajona la importancia de los derechos patrimoniales del propietario del copyright prima sobre los derechos morales.

Así, a excepción del derecho al reconocimiento de la autoría, no hubo, al menos hasta avanzado el siglo XX, un reconocimiento de los derechos morales del autor. Una vez que el autor cedía sus derechos mediante venta, herencia, donación, etc. perdía, merced a la aplicación de la first sale doctrine y salvo renuncia contractual expresa por parte del comprador, todo derecho sobre su obra. ${ }^{10}$ El nuevo propietario de la obra podía cercenar, modificar o añadir cuanto quisiera a la obra que había comprado ya que se entendía que, salvo por el acto de la autoría, era el propietario absoluto de la obra."

Este tipo de planteamiento respecto de la defensa de la propiedad intelectual ha sido entendido por los diferentes especialistas en historia del copyright del mundo académico anglosajón como una forma de defender la democratización de la cultura, una orientación en pro del interés público, en suma, una orientación utilitaria. ${ }^{12}$

Partiendo desde postulados diametralmente diferentes tenemos el desarrollo de los Derechos de Autor en la Europa continental. Herederos del debate ilustrado en torno a la concepción de la obra intelectual como producto supremo del ingenio humano, los legisladores continentales desarrollaron un entramado jurídico de defensa de la propiedad intelectual cuya base era la defensa del derecho moral. Desde esta perspectiva "Autorcéntrica", en la que el objeto protegido por la legislación de Propiedad Literaria se entiende como un "hijo del autor", los derechos morales son, salvo expresa renuncia contractual, inalienables. Se entienden que prestigio de la obra y prestigio del autor van parejos. El capital simbólico es la clave de un sistema en el que la protección al autor será más extensa que en el mundo anglosajón y en el cual no se concibe la posibilidad de la "democratización cultural" por la vía de la protección reducida al autor. ${ }^{13}$

Con un punto de partida legal y conceptual tan opuesto en cuanto a los términos y objeto de la protección de la propiedad intelectual (y en el marco de un mercado internacional en crecimiento) comienza el proceso de internacionalización de las leyes de propiedad literaria.

10 Zorina KHAN and Kenneth L. SOKOLOFF: "The Early Development of Intellectual Property Institutions in the ...", p. 237

11 En Inglaterra los derechos morales sobre el material sujeto a protección han sido añadidos a partir de 1988. Derechos de autor en plataformas e-learning, http://www.ugr.es/ derechosdeautor/ derechos autor.html

12 Ver Ronan DEAZLEY, Martín KRETSCHMER y Lionel BENTLEY: “The History of Copyright History: notes from an emerging discipline" en Privilege and Property Essays on the History of Copyright, Ronan DEAZLEY, Martín KRETSCHMER y Lionel BENTLEY (eds), Open Book Publishers, Cambridge, 2010. Y Zorina KHAN: "The Democratization of Invention: Patents and Copyrights in American Economic DeZorina KHAN: "The Democratization of Invention: Patents and Copyrights in American Economic De-
velopment, 1790-1920", Technology and Culture, Volume 49, Number 1, (January 2008), pp. 270-272.

I3 el caso continental, al menos en el entorno francés En el caso continental, al menos en el entorno francés y español, el proceso de democratización de la cultura se lograría mediante el establecimiento de los sistemas de educación obligatoria y el forma de gestión y extensión de la cultura de bajo costo pero innegable funcionalidad. 


\section{En contra de la "esclavitud blanca". La internacionalización de los Derechos de Autor y el} Copyright: un proceso lento y asimétrico

Qué decir hoy de los plagiadores que explotan a la esclavitud blanca de una tan desvalida profesión de las letras y de las artes [...] hay un grandísimo número de tratantes y traficantes de la esclavitud blanca y de los pobres autores.

Almeida Garret ${ }^{14}$

El proceso de establecimiento de una legislación internacional para la protección de la propiedad intelectual que rigiese el copyright o derecho de autor será más tardío que e orientado a defender la Propiedad Industrial. Tras esta asincronía en el desarrollo de una legislación internacional a este respecto se encuentra el hecho de que debían armonizarse dos tradiciones jurídicas muy diferentes. A esto ha de sumarse la falta de desarrollo de ferias y muestras internacionales que hiciesen necesario un desarrollo de leyes armonizadas para proteger a los participantes como ocurría en el caso de los productos de la industria protegidos por patentes y marcas $y,{ }^{15}$ por otro lado, el hecho de que los paises que finalmente firmaron el Convenio de Berna se encontraban en etapas muy diversas en el desarrollo de su mercado cultural.

Desde los años cuarenta del siglo XIX, y hasta que se ratifique el Convenio de Berna, las diferentes naciones occidentales deberán buscar la protección de las obras literarias, científicas y artísticas en otras naciones mediante el establecimiento de tratados bilaterales. En función de las tradiciones jurídicas de origen e intereses económicos se establecerán una serie de acuerdos que si bien sobre el papel mantenían una apariencia formal de equidad, en la práctica escondían graves diferencias en cuanto al aprovechamiento que una u otra nación podría hacer al respecto. Estas diferencias se centran esencialmente en torno a la cuestión de los plazos de protección, los requisitos para la obtención de la protección y la cuestión colonial.

En este proceso de creación de una red de Estados que respetasen los intereses de los autores nacionales España será un país pionero. Entre 1847 (año en que se aprueba la primera ley española sobre Propiedad Literaria) y la ratificación del Convenio de Berna en 1886 España firmará siete tratados internacionales a este respecto, una cifra tan solo superada por Francia. Tratados en los que se reconocerá la cláusula de nación más favorecida y trato nacional aunque de manera aún muy inmadura y en los que tratará de mantener en la medida de lo posible el control comercial sobre este tipo de activos intangibles con sus antiguas colonias. ${ }^{16}$

Lastrada por su difícil situación jurídica con las colonias, una ley de Propiedad Literaria sin apenas recorrido, un mercado editorial débil y en transición y una incorrecta gestión de su relación con las ex-colonias, España tendrá problemas para defender los derechos de autores nacionales en las principales naciones occidentales así como en un mercado que le era tan natural como inaccesible: el latinoamericano. Por su especial relevancia nos centraremos aqui en los tratados firmados con Francia e Inglaterra atendiendo tanto a las condiciones de los mismos como al trasfondo en el que se llevaron a cabo.

14 Joao Manuel MALHIERO DE FERAZ: "Algunos apuntes históricos sobre el nacimiento de la Propiedad Intelectual en Portugal", Documentación de las Ciencias de la Información, $n^{\circ} 26$ (2003), p. 224

15 Zorina KHAN: Intellectual Property and Economic Development: Lessons from American and European History, Maine, National Bureau of Economic Research and Bowdoin College, 2002 p. 5. Recuperado de internet (http://www.iprcommission.org/papers/pdfs/study papers/spra khan study.pdf)

16 Jhonny Antonio PABÓN CADAVID: “Aproximación a la historia del derecho de autor: antecedentes normativos", Revista La Propiedad Inmaterial, n. ${ }^{\circ} 13$ (2009). p. 89.
Negociaciones con Francia: Los tratados de 1854 y 1880

La Ley de Propiedad Literaria de 1847 recoge en su artículo 26 que el gobierno deberá celebrar convenios con cuantas naciones se avengan a firmarlos con objeto de proteger la propiedad de los autores de las respectivas naciones frente al fraude y la piratería de derechos. ${ }^{17} \mathrm{E}$ tratado bilateral franco-español sobre la Propiedad Literaria de $1854^{18}$ será el primer tratado internacional que España firmará al respecto. Irónicamente, a pesar de ello, y pese a hacerlo frente a una nación cuya potencia editorial era muy superior, las condiciones del tratado serán considerablemente más favorables que en tratados posteriores. Los puntos centrales de este tratado giran en torno a: el periodo de duración de la protección de las obras, los elementos que serán objeto de protección por el acuerdo, los requerimientos de registro y el acuerdo de defensa de los derechos de los autores de las naciones firmantes frente a ediciones en terceros países que pudiesen venderse en territorio de los firmantes.

Respecto de los elementos sujetos a la protección recogida en el tratado, se especifica que "Por obra literaria, científica y artística se entienden los libros, las composiciones dramáticas y musicales, los cuadros, dibujos, grabados, litografías, esculturas, mapas, y cualesquiera otras producciones análogas". ${ }^{9}$ Quedando excluidos de la protección estipulada en este tratado las obras de arte relacionadas con la industria agraria, fabril y manufacturera. Es decir, ambas naciones deciden legislar sobre todas las producciones intelectuales que pertenecen a la rama del derecho de autor, dejando la protección de aquellas que serán objeto de protección de las leyes de Propiedad Industrial para acuerdos paralelos. Esencialmente porque en este tipo de creaciones las diferencias entre legislaciones nacionales es muy amplia, tanto en tasas como en requisitos, etc

Es en lo tocante a los periodos de protección otorgados a los autores de ambas naciones donde España logra unos mayores beneficios. En lugar de adoptarse el principio de aplicación de la legislación nacional, se opta por la creación de unos plazos especiales. Según la legislación francesa, el autor original contaba con la protección de por vida y una extensión de diez años posterior a su muerte. En el caso español, esta era de por vida más un periodo de cincuenta años posterior a la muerte. En el acuerdo firmado entre ambas naciones se estipula que el periodo de protección será durante la duración de la vida del autor, más un plazo posterior de veinte años. Para un país cuyo mercado editorial se encontraba en pleno proceso de modernización, ${ }^{20}$ este acuerdo resultaba interesante, ya que si bien no garantizaba el mismo nivel de protección que la legislación nacional sí que permitía una extensión superior a la obtenida por la legislación francesa. Esto supone que los autores españoles, o las editoriales, según quien fuese el propietario de los derechos de autor, podían retener los beneficios de las obras a nivel internacional durante un periodo de tiempo que les resultaba bastante provechoso. Si las editoriales españolas no podían surtir el mercado internacional, especialmente el latinoamericano con su producción, al menos podían mantener cautivos los derechos de autor, obteniendo así beneficios derivados del cobro por autorizar a editoriales francesas, o evitar la edición por parte de estas, y garantizarse el monopolio sobre la edición de ciertos textos.

La cuestión del registro se mantiene en la línea de los reglamentos nacionales para la aplicación de la propiedad literaria. No obstante, en lugar de deber entregarse dos copias gratuitas en el Ministerio de Instrucción pública y en la Biblioteca Nacional, éstas deben entregarse en una oficina que se creará en Madrid al efecto (para las obras publicadas en Francia), o en

17 Gaceta de Madrid, 15 de Junio de 1847. pp. 1-2.

18 Archivo Histórico Nacional, Estado, Leg. 8463, Exp. 39

19 Ibid.

20 Jesús MARTÍNEZ MARTÍN: Vivir de la pluma La profesionalización del escritor 1836-1936, Marcial

Pons Historia, Madrid, 2009. pp. 37-39. 
Sección Bibliográfica del Ministerio del Interior, en París, para las obras publicadas en España. Más importante aún, no se cobrará en caso alguno ningún tipo de tasa o arancel salvo el papel sellado que contenga la expedición del título.

Uno de los problemas esenciales que se presentaron durante la negociación del tratado fue la cuestión colonial. Si bien se acordaba que el tratado era aplicable en todos los territorios nacionales de los firmantes, la particular relación de España con sus colonias planteó recelos por parte francesa. ${ }^{21}$ Este problema, resuelto a la altura de 1880 , se centraba en varios aspectos. Esencialmente en torno al estatus jurídico de las colonias, que si bien debían permanece amparadas por lo recogido en el tratado no lo estaban, y en torno a la falta de instituciones de registro en los territorios de ultramar, algo que generaba un vacío del cual los impresores no autorizados podían aprovecharse. No será hasta 1868 cuando se obligue mediante decreto a la aplicación de la ley de Propiedad Literaria en las colonias. Algo sólo obtenido tras un largo proceso de reclamaciones, que aunque encabezado por Anacleto Sánchez ${ }^{22}$, dueño de la imprenta "Las Novedades", manifestaba un amplio malestar del sector en los territorios coloniales. ${ }^{23}$

Cuando en 1880 se revise y modifique el tratado de 1853 los cambios no serán excesivos, pudiendo rastrearse en este nuevo acuerdo las pautas básicas que acabarán conformando las bases del Convenio de Berna de 1886 . Se extiende la protección a cincuenta años posterior a la muerte del autor (en España, con la ley de 1879 el plazo ya era de ochenta años) y se soluciona de manera definitiva la cuestión colonial mediante un reconocimiento explicito de los territorios en los cuales tendría aplicación la legislación.

Negociaciones con Inglaterra: Los tratados de 1857 y 1880

Si España había obtenido unas condiciones razonables en los tratados bilaterales con Francia, en el caso de los tratados con Inglaterra ocurrirá lo contrario. Sobre el papel los acuerdos alcanzados en principio parecían simétricos a excepción de la cuestión de las tasas de registro. Un análisis más minucioso pone de manifiesto que esto no es así. Las causas de esta disimetría en el aprovechamiento de los pactos alcanzados, la vamos a encontrar en la diferencia entre legislaciones nacionales. La legislación española, basada en el modelo de Derecho de Autor francés garantizaba a la altura de 1857 un periodo de protección establecido para la vida del autor más cincuenta años posteriores a su muerte, mientras que en el caso británico éste era de la vida del autor más una extensión de siete años a su muerte o un periodo de cuarenta y cinco años desde la publicación de la obra, lo que fuese más largo. En el tratado de $1857 \mathrm{se}$ aplica la noción de "trato nacional", es decir, se aplicará la legislación nacional propia de cada país. Esto suponía que las obras de autores españoles registradas en Inglaterra tenían una menor protección temporal que las obras de los ciudadanos ingleses registradas en España. Esto resultaba especialmente provechoso para Inglaterra, ya que mientras que en su territorio nacional podía seguir aplicando sus criterios de "democratización de la cultura" a través de su sistema de baja intensidad de la defensa del copyright, en España obtenía unos niveles altos de protección que favorecían los intereses de sus editores y autores.

21 José BELLIDO, Raquel XALABARDER y Ramón CASAS VALLÉS: "Commentary on the Colonial Projection of Spanish Copyright Laws (1855)", Primary Sources on Copyright (1450-1900), eds L. Bently \& M. Kretschmer, 2011. Recuperado de internet. (http://copy.law.cam.ac.uk/cam/tools/request/ showRecord?id=commentary s 1868)

22 "Solicitud de extensión a Ultramar de tratados de propiedad literaria", Ultramar, 165, Exp. "46, en AHN. Recuperado de internet (http.//pares.mcues/ParesBusquedas/servlets/ImageServlet?accion $=41 \&$ txt id imagen $=1 \&$ txt rotar $=0 \&$ txt contraste $=0 \&$ txt zoom $=10 \&$ \&apporigen $=\& c a-$ t?accion $=418$ becera $=\mathrm{N})$.
b.

23 José BELLIDO, Raquel XALABARDER y Ramón CASAS VALLÉS: “Commentary on the Colonial Projection of Spanish".
Por otro lado tenemos la cuestión del registro. En España no se aplicaba el criterio de la publicación forzosa, es decir, la obligación de imprimir el texto para obtener la protección (más allá de los ejemplares obligatorios para entregar en registro). En Inglaterra existía esta obligación de impresión lo que marcaba de nuevo una diferencia registral entre autores y editores ingleses y españoles. En España este particular había sido debatido por la comisión de estudio para la creación de la Ley de Propiedad Literaria de $1847^{24}$ dirigida por Manuel Bretón de los Herreros, pero había acabado por desestimarse por suponer una traba económica importante para autores y editores. Al margen del hecho de tener que depositarse una obra en la Stationers Hall de Londres y otra en la Biblioteca nacional en Madrid, hay una diferencia en las tasas de registro:

[...] no excederá de cinco reales vellón en España; ni de un chelín en Inglaterra; y los demás gastos por la expedición del certificado del mismo registro no excederán de la cantidad de veinte y cinco reales vellón en España, ni de cinco chelines en Inglaterra. ${ }^{25}$

El tratado de 1880 mantiene las condiciones generales del anterior acuerdo, especialmente las tasas de registro. El hecho de que las tasas de registro no aumentasen en los veintitrés años de duración del primer tratado hace plantearse la cuestión de si se partía efectivamente de unas tasas de registro elevadas. Algo que al poner este coste en comparación con el de obtener una patente de invención, demuestra no ser el caso. Con la reforma de la ley de patentes de 1878 , la cual abarataba sensiblemente el coste de la patente, el coste de solicitar una patente por veinte años se establecía en 40 reales para el primer año. En el periodo anterior a 1878 una patente de invención por veinte años debía pagarse en su totalidad en el primer plazo, ascendiendo el coste a 6000 reales, algo que era más del doble de un salario nominal anual de un carpintero, o un albañil. ${ }^{26}$

American Piracy: Un dificil juego a tres bandas.

En 1842, Charles Dickens se quejaba de la habitual práctica de la piratería de derechos en los EEUU en los siguientes términos:"[I Have] the exquisite justice of never deriving six pence from an enormous American sale of all my books". ${ }^{27}$ Una suave denuncia en una carta a un amigo que revela la cotidianidad de las prácticas editoriales piráticas en el territorio americano.

Una de las principales razones por las que España se apresura a firmar tratados para la protección de los derechos de autor con Francia e Inglaterra la encontramos en el mercado latinoamericano. Tras la independencia de las colonias y el establecimiento de las repúblicas americanas se produjo desde la década de los años treinta del siglo XIX un proceso de internacionalización del mercado editorial. El aumento demográfico de estas repúblicas, el crecimiento urbano, el aumento del porcentaje de población alfabetizada y la mejora de los transportes transformaron el territorio de las antiguas colonias en un mercado potente y por explotar. ${ }^{28}$ Aunque España partía con la ventaja idiomática y cultural de su parte, sus deficientes relaciones con los territorios emancipados y la inexistencia de un mercado editorial potente en nuestra nación actuaban como fuerte contrapeso. El desabastecimiento de obras españolas

24 Archivo Histórico Nacional; ESTADO, Leg. 11329. Exp. 15.

25 Archivo Histórico Nacional; ESTADO, Leg. 8464. Exp. 47.

26 José Patricio SÁIZ GÓNZALEZ: Invención, patentes e innovación en la España contemporánea , Madrid, OEPM, 1999. pp. 135-136.

27 Citado en Fred KAPLAN: Dickens, A Biography, New York, William Morrow, 1988. p. 125

28 Jhonny Antonio PABÓN CADAVID: "José María Torres Caicedo: el nacimiento de la identidad latinoamericana, las construcciones nacionales y el derecho de autor", Revista la propiedad inmate-

rial, n. ${ }^{\circ} 16$ (noviembre de 2012 ). p. 28

ish... 
impresas en la ex-metrópoli pronto comenzó a ser suplido por impresiones americanas sin autorización y por ediciones piratas creadas en Francia o Inglaterra. El potente mercado editorial francés acabó imponiéndose de manera lícita en la segunda mitad del siglo XIX, tras la firma de los convenios con España. Hasta ese momento, la mayor parte de las obras españolas vendidas en Latinoamérica e impresas en Francia eran de carácter pirata. ${ }^{29}$

Pero si las ediciones piratas francesas le estaban permitiendo copar el mercado latinoamericano ¿Por qué Francia se apresta a firmar un pacto tan ventajoso con España? El principal acicate para este movimiento diplomático lo encontramos en la competencia comercia con Gran Bretaña. Desde comienzos del siglo XIX encontramos a las editoriales inglesas entrando con fuerza en el mercado latinoamericano aún en formación. La imprenta de Rudolph Ackerman extendía imparable sus ventas de ediciones inglesas en lengua española por los territorios de ultramar..$^{\circ}$ Ante la perspectiva de la competencia con Gran Bretaña y enfrentada a la realidad de que las ediciones piratas podrían no acabar resultando tan rentables para Francia como habían venido siendo, Francia se apresta a firmar un tratado con España en unas condiciones muy favorecedoras para ambas naciones que permitirían a su potente y legal industrial editorial desembarcar en Latinoamérica.

Inglaterra por su parte firma los tratados con España por los siguientes motivos. En primer lugar, al establecerse éstos sobre la base del trato nacional, su doctrina de la democratización de la cultura queda protegida como ya hemos visto. En segundo lugar, Inglaterra encara el mercado latinoamericano con un doble problema. Por un lado están las editoriales piratas francesas que establecían una dura y desleal competencia. Como Ackerman reconocía: "se están imprimiendo en Francia todas las que ha publicado en lengua Castellana, con el designio de introducirlas en América, y venderlas á precios más cómodos, como es fácil hacerlo cuando no hay que pagar los originales". ${ }^{31}$ Aunque Inglaterra contaba con pactos para la defensa de los derechos de autor con las repúblicas latinoamericanas antes que la propia España, la garantía para obras españolas registradas en España pero publicadas en Inglaterra era fundamental. Por otro lado, Inglaterra se enfrentaba a la competencia de las editoriales piratas norteamericanas. EE.UU no reconoció los derechos de copyright sobre la obra de autores extranjeros hasta el año 1891. Por tanto, durante casi cien años los EE.UU. realizaron una piratería sistemática de los derechos de propiedad intelectual de autores foráneos. A la larga, tal y como Zorina Khan ha puesto de manifiesto, esta política resultó ser ruinosa para sus propias editoriales. No obstante, en aquel momento, Inglaterra fue una de las principales víctimas de esta política de piratería americana. El establecimiento de pactos con España le garantizaba si no una protección total de sus obras, al menos una base para la cooperación y una cierta defensa frente a las obras inglesas impresas ilegalmente en los EE.UU. e introducidas en España y Latinoamérica vía Cuba.

\section{Conclusiones}

El proceso de internacionalización de las leyes para la defensa de la propiedad intelectual fue lento y poco armónico. A la dificultad de legislar sobre bienes intangibles con un carácter indiscutible de bienes públicos puros, se debe unir la importante diferencia de base jurídica, filosófica y conceptual entre las dos grandes tradiciones legales. A esto hay que unirle la escasa integración del mercado editorial internacional y los diferentes intereses estratégicos de los distintos países. En el ínterin, cada nación trató de garantizar los derechos de sus autores y

29 Ibid.

30 Eugenia VERA ROLDAN: The British Book Trade and Spanish American Independence: Education and Knowledge Transmission of Knowledge in Transcontinental Perspective, Ashgate Publishing, 2003.

Jhonny Antonio PABON CADAVID: "José Maria Torres Caicedo: el nacimiento de la identidad I

noamericana," P. 28. editores en terceros países a través de tratados bilaterales. Estos tratados fueron más sencillos entre los países de la Europa continental que entre los países de tradición legal anglosajona y mucho más que los establecidos entre naciones de una y otra tradición. España, cuyo mercado antiguas colonias frente a Francia e Inglaterra mediante un proceso de reconocimiento de los derechos de autor de ambas nacionalidades. 


\section{EL PACÍFICO Y LA COLONIZACIÓN \\ DEL MUNDO “OCCIDENTAL"}

David Manzano Cosano

Escuela de Estudios Hispano-Americanos, CSIC- UCM

\section{Introducción}

El 25 de septiembre de 1513 el conquistador español Vasco Núñez de Balboa contempló desde el istmo de Panamá la Mar del Sur, produciéndose así la aproximación del Pacífico al imaginario del mundo "occidental”. La comprensión de este vasto océano será completada en los siglos posteriores, gracias a la acción de potencias como España, Portugal, Países Bajos, Francia, Rusia o Reino Unido, las cuales se afanarán en su conocimiento para desarrollar sus intereses económicos. Sin embargo, a pesar de los múltiples viajes que discurren por estas aguas y la consolidación de instituciones tan importantes como el Galeón de Manila, la Vereenigde Oostindische Compagnie (VOC) o la Compañía Británica de Indias Orientales, los mapas europeos de comienzos del siglo XIX aún presentarán grandes dificultades para dibujar con exactitud la totalidad de los archipiélagos de este océano. Entre otras razones, porque hasta las tres expediciones efectuadas durante la segunda mitad del siglo XVIII por el capitán inglés James Cook (1768-1779), el Pacífico era prácticamente desconocido para el viejo mundo,' pues éste sólo era capaz de representar nítidamente las regiones de Extremo Oriente y algunos puntos cruciales para la navegación de la Nao de China: áreas donde los brazos del poder europeo se habían extendido. El resto de sus millones de islas serán descritas de forma anómala, como evidencia el mapa de Walch elaborado entorno a 1802 (donde existen grandes dificultades para localizar sus archipiélagos), o la multitud de términos que se empleaban para aludir a la misma isla. ${ }^{2}$ Este desconocimiento será superado a lo largo del siglo XIX, como consecuencia de los logros científicos que obtienen las expediciones maritimas que se desarrollan al calor del Imperialismo. Un fenómeno que motivará la plena inserción de este extenso territorio en la red internacional liderada por las potencias "occidentales", agilizándose de esta manera e proceso de globalización del planeta.

Ersnest S. DODGE: Islands and empires: Western impact on the Pacific and East Asia, London, Oxford University Press, 1976.

2 A lo largo de la primera mitad del siglo XIX los expedicionarios emplean diferentes nombres para definir a un conjunto de isla. Así, por ejemplo, para aludir a la isla volcánica de Anatahan en el archipiélago de Marianas) emplean los nombres de Anataca, Antans, Intajan, Natan, Matan y San Joaquín.

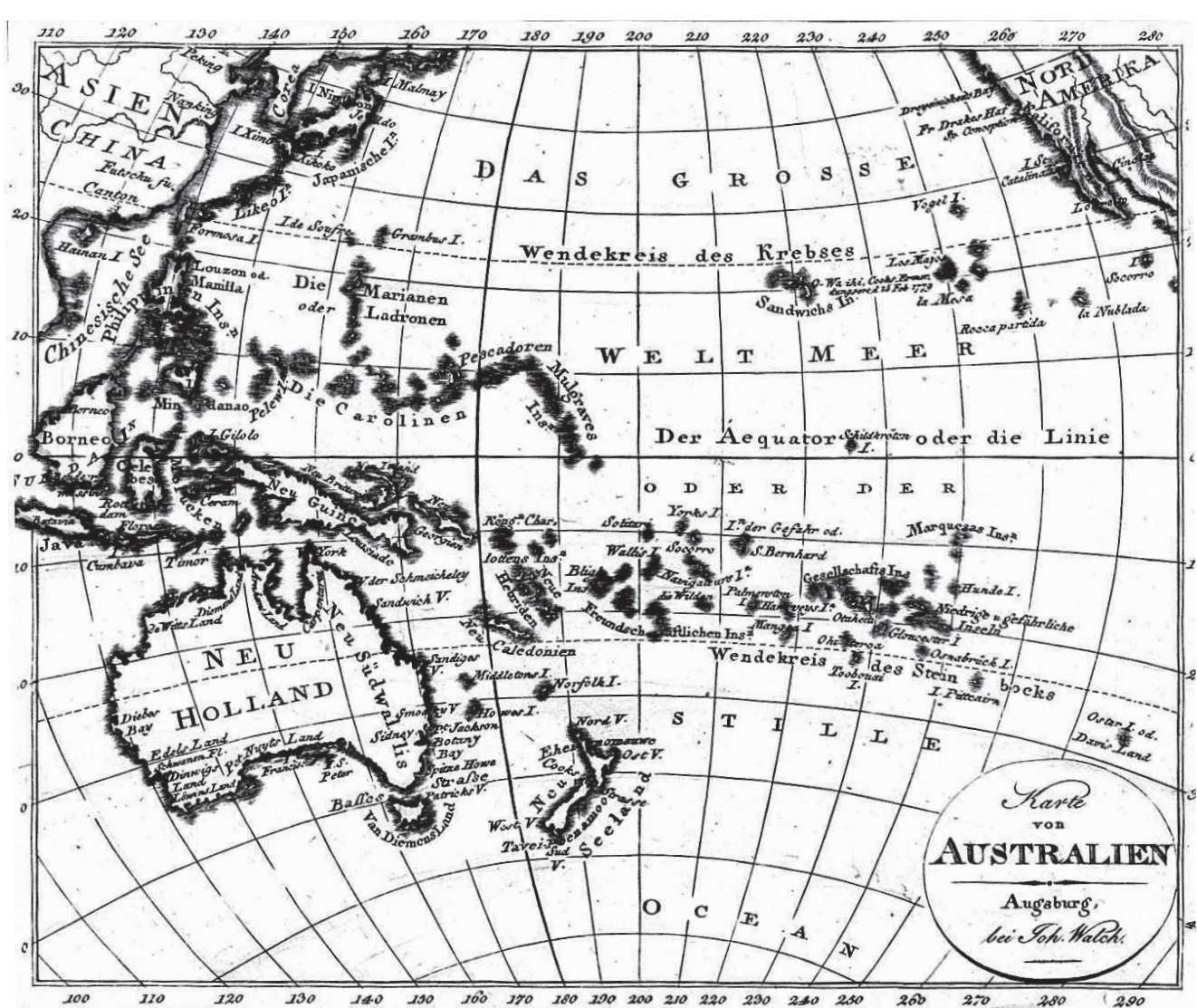

FALCH, Johannes (1757-1816): Karten von Australien. Augsburg: bei Joh Walch, 1802?, National Library of Australia. ${ }^{3}$

\section{El origen del mundo occidental en el Pacífico}

El germen de la presencia "occidental" en la Mar del Sur hemos de localizarlo en el mundo ibérico, gracias a los logros obtenidos por la expedición de Vasco de Gama (que alcanzó la India en 1498 , posibilitando a Portugal su asentamiento en Malaca), ${ }^{4}$ y los efectos del primer viaje de circunnavegación de la Tierra protagonizado por Magallanes y Elcano (1519-1522). Estos periplos condujeron a los poderes hispánicos a invertir en una serie de proyectos para conecta el territorio americano con el Extremo Oriente, consiguiendo este propósito la expedición de Legazpi y el viaje de tornaviaje de 1565 , atribuido supuestamente a Urdaneta. ${ }^{5}$ Así pues, dados los límites trazados por el tratado de Tordesillas de 1494 y el de Zaragoza de 1529 -el cual concretó el antimeridiano de la citada bula alejandrina (que debía de de fijar las fronteras de las monarquías ibéricas en el Extremo Oriente)-, España hizo del Pacífico su "Gran Lago". Mas, debemos de matizar esta afirmación tradicional, porque a lo largo de la Edad Moderna, la Corona hispana sólo se extendió por aquellos puntos que posibilitaron el desarrollo de su

3 En este mapa se puede apreciar algunos archipiélagos del Pacífico como las Marianas, las Carolinas, Nueva Caledonia, Wallis and Futuna, Hawai i i, etc. Sin embargo, la escala y la fisionomía de muchas de ellas no se corresponden con la realidad. Además, la descripción de algunas regiones como los márgenes centrales de la Melanesia y Polinesia o las islas al Este de Hawai'i presentan bastantes anomalías.

4 Alfonso de Alburqueque toma posesión de Malaca en 1511

5 Las investigaciones de Juan Gil, presentada en su conferencia que impartió el 10 de abril de 2012 en el Congreso Internacional del Galeón de Manila 1565-1815: Navegación Comercio e Intercambios culturales celebrado en la Escuela de Estudios Hispano-Americanos, pone en tela de juicio que Urdaneta fuera la cabeza pensante que consiguió conectar Filipinas con América, aprovechando la corriente de Kuro-shiwo. 
gran ruta comercial oriental del Galeón de Manila. ${ }^{6}$ De ahí, que estableciese Filipinas como la base de sus operaciones y sólo ocupasen las Marianas. El resto de los archipiélagos oceánicos prácticamente estuvieron marginados de las dinámicas del poder de los Estados europeos, estableciéndose algunas relaciones como consecuencia de los viajes de exploración que muchas potencias de la época establecieron en este vasto mar.

Así pues, las monarquías europeas no respetaron los límites fijados por el poder papal, al considerar que no era fuente de legitimidad para delimitar la zona de influencia mundial. Ante este pensamiento, Holanda y Reino Unido a finales del siglo XVI invirtieron en una serie de viajes de exploración por el Pacífico para participar de los pingües beneficios que los mercados asiáticos ofrecían, -como indican la acción de ingleses como Francis Drake ${ }^{7}$ o $\mathrm{Ca}$ vendish; ${ }^{8}$ la expediciones holandesas de Jaques Mahu y Olivier van Noort; ${ }^{9}$ o la fundación de empresas como la Compañía británica de las Indias Orientales en 1600 o la VOC en 1602 (la cual tendrá como centro de operaciones la isla de Java, actual Indonesia)-. La transformación de la coyuntura internacional en el ocaso del siglo XVII, aumentó el número de potencias internacionales que se aproximaron al Pacífico, como evidencia los deseos expansionistas de monarca francés Luis XIV y el zar ruso Pedro I, a la par que Reino Unido intensificó su política agresiva mediante la fundación en 1711 de la Compañía de la Mar del Sur-que se beneficio de las cláusulas acordadas en el tratado de Utrecht (1713)-. Pese a este incremento de la preocupación por el Pacífico, debemos de descartar que este territorio sea una pieza clave en el sistema internacional diseñado por los poderes europeos en el siglo XVIII, al no existir ningún tipo de ocupación efectiva "occidental" en el interior de sus aguas hasta comienzos de la centuria romántica, a excepción de las Marianas. A raíz de la apuesta de Inglaterra de colonizar la Nueva Holanda se intensificará la presencia occidental en el Pacífico.

A lo largo de los siglos, fueron muchas las expediciones que intentaron hallar la mítica Terra Australia Incógnita, siendo el gallego Luis Váez de Torres el primer europeo en atisbar sus costas norteñas en 1606. Ante el desinterés de España por esta zona, la VOC financiará la expedición de Abel Janszoon Tasman -que entre 1642 y 1644 recorrerá parte de este territorio para hallar un posible establecimiento (de ahí que sea conocida este territorio como Nueva Holanda hasta el siglo XIX). Sin embargo, tampoco la colonizará al creer que este territorio carecía de riqueza. No será hasta la Guerra de los Siete años (1756-1763) cuando las potencias europeas, principalmente Francia y Reino Unido, alienten su deseo por descubrir esta área, ${ }^{\circ}$ al iniciar una carrera de expansión por el Pacífico como arma para acrecentar su poder internacional. Esta lucha será ganada por Inglaterra, no sólo porque el Endevour del capitán Cook alcanzará primero las costas australianas (al llegar a finales de abril de 1770"1), sino porque este Estado será el único que expanda su

6 El Galeón de Manila fue la ruta creada por la corona hispana para conectar el Extremo Oriente con sus dominios. Así pues, dados los límites del tratado de Tordesillas, España hará llegar los productos asiáticos desde Filipinas a España vía América, por medio de una nao anual que poseía el monopolio comercial de surcar los mares del Pacífico.

7 En 1579 proclama el territorio de Nueva Albión (Norte de California) para la corona inglesa, ante su deseo de hallar el paso del Norte que uniese el Atlántico con el Pacífico.

8 Primer corsario inglés que deliberadamente circunnavegó el globo (1585-1588), capturando en 1587 el Santa Ana, uno de los cuatro Galeones de Manila que a lo largo de la Historia fueron apresados. Posteriormente, se sumarán a esta lista La Encarnación (1709), El Covadonga (1743) y La Santisima Trinidad (1762).

9 Expediciones holandesas que zarpa en 1598 desde Rotterdam en busca de las Indias Orientales por estrecho de Magallanes. La flota de Mahu será la primera en atravesar este paso, mientras que la de Olivier van Noort completará en 1601 el primer viaje de circunnavegación holandés.

10 Anteriormente habían atisbado sus costas el inglés William Dampier (1688) y el holandés Willerm Vlamingh (1696). Sin embargo, sus Estados no prestarán gran atención a sus hallazgos.

11 El primer viaje de Cook (1768-1771) fue financiado por la Real Sociedad de Tahití y tenía como misión administración en Oceanía a finales del siglo XVIII. Francia, a pesar de los expediciones de SurviIle (1769-70), Dufresne (1771-1772), La Perouse (1785-1786) y Entrecasteaux y Huon de Kermeadec (1791-1793) no establecerá ninguna colonia por sus altos costes, y abandonarán momentáneamente sus aspiraciones en el area como consecuencia del estallido de la revolución francesa.

Por el contrario, Inglaterra, como consecuencia de las transformaciones que se producen en su seno durante la segunda mitad del siglo XVII, sí decide colonizar Australia, al sufrir la pérdida de sus trece colonias americanas y al transformar su modelo económico, dado el triunfo de la revolución industrial. Pues el Reino Unido había deportado a una cantidad significativa de convictos a sus colonias americanas, existiendo un número considerable en Maryland y Maine. Una vez consumada la emancipación de los Estados Unidos, las antiguas colonias dejan de albergan los presidiarios británicos, por lo que este territorio comenzará a sufrir una sobrepoblación de este grupo. El hallazgo del capitán Cook, influirá a la clase dirigente inglesa a pensar en Australia como sustituto del destino de sus penados, de hecho, desde 1788 llegarán a este territorio numerosos barcos que los trasladarán. La transformación del destino de los reos británicos de América a Oceanía es un ejemplo de cómo el Reino Unido va a trasladar sus intereses coloniales, de ahí, el triunfo de la colonización del territorio que tendrá como epicentro a Sydney. Sin embargo, su éxito no se debe exclusivamente a este factor, de hecho, a mi entender el fundamento de la presencia británica en el área se encuentra en los efectos del triunfo de la revolución industrial, que demanda la expansión hacia nuevos mercados. Australia se convierte en nueva base comercial que dará apertura a una nueva ruta económica que conectará Oceanía con Extremo Oriente. Este interés será fundamental para que los herméticos imperios chinos y japonés comiencen a presentar leves síntomas de apertura a finales del siglo XVIII. ${ }^{12}$

De esta forma, el poder inglés inicia un camino de expansión por toda la Oceanía que le reporta grandes beneficios, por lo que el resto de las potencias seguirán sus sendas. Sin embargo, dado el gran desconocimiento del área, los Estados occidentales organizan una serie de expediciones científicas a lo largo del siglo XIX (sobre todo en la primera mitad) para decidir qué islas pueden ayudar a desarrollar la riqueza nacional, como indica la conducta desarrollada por el propio Reino Unido -cuya marina fondeará estos mares para proteger sus interés-, ${ }^{13} \mathrm{O}$ la actividad de Francia, Rusia y Estados Unidos. Francia una vez que supera las convulsiones internas de su revolución, retomará su proyecto expansivo por este océano, como demuestra las numerosas expediciones que patrocinan, las cuales intentan atraer la Melanesia y la Polinesia a su órbita; ${ }^{14}$ Rusia emplearán la misma política para defender sus aspiraciones en el Norte del

científica observar el tránsito de Venus- el cual se manifiesta en la Tierra cada 243 años-, al predecir Edward Halley que se produciría el 3 de Junio de 1769, pudiendo visualizarse de forma nítida en la recién descubierta Tahití. Su viaje transcurre paralelamente a la expedición del St Jean Baptiste liderada por el francés Surville, el cual se hallara muy próximo al Endeavour a finales de diciembre de 1769; Geoffrye BLAINE: Sea of Danger. Captain Cook and his rivals. Camberwell, Vic., Penguin, 2009.

12 En 1762 China establece un centro comercial en Guangzhou (Canton) y Japón permite la presencia de europeos en Deshima Island (Nagasaki) en el siglo XVIII; Mark BORTHWICK: Pacific Century. The Emergence of Modern Pacific Asia, Colorado, Westview , 2007.

13 La actividad de Fredrick William Beechey (quien en 1831 publica Narrative of voyage to the Pacific and Beering's Strail), Frances Price Blackwood (el cual realizará un viaje 1833 entre Australia y América en el Hyacint y, posteriormente se dedicará a descubrir entre 1843-1845 el estrecho de Amerres y el río Fly), George Anson Byron (quien traslada el cuerpo del rey Kamehameha II a Hawai' en 1824) o Jonh Hall (quien dará nombre a sus islas en 1824), es muestra de cómo el Reino Unido intenta controlar el Pacífico a lo largo del XIX. 14 Entre sus expediciones científicas más importantes podriamos destacar la desarollada por el Ura-
nie de Freycinet, (1817-1820), Le Coquille de Duperrey (1822- 1825), Hyacinthe Yves Phillipe Florentin nie de Freycinet, (1817-1820), Le Coquille de Duperrey (1822- 1825), Hyacinthe Yves Phillipe Florentin petit-Thouars (1836-1839), etc. 
Pacífico; ${ }^{15}$ los Estados Unidos también desarrollará una serie de proyectos institucionales con estos fines, pues desde 1812 a 1845 su marina realizará veinticinco expediciones en el Pacífico," siendo una de las más importantes la conocida como The United States Exploring Expedition, liderada por Charles Wilkes entre 1838-1842.

El deseo de las potencias por esta área estuvo consolidado por la expansión de sus grupos de presión, entre los que debemos mencionar la acción de los religiosos y el lobby económico de los comerciantes -donde destacará los balleneros en la primera mitad del siglo XIX-. Por el influjo que el Reino Unido aglutinó en el área, no ha de extrañarnos que ésta fuese la primera potencia en introducir a ambos agentes. Así, el primer ballenero que surcará el Pacífico en 1787 será el inglés Amelie. Tras él, el tráfico de estos comerciantes se disparará en el segundo cuarto del siglo romántico, llegando a existir entorno a 675 balleneros para los años cuarenta del siglo decimonónico, ${ }^{17}$ muchos de los cuales enarbolaban la bandera estadounidense. Por otro lado, e poder del elemento ideológico para atraer a un grupo a la órbita de la potencias, propició que éstas invirtieran en la difusión de sus comunidades religiosas. De esta forma, en 1797 se introduce la London Missionary Societe (LMS), y en el primer tercio del siglo XIX la acción de los metodistas estadounidenses y el Sacre Couer galo se visualizará a lo largo del Pacífico. Dados los logros de los grupos misioneros, otros países como Rusia o España apostarán también por la presencia de sus religiosos por este océano, produciéndose casos tan curiosos como la colonia de Nueva Nursia, sustentada por los misioneros españoles en el corazón de Australia occidental. ${ }^{8}$

Sin embargo, a pesar del incremento del interés del sistema internacional en el Pacífico, las potencias fueron muy reticentes a declarar estos territorios bajo su soberanía por los altos costes que ello le acarreaba. Por consiguiente, durante la primera mitad del siglo XIX éstas recelaron de colonizar el área, incorporándola a su zona de influencia por medio de sus lobbies económicos y religiosos. Sin embargo, esta tendencia se romperá con el olor del acecho de las potencias rivales, como manifiesta el traslado de la administración colonial de la metrópoli en Australia, Nueva Zelanda y Tahití. Éstos serán los únicos territorios de la Oceanía desconocida por los tiempos modernos, ${ }^{19}$ que fueron colonizados por los europeos antes de que finalizase la primera mitad del siglo XIX, como consecuencia de la rivalidad entre Francia y Reino Unido. Pero, está dinámica va a trastornarse en las segunda mitad de la susodicha centuria, debido a que las potencias desarrollarán la anexión o la declaración del protectorado como las prácticas que consolidan su dominio (como consecuencia del incremento de potencias internacionales que desean expandirse por el área y el aumento del ansia de las antiguas). Así pues, el peso del Pacífico aumentará considerablemente en el diseño del sistema internacional debido a una serie de factores de múltiple índole. Entre ellos podríamos aludir: al cambio de la estructura económica, dejando de percibirse la Mar del Sur como el océano de los ballenero ${ }^{20}$ y concebirse como un espacio donde se puede obtener valiosísimos recursos naturales como la copra, el guano o el sándalo; el aumento del poder de las nuevas potencias emergentes como Estados Unidos -la cual acrecienta su poder internacional tras superar su guerra civil (1860-

15 Los viajes emprendidos por: Adam Johann von Krusenstern y Yurii Lisianskiii (1803-1806), Leontii Hagemeister (1806-1809), Vasilii Gilouniv (1809-1814/1816), Mihail Lazerev (1813-1814/1819-1821), Fëdor Petrovich Lütke (primer viaje 1817-1819), rerdinand von Wrangel (1820-1824/1825-1827), Otto

16 Donald B. FREEMAN: The Pacific, London-New York, Routledge, 2010.

17 Ersnest S. DODGE: Islands and empires: Western impact on the Pacific and East Asia, London, Oxford University, 1976, p. 69

18 AA. VV.: The story of New Norcia: the West Australian Benedictine Mission, New Norcia, W.A.: The Benedictine Community of New Norcia, s.a. [1950]

19 Por tanto, no computamos ni las Marianas españolas ni la Guinea holandesa.

20 Actividad que, por cierto, vive su ocaso en los años cincuentas de este siglo protagonista, ante el

aumento de la demanda de petróleo como consecuencia del desarrollo del motor de combustión.
1865)-, y Japón -que, tras protagonizar su revolución Meiji (1868), se incorpora a las prácticas imperialistas-;21 la apertura del canal de Suez (1869) que acortará las distancia entre la Ma del Sur y Europa; el comienzo de los trabajos para construir el Canal de Panamá en 1881; y los efectos que causan el desarrollo del Imperialismo de los Estados europeos, donde no sólo es tablecerán una lucha encarecida Reino Unido y Francia como en el caso de la colonización de África, sino que a finales de la centuria irrumpirá con fuerza Alemania, ${ }^{22}$ ante sus deseos de usar el Pacífico como zona donde desarrollar su colonialismo.

El resultado de ello, será el aumento de la conflictividad internacional de estas aguas, de hecho, a finales del siglo (concretamente en 1889), el control por una determinada zona de la Oceanía (Samoa) va a deparar en un amago de conflicto bélico entre las potencias internacionales. Este episodio es sólo un ejemplo de cómo las prácticas agresivas de estos actores internacionales se acrecentará en la totalidad de los archipiélagos de este océano, al incluir sus islas dentro de las redes de poder internacional, culminando, de esta forma, el proceso de "occidentalización" iniciado en el siglo XV por los poderes ibéricos.

\section{Conclusiones}

El desarrollo de las dinámicas imperiales por parte del sistema internacional del siglo XIX supondrá la plena incorporación del área del Pacifico en esta sociedad global. Pues, durante la Edad Moderna la mayoría de los actos para legitimar los derechos de conquista de las potencias occidentales en la Oceanía no fueron acatados por la estructura del poder (como denota que desde el siglo XVI llegasen a estas islas diferentes expediciones europeas que ubicaron símbolos -como banderas o cruces religiosas- que no fueron reconocidos por el orden mundial). Sin embargo, la coyuntura decimonónica provocará el progresivo respecto de la extensión diplomática de las potencias mundiales en la Mar del Sur, dada la importancia geoestratégica y económica que ésta adquiere. De esta forma, el sistema internacional se preocupará en extender sus reglas de juego hasta puntos hasta entonces marginados, aconteciendo la centuria romántica a un redescubrimiento del Pacífico, como evidencia el desarrollo vertiginoso del fenómeno colonizador, que extenderá los poderes "occidentales" en la región. Las potencias se expandirán mediante la aplicación de un determinado modelo colonial caracterizado por el desarrollo de un proceso que sigue las siguientes etapas:

1. El reconocimiento del área de las expediciones científicas: Desde la circunnavegación hispánica de Magallanes y Elcano (1519-1522) las aguas de la Mar del Sur habían sido recorridas por diferentes naciones a lo largo de la Edad Moderna. Sin embargo, hasta mediados del siglo XVIII las potencias internacionales (principalmente Francia y Reino Unido) no apostarán por desarrollar una serie de expediciones científicas que explorasen el interior de la Oceanía, para conocer si es oportuno su dominio. Este proceso se manifestará de forma más clarividente en el siglo XIX, como consecuencia de la asunción de las prácticas imperialistas de todas aquellas potencias que entienden que la colonización de ciertas áreas del Pacífico pueden ayudar a aumentar sus cotas de poder.

21 El protagonismo que adquieren estas nuevas potencias emergentes se puede visualizar con una de las mayores expediciones que se desarrollaran en el este Océano, desarrollada conjuntamente entre Japón y EE.UU entre 1873-1874 para desarrollar el cable telefónico entre ambas costas, descubriendo las islas japonesas de las Aleutianas y las Trenches. Esta exploración está influida por los contactos establecidos por la North Pacific Exploring Expedition realizada entre 1853-1855. por los contactos establecidos por la North Pacific Exploring Expedition realizada entre 1853-1855,
liderada en su origen por Cad Walador Ringgold, que llega a Japón y establece buenas relaciones. 22 De hecho, ya a finales de los setentas a plica la política de expedición como carta de presentación De hecho, ya a finales de los setentas aplica la política de expedición como carta de presentación
para demandar territorios en el área. Entre sus expediciones destaca la realizada por Frederick para demandar territorios en el area. Entre sus expediciones destaca la realizada por Frederick Norte entre 1884-1888. 
2. La introducción de sus lobbies: Tras la delimitación de los territorios que son foco de interés de las potencias occidentales gracias a la acción de las expediciones, los Estados imperiales se apoyarán en sus grupos nacionales de presión -principalmente misiones religiosas y comerciantes- para influenciar a la élite oriunda. De esta forma, conseguirán atraer esta área a su zona de influencia sin afrontar los altos costes que puede acarrearle a la metrópoli su ocupación efectiva.

3. El reconocimiento internacional: El avance del Imperialismo incrementará las prácticas agresivas por parte de los diferentes actores internacionales que luchan por acrecentar su poder dentro del sistema internacional. Así, dados los atributos de poder que suponía la colonización de un territorio en el siglo XIX, las potencias mundial consolidarán su área de influencia frente a los deseos expansivos de un rival internacional mediante la proclamación del área como protectorado, anexionándolo posteriormente para acabar con cualquier tipo de especulación expansiva de otro actor global. Obviamente ambas acciones debían ser corroboradas por el sistema internacional, por lo que el uso de los instrumentos de poder de la Política Exterior de los Estados será clave en este cometido (siendo fundamental el papel que desempeñan en este punto los despachos de las cancillerías europeas que discuten el reparte colonial mundial).

Por consiguiente, la mayoría de los puntos del Pacífico fueron protagonistas de estas etapas a lo largo del siglo XIX, acotándose temporalmente las mismas -al multiplicarse las expediciones descubridoras durante la primera mitad de dicha centuria; comenzar a adquirir relevancia los grupos de presión "occidentales" tras el primer tercio del susodicho siglo; y ocupar efectivamente las potencias estas latitudes en su ocaso-. Sin embargo, dada la diversidad social, económica y política que encierra este vasto océano, debemos de matizar que el proceso aludido no es homogéneo, al producirse excepcionalidades. Ya que áreas como Nueva Holanda (donde el Reino Unido, ni siquiera se apoya en sus lobbies para preparar la colonización de Australia, al emprender un tipo conquista tendente a marginar al aborigen) se insertará dentro de la estructura del sistema internacional de forma precoz (si lo comparamos con el resto de Oceanía), mientras que la Micronesia y sus áreas circundantes padecerá el proceso aludido de forma tardía. Pese a ello, los pasos aludidos se podrán manifestar en todas las regiones del Pacífico a lo largo del siglo XIX, dejando esta centuria una impronta tendente a agilizar el proceso de "meeting point" que ha dado lugar a este mundo actual glocalizado, donde los poderes que se insertan en este gran océano son una pieza angular en la estructuración de su sistema internacional. 
EL PNV DE LA II GUERRA MUNDIAL A LA GUERRA

FRÍA (1945-1950). ANTÓN IRALA Y LA POLÍTICA DE

"BURUJABETZA"

David Mota Zurdo

Universidad del País Vasco-Euskal Herriko Unibertsitatea

\section{Introducción}

La II Guerra Mundial fue uno de los conflictos más cruentos y con mayor número de bajas de la Historia de la humanidad. Los campos de concentración y la represión ejercida por el Tercer Reich alemán hacia todo aquel discordante político, ideológico o religioso fue una dura prueba para una sociedad internacional que quedó moralmente dañada y que buscó alivio a su conciencia procesando en Núremberg a los principales responsables nazis de los crímenes y abusos contra la Humanidad. 'Tras el cese de las hostilidades, según han sostenido algunos historiadores, se vislumbraron dos polos políticos diferenciados, Estados Unidos y la Unión Soviética, que no tardaron en enfrentarse al defender dos concepciones diferentes de entender el mundo: capitalismo versus comunismo. ${ }^{2} \mathrm{~A}$ pesar de que reiteradamente se ha incidido en el importante protagonismo de estas dos superpotencias, así como la situación de encrucijada política en la que se encontró Europa entre 1947 y 1989, considerándosela en ocasiones como un mero instrumento al servicio de soviéticos y estadounidenses, hemos de destacar que diferentes personalidades como Jean Monnet, Denis de Rougemont, Alcide De Gasperi, Konrad Adenauer y Robert Schuman -por mencionar tan solo algunos nombres- que, siendo inspiradores de una nueva concepción de unidad europea como medio que garantizara el establecimiento de una paz duradera tras la posguerra, abogaron por una tercera vía de construcción de Europa sobre la base de principios como el federalismo y el humanismo cristiano. ${ }^{3}$ La historiografía ha señalado repetidas veces que el Viejo Continente se cimentó sobre la base de los proyectos de quienes han sido etiquetados como padres de Europa, pero se ha olvidado a importantes idealistas que, a pesar de no haber sido aún reconocidos, su papel, aunque fuera a menor escala, tuvo un impacto relevante sobre la construcción europea. ${ }^{4}$.

Durante las décadas de 1940 y 1950 el Partido Nacionalista Vasco (PNV) tuvo un protagonismo destacado dentro del movimiento europeísta y democristiano. Estuvo presente como miembro fundacional en la creación de los Nouvelles Equipes Internationales (NEI), una organización socialdemócrata que ideológicamente se apoyó sobre la doctrina política del humanismo cristiano de Jacques Maritain, que fue considerada como una alternativa al comunismo y al capitalismo durante la Guerra Fría. También participó en el Consejo Federal Español de Movimiento Europeo (constituido en febrero de 1949 en el 11 Avenue Marceau de París, sede

Tony JUDT: Postguerra. Una historia de Europa desde 1945, Madrid, Taurus, 2006, p. 76 y ss.

2 John Lewis GADDIS: La Guerra Fría, Barcelona, RBA, 2008

3 Enrique SAN MIGUEL: La civilización de los inconformistas. El ideal europeo en el pensamiento politico y la acción institucional (1919-1949). Madrid, Fundación Universitaria Española 2005, pp. 202205. José Manuel SAIZ: “La visión cristiana de los padres de Europa”, UNISCI Discussion Papers, 14 Mayo 2007, pp.115-129.

4 Tony JUDT: ¿Una gran ilusión? Un ensayo sobre Europa, Madrid, Taurus, 2013, p. 14 y ss. del Gobierno Vasco en el exilio) y creó un Consejo del Movimiento Europeo con el objetivo de promocionar la identidad europea y sensibilizar a la nación vasca de la necesidad de construir una Europa unida. ${ }^{5}$ Asimismo, en marzo de 1949, el PNV por medio de su declaración política, como José Antonio Aguirre, Manuel Irujo, Antón Irala o Francisco Javier Landaburu, que ya dieron ese paso hacia la democristianización del partido. ${ }^{6}$

Según las investigaciones de algunos autores, los años de la inmediata posguerra mundia han constituido una fase de transición en la historia del PNV, caracterizada, en lo concerniente al activismo político, como una etapa de extremos en la que el partido transitó entre la esperanza y la frustración pasando por la desilusión. Este periodo supuso a su vez un cambio de ciclo, evoluy la frustración pasando por la desilusión. Este periodo supuso a su vez un cambio de ciclo, evolu-
cionando desde posturas pro-republicanas a otras filo-monárquicas, marcado por un horizonte estratégico de búsqueda de representatividad propia en el escenario internacional y de consecución de la independencia territorial del País Vasco, previa restauración democrática en España. Para ello, haciendo uso de una estrategia basada en la resistencia interior como forma de lucha más eficaz contra el régimen, fue escorando su política hacia la conjugación de dos ámbitos, por un lado, hostigando al régimen dentro de España-aunque con dificultades debido a la caída de la red Álava, principal núcleo del PNV en el interior- a efectos de demostrar a las cancillerías internacionales su fuerte presencia interior $y$, por otro lado, llevando a cabo una serie de medidas orientadas hacia la unión con otras fuerzas de oposición, tales como la reorganización del partido, el apoyo al Gobierno republicano, el favorecimiento del plan de restauración monárquica de Indalecio Prieto, el impulso a las huelgas generales de 1947 y 1951 -dos de las más importantes del franquismo-y la participación en movimientos europeístas y federalistas.?

Con este artículo quiero traer a colación la discusión doctrinal existente dentro del seno del Partido Nacionalista Vasco en un año, 1949, que puede ser considerado clave en la Historia de dicho partido al constatarse su definitiva evolución hacia la democracia cristiana. Una controversia centrada en aspectos como la libertad, (con)federación y principio de nacionalidades sobre los que los principales ideólogos del PNV, Manuel Eguileor y Ceferino de Jeméin discutieron largo y tendido con los políticos del ala más pragmática del partido, Julio Jáuregu y Antón Irala. Considero suficientemente importante esta polémica doctrinal y estratégica por el papel desempeñado por el Partido Nacionalista Vasco dentro del Gobierno Vasco en el exilio el europeísmo y el federalismo.

\section{¿Quién fue Antón Irala?}

Antón Irala nació en Bilbao en el año 1909. Entre 1914 y 1919 realizó los estudios de educación primaria en el colegio de los Sagrados Corazones de Santo Domingo de la Calzada (La Rioja). Posteriormente estudió el bachillerato en el colegio de los Capuchinos de Lecaroz (Navarra) y en 1932 se licenció en Derecho por la Universidad de Deusto (Vizcaya). Tras afiliarse al PNV

5 Leyre ARRIETA: “El simbolismo poliédrico del no 11 de la Avenue Marceau de París", en Ludger MEES: La celebración de la nación. Simbolos, mitos y lugares de memoria, Granada, Comares Historia, 2012, pp. 117-134. ID.: Estación Europa: Ia política europeista del PNV en el exilio (1945-1977), Madrid, Tecnos, 2007

6 Javier TUSELL: Historia de la democracia cristiana en España, Madrid, Cuadernos para el diálogo, 1974, p. 98 y ss. José Luis DE LA GRANJA: “El PNV, del integrismo hacia la democracia cristiana”, en El nacionalismo vasco. Un siglo de Historia, Madrid, Tecnos, 2005, pp. 127-144. Fernando DE MEER "La Guerra Civil (1936 -1939). Nacionalismo y democracia", Vasconia, 26 (1996), pp. 239-243.

7 En cuanto a la organización del PNV en el interior, Santiago DE PABLO: En tierra de nadie. Los nacionalistas vascos en Álava, Vitoria-Gasteiz lkusager, 2008 , p. 281 y ss. Respecto al nadie. Lo nacionalistas vascos en Alava, Vitoria-Gasteiz, Ikusager, 2008, p. 281 y ss. Respecto al europeísmo
del nacionalismo vasco, Leyre ARRIETA: Estación Europa. La politica europeista del PNV en el exidel nacionalismo vasco, Leyre ARRIETA: Estación Europa. La politica europeista del PNV en el exi-
lio(1945-1977). Madrid, Tecnos, 2007 p. 73. ID. “Landaburu, el alavés europeista”, Sancho el sabio, 31 lio(1945-1977), Madrid, Tecnos, 2007 p. 73. Í.., "Landaburu, el alaves europeista", Sancho el sabio, 3 Nacionalista Vasco (1895-2005) Barco y Ludger MEES: El péndulo pat 
durante su etapa de estudiante, formó parte de la Juventud Vasca de Bilbao, a la que también pertenecían sus hermanos mayores. Durante el periodo republicano fue miembro del Secretariado General del partido en el que en abril de 1932, junto a Manuel Eguileor, José Luis Irisarri, Esteban Urquiaga "Lauaxeta" y Julio Jáuregui, desarrolló una importante labor de promoción del primer día de la patria vasca o Aberri Eguna en Bilbao, en el que fueron congregadas varios miles de personas. ${ }^{8}$ Un año después, también participó en el Aberri Eguna celebrado en San Sebastián, bajo el lema "Euzkadi-Europa", en el que intervinieron Telesforo Monzón, José Antonio Aguirre y Francisco Javier Landáburu, y que supuso uno de los primeros hitos en los que se internacionalizó el problema vasco, es decir las dificultades de articulación de las provincias vascas dentro del Estado español. ${ }^{9}$ Ocupó la secretaría general de Eusko Ikastola Batza (Federación de Escuelas Vascas), cargo que compaginó con el ejercicio de la abogacía en un bufete de abogados situado en la calle Iparraguirre $n^{\circ} 49$ de Bilbao, junto con un puesto de dirección en la conocida empresa vizcaína Harino Panadera Sociedad Anónima. ${ }^{10}$ Tras la constitución de Gobierno Vasco en octubre de 1936, fue nombrado secretario general de la Presidencia encargado de la organización y coordinación en tiempo de guerra. Tras la caída del frente norte, fue miembro de la delegación vasca situada en la Avenue Marceau de París, cuyo edificio adquirió el PNV con el oro del Banco de España que Irala consiguió traspasar de Bilbao a Baiona durante la guerra civil española. En 1938 fue nombrado delegado del Gobierno Vasco en Estados Unidos, donde formó parte del Servicio Vasco de Información. Durante la Segunda Guerra Mundial estableció contacto con el Federal Bureau of Investigation (FBI) y la Office of Strategic Services (OSS), organizando un grupo de espionaje para contrarrestar la penetración nazi, nipona, fascista y comunista en América Latina." Asimismo, fue representante del sindicato católico Solidaridad de Trabajadores Vascos-Eusko Langileen Elkartasuna en la Gran Manzana, y, junto a Jesús Galíndez, representó al Gobierno de Euzkadi en la O.N.U. en las sesiones celebradas entre 1945 y $1949 .{ }^{12}$ Durante el exilio participó en diversas organizaciones, como la Asociación de Juristas vasco-navarros, integrada en la Association Internationale des Juristes Démocrates. ${ }^{3}$

8 Jesús CASOUETE y José Luis DE LA GRANJA: “La celebración de la patria vasca: invención y evolución del Aberri Eguna", en Ludger MEES: La celebración de la nación. Simbolos, mitos, lugares de memoria, Granada, Comares Historia, 2012, pp. 135-157. ID.: "Aberri Eguna", en Santiago DE PABLO y Ludger M (et al.): Diccionario ilustrado de simbolos del nacionalismo vasco, Madrid, Tecnos, 2012, pp. 33-57.

9 Para el problema vasco véase: Mercedes ARBAIZA: La cuestión vasca. Una mirada desde la Historia, Bilbao, UPV-EHU, 200o. Gurutz JÁUREGUI: Contra el estado-nación: en torno al hecho y la cuestión nacional, Madrid, Siglo XXI, 1988. Luis CASTELLS y Arturo CAJAL (eds.): La autonomía vasca en la España contemporánea (1808-2008), Madrid, Marcial Pons, 2009. En relación al marco europeo o internacionalización de la cuestión vasca: Leyre ARRIETA: “Europa”, en Santiago DE PABLO y Ludger MEES (et al.): Diccionario ilustrado de símbolos..., pp. 282-293.

10 "Application for employment and personal history statement", National Archives and Records Administration (NARA) at College Park Maryland (EEUU), Office of Strategic Services Files, Signatura: RG 226/250/64/33/6 Leg. 7519, p. 8 .

11 María de los Ángeles ORDAZ: "El FBI y los vascos del exilio de 1939 en Estados Unidos", en Ronald ESCOBEDO, Ana DE ZABALLA y Óscar ÁLVAREZ: Emigración y redes sociales de los vascos en América, Vitoria, UPV-EHU, 1996, pp. 231-232. Juan Carlos JIMÉNEZ DE ABERASTURI y Rafael MORENO: Al servicio del extranjero. Historia del Servicio Vasco de Información (1936-1943), Madrid, Antonio Machado Libros, 2009, pp. 404 y ss.

12 Gobierno de Euzkadi era la denominación utilizada en la época para referirse al Gobierno vasco. Aqui se respeta la grafía original, pues Euskadi con " $z$ " es un término que no es aceptado por la Academia de la Lengua Vasca. Respecto al sindicato ELA-STV, María Luisa GARDE: ELA a través de dos guerras (1936-1946), Pamplona, Pamiela, 2001, p. 288. Dario ANSEL: ELA en la Segunda República. Evolución sindicalista de una organización obrera, Tafalla, Txalaparta, 2011. 13 En este foro participaron otros exiliados licenciados en Derecho del PNV, como el presidente vasco Irazusta, Jesús María Leizaola, José María Lasarte, Manuel de Irujo o Francisco Javier de Landaburu.

\begin{abstract}
Turia Leizaola, Jose Maria Lasarte, Manuel de Irujo o Francisco Javier de
\end{abstract}
Según el modelo de análisis aportado por José Luis de la Granja, Antón Irala formó parte de una generación de nacionalistas vascos nacidos en torno al año 1900, que con el advenimiento de la II República comenzaron a tener peso en el escenario político estatal'14. Estos contribuyeron a la evolución política del PNV Ilevándolo desde el integrismo político derechista al centro, para terminar aproximándolo estratégicamente a las izquierdas, en pos de la consecución del Estatuto Vasco. Ideológicamente, dieron el paso del integrismo a la asunción de postulados democristianos y, aunque esta generación fue distinta de la rama más ortodoxa del nacionalismo vasco, siguió unido a ella por el respeto a los principios fundamentales de la doctrina aranista. En cierto modo, fueron capaces de mantener la fidelidad a la filosofía del partido reinterpretando sus principios de forma más laxa y dinámica. ${ }^{15}$

\section{¿Cuál era la situación del PNV en la inmediata posguerra?}

Con la finalización de la guerra civil española en abril de 1939, enterrada la República, el Gobierno Vasco -nacido en octubre de 1936- prosiguió con el desarrollo de una política exterior propia, tal y como ya había hecho durante el conflicto, al haber sobrepasado varias de las disposiciones contempladas en el Estatuto de Autonomía de 1936 (artículo 9) y en la Constitución Republicana de 1931 (artículo 14). ${ }^{16}$ Para el Gobierno Vasco y el PNV, ante el ambiente de conflictividad que se vivía en Europa, la única alternativa viable pasaba por la realización de maniobras independientes dentro de la provechosa coyuntura internacional. ${ }^{77}$ De este modo, con el estallido de la Segunda Guerra Mundial, la política vasca se concentró en mostrar su apoyo a los Aliados ante una hipotética colaboración de Franco a favor de las potencias del Eje y, en consecuencia, el Gobierno encabezado por el jeltzale José Antonio Aguirre buscó engarzar a Euskadi dentro de los planes de las potencias occidentales (Francia, Gran Bretaña y Estados Unidos, principalmente) con el objetivo de que cuando acabara la guerra pudieran recuperar el autogobierno sobre el territorio vasco. ${ }^{18}$

Véase José Luis ORELLA: "Los juristas vasco-navarros exiliados y su participación en la Association Internationale des Juristes Démocrates (1945-1950)", Sancho el Sabio, 28 (2008), pp. 39-76.

14 José Luis DE LA GRANJA: "El legado de Aguirre y la generación nacionalista de 1936", Cuadernos de Alzate, 17 (1997), p. 69-83.

15 Ibid., p. 71. Para profundizar más sobre la evolución ideológica del PNV en esta etapa véase Javier TUSELL, Historia de la democracia cristiana en España, Madrid, Cuadernos para el diálogo, 1974. José Luis DE LA GRANJA: "El PNV, del integrismo hacia la democracia cristiana", en El nacionalismo vasco. Un siglo de Historia, Madrid, Tecnos, 2005, pp. 127-144 y Fernando DE MEER: "La Guerra Civil (1936 -1939). Nacionalismo y democracia", Vasconia, 26 (1998), pp. 239-244.

16 Artículo 9: "Las autoridades del País Vasco tomarán las medidas necesarias para la ejecución de los tratados y convenios que versen sobre materias atribuidas, total o parcialmente, a la competencia regional por el presente Estatuto. Si no lo hicieran en tiempo oportuno, corresponderá adopta dichas medidas al Gobierno de la República. Por tener a su cargo la totalidad de las relaciones exteriores [la cursiva es mía], ejercerá siempre la alta inspección sobre el cumplimiento de los referidos tratados y convenios y sobre la observación de los principios del derecho de gentes. Todos los asuntos que reduzcan este carácter, como la participación oficial en Exposiciones y Congresos internacionales, la relación con los españoles residentes en el extranjero o cualesquiera otros análogos, serán de la exclusiva competencia del Estado". En (pàgina web consultada el 5-3-2013) http:// www.lehendakaritza.ejgv.euskadi.net/r48-bopv2/es/bopv2/datos/1936/10/3600oo1a.shtml. Artículo 14: es "de la exclusiva competencia del Estado español la legislación y la ejecución directa en las materias siguientes:[...]3. Representación diplomática y consular y, en general, la del Estado en el exterior; declaración de guerra; Tratados de paz; régimen de Colonias y Protectorado, y toda clase de relaciones internacionales". En http://www.congreso.es/docu/constituciones/1931/1931 cd.pdf, página consultada el 5-3-2013

17 Imanol VILLA: Historia del País Vasco durante el Franquismo, Madrid, Sílex, 2009. p. 94

18 Respecto a la colaboración de Franco con las potencias del Eje, Javier TUSELL: "La tentación fascista y la supervivencia (1939-1951)", en Historia de España. Guerra y dictadura, Tomo 16, Madrid, Espasa 
Durante la guerra, el PNV y el Gobierno Vasco pusieron a favor de los Aliados toda su infraestructura político-propagandística e informativa (creación de un batallón militar ad hoc para luchar en los últimos frentes abiertos en el sur de Francia, trabajadores para la industria de guerra, servicios de espionaje, etc.). El lehendakari Aguirre ofreció la colaboración del Gobierno Vasco sin ningún tipo de condicionamiento, decisión que le costó no pocos enfrentamientos con Manuel Irujo (quien se había puesto al frente de la política vasca en el exilio entre julio de 1940 y agosto de 1941, habiendo creado para ello el Consejo Nacional Vasco), con el objetivo de hacer una declaración de intenciones y de marcar un hecho político para que, una vez victoriosas las potencias aliadas e iniciados los tratados de paz, el País Vasco formara parte de la reorganización territorial posbélica como Estado independiente..$^{19}$

Durante la posguerra mundial, la situación cambió drásticamente para el PNV, el Gobierno vasco y los restos de las instituciones políticas republicanas españolas en el exilio. Estos pensaron que derrotados los totalitarismos, el movimiento lógico pasaba por acabar con uno de los pocos regímenes que había firmado un tratado de amistad con el Eje y que, al igual que Portugal, se mantenía en pie. Sin embargo, Estados Unidos (el gran vencedor), una de las principales potencias con la que los vascos habían colaborado, sobre todo en Latinoamérica -aunque también en Francia y Gran Bretaña-, optó por defender sus propios intereses, en detrimento de unos teóricos compromisos adquiridos con los nacionalistas vascos, y practicó una política de carácter pragmático que, respecto al ámbito europeo-como ya había hecho en muchas otras ocasiones, como en el caso de la neutralidad durante la guerra civil españolasiguió la estela marcada por los británicos. Los problemas que acuciaban en aquel momento habían cambiado, ahora era el comunismo el que acechaba Europa, y, la España de Franco se presentaba como un excelente baluarte, como un bastión inexpugnable frente al bolchevis mo, muy diferente de unos nacionalistas vascos acusados de "rojo-separatismo" que estaban aliados con los republicanos españoles..$^{20}$ Así quedó expresado en un informe de la Central Intelligence Agency (CIA) de 1947:

Calpe, 2004, p. 504 y ss. En cuanto al término jeltzale destacar que hace referencia al lema JEL del PNV cuyo significado es Jaungoikoa eta Legi Zaharra (Dios y ley vieja). Es utilizado para describir a los políticos de esta tendencia. La estrategia política del gobierno Aguirre está muy bien explicada en Juan Carlos JIMÉNEZ DE ABERASTURI: De la derrota a la esperanza. Políticas vascas durante la II Guerra Mundial (1937-1947), Oñati, IVAP, 1999, p. 36 y ss. Santiago DE PABLO y Ludger MEES: El péndulo patriótico. Historia del Partido Nacionalista Vasco (1895-2005), Barcelona, Crítica, 2005, p. 228. 19 El Consejo Nacional Vasco fue creado por Irujo, ante la desaparición del lehendakari Aguirre en la
Europa ocupada por los nazis, como órgano rector de la política vasca en el exilio, con la intención de unir a todos los vascos (incluidos los navarros) y con la finalidad de aunar todos sus esfuerzos de lado de las democracias en la lucha contra los totalitarismos. Véase Juan Carlos JIMÉNEZ DE ABERASTURI: "Irujo en Londres. 1939-1945", Vasconia, 32 (2002), pp.99-132; ID.: De la derrota a la esABERASTURI: "Irujo en Londres. 1939-1945", Vasconia, 32 (2002), pp.99-132; ID.: De la derrota a la esperanza. Politicas vascas durante la II Guerra Mundial (1937-1947), , Oñati, IVAP, 1998; José Luis DE LA LRANJA, Justo BERAMENDI y Pere ANGUERA: "Los nacionalismos bajo la dictadura de Franco", en La España de los nacionalismos y las autonomias, Madrid, Sintesis, 2001, pp. 165-193; Xosé Manoel
NÚNNEZ: “Los nacionalismos periféricos entre el exilio y la renovación”, en Los nacionalismos en la NÚNEZ: "Los nacionalismos perifericos entre el exilio y la renovación", en Los nacionalismos en la
España contemporánea (s. XIX y XX), Barcelona, Hipótesis, 1999, pp. 119-125; José Antonio PÉREZ:

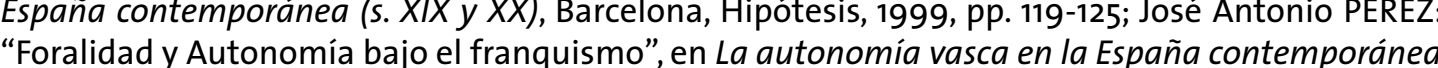
(1808-2008), Madrid, Marcial Pons, 2009, pp. 285-321; José Luis DE LA GRANJA: El siglo de Euskadi. EI nacionalismo vasco en la España del siglo XX, Madrid, Tecnos, 2003.

20 Sobre esta cuestión véase Ángel VIÑAS: En las garras del águila. Los pactos con Estados Unidos, de Francisco Franco a Felipe Conzález (1945-1995). Barcelona Crítica 2003 p. 55 yss. MÁs: La Batalla del Wolframio. Estados Unidos y España de Pearl Harbora la Guerra Fria (1941-1947) Madrid, Cátedra 2010 272 y ss. Fernando TERMIS: Renunciando a todo. El régimen franquista $y$ los Estados Unidos desde 1945 hasta 1963, Madrid, Biblioteca Nueva UNED, 2005, p. 12 y ss.
However antithetic Franco's political philosophy may be toward Democracy, he must presently favor the Western Powers as the only alternative to the Eastern, toward which he has demonstrated his antagonism [...]. The Franco Government, furthermore, is relatively secure for the time being. ${ }^{21}$

Este desesperanzador contexto causó un gran desánimo a los dirigentes políticos vascos, que interpretaron esta actitud de las democracias como una soberana traición a los principios del derecho internacional y que les condenaba al ostracismo. Francisco J. Landáburu, uno de los principales políticos del PNV durante el exilio, en su obra La Causa del Pueblo Vasco, señaló lo siguiente:

Nos ha hecho daño en nuestra conciencia sencilla que quien dirigió tan brillantemente la segunda guerra mundial por salvar la democracia, y cuya causa seguimos muchos vascos a través del mundo y aún en territorio enemigo con riesgo evidente de nuestras vidas, haya claudicado tanto en sus principios [...]. Las vestales de la democracia clásica han caído en la trampa estúpida del oportunismo, que consiste en que para combatir la tiranía hay que apoyarse en ciertos tiranos. Unos y otros fomentan la dictadura porque lo único importante para ellos es el color de las libreas de los déspotas. La moral una vez más, cambia con la ocasión y con la geografía. ${ }^{22}$

Aunque pudiera parecer que a los vascos se les cerraron todas las puertas, el establecimiento de la paz y los planes de reconstrucción europea sobre una base política demócrata cristiana, abrió una nueva vía de la que fueron actores protagonistas. Al final de la Guerra Mundial, los partidos democristianos se articularon como una alternativa política, defensora de la construcción de un ente supraestatal, libre de los viciados límites del nacionalismo, que marcó un antes y un después en el discurso político del PNV.

\section{Discusión doctrinal Eguileor, Irala, Jeméin y Jáuregui}

Paralelamente a estos altibajos en la política del exilio nacionalista vasco, surgió en el seno del PNV un debate de capital importancia entre Ceferino Jeméin, Julio Jáuregui y Antón Irala. Uno de los temas que más ampollas levantó entre estos destacados dirigentes jeltzales fue el término de unidad política y su significado, entendido dentro de la ortodoxia del partido como parte inherente a la idea de confederación nacional vasca -conocida como Confederación Euzkadiana- propuesta por Sabino Arana entre finales del siglo XIX y principios del XX. ${ }^{23}$ Para Antón Irala, tanto la unidad política como la idea de confederación eran aspectos que se complementaban e incluso uno se cimentaba sobre el otro. Sin embargo, diferenciándose de Jeméin, planteaba que la confederación debía fundamentarse sobre la libertad para separarse de las regiones y no sobre el derecho a separarse, ya que los concebía como conceptos completamente distintos y contradictorios. Lo expuso de la siguiente manera:

La simple afirmación de libertad para separarse no tiene sentido si sobre ella no se vuelca todo el contenido de la doctrina y filosofía cristiana sobre la libertad. Para el cristiano el

21 Informe de la CIA "The political future of Spain", 5 de diciembre de 1947, FOIA, ORE 56, p. 1. En http://www.foia.cia.gov/sites/default/files/document_conversions/89801/DOC_0000256629. pdf (web visitada en noviembre de 2012)

22 Francisco Javier LANDABURU: La causa del Pueblo Vasco. Razones de una actitud. Posibilidades de una actuación, Paris, s.n., 1956, pp. 5-6.

23 Antonio ELORZA: Un pueblo escogido: génesis, definición y desarrollo del nacionalismo, Barcelona, Crítica, 2001, p. 329 
concepto de libertad lleva consigo sentido moral. La libertad es condición imprescindible para que el hombre camine hacia la perfección y sólo actuando en y para la perfección se alcanza la libertad. La filosofía cristiana distingue perfectamente el libre albedrío (facultad, derecho a la libertad). Son términos distintos. La libertad consiste en utilizar el libre albedrío para el cumplimiento del deber. Si se utiliza el libre albedrío para eludir el cum plimiento del deber, se lleva a cabo un acto irracional, por decir así anti-humano, que no supone un ejercicio de libertad. [...] confundir [...] el concepto de libertad con el de derecho equivale tanto como a confundir el libre albedrio con la libertad; algo parecido como a emplear indistintamente la palabra democracia tal como la usan los occidentales y tal como la usan los soviéticos. ${ }^{24}$

Para Irala el mejor ejemplo de unidad política a través de la (con)federación se encontraba reflejado en la Constitución de los Estados Unidos de 1787. Así se lo explicó a Jeméin:

Nosotros el pueblo de los Estados Unidos [...] para formar una Unión más perfecta (sentido de perfección, no de unión más estrecha), hacer justicia, garantizar la tranquilidad doméstica, proveer una defensa común, promover el bienestar general, y asegurar las bendiciones de la libertad para nosotros y para nuestros hijos, ordenamos y establecemos esta Constitución de los Estados Unidos de América Como ve Ud no se habla de soberanía, de unidad nacional, ni de derechos... La esencia es: perfección = libertad. Ninguna de sus palabras tienen desperdicio. ${ }^{25}$

Respecto a esta cuestión Julio Jáuregui respondió a Irala en los siguientes términos:

Y ahí dejo a Irala, la solución de este problema; Sin Constitución Americana o con la Constitución Americana vigente, si todos o el noventa y cinco por ciento de los ciudadanos americanos residentes en el Estado miembro de California, quisieran que su territorio y que sus ciudadanos quedaran separados de los Estados Unidos Americanos y desearan incorporarse a los Estados Unidos Mexicanos, hoy limítrofe con ellos, ¿tendrían o no el derecho a separarse de Norteamérica y unirse a México? Para mí no ofrece duda la contestación afirmativa, al menos en derecho natural. ${ }^{26}$

Otro de los problemas que detectó y que Irala se propuso reinterpretar fue el derecho de una nación a constituirse como Estado sobre la base del principio de nacionalidades. En esta línea señala ba que Pascual Estanislao Mancini, padre de la doctrina que consideraba a la nación como fundamento del Derecho Internacional, sabía muy poco de libertad por su condición de liberal italiano. A su modo de ver, cuando se trataba sobre este asunto, la terminología utilizada era sino confusa al menos matizable. Irala se lo explicó así a Jeméin:"Para el bueno de Mancini era indudable que la palabra derecho había que tomarla en el sentido de tiene que o debe porque toda su batería la dirigió contra los Estados pontificios que debían desaparecer, según él, para formar la unidad nacional italiana". ${ }^{27}$ Para Irala, el derecho de una nación a constituirse como Estado no sólo era un término anárquico y caótico sino que suponía otorgar la misma legitimidad al derecho de separación, y añadía que "una nacionalidad no tenía porque tener derecho a ser independiente si con la independencia lejos de perfeccionarse se descompone"

24 Carta de Antón Irala a Ceferino Jeméin, 9-11-1948, sin lugar, AHNV, Fondo EBB 308-17, p. 4.

25 (La cursiva es mía). Carta de Antón Irala a Ceferino Jeméin, 25-11-1948, sin lugar, AHNV, Fondo EBB 308-17, p. 6.

26 Carta de Julio Jáuregui a Ceferino Jeméin, 23-11-1948, México D.F., AHNV, EBB 308-17 p. 5

27 Carta de Antón Irala a Ceferino Jeméin, 29-11-1948, sin lugar, AHNV, Fondo EBB 308-17, p. 3
.$^{28}$ De hecho, podía ocurrir que dentro de una nación, parte de ella quisiera ejercer su libertad a separarse, en cuyo caso condicionaría y sometería al resto pudiendo provocar conflictos. En clara referencia al régimen franquista, así lo explicó en la correspondencia mantenida con Ceferino Jeméin:

Y puede ocurrir que dentro de no mucho tiempo, la sociedad internacional tenga necesidad de romper a cañonazos la independencia de algunos que, basados en el principio de las nacionalidades, quieran utilizarla para la opresión de sus miembros, o para perturbar la comunidad internacional. ${ }^{29}$

Este conjunto de ideas, compendiadas en la tesis de burujabetza, se convirtieron en la premisa básica para toda su labor política durante el exilio, que locuazmente expuso a Ceferino Jeméin, Julio Jáuregui y Manuel de la Sota a través del siguiente ejemplo:

Diríamos que para el euzkeldun el concepto de libertad se expresaría de la siguiente manera: "gizona, almenez eta azkeixanik, bere buruban jaube ixan bihar da (Almenduak lotuezik bere buruba jaube biar dau). Apurando con la mejor buena voluntad el idioma español, podríamos traducir: Por medio de su libre albedrío y siendo libre, el hombre debe alcanzar la libertad. Pero hay que tener en cuanta que corrientemente filósofos y políticos más próximos a nuestra manera de pensar traducen de hecho la frase euzkerica en sus escritos y soflamas de la siguiente manera. El hombre que tiene libertad porque es hombre, el está en libertad adquiere la libertad, frase de expresión absurda y de contenido ininteligible. ${ }^{30}$

Para Irala nadie tenía derecho a privar al hombre de la razón por medios artificiosos, o emborracharle o hipnotizarle, lo que a su vez llevaba implícito que ninguna sociedad o nación actuara en este mismo sentido contra la voluntad individual. Para él, desde una concepción cristiana, la premisa de "bere buruaren jaube" (ser consciente de) impregnaba todos los ámbitos de la política:

Al hablar de la libertad se suele referir comúnmente a libertad económica, libertad política, libertad religiosa, etc. Todos estos conceptos no son más que aspectos del bere buruban jaube ixatia. En efecto, el hombre, para alcanzar esta situación, necesita medios materiales (libertad económica), ausencia de coacción por parte de las entidades políticas u otras que le priven fundamentalmente de ser azke (libertad política); precisa igualmente que nadie le impida cumplir con sus deberes para con Dios (libertad religiosa), etc. ${ }^{31}$

\section{Conclusiones}

Si bien es cierto que Irala no fue un europeísta nato como Landaburu buena parte del significado que otorgó a ciertos conceptos, como los anteriormente comentados, fue compartido por el ala menos ortodoxa del partido (incluidos los dirigentes del Gobierno Vasco) y marcó parte de su ritmo político a nivel internacional. Estos se mezclaron inextricablemente con la doctrina política de la nueva generación de nacionalistas vascos de 1936 , adaptando la ortodoxia sabiniana a los nuevos tiempos con el objetivo de reubicar al partido. Algunos autores

28 , Ibid., p. 4 .

29 Íbid., pp. 4-5.

30 Informe de Antón Irala a Ceferino Jeméin, sin fecha (¿1949?), sin lugar, AHNV, EBB 308-17, p. 6.

31 lbid, p. 7 
ya han apuntado el peso que pudo jugar Irala en el diseño de la política atlantista y, en menor medida europeísta, del Gobierno Vasco en las décadas de 1940 y $1950 . .^{32}$ Dicha política quedó marcada por una filosofía propia, que intentó aplicar durante todo el exilio, y a la que denominó como burujabetza o bere buruaren jabe izan (ser consciente de los propios pensamientos). ${ }^{33}$ De este modo, trabajó durante todo el exilio por la restauración de la democracia en base a la siguiente premisa: Euzkadi'k bear zaitu (Euskadi te necesita). ${ }^{34}$ Sin embargo, como han manifestado expertos en la política del PNV durante la Guerra Fría, este optimismo "se convirtió paulatinamente y dada la escasez de resultados tangibles que se derivaban de su presencia en congresos y reuniones de las organizaciones europeístas, en una política de la presencia que permitiera conservar esos lazos establecidos entre 1947 y 1949, sin pretensión de inmiscuirse ya en cuestiones de carácter internacional". 35

32 Véase Ludger MEES: El profeta pragmático. Aguirre, el primer lehendakari (1939-1960), Irún, Alberdania, 2006; Iñaki GOIOGANA: "Antón Irala y la primera delegación del Gobierno Vasco en los EEUU", Hermes, 31 (2009) y Iñaki BERNARDO: Galindez: la tumba abierta. Los vascos y los Estados Unidos, Bilbao, Gobierno Vasco, 1993, p. 182.

33 Carta de Antón Irala a Ceferino Jeméin, ¿enero/febrero? 1949, sin lugar, Archivo Histórico del Nacionalismo Vasco (AHNV), Fondo Euskadi Buru Batzar (EBB) 308-17

34 Este lema fue utilizado por la resistencia vasca y fue consigna del PNV en la clandestinidad durante el régimen franquista.

35 Leyre ARRIETA: "Red de relaciones europeas del PNV (1945-1977)", Cuadernos de Historia Contemporánea, 30 (2008), p. 331. 


\section{LA CORONA ESPAÑOLA: PROMOTORA DE LA}

\section{COMUNIDAD IBEROAMERICANA DE NACIONES}

Zorann Petrovici

Universidad Complutense de Madrid

\section{Introducción: la política iberoamericana de España antes del reinado de Juan Carlos}

Si dramático fue el encuentro entre españoles e indígenas americanos en los siglos XV y XVI, también dramática fue la ruptura entre la España peninsular y la España de ultramar en el siglo XIX. Ese dramatismo marcó de manera evidente a ambas sociedades y, por consiguiente, a las relaciones entre ellas, de tal manera que durante largos años serán bastante limitadas ya que se había ido fraguando un clima difícil, tenso, de recelos de unos hacia otros.'

Sin embargo, a principios del siglo XX, y coincidiendo con un ambiente de regeneracionismo de panorama cultural comenzamos a vislumbraruna reactivación de las relaciones con las repúblicas iberoamericanas, ya independientes. Esta corriente, como nos señalan Formentín Ibáñez y Villegas Sanz, tendrá una característica clara: su naturaleza privada e individual, en ningún caso impulsada desde el Estado. ${ }^{2}$ De gran trascendencia será la actuación de la Universidad de Oviedo quien, dado su espíritu americanista, emprenderá un proyecto de acercamiento intelectual a lberoamérica. El viaje que Rafael Altamira llevará a cabo entre 1909 y 1910 a varios países iberoamericanos supuso el espectacular punto de arranque para dicho proyecto, que se hará extensivo a otras instituciones intelectuales y culturales, e igualmente despertará el interés de las autoridades.

Será tan sólo con la dictadura de Primo de Rivera cuando se intensifiquen las relaciones diplomáticas y culturales dando idea de un renovado interés por la América hispana. Ahora bien, el régimen primorriverista reforzará el carácter conservador, tradicionalista y nostálgico que el proyecto americanista había tomado en algunos círculos desde el siglo XIX y será solamente con la llegada de la II República cuando desaparezca esta carga paternalista que se había imprimido al proyecto hispanoamericanista. Con el nuevo régimen igualmente se alcanzará por vez primera el pleno apoyo oficial. No obstante, esta actitud de la II República apareció con fuerza y brillo tan solo en sus primeros momentos de vida. Así, tras el primer bienio "como consecuencia de la inestabilidad política y social creciente, que obliga a orientar todas las fuerzas hacia los problemas internos, los Gobiernos republicanos van a irse olvidando de los iniciales objetivos iberoamericanos."

Como sintetiza Mario HERNÁNDEZ SANCHEZ-BARBA: "La crisis de América del siglo XIX", La Razón, 23 de junio de 2013.

2 Justo FORMENTíN IBÁÑEZ y María José VILLEGAS SANZ: Relaciones culturales entre España y América: La Junta para Ampliación de Estudios, Madrid, MAPFRE, 1992, pp. 47-48.

Para el viaje de Altamira consúltese Rafael ALTAMIRA Y CREVEA: Mi viaje a América, Oviedo, Universidad de Oviedo, 2007 (Madrid, 1911): así como las obras de Gustavo H. PRADO: Rafael Altamira en América (1909-1910) Historia e Historiografia del proyecto americanista de la Universidad de Oviedo, Madrid, CSIC, 2008 y Las lecciones historiográficas de Rafael Altamira en Argentina (1909) Apuntes sobre Ciencia, Universidad y Pedagogía Patriótica, Oviedo, Universidad de Oviedo, 2010.

Celestino del ARENAL: 1976-1992 Una nueva etapa en las relaciones de España con Iberoamérica,

Madrid, Casa de América, 1994, p. 26
La Guerra Civil va a hacer visible "el sentimiento de solidaridad y de comunidad" que existía ya a ambos lados del Atlántico. Por un lado, varias repúblicas iberoamericanas acogerán a miles de exiliados republicanos; por otro lado, ciertos sectores de aquellos países aplaudirán la En el fascismo español esa idea de Hispanidad va a tomar la forma de un pensamiento pseudoimperial encaminado no tanto hacia una concreción territorial - si bien esta arraigará en ciertos sectores - como hacia una percepción espiritual. El objetivo último será afirmar los derechos y la pretensión de España a un área de influencia.

Sin embargo, viendo la necesidad de mantener a toda costa el régimen, las autoridades franquistas empezarán a partir de 1942 un programa de cambio de la configuración de aquél. Entre los cambios que se fueran a emprender estaba el abandono de la idea pseudoimperial en Hispanoamérica: aparece con fuerza la noción de Comunidad Hispánica de Naciones; se depuran las connotaciones pro-Eje y anti-norteamericanas; las expresiones fraternidad y comunidad sustituirán a las de imperio, raza, maternidad o preeminencia. Se trata de sustituir el enfoque político por uno cultural, lo que se materializa en la sustitución del Consejo de la Hispanidad por el Instituto de Cultura Hispánica. Además, este giro es coronado por la pretensión de mostrar a España como puente entre Europa y América.

Hacia finales de los años 40 el rechazo a la España de Franco por parte de los países iberoamericanos va a estar compaginado con el apoyo de otros y ya en los años 50 se está abriendo el debate para caminar hacia la Comunidad Hispánica de Naciones. A través de acuerdos políticos, diplomáticos y económicos se esperaba caminar hacia una integración de estos países en torno a España, frente a otras integraciones que ya estaban en marcha y que se veían como exógenas, llegándose a proponer como meta por parte de las autoridades españolas una situación jurídica especial para los ciudadanos de la Comunidad Hispánica de Naciones concretada en la supranacionalidad hispánica. Celestino del Arenal señala con respecto a estos intentos de los años 50 que "con todo, las características ideológicas y políticas del Régimen franquista impedirán que las relaciones entre España e Iberoamérica, incluso en el terreno cultural, entren todavía en un terreno plenamente normalizado y fructífero."s

Más adelante, en los años 60 ya no se puede plantear una política basada en los presupuestos ideológicos, lo que encamina la política preferiblemente hacia el campo económico cuyo objetivo último, como señala Celestino del Arenal, ${ }^{6}$ era un incremento de la cooperación económica así como la progresiva inserción de España en las distintas organizaciones internacionales americanas, en calidad de observadora.

En todo caso, en estos años 60 la política iberoamericana de España va a adquirir una característica que la va a dominar hasta el final del franquismo. Nos referimos a su carácter instrumental, ya que la política iberoamericana será empleada siempre como instrumento para conseguir otros objetivos más allá de los propios proyectos que la definen. Esta circunstancia ya la habíamos visto en los inicios de la dictadura cuando se había empleado con el objetivo de conseguir un reconocimiento por parte de la comunidad internacional. Y lo volvemos a ve ahora ya que, ante el rechazo a su integración en la Comunidad Europea, España buscará en Iberoamérica otros espacios de integración. Así nos lo describe Celestino del Arenal en la ya citada obra:

La política iberoamericana continuó siendo una política de múltiples usos en función de las distintas coyunturas internacionales de la España franquista, utilizándose en última instancia, más allá de los beneficios económicos y políticos que de la misma podían deri-

5 Ibid., p. 42

6 Celestino del ARENAL: 1976-1992 p. 46 
varse, como política de prestigio, como política de sustitución, como política encaminada a reforzar la posición negociadora de España con Europa y los Estados Unidos, lo que ex plica su escasa consistencia a nivel global y su limitada eficacia. ${ }^{7}$

Prueba de esta estrategia de España es el hecho de que en el periodo 1969-1973, cuando las relaciones comerciales con la Comunidad Europea fueron cada vez mayores, se constataron progresivos y continuos retrocesos en las relaciones con Iberoamérica. Esta situación se acentúa en los años postreros del régimen franquista cuando a la intensificación del contacto económico y político con Europa se unen la crisis mundial de los años 1972-1973 así como la crisis del propio régimen. De nuevo, como al inicio de la dictadura de Franco, se acude a los países iberoamericanos para demostrar los apoyos que España tenía en el panorama internacional. Con Arias Navarro, la política exterior - y por extensión la política iberoamericana - se pone una vez más al servicio de la política interior.

Tras este breve repaso por la política de la España franquista hacia Iberoamérica podemos afirmar con Celestino del Arenal que "lo que el franquismo nunca desarrolló, ni podía hacerlo por su carácter totalitario, fue una política iberoamericana realista, coherente con los intereses nacionales, y solidaria en la democracia y el desarrollo con los países iberoamericanos, que era la única que permitiría sentar las bases de una real, y no sólo retórica, Comunidad Iberoamericana".

\section{Premisas de una nueva política iberoamericana}

La Corona, al igual que la clase política española comprendió pronto algo que el Rey verbalizó en uno de sus primeros viajes a Iberoamérica: que los países iberoamericanos estaban comenzando a experimentar - con matices - una época de gran desarrollo a todos los niveles y se convertían en una zona con grandes posibilidades, lo que hacía que se constituyesen como "el continente del futuro". 9 España era consciente de que podía contar con una posición aventajada en la zona con respecto a otras potencias occidentales. Pero era consciente al mismo tiempo de que la política que venía desarrollando de cara a lberoamérica no era la adecuada. Había que estructurar y edificar, en consecuencia, una política de nuevo cuño, moderna y atractiva.

Para el Rey era muy importante que se comprendiera con claridad que el mayor y más ambicioso de los objetivos de la nueva política iberoamericana de España - caminar hacia una Comunidad Iberoamericana de Naciones - no pretendía atentar contra la identidad propia de cada uno. Comprendió Don Juan Carlos que la soberanía nacional (en todos sus ámbitos, político, económico, cultural) es uno de los terrenos más sensible para estos países americanos en sus relaciones con España, ${ }^{10}$ y por lo tanto había que asegurar que aquella, al igual que sus peculiaridades y su propia identidad, irian a estar a salvo en las nuevas relaciones que comenzaban a entretejerse con España. Por ello, desde el primer momento, el Rey insistió reiteradamente en que España y las repúblicas iberoamericanas tienen muchos elementos que las aúnan pero que en ningún caso les impiden mantener sus identidades. Sabía que si lograba transmitir este mensaje y que calara en la conciencia de los iberoamericanos, tenía mucho terreno ganado. Así lo vemos en el primero de los discursos que pronuncia como Rey en tierra

7 Ibid., pp. 50-51.

8 Ibid., p. 59

9 "Sentimos con gran convicción que hay un futuro importante para los pueblos iberoamericanos, que se acercan a su más decisivo momento histórico de vigencia internacional [ [..] nadie nos podrá quitar la convicción de que lberoamérica es el continente del futuro." Cfr. JUAN CARLOS I: Discursos 1975-1995, Madrid, Congreso de los Diputados y Senado, 1996, p. 97.

10 Como lo es por demás para cualquier otro país a la hora de asentar sus relaciones internacionales con otros países. americana: "tenemos mucho en común: la lengua, la cultura, la historia, la sangre, la arquitectura de las ciudades y el estilo de vida, que nos aúnan, al mismo tiempo que nos permiten mantener la propia identidad, igual que las montañas, que se unen en la base, y se distancian nicantes que nos igualan sin quitarnos la identidad, elegiría sin duda nuestra lengua"."

Otro de los puntos que había que aclarar era el de la igualdad. Las relaciones con Iberoamé-
rica no podían ser - y no debían pretender serlo - desde una óptica de preeminencia o de paternalismo. Bien al contrario, habrían de serlo en pie de igualdad.

Estos dos aspectos - las relaciones de igualdad y la salvaguarda de la identidad propia en el marco de unas relaciones de conjunto - que el Rey se afana en comunicar a los pueblos iberoamericanos se inscriben dentro de un mensaje global que debía llegar con fuerza a las naciones iberoamericanas: la España que les hablaba en esos momentos era una España moderna, ${ }^{2}$ nueva y distinta y, en consecuencia, lo que les tenía que decir era igualmente nuevo y distinto.

En este sentido, el proceso democratizador de España estaba ya en marcha y había que hacerlo notar. Don Juan Carlos no deja escapar las oportunidades que tiene para hacer referencia a esta situación de España, señalando que la democracia - ya conseguida o en proceso de consecución - es un rasgo más que define conjuntamente a ambos lados del Atlántico. As lo vemos en el discurso que pronuncia ante la Comisión Delegada del Congreso Nacional de Venezuela en septiembre de 1977, en el que además, recurre a Venezuela como ejemplo en el que España puede fijarse para su propio devenir democrático:

Hoy podemos afirmar con satisfacción que Venezuela y España se encuentran firmemente embarcadas en este camino de una plena y eficaz representatividad. El proceso ha sido lento y trabajoso. Vuestro ejemplo fue, en su día, una prueba clara de cómo el pueblo puede lograr un amanecer de libertad y la consolidación de unas instituciones de democracia viva, a través del esfuerzo, la moderación y la participación activa de los ciudadanos. [...] El proceso que en los últimos tiempos está viviendo España ha estado fundamentalmente dirigido a crear el marco en el que todas las fuerzas representativas del país pudieran aportar su esfuerzo conjunto a la vida de la sociedad española. ${ }^{13}$

Y también ante el Presidente de Costa Rica el mismo mes:

Como Rey de otro pueblo que ha sabido encontrar su camino hacia las libertades públicas por la vía pacífica de una evolución sin traumas, vengo a expresar nuestra admiración por la estabilidad democrática e institucional de esta república fraterna. ${ }^{14}$

Los adelantos en materia económica, al igual que en los campos políticos, de justicia socia o de derechos humanos son desgranados por el monarca con el objetivo de convencer a sus interlocutores del cambio efectivo y cualitativo que estaba realizando España. ${ }^{15}$ Son precisamente esos cambios operados para lograr homologarse con los países occidentales modernos y democráticos, la mayor garantía que España puede aportar de su honestidad en el cambio profundo que quiere infundir a sus relaciones con Iberoamérica. A ello contribuye en gran me-

11 Ibid., p. 31.

12 A la Comisión Delegada del Congreso Nacional de Venezuela Don Juan Carlos le dijo el 9 de sep-

tiembre de 1977: "quiero transmitiros la íntima satisfacción que me embarga al dirigiros la palabra, como Rey de una nación moderna". Cfr. JUAN CARLOS I: Discursos..., p. 87.

13 Ibid., pp. 87-88.

14 lbid., p. 98

15 lbid., pp. 88-89. 
dida la variación sustancial en la dialéctica con respecto a cualquier otro periodo anterior, pero desde luego, con respecto a la mantenida durante el franquismo:

España entera mira hoy con respeto y con admiración a aquellos hombres que hicieron posible la independencia de la República Dominicana... ${ }^{16}$

Cuando, después de casi trescientos años de vida política en común, llegó para vuestros pueblos la hora de la independencia, fue aquella una lucha entre hermanos. Reconocemos hoy el recio espíritu de nuestra raza que alienta en los próceres americanos, como San Martín y Bolivar, tipos egregios de virtud hispánica a los que rendimos homenaje en Madrid en estatuas que el pueblo admira como pertenecientes a nuestra común historia. ${ }^{17}$

Pero no sólo en lo que al momento de la emancipación se refiere cambia el lenguaje y la concepción por parte de España; en lo relativo al trato que deben tener también se hace patente. Se quiere eliminar toda retórica tanto de las palabras como de los hechos. Así lo podemos ver, por ejemplo, en las palabras que el Rey dirige al Presidente de Costa Rica en septiembre de 1977: "he traído a colación dos momentos históricos de nuestra larga e íntima convivencia pacífica, por creer que ejemplarizan, con grandeza de espíritu y sin retórica, el sentido profundo y constructivo de lo que deben ser las relaciones en el seno de nuestra fraternidad "18 Y se encarga Don Juan Carlos de subrayar que no sólo de palabra pueden contar con el apoyo de España: "En todo momento y con hechos, España quiere estar a vuestro lado."19 Más aún, lo señala de manera tajante: "Nuestra política en este continente dejará de ser declarativa y lírica". ${ }^{20}$

\section{Concreción del proyecto iberoamericano. El papel de la Corona}

Para dar prueba de que efectivamente se trataba de una voluntad seria y decidida, el Rey se encarga de explicar con detalle las características de la política que el Gobierno está planteando para lberoamérica y que se resumirían en cinco grandes principios: el de interdependencia según el cual "los distintos aspectos - el político, el económico, el cultural o el de cooperación - se entrelazarán y coordinarán" para potenciarse y reforzarse el uno al otro; para contar con la certeza de que un determinado proyecto tiene claras posibilidades de llevarse a cabo con éxito, se activaría el llamado principio de credibilidad que habría de ser complementado por el de continuidad en base al cual se acudiría a la perseverancia para conseguir los objetivos propuestos "hasta agotar sus propias potencialidades"; en cuarto lugar, se habla de un principio de indiscriminación, coronando todo el entramado con el principio de comunidad que aseguraría que toda acción emprendida estaría siempre subordinada a "los intereses compartidos por todas las repúblicas iberoamericanas". 21

Pero Don Juan Carlos va aun más allá y propone un instrumento concreto a través del cual la política de España hacia Iberoamérica puede comenzar a reestructurarse. Nos referimos a Centro lberoamericano de Cooperación ${ }^{22}$ cuyas atribuciones marca ya el rey en este momento: orientará su acción hacia la investigación detallada de la compleja realidad actual y fu-

16 lbid., p. 31.

17 lbid., p. 37.

18 lbid., p. 98

19 lbid., p. 94

20 Ibid., p. 90.

21 Un análisis en profundidad de cada uno de estos principios, a través de los discursos del Rey, puede encontrarse en la obra de Victoria GALVANI: El Rey y la Comunidad Iberoamericana de Naciones, Madrid, Fundación CIPIE, 1987

22 Oue se crearía efectivamente en 1977, proviniendo del Instituto de Cultura Hispánica, ya mencionado. tura de la comunidad, formará para ello los especialistas que se requieren, estudiará las necesidades y las posibles maneras de hacer frente a ellas y ofrecerá sus resultados, tanto a los gobiernos como a las entidades públicas y privadas. El Centro estará desde el primer momento abierto a la colaboración de todos y buscará la cooperación de quienes, por vocación y por especialidad, comparten la fe y la urgencia con que desde allí deseamos la vigencia real y la prosperidad de esta América que nos es tan entrañable. ${ }^{23}$

Se trata - y así lo señala el monarca desde los primeros viajes a América - de crear una comunidad que construya mecanismos e instrumentos comunes para la actuación en el panorama internacional y en el seno de la propia comunidad. El Rey se encarga de exponer las norama internacional y en el seno de la propia comunidad.
razones por las cuales esa comunidad puede y debe existir.

En primer lugar, España y las repúblicas iberoamericanas cuentan con una historia compartida durante siglos ${ }^{24}$ que ha forjado a lo largo del tiempo una idiosincrasia común y ha dado como resultado una comunidad "poseedora de rasgos biológicos unitarios; solidaria en unas creencias básicas sobre el hombre, su dignidad y su destino; heredera de un patrimonio cultural que tiene no sólo la gloria del pasado, sino también la vitalidad del presente". La lengua y la cultura son las raíces que con más fuerza sobresalen de entre ese elenco de rasgos que conforman la idiosincrasia común de los pueblos iberoamericanos. La primera es presentada por el Rey como definidora de personalidades y de identidades. Son elocuentes las palabras de Don Juan Carlos a este respecto y por ello optamos por ofrecerlas casi en su integridad:

La lengua es la casa común en donde a cada uno de nuestros pueblos corresponde una habitación. [...] La lengua es nuestra sangre espiritual y establece la frontera exterior de nuestros pueblos en el mundo [...] En la memoria del niño y en la memoria del hombre las palabras incorporan imágenes, pero también incorporan con ellas las costumbres de un pueblo, sus reacciones vitales ya decantadas por el uso, sus rezos y sus leyes, su modo de gozar y de llorar, su pensamiento y su poesía. Hablar en una lengua determinada es insertarse en la corriente de un río que nos conduce y fertiliza. No estamos solos en el mundo. No hemos nacido ayer porque hablamos en una lengua que nos transmite la solidaridad de los vivos y de los muertos, la solidaridad de cuantos la hablaron desde hace muchos siglos hasta hoy. En última instancia es un repertorio de actitudes vitales que facilita nuestras acciones y representa el patrimonio común de sus hablantes. Emprendí este viaje para escuchar, con alegría, nuestra lengua de América. ${ }^{25}$

Por ello, aboga el Rey por potenciar y dar vida a la lengua en tanto que un idioma, que no está definitivamente hecho, pertenece a las distintas generaciones, que deben mantenerlo actualizado y flexible.

En segundo lugar, en aquellos momentos en que Don Juan Carlos hablaba a los pueblos americanos, se podía afirmar que estaba ya superado cualquier enfrentamiento o rencor histórico y, en consecuencia, era el momento propicio para emprender un proyecto de hermanamiento:

23 Ibid., p. 90.

24 "Permitidme que os diga que es difícil pasar por las calles y plazas de Tegucigalpa y no sentirse conmovido de tantos ecos de un pasado en el que se entremezclan las bellezas arcaicas de una cultura precolombina y a la vez las huellas de España". Cfr. "Discurso al Presidente de Honduras Juan Alberto Melgar y al pueblo hondureño, Tegucigalpa, 13 de septiembre de 1977", en JUAN CARLOS I: Discursos.., p.95.Y, por citar tan sólo otro ejemplo más:" "Disfrutamos de un pasado histórico vivido durante siglos p.95. Y, por citar tan sólo otro ejemplo mas: "Disfrutamos de un pasado historico vivido durante siglos
en común. Todos somos hermanos, en consolidada madurez, surgidos de un mismo tronco familiar." Cfr. Discurso al Congreso de la República de Guatemala en la conmemoraicón del CLVI aniversario de la independencia de Centroamérica, Guatemala, 10 de septiembre de 1977, en Ibid., p. 91.

25 lbid., p. 32. 
Formamos, en efecto [...] una comunidad curada ya de las heridas separadoras del pleito familiar de la emancipación y que está asumiendo saludablemente, como propia, toda su historia e integrando en la misma con respeto y orgullo a todos sus grandes personajes, lo mismo aquellos que empezaron hace siglos a construir nuestros paises que los que abandonaron, cuando les llegó la edad de la madurez, la tutela bajo la cual vivían. ${ }^{26}$

En tercer lugar, era importante subrayar como razón de peso para emprender el proyecto que les estaba proponiendo, la vocación americana de España. En múltiples ocasiones el Rey ha aludido a la voluntad americana de la Corona, del Gobierno español y de la propia nación. Pero el discurso de Don Juan Carlos en este punto va mucho más allá: habla de una España que, igual que se siente europea por razones obvias, "se considera con orgullo como una nación también americana, pues una parte importante de nuestro ser pertenece a América", ${ }^{27}$ lo que viene a significar no solamente un hermanamiento de dos naciones o de dos partes de mundo, sino una compenetración tal que, como dirá más tarde Julián Marías ${ }^{28}$, Iberoamérica sin España no se entiende, no es una realidad, de la misma manera que España sin Iberoamérica tampoco puede comprenderse y tampoco es real. Don Juan Carlos lo resumió diciendo que "todo español que viene a América encuentra en ella sus raíces".

El Rey esboza igualmente en estos primeros discursos el papel que la Corona está llamada a cumplir en medio del proyecto que se está planteando. Julián Marías dirá años más tarde que, dado que ha sido la Corona el vínculo que siempre ha habido entre España e Hispanoamérica desde el inicio de sus relaciones, sería necesariamente la Corona la que capitanee la creación de la Comunidad iberoamericana de naciones. Celestino del Arenal y Alfonso Nájera también aluden a esta idea al poner en evidencia que "la Corona, como institución constitucional en la actualidad y como expresión de una institución que históricamente ha desempeñado un papel integrador en el continente americano, aparece como el elemento que enlaza directamente con la historia, la lengua y la cultura que nos es común".29

Pero el Rey no sólo se atenía a unos razonamientos históricos para hacerse cargo de la responsabilidad de guiar los trabajos conducentes a dicha comunidad. Acudía a lo que comprendió que debería ser una característica fundamental de la política de España hacia Iberoamérica: la continuidad por encima de los cambios de gobierno, esto es, una política de Estado. Y es aquí donde cobraría pleno y vigente sentido la idea de Marías que acabamos de apuntar, ya que en la concepción política de la monarquía, entre sus principales atributos y beneficios está el de la continuidad. "La monarquía hace posible esa continuidad que tan necesaria es para que puedan conseguirse los supremos y permanentes fines que constituyen la esencia de la patria", resumió el Rey en Venezuela en el ya citado discurso. La Corona, además de "alentar esta voz de la cultura que hoy constituye el único mensaje pacificador y el único lenguaje universal", asume en consecuencia - y de una manera natural - la tarea de garantizar una política de Estado, que dé continuidad a sus líneas generales y a sus proyectos con independencia de las variaciones de la ideología y la personalidad propias de cada gobierno. ${ }^{30}$

26 Ibid., pp. 49-50.

27 Ibid., p. 37

8 Julian MARIAS: La Corona y la Comunidad Hispánica de Naciones, Madrid, Asociación Francisco López de Gomara, 1992, pp. 90-91.

29 Celestino del ARENAL y Alfonso NÁJERA: La Comunidad Iberoamericana de Naciones, Madrid, Centro Español de Estudios de América Latina, 1992, p. 371

30 Así lo recogen también los dos autores que acabamos de citar: "[la Corona] permite, al estar por encima de los vaivenes de la política diaria, representar la continuidad, mirar al largo plazo y dar (D) se ha de edificar la Comunidad Iberoamericana de Naciones.", Cfr. Ibid.

\section{Una coda: Cumbres Iberoamericanas}

Ha quedado patente en lo expuesto con anterioridad que se constata con claridad una distinción entre la política iberoamericana que España había llevado a cabo a lo largo del franquismo y la que se comenzará a proyectar a partir del acceso al Trono del Rey Juan Carlos I. Esa variación radica principalmente en una filosofía, unos postulados y unos objetivos distintos, en una interpretación diferente de los nexos históricos, culturales y lingüísticos, de la base y los pilares sobre los que se asientan las relaciones con Iberoamérica; variación que fue propiciada, sin duda, por un contexto político distinto.

En consecuencia, se desechó la idea de Hispanidad que había imperado en el franquismo, y cuyas connotaciones ya hemos señalado, en favor del concepto de Comunidad lberoamericana de Naciones. Al desechar la idea de Hispanidad también se abandonó la preeminencia que España poseía en función de aquella, y se dio paso a un modelo de relaciones basadas en la igualdad y la independencia. En definitiva, con la llegada de la Monarquía parlamentaria, se prescinde de una actitud basada únicamente en la oratoria y la lírica y vacía de contenido, que había caracterizado el modelo tradicional o conservador del franquismo, y se abre paso una política real con la implementación de acciones y proyectos concretos destinados a la cooperación en todos los ámbitos.

La Corona, como se ha visto, en cumplimiento del mandato constitucional pero también debido a la determinación del propio Rey Juan Carlos, ha impulsado desde el primer momento la operación de estos cambios radicales. Junto a la voluntad y trabajo de los diferentes gobiernos de España y de las repúblicas iberoamericanas, el empeño personal del monarca y la responsabilidad que asumió histórica y constitucionalmente la Corona, fueron decisivos para alcanzar en el año 1991 la constitución oficial y efectiva de la Comunidad Iberoamericana de Naciones, hacia la que se venía caminando desde el inicio del reinado de Don Juan Carlos.

Sensu stricto no podemos hablar de creación al referirnos a la comunidad iberoamericana ya que esta existía con anterioridad al momento de este acto de 1991 en el que, en consecuencia, solamente se trataba de reconocer la realidad de su existencia. La Declaración de Guadalajara supuso, por lo tanto, el reconocimiento jurídico y oficial necesario para su vigencia en el panorama internacional.

La señalada Declaración recoge en líneas generales los elementos que el Rey había empleado en sus discursos - y que hemos sintetizado en el presente trabajo - para certificar la exis tencia de la comunidad iberoamericana y defender la necesidad de que actuase como tal en el ámbito internacional: historia, cultura y patrimonio comunes; común apuesta por la democracia y la defensa de los derechos humanos y las libertades fundamentales; el compromiso con el desarrollo económico, social e institucional de los respectivos pueblos; la convicción de que la integración, la cooperación y los conciertos internacionales contribuyen en gran medida a la solución de los problemas compartidos por los diferentes países..

Si bien este proyecto se comenzó a fraguar en 1980 con los gobiernos de la UCD, será el gobierno socialista - que había asumido con fuerza este proyecto - quien lo ponga en marcha una década después. Lo que se quería crear era un foro multilateral iberoamericano que actuara como un foro de reflexión e instrumento impulsor de la cooperación multilateral iberoamericana, en el que todos los países pudieran participar en pie de igualdad, sin distinciones de ningún tipo. Otro de los objetivos perseguidos era afirmar la identidad y el protagonismo de lo iberoamericano en el nuevo escenario internacional que se estaba perfilando.31

El viaje que los Reyes de España realizan a México en 1990 será decisivo para el arranque de estas cumbres, en tanto que el Rey Juan Carlos aprovecha el viaje para plantear esta cuestión de

11. Celestino del ARENAL: "Las Cumbres Iberoamericanas: el largo y difícil camino hacia su institucionalización" en América Latina Hoy, 40 (2005), pp. 58-60. 
una manera directa al Presidente de México, Carlos Salinas de Gortari, quien hizo suyo el proyecto con entusiasmo y se comprometió a organizar la primera cumbre en su país para el año siguiente. A España y México se le unirá enseguida Brasil, siendo este grupo el que gestione la iniciativa inicial del proceso. Había ya, pues, compromiso para los tres años siguientes. Los presidentes del Grupo Río muestran, mediante una declaración, su interés en participar en estos encuentros. Se alcanzaba asi el principal objetivo de la nueva política iberoamericana de España, puesta en marcha a partir de 1976: crear una comunidad entre los países iberoamericanos, lo que implicaba, por un lado, la institucionalización de la dimensión multilateral iberoamericana de dicha política y servía, por otro lado, como refuerzo de la dimensión bilateral de la misma. ${ }^{32}$

En un primer momento se plantea como una estructura flexible y no permanente, encomendando la organización de la cumbre a una Secretaría Pro Tempore, que recaía en el país que la iría a organizar. Tampoco se perfiló con detalle el objetivo último del proyecto, dejando que sean los propios participantes quienes lo fuesen definiendo. Tras unos años de declive - en los que, no obstante, se aprobó el Convenio para la Cooperación en el marco de la Conferencia lberoamericana, estableciendo los principios reguladores de la cooperación e institucionalizaba sus mecanismos y procedimientos - en 1998 se crearía la Secretaría de Cooperación lberoamericana (SECIB), un paso importante en la institucionalización de estas cumbres. Entre sus objetivos destacamos la misión de dar seguimiento a los programas de cooperación aprobados en las Cumbres, dar apoyo a los responsables nacionales de la cooperación iberoamericana y a la Secretaría Pro Tempore en la preparación de las cumbres, así como gestionar la información y difusión pública de la cooperación e identificar fuentes de financiación. ${ }^{33}$ Este organismo es uno de los resultados del nuevo impulso que España estaba imprimiendo a las Cumbres, ante la certidumbre de su debilitamiento.

Unos años más tardes las Cumbres darán un salto cualitativo en su desarrollo - equiparable a una refundación - al transformar la SECIB en una Secretaría General lberoamericana (SEGIB) con el objetivo - necesario y oportuno - de conseguir una mayor cohesión interna, una mayor eficacia en la cooperación, una mayor presencia internacional y un reforzamiento político a nivel institucional. Aprobada por unanimidad su creación en la Cumbre de Santa Cruz de la Sierra (2003), se proyecta la aprobación de su Estatuto para la siguiente cumbre, en San José de Costa Rica, en 2004, cuando se establece que las funciones de la SEGIB estarán subordinadas a la estructura institucional de las Cumbres Iberoamericanas, sin dejar prácticamente ningún resquicio a una mínima autonomía. ${ }^{34}$

La celebración de las Cumbres Iberoamericanas - que alcanzaron en 2013 su XXIII edición - así como las numerosas e importantes acciones de cooperación llevadas a cabo a lo largo de estos años 35 ponen de manifiesto el acierto de quienes creyeron en la posibilidad de una integración de la Comunidad Iberoamericana de Naciones.

\section{Bibliografía}

Rafael ALTAMIRA Y CREVEA: Mi viaje a América, Universidad de Oviedo, Oviedo, 2007 (Madrid, 1911).

Celestino del ARENAL: 1976-1992 Una nueva etapa en las relaciones de España con Iberoamérica, Casa de América, Madrid, 1994

32 Ibid., p. 60.

33 lbid., p. 63.

34 lbid., pp. 66-67 y 70 .

35 Oue se pueden consultar a través de los informes ofrecidos por la Secretaría General Iberoameri-

cana: www.segib.org.
: "Las Cumbres Iberoamericanas: el largo y difícil camino hacia su institucionalización" en América Latina Hoy, 40, 2005.

Celestino del ARENAL y Alfonso NÁJERA: La Comunidad Iberoamericana de Naciones, Centro Español de Estudios de América Latina, Madrid, 1992.

Silvia ENRICH: Historia Diplomática entre España e lberoamérica, Madrid, Cultura Hispánica, 1990.

Justo FORMENTÍN IBÁÑEZ y María José VILLEGAS SANZ: Relaciones culturales entre España y América: La Junta para Ampliación de Estudios, MAPFRE, Madrid, 1992.

Victoria GALVANI: El Rey y la Comunidad Iberoamericana de Naciones, Fundación CIPIE, Madrid, 1987.

Mario HERNÁNDEZ SÁNCHEZ-BARBA: "La crisis de América del siglo XIX”, La Razón, 23 de junio de 2013.

JUAN CARLOS I: Discursos 1975-1995, Congreso de los Diputados y Senado, Madrid, 1996.

Julián MARÍAS: La Corona y la Comunidad Hispánica de Naciones, Madrid, Asociación Francisco López de Gomara, 1992.

Gustavo H. PRADO: Rafael Altamira en América (1909-1910) Historia e Historiografía del proyecto americanista de la Universidad de Oviedo, CSIC, Madrid, 2008.

Las lecciones historiográficas de Rafael Altamira en Argentina (1909) Apuntes sobre Ciencia, Universidad y Pedagogía Patriótica, Universidad de Oviedo, Oviedo, 2010. 


\section{UNA APROXIMACIÓN AL MUNDO}

\section{NÓRDICO-BÁLTICO: ALGUNAS NOTAS SOBRE}

SU CONCEPCIÓN Y SU UTILIDAD PARA EL ESTUDIO

DE ESPAÑA A FINALES DEL SIGLO XIX*

Alberto Sevillano Sánchez

Doctorando, Ernst-Moritz-Arndt-Universität Greifswald

La historiografía española ha descuidado tradicionalmente su atención a las regiones nórdica y báltica.' El carácter secundario atribuido a los contactos políticos, económicos y culturales entre nuestro país y aquellos que conforman estas dos regiones se ha visto reflejado en la citada ausencia de investigación relevante en la materia así como en la prácticamente inexistente impartición de enseñanzas universitarias al respecto, más allá de las llevadas a cabo de forma residual en los departamentos de Filología Alemana o Filología Eslava, centradas por otro lado principalmente en aspectos lingüisticos o literarios. Estamos ante regiones periféricas de Europa aunque existen ejemplos de mediadores culturales y transferencias culturales entre ellas.

El objeto de esta comunicación consiste en ofrecer una primera visión global de las regiones nórdica y báltica, unas regiones que se superponen en buena medida, con el objetivo de paliar este tradicional desconocimiento. Igualmente pretende invitar a un somero recorrido histórico que sirva de aproximación a la construcción propia y externa de esa identidad, con atención al papel de los relatos de viajeros españoles en un momento en el que aparecen movimientos en Europa como el panlatinismo, el pangermanismo o el paneslavismo, que sirven de contrapunto al panescandinavismo aquí estudiado. Finalmente hace especial énfasis en el papel desempeñado por los historiadores como region-builders, muy especialmente tras la caída del Muro de Berlín y en sus consecuencias prácticas.

\section{Similares pero no iguales: Escandinavia y Norden.}

Cabe hacer una primera distinción del término geográfico de Escandinavia que incluye a Suecia, Noruega y Dinamarca (si bien stricto sensu la mayor parte de la superficie de este último país se encuentra en la parte septentrional de la península de Jutlandia) con respecto a Norden, el Norte (en alemán y en sueco, entre otras lenguas) y que englobaría a los tres anteriores países junto a Finlandia e Islandia. Este concepto encuentra difícil acomodo directo en español, por lo que de manera general se utiliza la noción de países nórdicos o región nórdica.

1 Un buen ejemplo es la publicación de la monografía de Ricardo MARTín DE LA GUARDIA y Guillermo PÉREZ SÁNCHEZ: La Europa báltica. De repúblicas soviéticas a la integración en la Unión Europea (1991-2004), Madrid, Sintesis, 2010. Es una muestra del interés creciente por la historia más reciente de la región aunque con una interpretación restrictiva del término "báltico", que lo ajusta a las tres repúblicas de Estonia, Letonia y Lituania.

* Algunas de las reflexiones aquí incluidas aparecieron en Alberto SEVILLANO SÁNCHEZ: La identidad nas de las reflexiones aqui incluidas aparecieron en Alberto SEVILLANO SANCHEZ: La identidad nacional en Suecia en la segunda mitad del siglo XIX. Artur Hazelius y la fundación del Nordiska

列 posibles errores.
A lo largo del siglo XIX tiene lugar en los países nórdicos una reelaboración intelectual de este concepto en la medida que en la década de 1840 irrumpe el panescandinavismo (Skandinavism en sueco) como alternativa o como complemento al nacionalismo emergente en todo el continente europeo. Este movimiento fijaba su atención en el periodo histórico conocido como "Unión de Kalmar" (1397-1523), durante el que toda esta región quedó bajo una sola corona, con predominancia danesa. Impulsado sobre todo por estudiantes daneses y suecos, consideraba que existe una herencia cultural, religiosa y lingüistica común que facilitaría una unión de todos los países nórdicos, de forma que constituirían una gran potencia regional.

Se distinguen, no obstante, dos líneas de interpretación dentro del panescandinavismo. Una primera afirmaba que se trataba de un movimiento cultural y que tenía por único objetivo el acercamiento así como el intercambio científico y académico, mientras que una segunda defendía que su naturaleza iba más allá de lo estrictamente cultural y que, por lo tanto, el panescandinavismo tendría un evidente carácter político y económico. ${ }^{3}$ La primera línea tendría sus mejores representantes en la Universidad de Uppsala mientras que la segunda se situaría en las instituciones académicas sitas a ambas orillas del estrecho de Öresund: Lund y Copenhague. ${ }^{4}$

Como promotor inmediato del panescandinavismo destaca el poeta, eclesiástico y pedagogo danés Nikolai Frederik Severin Grundtvig (1783-1872). Este autor publica en 1810 un escrito ¿ES deseable la unificación de los países nórdicos?5 y que está directamente relacionado con el cambio dinástico que se estaba produciendo en Suecia tras la repentina muerte ese mismo año del príncipe danés Cristiano Augusto de Augestenborg, que había sido designado heredero de Carlos XIII. Este no contaba con descendencia alguna y había sustituido en el trono a su sobrino Gustavo IV Adolfo en 1809, después de un golpe de Estado liderado por el coronel Carl Johan Adlercreutz motivado en buena medida por el descontento militar existente tras la pérdida de Finlandia. ${ }^{6}$

Grundtvig ya había apelado en otras obras anteriores de carácter histórico al pasado común de los pueblos nórdicos, comparable en esplendor al de la civilización grecolatina y superior a la germánica, que se ve afectada por la irrupción de un racionalismo con bases teóricas contrarias al cristianismo. El poeta y dramaturgo romántico danés Adam Oehlenschlæger (1779-1850) también se había ocupado en su obra de ese glorioso pasado común y de la mitología nórdica: sus Poemas nórdicos de 1809 glosarán y magnificarán las figuras de héroes como Haakon e Grande o Balder el Bueno y en 1819 modernizará asimismo el texto de la Edda, la saga medieval más relevante.7 En 1829 le fue otorgado el doctorado honoris causa por la Universidad de

2 Neil KENT: The Soul of the North: a Social, Architectural and Cultural History of the Nordic Coun tries, 1700-1940, Londres, Reaktion Books, 2000, pp 238-247: Neil KENT: A concise History of Sweden, Cambridge, Cambridge University Press, 2011, pp 140-142.

3 No obstante, entre 1873 existió una unión económica monetaria escandinava entre Suecia y Dinamarca, a la que se unió Noruega en 1875 y que duraría hasta la Primera Guerra Mundial.

4 Fredrik NILSSON: I rörelse. Politisk handling under 1800-talets första hälft, Lund, Nordic Academic Press, 2000, pp. 83-98 y 117-149.

5 Nikolai Frederik Severin GRUNDTVIG: Er Nordens forening ønseklig? Ett ord till de svenske folk, Copenhague, Nordisk Forlag, 1905. El presente escrito está encabezado por un fragmento del drama del romántico alemán Friedrich Schiller La novia de Mesina, estrenado en 1803 en Weimar, que apela a la naturaleza como único elemento estable en un mundo lleno de odio entre los hombres.

6 Se ha venido señalando la falta de tradición revolucionaria en Escandinavia. Bernd Henningsen propone como explicación el concepto de theologia civilis: las obras de teólogos como Holberg Grundtvig y Kierkegaard hacen referencia a una creencia común en una sociedad políticamente responsable, que se ha traspasado a la literatura y a la cultura política y religiosa de los países nórdicos, sin olvidar la influencia del pietismo.

7 Oehlenschlæger también escribió la canción Det er ett yndigt land, actual himno danés. El himno sueco Du gamla, du fria (Tú, viejo, tú, libre) fue escrito por Richard Dybeck en 1844 en forma también de co Du gán la, du fria (Tú, vejo, tá, Ibre) fue escríso por Richard Dybeck en 1844 en forma tambien de década de 18 o aunque aún a día de hoy no ha sido declarado de manera oficial como himno nacional 
Lund. El rey sueco Carlos XIV Juan, el antiguo mariscal del ejército napoleónico Jean Baptiste Bernadotte, que accedió al trono sueco en 1818 , le concedió en esa misma ocasión una medalla por su aportación al panescandinavismo.

Si bien los estudiantes noruegos no prestaron excesiva atención al panescandinavismo en la medida que consideraban que podía apartarles de su objetivo primordial de conseguir la independencia nacional, se celebraron dos congresos que reunieron a estudiantes de los países nórdicos: en 1843, en la universidad de Uppsala y en 1845, en la de Copenhague. En un 1848 sacudido por las revoluciones (o intentos de revolución) a lo largo del continente europeo, el rey danés Federico VII accede al trono tras la muerte de su padre Cristiano VIII, y un año después tiene lugar una profunda reforma institucional por medio de la aprobación de un texto constitucional que pone fin al régimen absolutista vigente desde $1660 .^{8}$ Dinamarca desatiende la petición de Prusia de repartir entre ambos países la provincia de Schleswig (con una importante población de habla alemana) y da inicio a una primera guerra con esta potencia, en la que recibirá la ayuda de unos 4.500 voluntarios suecos y noruegos. En 1864 se reproducirá el conflicto entre Dinamarca y Prusia pero la postura de los dos vecinos nórdicos será la de la neutralidad, sin prestar la más mínima ayuda (situación, que en cierta medida, se repetirá en la Segunda Guerra Mundial). Dinamarca pierde en 1864 Schleswig y Holstein y sólo después de un referéndum, celebrado una vez terminó la Primera Guerra Mundial, recuperará una franja de Holstein. El panescandinavismo está tocado de muerte tras esta segunda guerra entre Dinamarca y Prusia. Señala el danés Uffe $\emptyset$ stergård especialista en nacionalismo en los países nórdicos, ${ }^{9}$ que estos manifiestos surgen como contrapartida a los movimientos nacionales italiano y alemán, siendo la única diferencia que los países nórdicos no se alían militarmente de manera suficientemente potente alrededor de un Estado fuerte como era el caso de Piamonte y de Prusia: no existiendo por tanto intereses fuerte "desde arriba", no podía haber unidad nacional "desde abajo", a pesar del interés mostrado por el monarca sueco Óscar I, sucesor de Bernadotte en el trono y que gobernó entre 1844 y $1859 .{ }^{10}$

\section{La visión desde el Sur}

El Norte es para los españoles un concepto históricamente maleable, como bien indica el historiador finlandés Peter Stadius, y que ya sea puede referirse a la Europa protestante, a Francia e incluso al mundo anglosajón incluyendo a Norteamérica, constituyéndose en un lieu de mémoire, en la terminología acuñada por el francés Pierre Nora." No olvidemos que la Edad Moderna es también un momento de intenso contacto entre España y los países nórdicos, como sucede durante la Guerra de los Treinta Años (1618-1648) y la expansión imperia española y sueca a lo largo y ancho del continente europeo, como ha sido señalado recientemente..$^{2} \mathrm{El}$ goticismo ofrece un buen ejemplo de conexión entre ambos espacios geográficos;

8 El rey Federico III después del desastre de la guerra contra Suecia, se hace con el poder con el apoyo de la burguesía de Copenhague y de una buena parte de las clases populares.

9 Coautor de la monografía sobre nacionalismo: Björn HETTNE, Sverker SÖRLIN y Uffe ØSTERGÅRD: Den globala nationalismen, Estocolmo, SNS Förlag, 2006 (revisión de la $1^{\mathrm{a}}$ edición publicada en 1998).

10 Uffe ØSTERGÅRD: “Nordic Identity between 'Norden' and Europe” en Luis BELTRÁN, Javier MAESTRO y Liisa SALO-LEE (eds.): European Peripheries in Interaction: the Nordic Countries and the Iberian Peninsula, Alcalá de Henares, Servicio de Publicaciones de la Universidad de Alcalá, 2002, pp. 151-204 (cita tomada de página 167).

11 Peter STADIUS: "The North as a Spanish realm of memory", en Bernd HENNINGSEN, Hendriette KLIEMANN-GESISNGER y Stefan TROEBST (eds.): Transnationale Erinnerungsorte: Nord- und südeuopäische Perspektiven, Berlín, Berliner Wissenschafts-Verlag, 2009, pp 109-122.

12 Enrique Johan CORREDERA NILSSON. Todos somos godos Las relaciones hispano-suecas desde 1640 hasta la Paz de Oliva, Madrid, Editorial Universidad Complutense de Madrid, 2009: ID: "Yo he hecho hasta la Paz de Oliva, Madrid, Editorial Universidad Complutense de Madrid, 2009; ID.: "Yo he hecho Copenhague y las limitaciones de la colaboración hispano-imperiat en la Guerra del Norte (1655- además el goticismo volverá a florecer en el ambiente intelectual nórdico a lo largo del siglo XIX como bien demuestra la fundación de sociedades como Göthiska förbundet. ${ }^{13} \mathrm{En}$ las pági nas de su revista Iduna publicaban artículos autores como Erik Gustaf Geijer o Esaias Tegnér, donde traspasaban a Suecia las ideas del Romanticismo de Herder y Fichte sobre el Volksgeist. No obstante, señala hoy el historiador Bo Stråth que el Romanticismo nórdico es más pragmático y orientado al individuo que el de los países de habla alemana: habla de una versión específica de ética protestante y que encuentra su expresión en unos ideales específicos de educación; la educación era un instrumento clave de auto-realización, un proceso bottom-up a diferencia de la Bildungsbürgertum alemana. ${ }^{14}$ Un ejemplo de ello son las folkskolor que nacen en Dinamarca y luego se extienden por toda Escandinavia y que pretenden extender la pedagogía defendida por Grundtvig y su intención de extender una educación de calidad a todas las capas de la población (incluidas las que vivían en el medio rural).

Precisamente el panlatinismo que surge en el Ochocientos como reivindicación de la unión política de Francia, Italia y España sobre la base de una herencia clásica y renacentista común y que adquiere un tono más reivindicativo tras la guerra franco-prusiana de 1870-1871, ofrece una visión de la civilización latina en contraposición del Norte: donde el sol del Mediterráneo es la fuente de alegría y de vida, en el Septentrión hay brumas; el Sur es la tierra del vino, de refinamiento, del gusto e incluso del Dios (católico). ${ }^{15}$ Esta misma contraposición es la que en contramos en los relatos de viajeros: el más conocido lo encontramos en las Cartas finlandesas de Ángel Ganivet publicadas en $1896 . .^{16}$ El propio Ganivet habla del panlatinismo como "una idea generosa que viene a los postres de los banquetes, al ruido de los taponazos que lanza el vino espumoso, cuando los hombres bien comidos y bien bebidos se sienten hermanos de todos sus semejantes, aunque sean de raza negra, y aun de los monos antropomorfos". ${ }^{17} \mathrm{Y}$ de igual manera, el escritor y diplomático granadino se referirá a que

al leer que Rusia ha adoptado medidas enérgicas para "rusificar" a los finlandeses, se piensa que todos los escandinavos entrarán en efervescencia y montarán en cólera contra las medidas de opresión, Nada más lejos de la realidad; los dinamarqueses, noruegos y suecos, que vistos desde lejos parecen hermanos, de cerca son menos que primos; hasta las lenguas que hablan, que parecen poco diferentes y que de hecho difieren poco al leerlas, son muy distintas al pronunciarlas

1660)" en Rubén GONZÁLEZ CUERVA y José MARTíNEZ MILLÁN (coords.): La dinastía de los Austria: las relaciones entre la Monarquía Católica y el Imperio, Madrid, Polifemo, 2011 (vol. 1), pp. 507-532

13 La tesis doctoral de Torkel Molin se ocupa extensamente de la creación en 1811 y funcionamiento de la sociedad hasta su extinción en 1844; Torkel MOLIN: Den rätta tidens mått: Göthiska förbundet, fornforskningen och det antikvariska landskapet, Umeå, Institutioner för historiska studier Umeå universitet, 2003

14 Bo STRÅTH, "Nordic Modernity : Origins, Trajectories, Perspectives” en Jóhann Páll ÁRNASON y Björn WITTROCK, Nordic Paths to Modernity, Nueva York-Oxford, Berghann Books, 2012, pp.25-48 (cita tomada de pp. 29-30).

15 Peter STADIUS: "Le monde latin et le Nord dans la géographie mentale de la fin de siècle" en Michel ESPAGNE (ed.): Le Prisme du Nord. Pays du Nord, France, Allemagne (1750-1920), Tusson, Du Lérot, 2006, pp. 71-81. Cita tomada de la página 78.

16 Ángel GANIVET: Cartas finlandesas. Hombres del Norte. Edición de Fernando García Lara. Estudio preliminar y notas de Nil SANTIÁŃEZ-TIÓ, Granada, Diputación de Granada - Fundación de la Caja de Granada, 1998

17 lbid., pp. 95-96. 
En la imagen de la política y de la sociedad finlandesa, Ganivet no hace en muchos casos sino describir el contrarreflejo de España. En la mayoría de ocasiones lo hace de manera implícita, pero no faltan ocasiones en que se torna explícita, como cuando dice que

[I]a mujer finlandesa sabe usar de su libertad. Como en España los padres dejan ir a sus hijos a estudiar a las capitales donde pueden seguir la carrera que se ha elegido, aquí se deja también ir a las hijas. Hay muchas señoritas que viven solas comos los hombres [...] No hay inconveniente en que una joven vaya a casa de un hombre soltero a dar lecciones 0

a tomarlas, ni en que a su vez invite a un amigo a tomar una taza de té y a charlar un rato'

o cuando habla de la organización política finlandesa, "pero en uno y otro sistema, lo esencial es que los diputados, ya sea con actas limpias como aquí, ya con actas limpias y sucias como en España, quedan elegidos e investidos de la augusta representación nacional". ${ }^{9}$

No solo en el relato de Ganivet sino el de siete viajeros españoles más, basó el finlandés Peter Stadius su estudio doctoral de la imagen finisecular que se hacía nuestro país de Septentrión: ${ }^{20}$ una imagen a medio camino entre la utopía y la distopía, entre una Arcadia del futuro y una Barbarie de la modernidad. Stadius señala tres categorías de discurso finisecular sobre los países nórdicos. En primer lugar, encontramos un discurso tradicionalista que está teñido de implicaciones negativas pues el Norte está poblado por protestantes alejados de la ortodoxia católica, no civilizados, con una moral disoluta, y que son salvajes y dados a los excesos con la comida y la bebida. En segundo lugar, se produce un discurso progresista que identifica a los países nórdicos, al igual que el resto de Europa, con la modernidad y la riqueza y esto se acentúa aún más tras el Desastre del 98 y la implantación de regeneracionismo entre una parte de los intelectuales españoles. En tercer lugar, podemos señalar un discurso latinista, con una visión crítica similar a la del tradicionalista, pero no basada tanto en razones religiosas sino en una objeción al progreso utilitarista, que es entendido por sus defensores como una forma nueva de barbarismo, puesto que se encuentra alejada de la tradición y de las características del Mediterráneo; esta visión está impregnada de una defensa de un cierto panlatinismo.

Si nos situamos ya en el siglo XX, es precisamente Norden el nombre que recibe el Consejo Nórdico constituido en 1952, y que resulta ser el primer anclaje de las iniciativas posteriores a la Segunda Guerra Mundial de cooperación y colaboración entre los países de la región y que a día de hoy incluye a Suecia, Noruega, Dinamarca, Finlandia, Islandia así como a las regiones autónomas (dotadas de diversos estatutos jurídicos) de las islas Åland, las islas Feroe y Groenlandia. Como dice el historiador finlandés Max Engman, la cooperación nórdica y la identidad nórdica no son, sin embargo, una alternativa a los estados nación, sino que están basadas en ellos y construidas a partir de ellos. Resulta ser un elemento de refuerzo a esas identidades nacionales y un elemento de demarcación frente a Europa: así resulta ser

18 lbid., pp. 159-160.

19 Ibid., p. 117. Para mayor abundamiento sobre las ideas sobre la mujer, su visión del sistema político o sobre su caracterización como escritor de viajes, consúltese los artículos de Luis ÁlVAREZ CASTRO, “Ángel Ganivet y sus Cartas finlandesas: Ideas sobre la mujer en el fin de siglo" (pp. 15-26), María Antonia LÓPEZ BURGOS, “Literatura de viajes: las Cartas finlandesas. La imagen del otro y la imagen propia" (pp. 179-186) y Antonio ROBLES EGEA, "Ángel Ganivet contra la democracia liberal" imagen propia" (pp. 179-186) y Antonio ROBLES EGEA, "Angel Ganivet contra la democracia liberal"
(pp. 221-231), todos ellos publicados en María del Carmen DÍAZ DE ALDA HEIKKILÄ (ed.): Estudios (pp. 221-231), todos ellos publicados en María del Carmen DIAZ DE ALDA HEIKKILA (ed.): Estudios
sobre la vida y la obra de Ángel Ganivet. A propósito de Cartas Finlandesas, Madrid, Castalia, 2000. o Peter STADIUS: Resan till Norr Spanska Nordenbilder kring sekelskiftet 1900, Helsinki, Finska Vetenskapens-Societeten - Suomen Tiedesura - Finnish Society of Sciences and Helsinki, Finska Veviajeros son Odón de Buen Julio de Lazúr Benicio Navarro, Ángel Pulido y Antonio de Zayas. un Norte democrático, protestante, progresista e igualitario frente a una Europa católica, conservadora y capitalista. Norden resulta ser en muchos campos un concepto útil. ${ }^{21}$

\section{En torno al Mare Balticum}

Si nos referimos a la región báltica, es el cronista medieval Adán de Bremen quien recoge en el siglo XI en primer lugar la denominación de mare Balticum ${ }^{22}$ en su crónica de la Iglesia de Hamburgo al describir la misión del arzobispo Unni tras las huellas de san Óscar hasta llegar a Birka. ${ }^{23}$ Una de las etapas de más intenso contacto entre los habitantes de la ribera del Báltico tiene lugar con la creación de la Liga Hanseática, que aseguraba el intercambio comercial, y la fundación de universidades, que permitían la circulación de ideas y de escolares (a la manera de mediadores culturales).

La importancia de la denominación de este área ha sido señalada entre otros muchos por Marko Lehti, ${ }^{24}$ que da tres ejemplos de nombres atribuidos a la región: "Baltic Sea Area", "North Eastern Europe" "Northern Europe": el primero de ellos procede del periodo de entreguerras (pero abandonado en la Guerra Fría) situaba el mar como centro pero sin definir las fronteras exteriores de la región. El segundo fue introducido en la década de los setenta del siglo XX por Klaus Zernack pero no ha contado con una gran recepción fuera del mundo universitario mientras que el tercero es deliberadamente ambiguo porque podría incluir no solo Escandinavia sino a Rusia y a Polonia en toda su extensión territorial decimonónica. Finalmente, Matt Klinge y David Kirby hablan en sus libros publicados en los noventa de "the Baltic World". 25

Merece la pena reseñar la idea de principios del siglo XX de Baltoscandia del geógrafo sueco Sten de Geer, ${ }^{26}$ inspirada en el concepto de Fennoscandia del geólogo finlandés Wilhelm Ramsay. Nueve factores geográficos, demográficos y culturales (que pasan por la roca que forma las penínsulas del norte de Europa, la raza nórdica, los dos grupos de lenguas habladas en la región, el protestantismo, la división política actual en estados así como el pasado común bajo los reinos de Dinamarca y Suecia) hacen que incluya bajo este concepto toda una región que incluye Suecia, Dinamarca, Noruega, Islandia, Finlandia, Estonia, Letonia así como la parte de la Unión Soviética fronteriza con Finlandia hasta la Península de Kola.

Señala Jörg Hackmann que el elemento dominador regía en la percepción y en los discursos ruso y alemán sobre el mar Báltico desde mediados del siglo XIX, ${ }^{27}$ que buscaban un equilibrio

21 Max ENGMAN: "Norden in European History", en Gerald STOURZH (ed.): Annährungen an eine europäische Geschichtschreibung, Viena, Verlag der österreichischen Akademie der Wissenschaft, 2002, pp. 15-34.

22 Lenguas como el español, el francés (mer Baltique), el inglés (Baltic sea), el polaco (morze Ba tyckie), el ruso (more Baltijskoe), el letón (Baltijas j ras) o el lituano (Baltijos juros) han heredado esta denominación del latín. Por otro lado, el alemán (Ostsee), el sueco (Östersjön), el danés (Østersøen) y el finés (Itämeri) hacen referencia al Báltico como el "mar del Este". En cambio, en estonio la de-

23 Michael NORTH: Geschichte der Ostsee. Handel und Kulturen, Múnich, C.H. Beck, 2011, p. 10

24 Marko LEHTI: "Mapping the Study of the Baltic Sea Area: From Nation-centric to Multinationa History", Journal of Baltic Studies, vol. 33, 4 (2002) pp.431-448; Marta GRZECHNIK: Regional Histories and Historical Regions. The Concept of Baltic Sea Region in Polish and Swedish Historiographies, Fráncfort del Meno, Peter Lang - Internationaler Verlag der Wissenschaften, 2012, pp. 18-19.

25 David KIRBY: Northern Europe in the early-modern Period: the Baltic World 1492-1772, Londres-Nueva York, Longman Group UK Unlimited, 1990; ÍD.: The Baltic World 1772-1993: Europe's Northern Periphery in the Age of Change, Londres-Nueva York, Longman Group UK Unlimited, 1995; Matti KLINGE: The Baltic World, Helsinki, Otava, 1994.

26 Sten DE GEER: Das geologische Fennoskandia und das geographische Baltoskandia, Estocolmo, s.n. 1928; Marta GRZECHNIK: Ibid., pp.93-95.

27 Jörg HACKMANN: "From Object to Subject:The contribution of small nations to region-building in North Eastern Europe", Journal of Baltic Studies, vol. 33, 4 (2002), pp. 412-430. Cita de pp. 416-417. 
de poder (así era el caso del conflicto por las Islas Åland tras la guerra de Crimea), mientras que en las pequeñas naciones dentro del imperio del zar era bien distinto, el de la definición de sus respectivos territorios frente a las élites ( $y$ tomando en consideración aspectos como el grado de proximidad lingüistica).

En efecto, existen otras perspectivas y ya es un lugar común afimar que con el final de la Guerra Fría y la caída del Muro de Berlín, los historiadores y los científicos sociales han (re)orientado su investigación al conjunto del mar Báltico de forma que han conseguido que "se ha recurrido a la historia como fundamento de una identidad cultural común, [...] en el discurso actual sobre la región del mar Báltico en campos de actuación política". ${ }^{28} \mathrm{Si}$ a lo largo de los siglos XIX y XX los historiadores habían desempeñado un importante papel como nation-builders, ahora les corresponde una función de region-builders y todo ello de acuerdo un interés mayor por la dimensión espacial y topográfica por parte de la historiografía. ${ }^{29}$ Como refiere Marta Grzechnik, los historiadores se enfrentan a una doble tarea: la educativa y la de la integración regional no olvidemos que existe aún un desconocimiento manifiesto del resto de países bálticos. ${ }^{30} \mathrm{Asi}$, en 2011 Michael North publica en alemán la más reciente Historia del Mar Báltico. Comercio y culturas ${ }^{31}$ donde repasa los últimos diez siglos de la región con marcado carácter divulgativo y afán de pergeñar una identidad regional; puede percibirse que existe una primera similitud con la obra de Fernand Braudel sobre el mundo mediterráneo,32 para aclarar que

no hay un único Mar Báltico sino varios espacios del Mar Báltico, que han sido constituidos y continuamente reinventados por parte de Adán de Bremen hasta Björn Engholm o los estrategas del Báltico de la Unión Europea y especialmente a través del comercio y de las culturas así como de sus protagonistas, comerciantes y artistas. ${ }^{33}$

Asimismo han surgido nuevas iniciativas institucionales de cooperación y colaboración internacional como es el caso del Consejo de Estados del Mar Báltico nacido en 1992 en buena medida de la iniciativa personal del ministro alemán de Asuntos Exteriores, Hans-Dietrich Genscher y de su homólogo danés Uffe Ellemann-Jensen, y que al que hoy pertenen todos los países ribereños del Mar Báltico además de Noruega, Islandia y la Comisión Europea en calidad de miembros, así como Francia, Gran Bretaña, los Países Bajos, Italia, Ucrania y Estados Unidos a título de observadores. En 1998 surge la Euroregión báltica, impulsada a nivel local por municipios de Dinamarca, Letonia, Lituania, Polonia, Rusia (la región de Kaliningrado) y Suecia. En paralelo, las tres repúblicas bálticas han desarrollado una política de cooperación internacional: así el Consejo Báltico agrupa las actividades de la Asamblea Báltica y el Consejo de Ministros Báltico. Y toda una serie de actividades de trabajo conjunto en el ámbito educativo, académico y artístico se han desarrollado al albur del mar Báltico. Como señala Witold Maciejewski, no existe una voluntad de construir ni un bloque militar ni una unión económica en torno al mar Báltico, ni tampoco demandas externas o restricciones que obliguen a cons-

28 Jörg HACKMANN y Robert SCHWEITZER: “Nordosteuropa als Geschichtsregion - ein neuer Blick auf den Ostseeraum?", en Jörg HACKMANN y Robert SCHWEITZER: Nordosteuropa als Geschichts-
region. Beiträge des III. Internationalen Symposiums zur deutschen Kultur und Geschichte im euroregion. Beiträge des III. Internationalen Symposiums zur deutschen Kultur und Geschichte im
päishen Nordosten vom 20.-22. September 2001, Lübeck, Schmidt-Röhmild, 2006, pp. 13-25.

29 Karl SCHLÖGEL: En el espacio leemos el tiempo. Sobre Historia de la Civilización y Geopolitica. Madrid, Siruela, 2007.

o Marta GRZECHNIK: "Making use of the past: The role of historians in Baltic Sea region building", Journal of Baltic Studies, vol. 43, 3 (2012), pp. 329-343 (cita tomada de página 338).

11 Michael NORTH: Ibid.

32 Fernand BRAUDEL : La Méditerrannée et le monde méditerranéan à l'époque de Philippe II, Paris, Armand Colin, 1966

33 Michael NORTH: Ibid., p.10. truir una organización fuerte. La región del Mar Báltico es una soft invention a la que se puede contribuir con el mejor conocimiento y experiencias de las partes implicadas. ${ }^{34}$

\section{Breves conclusiones}

A modo de conclusiones de este comunicación, cabe recordarse que existe una tradición de contacto entre España y las regiones báltica y nórdica. Constituye un campo de estudio científico con enorme potencial en la medida que nos permite reconsiderar la retórica entre centro y periferias en Europa y de igual manera existe un potencial en el análisis de las transferencias culturales existentes. Si bien a título de ejemplo se inició en 1997 una actividad de colaboración universitaria (aunque suspendida) dentro del proyecto "Encuentros históricos España-Suecia", coordinados inicialmente por la parte española por parte de Enrique Martínez Ruiz y Magdalena de Pazzis Pi Corrales, profesores del Departamento de Historia Moderna de la Universidad Complutense de Madrid35. En lo referente a este periodo destaca el Encuentro "Quan la llum venia del nord. Suècia, Noruega i la Catalunya modernista" ${ }^{6} 6$ donde se analizaron las influencias culturales de estos dos países y los ecos que llegaban del proceso de independencia noruego como referente para el nacionalismo catalán. Y si bien existen proyectos paralelos, entendemos que es muy deseable la reactivación de la cooperación científica a nivel regional entre España y los países nórdicos y los países del Mar Báltico en el marco de un espacio universitario y académico europeo, pues conduciría sin duda alguna a un mejor análisis histórico de las respectivas identidades y abundaría en una colaboración más estrecha a niveles políticos, económicos, sociales, culturales, educativos... Y no debe dejar de pensarse en el papel desempeñado por los historiadores a la hora de crear esa identidad regional. No en vano y como concluye la polaca Marta Grzechnik, el éxito de los historiadores con respecto a la región en torno al Mar Báltico no debe ser sobrestimado en la medida que "las narrativas históricas, aunque útiles a la hora de delimitar conciencias sociales, no son suficientes para formar regiones e identidades si esas regiones no están unidas por una cooperación política y económica" 37

34 Witold MACIEJEWSKI (ed.): The Baltic Sea Region. Cultures, Politics, Societies, Uppsala, Baltic University Press, 2002, p. 33. Es inevitable pensar en el concepto de soft power del politólogo estadounidense Joseph Nye.

35 Magdalena DE PAZZIS PI CORRALES, "El proyecto Encuentros históricos España-Suecia", Cuadernos de Historia Moderna, 26 (2001), pp. 205-223.

36 Enrique MARTíNEZ RUIZ y Magdalena DE PAZZIS PI CORRALES (eds.): Cuando la luz venía del Norte. Suecia, Noruega y la Cataluña modernista. Encuentros históricos España-Suecia, Madrid, Fundación Berndt Wistedt, 2001

37 Marta GRZECHNIK: "Making use of the past: The role of historians in Baltic Sea region building",

Journal of Baltic Studies, vol. 43,3 (2012), pp. 329-343 (cita tomada de página 341). 



\section{POLITICAS RELIGIOSAS OFICIALES DE MARRUECOS}

\section{DIRIGIDAS A LA POBLACIÓN EMIGRADA*}

Lidia Fernández Fonfría

Universidad de Salamanc

\section{La comunidad marroquí residente en el extranjero (CMRE)}

En este apartado, a modo de introducción, se aborda la importancia de la comunidad marroquí residente en el extranjero y se aportan algunos datos relevantes acerca de la misma, haciendo especial hincapié en la asentada en España.

Antes de comenzar es necesario aclarar que los propios Marroquies Residentes en el Extranjero (MRE) rechazan ser definidos como inmigrantes o emigrados, y prefieren el uso de términos como "transnacionales" o "ciudadanos del mundo".' Este fenómeno es especialmente notable en aquellos que han sufrido un proceso de naturalización. ${ }^{2}$

También es conveniente señalar que Marruecos considera que la nacionalidad marroquí no se pierde jamás, de modo que lo habitual es que los MRE tengan doble nacionalidad, hecho que reafirma la importancia de la defensa y reivindicación de la identidad nacional marroquí por parte de Marruecos.

Recientes estudios indican que se observa una tendencia a que la identidad religiosa supla a la identidad nacional, especialmente entre las generaciones más jóvenes, pues la religión se convierte en un refugio para los inmigrantes en situaciones de tensión y hostiles, como pueden ser las que se dan en la actualidad en España e Italia. ${ }^{3} \mathrm{~A}$ este respecto, es interesante señalar que algunos acontecimientos históricos concretos que atañen al mundo árabe han marcado determinadas tendencias entre los inmigrantes. Las dos guerras del golfo y el conflicto de Palestina han reforzado la idea de unión entre los inmigrantes que se sienten más marroquies y musulmanes. Ello, unido a las condiciones negativas que se vienen dando desde la crisis económica iniciada en el año 2009 favorecen la reivindicación de su arabidad y la unión entre los inmigrantes de un mismo credo. ${ }^{4}$

En Marruecos, la migración ejerce un importante impacto sobre las trasformaciones sociales del país. Como mínimo, uno de cada seis marroquíes vive en el extranjero, de modo que el fenómeno migratorio afecta al $10 \%$ de la población. ${ }^{5}$ Por este motivo, en las dos últimas

Trabajo realizado durante una estancia de investigación en la Facultad de Letras de la Université Trabajo realizado durante una estancia de investigación en la Facultad de Letras de la Université Abdelmalek Essaâdi (Tetuan
tos Exteriores y la AECID.

1 Zakya DAOUD: La diaspora marocaine en Europe, Casablanca, La croisée des chemins, 2011, pp. 15 y 29.

2 lbid., pp. 19-21.

3 Se trata de países con una recepción de inmigrantes más reciente y, por lo tanto, con estructuras menos preparadas para afrontar la problemática específica de este fenómeno. Asimismo, ambos paises están siendo especialmente castigados por la actual crisis económica, lo que favorece un clima de rechazo hacia los inmigrantes. Véase ibid., pp. 21 y 27.

4 Ibid., p. 109

5 Ibid., p. 30. décadas, y especialmente desde la llegada al Trono de Muhammad VI, se observa una atención sin precedentes por parte del Estado sobre las cuestiones relativas a los MRE, pues se ha comprobado la importancia de éstos últimos en el impulso del desarrollo y modernización de Marruecos.

Uno de los hechos que manifiesta el creciente interés del Estado marroquí por los MRE, es su presencia en los discursos reales de Muhammad VI, ${ }^{6}$ especialmente desde 2004. El aumento de las referencias a los MRE coincide con la reforma de la esfera religiosa emprendida en e año 2004, y suele relacionarse con la integridad territorial e identitaria del país. De este modo, no es extraño que en los discursos reales con motivo del aniversario de la Marcha Verde de 2005, 2006 y 2007 se abordase el tema de los MRE y su importancia en el Marruecos actual. Los temas que abordan dichos discursos giran en torno un dossier estratégico en el que cabe destacar los siguientes aspectos:?

- Necesidad de reestructurar la Fundación Hasan II para que sea más efectiva.

- Promoción de la defensa de los derechos de los MRE y preservar su dignidad, tanto en e país de acogida como en Marruecos con el objetivo de garantizar "la preservación de su identidad cultural y religiosa, auténticamente marroquí, identidad que se basa en los principios de tolerancia, moderación y respeto a las diferencias, así como el deseo de encarnar los valores constructivos del Islam".

- Refuerzo de la enseñanza de la lengua árabe y la cultura marroquí a los niños de la comunidad marroquí residente en el extranjero. 9

- Mayor participación y representación de los MRE en las instituciones nacionales.

- Revisión de la ley electoral para permitir a los MRE estar representados en la Cámara de Representantes, ${ }^{\circ}$ así como la creación de circunscripciones electorales en el extranjero.

- Creación de un Consejo Superior de la Comunidad Marroquí en el Extranjero, establecido de manera democrática y transparente, cuyos objetivos fundamentales son prestar especial atención a las cuestiones de culto y culturales y a las relacionadas con la identidad, así como poner fin a la duplicación de funciones y multiplicidad de actores que intervienen en ellas.

6 Fundamentalmente en los discursos de Muhammad VI con motivo de la celebración del 30, 31 y 32 aniversario de la Marcha Verde.

7 Abdelkrim BELGUENDOUZ: "Le traitement institutionnel de la relation entre les Marocains résidant à l'étranger et le Maroc", Raports de recherche, 2006/06 (2006), European University Institute - Robert Schuman Centre for Advanced Studies, $p .20$.

8 Traducción propia de fragmentos del discurso de Muhammad VI, con motivo del aniversario de la Marcha Verde, pronunciado el 6 de noviembre de 2006

9 Es necesario indicar que hasta 2006, Marruecos no tenía ningún centro cultural en el extranjero. En cuanto a la rer que se aplicase en las elecciones legislativas de septiome de 2007 "las autoridades anula ron esta intención por motivos técnicos y logísticos, relativos a la dificultad de organizar elecciones en los diferentes paises de residencia de los emigrantes marroquies" (Mourad ABOUSSI: "La nueva política misratoria marroqu ante retos de transnacionalismu y codras ABOUSS: (Revista de Estudios Internacionales del Mediterráneo) 10 (2011), p. 106. Extraido de internet: htRs://g7e bstuf-a-62ch3a1a-s-sites googlegroups.com/site/teimrevista/archivos-1/Aboussi tps://97eab39f-a-62 cb3a1a-s-sites.googlegroups.com/site/teimrevista/archivos-1/Aboussi,

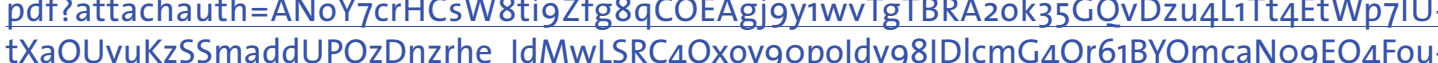
J4Bj ZyyFWbiiW MKNPHUSFs 


\section{MRE en Europa y España}

a mayoría de los MRE se encuentran en Europa, alcanzando la cifra aproximada de $4,5 \mathrm{mi}$ llones en la actualidad " siendo una de las mayores diásporas en Europa. España es el segundo país europeo con mayor número de inmigrantes marroquíes tras Francia.

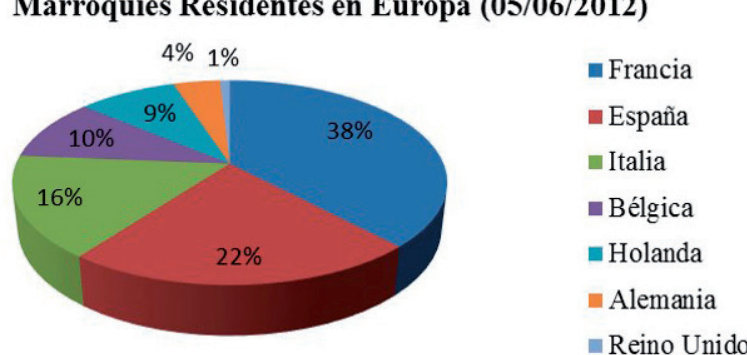

Gráf. o1 MRE en Europa (Fuente: Elaboración propia a partir de los del Ministerio de Asuntos de la Comunidad Marroqui Residente en el Extranjero).

En cuanto a los MRE en España ${ }^{13}$ Bernabé López García ${ }^{14}$ señala que hay tres etapas en su evolución. La primera recoge la migración postcolonial hasta 1970 con gran presencia de emigrantes rurales procedentes del norte de Marruecos, básicamente de la antigua zona del Protectorado. ${ }^{15}$ La segunda coincide con la crisis económica de comienzos de los años 60 y el cierre de fronteras. Se produce un cambio en el perfil de los emigrantes pues ahora provienen de grandes ciudades con tradición migratoria a otros países europeos. La tercera etapa comienza con la primera regulación de la inmigración en España (1985), y se observa el inicio del fenómeno de la inmigración clandestina y el aumento de los inmigrantes procedentes de localidades del interior de Marruecos.

1 No se conoce la cifra exacta, puesto que no se incluyen los menores de 16 meses. Zakya DAOUD: La diaspora marocaine en Europe..., p. 35. Las cifras oficiales estimaban que en 1990 había un millón y medio de MRE, de los cuales la mayoría (1.200.000) estaban instalados en Europa (Joan LACOMBA: Migraciones y desarrollo en Marruecos, Madrid, Catarata, 2004, p. 93)

12 Disponible en: http://www.marocainsdumonde.gov.ma/minist\%C3\%A8re-des-mre/mre-en-chiffres.aspx . [Consultado el 26/og/2013]. También disponible la información detallada por continentes, paises y demarcaciones consulares en: http://www.marocainsdumonde.gov.ma/media/67900/mre\%20en\%20chiffre_fr_z.pdf [Consultado el 26/09/2013].

13 Sobre este aspecto véase ibid., pp. 229-239; Víctor PÉREZ-DÍAZ, Berta ÁLVAREZ-MIRANDA y Elisa CHULIÁ: "La inmigración musulmana en Europa. Turcos en Alemania, argelinos en Francia y marroquies en España", Estudios sociales, Madrid, Fundación La Caixa, 2004; Bernabé LÓPEZ: Atlas de la inmigración magrebi en España, Madrid, Ministerio de Trabajo y Asuntos Sociales, 1996, http:// www.uam.es/otroscentros/TEIM/Observainmigra/Atlas\%201996\%20inicio.htm [consultado el 31/08/2013]; Bernabé LÓPEZ y Muhammad BERRIANE: Atlas de la inmigración marroquí en España, Madrid, Ministerio de Trabajo y Asuntos Sociales, 2004, http://www.uam.es/otroscentros/TEIM/ Observainmigra/Atlas\%202004\%20inicio.htm [consultado el 31/08/2013]; José CAZORLA: "La inmigración marroquí en España. Datos, opiniones y previsiones", Revista Internacional de Sociología, 12 (1995), pp. 117-144; Aurelio CEBRIÁN: “Características de la inmigración marroquí en España. El ejemplo de la Comunidad de Murcia”, Cahiers Géographiques, 5 (2008), pp. 57-70.

14 Joan LACOMBA: Migraciones y desarrollo en Marruecos..., pp. 95-97 y Bernabé LÓPEZ: "Marroquíes en España (1991-2001): la confirmación de los perfiles de origen", ponencia presentada en el III Congreso sobre la inmigración en España, Granada, 2002.

15 Los emigrantes procedentes del Norte, Rif y Hebala suponen casi el 70\% de la emigración marroquí en España hasta finales de los años 80

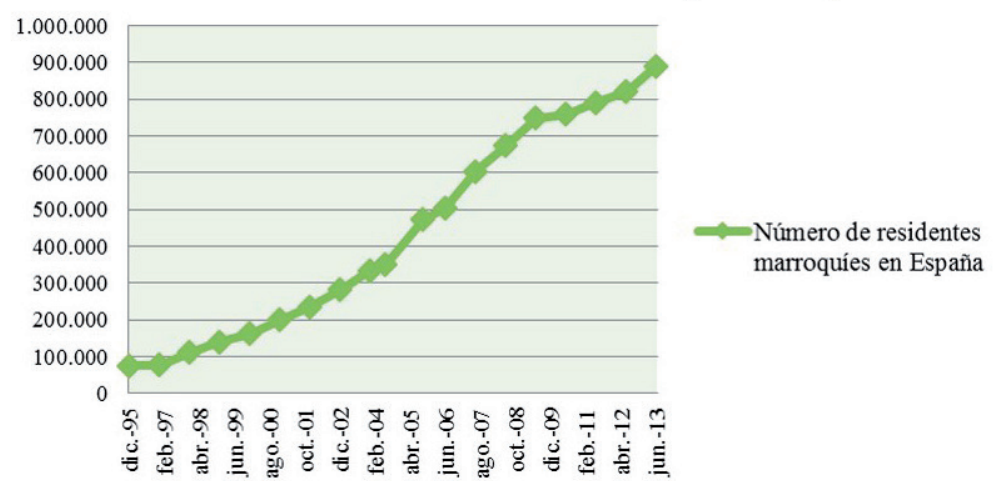

Gráf. 02 Evolución del número de residentes marc de los datos del Observatorio Permanente de la Inmigración: "Extranjeros con certificado de registro o tarjeta de residencia en vigor en España", Ministerio de Empleo y Seguridad Social).

A partir de 2008, la crisis económica y el desempleo se ceban con los inmigrantes en España, y como consecuencia, en 2009 se decreta una nueva ley de extranjería, mediante la que sólo pueden entrar al año 7.000 personas legalmente, por lo que los controles de inmigración ilegal se endurecen y aumentan. Paralelamente, se observa un incremento del racismo, pues a raíz de la crisis económica se reavivó un racismo ancestral y una ola de xenofobia dirigida especialmente hacía los marroquíes, la segunda población más numerosa tras los rumanos, pues la opinión pública los considera el colectivo más rebelde y el menos integrado en la sociedad española. ${ }^{16}$

\section{La práctica religiosa en Europa ${ }^{17}$}

En toda Europa, la práctica religiosa del $12 \%$ de los MRE es regular y del $24 \%$ es semanal, pero en España e Italia, los países de inmigración más reciente, estas cifras son superiores a la media europea. El número de musulmanes practicantes a diario y semanalmente suman el $47 \%$ de los MRE en Europa y el $36 \%$ entre algunos jóvenes en la media europea. En España el $25 \%$ de los jóvenes es practicante de manera habitual.

En lo referente a la asistencia a la mezquita, el $38 \%$ de los MRE en Europa no acude a las mezquitas, siendo las mujeres las que acuden con menor frecuencia. Asimismo, sólo un cuarto de los hijos de inmigrantes siguen las actividades impulsadas por las mezquitas.

$\mathrm{El} 34 \%$ de los marroquíes en Europa se queja de sufrir discriminación religiosa, especialmente en Italia, Holanda y Francia. A pesar de ello, el 70 \% realiza el ramadán en su país de acogida sin manifestar inconvenientes o problemas en realizarlo. Esta percepción de rechazo social y

16 Basta mencionar que en un estudio realizado por Joan Lacomba, basándose en los resultados de una encuesta a la población, se indica que el $83 \%$ de los españoles piensa que los musulmanes son fanáticos, un $60 \%$ violentos y un $42 \%$ arrogantes. Joan LACOMBA: "Inmigrantes y musulmanes: exclusión e integración en el nuevo medio", Documento de trabajo $n^{\circ} 5$ Madrid, Casa Árabe 2009 . 6. https://www.google.es/url?sa=t\&rct=j\&q=\&esrc=s\&source=web\&cd=4\&cad=rja\&ved=0CEgO-

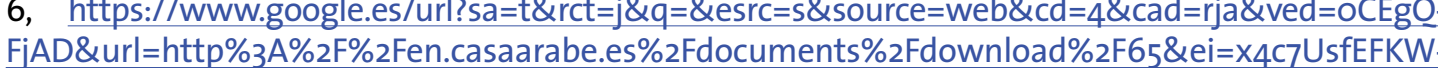

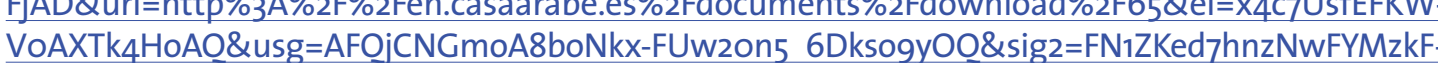
OPg\&bvm=bv.52434380,d.d2k [consultado el og/10/2013]. Véase también Zakya DAOUD: La diaspora marocaine en Europe..., pp. 72 y 237; Pedro CASTÓN y Rosa María SORIANO: "La inmigración en la opinión pública española", en Francisco HERRERA et al. (eds.), Inmigración, interculturalidad y convivencia l, Ceuta, Instituto de Estudios Ceuties - Ciudad Autónoma de Ceuta, 2002, pp. 347-361; Virginia MIRANDA: "Un $42 \%$ de españoles no quiere marroquíes. Jaque al moro", El Siglo de Europa, $n^{\circ} 401$ (2000), pp. 14-17.

17 Véase Zakya DAOUD: La diaspora marocaine en Europe pp.84-86 y Berta ÁLAREZ-MIRANDA:" diversidad de los inmigrantes musulmanes en Europa", Mediterráneo ecoń́mico, 14 (2008), Pp. 185-202, especialmente pp. 188-192. 
clima de hostilidad provoca reacciones diversas entre los jóvenes MRE, pues se observa una tendencia a oscilar entre la asistencia a la mezquita, el repliegue identitario y las provocaciones. Igualmente, las segundas generaciones están más inclinadas a la religión que las primeras. Así, el $45 \%$ de las segundas generaciones quieren ser reconocidas en su religión frente al $30 \%$ de las primeras, a pesar de que la religiosidad es esencial para los primeros emigrantes. ${ }^{18}$

En cuanto al aspecto religioso de los inmigrantes musulmanes en España, tal y cómo señala Lacomba, ${ }^{19}$ se declaran religiosos y consideran que la religión es muy importante en su vida. No obstante, su religiosidad no está reñida con la defensa de un Islam tolerante y abierto.

La creciente visibilización de la práctica del Islam en un entorno ajeno al musulmán como Europa, debe entenderse no como una islamización de las costumbres, sino más bien como un fenómeno que atiende a cuestiones de integración y búsqueda de afinidad. De este modo, inmigrantes musulmanes que no frecuentaban las mezquitas en su país de origen sí lo hacen en su país de acogida, pero no porque su religiosidad haya aumentado sino porque es prácticamente el único lugar en el que pueden practicar su religiosidad y encontrar a otros inmigrantes como ellos, con sus mismas inquietudes y problemas. Esto nos lleva a la concepción de la mezquita como "punto de encuentro, intercambio de informaciones, entreayuda y obtención de recursos y servicios, más allá de las necesidades meramente espirituales", ${ }^{20}$ así como un lugar que proporciona un refugio y respetabilidad, especialmente en contextos hostiles. ${ }^{21}$

Importancia económica de los MRE

Uno de los aspectos más relevantes de la inmigración es su papel en la economía marroquí, pues se trata de la principal fuente de divisas del país.

El canal oficial ${ }^{23}$ de transferencias se estima en el $68,5 \%$, siendo el resto de vías estimadas

18 Zakya DAOUD: La diaspora marocaine en Europe..., p. 188; Berta ÁLVAREZ-MIRANDA: "Aquí y allí. Vínculos transnacionales y comunitarios de los inmigrantes musulmanes en Europa", Documentos de Trabajo, 9 (2007), Real Instituto Elcano, p. 13, http://www.realinstitutoelcano.org/wps/wcm/connect/64a98a004fo18753bccofc3170baead1/DT9-2007 Alvarez-Miranda inmigrantes musulmanes. pd? MOD-AJPERES\&CACHED 64 ag8a004

19 Joan LACOMBA: “Inmigrantes y musulmanes: exclusión e integración en el nuevo medio"..., pp. 8-9. 20 lbid., p. 10.

21 Sobre la islamofobia es interesante el fenómeno de la representación del musulmán como un "homo islamicus" amenazante, retrógrado y violento que describe Gema Martín Muñoz. Véase Gema MARTÍN: Musulmanes en la UE - Discriminación e Islamofobia sobre discriminación. Traducción del Informe del Observatorio Europeo del Racismo y la Xenofobia, Madrid, Casa Árabe, 2007, p. 7; Gema MARTín y Ramón GOSFROGUEL (eds.): La islamofobia a debate. La genealogía del miedo al Islam y la construcción de los discursos antiislámicos, Madrid, Casa Árabe, 2012.

22 Sobre los datos económicos es interesante consultar Zakya DAOUD: La diaspora marocaine en Europe..., pp. 121-124; Joan LACOMBA: Migraciones y Desarrollo en Marruecos..., pp. 121-136; Muhammad KHACHANI: "El impacto de la migración en la sociedad marroqui", / Congreso Internacional sobre Desarrollo Humano, Madrid, 2006, http://www.reduniversitaria.es/ficheros/Muhammad\%20 KhaDesarrollo Humano, Madrid, 2006, http://www.reduniversitaria.es/ficheros/ Muhammad\%20Kha-
chani\%20(e).pdf [consultado el o3/10/2013]; Iñigo MORÉ: "Las remesas de los emigrantes en España: una oportunidad para la acción exterior". Madrid, Real Instituto Elcano, 2005 http:/ /www. realinstitutoelcano.org/documentos/167/Mor\%Eg\%20pdf.pdf [consultado el 03/10/2013]; I ID.: "Las realinstitutoelcano.org/documentos/167/Mor\%E9\%20pdf.pdf [consultado el $03 / 10 / 2013$ ]; ID.: "Las nes de origen", en Bernabé LÓPEZ y Muhammad BERRIANE (eds.): Atlas de la inmigración marroqui en España, Madrid, TEIM (UAM) - Secretaría de Estado de Inmigración y Emigración, Ministerio de Trabajo y Asuntos sociales, 2004 pp. 130-133, http.//www.uam es/otroscentros/TFIM/Observainmigra/Atlas\%202004/05\%20Regiones\%20Origen/More Las\%20sorprendentes\%20remesas.pdf [consultado el 03/10/2013]; Mohammed DAHIRI: “Las remesas económicas y sociales de la diáspora marroqui y sus efectos en Marruecos", Miscelánea de Estudios Árabes e Islámicos (MEAH) 60 (2011) pp. 79-105, http://digibug.ugr.es/bitstream/10481/18615/1/Dahirin1.pdf [consultado el 03/10/2013].

23 Se indican unicamente los datos referidos a las transferencias oficiales, pues no es posible apor- en 65 millones a los que hay que añadir otros 5 millones de transferencias de dinero líquido gastado en las vacaciones y 7 millones en prestaciones sociales. ${ }^{24}$

En 2008 hay 32 millones de Dirhams marroquíes procedentes de Europa, de los cuales 7,8 vienen de España, siendo el primer país seguido de Italia. El 10,6\% de las transferencias viene de España. ${ }^{25}$ Se calcula una media de 86.311 DHM por emigrante según las transferencias oficiales ${ }^{26}$ y un aumento anual del $15 \%$ de todas las transferencias.

En cuanto a los datos económicos relativos a España señalaremos que en 2001, según los datos de Moré, ${ }^{27}$ se calcula que cada marroquí residente en España envió 18.429 DHM (1.642 $€)$ si se considera que había 2 millones de emigrantes, o bien $12.286 \mathrm{DHM}(1.094 €)$ si fuesen 3 millones. Así, desde España se enviarían entre 3,8 y 6 millardos de dirhams (349-558 millones de $€$ ), siendo el tercer país tras Francia e Italia. Según el gobierno marroquí, en 2002 España envió remesas por valor de 1,9 millardos de DHM (171 millones de $€$ ), equivalente al 5,36\% de todas las remesas que recibió Marruecos.

Con su aporte económico, los MRE ayudan a sus familias en Marruecos, incluso después de la muerte de sus padres, impulsando el desarrollo económico y social del país. Así, entre el 53 y el $71 \%$ de las transferencias cumplen la función de ayudar a las familias para compensar los déficits socio-económicos de Marruecos, siendo su principal papel el mantenimiento de la estabilidad del país, cumpliendo la función de una especie de seguridad social que reduce la pobreza ${ }^{28}$ y permite el desarrollo humano, social y económico.

Se observa, entre los MRE, el deseo y la previsión de envejecer en Marruecos tras su retiro, lugar donde preparan su jubilación y funeral. $29 \mathrm{M}$. Aboussi señala que, según un estudio realizado en 2008 por el Alto Comisariado del Plan sobre la inserción socioeconómica de los MRE, esta intención de retorno al país de origen disminuye de generación en generación, al igua que el envío de dinero y las inversiones..$^{30}$

tar datos fiables sobre las transferencias realizadas mediante cauces extraoficiales o paralelos. Es necesario hacer notas que en el caso concreto de España, debido a su cercanía geográfica con Marruecos, hay una mayor facilidad para la entrada de transferencias por vias no formales y por lo tanto, su cuantificación es más complicada.

24 Zakya DAOUD: La diaspora marocaine en Europe..., p. 121.

25 lbid., p. 122

26 lbid., p. 123

27 Iñigo MORÉ:Las remesas de los emigrantes en España: una oportunidad para la acción exterior..., p. 19. 28 Zakya DAOUD: La diaspora marocaine en Europe..., p. 128.

29 Varios investigadores coinciden en que la principal inversión de los MRE es la inmobiliaria como Zakya DAOUD: La diaspora marocaine en Europe..., pp. 24-26; Joan LACOMBA: Migraciones y Desarrollo en Marruecos..., pp. 131-136; Mohammed LAZAAR: “La migration internationale et la stratégie rrollo en Marruecos..., pp. 131-136; Mohammed LAZAAR: "La migration internationale et la strategie
d'investissemenet des émigrés", Revue de Géographie du Maroc, 15, $n^{\circ} .1-2$ (1993), pp. 167-180; Jord d'investissemenet des émigrés", Revue de Géographie du Maroc, 15, $n^{\circ} .1-2$ (1993), pp. 167-180; Jord
BACARÍA: “Las transferencias de los emigrantes magrebies desde España", Migración y cooperaBACÁn mediterráneas. Transferencias de los emigrantes residentes en España e Italia, Barcelona, Icaria ción mediterraneas. Transferencias de los emigrantes residentes en España e Italia, Barcelona, Icaria, 1998, p. 83. No obstante, Joan LACOMBA apunta que este fenómeno no se da en España, donde
la vivienda no supone la principal inversión en Marruecos de los inmigrantes debido a las dificultades que impiden este tipo de inversiones. Joan LACOMBA: Migraciones y Desarrollo en Marruecos..., pp.132-134.

30 Mourad ABOUSSI: "La nueva política migratoria marroqui ante retos de transnacionalismo y codesarrollo", REIM (Revista de Estudios Internacionales del Mediterráneo), 10 (2011), p. 109. https:// gratoria-marrogui-ante-restos-de-transnacionalismo-y-codesarrollo [consultado el 11/11/2013]. 


\begin{tabular}{|c|c|c|c|c|c|c|}
\hline \multicolumn{2}{|c|}{$\begin{array}{l}\text { Evolución de remesas económicas } \\
\text { de MRE (1970-2013) }\end{array}$} & \multicolumn{5}{|c|}{ Ranking de paises emisores (millones de dirhams) } \\
\hline Año & Millones de Dirhams & País de origen & 1982 & 1992 & 2003 & 2012 \\
\hline 1970 & $316,8 €$ & Francia & 3.641 & 11.810 & 15.460 & 21.610 \\
\hline 1975 & $2.159,6 €$ & Italia & 14 & 805 & 4.398 & $5.606,2$ \\
\hline 1980 & $4.147,6 €$ & España & 15 & 196 & 3.205 & $4.937,9$ \\
\hline 1985 & $9.732,2 €$ & Bélgica & 386 & 1.270 & 2.072 & 3.211 \\
\hline 1990 & $16.537,2 €$ & Holanda & 395 & 1.725 & 2.041 & $1.746,5$ \\
\hline 1995 & $16.819,9 €$ & Reino Unido & 52 & 231 & 1.669 & $1.424,9$ \\
\hline 2000 & $22.961,6 €$ & Alemania & 257 & 988 & 1.185 & $2.123,1$ \\
\hline 2001 & $36.858,1 €$ & EEUU & 24 & 114 & 2.026 & $3.114,7$ \\
\hline
\end{tabular}
Sin embargo, y estrechamente vila el 80 y el $90 \%$ de las inversiones, ${ }^{33}$ seguida de la creación de negocios que ponen en manos de sus familiares y ayudar al desarrollo de su zona de origen. ${ }^{34}$ Merece una especial mención la contribución al

31 Datos referidos al periodo entre enero y agosto de 2013

32 Evolución de las remesas económicas disponible en: http://www.oc.gov.ma/portal/tableau-bordan.php y http://www.oc.gov.ma/portal/fr/content/statistiques-des-\%C3\%Agchanges-ext\%C3\%Agrieurs/balance-des-paiements [consultado el 02/10/2013]. Ranking de paises emisores accesible en: http://www.oc.gov.ma/portal/fr/content/statistiques-des-\%C $3 \%$ Agchanges-ext\% $3 \%$ Agrieurs/balance-des-paiements y http://www.oc.gov.ma/portal/sites/default/files/accueil\%20-\%20 BdP/BP\%202012\%20Donn\%C3\%Ages\%20pr\%C3\%Agliminairesl.pdf [consultado el 03/10/2013].

33 Zakya DAOUD: La diaspora marocaine en Europe..., pp. 131-132.

34 Para una descripción más detallada del tipo de inversión que realizan los residentes en España véase Joan LACOMBA: Migraciones y Desarrollo en Marruecos..., pp. 131-134. mantenimiento de las solidaridades tradicionales, pues mediante donaciones para la mezquita, el pago del imam, la financiación de moussems o la organización de campañas de circuncisión de los niños nacidos en familias pobres, consiguen cierta legitimación social. 35

Los MRE son conscientes de su importancia y exigen una modernización y cambios en Marruecos, y "de manera general, critican una sociedad muy cerrada, alejada de la modernidad, donde hay mucha pobreza e ignorancia, un retraso social que les resulta difícil de aceptar". ${ }^{6}$ Asimismo, reclaman el acceso a la lengua y cultura marroquíes. Se trata, pues, de agentes de transformación económica, cambio social y modernización, que desean ser considerados ciudadanos marroquíes al mismo nivel que sus compatriotas residentes en Marruecos.

\section{Instituciones oficiales destinadas a los $\mathrm{MRE}^{37}$}

\section{El Ministerio de Habices y Asuntos Islámicos ${ }^{3}$}

Creado en 1955, su objetivo es ocuparse de gestionar los asuntos religiosos y los Habices (bienes de manos muertas o legados píos). Al mismo tiempo, garantiza el control sobre las doctrinas religiosas -convirtiendo en oficiales las que el monarca considera más provechosas-, sobre los ulemas y los predicadores libres al dotarlos de un sistema estructurado en el que se deben integrar.

En cuanto a su labor con los MRE, se encarga de enviar predicadores a los países con mayor número de marroquíes, con el objetivo de proteger la identidad religiosa de los MRE, especialmente mediante la educación religiosa, civil y espiritual acorde con el Islam moderado, tolerante y pacífico que defiende Marruecos.

Ministerio Delegado para la Comunidad Marroquí Residente en el Extranjero ${ }^{39}$

Creado el 31 de julio de 1990, tras el discurso de marzo de Hasan II en el que el monarca nombraba Ministro encargado de los asuntos de la CMRE ${ }^{\circ}$ a Rafik Haddaoui. El origen de este Ministerio radica en que no se atendian las necesidades de una emigración que ya no se limitaba a la laboral y cuyas necesidades iban más allá de los acuerdos de mano de obra. Entre

35 Especialmente los inmigrantes de primera generación. Ibid., p. 148

36 Ibid., p. 144

37 Es importante señalar que existen otras instituciones no oficiales y de carácter asociativo como el Consejo democrático Civil de los Marroquíes del Mundo y la Alianza Mundial de los Marroquíes en el extranjero entre otras.

38 Este ministerio, junto al Ministerio de Interior, es uno de los conocidos como "ministerios de la soberanía", pues es el propio rey quien decide sobre ellos y no el Primer Ministro. Para ampliar información sobre las instituciones religiosas oficiales de Marruecos véase Mohsine ELAHMADI: Islamisme et modernité au Maroc post-colonial, Lille, Atelier national de reproduction des thèses, 2004 ; y Abdelkrim BELGUENDOUZ: "Le traitement institutionnel de la relation entre les Marocains résidant à l'étranger et le Maroc"..., pp. 20-21. La página web del Ministerio de Habices y Asuntos Islámicos, inaugurada el 2 de noviembre de 2005 , es la siguiente: http://habous.net/fr/ [Consultado el 30/08/2013]. Es especialmente interesante el apartado sobre las mezquitas en su web: http://www.habous.net/mosquee.html [Consultado el 30/08/2013].

39 Su página web: http://www.marocainsdumonde.gov.ma/ [Consultado el 30/08/2013]. Un buen estudio sobre esta institución es el realizado por Abdelkrim BELGUENDOUZ: "Le nouveau ministère chargé de la Communauté marocaine résidant à l'étranger: quelle stratégie ?", CARIM Research Report, 2 (2009), European University Institute - Robert Schuman Centre for Advanced Studies, http://cadmus.eui.eu/bitstream/handle/1814/10788/CARIM RR 2009 02.pdf? sequence=1 [consultado el $09 / 10 / 2013$ ]

40 Decreto 2.91.98 de 9 de junio de 1993 sobre las atribuciones y organización del Ministerio de Asuntos de la Comunidad Marroquí Residente en el Extranjero publicado en el Boletín Oficial del Reino de Ma de la Comunidad Marroquí Residente en el Extranjero publicado en el Boletín Oficial del Reino de Maral de Gobierno: 16 de junio de 1993. Los textos pueden consultarse en la web de la Secretaría Genedel Primer Ministro por lo queno goź de autonomí hasta la reforma del Gabinete Jettou de 2002. 
sus competencias se encontraban la firma de acuerdos y convenios con otros países, realizar estudios sobre la emigración y defender los intereses de los MRE, entre otras. Así, se observa que sus funciones son muy similares a las desarrolladas por la Fundación Hassan II.

En febrero de 1995 las actividades de este ministerio fueron paralizadas y sus estructuras puestas en hibernación. En 1997, se decidió que se transfirieran sus competencias al Ministerio de Asuntos Exteriores y Cooperación y poner fin a dicho ministerio ${ }^{41}$. Posteriormente, en 2007 tras un proceso de reajustes, este Ministerio pasa a depender del Primer Ministerio.

En 2003 la ministra delegada de los MRE junto con el ministro de Asuntos Exteriores y Cooperación presentaron una propuesta de estrategia, aprobada por el Consejo de Gobierno de Rabat el 13 de marzo de 2003, en la que se exponía la importancia de los MRE y se precisaban los objetivos de dicha estrategia, pero no se aportaba ni un diagnóstico, ni una visión prospectiva, ni un plan de acción, así como ningún objetivo preciso. Este hecho, tal y como indica Belguendouz,42 manifiesta que el observatorio de los MRE de la Fundación Hasan II no funciona como debería.

El Ministerio tiene los siguientes programas:

1. Programa social.

2. El programa Cultural y educativo.

3. Programa de Acompañamiento administrativo de los MRE.

4. Programa integrado de comunicación e información.

5. Programa de acompañamiento de los Inversores MRE. ${ }^{4}$

6. Movilización de las competencias marroquíes al extranjero.

De todos ellos, el que más nos atañe es el Programa cultural y educativo, centrado en las siguientes prioridades:

En el dominio cultural:

- Creación de centros culturales en los principales países de acogida. ${ }^{44}$

- Organización de Universidades de verano en beneficio de los jóvenes MRE de entre 18 y 25 años.

- Organización de jornadas culturales en el país de acogida.

- Organización de estancias culturales (20 anuales) en beneficio de los jóvenes MRE.

- Apoyo a la asociaciones activas en el dominio cultural en beneficio de los MRE.

- Organización de giras teatrales y de conciertos artísticos en favor de la CMRE, incluyendo los reclusos en las cárceles de los países de acogida.

- Coordinación de la participación de los MRE en la celebración de la Fiesta del Trono.

- Apoyo a las realizaciones artísticas y culturales de los MRE.

- Creación y apoyo de programas culturales anuales en colaboración con centros culturales marroquíes.

- Preparación de programas de intercambio cultural y deportivo en beneficio de los jóvenes MRE. En el dominio educativo:

- Promoción de la integración de la enseñanza de la lengua árabe en los programas educativos de los países de acogida.

- Apoyo de la enseñanza extraescolar de la lengua árabe y de la cultura marroquí en beneficio de los niños MRE, mediante la organización de sesiones de formación para los profesores y los responsables administrativos y pedagógicos que trabajan en asociaciones de MRE

41 Abdelkrim BELGUENDOUZ: "Le traitement institutionnel de la relation entre les Marocains résidant à l'étranger et le Maroc"..., p. 7

42 Ibid., p. 16.

43 En octubre de 2013 se ha creado un portal especifico para este aspecto: http://www.maghribank.ma.

44 Se han construido o están construyéndose 6 centros: Bruselas, Montreal, Túnez, Tripoli, Amste

dam y Mantes-la-Jolie. y la disposición de las organizaciones de MRE que trabajan en el campo de la educación, los libros escolares y herramientas de enseñanza en el país de origen.

- Desarrollo de la enseñanza a distancia de la lengua árabe y de la cultura marroquí en beneficio de los niños MRE.

- Apoyo técnico y financiero a las asociaciones de MRE activas en la enseñanza de la lengua y de la cultura amazig en beneficio de los niños MRE.

- Apoyo académico a los estudiantes de familias pobres marroquíes residentes en algunos países árabes y africanos.

- Asignación de una cuota anual de 1.000 becas anuales a estudiantes de familias pobres MRE.

- Apoyo a la integración escolar de los alumnos y de los estudiantes emigrados de regreso a Marruecos.

Asimismo, el Ministerio oferta una guía y un programa de acompañamiento para los MRE. 45 Cabe destacar que en el año 2010 se puso en marcha una operación especial con motivo de mes de Ramadán, la conocida como Operación Ramadán. ${ }^{46}$ Se trata de un programa que pretende promover el acompañamiento social de los MRE en situación vulnerable. El programa comprende la preparación de más de 100.000 ifțār, la distribución de 5.000 porciones alimentarias y la celebración de una decena de noches culturales y espirituales con motivo de la "Noche del Destino" y de la Fiesta de Fin de Ramadán. Entre los beneficiarios de esta operación, tienen preferencia los menores, los detenidos, los antiguos combatientes, los discapacitados y los estudiantes residentes en centros de acogida. Se ha proporcionado ayuda en 12 países de acogida ${ }^{47} y$ han colaborado 71 asociaciones de MRE además de los centros diplomáticos y consulares en el extranjero.

Por último es necesario mencionar el programa Dar al Maghrib, ${ }^{48}$ cuyo objetivo fundamental es la consolidación de vínculos con la comunidad marroquí residente en el Extranjero, especialmente en el ámbito cultural.

Mediante dicho programa, se han creado o están en curso de creación 6 centros culturales ${ }^{49}$ con la intención de reforzar el sentimiento de pertenencia e identificación con la identidad cultural marroquí mediante el conocimiento de su cultura de origen, prestando especial interés en los jóvenes. Sus principales actividades son la creación de bibliotecas, la enseñanza de lenguas y culturas de Marruecos y el conocimiento de la civilización y de la herencia cultural marroquí mediante actividades culturales como exposiciones, clubs de lectura, conferencias, espectáculos y proyecciones.

Fundación Hasan II para los MRE 50

Creada en 1990 por el rey Hasan II y presidida, desde el verano de 1996, por la princesa Lalla Maryam, esta fundación se rige por la ley $n^{\circ} 19 / 89$ promulgada en el Dahir $n^{\circ} 1-90-79$ del 13 de

45 Disponible en el siguiente enlace: http://es.marocainsdumonde.gov.ma/media/5334/guide mre p1-ar-1.pdf [consultado el 01/10/2013].

46 Puede obtenerse más información en: http://es.marocainsdumonde.gov.ma/comunicados-de-prensa/op\%C3\%Agration-ramadan-2010.aspx [consultado el 30/09/2013].

47 Los países en los que más se ha trabajado son Francia, Italia, Bélgica, España, Alemania, Finlandia, Grecia, Inglaterra, Senegal, Costa de Marfil, Estados Unidos, Canadá y China.

48 Para más información véase: http://www.marocainsdumonde.gov.ma/minist\%C3\%A8re-desmre-et-des-affaires-de-la-migration/dar-al-maghrib/le-programme-dar-al-maghrib-\% $3 \%$ Aotravers-le-monde.aspx [consultado el 13/11/2013].

49 Los centros se ubican en Montreal, Bruselas, Túnez, Trípoli, Ámsterdam y Mantes-la-Jolie. Actualmente, solo está en funcionamiento el de Montreal, el resto aún no han sido inaugurados. La web del centro de Montreal es http://daralmaghrib.cal [consultado el 10/11/2013].

50 Su página web: http://www.fhrmre.ma/ [Consultado el 30/09/2013]. 
julio de 1990.51 Se trata de una fundación sin ánimo lucrativo cuyo objetivos son mantener los lazos fundamentales que los MRE tienen con su patria y ayudarles a superar las dificultades que encuentran en el hecho de su inmigración. Para ello, ofrece un amplio programa dentro del ámbito cultural, jurídico, económico y social.

En 1997, se reorganizó para incluir un observatorio de los MRE y en abril de 1998 se anunció una reforma de la Fundación en la que se especificaban sus nuevos estatutos..$^{52}$

Sus objetivos se centran en los siguientes ámbitos:

Promoción cultural: Destaca la enseñanza de la lengua árabe y de la cultura marroquí a los niños MRE porque entre sus objetivos esenciales se encuentra la preservación de la identidad cultural de los niños de esta comunidad y la consolidación de los lazos con su país de origen. Para ello, se celebran estancias culturales, que ofrecen a los participantes la oportunidad de descubrir y apreciar la riqueza de su cultura de origen. Igualmente, destaca la cuestión religiosa, pues el Islam constituye la base de la identidad cultural y social de Marruecos.

Asistencia jurídica: Desde 1998, la Fundación ha sido el principal destino de las peticiones hechas por MRE.

Promoción económica: La misión de la Fundación es la de actuar para la promoción de migrante económico. Esto es, aportar la información económica, el apoyo, la orientación, la supervisión de los inversores migrantes y el apoyo en caso de dificultades.

Cooperación internacional: La Fundación sigue ampliando su ámbito de cooperación y colaboración con los gobiernos, las ONG, las organizaciones internacionales especializadas en cuestiones de migración en Marruecos y en el país de residencia y con las asociaciones de marroquíes fuera de su la diversidad y la pluralidad de intereses.

Observatorio de la CMRE (OCMRE): La recogida y tratamiento de los datos relativos a la diáspora marroquí es una prioridad, por ello, la Fundación creó una estructura permanente dedicada a la observación y el análisis de la situación de los MRE.

A continuación, profundizaremos en la labor de la Fundación Hasan II en el ámbito de la promoción cultural. Para ello, nos centraremos en tres aspectos:

1. Enseñanza de la Lengua Árabe y Cultura Marroquí (ELACM).

2. Estancia cultural.

3. Animación religiosa.

La enseñanza de la lengua árabe y la cultura marroquí (ELACM)

El primer aspecto a destacar es la promoción de la Enseñanza de la Lengua Árabe y la Cultura Marroquí (ELACM). Este tipo de iniciativas, destinadas a los niños y jóvenes, comenzaron en los años 70 en respuesta a la demanda de la comunidad marroquí preocupada por garantizar a sus hijos la oportunidad de reintegrarse fácilmente en las escuelas de Marruecos en caso de retorno definitivo. La opción de regresar era, poco a poco, abandonada y la ELACM pasó a se una enseñanza de ayuda a la integración en las sociedades de acogida. Con el paso del tiempo se convirtió en un en un factor de consolidación de los vínculos con el país de origen y de salvaguarda de la identidad cultural marroquí.

Hoy en día, la ELACM moviliza los medios humanos y financieros de casi el $85 \%$ de los recursos de la Fundación, emplea 576 docentes y tiene una media de 75.387 beneficiarios por año.

Uno de los aspectos a los que más atención se ha prestado es la reestructuración del cuerpo docente. Para ello, se han tomado una serie de medidas como la adopción de criterios objeti-

51 Publicado en el Boletín Oficial del Reino de Marruecos nº 4055 de 18 de julio de 1990. Se puede consultar el texto legal de su creación en la siguiente web: http://www.fhzmre.ma/la-fondation/ textes-de-creation.html [Consultado el 30/09/2013].

52 Abdelkrim BELGUENDOUZ: "Le traitement institutionnel de la relation entre les Marocains rési-

dant à l'étranger et le Maroc"..., p. 8. vos para su selección mediante un concurso de oposiciones. Asimismo, se ha puesto en marcha un proceso de renovación progresiva de los docentes.

Es necesario destacar que el reparto de los docentes se ha realizado en función de la importancia de la comunidad marroquí en los países de acogida. Por ello, el $78 \%$ se concentra en Francia y Bélgica, ocupando España el tercer lugar.

El número de los niños beneficiados ha pasado de 34.482 en el curso escolar 1990/1991, a 75.387 durante el curso 2011/2012.

Las cifras anteriores no se aplican a la educación proporcionada por todas las asociaciones y mezquitas, que desempeñan un papel importante en la ELACM. ${ }^{33}$ Por ello, la Fundación pone a su disposición los fondos de libros, manuales escolares y cuentos de Historia editados en Marruecos, para enriquecer sus bibliotecas. Este programa ha beneficiado a las asociaciones donde el número de estudiantes es inferior a 100 niños. También 200 organizaciones se han beneficiado de los fondos documentales de más de 143.000 libros.

Asimismo, la Fundación ha decidido introducir las TIC para lograr una plataforma de aprendizaje de la lengua árabe en internet ${ }^{54}$ para los niños marroquíes residentes en el extranjero, con el objetivo de reducir el costo de este servicio y asegurar la generalización de esta enseñanza. Existen cuatro tipos de enseñanza en función del lugar en que son impartidos:

- La enseñanza preescolar. Su tasa de cobertura es del $1 \%$ (1.085 niños).

- La enseñanza integrada dispensada en el seno de las escuelas públicas durante los horarios reglamentarios de trabajo. Su tasa de cobertura es del 14 \% (10.573 niños).

- La enseñanza diferida dispensada en las escuelas públicas fuera del horario reglamentario de trabajo. Su tasa de cobertura es del $59 \%$ (44.157 niños).

- Enseñanza paralela a iniciativa de las asociaciones y en los locales de las asociaciones y las mezquitas. Su tasa de cobertura es del $26 \%$ (19.572 niños).

\section{Las estancias culturales}

En el terreno cultural destaca la organización de estancias culturales. La estancia cultural es la evolución, desde 1998 de las colonias de vacaciones. Benefician anualmente a casi mil niños marroquies entre 9 y 13 años, ofreciendo una estancia de 2 semanas que combina los aspectos lúdicos con los culturales. Se vincula con los objetivos asignados a la enseñanza de la lengua árabe y de la cultura marroquí.

Este programa ha ido en aumento, pues ha pasado de 318 niños beneficiados en 1998 a 876 en 2012.

Animación religiosa

- Por último, a nivel religioso, los esfuerzos de la fundación se centran en los siguientes puntos:

- Iniciativas de acompañamiento.

- Distribución de libros de Corán y de manuales sobre el rito malikí.

- Apoyar a las mezquitas y las asociaciones que operan en el dominio del aprendizaje de la lengua árabe (manuales escolares, formación de docentes, etc.)

- Apoyar a las mezquitas que organizan concursos de recitación del Corán en beneficio de los niños.

- Programación de giras periódicas de grupos de música sagrada.

- Colaborar con las grandes mezquitas, centros y asociaciones para organizar la celebración de reuniones y simposios sobre los desafíos del Islam y los problemas actuales.

53 En el curso 2011/2012 este tipo de enseñanza se aplicaba en 2.411 colegios públicos y 441 asociaciones y mezquitas.

54 Esta plataforma estará disponible en la web http://www.e-madrassa.ma/ [consultado el 02/10/2013]. 


\begin{tabular}{|c|c|c|c|c|}
\hline PAís & $\begin{array}{c}\text { PROF. } \\
\text { UNIVERSITARIOS }\end{array}$ & PREDICADORES & IMAMES & TOTAL \\
\hline Francia & 17 & 19 & 22 & 58 \\
\hline Alemania & 17 & 13 & 15 & 45 \\
\hline Países Bajos & 8 & 10 & 14 & 32 \\
\hline Italia & 12 & 16 & 2 & 30 \\
\hline Bélgica & 9 & 10 & 10 & 29 \\
\hline España & 5 & 14 & 7 & 26 \\
\hline Canadá & 3 & 5 & 1 & 9 \\
\hline Estados Unidos & 2 & & 1 & 3 \\
\hline Suecia & 2 & & 1 & 3 \\
\hline Dinamarca & 1 & & 1 & 2 \\
\hline Gran Bretaña & 2 & & & 2 \\
\hline Suiza & 1 & & & 1 \\
\hline Noruega & 1 & & & 1 \\
\hline TOTAL & 80 & 87 & 74 & 241 \\
\hline
\end{tabular}

Gráf. 05 Efectivos destinados en Europa en el mes de Ramadán 2012/1433 35 (Fuente: elaboración propia a partir de los datos de la Fundación Hasan II)

Fundación Muhammad $V$ para la Solidaridad 56

Creada en el año 2000 para ocuparse de la organización de la llamada Operación Tránsito o marhaba57 (Bienvenida), centrada en la estancia vacacional de los MRE, competencia hasta ese momento de la Fundación Hasan II.

Proporciona ayuda logística en el pasaje y circulación de los MRE entre los puertos de entrada y su destino final en Marruecos. Para ello, dispone de varios centros de recepción en el extranjero-Génova, Algeciras, Almería, Sète, Nápoles y Vendres-y en Marruecos: los puertos de Tánger, Nador, Alhucemas, la frontera de Ceuta y en los aeropuertos de Oujda y Casablanca y en áreas de reposo de Larache, Taourirt, Gueznaya, Tazaghine y Ras El Ma.

\section{El Consejo de Ulemas para los Marroquies Residentes en Europa ${ }^{58}$}

Entre las políticas religiosas más relevantes dirigidas a la comunidad marroquí en el extranjero, quizás la más destacada sea la creación del Consejo de Ulemas para los Marroquíes Residentes en Europa. 59

En 2008, en el discurso que el rey Muhammad VI pronunció ante los ulemas anunciando la creación de dicho Consejo, aseguraba que mediante él se pretende favorecer la apertura de asuntos relacionados con la religión y la cultura de la comunidad marroquí. Se presentó como una ayuda para proteger la fe y los valores propios de la identidad marroquí contra el avance

55 Extraído de la web de la Fundación Hasan II: http://www.fh2mre.ma/promotion-culturelle/animation-religieuse/mission-en-cours.html [Consultado el 01/10/2013].

56 Su página web es la siguiente: $h t t p: / / w w w . f m 5 . m a /$ [Consultado el 02/10/2013]

57 Funciona entre el 15 de junio y el 15 de septiembre de cada año.

58 Para más información véase Mohammed EL-KATIRI: "The Institutionalisation of Religious Affairs: Religious Reform in Morocco", The Journal of North African Studies, 18, 1 (2012), pp. 62-64.

59 Dahïr Chérifien $n^{\circ} 1.08 .17$ publicado el 6 de noviembre de 2008. del fundamentalismo y el extremismo. La creación de este consejo responde a la necesidad de personal religioso cualificado con un elevado conocimiento de las ciencias religiosas y un am plio conocimiento de la realidad europea, capacitado para resolver las necesidades religiosas de los marroquies en el extranjero.

El Consejo principal tiene su base en Bruselas y está previsto establecer 18 consejos locales en toda Europa. Actualmente, dichos consejos no están operativos y se está estudiando qué características principales deben tener para adaptarse a las diferentes realidades europeas.

Su funcionamiento es el mismo que el de los Consejos de Ulemas de Marruecos, pero adap-

tado a las realidades contextuales de sus países de acogida. Los principales objetivos de esta institución son:

- Nombrar imames y predicadores permanentes para las mezquitas propiedad o gestionadas por las comunidades marroquíes en Europa. Esta medida es más lógica que la práctica de nombrarlos únicamente durante el mes de ramadán practicada anteriormente.

- Formar a los imames ${ }^{60}$ con amplios conocimientos sobre la cultura y el idioma del país de acogida.

- Promover un Islam moderado y tolerante, dentro de la doctrina malikí entre los MRE, especialmente entre los jóvenes.

- Apoyar la expedición de fetuas para los MRE, lo que indica que las fatuas de los Consejos de Ulemas de Marruecos son válidas sólo en el territorio marroquí.

- Establecer la cooperación científica con los gobiernos europeos y otras organizaciones e instituciones islámicas con similares objetivos.

De este modo, observamos que se trata de una medida de aproximación a los MRE y la creación de un órgano de control de la esfera religiosa por parte del gobierno marroquí para evitar y frenar la influencia del Islam no malikí.

\section{Consejo Consultivo de los Marroquíes Residentes en el Extranjero (CCME) ${ }^{6}$}

Muhammad VI anunció, en el discurso por el 30 aniversario de la Marcha Verde (2005), la creación de un "Consejo Superior de la Comunidad Marroqui en el Extranjero, constituido de forma democrática y transparente, con todas las garantías de credibilidad, eficiencia y representatividad auténtica". Sin embargo, la creación del Consejo Consultivo de los MRE mediante el Decreto Real $n^{\circ}$ 1-07-208 de 21 de diciembre de 2007 determinó que se trataría de un Consejo dependiente del rey, con carácter consultivo y con un mandato de 4 años. Está conformado por dos categorías de miembros:

- Los deliberantes: el Presidente, el Secretario General y $50^{62}$ miembros elegidos entre los MRE que destacan profesional y socialmente.

6o Sobre el papel e importancia de los imames como autoridad religiosa véase Frank PETER: "Individualization and Religious Authority in Western European Islam", Islam and Christian-Muslim Relations, 17 (2006), pp. 105-118; Joan LACOMBA: "La inmigración musulmana y el Islam institucionalizado. La figura de los imames inmigrados", Migraciones, 7 (2000), pp. 155-194 y Jean-François HUSSON: Training Imams in Europe. The Current Statut, Bruselas, King Baudouin Foundation, 2007, http://www.kbs-frb.be/publication.aspx?id=294955\&langtype $=1033 \&$ src=true [consultado el og/10/213].

61 Su página web: http://www.ccme.org.ma/. Un buen análisis sobre esta institución son los trabajos de Abdelkrim BELGUENDOUZ: “Le Conseil de la communauté marocaine à l'étranger. Une nouvelle institution en débat", CARIM Research Report, 1(2009). European University Institute - Robert Schuman Centre for Advanced Studies, http://cadmus.eui.eu/bitstream/handle/1814/10787/CARIM RR 2009_01.pdf?sequence=1 [consultado el og/10/2013] e I I D.: "Le traitement institutionnel de là relation entre les Marocains résidant à l'étranger et le Maroc"..., pp. 40-42.

62 En un primer momento se nombraron sólo 37 miembros, pues se trataba de un consejo transitorio durante un periodo de 4 años. 
- Los observadores: se trata de 17 miembros entre los que se encuentran 10 ministerios y otras 7 instituciones destacadas por su implicación con los MRE.

Su misión es elaborar y proponer al rey Muhammad VI estrategias homogéneas para defender mejor los intereses de los marroquíes en la diáspora.

La dirección del CCME la conforman el presidente del Consejo, ${ }^{63}$ su secretario general ${ }^{64}$ y los presidentes de los siguientes 6 grupos de trabajo compuestos de miembros del CCME y de representantes de diferentes ministerios marroquíes:

- Acercamiento a las mujeres y las nuevas generaciones.

- Culto y educación religiosa.65

- Competencias científicas, técnicas y económicas para el desarrollo solidario.

- Administración, derechos de los usuarios y políticas públicas.

- Ciudadanía y participación política.

- Cultura, educación e identidad. ${ }^{66}$

Un aspecto que es importante señalar es que la falta de transparencia y democracia en el procedimiento por el que son elegidos los miembros y en lo referente a sus competencias son el objeto de numerosas críticas que han motivado el surgimiento de movimientos ${ }^{67}$ tales como el Movimiento de los Marroquíes Demócratas en el Extranjero, ${ }^{68}$ el movimiento Daba 2012 pour tous, ${ }^{69}$ el Foro Civil de Marroquíes en Europa o el Comité de Marroquies del Exterior para la Revisión de la Constitución. ${ }^{\circ}$

En síntesis, tal y como ya indicó A. Planet, ${ }^{71}$ la creación de este Consejo demuestra la importancia dada por el régimen marroquí y el interés personal del monarca a la cuestión migratoria. Asimismo, se pretende asegurar el mantenimiento de vínculos más estrechos de los MRE con su país de origen, con el fin de que se reconozca la autoridad religiosa y política del monarca y se muestre el compromiso con la integridad territorial de Marruecos.

\section{Medios de comunicación destinados a los MRE}

En plena era de las nuevas tecnologías, conservar el vínculo de unión con el país de origen es cada vez más sencillo, y los marroquíes que residen en el extranjero disponen de una amplia variedad de opciones mediante las que reducir la distancia, eliminar las fronteras y favorecer el contacto con su país y cultura originarios.

Berta Álvarez-Miranda señala que la antigüedad de la migración influye en la tendencia a seguir las noticias en la lengua materna. Pero matiza que lo hace en el sentido contrario la

63 Driss El Yazami.

64 Abdellah Boussouf.

65 Dirigido por Abdallah Redouane.

66 Dirigido por Younes Ajarrai.

67 Sobre estos movimientos consúltese Ana I. PLANET CONTRERAS: "El Estado marroquí ante sus emigrantes y la ciudadanía marroquí en la diáspora", ARI 59/2011, Real Instituto Elcano, 2011, pp. 4-5, http://www.realinstitutoelcano.org/wps/portal/rielcano/contenido?WCM_GLOBAL CONTEXT=/elcano/elcano_es/especiales/crisismundoarabe/analisis/rie/ari59-2011 [consultado el $9 / 10 / 2013$

68 Constituido en agosto de 2009. Su rama española lo hizo en octubre de 2009

69 Reunido por primera vez el 10 de agosto de 2009, este movimiento agrupa más de 450 asociaciones. Su página web es la siguiente: www.daba2012.com.

70 Constituido el 21 de marzo de 2011 con el fin de participar en el proceso consultivo. Véase Mourad ABOUSSI: "La nueva política migratoria marroquí ante retos de transnacionalismo y codesarrollo", REIM (Revista de Estudios Internacionales del Mediterráneo), 10 (2011), p. 111.

71 Ana I. PLANET CONTRERAS: El Estado marroqui ante sus emigrantes y la ciudadanía marroqui en la diáspora... hipótesis de que los extranjeros recién llegados mantienen un vínculo transnacional más intenso que sus predecesores. Así, indica que "un $89 \%$ de quienes migraron antes de 1985 siguen las noticias en la lengua materna, seguidos del $80 \%$ de quienes migraron entre 1985 y 1994, y de un $60 \%$ de quienes llegaron a Europa después de 1995".72 Igualmente, en otro estudio comparativo entre los inmigrantes musulmanes residentes en Europa, apunta que el $59 \%$ de los marroquíes de Madrid sigue las noticias en su lengua materna, prestando especial atención a las noticias de televisión (56\%), mientras que la radio y los periódicos tienen menor audiencia $(11 \%$ y $5 \%) .{ }^{73}$

Televisión

Como se ha anticipado, el medio de comunicación con mayor audiencia es la televisión (vía satélite) ${ }^{74}$ y por ello, destacaremos los contenidos y cadenas que más nos atañen en la búsqueda de preservar la identidad y la cultura marroquí en el extranjero.

Al AoulaSat (SNRT 1):75 Se trata de la primera cadena generalista pública marroquí y en general, tiene la misma programación que Al Aoula terrestre. Está dirigida, principalmente a telespectadores en Marruecos, el mundo árabe y Europa.

$2 \mathrm{M} \mathrm{Maroc:}{ }^{76}$ Es el segundo canal generalista de Marruecos. Emite principalmente en árabe y algunos programas en francés.

Al Maghribya (SNRT 5):"77 Es el canal público generalista dirigido a los marroquíes expatriados. Emite redifusiones de una parte de los programas de Al-Aoula y algunos de $2 \mathrm{M}$. Como peculiaridad hay que destacar que sólo es accesible por satélite.

Assadissa (SNRT 6): $:^{78}$ Creada por el rey Muhammad VI el 2 de noviembre de 2005 y dependiente de los ministerios de Comunicaciones y de Asuntos Islámicos, se trata de una cadena pública de contenido religioso. Aunque su contenido fundamental es de tipo islámico, centrado en textos de Corán, el Hadit y su exégesis, también se pueden encontrar temas relacionados con la salud, la familia, la juventud y asuntos sociales en general, siempre desde un punto de vista religioso. Destacaremos la importancia que adquiere durante el mes de ramadán momento en que su audiencia se incrementa considerablemente y sus horas de emisión aumentan a 14 horas diarias, incluyendo la retransmisión en directo de las Conferencias Hasaníes que preside el rey Muhammad VI y de las diferentes oraciones desde la mezquita Ḥasan II de Casablanca. Igualmente, durante dicho mes, su parrilla se divide en entre varias nuevas producciones que destacan las características específicas de Marruecos y su autenticidad en el ámbito de las tradiciones y prácticas religiosas. El 19 de junio de 2006, el rey Muhammad VI

72 Berta ÁLVAREZ-MIRANDA:"Aquí y allí. Vínculos transnacionales y comunitarios de los inmigrantes musulmanes en Europa...", p. 13.

73 ÍD.: "La diversidad de los inmigrantes musulmanes en Europa...", pp. 195-196.

74 El $89 \%$ de los marroquíes en el extranjero ve las cadenas marroquíes, y el $54 \%$ presta especia atención a las noticias (Zakya DAOUD: La diaspora marocaine en Europe..., p. 155). Sobre el uso de la televisión por parte de los inmigrantes marroquies en Bilbao véase Josu AMEZAGA ALBIZU: "Biladi: usos de la televisión por satélite entre los y las inmigrantes magrebíes en Bilbao", ZER (Revista de Estudios de Comunicación), 10 (2001), www.ehu.es/zer/zer1o/10amezaga.htm [Consultado el 10/09/2013].

75 Creada el 3 de marzo de 1962 con el nombre TVM (Televisión Marroqui),y posteriormente, en 2007 sufre una breve reforma de contenido para modernizarse y cambia su nombre por el actual. Su página web: http://www.alaoula.ma/.

76 Creada el 4 de marzo de 1989 y hasta 1996 gestionada por varias instituciones privadas y públicas. Tras superar algunos problemas económicos, en 1996 pasó a ser gestionada por el Estado marroquí, poseedor del $68 \%$ de capital. Su página web: http://www.2m.ma/.

77 Su página web: http://almaghribia-tv.ma/.

78 Comenzó a emitir el 2 de noviembre de 2005. Su página web: http://www.assadissatv.ma/.

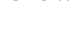


estrena un programa televisivo para la predicación y la formación religiosa en las mezquitas. Esencialmente se retransmite en árabe, pero también hay espacios en francés y amazig.

Radio

Radio Mohammed VI du Saint Coran:79 Comenzó a emitirse el 16 de octubre de 2004. Se trata de una cadena pública con programación de temática religiosa, cuyos contenidos son similares a su equivalente en televisión.

Radio Al Wataniya: ${ }^{80}$ Radio nacional pública que propone una programación generalista y diversificada.

Radio Chaine Internacional: ${ }^{81}$ Radio pública nacional de corte generalista y de difusión internacional. Entre sus objetivos destaca la valoración de la diversidad lingüística de Marruecos y su apertura sobre la escena internacional y la promoción y difusión de la cultura y civilización marroquíes.

Mención aparte merece el proyecto Synergies des marocains du monde. ${ }^{82}$ Creada en colaboración entre el Ministerio Delegado de los Marroquíes Residentes en el Extranjero y la Asociación Médica de Ayuda al Desarrollo entre Auvernia y Marruecos ${ }^{83}$ (AMDAM). Se trata de un conjunto de medios de comunicación que cuenta con una web y televisión digital destinada a los MRE. Se describe como una espacio de intercambio y de diálogo abierto a todos los marroquies del mundo. entre sus objetivos está el apoyo técnico a las asociaciones que trabajan en el ámbito de los MRE, la creación de redes y asociaciones de la inmigración marroquí, el asesoramiento sobre cuestiones migratorias instituciones nacionales e internacionales y los derechos de los migrantes y llevar a cabo estudios y encuestas sobre la inmigración marroquí. Es especialmente interesante el espacio dedicado a la televisión, en el que se encuentran contenidos relativos a asociaciones, competencias y entrevistas a personalidades destacadas.

\section{Conclusiones}

El objetivo fundamental de la creación de diferentes instituciones oficiales marroquíes y medios de comunicación dirigidos a los MRE consiste en preservar la relación entre éstos y Marruecos, buscando patrocinar la identidad cultural marroquí, especialmente el aspecto religioso y lingüístico, a la vez que potencia su integración en el país de acogida, todo ello sin perder los recursos económicos que este sector de proporciona. Igualmente, se busca controlar en la medida de lo posible, las tendencias religiosas extremistas a las que pueden sucumbir de los MRE y promover la formación de imames que prediquen un Islam malikí moderado, acorde con los intereses de Marruecos.

Sin embargo, este creciente interés del Estado marroquí por su población emigrada también tiene su parte negativa. Tras analizar las diferentes instituciones involucradas con los MRE, se observa una duplicidad de funciones entre ellas, puesto que existen numerosas actividades solapadas con los diferentes organismos (Fundación Hasan II, Fundación Muhammad V Ministerio de los MRE, etc.), tales como la enseñanza de la lengua árabe y la cultura marroquí, o la operación de tránsito estival.

Igualmente, se aprecia que las prácticas de los MRE son económicas, sociales y culturales, pero no políticas, y eso genera polémicas, pues, conscientes de su importancia, reclaman mayor presencia política, lo que supone una amenaza para la soberanía del Estado.

9úgína web:http//wwwidaatmohammedassadiss.mal.

8o Su página web: http://www.alidaa-alwatania.ma/.

81 Su página web: http://www.chaineinter.ma/.

82 Su página web: http://www-synergies-des-marocains-du-monde.com/.

83 Su página web: http://www.amdamfr.com/.
En cuanto al uso de los medios de comunicación, una de sus funciones fundamentales es la retransmisión de las ceremonias religiosas nacionales en las que el rey tiene especial importancia. En este sentido, podemos destacar la celebración de la Fiesta del Trono, el 'íd mîlâd al-Nabī (celebración del nacimiento del Profeta), el al-īd al-Kabīr y el al-Tid al-Sagīr. Este uso no es nuevo, pues ya era uno de los recursos más usados por Ḥasan II para potenciar y difundir su imagen como Amir al-Mu'minīn en sus intervenciones religiosas. De este modo, los MRE pueden mantenerse vinculados con los acontecimientos más destacados en su país de origen e incluso integrarse en ellos. Una clara muestra de ello, es la participación de un grupo de MRE en la Fiesta del Trono, celebración que es retransmitida por televisión y radio, y por consiguiente, con una gran audiencia tanto dentro como fuera de las fronteras marroquíes. 


\section{EL ESTABLECIMIENTO DEL PROTECTORADO HISPANO-FRANCÉS EN MARRUECOS.}

\section{UNA VISIÓN LOCAL}

María Gajate Bajo

Universidad de Salamanca cutivo de Canalejas. ${ }^{2}$ Con razón, El Socialista rechazaba por igual el comportamiento militarista de ambos países. ${ }^{3}$

Tan pronto como el general Bremond llegó a la mentada ciudad, en mayo, Alfau contestó con la ocupación de algunas posiciones cercanas a Ceuta. La Vanguardia, sin embargo, consideraba que no bastaba. ${ }^{4} \mathrm{Y}$ efectivamente poco después se registraban sendos desembarcos en Larache y Alcazarquivir, ciudades supuestamente también violentadas por grupos de rebeldes marroquíes. El órgano obrero, por el contrario, ponía el grito en el cielo y despotricaba además contra la actitud hipócrita, esto es, complaciente, del Trust. 5 Durante la Semana Trágica, el rechazo de este consorcio hacia la guerra había sido firme, pero ahora guardaba silencio ante las operaciones que se desarrollaban en el Kert y hasta El Imparcial apelaba a un "ineludible deber" para justificar los avances. ${ }^{6}$ Marruecos evidentemente jugaba un papel clave en la confrontación partidista. Y no era lo mismo que gobernase Maura o Canalejas.

El jefe liberal estaba arrojando mucha leña al fuego para combatir un nada encubierto protectorado francés sobre el Sultanato. Los diarios más conservadores, entre tanto, aprovechaban estas semanas de apogeo del "espíritu conquistador" para desquitarse con todos los

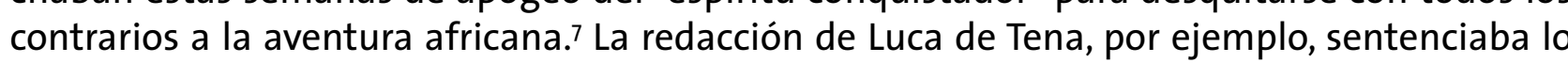
que sigue: "El pueblo español se halla ya bien apercibido de que el problema marroquí es para él cuestión de vida o muerte". ${ }^{8}$ Adhesión incondicional y nada más. Ésta era la idea que se pretendía infundir entre los lectores, entre la opinión con más ansias por formarse.

Alemania, desde luego, no estaba dispuesta a permanecer ajena a lo ocurrido. Por eso el Reich, muy alarmado ante esta indisimulada carrera, envió el 1 de julio de 1911 un cañonero Panther a Agadir, enclave costero de gran potencial estratégico para Francia. Al igual que durante la crisis de Tánger, en 1905, Guillermo II protagonizaba así un golpe de efecto ante la colérica mirada de los galos. Según El Imparcial, el arrebato alemán parecía previsible, pero había que obrar con calma:

El acuerdo de 1907 sobre el statu quo mediterráneo y atlántico se refiere a los territorios y posesiones españolas y francesas, no a las esferas de influencia. Y en la situación de España, tener el derecho de ser neutral es tener la obligación de no dejar de serlo. ${ }^{9}$

Dicho de un modo más vulgar, nada de secundar al gabinete parisino.

Una opinión similar se sostenía desde las páginas de La Vanguardia. Ésta se afanaba ahora en recomendar prudencia, atenta a la reacción inglesa. Como nota curiosa, Sánchez Pastor, que era uno de los redactores más interesados en la cuestión africana, reparaba en la conducta de la opinión pública. A ella aludía como "expectante, sin entusiasmos ni temores, actitud que revela por el momento un verdadero deseo de conocer el interés que nos mueve, las cirque revela por el momento un verdadero deseo de conocer el interés que nos mueve, las cir-
cunstancias que nos obligan a avanzar en el territorio marroqui y los beneficios que todo ello pueda reportarnos"..$^{\circ}$ Pero España a su vez respondía en agosto adueñándose de Arcila. desacreditar a sus rivales interfiriendo en el juego colonial. Gran Bretaña, se mantenía en un segundo plano. Eso sí, siempre y cuando su dominio sobre Gibraltar no se viese amenazado.

El avance galo sobre una hostilizada Fez en 1911 hizo definitivamente saltar las chispas en tre los contendientes europeos. En el terreno periodístico, el otro gran campo de batalla, tal vez $A B C$ fuera quien más claramente manifestó su repudio hacia ese agresivo colonialismo francés y, de paso, hacia los pacifistas peninsulares.' Pero la suerte no estaba de parte de éstos. La prensa desempeñó, y aún lo hace hoy, un papel capital a la hora de condicionar nuestra visión sobre la política internacional y sobre el otro, el marroquí en este caso. La estrategia adoptada por El Imparcial, en cambio, fue la opuesta: y no porque no recelase de los vecinos ultrapirenaicos, sino porque aprendió a esgrimir sus mismos argumentos para espolear al eje-
2 "Obras son amores", El Imparcial, 5 de mayo de 1911.

3 "La conquista de Marruecos", El Socialista, 3 de mayo de 1911

4 Emilio SÁNCHEZ PASTOR: “La vida política”, La Vanguardia, 4 de junio de 1911

5 "La prensa y la guerra", El Socialista, 16 de junio de 1911.

6 “El desacuerdo franco-español", El Imparcial, 11 de junio de 1911.

7 Manuel SÁNCHEZ DE ENCISO: "Barrenando a España", El Debate, 13 de junio de 1911.

8 Tomás MAESTRE: “Los asuntos de Marruecos", $A B C, 13$ de junio de 1911.

"Intervención alemana en Marruecos", El Imparcial, 2 de julio de 1911.

10 Emilio SÁNCHEZ PASTOR: “La vida política”, La Vanguardia, 6 de julio de 1911. 
La noticia era muy bien acogida entre la opinión conservadora. $A B C$, emulando a órganos ultraderechistas como El Debate," no había vacilado antes en solicitar incluso una urgente modificación en el sistema de alianzas. A España le convenía decantarse por los alemanes: "En el choque de las naciones, el débil no puede ser neutral; la neutralidad supone la enemistad manifiesta de los dos pueblos que luchan".12

Al borde del conflicto mundial, la firma de un convenio franco-germano en noviembre de 1911 pudo disipar las tensiones continentales. En el $A B C$ y El Debate este pacto cayó como un enorme jarro de agua fría. ${ }^{13}$ Pero lo cierto es que así fue como Francia logró despejar su camino en $\mathrm{Ma}$ rruecos. Meses después, en marzo, sellaba el tan ansiado acuerdo de protectorado con el Sultán

Tras unas durísimas conversaciones, España también vería su sueño hecho realidad con la firma del tratado hispano-galo, piedra angular del protectorado bipartito. Nada más firmarse la tregua centroeuropea, Pío Baroja -como tantos otros intelectuales que reflexionaron sobre este malhadado asunto- había divagado en El Imparcial sobre cuál debía ser el proceder español ante la cuestión marroquí. Según su criterio, la mayoría del país, hasta el momento, no se había mostrado ni guerrera ni pacifista, sino utilitaria:

Tenemos una cosa cotizable. ¿Hay que cambiar? Cambiémosla por algo bueno. ¿Hay que vender? Vendámosla lo más cara posible [...] Entre dos comerciantes que pactan, el que intenta hacer intervenir la caballerosidad y el honor en sus diferencia no prueba que es un hidalgo, sino un imbécil". ${ }^{14}$

Lamentablemente, el prestigioso escrito no aclaraba cuál era esa cosa cotizable. Quizás se refiriese a la posesión de las Canarias o a las plazas de soberanía africana. Pero entramos en el fangoso terreno de la conjetura.

En cualquier caso, no se registraron cambios ni ventas, pero sí recortes. Según los socialistas, con este acuerdo hispano-francés se confirmaba el despojo marroquí. Y se advertía, premonitoriamente, que el Sultanato acarrearía muchos problemas porque España era mala colonizadora y peor administradora. ${ }^{15} \mathrm{El}$ liberalismo progresista al menos enfatizó la tenacidad con que actuó la diplomacia cortesana. Sin embargo, entre sus exhortaciones de cara al futuro, ya se apreciaba también un considerable temor:

Si consagramos exclusivamente los tesoros a la acción africana, el contraste entre el forzoso despilfarro alli y la penuria y la escasez aquí, será elemento muy sugestivo entregado a cuantos aspiren a difundir entre las multitudes la cólera y acrecentar en las masas de la sociedad española todos los sentimientos de subversión. ${ }^{16}$

Como consuelo para los conservadores quedó el hecho de que el ejecutivo de Madrid se garantizaba la autonomía jurisdiccional en su zona. ${ }^{17}$ No obstante, El Debate fue incapaz de

1 P. URGEL."COnducta maquiavélica de Francia", El Debate, 29 de marzo de 1911

12 Tomás MAESTRE: “El conflicto europeo", $A B C, 3$ de julio de 1911

3 "El acuerdo franco-alemán", $A B C, 4$ de noviembre de 1911; “El tratado franco-alemán”, El Debate, 6 de noviembre de 1911. El sentimiento de rabia iría en aumento al hacerse pública la parte secreta del tratado hispano-francés de 1904, el más claro precedente del acuerdo sellado en 1912 y que ratificaba, efectivamente, la influencia española sobre las ciudades de Larache y Alcazarquivir. Consúltese Alfonso GAYO: " $A B C$ en París. El tratado secreto", $A B C, 14$ de noviembre de 1911. 14 Pío BAROJA: "Examen de criterios", El Imparcial, 30 de noviembre de 1911.

15 "El tratado con Francia", El Socialista, 20 de diciembre de 1912

16 "La firma del tratado", El Imparcial, 28 de noviembre de 1912.

17 "El reparto de Marruecos. Texto del tratado franco-español", $A B C, 1$ de diciembre de 1912. contener su furia al contemplar cómo la alianza con la Entente había desembocado en la mutilación de la vieja zona de influencia. ${ }^{18}$

El ejecutivo español, en efecto, no orquestó ninguna de las negociaciones y hubo de aceptar a regañadientes la internacionalización de Tánger, cuyo estatuto no se aprobaría hasta febrero de 1924, y la competencia exclusiva del Residente General Francés, Lyautey, con sede en Rabat, para todo lo relacionado con la política exterior marroquí. ${ }^{19}$ El Protectorado fue, además, en términos administrativos, una realidad muy compleja. El interventor sería el hombre encargado de obtener información sobre las cábilas, su armamento, estado de salud, lecturas a su disposición... La meta final consistiría en arrastrar a los marroquíes hacia la "civilización", o, como sintéticamente expresaba el comandante Díaz de Villegas, "vamos a Marruecos, no contra Marruecos, sino con Marruecos".20

La realidad resultó muy alejada de la teoría: España no tenía experiencia colonizadora previa y los militares acabaron adueñándose de la gestión del poder, al menos, hasta 1926-1927.2 Incluso, cuando el fomento de la llamada "acción política" fue la consigna adoptada por todos los gobiernos. Historiadores como Richard C. Pennell precisamente sitúan aquí el origen de las dificultades experimentadas por los españoles en el continente africano: "Al tratar de poner en práctica una política basada en conceptos erróneos acerca del carácter de la sociedad marroquí, el Ejército español ayudó a que se creara una sólida resistencia". ${ }^{22}$ No le faltaba un ápice de razón. Las subvenciones para ciertos cabecillas desprestigiaron a los sectores colonialistas y trastocaron los equilibrios entre las cábilas. Pero, además, muchos de los "pensionados" acabarían volviéndose contra España. El caso de Abd-el-Krim y lo ocurrido en Annual y Monte Arruit constituirían la mejor expresión de lo enunciado.

Con la ocupación de Tetuán, en febrero de 1913, se intentó poner el broche de oro a esta turbulenta historia. Mientras El Debate aún rememoraba su anterior pérdida y la achacaba, cómo no, a los ingleses, ${ }^{23}$ la satisfacción inundaba redacciones como la del $A B C$, que no reparaba en dispensar halagos al Ejército. ${ }^{24}$ Tampoco El Imparcial disimuló su alegría ante el desarrollo pacífico de la operación. ${ }^{25}$ Pero en realidad, pronto se iniciaría una nueva campaña que no cesó hasta el estallido de la Gran Guerra. Acertado se había mostrado El Socialista al sentenciar que "la estéril vanidad de haber ensanchado el territorio patrio va a costarnos más cara de lo que parece" ${ }^{26} \mathrm{El}$ órgano obrero asimismo recalcaba, en contraste con otras publicaciones, que la toma de Tetuán había sido acogida por la opinión con indiferencia. ${ }^{27}$

Andrés de MONTALVO: “El tratado franco-español”, El Debate, 13 de diciembre de 1912. Del mismo autor también: "Nuestra amistad con Francia e Inglaterra", El Debate, 17 de diciembre de 1912.

19 Alfonso de la SERNA: Al sur de Tarifa: España-Marruecos, un malentendido histórico, Madrid, Marcial Pons, 2001, p. 216

20 José DÍAZ DE VILLEGAS: Lecciones de la experiencia (enseñanzas de las campañas de Marruecos), Toledo, Sebastián Rodríguez, 1930, p. 128.

21 José Luis VILLANOVA: Los interventores. La piedra angular del Protectorado de España en Marruecos, Barcelona, Bellaterra, 2006

22 Richard C. PENNELL: La guerra del Rif. Abd-el-Krim el-Jattabi y su estado rifeño, Melilla, Biblioteca de Melilla, 2001, p. 72 .

23 "La bandera española ondea en Tetuán", El Debate, 20 de febrero de 1913

24 "La ocupación de Tetuán", $A B C, 21$ de febrero de 1913.

25 "Misión de paz", El Imparcial, 21 de febrero de 1913.

26 "Hacia lo desconocido", El Socialista, 21 de febrero de 1913.

27 "La cuestión de Marruecos", El Socialista, 28 de febrero de 1913. 


\section{El ejemplo salmantino. Pascual Meneu y su visión de la cuestión marroquí}

Una vez perfilada esta panorámica de los acontecimientos y del rumbo adoptado por la prensa de mayor tirada, conviene apuntar que los estudios a propósito del impacto -ya sea económico, político, social, etc. - de la cuestión marroquí en algunas ciudades españolas se han incrementado en los últimos años. En particular, es bastante lo que se conoce sobre capitales de la periferia, tales como Barcelona o Valencia. Mucho más desconocida es la España interior Tal vez, porque la guerra no provocó en su momento tan sonoras campañas de oposición. $O$ porque la posibilidad de establecer vínculos económicos con el Sultanato resultase escasa.

Por ejemplo, en Salamanca, la ratificación del acuerdo de Protectorado no generó una excesiva curiosidad, ni mucho menos entusiasmo. Esta divergencia con los diarios de las grandes capitales resultó notoria y obedeció a que estos últimos siempre se mostraron más sujetos a los dictámenes de los grandes partidos políticos y del Poder. Tampoco, y en contraste con la actitud de las militantes masas obreras de Cataluña, el sentimiento antimilitarista y anticolonialista caló entre clases populares de Salamanca. Todo ello se puede atribuir aquí a la escasa movilización obrera y sindical, a la precariedad laboral y al poder de la oligarquía terrateniente. Y también a la ausencia de grandes núcleos industriales que concentrasen a cientos de trabajadores, lo cual favorecía una estructura empresarial muy atomizada y alentaba unas relaciones laborales caracterizadas por el paternalismo patronal y aferradas a la doctrina social de la Iglesia.

Para el "sentir" progresista, encarnado en El Adelanto, el periódico más reputado y longevo de la ciudad, se dibujaba una nueva fuente de complicaciones en el horizonte. ${ }^{28}$ Particularmente mal se habían acogido las noticias referidas a los recortes en Ifni y en la zona septentrional. ${ }^{29} \mathrm{Y}$ al conocerse la entrada de las tropas españolas en Tetuán, "Argos", uno de los corresponsales más irónicos de la capital, espetaba: "iAlbricias! la ocupación de Tetuán se ha verificado sin disparar un tiro [...] El señor conde de Romanones [...] se congratula de que se haya realizado, como el ambiente público pedía tranquila y pacíficamente"..30 Obviamente, el reportero cuestionaba que existiese tal demanda.

El Salmantino, de ideología integrista, recibiría asimismo mal la firma del tratado hispano-francés. Ante el "entusiasmo desbordante" de gran parte de la opinión pública, creía conveniente no prodigar "aplausos excesivos". La explicación aportada era sencilla: por una parte, se había derramado hasta el momento mucha sangre y dinero en el territorio africano; por otro lado, el convenio era muy impreciso en cuestiones referentes a las fronteras, la religión, la enseñanza, la economía o la organización militar... El motivo real del rechazo era aún más simple: además de que había sido suscrito por un gobierno liberal, el acuerdo confería más competencias a Francia en Marruecos que a España. ${ }^{11}$ Mucho más vehemente y acrítica, aunque también más acorde con la tónica nacional, fue su contestación a la ocupación de Tetuán. ${ }^{32}$

Entre los más interesados en la marcha de los asuntos africanos, Pascual Meneu ocupó un lugar muy destacado en Salamanca. Valenciano de nacimiento y discípulo del prestigioso arabista Francisco Codera, es hoy un gran desconocido. Pero sus contribuciones en la prensa local, siempre tan repletas de datos técnicos, contribuyeron como pocas a que los vecinos del Tormes se forjasen una idea sobre las directrices de la política exterior española.

Meneu se había incorporado a la vida universitaria salmantina en 1909 y permaneció en esta institución, ocupando las cátedras de árabe y hebreo, hasta 1922, cuando se trasladó a Granada. En su juventud, había vivido en Tánger y junto con el franciscano padre Lerchundi

28 "Argos" (Benigno Pallol): "Madrid al día. Problemas", El Adelanto, 29 de noviembre de 1912. 29 Alfredo RIVERA: “La actualidad del tratado franco-español", El Adelanto, 31 de octubre de 1912 30 "Argos" (Benigno Pallol): "Madrid al día. Fecha histórica", El Adelanto, 22 de febrero de 1913.

31 "La discusión del tratado franco-español", El Salmantino, 17 de diciembre de 1912.

32 "Información telegráfica para El Salamantino", El Salmantino, 20 de febrero de 1913. había levantado la primera imprenta española con caracteres arábigos. ${ }^{33}$ En Salamanca, logró cierta notoriedad pública, además de gracias a sus escritos marroquies, por su participación en las "campañas agrarias" de los universitarios, celebradas en 1912-1914. ${ }^{34}$ Entre sus objetivos figuró la denuncia de la situación de los braceros de la provincia y la demanda de un cambio legal para las rentas rústicas. Como apunte más anecdótico, cabe señalar que pronunció el discurso de apertura del año académico en 1916.35 De comportamiento campechano, práctico y muy culto, fue además compañero de excursiones y fiel amigo de Miguel de Unamuno, lo que no impidió que sostuvieran agrias discrepancias, como la referida a la cuestión marroquí.

Para combatir el desencanto reinante al hilo de la reanudación de las conversaciones con Francia, después de lo de Agadir, El Adelanto decidió acoger entre sus páginas los trabajos de este persuasivo arabista. Su primer artículo data de enero de 1912, apenas resuelto el incidente y cuando ya se daban por seguras algunas pérdidas para España. Meneu subrayaba que Francia reivindicaba un protectorado en exclusiva, alegando que de esta forma compensaría pasadas pérdidas, y continuaba:

La prensa española, que hace causa nacional y no afrancesada en este asunto sale a la defensa de los intereses de la patria en el Magreb, asegurando que en las zonas Norte y Sur España tiene seculares intereses, recientemente corroborados con sacrificios de sangre de sus valerosos hijos, con dispendios costosos del tesoro nacional, con esfuerzos mentales y pecuniarios de nuestros africanistas, lingüistas y filólogos y el no menos generoso de generales, jefes, oficiales y misioneros franciscanos, a la vez que los realizados por el comercio y las empresas de navegación. ${ }^{36}$

En Salamanca tan sólo se conocían los más recientes gastos en sangre y dinero, pero el dis curso sobre el esfuerzo intelectual de los africanistas, en la acepción más amplia del vocablo, resultaba muy artificial. Seguramente por esta razón, algunas semanas después, Meneu reparaba en los derechos históricos de España en Marruecos, derivados de la cercanía geográfica. ${ }^{37}$ Sobre todo, su mayor empeño consistía en prevenir a la opinión pública local contra posibles agravios, advirtiendo esto: "Un sultán que ya no reina, sino que le hace reinar Francia [...] un sultán en tan precaria situación material y moral, no debe ni puede vender tierras del dominio público a nadie, ni personas ni asociaciones, y menos aún si estas entidades son francesas"..$^{8}$ Estas ventas se estaban registrando, en efecto, en las cercanías de Larache.

Pero más preocupantes, si cabía, le parecían algunos rumores -aunque pronto se vería que eran completamente infundados- que apuntaban a la internacionalización de Tetuán. En la práctica ello acarrearía el aislamiento y asfixia de Ceuta. Algo que no se podía tolerar. Así las cosas, la guerra puramente defensiva se entendía como una necesidad. El pensamiento de

33 Laureano ROBLES: "El arabista castellonense Pascual Meneu, amigo de Unamuno (Cartas inéditas)", Boletín de la Sociedad Castellonense de Cultura, 70 (1994), pp. 197-240. I. I..."Nuevas aportacio-
nes sobre Meneu", Boletín de la Sociedad Castellonense de Cultura, 80 (2004), pp. 355-399.

nes sobre Meneu", Boletín de la Sociedad Castellonense de Cultura, 80 (2004), pp. 355-399.
34 Antonio RODRÍGUEZ DE LAS HERAS.: "Las campañas agrarias de los intelectuales (Salamanca, 1913)", en José Luis GARCíA DELGADO (ed.): La cuestión agraria en la España contemporánea, Madrid, Cuadernos para el Diálogo, 1976, pp. 363-391.

35 Pascual MENEU: Discurso leido en la solemne apertura del curso académico de 1916 a 1917 por Pascual Meneu, Catedrático de Lengua hebrea y lengua Arábiga, Salamanca, Imp. y Lib. de Francisco Núñez Izquierdo, 1916. El catedrático no tuvo empacho en reconocer que el acto no tenía más que un mero valor ritual y, de paso, defender su supresión. Así los estudiantes ganarían un día más de actividad docente.

36 Pascual MENEU: "La cuestión de Marruecos. La zona sur", El Adelanto, 2 de enero de 1912.

37 Pascual MENEU:"Posible solución a la cuestión e Marruecos", El Adelanto, 13 de enero de 1912.

38 Pascual MENEU: “Tetuán no puede ser internacionalizada”, El Adelanto, 17 de enero de 1912. 
Meneu había evolucionado desde la "propaganda científica" a favor del colonialismo, cuando años antes se responsabilizaba del traslado veraniego de algunos rifeños a Salamanca, para hacer de ellos "hombres de carrera", ${ }^{39}$ hasta el militarismo más complaciente. El papel desempeñado por Francia y la tenacidad de sus diplomáticos habían tenido un peso determinante en la gestación de este cambio. He aquí su colaboración más enardecida en la prensa local:

Pensar actualmente sólo en los dispendios y sangre heroica que derrama la lucha, sin mirar en los beneficios momentáneos y postrimeros que la contienda bélica ha de traer, es ver con vista miope [...] La primera ventaja que nos ofrece la guerra del Rif es la rehabilitación de nuestro Ejército [...] La finalidad de esta guerra no puede ser la posesión de las minas de Beni-bu-Ifrur [...] Esta guerra de 1912, como la de los años anteriores, es vivificadora del porvenir de España, y quien la contradiga es un afrancesado y reo de un delito de lesa patria..$^{\circ}$

Además, otra de las preocupaciones del catedrático fue la defensa de la soberanía española en las Canarias, garantizada en teoría por el Convenio de 1904. Y cierta alarma le causaba la pretensión gala de adueñarse de Cabo de Agua y una franja territorial al oeste del río Muluya, del valle del Uarga y de Alcazarquivir. En su conjunto, la actitud francesa era calificada de vergonzosa: estaban luchando por incumplir todo lo pactado y despojar a España de su zona de influencia. ${ }^{41}$ Curiosamente, aún peor parado resultaba a su juicio el socialismo:

Es bochornoso, aflictivo, desconsolador, ver los anuncios del partido republicano socialista español, señalando fechas próximas, casi inmediatas, para celebrar en ciudades y pueblos mitingueos contra la guerra de Melilla, como si sin soldados ni Ejército bien organizado, fuera posible mantener muchos derechos consignados en los tratados [...] No me arrepiento de la conferencia que di hace unos años en Castellón, defendiendo que los intereses de España en Marruecos estaban en oposición y en pugna con los de Francia y con los de Inglaterra, mientras iban a la par con los de Alemania [...] Es tarde pero hay que decir la verdad en todo tiempo 42

En fin, que desde comienzos de 1912, el órgano del liberalismo salmantino publicitaba las opiniones de un pensador que sin ser germanófilo, justificaba este posicionamiento en materia exterior. El Adelanto, por su parte, le agradecía todas sus contribuciones periodísticas porque estaban colmadas de datos y de un hondo "sentir patriótico". Pero también debido a que "en sostener nuestros derechos Es evidente, si se atiende a estas palabras, que la unanimidad de pareceres a la que se aludía páginas atrás, esa adhesión a la causa colonial que intentaba procurarse a toda costa, seguía esgrimiéndose como arma propagandística en defensa de la intervención española en $\mathrm{Ma}$ rruecos. El dominio sobre el norte de este país era presentado, sistemáticamente, como una garantía de la independencia nacional.

39 Su idea cardinal en 1909 era la de la penetración pacífica en Marruecos por medio de la educación "Si este plan se hubiera seguido desde el año 60 del siglo pasado, después de nuestras guerras con África, hoy serían otras nuestras relaciones con Marruecos". En Pascual MENEU: “El problema marroquí. La propaganda científica", El Adelanto, 5 de agosto de 1909.

40 Pascual MENEU: “La guerra vivificadora”, El Adelanto, 24 de enero de 1912.

41 Pascual MENEU: "Marruecos y las negociaciones", El Adelanto, 26 de abril de 1912; "Marruecos y las negociaciones II", El Adelanto, 30 de abril de 1912.

42 Pascual MENEU: "La cuestión de Marruecos", El Adelanto, 19 de marzo de 1912.

43 "Francia y Marruecos", El Adelanto, 21 de marzo de 1912.
En mayo de 1912 se publicaba la última contribución de Meneu en El Adelanto. Ya en el tramo final de la disputa, cuando poco faltaba para sellarse el tratado hispano-galo, el profesor se apresuraba a reflexionar sobre el criterio conveniente para la delimitación de zonas él apostaba por uno atento a los accidentes geográficos antes que a la división en cábilas. Aunque no justificaba demasiado su razonamiento, limitándose al empleo de criterios historicistas, el catedrático sentenciaba que las regiones de Gomara y Yebala eran indiscutiblemente áreas de acción española. ${ }^{44}$

El integrismo -toca ahora reparar en otro diario local- también contó con un sólido número de lectores en la meseta. Y, de hecho, EI Salmantino se anticipó bastante a EI Adelanto a la hora de cargar las tintas contra los franceses y alimentar la propaganda colonialista. Antes de alcanzarse la tregua franco-germana, este diario ya divagaba sobre sus posibles derivaciones para España:

Si para reconocer su Protectorado, Francia ofrece compensaciones a Alemania, prepárese también para concederlas a las demás potencias signatarias de Algeciras y mucho más a España, que tiene en Marruecos la base de su porvenir e independencia y derechos reconocidos. 45

En un muy segundo plano quedó el contenido en sí del pacto entre las grandes potencias. Curiosamente, el encargado de presentar con calma esas plausibles consecuencias ante la opinión pública fue el mismo profesor Meneu. Pero el tono adoptado en su discurso resultó menos apasionado. Más técnico y, desde luego, farragoso. No era raro entonces que un mismo redactor o intelectual colaborase en distintos medios periodisticos, pero sí chocante que lo hiciese en un marco geográfico tan reducido. Probablemente, porque su voz y prestigio no hallaban contestación. En su primera colaboración para este periódico, el catedrático reflexionaba sobre el origen de la crisis de Agadir e insinuaba que éste residía en la negativa -francesa en el fondo aunque española en las formas- a permitir el amarre de un cable germano en Rabat.

Entre todas las noticias, falsas unas, verdaderas otras, y entreveradas, muchas, me sorprende una de importancia: la de que España no otorgó a Alemania la concesión de amarrar un cable en Canarias, porque la gran nación pretendía también fijarlo en Rabat, cosa que no podía consentir España, sin mengua de la cordialidad y caballerosidad hacia la simpática Francia. ${ }^{46}$

Además, los límites de las futuras zonas de España en Marruecos eran puestos en entredicho: los del área norte por su indefinición; y los del sur, por considerarse que iban a ser tratados como moneda de cambio por parte de Francia.

En otro trabajo periodístico, Meneu ahondó en las acotaciones de esta región sur marroquí, que se cedería a España con objeto de garantizar la soberanía sobre las islas Canarias. ${ }^{47}$ Aunque, sin duda, fue su tercera aportación para el rotativo integrista la más interesante y agresiva. España perdería gran parte de Guinea y el catedrático comentaba: "Oueda atada al carro triunfal de Francia y al menosprecio de Alemania, que no puso las garras de sus reales águilas en Agadir para amparar a la nación de los Reyes Católicos, sino para hacer su negocio". ${ }^{8}$ Claro que se reconocía la ambición territorial del káiser, pero a Meneu le indignaba que España no se hubiese "atado a su carro".

44 Pascual MENEU: “Las negociaciones franco-españolas”, El Adelanto, 15 de mayo de 1912 45 "La gestación del problema marroquí", El Salmantino, 11 de octubre de 1911.

46 Pascual MENEU: “La cuestión de Marruecos", El Salmantino, 31 de octubre de 1911.

47 Pascual MENEU: “La cuestión de Marruecos II", El Salmantino, 4 de noviembre de 1911.

48 Pascual MENEU: "La cuestión de Marruecos III", El Salmantino, 7 de noviembre de 1911. 
Poco después y al hacerse público, ipor fin!, el articulado completo de los Convenios de 1904 y 1905, el sentimiento de desazón en el órgano conservador aumentaría. Francia estaba viendo hecho realidad su sueño a costa de aplastar derechos reconocidos a España. La redacción se fustigaba aún más recordando un fallido pacto de 1902, la eterna oportunidad perdida (porque éste sí fue bastante generoso con Madrid). Y descargaba culpas sobre los profesionales de la diplomacia porque "tienen abandonada su misión con la aquiescencia y consentimiento del gobierno". 49

Fue en estas amargas circunstancias en las que Meneu escribió sus últimos artículos para $E l$ Salmantino. Con rabia apenas contenida, fue él otra vez el encargado de presentar ante las filas integristas los pormenores de estas conversaciones. Como de costumbre, lamentó los recortes, la frustrada aspiración sobre Tánger y los regateos franceses en el río Sus..$^{\circ}$ La "espinita" de Tánger, sabido es, quedaría clavada durante años en el pensamiento de una considerable parte del país.

A modo de conclusión, cabe recalcar el papel fundamental que la prensa jugó a la hora de presentar y orientar a la opinión pública en los vericuetos de la política marroquí, sobre todo, durante años tan convulsos como lo fueron 1911 y 1912. La diplomacia, en este periodo que precedió a la Gran Guerra y cuando el Sultanato se convirtió en un “área caliente" del planeta, actuaba entre bambalinas y sólo algunos destellos de luz llegaban a la masa, precisamente, a través de los periódicos. En Salamanca, fue Pascual Meneu quien intentó asumir esta tarea con paciencia y grandes dosis de conocimiento.

Sin embargo, se necesitaría un gran desastre para que Marruecos copase las portadas de la prensa y los salmantinos dirigiesen su más atenta mirada hacia allí.

49 "Nosotros somos...", El Salmantino, 1 de diciembre de 1911.

50 Pascual MENEU: "Momento solemne de las negociaciones sobre Marruecos", El Salamantino, 22

de marzo de 1912; "Último momento de las negociaciones", El Salmantino, 23 de marzo de 1912. 


\section{ESCUELA Y COLONIZACIÓN: \\ EL CASO DEL PROTECTORADO ESPAÑOL \\ EN MARRUECOS (1912-1956)}

rene González González

IREMAM-CNRS/GRESAM-UCLM

El establecimiento del Protectorado español en el Norte de Marruecos supuso para España la necesidad de crear una política colonial, donde la educación se convirtió en un instrumento más al servicio de la colonización. Así lo señalaba el Alto Comisario, Gómez Jordana, en 1919: "Es indudable que la difusión de la enseñanza ha de ser la base primordial de nuestro afianzamiento en el Protectorado y siendo mirado con el mayor cariño todo lo que atienda en cualquier orden a su propagación".' España creó un modelo de escuela colonial en torno a tres tipos de centros educativos: escuela española, escuela hispano-árabe y escuela hispano-hebrea. Estos centros estaban destinados a formar a la población marroquí y española residente en la zona y tenían como objetivo final instruir a una población bajo un ideario pro-español afín a colonizador para que trabajase y colaborase con él como traductores, intérpretes, secretarios, obreros.... Este modelo de escuela era novedoso para España, si bien con anterioridad se había implementado modelos similares en otros países del Mediterráneo como la actual Turquía, Líbano ${ }^{3}$ o Argelia. ${ }^{4}$

\section{La coexistencia de modelos educativos}

Desde mediados del siglo XIX diversos países europeos e instituciones privadas abrieron en el norte de Marruecos diferentes escuelas que introdujeron nuevos modelos educativos en la región dirigidos, cada uno de ellos, a un sector de la población en función de su nacionalidad y confesión religiosa. ${ }^{5}$ Sin embargo, no fue hasta el establecimiento del Protectorado, en 1912, cuando este modelo comenzase a definirse con mayor claridad coexistiendo, durante todo e periodo, un triple sistema de enseñanza: ${ }^{6}$ escuela tradicional, escuela colonial y escuela na-

1 Nota del Alto Comisario, Francisco Gómez Jordana, Tetuán 18 de enero de 1919. Archivo General de la Administración de Alcalá de Henares (AGA), Sección África, Dirección General de Marruecos y Colonias: sección de educación, Caja M-330, Exp. 1 .

2 Selcuk Aksin SOMEL: The modernization of public education in the Ottoman Empire 1839-1908. Islamisation, autocracy and discipline, Leiden, Brill, 2001; y Max ROCHE: Éducation, assistance et culture françaises dans l'Empire Ottoman, Istambul, éditions Issis, 1989.

3 Jacques THOBIE: Les intérêts culturels français dans l'Empire ottoman finissant. L'enseignement laïque et en partenariat, Leuven, Peeters, 2009

4 Fanny COLONNA: Instituteurs algérien 1883-1939, Office des publications universitaires, Alger, 1975.

5 Irene GONZÁLEZ: "La política educativa española en el norte de Marruecos (1860-1912)" en Francisco Javier MARTÍNEZ e Irene GONZÁLEZ (coords.): Regenerar España y Marruecos. Ciencia y educación en las relaciones hispano-marroquies a finales del siglo XIX, Madrid, CSIC-Casa Árabe, 2011, pp. 219-251; y José DOMINGUEZ: La presencia educativa española en el Protectorado de Marruecos, Ceuta, Instituto de Estudios Ceuties, 2008

6 Irene GONZÁLEZ: "Escuelas, niños y maestros: la educación en el Protectorado español en Marruecos" Awraq, 5-6 (2012), pp. 117-133; e Irene GONZÁLEZ: "Educación, cultural y ejército: aliados de la politica colonial en el Norte de Marruecos", en Manuel ARAGÓN El Protectorado español cionalista. El triple modelo educativo evidenciaba una relación asimétrica entre la comunidad escolar española y la marroquí.

El modelo de la escuela tradicional estaba representado por las escuelas coránicas -ligadas a las mezquitas para los marroquíes musulmanes-, y por las escuelas talmúdicas -vinculadas a las sinagogas y a las que asistían los marroquies de confesión hebrea-. Este tipo de educación había permanecido inalterado durante siglos. Se basaba en la enseñanza religiosa a través del estudio del Corán y del Talmud, y de la lengua árabe y hebrea respectivamente.

El modelo colonial estaba compuesto por aquellas escuelas creadas por España para estudiantes españoles y marroquíes e incluía diferentes centros de enseñanza: enseñanza española, tanto privada como pública, destinada a una población española; escuelas hispano-árabes y escuelas hispano-hebreas, dirigidas a una población marroquí de confesión musulmana y judía respectivamente, en las que España y lo español articulaban sus diseños curriculares y que se complementaban con elementos propios de ambas culturas como la lengua, árabe o hebrea, y la religión, musulmana o judía. España consideraba que la introducción de estas materias suponía un gran paso que le posibilitaría un acercamiento a la población local, le permitiría favorecer la implantación lingüística del español y la formación de una elite marroquí bajo los principios ideológicos del colonizador. Este esquema educativo era similar al de otros países colonialistas como Francia, ${ }^{7}$ que contaba en el norte de Marruecos con las escuelas financiadas por la Alianza Francesa, ${ }^{8}$ las escuelas franco-árabes y los centros de la Alianza Israelita Universal. ${ }^{9}$

La enseñanza española privada corría a cargo de las órdenes religiosas, ${ }^{10}$ como los Padres Franciscanos y la Compañía de María, se localizó en núcleos urbanos como Tetuán, Larache y Alcazarquivir. La enseñanza impartida en estos centros seguía los diseños curriculares existentes en la Península. La enseñanza española pública y privada podía ser graduada -un profesor por nivel o grado en donde cada grupo reunía estudiantes de edades y conocimientos similares-o unitaria -un solo profesor y aula para niños de edades y niveles diferentes, localizándose en núcleos urbanos pequeños o en barrios urbanos periféricos-. En una primera fase se fomentó la creación de escuelas unitarias como consecuencia de la falta de recursos económicos y docentes, que progresivamente fueron transformándose en escuelas graduadas. Este fenómeno fue similar al peninsular."1

Marruecos. La historia transcendida, Bilbao, Iberdrola, 2013, pp. 341-361.

7 Spencer. D. SEGALLA: The Moroccan Soul. Trench Education, Colonial Ethnology, and Muslim Resistance 1912-1956, University of Nebraska Press, 2009; Pierre VERMEREN: École, élite et pouvoir au Maroc et en Tunisie au XXe siècle, Rabat, Alizés, 2002; y Pierre VERMEREN: La formation des élites marocaines et tunisiennes des nationalistes aux islamistes 1920-2000, Paris, La Découverte, 2001.

8 Andre CHOURAQUI: Cents ans d'Histoire. LAAlliance Israelite Universelle et la renaissance juive contemporaine (1860-1960), Paris, Presses Universitaires de France, 1965.

9 André KASPI (dir.): Histoire de l'Alliance Israélite Universelle. De 1860 à nos jours, Paris, Armand Colin 2010; Michael LASKIER: The "Alliance Israelite universelle" and the Jewish communities of Morocco, 1862-1962, State University New York Press, 1983; A. RODRIGUE: De l'instruction à l'émancipation. Les enseignants de l'Alliance israelite universelle et les Juifs d'Orient 1869-1939, Paris, Almann-Lévy, 1989; Irene GONZÁLEZ: “La Alianza Israelita Universal a través del prisma del norte de Marruecos: su labor educativa (1862-1912)", en Eloy MARTIN y Maite OJEDA: Judios entre Europa y el norte de África, Barcelona, edicions Bellaterra, 2011, pp. 73-92.

10 José DOMINGUEZ: La presencia educativa...; Ramón LOURIDO: El cristianismo en el Norte de África. Madrid, Ed. Mapfre, 1993; Y Ramón LOURIDO: Marruecos y el Padre Lerchundi, Madrid, Ed. Mapfre, 1996. 11 Antonio VIÑAO: Educación y modernidad en la España del siglo XX, Madrid, Marcial Pons, 2004 Antonio VINAO: Innovación pedagógica y racionalidad científica. La escuela graduada pública en en la España contemporínea, Madrid, Editorial Tecnos, 1999. 
La enseñanza hispano-árabe, ${ }^{12}$ por su parte, estaba destinada a la población marroquí y fue uno de los instrumentos de control de la población en el ámbito rural, dada su vinculación y localización en puntos estratégicos: zocos, caminos, carreteras... Junto a las oficinas de intervención era habitual encontrar la consulta del médico y la escuela hispano-árabe a la que asistía la población española, siempre que no hubiese una escuela española en la localidad, y los hijos de los marroquíes que trabajaban con el interventor, los hijos de los "moros amigos" y de la elite local. Similares a los centros hispano-árabes fueron las escuelas hispano-israelitas, destinadas a la población de confesión hebrea de las ciudades de Tetuán, Larache, Alcazarquivir o Arcila.

El tercer modelo educativo existente en el Protectorado fue la escuela nacionalista. El movimiento nacionalista marroquí reivindicó desde un primer momento la introducción de mejoras políticas y sociales en el Protectorado. ${ }^{13}$ En paralelo a las demandas, Abdesalam Bennuna y Mohamed Daud, considerados como los padres del nacionalismo tetuaní, crearon en Tetuán en 1925, la primera escuela nacionalista. Se trataba de la Escuela Ahlía. La escuela fue creada siguiendo el diseño curricular europeo y turco, donde la enseñanza de la historia, la geografía y la literatura de Marruecos ocupaban un lugar preferente. El idioma oficial en estas escuelas era el árabe, en oposición a las escuelas del modelo colonial donde el español se erigía en la principal lengua de enseñanza. A ellas asistían los hijos de la clase media marroquí vinculada al movimiento nacionalista. Sus estudiantes fueron becados por la Alta Comisaría a partir de 1937, ${ }^{14}$ para que continuaran los estudios medios y superiores en España, Egipto y Palestina.

\section{Jugando con los nombres, bailando con los conceptos: la instrumentalización de la escuela} hispano-árabe

a zona en la que España estableció su Protectorado se caracterizaba por la atomización en pequeños núcleos poblacionales. La forma de organización social que imperaba fuera de los grandes núcleos urbanos era la cabila o tribu en torno a un pequeño núcleo o asentamiento, cuya población se encontraba dispersa en los alrededores y alojada en viviendas que concentraban a una amplia red familiar. Esta circunstancia tuvo como consecuencia directa el difíci control del territorio. España debía articularlo's si deseaba ejercer un control efectivo sobre él. En este contexto la escuela era percibida como un instrumento complementario que permitía reforzar el control político y militar. De este modo, España pretendía un triple objetivo: articular el territorio, contrarrestar las resistencias y recelos a la penetración colonial lideradas por Abdelkrim el Jattabi y Rasisuni y formar a una población bajo el ideario colonial.

El control político-militar ejercido por España sobre el territorio, durante los primeros años del Protectorado, fue parcial y vinculado a núcleos urbanos en los que el ejército, diplomáticos, empresarios y comerciantes españoles se habían establecido con anterioridad a $1912 .{ }^{16}$ Durante

12 Geoffrey JENSEN: “Toward the « Moral Conquest » of Morocco: Hispano-Arabic Education in Early Twentieth-Century North Africa", European History Quarterly, 31 (2001), pp. 205-229.

13 Abdelmajid BENJELLOUN: Pages d' histoire du Maroc: le patriotisme marocain face au protectorat espagnol, Rabat, 1993; y Jean WOLF: Maroc: La Vérité sur le Protectorat Franco-Espagnol. L'Epopée d'Abd el Khaleq Torres, Casablanca, Ed. Edif.-Balland, 1994.

14 Irene GONZÁLEZ y Bárbara AZAOLA: "Becarios marroquíes en El Cairo (1937-1956): una visión de la política cultural del protectorado español en Marruecos", Awraq, XXV (2008); Toumader KHATIB: Culture et politique dans le mouvement nationaliste marocain au Machreq, Tetouan, Publications de l'Association Tétouan Asmir, 1996.

15 José Luis VILLANOVA: El Protectorado de España en Marruecos. Organización política y territorial, Barcelona, edicions Bellaterra, 2004; María Rosa de MADARIAGA: Marruecos ese gran desconocido: breve historia del Protectorado español, Madrid, Alianza Editorial, 2012; y Manuel ARAGÓN: EI Protectorado español en Marruecos. La historia transcendida, Bilbao, Iberdrola, 2013.

16 Eloy MARTíN: Marruecos y el colonialismo español (1859-1912). De la guerra de África a la "penetra-

ción pacífica", Barcelona, ediciones Bellaterra, 2002. los primeros años del Protectorado el número de escuelas creadas por España fue reducido, circunscribiéndose a las regiones de Yebala y Kert y quedando las regiones centrales de Gómara y Rif sin escuelas españolas e hispano-árabes. No fue hasta comienzos de 1916, tras la creación regular, escuelas en las regiones del interior. ${ }^{17}$ De manera paulatina, las escuelas comenzaron a llegar al ámbito rural. En 1927, año en el que finalizó el periodo del control del territorio tras la muerte de Raisuni y la derrota de Abdelkrim, la Alta Comisaría había abierto escuelas en todas las regiones, si bien en las regiones del interior sólo cuatro cabilas contaban con centros hispano-árabes. A partir de 1936, bajo el gobierno franquista, el proceso de apertura de centros hispano-árabes fue más generalizado alcanzando en 1956 a un elevado número de cabilas.

Las escuelas hispano-árabes sufrieron modificaciones a lo largo de todo el Protectorado, si bien, se trataron de reformas más nominales que estructurales. Fueron numerosos sus cambios de denominación, modificándose el continente pero no así el contenido. Estas escuelas fueron conocidas como escuelas consulares, escuelas indígenas, escuelas de avanzadas, escuelas hispano-árabes y escuelas marroquíes. Los cambios de denominación permiten analizar las distintas visiones que la administración española tuvo de ellas en cada momento. EI cambio de denominación de los centros escolares no supuso el cierre de las viejas escuelas y la apertura de nuevas. La vida del centro docente seguía su ritmo natural.

En los años que giraron en torno a 1912, la documentación de la época se refiere a ellos como escuelas consulares dado que se encontraban vinculadas a las oficinas consulares, llegando incluso a ocupar algunas de ellas las instalaciones del consulado, ejerciendo el secretario o traductor de la legación como maestro de la escuela. Mientras que la escuela de Tetuán tras su creación en 1908, recibió el nombre de escuela consular, el mismo modelo de escuela creado por España en Tánger, en el mismo periodo, era conocida como escuela hispano-árabe, nombre que empezó a recibir la escuela tetuaní tras la instauración del Protectorado. En la década de 1920 se observa cómo las escuelas hispano-árabes ubicadas fuera del ámbito urbano recibían el nombre de escuelas de avanzadas, siempre y cuando su creación estuviese ligada a la reciente instalación de un cuartel o un destacamento militar, y escuelas de indígenas, si se encontraban en zonas militarmente controladas por el ejército español. Estos términos fueron utilizados por personalidades como el Teniente Coronel Capaz o el inspector de enseñanza Manuel Chacón por el papel político-social que concedían a la escuela. En las escuelas de avanzadas y de indígenas la docencia recaía normalmente en oficiales del ejército o en párrocos castrenses. La enseñanza giraba en torno al aprendizaje de la lectura, escritura nociones básicas de matemáticas y conceptos de historia y geografía española. La enseñanza impartida dependía tanto del nivel de conocimiento como del interés del profesor, en cuyas aulas, en ocasiones, se mezclaban estudiantes marroquíes y españoles. Los profesores apenas contaban con materiales de apoyo, impartiendo las clases en aulas improvisadas en los cuarteles militares o en medio del campo, auxiliándose de una pequeña pizarra. Se trataban por tanto de un tipo de escuela unitario. Por otra parte, el hecho de que estas escuelas fuesen denominadas como escuelas indígenas hacían referencia directa tanto al tipo de población al que estaban dirigidas como a la imagen y a la percepción que el administrador colonial tenía de la población, ${ }^{18}$ recalcando así la diferencia entre colonizador y colonizado.

Las escuelas de avanzada e indígenas estuvieron ligadas por tanto a la ocupación y al control del territorio por parte del ejército español, lo que potenciaba el papel de la escuela como

17 Irene GONZÁLEZ: "El ejército, actor de la política educativa española en el norte de Marruecos durante el Protectorado", Revista de Historia Militar, año LVI, $n^{\circ}$ extraordinario II (2012), pp. 69-100.

18 Josep Luís MATEO: El moro entre los primitivos, Barcelona, a Caixa 1997:y Eloy MARTiN: La imagen del magrebi En España. Una perspectiva histórica siglos XVIXX, Bargi y Eloj MARTiN: La inagen del magrebi en España. Una perspectiva historica siglos XVI-XX, Barcelona, edicions Bellaterra, 2002 
agente colonial. En ellas el colonizador venía a reproducir lo que Louis-Jean Calvet definió como dogma del colonialismo glotófago, ${ }^{19}$ la imposición de la lengua del colonizador como vía en la que expresar concepciones, nociones y conceptos científicos modernos consecuencia de la incapacidad de las lenguas colonizadas para cumplir con dichas funciones. De esta forma el colonizador tendía a establecer su cultura frente al vacío cultural que creía encontrar en la sociedad colonizada, estableciendo su cultura y acentuando la política lingüistica de exclusión, en la que la lengua dominada, en este caso el árabe, era expulsada o relegada a un segundo plano de las esferas de poder y de decisión, y donde los hablantes que no aprendieran la lengua del colonizador quedarían excluidos de esas mismas esferas. ${ }^{20}$ Así lo expresaba el interventor local de Larache en 1917:

Mejorar nuestra política de atracción en la Zona procurando crear en ella verdaderos centros de enseñanza en los que a la par que se cultive el espíritu sirvan de pretexto o motivo para que sean más estrechos y cada vez más íntimos los lazos que nos liguen a sus habitantes (...) Si los españoles que aquí residimos hemos de llevar a cabo una labor pacificadora, de orden y educativa se impone ir haciendo más sólidos los cimientos de aquella fijando la atención en la escuela. ${ }^{21}$

Para la Alta Comisaría, la enseñanza ejercía un papel destacado en la política de control social de la población. A este respecto, Durkheim ${ }^{22}$ afirmaba que para que la enseñanza dotase de entidad a la sociedad, ésta debía estar bajo el control de una entidad superior, bien fuese un Estado o un grupo social que ostentase el poder, quedando la enseñanza al servicio de grupo dominante que en un contexto colonial haría que el alma de la patria quedase dividida. De esta forma, la Alta Comisaría actuaba como catalizador social sin cuyo control educativo se asistiría a una fragmentación social que imposibilitaría o dificultaría el control de la población y del territorio ${ }^{23}$

Hasta ahora, donde no llegaron nuestras armas no pudo llegar el maestro; pero cuando menos, difundamos la enseñanza en las zonas que vayamos pacificando, para que se identifique con nosotros la juventud y salgan de ella, andando al tiempo, los funcionarios, los industriales, los agricultores, hasta los literatos anhelados por todos, en los que conservando los principios fundamentales y el dogma del pueblo musulmán, se derrumben con asolador estrépito, a impulsos de la ciencia, estas férreas e inquebrantables barreras

19 "Hay dos dogmas de los que el colonialismo glotófago no puede prescindir. El primer dogma es aquel según el cual los colonizados sólo tienen cosas que ganar aprendiendo nuestra lengua, que les abrirá las puertas de la civilización, del mundo moderno. El segundo estipula que, de cualquier forma, las lenguas indigenas serían incapaces de cumplir esa función, incapaces de vehicular nociones modernas, conceptos científicos, incapaces de ser lenguas de enseñanza, de cultura o de investigación. Se desarrolla así un discurso elaborado por blancos, para blancos y para aquellos a los que su educación, sus intereses incitan a considerarse y a comportarse como blancos". Louis-Jean CALVET: Lingüistica y colonialismo. Breve tratado de glotofagia, Madrid, Ediciones Júcar, 1981, p. 116

20 lbidem, pp. 62-63.

21 Oficio remitido por el interventor local de Larache al Ministro de Estado referente a la Enseñanza, el 15 de marzo de 1917. AGA, Sección África, Dirección General de Marruecos y Colonias: sección de educación, Caja-M 325, Exp. 2

22 Émile DURKHEIM: Educación y sociedad, Barcelona, Ediciones Península, 1996, pp. 73-75. 23 "El servicio más desinteresado que España pueda prestar al país protegido, es sin duda alguna, por la enseñanza que tiene como base nuestro idioma y como fin de cultura general, el preparar a los indigenas par que comprar a los del Protectorado de España en Marruecos, 1932. Biblioteca Nacional de Madrid (BNE), p. 12 que forjó la barbarie y el fanatismo, para petrificar y embrutecer en el aislamiento a las instituciones y a los habitantes de Marruecos. ${ }^{24}$

A pesar de que estas escuelas estaban dirigidas a la población marroquí de confesión musulmana se observaron algunos casos en los que los centros contaban con una mayoría de alumnado español y una minoría de estudiantes marroquíes. En 1928, tras la inauguración de la escuela de Uad Lau, la matrícula de sus estudiantes se cifraba en 68 niños marroquíes y 6 españoles. ${ }^{25} \mathrm{El}$ caso contrario fue el de la escuela de la ciudad de Alhucemas. La creación de Alhucemas -Villa Sanjurjo en aquella época- permitió un acceso más rápido a la zona y un ahorro de tiempo, dinero y esfuerzo para las tropas españolas facilitando, además, al aprovisionamiento de viveres. El control de la zona y el incremento del número de tropas desplegadas facilitaron el traslado de población civil y el aumento de la colonia infantil, lo que motivó en 1927 la apertura de la primera escuela española en la ciudad. En Alhucemas, la población existente formaba parte del sistema militar o administrativo, con predominio de la población masculina sobre la femenina y con una presencia reducida de población musulmana. Este hecho condicionó que el alumnado de la escuela fuese eminentemente español a pesar de tratarse de una escuela de tipo hispano-árabe. A veces la documentación de la época se refería a estos centros como escuelas de tipo "mixto", con ello se referían a que en el mismo aula se encontraban es tudiantes españoles y marroquíes, más que de centros femeninos y masculinos.

Tras el fin del periodo de pacificación o de control del territorio, este tipo de escuelas pasó a tener una sola denominación: escuelas hispano-árabes. El concepto hispano-árabe remarcaba su doble carácter de centro en el que se formaba en español y en árabe, si bien las materias relacionadas con España y la enseñanza del español continuaban manteniendo un lugar preferente, al igual que el profesorado que era eminentemente español. Desde fechas tempranas, la administración española intentó controlar la selección del profesorado musulmán en estas escuelas puesto que consideraba que sus docentes debían cumplir con unos requisitos de "cuidada moralidad y formación". Sus docentes, españoles y marroquies, debían dar ejemplo a los estudiantes y a la sociedad, y ser próximos al administrador y a su discurso colonial evitando que se pudiese educar a sus alumnos bajo un ideario opuesto o problemático al defendido desde la Alta Comisaría.

Muy Señor Mío: siendo las Escuelas Hispano-Árabes el medio principal de difundir nuestro idioma entre la juventud musulmana de las ciudades de la Zona del Protectorado y de algunos poblados europeos de la misma, es, entre sus enseñanzas, la koránica, el principal aliciente para la familia del alumno, por lo que la Administración del Protectorado ha puesto especial cuidado en que el cargo de fakih indígenas en dichos centros de enseñanza recaiga siempre en indígenas de reconocida moralidad y acreditados como buenos maestros del korán; propósitos que se han conseguido, pues se dispone de un buen plantel de fokoha, no obstante sus modestas remuneraciones (1080 pesetas), que resultan muy reducidas, dada la creciente carestía de la vida en las ciudades del Norte de Marruecos, y notoriamente desproporcionadas si se comparan con los sueldos que perciben modestos subalternos indígenas de la Administración del Protectorado y de las Corporaciones Municipales: 1500 los celadores urbanos; 1800 los ordenanzas de las Delegaciones; 1500 los de Telégrafos; 1227 los cabos de Policía Indígena y etc. ${ }^{26}$

24 Tomás GARCíA: España y su Protectorado en Marruecos (1912-1956), Madrid, CSIC, 1957, p. 207

25 Nota enviada por el Servicio de Información al director de Intervención civil de la Alta Comisaría de España en Marruecos. Tetuán, 27 de agosto de 1928. AGA, Sección África, Alto Comisariado de España en Marruecos, Archivo del Protectorado de Marruecos, Caja M-2045, Leg. 3487.

26 Escrito $n^{\circ} 679$ del Secretario General de la Alta Comisaría de España en Marruecos al Director Ge- 
El golpe de Estado dado por el general Francisco Franco supuso la introducción de una nueva reforma de este modelo educativo. La Alta Comisaría, en 1937, tan solo unos meses después del golpe franquista, procedió a la regulación de la enseñanza hispano-árabe. El objetivo de la reforma era la marroquinización de la enseñanza, transformando el modelo educativo colonial hispano-árabe en un modelo "nacional" de enseñanza sustentado sobre el árabe como lengua vehicular y en la enseñanza religiosa del Islam. El concepto hispano-árabe era remplazado por el concepto marroquí, lo que suponía el reconocimiento, por parte de España, de una identidad nacional basada en conceptos lingüísticos y religiosos, siguiendo los principios de respeto y de no intromisión al que aludían los tratados de 1912 de establecimiento del Protectorado.

El proceso de marroquínización iniciado por el gobierno franquista debía estar acompañado por una progresiva marroquínización del docente. El profesorado español debía dar paso, de manera paulatina, a un profesorado marroquí que se encargaría de todas las clases de centro, a excepción de las clases de español que seguirían a cargo de docentes españoles con conocimientos de árabe. Las escuelas debían estar dirigidas por marroquíes y el grueso del profesorado debía ser marroquí. La dirección del centro recaería en un mudarris, o maestro, que velaría por el cumplimiento del reglamento y de todo cuanto afectase a la escuela y contaría con un asesor, cargo desempeñado por un profesor español. A través de la figura del asesor español, la Alta Comisaría mantenía el control sobre las escuelas ${ }^{27}$ y concedía su gestión a los docentes marroquíes, si bien se aseguraba de estar informado de todo lo que en ellas sucediese e interviniendo en aquellas cuestiones que considerase necesarias. La aplicación de dicho proceso no fue inmediata. La Alta Comisaría consideró que, dada la carencia de un profesorado marroquí cualificado, se recurriría al profesorado español hasta que hubiese una generación de jóvenes marroquíes, formados en España o en Europa, capacitados para asumir estas tareas. Dicho relevo sólo se produjo de forma puntual en algunos centros, no siendo generalizado durante el Protectorado.

\section{La otra cara de la política educativa}

Al finalizar el Protectorado en 1956 la educación distaba de ser generalizada. En 1942 la Alta Comisaría promulgó el primer decreto que estableció la obligatoriedad de la enseñanza para los estudiantes españoles menores de catorce años, siendo necesario esperar hasta 1954 para que se aplicase en los mismos términos para los estudiantes marroquíes. El número de estudiantes marroquíes matriculados en la Zona española en el año 1953 se cifró en un $8 \%$, alcanzando un $22 \%$ en la zona francesa del Protectorado. Si se analizan dichas cifras en función de la confesionalidad -musulmana o hebrea- se observa cómo los índices de escolarización son mayores entre los estudiantes hebreos. La concentración de la comunidad hebrea en localidades concretas como Tetuán, Larache o Arcila hizo más fácil su escolarización, aunque en muchos casos se trataba de familias humildes que debían hace un esfuerzo económico y familiar para poder enviar a sus hijos a las escuelas. Las cifras y las políticas emprendidas tanto por los agentes coloniales como por la población local hacen pensar en la enseñanza como una cuestión de elite.

Al finalizar el Protectorado, las escuelas coránicas o msid mantenían su influencia entre la población local, que prefería enviar a sus hijos a estos centros a que aprendieran cuestiones básicas de lengua, álgebra y religión para posteriormente incorporarse al mercado laboral. E recelo y la desconfianza de la población marroquí hacia toda enseñanza no tradicional fue uno de los problemas con los que la escuela hispano-árabe se tuvo que enfrentar. Tres fueron

neral de Marruecos y Colonias. Tetuán, 25 de julio de 1923. AGA, Sección África, Dirección General de Marruecos y Colonias: sección de enseñanza, Caja M-336.

27 Amina ABDELKRIM: La enseñanza primaria en el Norte de Marruecos durante la primera mitad del siglo XX, Madrid, Artes Gráficas Benzal, 1968, pp. 12-13. las causas: temor a la pérdida de elementos identitarios culturales árabo-musulmanes, recelo a que se educase a los jóvenes marroquíes bajo las doctrinas del catolicismo, que se les alejase del Islam y se les convirtiera a la religión del colonizador, y el temor a que fuesen puntos de reclutamiento militar para el ejército español. La marroquínización del modelo educativo hispano-árabe supuso estadísticamente un aumento del nivel de escolarización, si bien ésta se mantuvo siempre por debajo de los niveles españoles. En el curso 1935-1936 había matriculados un total de 6.829 estudiantes españoles y 2.176 marroquíes musulmanes según los datos proporcionados por Fernando Valderrama. ${ }^{28}$ En el curso 1940-1941 las matrículas habían ascendido a 9.415 y 3.544 respetivamente, mientras que la escolarización de los estudiantes hebreos en las escuelas españolas era de 660. En el curso 1953-1954 los datos aportados por el Anuario Estadistico de la Zona del Protectorado Español en el Norte de Marruecos indicaban que había 10.616 españoles, 10.124 marroquíes musulmanes en escuelas hispano-árabes y 1.238 marroquíes hebreos en secciones de hebreo de los centros españoles.

Por otra parte, si se analiza la red educativa hispano-árabe y nacionalista se observa cómo su implantación en el territorio distaba de ser total. El número de escuelas hispano-árabes se había incrementado a lo largo de todo el Protectorado, sin embargo, en 1956, las escuelas no habían llegado a todas las cabilas que conformaban la zona española. En el momento de la independencia, las cabilas rifeñas de Beni Ulichek y Beni Seddat, las de Beni Ersin y Beni Selman, en la región de Gómara, y las de Beni Lait y Uadras en la región de Yebala, no disponían de escuelas, a diferencia de la región del Kert cuyas cabilas contaban todas ellas con al menos una escuela hispano-árabe. Las escuelas nacionalistas contaban con un menor número de centros. La primera escuela fue abierta en Tetuán en 1925, siguiéndole la escuela de Alcazarquivir en 1938, la de Larache en 1939, Chauen en 1947 y Nador en 1952. El déficit de centros docentes dificultó además la generalización de la enseñanza, a lo que se sumaban las condiciones de precariedad económica de muchas de las familias. Se trataba de familias de condición humilde que en muchos casos no podían permitirse enviar a sus hijos a la escuela, ya que recaían sobre ellos labores familiares, como el cuidado del ganado o la búsqueda de agua.

La política colonial española desarrolló una amplia red de centros educativos aunque estos fueron insuficientes al final del Protectorado. El grado de efectividad alcanzado en su política respecto a los estudiantes marroquíes fue reducido. El hecho de que se tratase de una enseñanza que no alcanzase a toda la población la convirtió en una enseñanza de elite. El objetivo final perseguido por el colonizador fue limitado. El hecho de que el bachillerato hispano-marroquí no comenzase su andadura hasta el curso 1942-1943 obligó a que los estudiantes que deseasen o pudiesen costearse una enseñanza secundaría pública tuvieran que acudir Ceuta, a Melilla o trasladarse a la Península, lo que disminuyó el número de estudiantes que completaban su formación en un nivel más elevado. El hecho de que no todos los estudiantes pudiesen seguir su formación en la enseñanza secundaría dificultó la creación de un grupo que pudiese ocupar puestos medios y altos en la administración. Ello hizo imposible una regeneración del personal administrativo y educativo en la que el personal laboral español diese relevo al marroqui. España creaba por un lado instrumentos que favorecín la formación de dicha clase pero por otro se aseguraba obstaculizar dicho relevo que le permitía mantener el control sobre el entramado colonial. 


\section{Conclusión}

La instrumentalización política educativa por parte de la Alta Comisaría tuvo resultados limitados al final del Protectorado. El Marruecos independiente debía afrontar nuevos retos heredados de la experiencia colonial hispano-francesa: unificación del sistema educativo, generalización de la enseñanza, marroquinización del docente y arabización de la enseñanza. Los esfuerzos realizados por España a nivel educativo se mostraron insuficientes. A pesar del in cremento del número de escuelas, la creación de un sistema educativo propio hispano-árabe,

su marroquinización y la de sus docentes, las medidas no siempre encontraron la plasmación deseada, existiendo un desfase entre la normativa y su aplicación. La enseñanza hispano-árabe fue una enseñanza de elite cuyos estudiantes no siempre se insertaron laboralmente en el sistema administrativo colonial, ocupando puestos medios y bajos de la administración, situación que no fue siempre bien valorada por parte marroquí. 


\section{INSTITUCIONES CIENTÍFICAS DURANTE \\ EL PROTECTORADO: LA ESCUELA DE \\ ESTUDIOS ÁRABES (CSIC)}

Escuela de Estudios Árabes (CSIC)

\section{Introducción}

Desde el inicio de la expansión colonial en Marruecos, los arabistas universitarios españoles, aquellos cuyo campo de estudio se centraba principalmente en el pasado arabo-islámico de la Península lbérica, evitaron implicarse de manera directa en ella, al contrario de lo que hicieron los Ilamados africanistas, cuya labor estuvo estrechamente vinculada al colonialismo.

Sin embargo, no todos los arabistas opinaban lo mismo como puede observarse en el siguiente artículo sobre "la cuestión de Marruecos" que el catedrático de árabe de la Universidad de Zaragoza, Julián Ribera Tarragó, envió a Marcelino Menéndez Pelayo en 1902.

En una postal que acompañaba a dicho artículo, Ribera explicaba las razones que le llevaban a preocuparse por este tema:

Querido maestro: Ahí va, otro esperpento sobre la cuestión marroquí. No crea V. que con esto me distraigo de arabismos. He de hacer como la clueca que enseña á picar á los polluelos. Si los arabistas no tienen más porvenir que las cátedras de árabe, de las universidades, estamos perdidos. Yo quiero asegurar caminos para los que vengan. Además de sus filósofos necesitamos jurídicos, literatos, \&. y hay que abrir puertas. Al invierno volveré á mis Universidades musulmanas. Según parece, nos llevan á Madrid. El consejo de V. no nos faltará. En eso confío.'

Como se puede apreciar, Ribera considera que los arabistas, aparte de permanecer en las aulas, también pueden realizar una labor más práctica. No era la primera vez que un arabista exponía la necesidad de unir los estudios académicos a la acción colonial española en el Norte de África. Así lo hizo Eduardo Saavedra Moragas desde la presidencia de la Asociación Española de Africanistas y Colonistas; sociedad de la que también formó parte Francisco Codera, maestro de Ribera, que ejerció una gran influencia en éste. Por lo que no es de extrañar el interés que Ribera muestra por Marruecos.

La falta de formación en lengua, religión, costumbres, psicología, etc. de las embajadas llevó a Julián Ribera a presentar un proyecto para la creación de un Centro de Arabistas, ${ }^{2}$ que formara y preparara al personal que se había de destinar al Norte de África y en especial a Marruecos (arabistas, intérpretes, militares, comerciantes, diplomáticos, archiveros, bibliotecarios, etc.).

1 Marcelino MENÉNDEZ PELAYO: Menéndez Pelayo digital: obras completas, epistolario y bibliografia, Madrid, Fundación Ignacio Larramendi: Fundación MAPFRE, 2009. Recuperado de internet (http://www.larramendi.es/menendezpelayo/iir8n/corpus/unidad.cmd?idCorpus=1002\&idUnidad=159032\&posicion=1).

2 Bernabé LÓPEZ GARCÍA: "Julián Ribera y su "taller" de arabistas: una propuesta de renovación", Miscelánea de Estudios Árabes y Hebraicos, vol. XXXII-XXXIII (1983-1984), pp. 111-128.
Dicho proyecto llegó a publicarse en la Gaceta de Madrid el 8 de septiembre de 1904, pero no logró llevarse a cabo. En su preámbulo se recoge lo siguiente:

La importancia excepcional que para el conocimiento de nuestro pasado y para la orientación de nuestro porvenir tiene indudablemente el estudio de los pueblos musulmanes, de su lengua, de su civilización, de su historia, de su dominación en España y de su estado actual, hizo pensar al Gobierno de V. M., en la conveniencia de favorecer, de alentar, de proteger esta clase de conocimientos é investigaciones; y así como hoy son obra exclusiva de unos pocos, que llevados de su amor á la ciencia y al trabajo cultivan, sin ajeno auxilio tan interesantes materias, sean el día de mañana conocimientos comunes y más divulgados en nuestro país

(...)Parecerá á alguno paso atrevido y contrario á nuestros hábitos la forma nueva de verdadero trabajo de investigación, de autonomía y de libertad que tienen, y se desea no pierdan, estos estudios; mas en ello justamente, y en la independencia económica y administrativa de esta institución, estriba la confianza del Gobierno de alcanzar con ella grandes beneficios para la Patria.

¡Ojalá que esta iniciativa encuentre calor en la opinión culta del país y despierte entusiasmo y simpatía por estudios tan científicos como útiles y verdaderamente necesarios para nosotros!3

Con este centro, Ribera trata de romper la línea que hasta ahora seguían los arabistas y unirse así a los africanistas y funcionarios del Estado, cuya labor se centraba en el mundo musulmán. Para ello, el Centro debería ser eminentemente práctico, donde todo aquél que quisiera adquirir conocimientos árabes pudiera acercarse y trabajar directamente con los maestros. Planteaba, por tanto, una especie de "taller de arabistas", sin exámenes, ni horarios.

La relación de este centro con el Norte de África, especialmente con Marruecos, se puede observar claramente en el articulado del decreto. Según el mismo, el Centro "establecerá escuelas españolas para moros en el Noroeste de África". También se establecerán escuelas españolas para judíos. Los trabajos, según el artículo 9, "consistirán en conversaciones en árabe y dialectos marroquíes, traducciones, investigaciones, exploraciones, expediciones y viajes por África, por Marruecos especialmente, descubrimientos y publicación de todas las obras y trabajos útiles para la Sociedad española en tan interesante materia". El artículo 11 recoge que "las principales labores é investigaciones versarán sobre Lengua árabe, hablada y escrita, especialmente el marroquí; Lengua Hebrea en sus varios dialectos, Historia y Geografía del Noroeste de África, Derecho musulmán en Marruecos, costumbres comerciales, contratos, literatura árabe, y sobre constitución política y religión del mismo Imperio". Continuación de este artículo es el 13, en el que se expone que "Se estudiará la Historia de nuestra Península en todas sus relaciones, influencias y contactos con las razas y civilizaciones árabes y la historia del Imperio de Marruecos; haciéndose cuantos trabajos de erudición, averiguación é indagación puedan completar y perfeccionar mejor el conocimiento del Noroeste de África, de los pueblos que habitaron aquellas regiones y de sus habitadores actuales; asi como también de la dominación de los moros en España y de sus consecuencias de toda especie. Se harán además en este periodo, exploraciones, expediciones y viajes en el Continente Africano, especialmente en los territorios del Mogreb, dedicados, no sólo al estudio geográfico é histórico, sino al comercial y político de la región". Otro dato de interés nos lo aporta el art. 16: "El Centro formará á sus expensas una Biblioteca y un Museo Árabes". Se realizarán otros trabajos, como

3 Gaceta de Madrid (1904): "Real Decreto disponiendo que el Estado tome bajo su protección el Centro de Arabistas constituido por los discipulos de D. Francisco Codera y dictando instrucciones para su funcionamiento", Gaceta de Madrid 252 (8 de septiembre de 1904), pp. 845-846. 
la elaboración de diccionarios árabe-español y español-árabe, así como marroquí-español y español-marroquí.

Una vez acabada su formación, los jóvenes obtendrán un certificado de aptitud, y la Junta del Centro "deberá proponerlos á los Ministerios de Estado, Guerra é Instrucción Pública para las comisiones y cargos en que sean útiles á la Patria, y los respectivos Ministerios podrán tomar en cuenta su competencia y servicios" (artículo 28).

Este Centro jamás llegó a encontrar los apoyos necesarios para ponerse en marcha. Sin embargo, estas ideas no caerán en saco roto, como se irá viendo, pues años después irán surgiendo una serie de instituciones que se fundamentarán en este proyecto, alentadas por un creciente número de arabistas que decidieron no mantenerse al margen de la acción colonial, y comenzaron a reivindicar su lugar como expertos. ${ }^{4}$

Cuando en 1907 se creó la Junta para Ampliación de Estudios, Ribera formó parte de la misma, logrando que jóvenes arabistas fueran becados para realizar sus estudios en Marruecos, con el fin de aprender el árabe hablado y recoger textos populares. Asimismo, pocos años después, Ribera y su discípulo, Ramón García Linares, impartieron clases en el Instituto Libre de Enseñanza de las carreras diplomática y consular. Las materias que impartieron fueron Historia de Marruecos, Instituciones jurídicas de los pueblos musulmanes y en especial del Imperio marroquí, y Árabe literal y vulgar. También se crean cátedras de "árabe vulgar" en las Escuelas Superiores de Comercio de Barcelona, Valencia, Málaga, Cádiz, Palma de Mallorca y Santa Cruz de Tenerife y se abre de una sección de árabe en el Centro de Estudios Históricos, de la que serán continuadoras las Escuelas de Estudios Árabes de Madrid y Granada.

La sección de árabe del Centro de Estudios Históricos se dividía en dos ramas, una dedicada al estudio de la civilización hispano-musulmana, y otra dedicada a los dialectos del Norte de África y a las materias de actualidad. Con ello pretendían dar rigor científico al conocimiento y la experiencia directa.

En 1913 se crea la Junta de Enseñanza de Marruecos para responder a las nuevas necesidades resultantes del establecimiento del Protectorado español en Marruecos. Esta Junta estaba orientada a la "educación de los residentes en Marruecos y a la preparación del personal idóneo para los cargos que exigiesen conocimientos de la historia, derecho, civilización o lengua del pueblo marroqui". 5 Vocal de esta Junta fue Ribera, quien personalmente viajó a Marruecos para conocer la situación de las escuelas españolas, musulmanas, judías y francesas de Larache, Alcazarquivir, Tetuán y Tánger. Huelga decir que los objetivos marcados por la Junta siguieron, en cierto modo, la línea marcada por Ribera y sus seguidores que, sin embargo, no llegarán a tener su ansiado centro de arabistas.

En 1916, por una serie de desacuerdos con otros miembros de la Junta, los arabistas abandonan la Junta para Ampliación de Estudios, el Centro de Estudios Históricos y la Junta de Enseñanza en Marruecos. El arabismo español quedará en cierto modo aislado, hasta que en 1932 se crean las Escuelas de Estudios Árabes de Madrid y Granada.

La fundación de estas dos Escuelas será el punto de partida para el florecimiento de la labor investigadora y científica en la zona del Protectorado español. Habrá que esperar a la década de los treinta para poner en práctica el proyecto de Ribera. Proyecto que apenas podrá ver, pero que tendrá en sus discípulos a sus mayores promotores. A lo largo de esta década verán la luz el Instituto Jalifiano Muley el Hassan de Estudios Marroquíes, el Centro de Estudios Marroquíes y el Instituto General Franco de Estudios e Investigación Hispano-Árabe.

Antes de centrarnos en el tema objeto de esta exposición, nos detendremos brevemente en estas instituciones.

4 Manuela MARín: "Orientalismo en España: estudios árabes y acción colonial en Marruecos (18941943)", Hispania. Revista Española de Historia, vol. LXIX, 231 (enero-abril de 2009), pp. 117-146.

5 Bernabé LóPEZ GARCÍA: "Julián Ribera y su "taller"..., p. 126.

\section{El Instituto Jalifiano Muley el Hassan de Estudios Marroquíes}

Es una institución científica creada en Tetuán en $1937,{ }^{6}$ cuya misión era

Fomentar el renacimiento y desarrollo de la cultura islámica; funcionar como Instituto de investigación y estudios; ser lazo entre la cultura árabe y la española; servir como escuela de perfeccionamiento para Profesores e investigadores; y, por último, actuar como medio de difusión en el mundo civilizado de la aportación del Andalús y de Marruecos a la obra de la cultura.

El Instituto estará formado por una Biblioteca, un museo y varias secciones de Investigación e Información Cultural, que serán: Lengua y Literatura árabe, Historia de Marruecos, Geografía y Etnografía de Marruecos, Derecho musulmán e Instituciones islámicas, Sociología y Folclore marroquí, Derecho Público del Protectorado y legislación comparada con la Zona del Protectorado francés y países norteafricanos, Movimientos renacentistas del mundo musulmán, Geografía e Historia de los países árabes, Arqueología y Prehistoria de Marruecos, Arte marroquí, Filosofía islámica comparada con la filosofía antigua y moderna, Civilización árabe española, Traducciones y publicaciones.

El Instituto debía también fomentar el intercambio cultural y ejercer de enlace con los Centros de Investigación y de Estudios árabes de España y de otros países.

El Instituto se erigió en centro de formación y de perfeccionamiento para profesores e investigadores marroquíes. Para ello se estimularon los contactos con el mundo científico oriental -Egipto- y occidental -España-, el intercambio de manuscritos con la Biblioteca Nacional de Madrid y la Biblioteca de El Escorial, y la adquisición de material bibliográfico en árabe, español y alemán. El francés quedaba excluido.?

Se realizarían excursiones científicas y se publicaría periódicamente una revista. Se ins tituyó el premio Muley Hassan, para cada una de las secciones arriba mencionadas, que se concedía anualmente. Podía aspirar a dicho premio cualquier escritor de la lengua árabe de cualquier parte del mundo. La lengua oficial del Instituto será la árabe.

\section{Centro de Estudios Marroquies}

El Centro es continuador de la Academia de Árabe y Beréber de Tetuán (1929-1938). Dicha academia fue creada, inspirándose en el Institut des Hautes Études Marocaines de Rabat, con el objeto de formar en ella no sólo a los jefes y oficiales de los cuerpos que allí residian, sino a todo el personal allí destinado. La Academia se dividía en dos secciones: una general, en la que se enseñaba árabe literal y árabe vulgar a los funcionarios, militares y civiles de Protectorado, y otra específica, para aquellos que quisieran formar parte del cuerpo de intérpretes de árabe y beréber.

En 1938 la Academia cambia su denominación por Centro de Estudios Marroquíes, cuya función era formar a los funcionarios que habían de prestar servicio al Protectorado en una cultura fundamentalmente marroquí; y la extensión y divulgación cultural en la Zona, el intercambio cultural con organismos de fuera de la misma y el fomento de las investigaciones sobre temas marroquies. A partir de 1947, se convierte también en sede de la academia de

6 Boletín oficial de la Zona de Protectorado Español en Marruecos (1937): "Dahir Jalifiano disponiendo la creación del 'Instituto Jalifiano Mulai Hasan, de Estudios Marroquíes"', BOZPEM 4 (10 de febrero de 1937), pp. 106-107.

7 Irene GONZÁLEZ GONZÁLEZ: Escuela e Ideología en el Protectorado español en el norte de Marruecos (1912-1956), Tesis Doctoral, Universidad de Castilla la Mancha, 2010. 
Interventores y su sección de Extensión Cultural, organizará ciclos de conferencias y cursos monográficos sobre temas hispano-marroquíes.

El Centro, a lo largo de su existencia, no encontró los apoyos suficientes para alcanzar los objetivos y la difusión que requería. La falta de alumnado hizo que hubiera que reclutar a es tudiantes de Semíticas de la Península, especialmente de Granada. Sin embargo, pocos fueron los que completaron sus estudios.

\section{Instituto General Franco de Estudios e Investigación Hispano-Árabe}

Este instituto tiene su origen en 1938 y fue creado con el fin de recuperar la memoria del pasado común andalusí.

El nombre del centro no era, pues, casual. Se apelaba a la figura del general Franco como nexo entre Al-Andalus y el renacimiento cultural marroquí. La labor del Instituto se centraba en la publicación de manuscritos árabes, marroquíes y españoles, para su difusión traba en la publicación de manuscritos árabes, marroquies y españoles, para su difusión
en el mundo musulmán, en la traducción al español de las obras árabes para el estudio de investigadores españoles y extranjeros, en la publicación en español y en árabe de aquellas obras de mayor importancia custodiadas en los archivos españoles referentes a la España musulmana y a las relaciones entre España con el norte de África, así como en la reedición anotada de obras en árabe y español que se encontrasen agotadas y cuya valía lo hiciese aconsejable, y en la traducción al árabe de las obras españolas más representativas. ${ }^{9}$

De lo expuesto en líneas anteriores, cabría concluir que, de una u otra manera, profesores y alumnos de las Escuelas de Estudios Árabes, especialmente la granadina, se hallaban vinculados a estas instituciones.

\section{Escuela de Estudios Árabes de Madrid y Granada}

El ministro de Instrucción Pública de la República, Fernando de los Ríos, promovió la creación de las escuelas de Estudios Árabes de Madrid y Granada, en 1932. Con ello procuraba "responder a la necesidad que tenía el país de promover los estudios sobre el mundo islámico por su historia, sus fronteras y la existencia de una tradición de investigación acerca del tema con figuras como Francisco Codera, Miguel Asín Palacios y Julián Ribera". ${ }^{\circ}$

El arabismo español a diferencia de lo que ocurre en muchas naciones de Europa, ni es para nosotros una pura curiosidad científica, sin contacto con el medio ambiente y desarraigada de todo interés humano, ni enlaza el fervor espiritual con conveniencias mercantiles o imperialistas. Los estudios árabes son, para nosotros, una necesidad intima y entrañable, puesto que como decíamos al comienzo, se anudan con muchas páginas de nuestra historia, revelan características de nuestra literatura, muestro pensamiento y nuestro arte, se adentran en nuestro idioma y hasta, tal vez, más o menos, en nuestra vida."

Así se expresaban Asín Palacios y García Gómez, los directores de las Escuelas de Madrid y Granada, respectivamente, en la "Nota Preliminar" del primer número de la revista Al-Andalus.

8 J.P. ARIAS TORRES y Manuel C. FERIA GARCíA: Los traductores de árabe del Estado español: del Protectorado a nuestro dias, Barcelona, Bellaterra, 2013, pp. 235-254

9 Irene GONZÁLEZ GONZÁLEZ: Escuela e Ideología..., 2010, p. 452

10 Antonio SANTAMARÍA GARCíA: Centros de la Junta para la Ampliación de Estudios e Investigaciones Cientificas, Madrid, CSIC, 2007. Recuperado de internet (http://digital.csices/bitstream/10261/5294/1/CENTROS.pdf).

11 Miguel ASÍN PALACIOS y Emilio GARCÍA GÓMEZ: “Nota Preliminar”, Al-Andalus, I, 1 (1933).
La Escuela de Madrid tenía como fin primordial “dirigir y fomentar las investigaciones científicas sobre la Historia, la civilización y la vida Dusulmana, singularmente en España, en to dos sus aspectos, y publicar ediciones, traducciones y estudios sobre autores musulmanes, as como una revista que sea órgano de la Escuela" ${ }_{12}$

Ésta última estaba formada por seis secciones: Historia de las ciencias y de las ideas en el Islam; Historia política de los musulmanes españoles; Derecho e Instituciones musulmanas; Filología y Literatura árabes; Estudios marroquíes y Dialectología; y Arte y Arqueología árabes. Aunque existía una sección dedicada a los estudios marroquíes, apenas tuvo ninguna repercusión, pues fue en las otras secciones donde se centró principalmente la actividad de la Escuela.

Por otro lado, la Escuela de Granada tenía como fin la enseñanza superior de la lengua y civilización árabes, el hebreo bíblico y rabínico, y la atracción de la juventud musulmana labores que completará con trabajos de investigación científica. Asimismo, debía atraer estudiantes marroquíes a sus aulas, organizando enseñanzas acomodadas a su religión y cultura, y llegando, si fuera posible, a establecer una residencia. Además, se organizarían actividades de difusión en las que se invitarían a especialistas nacionales y extranjeros para que dieran cursos y conferencias. ${ }^{3}$

La organización del centro quedaba vertebrada en cuatro secciones: Filología, en la que se incluían Árabe clásico, Literatura arábigo-española, Árabe vulgar marroquí, Hebreo Bíblico y Lengua castellana para orientales; Derecho e Instituciones Islámicas; Historia Política y Cultural de los musulmanes, en esta sección también se estudiaba la Historia de los judíos; y Arte y Arqueología Arábiga.

La Escuela de Granada tenía la obligación de investigar y publicar los resultados en los campos relacionados con las cuatro secciones, de acuerdo con la Escuela de Madrid. Así fue como nació la revista Al-Andalus, predecesora de la actual Al-Oan ara.

Los objetivos de esta escuela se resumían de la siguiente manera:

En el ámbito estrictamente universitario, ampliar los estudios arábigos eruditos dotándolos de medios técnicos -bibliotecas, seminarios, etc. - de que carecían; ejercer alguna influencia en la vida social de la ciudad cuyo pasado está tan ligado a sus actividades, interesando, en cierto modo, a todos sus habitantes, desde el intelectual hasta el obrero; $y$ servir de principal nexo de unión entre nuestra patria y la juventud musulmana, que nos mira con tan fraternal simpatía y cordialidad. ${ }^{4}$

Las dos Escuelas podían expedir grados de suficiencia a sus alumnos, que "les servirán para oposiciones y concursos a cátedras de estas especialidades, a puestos diplomáticos o consula res en países de lengua árabe, o a plazas de archiveros, bibliotecarios o arqueólogos en centros donde se custodian fondos árabes". ${ }^{15}$

\section{La Escuela de Granada}

La elección de Granada para que acogiera a esa juventud musulmana a la que la se pretendía atraer, queda reflejada en el siguiente texto de Asín Palacios:

Convendrá que los centros urbanos en que residan no sean las más populosas capitales, en las que la cultura de la España tradicional ha sido casi absorbida por esa pseudo-civilización

12 "Información Oficial", Al-Andalus, I (1933), p. 235

13 "Información Oficial", Al-Andalus..., p. 236

14 Escuela de Estudios Árabes: Escuela de Estudios Árabes de Granada (Casa del Chapiz): curso 19341935, E. MAESTRE (ed). Recuperado de internet (http://digital.csic.es/bitstream/10261/22580/1/ eea1.pdf).

15 “Información Oficial”, Al-Andalus...p. 237 
europea y cosmopolita del bar y del fox-trot yanqui o del cabaret francés, sino más bien en alguna de esas ciudades provincianas, propicias al recogimiento y al estudio, que además despierten, por sus monumentos y ambiente medieval, el recuerdo de nuestras tradiciones, al par que el de la cultura hispanoárabe. ${ }^{16}$

Granada, con su Escuela de Estudios Árabes, se convierte en el lugar idóneo para que este proyecto se lleve a cabo

Esta Escuela comenzó su andadura el 21 de noviembre de 1932. Unos meses antes, S. A. I. el Jalifa de la Zona Española en Marruecos visitó las obras que se estaban realizando para acondicionar las Casas del Chapiz, sede en la que se establecería el centro. Durante esta visita, realizada el 30 de mayo de 1932, el Jalifa Muley Hassan ben al-Mehdi inauguró la Escuela de Granada, quedando patente el deseo de hermanamiento entre España y Marruecos, así como la intención de atraer a los jóvenes estudiantes marroquíes.

En un principio, la Escuela de Granada estuvo regida por un Patronato formado por cinco miembros: el Rector de la Universidad de Granada el Decano de la Facultad de Letras, el Arquitecto-Director de la Alhambra, el Catedrático de Árabe de la Facultad de Letras de Granada, a quien se le da la dirección de la Escuela, y un catedrático de la misma Facultad.

Entre sus objetivos, expuestos más arriba, destacaba la enseñanza de las lenguas árabe y hebrea, así como la difusión del conocimiento de la civilización árabe. Sin embargo, estos objetivos no tardarían en cambiar.

El fin de la Guerra Civil, que supuso un duro paréntesis en la historia de la Escuela, coincidió con el nacimiento del CSIC. Las Escuelas de Madrid y Granada pasaron a formar parte del mismo, integrándose en el Instituto Arias Montano de Estudios Árabes y Hebraicos. Más tarde ambas Escuelas formaron el Instituto Miguel Asín. Tras varios años la Escuela de Madrid volvió a llamarse Instituto Arias Montano, mientras que el nombre de Escuela de Estudios Árabes pasó a designar únicamente a la sede de Granada.

La integración en el CSIC supuso un cambio de rumbo en la Escuela de Granada que, a partir de este momento, debía prestar más atención al campo de la investigación. Se extinguió el patronato que la regía, cambiaron algunos estatutos y secciones, y la docencia quedó prácticamente en manos de la Facultad de Letras.

\section{La Escuela de Granada y la acción colonial}

De acuerdo con los objetivos de su Ley fundacional

La Escuela se ha preocupado, en la medida que sus medios y su desenvolvimiento lo han ido permitiendo, en atraer a sus aulas a la juventud musulmana que aspire a realizar estudios árabes con arreglo a la técnica científica moderna o a cursar en los Centros oficiales de Granada; e incluso ha ayudado económicamente a algunos de dichos alumnos."

Sin embargo, en un breve periodo de tiempo, se entendió que era una equivocación tratar de atraer a los jóvenes musulmanes para que estudiaran en Granada lengua y literatura árabes. Para estos jóvenes, poco sentido tendría iniciar en dicha ciudad estudios que bien podrían realizar en sus lugares de origen. Lo que realmente les interesaba a los "orientales", era adquirir conocimientos científicos y técnicos.

16 Miguel ASÍN PALACIOS: "Por qué lucharon a nuestro lado los musulmanes marroquíes", Obras escogidas, Madrid, CSIC, 1946-1948, p. 151

7 Escuela de Estudios Árabes: Escuela ... Recuperado de internet (http://digital.csic.es/handle/10261/22580).
Teníamos ya el espíritu, pero nos faltaba todavía elegir la materia concreta de trabajo. Se habló entonces, como tantas otras veces, de una Universidad musulmana. Este proyecto lo estimamos y lo seguimos estimando irrealizable por el momento, y lo será durante muchos años. Traer estudiantes musulmanes a Granada para estudiar lengua y literatura árabes es un programa muy poco atractivo para ellos, y que pueden cumplir con mucho mejor fruto en sus respectivos países. Lo que interesa a los orientales es la adquisición de conocimientos científicos y técnicos. Ahora bien: confesemos que nos hubiera sido muy difícil desviar hacia nuestras ciudades la corriente estudiantil islámica que se dirigía, en aquellos tiempos, a las Universidades o a los grandes politécnicos de París, Londres, Berlín, Roma o Bruselas. Ni siquiera la lengua española -no nos engañemos- tienda rango internacional en Oriente. Hubiera sido, sí, hacedero cambiar algunos estudiantes de Letras, traer a pasar una temporada entre nosotros a algún poeta o erudito y celebrar algún Curso de Vacaciones; pero la situación, primero de España en aquellos años y del mundo, hicieron irrealizables incluso estas modestas perspectivas. En este terreno nos limitamos a lo factible: tener entre nosotros a unos cuantos estudiantes de nuestra zona de Protectorado marroquí, designados por la Alta Comisaría, de los cuales los más brillantes acaban de terminar ahora sus Licenciaturas. ${ }^{18}$

Tal y como sugirió Emilio García Gómez, director de la Escuela de Estudios Árabes y Catedrático de Árabe de la Facultad de Letras, en su texto, se intentó atraer a orientales a través de cursos de vacaciones. En el año 33, la Universidad de Granada, institución a la que la Escuela de Estudios Árabes se encuentra fuertemente vinculada desde sus inicios, organizó un curso de verano dedicado especialmente a orientales en las Casas del Chapiz. Las materias impartidas, en francés, inglés y español, fueron literatura, historia y costumbres españolas, además de otras relacionadas con los "abundantes vestigios de la civilización árabe que subsisten aún en España".19 Pese a todo, estos cursos no obtuvieron los resultados esperados, por lo que la Escuela tuvo que limitarse a acoger a algunos estudiantes de la zona española del Protectorado.

Con tal fin, se refrenda el Decreto de 16 de febrero de 1934, por el cual la Escuela de Estudios Árabes crea cuatro becas, cada una dotada de 4000 pesetas anuales, para estudiantes musulmanes designados por el Gobierno, a propuesta del comisario superior de Marruecos. Estas becas no eran las primeras que se daban a estudiantes marroquíes y con el paso del tiempo irían aumentando en número, llegando a tener la Escuela en algunos cursos más de quince becarios. Estas becas no eran las primeras que se daban a estudiantes marroquíes. Existían ayudas, tanto pecuniarias como de enseñanza gratuita en centros españoles, para un cierto número de estudiantes del Protectorado español. Estos complementaban su formación en carreras como magisterio, medicina, peritaje agrícola e industrial, etc. La novedad de estas becas fue el reconocimiento de la Escuela como centro en el que "los estudios de disciplinas puramente islámicas podian ser ampliados y perfeccionados".20

Es plausible la iniciativa desde el punto de vista científico, porque la formación técnica que los becarios reciban en ella puede formar a la larga un pequeño núcleo de estudiosos que contribuya a divulgar y extender en nuestra zona la afición a las ciencias del Islam, estudiadas con criterio más racional que el hasta ahora usado por los musulmanes. Mayor es aún la trascendencia política de la medida: los mejores auxiliares que las naciones

18 Emilio GARCÍA GÓMEZ: Silla del moro y nuevas escenas andaluzas, Madrid, Revista de Occidente, 1948, pp. 152-153.

19 Boletín de la Universidad de Granada (1933): “Crónica Universitaria”, BUGR 23 (abril de 1933), p. 251252.

20 “Información Oficial”, Al-Andalus, II (1934), p. 259. 
europeas han tenido para consolidar su influencia en los países musulmanes por ellas protegidos o dominados, han salido de los centros de enseñanza media y superior para indígenas que aquéllas crearon con profesorado predominantemente europeo. Era fremación que forzosamente tiene que producir toda enseñanza dada con la mira de realzar la importancia de la nación que la ha establecido. ${ }^{21}$

Uno de los principales propósitos de estos estudios era alejar a los jóvenes de la zona española del Protectorado del nacionalismo musulmán creciente en aquella época procurando de este modo que se formaran en Granada, en lugar de acudir a las Universidades de Fez, Túnez - El Cairo. España trataba asi de ocupar un lugar privilegiado en las relaciones con los países árabes, especialmente con Marruecos, convirtiéndose en garante del legado arabo-islámico, defendiendo el papel que al-Andalus jugó en él, pretendiendo así distanciarse del resto de "naciones que protegen países musulmanes", 22 que veían peligrar su posición.

Para alcanzar dicho fin, a lo largo de estos primeros años, se realizaron varios viajes y expediciones científicas a varios países árabes, especialmente Marruecos, con la intención de permitir a profesores y alumnos conocer aquello que habían aprendido en las aulas, y dar a conocer lo que en la Escuela se estaba haciendo.

El primer viaje del que tenemos noticia es el realizado en abril de 1933 a Rabat y Fez. El motivo fue la participación de una importante delegación española, formada por miembros de las Escuelas de Estudios Árabes de Madrid y Granada, la Academia de la Historia, la Universidad de Granada, la Dirección de Marruecos y la Alta Comisaría de España en Marruecos en el VIII Congreso de Estudios Superiores Marroquíes. Esta delegación pudo "demostrar a Francia y a las demás naciones adheridas el interés que España siente por los estudios relativos a la civilización islámica".23

A todo el elemento musulmán de Marruecos le ha gustado saber que en España hay una tradición antigua de estudios arábigos, y que ahora, en las Escuelas de Estudios Árabes de Madrid y de Granada, se acelera el ritmo en la marcha de estos trabajos. En suma, este Congreso de Estudios Marroquíes ha producido el favorable efecto de dar a conocer directamente el desarrollo del arabismo español. ${ }^{24}$

Unos meses más tarde la Escuela de Estudio Árabe participó en un crucero científico por el Mediterráneo organizado por la Facultad de Filosofía y Letras de Madrid. El itinerario escogido -Túnez, Egipto, Palestina, Turquía, Sicilia, Nápoles- hacía imprescindible la participación de la Escuela. A esta expedición científica, le seguirá otra serie de viajes que se centrarán, principalmente, en Marruecos.

En 1935 se realizó la primera expedición científica a la otra orilla. Esta estuvo formada por el Rector de la Universidad de Granada, cinco profesores y doce alumnos de la Escuela de Estudios Árabes de Granada, diez alumnos de la Universidad de Granada, y cuatro alumnos y dos profesores de la Escuela de Estudios Árabes de Madrid. Los expedicionarios visitaron Tánger, Arcila, Larache, Alcázarquivir, Rabat, Salé, Casablanca, Volubilis, Muley Idris, Mequínez, Fez, Tetuán, Xauen y Ceuta.

21 lbid., pp. 259-260.

22 Ibid., p.26o

23 "Información Oficial", Al-Andalus, I (1933), p. 492.

24 "Información Oficial", Al-Andalus, I (1933), p. 494
En todos estos puntos visitaron con detenimiento los monumentos y colecciones y consideraron atentamente los diversos y pintorescos aspectos de la vida indígena. Fueron, además, obsequiados con continuos agasajos, que pusieron entre las horas de estudio gratos paréntesis de cordialidad y camaradería. ${ }^{25}$

Asimismo, a lo largo de este primer viaje se establecieron relaciones con otras instituciones científicas como el Institut des Hautes Études Marocaines de Rabat, dirigido en aquel momento por Lévi-Provençal, quien en los años siguientes visitará con frecuencia las Escuelas.

Además de las expediciones, se realizaron cursos, seminarios, exposiciones e intervenciones relacionados con temas y cuestiones hispano-árabes e hispano-marroquíes. Éstos estaban orientados principalmente a orientalistas, pero, en algunas ocasiones, también se organizaban cursillos para estudiantes y profesores marroquíes.

De mediados de abril a mediados de mayo de 1939, un grupo de dieciocho alumnos marroquíes del Magisterio musulmán asistieron a un curso organizado por la Escuela, en el que se impartieron las siguientes materias: Lengua, Arte, Influencia de la cultura árabe, Historia, Literatura, Vida y costumbres españolas e Influencia del arte árabe. A lo largo de la estancia, también se realizaron visitas a los monumentos árabes de la ciudad.

Durante la década de los cuarenta, no sólo Granada fue la sede de las actividades arabistas. A través de la Extensión Universitaria se programan cursos y seminarios en Tánger y otros lugares norteafricanos.

Por otro lado, una de las labores de la Escuela era "ejercer alguna influencia en la vida social de la ciudad cuyo pasado está tan ligado a sus actividades, interesando, en cierto modo, a todos sus habitantes, desde el intelectual hasta el obrero". ${ }^{26}$

Un claro ejemplo fue la Exposición Hispano-marroqui de 1939. Durante las fiestas del Corpus, el Ayuntamiento de Granada, bajo la dirección técnica de la Escuela de Estudios Árabes, organizó en el Corral del Carbón una exposición de industrias granadinas y marroquíes. En ella se mostraron telares, alfares, talleres de esteras, artesanos del hierro, cuero y nácar, incluyéndose también una degustación de platos típicos de la región. Invitada especial fue la Escuela de Artes Indígenas de Chauen.

\section{La Casa de Marruecos}

Desde sus inicios, uno de los objetivo de la Escuela era la creación de una residencia para los becarios musulmanes. Estos alumnos tuvieron que residir en la sede de la Escuela hasta que en 1945 un "dahír" jalifiano creó la Casa de Marruecos ${ }^{27}$ Dicha institución estuvo subvencionada por la Alta Comisaría y el Ministerio de Educación Nacional.

Los alumnos internos de esta residencia eran, en su mayoría, becarios marroquíes de la Alta Comisaría, de las Intervenciones del Protectorado o de la Escuela de Estudios Árabes que realizaron estudios en España, así como estudiantes españoles procedentes de la zona española del Protectorado.

La Casa de Marruecos se encontraba en el actual Carmen de la Victoria, frente a la Escuela, y se hallaba bajo la tutela, dirección y vigilancia de ésta.

25 "Noticias", Al-Andalus, III (1935), p. 231.

26 Escuela de Estudios Árabes: Escuela.... Recuperado de internet: http://digital.csic.es/handle/10261/22580.

27 Boletín oficial de la Zona de Protectorado Español en Marruecos (1945): "Dahir estableciendo la "CASA DE MARRUECOS " en Granada residencia que será de los estudiantes marroquies que cursen sus estudios en España", BOZPEM 22 (27 de julio de 1945), p. 614-615. 
La "Casa de Marruecos» ha establecido para ellos un régimen especial que difiere notablemente del que, por lo común, se aplica en la generalidad de los internados. El establecimiento atiende a cubrir todas sus necesidades económicas y a completar la formación que reciben en los Centros docentes instituidos para la enseñanza de jóvenes españoles y a los cuales asisten.

Les da alimentación y casa; paga los gastos de desplazamiento desde sus habituales residencias a Granada; organiza y costea viajes de estudio a otras poblaciones españolas; les adquiere, por cuenta del Centro, sus libros de texto y todo el instrumental de trabajo que necesitan; abona sus gastos de matrícula, cuando, en determinados casos, la Ley no se la concede gratuitamente; les costea servicio de médico, practicante y medicamentos; satisface, en fin, todas sus necesidades, incluso el lavado y costura de ropa y hasta la asistencia a espectáculos públicos o diversiones honestas; y, en alguna ocasión, en que se estimó razonable hacerlo, adquirió ropa, especialmente de invierno, para más de un becario que, según el asenso unánime de sus compañeros no podía adquirirlas por sus propios medios.

La «Casa de Marruecos» ejerce también una discreta vigilancia sobre la vida que, fuera del establecimiento, hacen los internos; y dentro de él mantiene una rígida disciplina, atendiendo, especialmente, a la educación de los becarios. Funcionarios del Centro presiden el comedor y dirigen el estudio, informándose personalmente del comportamiento y aplicación que observan los becarios en los Centros docentes españoles a que asisten. Finalmente, la «Casa de Marruecos» completa la formación cultural de sus internos con enseñanzas de Lengua y Literatura Españolas y de Árabe Literal, enseñanzas especialmente organizadas para ellos.

La «Casa de Marruecos» constituirá un elevado exponente de nuestra acción marroquí y es ya una manifestación clara de los desvelos con que el Estado español atiende a la formación cultural de la juventud musulmana. ${ }^{28}$

Esta residencia alojó a una quincena de alumnos marroquíes al año, hasta que a finales de los años cincuenta pasó a ser residencia universitaria y se convirtió en el Colegio Mayor Nuestra Señora de la Victoria.

\section{La formación de funcionarios para la Alta Comisaría}

Otro objetivo de la Escuela de Estudios Árabes de Granada era la formación de funcionarios especializados que fueran destinados a la Alta Comisaría de España en Marruecos.

En el año 44 un grupo de becarios españoles que iban a realizar Estudios Superiores de Traducción e Interpretación en el Centro de Estudios Marroquíes de Tetuán tuvieron que iniciar su formación en la Escuela de Estudios Árabes, debido a un retraso en la documentación. La Escuela, gracias a las gestiones de su director Luis Seco de Lucena, comienza a funcionar como centro preparatorio de aspirantes a intérpretes de la Alta Comisaría.

Para ello se elaboró un programa específico que integraba las siguientes materias: Árabe vulgar, Beréber rifeño, Geografía de Marruecos, Sociología marroquí y Derecho Administrativo del Protectorado. Este programa se completaba con asignaturas comunes a los alumnos de Semíticas: Árabe literal, Literatura árabe clásica, Literatura arábigo española Explicación de textos árabes, Historia del Occidente musulmán, Historia de la España musulmana y Derecho islámico. ${ }^{29}$

28 L.SECO DE LUCENA: “Los estudios árabes en España”, África. Revista de Acción Española, Madrid, 58 (1946), pp. 29-31.

29 J. P. ARIAS TORRES y Manuel C. FERIA GARCÍA, Los traductores de árabe..., p. 251-254
Esta primera promoción completó dos cursos en la Escuela, luego los alumnos continuaron sus estudios en el Centro de Estudios Marroquíes. De los quince becarios que comenzaron, sólo siete llegaron a Tetuán. Y de éstos, tres no terminaron sus estudios. A esta promoción siguieron otras. Muchos de ellos no llegaron a entrar en el Cuerpo de Interpretación. ${ }^{30}$

A partir del año 51, la Delegación de Educación y Cultura de la Alta Comisaría de España en Marruecos reconoce las enseñanzas que se dan en la Escuela, integrándola en la carrera de Interpretación. Igualmente, crea cuatro medias becas para alumnos que aspiraran a cursar dichos estudios en la Escuela de Estudios Árabes de Granada. Los becarios que aprobaran serían trasladados a Tetuán para continuar alli su formación a partir del segundo año de la carrera.

Se pretendía así acercar a la juventud española a un arabismo más práctico, favoreciendo los estudios árabes.

A principios de los cincuenta, la Escuela de Estudios Árabes había destinado a la Alta Comisaría: dos interventores, cuatro traductores intérpretes, tres profesores de enseñanza media y cinco maestros. Asimismo, ejercían diversas profesiones universitarias en Marruecos varios jóvenes musulmanes que cursaron estudios en las Facultades de la Universidad granadina, y que fueron becarios de la Escuela. ${ }^{31}$

\section{Conclusión}

La creación de las Escuelas de Estudios Árabes, especialmente la de Granada, supuso un gran avance para el arabismo español y la realización del sueño de Julián Ribera. Por fin nacía un centro capaz de preparar y formar a aquellos funcionarios, diplomáticos o civiles, que quisieran participar en la empresa colonial. Y no sólo eso, sino que se encargaría también de la formación de estudiantes marroquíes que decidieran estudiar en la Península con el fin de lograr a su vuelta importantes puestos en la Administración del Protectorado.

La Escuela lograba así, en la medida de sus capacidades, que el arabismo español participara en la acción colonial.
30 Ibid., p. 176

31 Escuela de Estudios Árabes de Granada, Dirección General de Relaciones Culturales (ed.), 1952. Recuperado de internet: $\mathrm{http}: / /$ hdl.handle.net/10261/24274. 


\section{LOS JUDÍOS SEFARDÍES, ¿UNA HERRAMIENTA \\ PARA LA COLONIZACIÓN? \\ FILOSEFARDISMO EN LOS PRINCIPIOS \\ DEL PROTECTORADO}

Eva Touboul Tardieu

Université Lumière-Lyon 2 / CREC

Que no olviden los españoles que en Marruecos está cifrado el porvenir de España, desde los días en que una Reina clarividente nos legó, en su testamento admirable, el encargo de no cesar en la conquista de África.

Y al otro lado del Estrecho, millares de españoles que allí arrojó esa misma Reina quizás para que fueran semilla de donde arrancara el árbol, nos esperan con los brazos abiertos y con el amor a España en los corazones, para ayudar en una conquista civilizadora a la nación que, según frase deslumbradora de Castelar, engarzó el mar como una esmeralda en sus sandalias y el sol como un brillante en su corona.

Los apetitos económicos de los Estados Unidos que su participación en la guerra de Cuba a duras penas escondía, habían sido la comidilla de la prensa española a lo largo de los tres años del conflicto. De allí que la derrota de 1898 se vivió como una inmensa vejación y constituyó un climax en la finisecular crisis de identidad de España. En efecto, las últimas dos décadas del s. XIX son los años del auge de la expansión colonial de las grandes potencias europeas, Francia e Inglaterra principalmente, pero también el recién constituido Imperio alemán. Por consiguiente, al verse despojada de las últimas joyas de su corona, España interroga su lugar en el concierto de las naciones. En este marco se van desarrollando el regeneracionismo, que procura curar la nación española enferma, y una de sus principales secuelas, el Hispanismo, aspiración a sustituir un imperio cultural al difunto imperio colonial. El principal campo de aplicación del Hispanismo (más tarde llamado "Hispanidad") son las relaciones hispanoamericanas, con el restablecimiento de relaciones culturales privilegiadas entre la madre-patria y las repúblicas-hijas, según el léxico empleado en la época. Otras dos ramas son particularmente notables en el Hispanismo: por una parte, el Africanismo, que, siguiendo las prescripciones del documento conocido como "Testamento de la reina Isabel la Católica", considera África, y más específicamente Marruecos, como la prolongación de la Península; por otra parte, el Sefardismo, que pretende restablecer relaciones con los descendientes de los judios expulsados de España en 1492, que en su exilio han pasado a designarse a sí mismos como españoles (sefardim, en hebreo) y siguen utilizando como idioma vernáculo el judeoespañol.

La creación del Protectorado de Marruecos, en 1912, por el Tratado de Fez, tiene entonces un valor muy específico para España: por una parte, le permite regresar a la mesa de las grandes naciones, puesto que, de algún modo, la zona costeña y rifeña que se le atribuye se puede considerar una nueva forma de colonia, con reglas específicas, ya que se deben compaginar las autoridades españolas y autóctonas. Por otra parte, en Marruecos confluyen en Africanismo y el Sefardismo, dado que allí residen grandes comunidades judeoespañolas. Por consiguiente el Protectorado se convierte en oportunidad de concretización de las teorías filosefardistas

1 Manuel L. ORTEGA, Los hebreos en Marruecos (Madrid, 1919), Málaga, Editorial Algazara, 1994, p. 346.

\section{El sefardismo}

A principios del s. XX, el senador Ángel Pulido Fernández, con la ocasión de un viaje por los Balcanes, toma conciencia de la pervivencia del idioma castellano entre las comunidades judeoespañolas de la zona, que representan varios millones de locutores. Emprende entonces una campaña de recuperación de los a quienes designa como "españoles sin patria".

Dirige su acción tanto hacia los españoles como hacia los sefardíes, publicando varios artículos en la prensa nacional, que luego recopila en un primer libro, Los israelitas españoles y el idioma castellano (1904).2 Basándose en las cartas recibidas a raíz de dicha publicación, y en las repuestas a una encuesta que envió a correspondientes sefardíes por el mundo, publica al año siguiente la que será su obra maestra, Intereses nacionales. Españoles sin patria y la raza sefardí. ${ }^{3}$ Aunque en su primer libro se centraba en las comunidades judeoespañolas de los Balcanes, fuente de su filosefardismo, las circunstancias internacionales de la firma de la Entente Cordiale entre Inglaterra y Francia, y el consiguiente establecimiento del Protectorado francés en Marruecos le llevan a dedicar muchas páginas a la situación marroquí para procurar determinar un programa de acción para España en la otra orilla del Mediterráneo.

Su campaña recibe muy buena acogida entre los grupos liberales españoles, como se refleja en los testimonios, más o menos novelados, de quien fue uno de los protagonistas del prime sefardismo, Rafael Cansinos Assens. ${ }^{4}$ El movimiento iniciado por Pulido desemboca en 1910 en la creación en Madrid de la Alianza Hispano-Hebrea, patrocinada por el propio rey Alfonso XIII.

\section{La oportunidad marroquí}

Si ya desde 1905 Pulido se interesó por los sefardies de Marruecos, es que conformaban la población judía hispanohablante más cercana geográficamente hablando.

En Españoles sin patria y la raza sefardí, el senador estima en 150.000 el número de judíos que viven en Marruecos en aquella época, 5 de una población de unos 5,4 millones. ${ }^{6}$ Quince años más tarde, Manuel L. Ortega habla de entre 200 y 250 mil judíos en un total de ocho o nueve millones de habitantes.? La población judía del Imperio jerifiano se divide en dos categorías principales: los judíos del interior del país son, en su mayoría, autóctonos convertidos al judaísmo al principio de nuestra era: se les suele designar como toshavim, o residentes. En la parte costeña, que es la del Protectorado español, vive una mayoría de megorashim, o exiliados, que son los descendientes de los judeoespañoles expulsados por los Reyes Católicos. El grupo de los toshavim se divide a su vez en tres subgrupos lingüisticos: los que hablan judeoberéber, y viven en las zonas rurales; los que hablan judeoárabe, como las comunidades de Marrakech, Agadir o Mazagrán; y los que incorporaron al judeoárabe palabras españolas, al integrarse los megorashim en las comunidades preexistentes, como fue el caso en Rabat, Mequínez o Salé, por ejemplo. En cambio, en las comunidades compuestas de manera casi ex-

2 Ángel PULIDO FERNÁNDEZ, Los israelitas españoles y el idioma castellano, (Madrid, 1904), Barcelona, Riopiedras Editores, 1992.

3 Ángel PULIDO FERNÁNDEZ, Intereses nacionales. Españoles sin patria y la raza sefardi, Madrid, Establecimiento Tipográfico de E. Teodoro, 1905. Recuperado de internet (http://archive.org/stream/ espanolessinpatoopuli\#page/n7/mode/2up). Última consulta el 30/06/2013.

4 Rafael CANSINOS ASSENS, Las Luminarias de Janucá (2a edición), Buenos Aires, Editorial Candelabro, 1961 ; í.., La novela de un literato (Hombres, ideas, escenas, efemérides, anécdotas...), Madrid, Alianza Editorial, 2005, T. 1.

5 Ángel PULIDO FERNÁNDEZ, Intereses nacionales. Españoles sin patria y la raza sefardí.., p. 490.

6 Robert ESCALLIER, "Le Maroc, en transition démographique", Méditerranée, 81 (1995), p. 107 Recuperado de internet (http://www.persee.fr/web/revues/home/prescript/article/medit_o025-8296 1995 num 81 1 2881). Última consulta el 10/09/2013.

7 Manuel L. ORTEGA, Los hebreos en Marruecos..., p. 137 
clusiva de megorashim, el idioma hablado era la haketía, o sea el judeoespañol más cercano al que se hablara en la España medieval, aunque se habían ido incorporando palabras árabes a lo largo del tiempo. Cualquiera que fuera su origen, el estatuto jurídico de los judíos de Marruecos era el mismo que en el resto del Imperio otomano: eran dhimmis, o sea que debían pagar un impuesto específico, y estaban sometidos a una serie de obligaciones y prohibiciones.

Tanto en la guerra de África (1859-1860) como a partir de la creación del Protectorado, los españoles se encuentran en contacto casi exclusivamente con las comunidades de megorashim, o sea las que han conservado una lengua muy próxima al castellano, y, por lo tanto, con las que es más fácil comunicarse. Los historiadores tanto como los testigos señalan la ambivalencia de los sentimientos de dichas comunidades sefardies hacia España: es una madrastra que los echó de su tierra cuatro siglos antes, y sin embargo siguen añorando Sefarad, la mítica España medieval. Cuando se produce el primer contacto entre los sefardíes de Marruecos y la España contemporánea en 1859, con la ocasión de la Guerra de África y la ocupación de Tetuán el entusiasmo de las poblaciones judías es notable, tanto más que significaba para ellas el final de la opresión musulmana que venían sufriendo en los últimos tiempos. Los dos años de la ocupación de Tetuán desembocan en un redescubrimiento mutuo, del que deja constancia la literatura, ${ }^{8}$ y una mejora de la situación de la comunidad israelita tetuaní. Sin embargo, cuando España vuelve a abandonar la ciudad, no permanece nada de la organización administrativa ni de los vínculos establecidos con los judíos hispanohablantes.

Cuando el Tratado de Fez crea en 1912 el Protectorado español de Marruecos al lado de francés, las autoridades buscan apoyos para conseguir una "penetración pacífica" del país, en la terminología oficial. Entonces se vuelven las miradas hacia los sefardies, cuya hispanidad se empeñan en describir numerosos ensayos y artículos. ${ }^{9}$ Según éstos, dicha hispanidad sefardi se basa en dos elementos principales, el uso del idioma judeoespañol y las características raciales. Para la mayoría de los ensayistas, el hecho de que los sefardíes de Marruecos sigan hablando español es señal de su apego a la antigua madre patria, de su amor indefectible y nostálgico:

Esta supervivencia de nuestra habla primitiva, recia y jugosa de la edad de oro, con todos sus arcaísmos nobles y simpáticos, sólo se debe al amor profundo que los judíos sienten por su antigua patria, de la que guardan tradicionalmente mil recuerdos y leyendas, que les enorgullece y les cautiva. ${ }^{10}$

En algunos textos acaban convirtiéndose en parangón del patriotismo, ya que el suyo resistió a tantas pruebas:

España es la inmensa nostalgia de su vida, y quieren proclamar, con voz muy alta, que llevan sangre del raudal español. En sus negras pupilas lancinantes arden las lágrimas de su éxodo [...] ¡Oh, los nobles sefardíes que aman a España con lírico fervor y cálido entu-

8 Véanse por ejemplo Pedro Antonio de ALARCÓN, Diario de un testigo de la guerra de África (1860), 7a edición, Madrid, Est. Tip. Sucesores de Rivadeneyra, 1917, 2 T. Recuperado de internet (http://sirio.ua.es/libros/BEducacion/diario_guerra_de_africa_//index.htm y http://sirio.ua.es/libros/BEducacion/diario guerra de africa II/index.htm). Última consulta el 24/07/2013; Gaspar NÚÑEZ DE ARCE, Recuerdos de la campaña de África, Madrid, Imprenta a cargo de José M. Rosés, 1860. Recuperado de internet (http://www.cervantesvirtual.com/obra-visor/recuerdos-de-la-campana-de-africa--o/html/). Última consulta el 24/07/2013; Benito PÉREZ GALDÓS, Aita Tettauen (1905), Madrid, Alianza Editorial, 1989.

9 Por ejemplo: Isaac MUÑOZ, En el pais de los Cherifes, Madrid, Imprenta Helénica, 1913; Manuel L. ORTEGA, Los Hebreos en Marruecos.

10 Francisco de Asís CABRERA, "La acción de España: Los Hebreos", Revista de la Raza, 95 (1923), p. 23. siasmo, después de cuatro siglos de destierro, lo cual es propio de hombres iluminados por todos los fuegos patrios!"

Los testimonios de los propios sefardíes marroquies se sacan a colación para demostrar dicho patriotismo:

Los judíos de Marruecos, particularmente los de Tánger y Tetuán, sienten especial predilección por España, y cuanto a ella se refiere tiene interés directo para nosotros, lloramos sus desgracias, como nos regocijamos de sus triunfos, España es nuestra patria, esa tierra bendita donde descansan los restos de nuestros antepasados, y natural es que sintamos por ella cariño y veneración ${ }^{12}$.

El principal colaborador de Pulido, Manuel L. Ortega, llega a escribir que "es preciso que veamos en el sefardita a un español más, tan español como el que ha nacido en España, porque lleva el amor a la patria común en el corazón". ${ }^{3}$ Esta asimilación de los sefardies a los demás españoles pasa también por el recalcar su pertenencia étnica al pueblo ibérico: "Los sefardíes reúnen las características de la familia latina: viveza de entendimiento, facultad de asimilación fácil comprensión de las cosas e imaginación fecunda", 14 escribe Ortega. "Étnicamente, el sefardí del s. XX es un íbero; espiritualmente, no puede negar que es un latino", 15 añade Ignacio Bauer $y$ Landauer, presidente (jasquenazí!) de la comunidad judía madrileña. Se trata sobre todo de diferenciarlos de los demás judíos, los centroeuropeos, borrando en cierto modo sus características más hebraicas. Rodolfo Gil Benumeya escribe que "el judío adquirió en España lo que le faltaba: aristocracia. Gesto. Pompa. Aún hoy el hebreo-español se distingue de los otros hebreos por el empaque. Es un hebreo vertical. No es un hebreo diagonal, un hebreo de Ghetto".16

En cierto modo, lo que afirman los filosefardistas es que el judeoespañol es un judío mejorado gracias a su inmersión en la cultura peninsular que lo liberó de los lazos que lo tenían preso de una tradición religiosa rígida. Según ellos, la sangre hispánica ha hecho de los sefardíes una elite, cuando los asquenazíes constituyen la plebe del pueblo judío. Hasta en el mismo seno de la comunidad judía marroqui se encuentran esas diferencias, apuntadas por Pulido ya en 1905:

Ni los israelitas de la misma costa se consideran entre sí iguales; los de Tánger y Tetuán representan la aristocracia; forman lo más selecto, y constituyen una sociedad singularmente distinguida, así por su cultura, como por su posición y su influencia [...] Sin embargo, estiman como de superior condición a los comerciantes y a los que por sus viajes a Londres, París, Marsella, han endulzado sus costumbres, y han adquirido un barniz de instrucción que no es general entre sus correligionarios. ${ }^{17}$

Puede sorprender esta insistencia en diferenciar entre asquenazíes y sefardíes, pero se debe recordar el contexto de la época: en una España de la que desaparecieron físicamente los judíos desde hace más de cuatro siglos, el sentimiento antijudaico sigue muy presente, a través

11 Felipe VERDEJO IGLESIAS, “Los sefardíes añoran España en su destierro. Conducta que debe seguir España en Marruecos y en Oriente", Revista de la Raza, 162 (1929), p. 27.

12 Manuel L. ORTEGA, Los hebreos en Marruecos..., p. 222.

13 Ibid., p. 340.

14 lbid., p. 263.

15 Ignacio BAUER, "España y los sefardíes", en Ignacio BAUER, Problemas nacionales: por la grandeza de España, Madrid, Biblioteca hispano-marroquí, 1921, p. 28

16 Rodolfo GIL BENUMEYA, “Hacia un panorama sefardi”, La Gaceta Literaria, 67 (1929), p. 5.

17 Ángel PULIDO FERNÁNDEZ, Intereses nacionales. Españoles sin patria y la raza sefardí.., p. 161 
de manifestaciones culturales tan inocentes como los refranes, ${ }^{18}$ las procesiones de Semana Santa, ${ }^{19} \mathrm{O}$ las representaciones propaladas por la literatura..$^{20}$ Por lo tanto, si quieren convencer a sus coetáneos de la oportunidad de utilizar la presencia de judíos favorables a España para la llamada "penetración pacífica" de Marruecos, es para Pulido y sus seguidores absolutamente imprescindible convertirlos en figuras aceptables. Esa labor de modificación de las representaciones lleva a veces a los filosefardistas a caer en otros tópicos que hacen del sefardí un como ser superior, que se ha quedado lo mejor de lo hispano y de lo hebreo.

Otro argumento, tal vez de mayor peso aún, a favor de una recuperación de los sefardies del Protectorado por España es su posición en el sector económico y comercial de la región. En algunos textos se afirma que en todas la regiones donde vivan sefardíes, el idioma vernáculo para el comercio es el español. Es una oportunidad que no debe dejar de aprovechar la economía española, que podría establecer por este medio relaciones privilegiadas con los dueños de los distintos mercados. En una carta dirigida a Ángel Pulido escribe Pablo Vallescá, presidente de la Asociación Mercantil, Industrial y de Propietarios de Melilla:

En esta Plaza habita una colonia hebrea rica e importante compuesta de 1.300 individuos descendientes en su mayoría de los que fueron expulsados de nuestra Patria y que son los que sostienen en sí, exclusivamente, el comercio con el Imperio.

Por este motivo comprendemos la verdad que encierra su citada comunicación y cuan urgente es que el Gobierno y la opinión ilustrada se preocupen de una cuestión que puede ser de trascendentales consecuencias para la influencia de España en Marruecos. [...] Creo que convendría que nuestros Gobiernos se preocuparan de relacionarse con los judíos, porque el hebreo, por sus aptitudes especiales para el comercio, por la solidaridad que hay entre todos los de su raza, y por hallarse esparcidos por todo el Imperio, constituye un excelente medio de penetración pacífica en Marruecos. ${ }^{21}$

Ortega dedica un capítulo entero a los lazos económicos que se deben establecer entre España y Marruecos, puesto que considera que el mercado magrebí debe ser de España. Por eso cuando establece la lista de las acciones que España tiene que llevar a cabo de manera imprescindible en Marruecos, indica que es necesario

Impulsar las relaciones comerciales, organizando excursiones de comerciantes españoles a Marruecos y de comerciantes hebreos a España, creando asimismo exposiciones permanentes de productos españoles en las ciudades de Tánger, Tetuán, Larache, Melilla, Casablanca y Mogador. ${ }^{22}$

La necesidad que tiene España de los sefardies para ocupar un lugar en el comercio marroquí es pues evidente, y justifica hasta cierto punto las alabanzas que multiplican los filosefardistas para convencer a las elites españolas de pasar por encima de sus prejuicios religiosos y raciales por el bien de la economía patria.

18 Véanse el estudio realizado por Gonzalo ÁLVAREZ, EI Antisemitismo en España. La imagen del judio (1812-2002), Madrid, Marcial Pons Ediciones de Historia, 2002, pp.61-70.

19 Mercedes GARCía y Eva TOUBOUL, “En el patio de Caifás: la representación del judío en la saeta”, Revista de flamencología, 21 (2005), pp.31-53.

20 Véanse por ejemplo los capítulos dedicados al mellah tetuaní en Ernesto GIMÉNEZ, Notas marruecas de un soldado, (Madrid, 1923), Barcelona, Planeta, 1983, Ilenos de clichés conformes con las representaciones orientalizantes de los judíos desde la segunda mitad del $\mathrm{s}$. XIX.

21 Ángel PULIDO FERNÁNDEZ, Intereses nacionales. Españoles sin patria y la raza sefardí.., p. 505.

22 Manuel L. ORTEGA, Los hebreos en Marruecos..., p. 345

\section{Conquistar a los sefardíes}

Pero este último punto tiene su otra vertiente: que a pesar de las apariencias y del entusiasmo de los filosefardistas, también hace falta convencer a los judeoespañoles para que se adhieran al proyecto español. Se trata pues de galardonar su fidelidad y su apego a España, así como de consolidarlos:

Si sabemos seguir una política culta, inteligente, comprensiva y cariñosa, como la inició y desarrolló, en parte, la España de Felipe IV, con el inteligente Conde-Duque de Olivares, a buen seguro que en todo el Mogreb serán nuestros introductores y representantes, nuestros guías y nuestros mediadores de lengua con los musulmanes. ${ }^{23}$

Para lograrlo, se enfoca en dos ejes principales, la cuestión de la nacionalidad y la enseñan $z a$, que tiene que ver con el tema lingüístico. En ambos casos, la referencia a la política llevada a cabo por Francia en el norte de África es inevitable.

A pesar de que Pulido los designara tiempo antes como "españoles sin patria", en los principios del Protectorado los sefardies siguen siendo a lo sumo protegidos de la Corona española. Por eso cuando concluye Manuel L. Ortega su ensayo dedicado a los hebreos en Marruecos proponiendo lo que considera un programa mínimo de acción a favor de los judíos del Protectorado, encabeza la lista el

Promulgar una ley parecida a la que dictó en Francia para la Argelia el Ministro M. Crémieux el 24 de Octubre de 1870, concediendo la nacionalidad española, con todos los derechos civiles y políticos, a los israelitas residentes en el Marruecos español y en nuestras posesiones de África. ${ }^{24}$

Tal restauración de la nacionalidad española también permitiría, en cierto modo, compensar el Decreto de Expulsión de 1492 que oficialmente sigue vigente, pues nunca se abrogó. Sería una forma de reanudar con la historia interrumpida. Ésta es en efecto una de las mayores preocupaciones de los filosefardistas: borrar la mancha vergonzosa de la decisión de los Reyes Católicos, calificada como "decreto inicuo," ${ }_{25}$ "pecado", ${ }^{26}$ o deuda contractada con los hijos de Sefarad. ${ }^{27} \mathrm{Un}$ primer paso se da bajo el Directorio militar, con la promulgación, en diciembre de 1924, de un decreto destinado a facilitar la naturalización de aquéllos que puedan demostrar ser de origen español o sean protegidos de la Corona. ${ }^{28}$ Es notable el hecho de que el prólogo del Decreto evoca a los antiguos protegidos españoles y descendientes de familias españolas fincados "en las naciones de Oriente y en algunas del Continente americano", pero no de los sefardíes de Marruecos, lo que delata el poco caso que se les hace. Verdejo Iglesias, que vivió muchos años en Marruecos, relata a finales de los años 1920 que alli conoció a muchos sefardíes deseosos de nacionalizarse, pero impedidos por trabas burocráticas ${ }^{29}$ El entonces diplomático Agustín de Foxá, en un informe de 1932, detallará la cronología de la aplicación del decreto, confirmando que se frenaron de manera deliberada las peticiones de expedientes de naturalización para limitar el número de

23 Felipe VERDEJO IGLESIAS, “Los sefardies añoran España en su destierro...”, p. 25

24 Manuel L. ORTEGA, Los hebreos en Marruecos..., pp. 343-344.

25 lbid., p. 325

26 J.N., “Los hebreos en España”, Revista de la Raza, 121 (1925), p. 15.

27 Felipe VERDEJO IGLESIAS, “España hebrea”, Revista de la Raza, 175 (1930), p. 19

28 Real decreto del 20 de diciembre de 1924, Gaceta de Madrid, no 356 , 21/12/1924, pp. 1322-1323. Recuperado de internet (http://www.boe.es/datos/pdfs/BOE/1924/356/A01322-01323.pdf). Última consulta el 11/09/2013

29 Felipe VERDEJO IGLESIAS, “Los sefardíes añoran España en su destierro...”, pp. 24-26. 
documentos expedidos..$^{30}$ Lo que más temen los filosefardistas es que cansados de esperar que la antigua madre patria se digne a acercarse a ellos, los sefardies de Marruecos acaben mirando hacia Francia, mucho más acogedora como lo ha mostrado su política hacia los judíos de sus colonias y protectorados. La consecuencia sería una clara pérdida de oportunidades comerciales en la misma zona del Protectorado español.

Francia es la mayor obsesión de los españoles que se interesan por los judeoespañoles de Marruecos. En efecto, ven en ella una amenaza cultural con potenciales repercusiones económicas. Desde principios de los años 1860, la Alliance israélite universelle había desarrollado una red de centros escolares francohebraicos. Los fundadores de la AIU tenían como objetivo llevar la cultura y la educación occidental a sus correligionarios del Mediterráneo, a los que veían como bastante atrasados, en particular por su uso de lenguas vernáculas específicas, consideradas como meros dialectos. La gran obra, indudablemente, de las escuelas de la AlU fue hacer de sus alumnos perfectos francófonos, en una época en que el francés era el idioma de la cultura por antonomasia. Como lo señala el hebraísta José María Millás i Villacrosa en 1927,

Francia, hace ya algunos lustros que viene realizando una gran labor entre la población hebrea de Marruecos; en casi todas las ciudades importantes hay escuelas de la 'Alliance israélite universelle'. La juventud hebrea recibe en ellas una instrucción solidísima y a la francesa, que la hace apta para la vida internacional. ${ }^{31}$

La consecuencia es que a la hora de establecer relaciones comerciales con otro país, Francia aparece como interlocutor evidente. Ya en 1905 Pulido había dado el grito de alarma, al leer que la prensa francesa daba por descontada la adhesión de la comunidad judía al proyecto colonial francés, gracias a los lazos particulares que la AIU venía tejiendo con ellos. ${ }^{32}$ Pulido no pretendía luchar contra la Alianza, sino aprovechar su red, introduciendo en las escuelas profesores españoles pagados por la Corona, que irían recordando a los alumnos su hispanidad, devolviéndoles el orgullo por el idioma, y enseñándoles un castellano moderno que les permitiera desenvolverse en las relaciones comerciales con España y América Latina. ${ }^{33}$ En su libro de 1919, Ortega señala que se cumplió muy parcialmente la sugerencia de Pulido, con el envío de un profesor a cada una de las escuelas de la AIU de Tetuán y Larache, donde dan una hora diaria de clase en español, pero es todavía insuficiente:

Los esfuerzos patrióticos de estos beneméritos profesores no pueden vencer la influencia francesa. Los hebreos se educan y se instruyen en francés, aprendiendo a admirar y a respetar la gran nación transpirenaica desde sus primeros años. Sin la influencia del hoga donde se habla el castellano, y donde se conserva como algo sagrado el recuerdo de Castilla, pronto desaparecería nuestro idioma de entre los judíos marroquíes. ${ }^{34}$

En las siguientes páginas de su estudio, Ortega desarrolla dos líneas posibles de acción para España. Por una parte, proponer hacerse cargo de las escuelas que tiene la AlU en el Protectorado, desde el punto de vista tanto pedagógico como económico, lo que permitiría que la organización francesa desarrollara su labor educativa en otras regiones del mundo más

30 Agustín de FOXÁ, "Los Sefarditas de los Balkanes, Informe al Excmo. Ministro de Estado", Madrid, 18/10/1932, Archivo del Ministerio de Asuntos Exteriores, Sección de Europa, leg. R 698/1, pp. 36-37. 31 José María MILLÁs I VILLACROSA, "Los hebreos del Norte de África”, La Gaceta Literaria, 8 (1927), p. 3 .

32 Ángel PULIDO FERNÁNDEZ, Intereses nacionales. Españoles sin patria y la raza sefardí..., p. 166.

33 Ibid., pp. 493-494.

34 Manuel L. ORTEGA, Los hebreos en Marruecos..., p. 266 necesitadas; ${ }^{35}$ por otra parte, Ortega, inspirándose en el modelo de la Alliance, diseña un programa de funcionamiento muy detallado para unos centros hispanohebreos, que ofrecerían una instrucción tanto general como religiosa:

Los estudios religiosos, que para el buen hebreo son de máxima importancia, comprenderán, como hasta hoy, la lectura y escritura hebreas, Tefilá Parechá, etcétera, con el aumento de asignaturas que a continuación se expresan y con arreglo a la edad y capacidad de los escolares y a la clase y grupo a la que pertenezcan: Nebiim ketubim (Biblia) con notas y comentarios; Dinim, para lo cual puede servir de texto el Kitsur Shulján Aruj; Rashí y Targúm Unkelos para todo el Pentateuco (Los cinco libros de Moisés); Didkuk (Gramática hebraica). Conversación y lecturas selectas de autores antiguos y modernos; Historia elemental del pueblo judío. Para esta clase de estudios existen hoy numerosos y apropiados libros de texto y ejercicio, editados por las grandes casas editoriales de Rusia, y compuestos por los más renombrados pedagogos y escritores hebreos.

La enseñanza profana, o sea la de artes y ciencias, se regirá por un método especial, mixto de primera y segunda enseñanza. Las tres clases inferiores (niños de 5 a 11 años) se regirán por el plan de las escuelas primarias españolas. Estas clases estarán a cargo de un maestro nacional graduado, con auxiliares hebreos, hijos de la zona y ex-alumnos aventajados de la Alianza.

En las tres clases superiores (niños de 11 a 14 o 15 años) cursarán con libros de textos de los Institutos Generales y Técnicos las asignaturas siguientes: Gramática castellana, Retórica y poética, Geografía de España y universal, Aritmética y Algebra, Historia de España y universal, Gimnasia, Dibujo, y nociones de Física y Química. Estas cátedras podrán ser desempeñadas por dos o más licenciados en Letras o Ciencias, uno de los cuales, el de mayor graduación, ejercerá el cargo de director de la escuela. Los certificados de aprobado de las asignaturas tendrán validez académica en los Institutos de España para aquellos alumnos que quisieran continuar los estudios de bachillerato.

El idioma francés debe ser obligatorio. El inglés y el árabe lo enseñarán profesores hábiles, pero su aprendizaje será voluntario. ${ }^{36}$

En estas líneas el publicista muestra su voluntad de concebir un nuevo modelo educativo, que en realidad se distinguiría del de la Alliance, al otorgar un espacio mayor a lo confesional, que en las escuelas de la AIU se consideraba asignaturas segundarias. Otra particularidad es la composición del equipo docente, puesto que no se plantea emplear a autóctonos que tengan carrera para impartir las asignaturas profanas, ni se evoca la posibilidad de formarlos, cuando éste es uno de los mayores éxitos de la AIU, el haber impulsado la creación de una serie de éste es uno de los mayores éxitos de la AIU, el haber impulsado la creación de una serie de
maestros locales que tras haberse graduado en París volvían a su país a asumir la transmisión de la doble cultura francesa y judía que habían recibido como alumnos.

Por fin se puede notar un anhelo de modernismo al considerar la importancia de los idiomas: imponer el aprendizaje de la lengua francesa, en el contexto del Protectorado, parece lógico, y hasta imprescindible; ofrecer la posibilidad de estudiar inglés y árabe es tener en cuenta la realidad del país, en el que la mayoría de la población era de habla árabe (aunque aquí sería interesante saber a qué lengua árabe se refiere Ortega, si árabe dialectal o clásico), pero también un contexto internacional en el que paulatinamente el inglés se está convirtiendo en lingua franca imprescindible para los negocios.

35 Ibid., p. 267.

36 lbid., pp. 277-278. 
Si es cierto que en los años 1920 nacen escuelas hispanohebraicas, parece no haber sido en cantidad suficiente, porque cada vez que, en aquella época, se evoca en la prensa y los ensayos este tipo de establecimiento, es para denunciar la desidia del Estado a la hora de desarrollar una estructura que permita atraer hacia España a los sefardies marroquíes. ${ }^{37}$

\section{Un balance contrastado}

Las realizaciones concretas en los años que van de la creación del Protectorado a la Guerra civil española son escasas. Hace falta reconocer que, cuando se interesan por la temática sefardí, los políticos españoles miran mucho más hacia las comunidades establecidas en los países nacidos del despedazamiento del Imperio otomano que hacia Marruecos, por motivos ciertamente económicos, pero también de representación: a pesar de los esfuerzos por resaltar el hispanismo de los sefardies, queda cierto recelo por su parte judía. Además, como lo escribía el profesor Hassán en 2000 , pensaron que los sefardíes iban a comportarse como sujetos pasivos de los intereses de España, y no como sujetos activos de sus propios intereses ${ }^{38}$. Por su parte, los judeoespañoles de Marruecos anhelan una reconciliación con una España que ya no existe, la Sefarad medieval, y cuando miran hacia la Europa contemporánea, Francia es el objeto de su interés, por su peso en el escenario político internacional. En esto se puede decir que la campaña española de acercamiento a los sefardíes de Marruecos constituye un buen reflejo del funcionamiento, destinado al fracaso, del filosefardismo español, diálogo de sordos entre dos comunidades imaginarias.

37 Véase José María MILLÁS I VILLACROSA, "Los hebreos en el Norte de África”, La Gaceta Literaria, 8 (1927), p. 3; Emilio PORTILLO, "Recuerdos y esperanzas (con motivo de la inauguración de la Escuela Hispano-Hebrea de Larache)", Renacimiento de Israel, 205 (1932), pp. 7-8; "Es necesario atenderlos: Los sefardies de Melilla y la Enseñanza", Nuestra Raza, 126 (1935) [desde el número 124 de la revista, las páginas no llevan número].

8 lacob M. HASSÁN, “Realidad y fantasía en las relaciones recíprocas España-sefardíes”, en España y la cultura hispánica en el sureste europeo, Atenas, Ministerio de Asuntos Exteriores, 2000, p. 359. 
Parte 3.

ESPAÑA Y LA GUERRA

FRÍA CULTURAL 
La propuesta del taller «España y la guerra fría cultural», presentada en el marco del IV Congreso de Jóvenes Investigadores en la Historia Contemporánea, estaba motivada en la voluntad de sondear la tipología de temáticas y metodologías que actualmente están siendo abordadas, desde la colectividad de jóvenes investigadores, en el marco del amplio ámbito de la guerra fría cultural.

Durante los años cincuenta, la firma de diversos acuerdos con EE. UU. y el establecimiento en España de las bases militares estadounidenses contribuyeron a la política de sostén activo de la dictadura franquista por la gran democracia norteamericana. Sin embargo, es evidente que, la dictadura - una notoria anomalía en el contexto de la Europa occidental- no contaba con la simpatía de un notable sector de líderes políticos estadounidenses, más proclives a un sistema político homologable al de una democracia parlamentaria. Desde las postrimerías de dicha década y a lo largo de los años sesenta, se registró una creciente actividad de los grupos de oposición y, sobre todo, un claro auge de la influencia ejercida, en amplios sectores de la sociedad, por el Partido Comunista, al mismo tiempo que, entre ciertos grupos políticos y culturales vinculados al propio régimen, surgía la reivindicación de una paulatina apertura y modernización de España. Ante tal panorama, ciertas elites estadounidenses y sus aliados políticos en la Europa comunitaria entendieron que cabía tratar de ayudar a determinados grupos de la sociedad española, con vistas a contribuir, en perspectiva, a la estabilidad política grupos de la sociedad española, con vistas a contribuir, en perspectiva, a la estabilidad política
de la Península y, cuando fuese posible, a una transición lo más controlada y menos dramática posible. El camino consistía no únicamente en ofrecer preparación, relaciones y contactos a las elites políticas, intelectuales y culturales representativas de los opositores, sino, asimismo, a los sectores más avanzados del régimen. Simultáneamente a esta actuación entre las elites sociales, se impulsó igualmente la intervención en los ámbitos estratégicos de la organización de la acción colectiva, tales como el sector sindical o el estudiantil.

Desde hace años, se están llevando a cabo en España investigaciones sobre la diplomacia pública, los intercambios de líderes, y acerca de los programas oficiales de la propaganda estadounidense, así como sobre fenómenos como la americanización, o más ampliamente sobre los vínculos entre los procesos locales y los organismos o procesos internacionales. En este sentido, el artículo que firman Lorenzo Delgado y Pablo León Aguinaga en las Actas del Congreso de la Asociación de Historia Contemporánea, celebrado en septiembre de 2010, en la Universidad de Santander, que lleva por título «De la primacía estratégica a la difusión de modelo americano: Estados Unidos y la España del franquismo», constituye un importante recuento bibliográfico de los estudios sobre los diversos canales que cimentaron y definieron, durante los periodos considerados, las relaciones entre España y Estados Unidos.

Por el contrario, un repaso a la historiografía reciente evidencia que son muy notables aún las lagunas en lo referente a las relaciones hispano-rusas en el siglo XX, así como a la ofensiva propagandística o las campañas de influencia realizadas, en el interior y el exilio, por parte de la extinta Unión Soviética. Cabe indicar que no se trata tan solo de un problema de la historiografía española, sino de una característica general de los estudios internacionales sobre la guerra fría cultural, o la guerra fría ideológica, pues estos suelen priorizar, de forma muy desta(Caute, 2003 : bre la influencia comunista en amplios grupos de oposición parece constituir un lugar común entre los investigadores del antifranquismo, todavía hoy desconocemos la verdad contrastada acerca de su extensión real, en activos humanos y en dinero, y las características exactas de su acción directa hacia y entre los diferentes colectivos antifranquistas. Cabe añadir que las escasas aproximaciones al Movimiento por la Paz —eje principal de la campaña ideológica de influencia encubierta promovida por la URSS-, así como a la historia de la actuación política y cultural del Partido Comunista de España durante el franquismo, tanto desde el exilio como en el interior, revelan cierta persistencia en retratar dichos fenómenos desde el ángulo meramente nacional, sin tomar en cuenta los objetivos políticos de la URSS o las dinámicas cambiantes a escala internacional, que repercuten en los mensajes ideológicos y las políticas promovidos en el contexto local. Merece la pena recordar, por supuesto, que la opacidad de los archivos rusos o las dificultades en el acceso a los fondos particulares de los principales líderes intelectuales del PCE, representa un serio problema para llevar a término, en el momento presente, semejantes investigaciones.

Otro vacío, a nuestro entender, está constituido por la ausencia de consideración por la actual historiografía en referencia a España, de la acción encubierta, tanto estadounidense como soviética. La covert cold war fue realizada de forma subrepticia, movilizando a los particulares, los entes privados o los organismos locales e internacionales, y el único denominador común de todas aquellas iniciativas era que debían mostrarse, de cara al público externo, así como hacia sus propios integrantes, como completamente independientes de cualquier posible nexo con las estructuras de poder político de ambas potencias. Precisamente, el carácter no oficial de dichos vínculos y las características específicas de las acciones de influencia desplegadas hacia actores y entes, en principio, completamente independientes - personas, grupos, revis tas, editoriales, asociaciones, sindicatos, partidos políticos, etc. -, para influir en determinados objetivos políticos o ideológicos, hacen que dichas operaciones no oficiales fueran muy distintas de las acciones de la propaganda oficial, las relaciones en el seno de la diplomacia o de cualquier otro tipo de colaboración abierta, realizada con la presencia explícita, bien de la financiación gubernamental o particular (por ejemplo, de las fundaciones privadas norteamericanas), bien de las estructuras políticas de ambas potencias. En el caso concreto de España, la acción encubierta fue desarrollada entre la disidencia antifranquista, tanto en el interior de país como en el exilio, con la finalidad de abastecer de financiación y ayuda a diversos grupos afines ideológicamente o, simplemente, no antagonistas, para lograr determinados objetivos políticos, tanto en el propio escenario nacional como en el tablero internacional de la guerra fría (América Latina y el exilio republicano español).

Al lanzar nuestra propuesta de taller, entendíamos que era necesario encontrar un punto de encuentro para debatir las circunstancias, las motivaciones, los objetivos y los condicionantes, así como los resultados, a corto y largo plazo, de las campañas de influencia soviética y estadounidense en el transcurso de la guerra fría, realizadas con ayuda de individuos, grupos y organismos adscritos a un sinnúmero de actividades desarrolladas en todos los ámbitos de la cultura (o la civilización): artístico, intelectual, académico, estudiantil, de activistas de los derechos humanos, político, sindical, etc. Nuestra aspiración era lograr que los fenómenos producidos durante la posguerra en España, o en el ámbito del exilio de 1939, fueran considerados, durante el desarrollo del panel, en conexión con los fenómenos de orden internacional y dinámicas universales promovidos por ambas potencias y sus aliados internacionales, que actuaron siempre de acuerdo con sus prioridades particulares. Finalmente, la propuesta pretendía, asimismo, responder positivamente a la necesidad de incorporar la propia perspectiva 
de la guerra fría como herramienta de análisis e interpretación de las recientes producciones artística, literaria, o filosófica españolas.

En suma, la mesa-taller dedicada a la guerra fría cultural fue convocada con la voluntad de reforzar, en la historiografía española, un nuevo y estimulante territorio de investigación en el ámbito de los estudios históricos y culturales, cuyo fin es la incorporación activa de la perspectiva de la guerra fría ideológica e intelectual a las investigaciones sobre el franquismo, el antifranquismo y la transición.

$$
\cdots
$$

Pese a las evidentes limitaciones, trataré de resumir, a continuación, las aportaciones de los participantes de la mesa.

Abrió el panel la comunicación de la doctora Noemí de Haro García, investigadora Juan de la Cierva de la Universidad Autónoma de Madrid, presentada bajo el título «La imagen de España en la guerra fría: arte, oficialidad y disidencia». Comenzó con una reflexión acerca de la construcción estética de la propaganda vinculada a «lo nacional», por parte de los representantes de los campos rivales de los órganos franquistas; a saber, la oposición antifranquista y el exilio Aquella perspectiva le permitió echar luz sobre la pluralidad de los agentes culturales que se movían dentro de los parámetros bipolares de la guerra fría. Adentrándose en su especialidad, De Haro analizó el proceso a través del cual el realismo devino la estética antifranquista por antonomasia, en respuesta, precisamente, a la política cultural del régimen, que, durante años, había estado apoyando el informalismo estético. La conclusión del estudio afirma que los artistas antifranquistas lograron construir una comunidad dentro del movimiento socia antifranquista, capaz de imaginarse y reconocerse a sí misma, mediante su obra creativa. A este propósito, la autora señaló, de forma reveladora para los fines del panel, que el realismo antifranquista, como opción estética, ideológica o ética dentro de la cultura, habitualmente se viene estudiando tomando como paradigma tan solo su base nacional; lo que —advierte De Haro- no se corresponde con la realidad histórica, ni tampoco con las apreciaciones personales de los protagonistas de aquellos complejos procesos.

El siguiente en tomar la palabra fue el doctor Igor Contreras Zubillaga, de la École des Hautes Études Superieurs Socials de París, quien decidió la no inclusión de su contribución («El 1er Festival de Música de América y España (14-31 octubre 1964): música, política y diplomacia en la España franquista durante la guerra fría») - que tiene previsto aparecer como parte integrante de su tesis doctoral- en las Actas del Congreso. Su ponencia supuso una aportación sobre la música, el panhispanismo y el imperialismo español durante el franquismo, a la vez que evidenció la necesidad de ubicar la cultura de la disidencia antifranquista en su justo contexto franquista y de valorar críticamente la utilización, por parte de la dictadura, de los productos culturales antifranquistas. Desde la perspectiva de los objetivos del panel, es de destacar el apunte, trazado por el autor, sobre la complejidad —la pluralidad- del arte y la cultura creados bajo la presión de la guerra fría, así como de los aprovechamientos políticos de los creadores de la cultura.

Sobre el tema de la música y la propaganda franquista, y, más en concreto, acerca de la influencia del modelo musical norteamericano en el exitoso modelo de festivales celebrados en España, trataba la aportación del doctor Jesús Ferrer Cayón, procedente de la Universidad de Cantabria. En su comunicación — titulada «Del Hollywood Bowl a los Festivales de España: José Iturbi o Bienvenido Mister Marshall»-, el autor señalaba, con acierto, que «la cultura en su vertiente artístico-escénica (esencial a la hora de configurar la imagen de un pueblo)»), constituía con acusado protagonismo la estrategia legitimadora del régimen franquista más allá de sus fronteras. La música y los festivales que copiaban en España los grandes eventos musicales estadounidenses, así como los lazos establecidos en el terreno de las políticas cul- turales entre ambas sociedades, estaban destinados, por deseo expreso del régimen, a contrarrestar el aislamiento diplomático padecido por España y a tratar de consolidar su posición en el tablero internacional de la guerra fría.

Propuestas más analíticas fueron presentadas por dos doctorandas, María del Pilar Loranca de Castro, vinculada a la Universidad Autónoma de Madrid, y Eva Nieto McAvoy, vinculada al Birkbeck College de la Universidad de Londres. La aportación de la primera de ellas — «España y la guerra fría cultural: la influencia estadounidense en el cómic durante el franquismo»- se centró en estudiar la influencia de los EE. UU. en el cómic español durante la dictadura, analizando aspectos como su anticomunismo, su defensa del capitalismo y, en general, su American Way Life. El estudio introducía su tema destacando las características principales del cómic español en los años treinta y señalando la utilización política del tebeo durante la Guerra Civil. Pretendía, de este modo, llamar la atención sobre las motivaciones políticas e ideológicas en la influencia estadounidense en el cómic español, así como en los intereses del propio franquismo.

Por su parte, la contribución de Eva Nieto — «La tabernita de Frank: Arturo Barea y la guerra fría en la $\mathrm{BBC}$ - ponía de manifiesto la colaboración del relevante escritor exiliado español con las estructuras culturales participantes en la guerra fría cultural, como fue el caso de la BBC. Señalaba la adscripción ideológica del escritor al socialismo democrático "tercerista», que impulsaba una política de independencia frente a la política de los bloques. El texto considera los más de 850 guiones de programas de radio escritos por Barea y los interpreta en relación con los discursos de la propaganda británica en la Segunda Guerra Mundial y, más tarde en la guerra fría; es decir, «en el contexto de la estrategia general de la BBC de broadcasting britishness y selling democracy a través de su Servicio Mundial». A este propósito, cabe recordar que la «tercera fuerza» del socialismo británico representó en su día una alianza entre los miembros del Partido Laborista, los sindicatos e intelectuales de la izquierda. En las conclusiones del artículo, Nieto afirma que Arturo Barea contribuyó con sus creaciones a reforzar aquel mensaje político por considerarlo la opción política más acorde con su propio antifranquismo de cariz democrático y socialista.

Continuando con nuestro relato, sendas comunicaciones de dos investigadoras pioneras en el dominio de la amplia relación cultural y política sostenida por los españoles con la Rusia soviética, antes y después de la Guerra Civil, fueron presentadas por las doctoras Magdalena Garrido Caballero y Luiza lordache. La primera, profesora en la Universidad de Murcia, presentó el paper titulado "La propaganda soviética en el exterior», cuyo objetivo era exponer los medios a través de los cuales se proyectó la propaganda soviética en España y en Gran Bretaña, a la vez que destacar el papel desarrollado por el asociacionismo con la Unión Soviética en las relaciones Este-Oeste, en calidad de canalizador de las simpatías y la difusión de las directrices soviéticas y la propaganda favorable a su modelo en Europa Occidental. Concluía la comunicación aseverando que la cultura se utilizó como medio de aproximación y vehículo de propaganda política a favor del citado modelo soviético, fenómeno que debe ser analizado desde la perspectiva del asociacionismo internacional con organismos sostenidos por la Unión Soviética durante la Guerra Fría.

Por su parte, experta en el tema del Gulag, la doctora Luiza lordache, actualmente vinculada a la Universidad Internacional de Cataluña, presentó el artículo titulado «Los repatriados españoles de la URSS en el marco de la guerra fría: entre la DGS y la CIA (1956-1961)». En él, se aborda el caso de un grupo de españoles que, habiendo caído víctimas del Gulag, posteriormente fueron utilizados por la maquinaria de la propaganda franquista y, también, la norteamericana. Estas personas, reincorporadas a España a través de las repatriaciones oficiales sobrevenidas entre 1954 y 1959, fueron objeto de procesos de acoso policial, investigación y vigilancia, así como de interrogatorios por parte de las autoridades franquistas. Por su parte, de 1957 a 1960, la CIA desplegó, asimismo - revela lordache-, "un programa de interrogatorios por cuyo tamiz pasaron 1.800 repatriados y que tuvo como resultado más de 2.000 informes 
positivos en inteligencia. La operación del organismo, que se centró en campos prioritarios como la producción armamentística y el potencial militar la URSS, representó un avance en los conocimientos sobre el conjunto del sistema soviético en el marco de la guerra fría".

Finalmente, dos comunicaciones de los doctores Antonio Muñoz Sánchez y Francisco Javier Rodríguez Jiménez nos aproximaron, respectivamente, a las relaciones de carácter internacional sostenidas por agrupaciones políticas y sindicatos españoles con organismos homónimos o amistosos del exterior. Actualmente investigador Marie Curie en la Universidad de Lisboa, en su contribución titulada «Preparando el camino a la democracia: las relaciones de la socialdemocracia alemana y el antifranquismo», Muñoz Sánchez explora los contactos del Partido Socialdemócrata de Alemania (SPD) y los sindicatos alemanes con el socialismo español, durante el primer lustro de los sesenta, establecidos con vistas a forjar una auténtica estrategia de relaciones, diferente a la que, hasta entonces, habían sostenido la Internacional Socialista (IS) y la Confederación Internacional de Organizaciones Sindicales Libres (CIOSL). Al hilo de una lectura crítica de la posición mantenida por los representantes políticos del exilio socialista, la aportación del doctor Muñoz Sánchez valora positivamente las relaciones mantenidas entre el SPD y los socialistas españoles del interior; en concreto, Enrique Tierno Galván. Se señalan, igualmente, los contactos realizados con algunos organismos del exilio, como el Centro de Documentación y Estudios, dirigido por Julián Gorkin, a fin de llevar a cabo un acercamiento constructivo a los grupos de la oposición e identificar políticas comunes. La comunicación planteó, en definitiva, el problema - ciertamente complejo- de los canales de la actuación, desde el exterior, hacia los grupos opositores en una dictadura, así como de las inevitables resistencias que tales políticas podían provocar.

Por su parte, Francisco Javier Rodríguez, investigador Juan de la Cierva de la Universidad de Salamanca, presentó la comunicación titulada "¿"Otro tentáculo más del Imperio Yanqui". Sindicatos estadounidenses y españoles durante el franquismo". Dedicada a las relaciones de la poderosa central sindical americana, AFL-CIO, con los sindicatos españoles, tanto los clandestinos como el vertical, vinculado al régimen franquista, el autor destaca en su contribución que la crítica ejercida al franquismo por el AFL-CIO constituye una prueba que desacreditaría las visiones, «un tanto maniqueas», de la guerra fría en las que se define a los sindicatos estadounidenses como otro «tentáculo más del Imperio Americano». A este respecto, se llama la atención sobre el hecho de que los sindicalistas norteamericanos rechazaban los cantos de sirena del franquismo, así como la propia política del Gobierno norteamericano hacia España, lo que, según Rodríguez Jiménez, no permite interpretarlos como instrumentos de su «imperio». Con la progresiva desaparición de cierta empatía hacia los republicanos exiliados a raíz de la guerra civil, y a causa del distanciamiento temporal, se produjeron rupturas entre los líderes sindicales estadounidenses de sus contrapartes en el exilio y su acercamiento progresivo, y fecundo, a los agentes sindicales en el interior.

Durante la introducción al debate posterior - excesivamente corto, pese a los esfuerzos de la coordinación-, se puso de relieve que las aportaciones, tal como hemos podido comprobar, se refieren a temas muy diversos, tratados, además, desde distintos enfoques. Por dicha razón, nos pareció preciso llamar la atención sobre la necesidad de centrar la definición de varios conceptos que merecen ser incorporados a nuestras investigaciones. En este sentido, se destacó la conveniencia de diferenciar la propaganda institucionalista - llevada a cabo a través de los canales de la llamada «diplomacia pública»-, así como las acciones de influencia realizadas por diferentes programas gubernamentales, de los programas y acciones independientes (de orientación cultural, ideológica o política), realizados por entes privados como, por ejemplo, fundaciones o asociaciones, cuyas agendas y modo de funcionamiento no estaban supeditados al Gobierno nacional.

Se señaló que, al margen de estas dos categorías que, inevitablemente, pecan de cierto esquematismo - la gubernamental u oficial, y la particular o privada-, existe el ámbito vincu- lado a la, ya mencionada, acción encubierta. La financiación encubierta fue otorgada de forma inoficial, en el caso estadounidense, por la CIA, al margen de las estructuras democráticamen te elegidas del país norteamericano (como el Congreso) mientras que, en el caso soviético, se hacía lo propio mediante el Kominform, y después de su disolución, en 1956, a través de los partidos comunistas nacionales, presentes y activos en los distintos países del mundo. De esta manera, la acción encubierta posibilitó una actuación discreta entre los grupos que constituian su objetivo, gracias a las diversas conexiones no oficiales - personales, logísticas, financierasexistentes entre las estructuras políticas y las empresas culturales, fundaciones, asociaciones, sindicatos, agrupaciones políticas, etc. que actuaban en el seno de las comunidades locales 0 internacionales. Cabe puntualizar aquí que el vínculo financiero no implicaba automáticamente, al menos en el caso estadounidense, la supeditación acrítica de la propia agenda de muchos de esos organismos a alguna determinada política del Gobierno nacional, aunque podían registrarse, a menudo, muchas coincidencias. En el caso soviético, los márgenes de la libertad eran, posiblemente, menos amplios - a causa del carácter vertical de su organigrama político y la represión política ejercida en el interior-y la pluralidad de posturas y de agendas, muy limitada, entre otros motivos por la inexistencia de conceptos como lo "particular» o lo "privado" en la realidad social y cultural del antiguo imperio del Este. Esto ayudaría a explicar se hace plausible aventurar tal hipótesis que la comunidad científica internacional haya otorgado un interés notablemente menor a la guerra fría soviética y a los productos políticos o culturales derivados de ella, que a la guerra fría y los productos de su homólogo estadounidense. Pese a todo, es indudable que en ambos casos dichas interdependencias, límites y roces entre las agendas estatales y las particulares, que confluían en las iniciativas y las operaciones no oficiales, exigen ser analizados con toda cautela, teniendo en cuenta, entre otros numerosos factores, los variantes contextos ideológicos por los que discurrió la guerra fría.

En el debate surgido, se señaló también la necesidad de considerar siempre la pluralidad de las manifestaciones culturales o políticas producidas bajo la dualidad artificial de la guerra fría y, en consecuencia, hablar de las culturas y no de una única cultura de la guerra fría. Precisamente a causa de que las dos máximas potencias se mostraron capaces de articular y movilizar alrededor de sus objetivos - calculados tanto a corto como a largo plazo-, a las elites internacionales y a tantos sujetos particulares pertenecientes a todos los países de la posguerra, merece la pena considerar la guerra fría como un conflicto sentido y espontáneamente comprendido como propio por todos los que, de una u otra manera, participaron en ella. De esta manera poco conflictiva, las luchas particulares y las agendas privadas resultaran coincidentes, en muchas ocasiones, con los intereses de las superpotencias.

Otro punto que se destacó que conviene tener presente al abordar el ámbito de la guerra fría cultural, versó sobre las características de los destinatarios de las diferentes acciones; es decir, de los llamados grupos-objetivo. Así, el que algunos organismos que recibían financiación encubierta por la CIA - los sindicatos norteamericanos o el Congreso por la Libertad de la Cultura, por ejemplo- fueran críticos con su Gobierno, no quiere decir que no realizaran una tarea muy útil para su país dentro de la guerra fría. La cuestión es que su tarea estaba pensada de una manera radicalmente original, puesto que - destinada a sectores netamente de izquierdas- era tan solo mostrándose críticos con ciertos aspectos de la política exterio de Washington, sobre todo durante las presidencias republicanas, que sus acciones podian ganar confianza y peso en sus destinatarios auténticos, sobre todo en los llamados países de tercer mundo. Precisamente, debido a que, muy pronto, se revelaron las limitaciones de una propaganda gubernamental u oficial «que, por sí sola, era incapaz de modificar las actitudes de la gente cuando estas se basaban en realidades políticas evidentes" (Niño, 2012: 132) - he cho que, en tantos lugares del mundo, había dado pie a un acentuado antiamericanismo en los sectores de la izquierda-, había devenido imprescindible poner en marcha una ofensiva ideológica radicalmente diferente, en la que una cierta crítica al Gobierno norteamericano era 
bien vista, y hasta deseada, puesto que contribuía a un trabajo eficaz entre los sectores de la izquierda internacional.

Evidentemente, al margen de las preocupaciones metodológicas, surgió entre todos los asistentes el problema de la falta de acceso a archivos o fuentes de financiación estables para llevar a cabo las investigaciones enmarcadas en el campo de la guerra fría cultural, ideológica o política. Como es sabido, en España, el problema del acceso a los archivos presenta más dificultades que en otros países, porque la gestión transparente del material documental en nuestro país revela un serio atraso con respecto a otros países de Europa, acompañado, con frecuencia, del desdeñoso silencio administrativo ejercido hacia la comunidad científica.

Una vez concluido el encuentro, creemos sinceramente que este seminario-taller ha supuesto la aportación de nuevos documentos procedentes de archivos nacionales e internacionales, a la vez que ha permitido la confluencia de diversas temáticas con el común denominador de conflicto internacional de la guerra fría. En suma, ha comportado un nuevo paso en la tarea de consolidación, en el ámbito español, de nuevas líneas de investigación de un tema caracterizado por una notoria complejidad. El principal logro de la mesa fue discutir, entre todos, nuevos marcos de metodología y análisis, a partir de los trabajos presentados, donde aparecen muy equilibrados - y es muy positivo, a nuestro entender- el elemento descriptivo, de análisis de la documentación histórica, con el elemento interpretativo, que utiliza nuevas ópticas (transversalidad, fenómenos trasnacionales...). Se destacó que la pluralidad de los fenómenos que engloba la categoría guerra fría cultural o guerra fría ideológica exige considerar asimismo la pluralidad de las culturas e ideologías manifestadas durante dicho periodo. Además, sería ineludible una adecuada acotación de conceptos que sostienen nuestro aparato crítico, y, a este propósito, los investigadores pueden echar mano de los términos acuñados por expertos internacionales, sobre todo del ámbito anglosajón. Por poner un ejemplo concreto, "State-Private Network", una útil expresión acuñada por Scott Lucas (Scott Lucas, 1999) para denominar a las redes estatales-particulares de la guerra fría, permite diseccionar la "libre" convergencia de intereses detrás de los valores imperantes en la posguerra, así como a los objetivos y las motivaciones tanto de los grupos particulares como los de las potencias. Llegados a este punto, es ineludible señalar que, a pesar de esa necesidad evidente de incorporación progresiva de trabajos extranjeros a nuestra propia historiografía, los investigadores padecemos aún una acentuada ausencia, en las bibliotecas españolas, de la bibliografía internacional especializada en el ámbito que nos ocupa.

Desde la coordinación del encuentro, esperamos que nuestra propuesta del taller haya servido, siquiera en un pequeño grado, para seguir con los insustituibles contactos académicos, diálogos y debates para asentar la disciplina en España. En nuestra opinión, se hace imprescindible, en particular, superar tales consideraciones de la guerra fría cultural o ideológica que cindible, en particular, superar tales consideraciones de la guerra fría cultural o ideológica que do a la realidad del período, contemplar las formas mediante las que el propio Estado - sus objetivos, prioridades, exigencias...- había llegado a incorporarse a los mundos interiores de los sujetos privados, de forma, aparentemente, natural y fluida. Tal como lo hacían los ensayos reunidos en el volumen colectivo, The US Government, Citizen Groups and the Cold War de Helen Laville y Hugh Wilford, consideramos muy enriquecedor ir más allá de las interpretaciones de la guerra fría centradas en los Estados ('top-down' interpretations), y, por el contrario, explorar el compromiso y la movilización de grupos e individuos independientes, con vistas a proporcionar, de esta forma, un original enfoque en el estudio de las relaciones internacionales. Tal óptica considera como muy importante superar la perspectiva bilateral, o polarizada, de las relaciones plasmadas durante la posguerra y abrir un horizonte de mucha mayor complejidad, con atención dispensada a los grupos participantes, canales, objetivos y fines, as como también, a las negociaciones de las distintas agendas. Como natural consecuencia de tal comprensión de la guerra fría, la aprehenderemos, más que como un conflicto militar en potencia, en su calidad esencial de un inédito enfrentamiento entre valores profundos y modelos de civilización alternativos, con sus consiguientes retóricas e imaginarios. En tal consideración, a nuestro parecer, deberían incorporarse todas las disciplinas humanistas, llamadas a colaborar en ofrecer una verdad sobre la realidad pasada que se escapa a los mecanismos de las macropolíticas y que propone una reflexión sobre los casos particulares o marginales, que, queriéndolo o no, sostienen las realidades hegemónicas.

Terminemos señalando que, pese a los esfuerzos, el desarrollo de esa nueva disciplina en España se ve lastrada por dos problemas presentes en la universidad española. Al margen de la evidente precariedad en la que se insertan los esfuerzos de los investigadores de la guerra fría cultural y la guerra fría ideológica, uno de los principales problemas a los que nos enfrentamos es que las universidades españolas siguen apostando por centros de estudios que reúnen expertos de una sola disciplina. Cabe destacar, a este respecto, que este nuevo ámbito de estudios exigiría exceder el mero trabajo con las fuentes y abordar interrogantes sobre los marcos de interpretación o límites epistemológicos, con lo que la colaboración de otras disciplinas, como la filosofía, las ciencias políticas o la filología (esta última por su acceso crítico al lenguaje y al discurso ideológico) podría resultar muy enriquecedora. Sin embargo, queda patente que la transversalidad que debería, en nuestra opinión, imperar en la praxis cotidiana de las ciencias humanas y sociales, no halla trasposición al exterior en las propias estructuras universitarias. El aislamiento actual entre las diversas disciplinas es patente y son muy escasos, en nuestro país, los centros donde libremente puedan confluir debates acerca de las distintas aproximaciones metodológicas o enfoques complementarios, o siquiera la mera transferencia de conocimientos entre las diversas disciplinas de humanidades.

\section{Bibliografía}

CAUTE, David, «Foreword» en: Scott-Smith, Giles; Krabbendam, Hans (ed.), The Cultural Cold War in Western Europe 1945-1960, London; Portland (Oregon), Frank Cass, 2003, pp. VII-IX.

DELGADO, Lorenzo; León Aguinaga, Pablo: «De la primacía estratégica a la difusión del modelo americano: Estados Unidos y la España del franquismo", en Nuevos horizontes del pasado: culturas politicas, identidades y formas de representación, ed. de Á. Barrio Alonso, J. de Hoyos Puente, R. Saavedra Arias; Santander, Publican, 2011, pp. 171-185.

LAVILLE, Helen; WILFORD, Hugh (ed.), The US Government, Citizen Groups and the Cold War, London; New York, Routledge, 2006.

Lucas, Lucas, Freedom's War: The American Crusade against the Soviet Union, New York, New York University Press, 1999.

NIÑO, Antonio, La americanización de España. Madrid, Libros de Catarata, 2012. 


\section{LA IMAGEN DE ESPAÑA EN LA GUERRA FRÍA}

\section{ARTE, OFICIALIDAD Y DISIDENCIA}

Noemi de Haro García

Universidad Autónoma de Madrid

¿Qué impacto tuvo la incorporación de la España franquista a las dinámicas de la Guerra Fría?, ¿cómo afectó esto al campo del arte?

En este artículo analizaremos algunas de las transformaciones que se produjeron en el mundo artístico de finales de los años cincuenta y los años sesenta en relación con la Guerra Fría cultural. Concretamente cómo éstas afectaron al modo en el que se habían seleccionado y expuesto hasta entonces las características del arte en relación con la definición de una identidad nacional. Para ello no nos ocuparemos solamente del caso de las manifestaciones artísticas apoyadas por el régimen sino también de ejemplos correspondientes a aquellas que suponían propuestas plásticas opuestas a la hegemónica.

Aunque no es extraño encontrar referencias al contexto de la Guerra Fría en la bibliografía que trata el arte del periodo, la Historia del Arte que se ocupa de estas cuestiones se centra sobre todo en el apoyo oficial recibido por el arte informalista y los premios internacionales obtenidos gracias a ello.' Por otra parte, si bien algunos estudios de la política artística del franquismo en esos años hacen mención, por ejemplo, a las políticas culturales promovidas por Estados Unidos durante la Guerra Fría y parecen indicar un cierto paralelismo con lo que sucedía en España, ${ }^{3}$ rara vez se estudia el lugar ocupado por la España franquista en dichas políticas. ${ }^{4}$ Finalmente, resulta igualmente infrecuente encontrar análisis de la labor de los artistas antifranquistas que tengan en cuenta su participación en dinámicas internacionales. De esta manera su trabajo y su posición se suele presentar como una mera respuesta al franquismo y a lo que sucedía dentro del país. 5

1 Este trabajo se ha realizado gracias a un contrato postdoctoral "Juan de la Cierva" y se enmarca dentro del proyecto de investigación HAR2012-32609.

2 En este sentido véanse las publicaciones de Julián DíAZ SÁNCHEZ: La idea de arte abstracto en la España de Franco, Madrid, Cátedra, 2013; ÍD.: El triunfo del informalismo: Ia consideración de la pintura abstracta en la época de Franco, Madrid, Metáforas del Movimiento Moderno, 2000; ID.:"Al calor de la Guerra Fría. Opciones del arte español en la posguerra europea", en Serge GUILBAUT (comisario): Bajo la bomba. El jazz de la guerra de imágenes transatlántica: 1946-1956, Barcelona, Madrid, MACBA, MNCARS, 2007; ID.: "El arte y la crítica. Estrategias de modernidad en España en los años 50 ", Revista de historiografia, 13, 2010, pp. 56-65; Jorge Luis MARZO: :Puedo hablarle con libertad, excelencia? Arte y poder en España desde 1950, Murcia, CENDEAC, 2009; íD.: Arte moderno y franquismo. Los origenes conservadores de la vanguardia y de la politica artistica en España, 2006, http://www.soymenos.net/arte_franquismo.pdf; Genoveva TUSELL:"La internacionalización del arte abstracto español: el intercambio de exposiciones con los Estados Unidos (1950-1964)", Espacio, Tiempo y Forma, 16 (2003), pp. 223-232; ÍD.:"The Internationalisation of Spanish Abstract Art (1950-62)", Third Text, $20: 2$ (2006), pp. 241-249.

3 Es el caso de trabajos como el de Julián DÍAZ SÁNCHEZ: La idea de arte abstracto.

4 Una aproximación al estudio de la relación entre la política artística franquista y la política artística internacional estadounidense implementada durante la Guerra Fría en Europa se encuentra en Noemi DE HARO GARCÍA: "Culture Will Set You Free: Art and Politics in Cold War Spain (1951-1964)", Konsthistorisk tidskrift / Journal of Art History, 82:4 (2013), pp. 287-303.

5 Aquellos casos en que los agentes implicados entablaban conversaciones y debates cuyo escenario
La relación entre la producción plástica y la identidad nacional no es una preocupación nueva en la Historia del Arte. Está íntimamente relacionada con la trayectoria del nacionalismo español cuyos inicios se sitúan, como mínimo, en el siglo XIX. En el caso de la pintura esta identidad nacional se ha identificado habitualmente con una nómina de grandes genios patrios (con Velázquez y Goya a la cabeza, y Picasso como la última de sus grandes figuras) y con determinadas características estéticas entendidas en un sentido amplio. ${ }^{6}$ Álvarez Junco ha explicado cómo a raíz de la pérdida de las colonias españolas en Cuba en 1898 (el conocido "Desastre del 98") las acciones encaminadas a la "nacionalización de las masas" recibieron un fuerte impulso materializado no sólo por el uso de símbolos, días festivos y conmemoraciones sino, sobre todo, a través de una política educativa a través de la que difundir la "tradición" española. Los intelectuales de la Generación del 98 y los regeneracionistas reclamaban una "regeneración patria", aunque sus propuestas para llevarla a cabo eran divergentes puesto que respondian a la diversidad de sus ideas políticas.?

Los intelectuales de la Generación del 98 habían encontrado la imagen de la personalidad española en el arte y la literatura. En el caso de las artes plásticas se daba especial importancia al paisaje castellano que se consideraba la más genuina expresión del carácter español. En esos años se reivindicó el estudio de la pintura clásica y se publicaron numerosos libros sobre artistas como Goya, Ribera, Velázquez o El Greco, ${ }^{8}$ pintores todos ellos que fueron considerados como modelo por los artistas junto con otros como Solana, Valdés Leal, Alenza o Regoyos. ${ }^{9}$ Las mismas figuras históricas aparecían tanto en los manuales educativos de corte más progresista y laico como en los católicos, si bien cada uno estaba orientado de un modo diferente destacando de cada figura los rasgos que mejor sintonizaban con cada posición. ${ }^{\circ}$ De la tradición existente bebieron las iniciativas culturales republicanas encaminadas a cohesionar al país" si bien, según Carolyn P. Boyd, los republicanos no habrían tenido éxito en su proyecto y no lograron crear un sentimiento de historia compartida que permitiera construi una base sólida para el proyecto republicano. En su análisis Boyd concluye que la comunidad imaginada creada por los republicanos con estas iniciativas culturales iba más allá de lo nacionalista puesto que se trataba de una comunidad de republicanos ${ }^{12}$ cuyos horizontes habría que entender que estaban situados en un marco internacional.

Durante la Guerra Civil tanto los sublevados como los republicanos se presentaron como defensores de la identidad nacional. ${ }^{33} \mathrm{En}$ ambos casos se emplearon las imágenes para construir la identidad propia como "española" y la del contrario como la de un "otro" extranjero tanto si

físico no era (sólo) España son una notable (y significativa) excepción en relación con esto. Es el caso de la conocida polémica entre Josep Renau y Franciso Claudín en relación con el realismo. Véase Mónica NÚÑEZ LAISECA: "El realismo español fuera de España, transmisión y lectura de una identidad estética durante la guerra fría", y Julián DíAZ SÁNCHEZ: "Una polémica (frustrada) de partido", ambos en Miguel CABAÑAS BRAVO (coord.): El arte español fuera de España, Madrid, CSIC, 2003.

6 Sobre la definición y categorización del concepto de pintura española véase Javier PORTÚS PÉREZ El concepto de Pintura Española. Historia de un problema, Madrid, Verbum, 2012.

7 José Álvarez JUNCO: Mater dolorosa, Madrid, Taurus, 2001, pp. 584-594.

8 María del Carmen PENA: Pintura de paisaje e ideología. La generación del 98, Madrid, Taurus, 1983, p. 45

9 José Luis BERNAL MUÑOZ: Arte y literatura en la Edad de Plata. La mirada del 98, Madrid, Ministerio de Educación y Cultura, 1998, p. 286

10 Algunos ejemplos de ello en Carolyn P. BOYD: Historia patria: politics, history and national identity in Spain, 1875-1975, Princeton, Princeton University Press, 1997, p. 226.

11 Un análisis de las mismas en Sandie E. HOLGUIN: Creating Spaniards: Culture and National Identity in Republican Spain, Wisconsin, University of Wisconsin Press, 2002.

12 Carolyn P. BOYD: Historia Patria..., p. 231.

13 Un análisis de esto se encuentra en Xose Manoel NÚÑEZ SEIXAS: iFuera el invasor! Nacionalismos y movilización bélica durante la guerra civil, Madrid, Marcial Pons, 2006. 
se lo veía sujeto a las órdenes del fascismo y el nazismo, como si se entendía que formaba parte de la conjura judeo-masónica orquestada por Moscú. Como recuerda Núñez Seixas, a diferencia de lo que ocurrió en el bando sublevado, en el bando republicano el nacionalismo fue un argumento legitimador pero no el único ni el principal. ${ }^{14}$ Esto vendría a confirmar en cierto sentido las ideas de Boyd. Sin embargo, Núñez Seixas también se refiere al efecto "(re)nacionalizador" de la guerra. Esto habría sido asi no simplemente a causa del bombardeo constante de propaganda en la cual se definía a la guerra como "nacional", sino porque se presentaba una imagen del "otro" (siempre definido como enemigo y extranjero) construida sobre modelos previos que, no obstante y precisamente a causa de la guerra, se hacían más verosímiles. ${ }^{15} \mathrm{Habrí}$ que entender que este efecto renacionalizador de la guerra, que contribuía a hacer más real y presente la tradición inventada que sustentaba el discurso nacionalista español, se habría producido tanto en el caso de los republicanos como en el de los sublevados.

Después de la guerra definir el sentido de la nación fue un elemento central para legitimar el poder del dictador. El franquismo recurrió a destacadas figuras y símbolos de dicha tradición nacional para construir su imagen ${ }^{16}$ además de buscar e incorporar elementos nuevos con esta misma intención. Por su parte los "vencidos" también se definieron en términos nacionalistas y se volvieron hacia elementos de la tradición construida anteriormente (que había sido reforzada durante la guerra) para hacerlo. En muchos casos unos y otros se referían a las mismas figuras históricas (por ejemplo, en el caso de las artes plásticas, todos ellos tenían a Velázquez y a Goya como modelos) sin bien muchas veces las interpretaban en sentidos muy distintos.

Además de por medio de la violencia que no dejó jamás de ejercerse para imponer el orden dictatorial, el franquismo se mantuvo gracias al equilibro que logró mantener entre los distintos grupos de poder existentes (a los que la historiografía se refiere frecuentemente como las "familias"). De hecho, esto se había tenido que hacer ya durante la guerra: Miriam Basilio ha estudiado cómo el bando insurgente se valió de imágenes que combinaran las tradiciones visuales de las distintas facciones conservadoras que lo componían para construir una identidad común bajo el mando de Franco. ${ }^{7}$ Gracias a la cultura y a las imágenes, era posible transmitir un sentido de la nación que era fundamental para legitimar a la dictadura y que también tuvo que ir cambiando para mantenerse a lo largo del tiempo.

Los investigadores se han referido a esta capacidad de transformación tanto en relación con el primer franquismo como con los últimos años de la dictadura. En un caso esto se ha interpretado esto en clave gramsciana, refiriéndose a la capacidad del franquismo para mantener una hegemonía cultural en la que era fundamental negociar entre formas culturales heterogéneas, ${ }^{1}$ en otro se ha llegado a hablar de un régimen político "cyborg" caracterizado por le hecho de que al mismo tiempo que preconizaba una ideología nacionalista y orgánica, a partir de mediados del siglo XX (cuando se produjeron la apertura de la dictadura al exterior y la modernización del régimen) buscaba e incorporaba avances tecnológicos que asegurasen su propia supervivencia. ${ }^{19}$

14 lbid., p.431.

5 Ibid., p.431.

16 Sobre la construcción de este universo simbólico en los primeros años de la posguerra véase Ángel LLORENTE HERNÁNDEZ: Arte e ideología en el franquismo (1936-1951), Madrid, Visor, 1995; Vicente SÁNCHEZ BIOSCA (coord.): Materiales para una iconografía de Francisco Franco, Archivos de la Filmoteca n $42-43$, octubre 2002-febrero 2003; Zira BOX: España, año cero: la construcción simbólica del franquismo, Madrid, Alianza, 2010; Dacia VIEJO-ROSE: Reconstructing Spain. Cultural Heritage and Memory after Civil War, Brighton, Portland, Toronto, Sussex Academic Press, 2011.

17 Miriam BASILIO: “Genealogies for a New State: Painting and Propaganda in Franco's Spain, 19361940", Discourse, 24:3 (2002), pp. 67-94.

18 Jo LABANYI: “The Early Francoist Folkloric Film Musical", en Jo LABANYI (ed.): Constructing Identity in Contemporary Spain, Oxford, Oxford University Press, 2000, p. 220.

19 Francisco LARUBIA-PRADO: "Franco as Cyborg: 'The body Re-formed by Politics: Part Flesh, Part
En todo caso, parece claro que fue su capacidad para transformarse, negociar e integrar la diversidad de la realidad en la que se encontraba en un todo que pretendía ser unitario y orgánico lo que permitió la supervivencia de la dictadura franquista. Cuando se firmaron los acuerdos con Estados Unidos y el Vaticano en 1953 se estaban también anudando unas relaciones que situaban a España en el bloque occidental de la Guerra Fría. Esto llevaba aparejada una escala de valores que presentaba coincidencias pero también diferencias con la que hasta entonces había privilegiado el régimen. Al igual que la firma de los pactos había exigido una larga preparación antes de poder ser una realidad, los cambios en la escala de valores se habían iniciado tiempo atrás.

En lo que se refiere al campo plástico el régimen empezó a dar voz poco a poco a aquellos que, dando una vuelta de tuerca a la definición de las características del "arte español", hacían posible el diálogo entre los valores tradicionales (y muy españoles) anteriores y otros que tenían mucho que ver con los que se apoyaban en el campo del arte estadounidense donde se señalaba a la abstracción del expresionismo abstracto como la nueva vanguardia. De esta manera no se renunció a las líneas principales de la definición del arte español, sino que éstas fueron actualizadas para que respondieran a las necesidades de los nuevos tiempos, respaldando el rumbo artístico oficial. Se trataba de hacer ver que la abstracción practicada por los pintores españoles se insertaba de un modo coherente en el relato existente de la Historia del Arte español y que por tanto no suponía el rechazo de los valores "españoles" ni podía interpretarse como una opción que rompiera con la tradición. Es más, gracias a estas transformaciones en el campo artístico la abstracción informalista aparecía como la verdadera recuperadora de la mejor tradición artística hispánica.

El apoyo oficial recibido por esta posición de artistas y críticos abiertos a la abstracción implicaba también que fueran perdiendo voz y poder el grupo y las ideas que hasta entonces habían definido las líneas de actuación oficiales en el campo artístico dentro de las cuales no había lugar para la estética abstracta. Las voces de protesta de algunos componentes de este grupo se pueden escuchar, por ejemplo, en la conocida polémica que acompañó a la organización y celebración de la I Bienal Hispanoamericana de Arte. Éstos interpretaban lo sucedido en la clave de los antiguos valores que identificaban al arte abstracto con el "otro" republicano, extranjero y anti-español. ${ }^{20}$

Las respuestas a las acusaciones, por su parte, dejaban claras al menos tres cosas: que sola mente se trataba de la habitual pugna entre académicos y jóvenes renovadores, que la clave de lectura del enfrentamiento había de evitar lo extraartístico ${ }^{21}$ y que los jóvenes renovadores no formaban parte de la "anti-España" porque eran "hombres de Franco, de España y de Cristo". ${ }^{22} \mathrm{El}$ arte de la España franquista que podía pactar con el bloque occidental mostraba su carácter vanguardista en su ser abstracto, aseguraba su consonancia con la identidad nacional en los discursos generados para explicarlo donde se hablaba de su carecer netamente español, de su espiritualidad y su relación con los grandes maestros de la pintura española, e indicaba su ruptura con el pasado (académico pero zacaso no se trataba también de un pasado que podía asociarse con el fascismo?) en la polémica generada.

Machine", Journal of Spanish Cultural Studies, 1:2, (2000), pp. 135-152.

20 La narracion documentada de dicha polémica se puede encontrar en Miguel CABAÑAS BRAVO: hito de la I Bienal Hispanoamericana de Arte, Madrid, CSIC, 1996.

21 Dionisio RIDRUEJO: “La campaña de los mediocres”, Arriba (Madrid), 17 de noviembre de 1951, citado en Miguel CABAÑAS BRAVO: El hito de la I Bienal..., pp. 583-584.

22 VV.AA.: "Réplica a un ataque. Artistas de España, combatientes del ejército de Franco y militantes del Movimiento Nacional, rechazan la aviesa y confusionista maniobra de los que quieren desCABAÑAS BRAVO: El hito de la I Bienal..., p. 577. 
No en vano Víctor Nieto Alcaide identifica en la polémica y en las publicaciones motivadas por la I Bienal Hispanoamericana la generación de un tópico historiográfico, de un punto de inflexión mítico para la historia de las relaciones del franquismo con el arte. ${ }^{23}$ Gracias a esta polémica se creaba un momento de cambio y de ruptura con lo anterior, que se podía difundir como ejemplo de la nueva actitud del franquismo ante la cultura. La abundante literatura generada en torno al certamen de 1951 quizá habría de ser interpretada no sólo como un reflejo de su repercusión social, sino como parte de una estrategia encaminada a construir un evento, un hito para un relato consciente. Además, este tipo de discusiones y de decisiones acerca la estética que había de ser apoyada oficialmente no debía de resultar ajena para los Estados Unidos donde también se habían producido transformaciones en el discurso artístico apoyado oficialmente así como enfrentamientos parecidos. ${ }^{24}$ ¿No sería interpretado como un indicio positivo que en la España franquista fuera posible una discusión parecida a la que había en países que se consideraban ejemplo de democracia y libertad?

La nueva política artística franquista fue criticada asimismo por los intelectuales exiliados que llevaron a cabo una campaña en su contra y organizaron exposiciones alternativas a la misma. Los exiliados, con Picasso a la cabeza, se consideraban los representantes legitimos de la verdadera España y organizaron lo que denominaron "una iniciativa española, precisamente española" 25 que se concretó en las exposiciones "contrabienales". Antonio Aparicio señalaba en el prefacio del catálogo de la Exposition Hispano-Americaine celebrada en París que en la I Bienal no había arte español porque el "espíritu creador español" había tenido que emigrar para poder sobrevivir, los artistas españoles habían tenido que alejarse de España para mantenerse fieles a su esencia. ${ }^{26}$ Desde México, Josep Renau también situaba el evento franquista al margen del arte español y declaraba que a pesar de sus intenciones los "verdugos" no habían podido manipular las tradiciones nacionales, el "glorioso espíritu del arte español" había estado ausente de la Bienal. 27

Con todo, aún habían de pasar algunos años para que aparecieran bajo la dictadura las primeras obras del informalismo y para que el régimen las presentara en representación de país a los certámenes internacionales. Estas obras, seleccionadas, explicadas y reconocidas internacionalmente como ejemplos de modernidad y españolidad, son consideradas una de las piezas fundamentales en la reubicación del país en el panorama artístico internacional de esos años. Así Luis González Robles, el comisario por antonomasia de dichas selecciones oficiales, se refería a la "clara filiación ibérica" ${ }^{28}$ de su envío a la bienal de Venecia de 1958 que era casi exclusivamente informalista.

El informalismo y sus discursos explicativos han de considerarse el producto de la negociación entre los valores artísticos ya aceptados por el régimen y aquellos otros que formaban parte del bloque cultural en el que el país se había incorporado. Por otra parte, podría decirse

23 Víctor NIETO ALCAIDE: "Recuperación y persistencia de la vanguardia”, en Javier TUSELL y Álvaro MARTÍNEZ NOVILLO (comis.): Arte para después de una guerra (catálogo de la exposición), Madrid, Comunidad de Madrid, 1993, pp. $77-90$

24 Véase, por ejemplo, Frances S. SAUNDERS, The Cultural Cold War, Nueva York, New Press, 2000; Michael L. KRENN: Fall-out Shelters for the Human Spirit. American Art and the Cold War, Chapel Hill y Londres, University of North Carolina Press, 2005; Serge GUILBAUT: De cómo Nueva York robó la idea de arte moderno, Barcelona, Tirant lo Blanch, 2007

25 "Carta de Picasso a los Artistas de Habla Española", El Nacional (suplemento dominical), 237, 14 de octubre de 1951, p. 7, citado en Miguel CABAÑAS BRAVO: El hito de la I Bienal..., p. 313.

26 Antonio APARICIO: "Prefacio", Exposition Hispano-americaine, París, Galerie Henri Tronche, 1951.

27 Josep RENAU: "Sobre la bienal franquista", Nuestro tiempo, 6 (julio de 1952), pp. 35-44, citado en Miguel CABAÑAS BRAVO: El hito de la I Bienal..., p. 544

28 Luis GONZÁLEZ ROBLES: "Presentación", España en la XXIX Bienal de Venecia, Madrid, Dirección General de relaciones Culturales, Pabellón de España, 1958. que en el caso español la separación entre arte y política se llevó a cabo a partir de la lectura en clave meramente artística de una pugna (la provocada por la selección de obras para la I Biena Hispanoamericana) que unos años antes se habría considerado política. A partir de entonces, en el campo de las artes plásticas ya no era posible identificar una posición política en función de la opción estética (sí, en cambio, se podía hablar de posiciones más o menos cercanas a la académica). Se terminaba así con una "anti-España" plástica. Si aparecía alguna propuesta artística que pudiera considerarse contraria al régimen, su vinculación con la política la desautorizaba como arte. Aparentemente el antifranquismo se quedaba sin estética que lo pudiera identificar. $\mathrm{O}$ al menos, eso podía parecer a primera vista.

El movimiento antifranquista que inició su andadura en el interior de país en los años cincuenta encontró en el apoyo oficial dado al informalismo el "otro" frente al cual definirse estéticamente y hacer que sus discursos fueran reconocibles. Poco importaba que el régimen diera su apoyo a otras iniciativas estéticas además de a la abstracción informalista: el movimiento antifranquista ya había definido las características estéticas de su contrario y, en consonancia con la división de bloques, haría del "realismo" su bandera.

Junto con otros muchos intelectuales, fueron los artistas plásticos vinculados a los movimientos sociales antifranquistas quienes con sus obras hicieron posible que la comunidad imaginada de estos movimientos pudiera efectivamente, imaginarse y reconocerse. Ellos fueron los "otros" por excelencia en relación con el arte oficial abstracto. Sin embargo, como ya se ha indicado anteriormente, su trabajo no suele analizarse en el marco de una dinámica internacional. Habitualmente se estudian y presentan las opciones del realismo antifranquista solamente en relación con la dictadura, convirtiéndolas en un caso singular que solo tiene que ver con España y que sólo responde plástica y críticamente a lo que sucedía en el país. Pero esto no se corresponde con lo que se puede encontrar en las obras o en los testimonios de algunos de los artistas que participaron en el movimiento antifranquista.

Ricardo Zamorano, pintor vinculado a la red de Estampa Popular y activo militante del Partido Comunista de España (PCE) en la clandestinidad durante la dictadura, explicaba en 2006 que en el mundo de la cultura de finales de los años cincuenta estaban enfrentados el realismo y la abstracción, apoyados respectivamente por la Unión Soviética y Estados Unidos. Según se desprendía de las palabras de Zamorano, esta división binaria del panorama plástico internacional parecía ser la causante de que en España se hubiera dado un apoyo oficial a la abstracción, dejando de lado al realismo. ${ }^{29}$ También era la causa de que los intelectuales antifranquistas no solo emplearan las redes de difusión relacionadas con los partidos comunistas sino que explicaran su posición estética en la pintura como "realista". Y explica el hecho de que en muchas de las obras de artistas antifranquistas se encuentren mensajes críticos con Estados Unidos, de su carácter imperialista y del capitalismo del que éste se consideraba más claro representante. ${ }^{30}$

Este caso se podría considerar un buen ejemplo de cómo las construcciones culturales de la Guerra Fría crearon consenso al tiempo que limitaron el abanico de opciones ideológicas, como indica David Ryan ${ }^{31} Y$, podríamos añadir, estas construcciones culturales también condicionaron el repertorio de explicaciones estéticas y de narraciones que se elaboraron y di-

29 Ricardo Zamorano, 16 de enero de 2006, Madrid, entrevista realizada por Noemi DE HARO GARCÍA. 30 Un análisis de la crítica al modelo americano en el trabajo de los artistas antifranquistas en Noemi DE HARO GARCÍA: "El modelo americano y las imágenes del arte antifranquista en España", en Ángeles BARRIO ALONSO, Jorge DE HOYOS PUENTE y Rebeca SAAVEDRA ARIAS (eds.): Nuevos horizontes del pasado. Culturas políticas, identidades y formas de representación, Santander, Universidad de Cantabria, 2010, s/p (publicación en formato digital).

31 David RYAN: "Mapping Containment: The Cultural Construction of the Cold War", en Douglas FIELD (ed.): American Cold War Culture, Edimburgo, Edinburgh University Press, 2005, pp. 50-68. 
fundieron para explicar lo que estaba sucediendo. Un análisis mínimamente atento muestra cómo la noción de realismo a la que hacían referencia los discursos antifranquistas combinaba a un tiempo la tradición realista de la pintura española que había sido definida tradicionalmente como parte de la identidad nacional, la división binaria del mundo estético resultante de la Guerra Fría, el diálogo con otras opciones artísticas realistas (por ejemplo en cine o en literatura) y la construcción de una alteridad franquista abstracta cuyo carácter construido y engañoso se denunciaba. También se hacía hincapié en una identidad española definida por la diversidad. Frente a la defensa de una españolidad franquista unitaria, monolítica, con un solo rostro abstracto, las iniciativas disidentes unieron sus fuerzas y sostuvieron la existencia de una diversidad de opciones plásticas, todas ellas legitimas por su españolidad.

En el programa de mano de la exposición 36 Peintres Contemporains d'Espagne celebrada en 1961 en la Maison de la Pensée Française se denunciaba el uso que el régimen hacía del arte informalista para insertarse en el panorama internacional. Junto con ello se acusaba a la dictadura de no haber presentado el arte español tal y como era, con sus caracteres auténticos; éste había sido adaptado a las exigencias de una vanguardia internacional, disimulando las tendencias artísticas que "rechazaban categóricamente toda influencia del snobismo mercantil". ${ }^{2}$ Para mostrar los rasgos del arte nacional la exposición decía renunciar a la unidad y la coherencia y reunía representantes de las "cuatro dimensiones" en que se desarrollaba el arte español. ${ }^{33}$ El franquismo no permitía ni apoyaba la libertad de creación sino que silenciaba todo aquello que se salía de los esquemas establecidos.

Es indudable que justificar el eclecticismo de las propuestas estéticas presentes en la exposición apelando a la pluralidad de la realidad del arte español tenía mucho de opción táctica y pragmática. Por otra parte, reunir a la mayor cantidad posible de agentes contra e franquismo, por muy diversos que fueran, estaba en consonancia con la línea de actuación del PCE y su llamamiento a la "reconciliación nacional" en 1956.34 La negociación y la convivencia de la pluralidad se mostraban como características del antifranquismo. Un buen ejemplo de esto es la configuración de Estampa Popular. Esta red de artistas antifranquistas estuvo activa desde los años sesenta hasta iniciados los ochenta y contó con núcleos por todo el país. ${ }^{35}$ Algunos, como los del País Vasco, Valencia, Galicia o Cataluña, reclamaban identidades nacionales y tradiciones no españolas sino valencianas, gallegas o catalanas lo cual no era obstáculo para la actuación conjunta.

A mediados de la década de los sesenta muchos intelectuales vinculados al movimiento antifranquista desde las artes plásticas ya no parecían querer presentarse como los verdaderos representantes de la esencia española. No era extraño que la narración heredada se pusiera en duda cuando se estaban llevando a cabo reflexiones críticas acerca de cómo el

32 Martín JIMÉNEZ: 36 Peintres Contemporains d'Espagne, Paris, Maison de la Pensée Française, 1961, s/p.

33 La nómina total de artistas incluidos en el catálogo fue:Zabaleta, Vázquez Díaz, Aleu, Álvarez, Barjola, Caballero, Calvo, Caneja, Cardenas, Clavo, Delgado, Dans, Equipo 57, Gal, Guinovart, Garrido, García Ochoa, Genovés, Guillermo, Labra, Lafuente, Laffon, López García, Macarrón, Mateos, Mignoni, Millares, Mozos, Muñoz, Ortega, Pacheco, Palacios, Pena, Ràfols-Casamada, Saura, Martínez Novillo, Zamorano. Grabados, Alvarez, Clavo, Grupo Sevilla y Ortega.

34 El texto contenido en el folleto Por la reconciliación nacional, por una solución democrática y pacífica del problema español se retransmitió por Radio España Independiente en junio de 1956. En agosto de ese año fue aprobada como línea de actuación del partido en la reunión del Comité Central. Cfr." "Por la reconciliación nacional, por una solución democrática y pacífica del problema español", Boletín de Información, VI: $\mathrm{n}^{\circ}$ extraordinario (1956), s/p.

35 Sobre la actividad de esta red artística véanse Noemi DE HARO GARCÍA: Grabadores contra el franquismo Madrid, CSIC 2010. ID. "La breve, pero intensa, actividad de Estampa Popular Catra el franquismo, Madrid, CSIC, 2O10,'ID." La breve, perointensa, activid

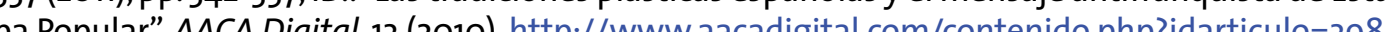

poder empleaba la cultura y los medios de comunicación para mantener su dominio sobre la población, cuando el pop entraba en el mundo de las exposiciones internacionales y, con él, las referencias a la sociedad de consumo (muchas veces en tono crítico) o cuando los análisis de lenguaje derivados del estructuralismo sacudían ciertos sectores intelectuales y afectaban a las reflexiones sobre las imágenes.

Los intelectuales más jóvenes, aquellos que estaban más familiarizados con estas ideas, fueron los primeros en plasmar la crítica a la construcción de la identidad en su trabajo. Las pinturas de los grandes maestros de la pintura española eran utilizadas a modo de citas, desgajadas de su contexto y compuestas para modificar su significado, actualizándolo. Los genios españoles y sus obras eran considerados como uno más de los productos de consumo que el régimen había administrado para construir y ejercer la hegemonía cultural.

Los críticos vinculados a estas iniciativas artísticas señalaron el carácter artificial e interesado de las asociaciones que hasta entonces se habían hecho entre las obras de los artistas españoles (concretamente el informalismo) y una tradición igualmente española con una serie de características fijas. Así lo afirmaba Juan Antonio Aguirre en $1969^{36}$ y también lo harían los artistas y críticos vinculados a la exposición España, vanguardia artística y realidad social: 1936-1976. Uno de los comisarios de dicha muestra, Valeriano Bozal, criticaba que numerosos críticos y artistas considerasen que la pintura de El Paso reflejase la tradición pictórica española (dramática, sobria en el color, expresiva) para él "esta afirmación (...) no es más que una lamentable concesión a una consideración tópicamente idealista de nuestra cultura que convierte fenómenos históricos en creencias intemporales". ${ }^{37}$ A pesar de todo, todavía hoy es frecuente que la Historia del Arte español explique el trabajo de los artistas recurriendo a los tópicos nacionales y que defina éstos en unos términos y según unos esquemas que deben mucho al modelo que se fraguó y difundió al calor de la Guerra Fría.

36 Juan Antonio AGUIRRE: Arte último. La "Nueva Generación" en la escena española, Madrid, Julio Estévez, 1969.

37 Valeriano BOZAL: “La imagen de la posguerra”, en Valeriano BOZAL y Tomás LLORÉNS (coords.): España, vanguardia artistica y realidad social: 1936-1976, Barcelona, Gustavo Gili, 1976, p.101. 


\section{DEL HOLLYWOOD BOWL A LOS FESTIVALES DE ESPAÑA} JOSÉ ITURBI, O BIENVENIDO, MISTER MARSHALL*

Jesús Ferrer Cayón

Hollywood Bowl: Teatro al aire libre con capacidad para 25.000 personas (veinticinco mil), situado en Hollywood, California.

El Hollywood Bowl, uno de los centros turísticos de la ciudad del Cine, se convierte en verano (julio y agosto) en el centro de la vida musical de Estados Unidos, por sus famosos conciertos nocturnos, a cargo de los solistas, orquestas y ballets más famosos del mundo.

Este texto se encuentra manuscrito en el dorso de la fotografía del Hollywood Bowl que el cónsul español en Los Angeles, José Pérez del Arco, trajo consigo en su visita a España en 1950. La Hollywood Bowl Association, entidad que dirigía y administraba el célebre auditorio de Highland Avenue, se había dirigido a él con el fin de que efectuara las gestiones oportunas para que España "tomara parte de manera oficial en un concierto homenaje a las aportaciones españolas a la música mundial", que estaba previsto se celebrara en agosto de ese año. También le había expresado su deseo de que la figura central del evento fuera el afamado pianista valenciano José Iturbi. Dicha fotografía ilustraba una "Nota para el director", emitida desde el Instituto de Cultura Hispánica (ICH), en la que se explicaba con detalle el proyecto de cuyo contenido se desprende la repercusión extra-musical que estaba previsto tuviera el evento para el gobierno franquista, dado su interés en acercar posiciones con la administración yanqui:

La ceremonia del homenaje consistirá en mezclar tierra española con la tierra del Hollywood Bowl, (...).

A efectos informativos hay que hacer constar que la Hollywood Bowl Association, al dirigirse al Sr. Pérez del Arco, solicitando su cooperación, insistió en la trascendencia publicitaria que este festival ha de tener para España, ya que se celebrará exactamente en medio de la estación musical del Bowl (razones climáticas -siendo todos los conciertos por la noche- limitan la temporada del Bowl a los meses de julio y agosto, durante los cuales desfilan por su escenario figuras máximas de la música mundial (Rubinstein, Toscanini, Heifetz, Stokowski, Kousevitzki, el mismo Iturbi -que actuará como solista contratado en el Bowl el 24 de agosto, etc, etc.-) y, formando parte de una campaña de publicidad de teatro, será dicho acto ampliamente recogido por la prensa general y musical de los Estados Unidos.

* Quisiera agradecer la información facilitada por Carol Merrill-Mirsky y Steven Lacoste, directora y archivero, respectivamente, del Hollywood Bowl Museum and Archives, así como la referencia hemerográfica (Documenta, 681) proporcionada por la profesora Gemma Pérez Zalduondo.

1 Fotografía del Hollywood Bowl (Los Angeles, 1950?), Archivo General del Ministerio de Asuntos Exteriores (AGMAE), Fondo de Cultura, Carpeta: José Iturbi (pianista): 1941-1956", Legajo: R-5311, Exteriores (AGMAE), Fondo de Cultura, Carpeta: Jose Iturbi (pianista): 1941-1956, Legajo: R-5311,
Expediente: 14.

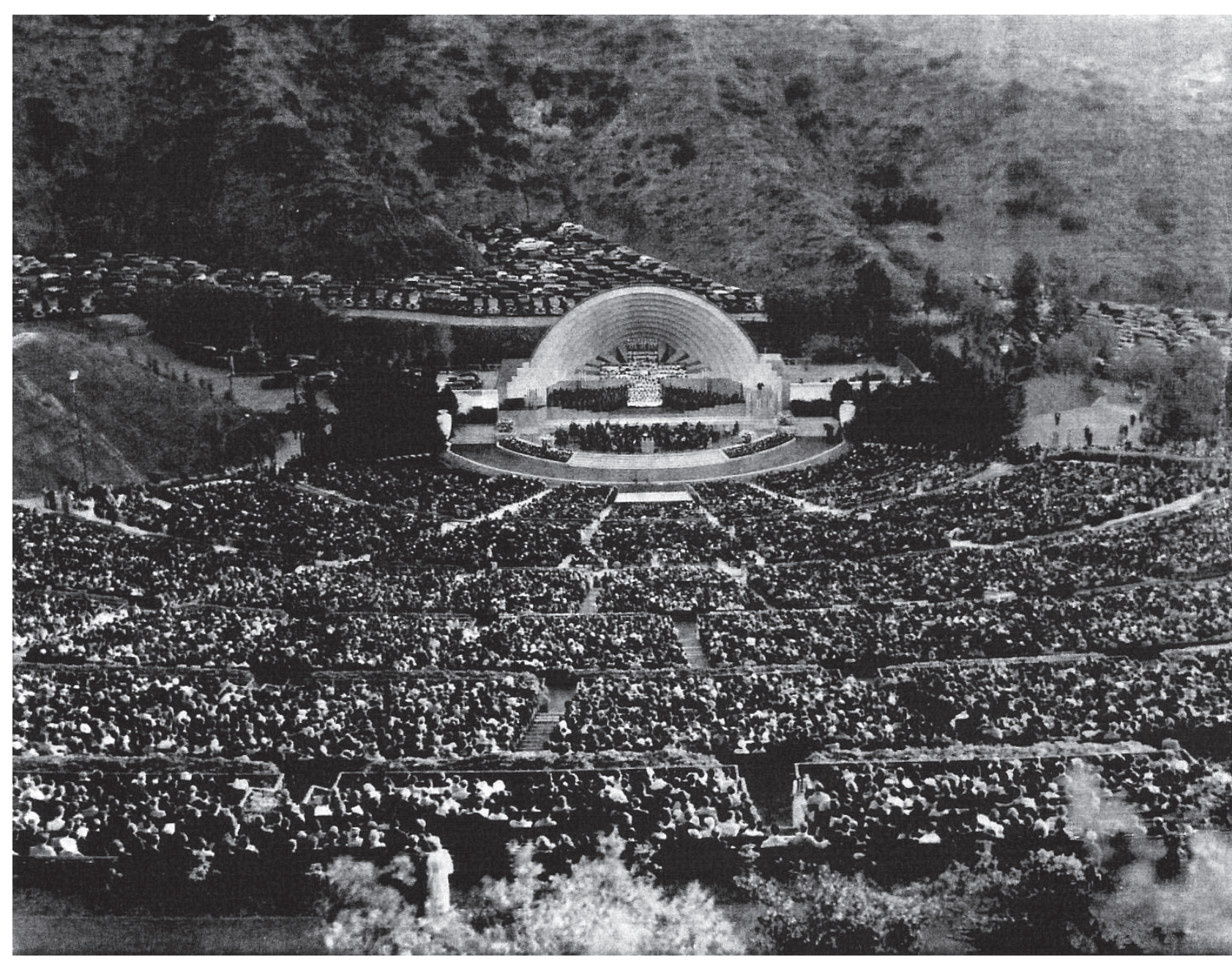

Naturalmente, dada la ocasión especialísima y única de este festival musical español, y dado el carácter de centro musical de los Estados Unidos que posee el Hollywood Bow en verano, el Consulado de España en Los Angeles tomará las medidas necesarias para asegurar a este acto la máxima trascendencia y para revestir la ceremonia simbólica de donación de tierra española, de la mayor solemnidad, tratando de obtener se decore profusamente el escenario con banderas de España y de los Estados Unidos y elaborando un programa de discursos o dedicaciones que supongan el máximo homenaje a la aportación de España a la música del mundo.

El origen de este festival español debe ponerse en relación con la operación articulada ese mismo año desde el ICH, para contrarrestar el aislamiento diplomático que España padecía

En el Auditorium del General, Petroleum Building se ha inaugurado solemnemente el ciclo de conferencias sobre temas de cultura española, organizado por el Consulado de España en esta ciudad. La primera ha estado a cargo del cónsul de España en Los Angeles, D. José Pérez del Arco, quien disertó sobre el tema "Características de la cultura española". Después se proyectaron unas cien diapositivas en color, de paisajes, monumentos y ciudades españolas. La segunda conferencia del ciclo versará sobre "Velázquez" y ha despertado tal interés que ya no hay localidades para asistir al acto. ${ }^{3}$

2 ICH: "Nota para el director" (Madrid, 5 de junio de 1950), ibid.

3 EFE: “Conferencia sobre cultura española en Los Angeles", $A B C, 14$ de enero de 1950, p. 8. 
Una información que, no por casualidad, compartía página periodística con sendas noticias relativas a la posición favorable de Estados Unidos, Inglaterra, Francia y Bélgica para que fuera revocada la resolución (que recomendaba la retirada de embajadores de Madrid) aprobada en 1946 por Naciones Unidas y pudiera así incluirse a España en el Pacto Atlántico. Como tampoco era casual la elección de Iturbi, quien ya había manifestado su malestar porque España no fuera "mejor conocida en el extranjero", durante su regreso a Valencia en 1947, entre medias de dos recitales en Londres, ${ }^{4}$ ciudad en la que un año después apadrinaría el debut internacional de Ataúlfo Argenta en los Festivales de Harringay:

Pianista, director, músico... Recuerdo la vuelta [de Iturbi], después de nuestra guerra. Fue el marqués de Bolarque, gran amigo suyo, quien le trajo [en 1948] para tocar y dirigir, al tiempo, en los conciertos de la Orquesta de Cámara de Madrid. Fue un gran acontecimiento del que Ataúlfo Argenta, el titular del conjunto, era el más alegre voceador. Sólo uno, dos años más tarde. Iturbi fue su padrino internacional: lo llevó a Londres y en $\mathrm{Ha}$ rringay Arena, ante diez mil personas, tocó, dirigido por el joven maestro castreño que abría de esa forma las rutas del mundo. Me parece vivir aquella jornada de la que fui testigo directo en junio de 1948. Y revivo el júbilo de Iturbi por el triunfo del compatriota, sus comentarios, en un inglés animado por frases en las que aparecían giros valencianistas que ni el tiempo ni la distancia pudieron apagar jamás. ${ }^{5}$

Un debut, el del joven maestro Argenta, que a la vez supuso un capítulo esencial en la proyección político-cultural del régimen franquista en Europa:

Cuando termina esa temporada musical de 1949 a 1950, en la vida del director de la $\mathrm{Na}$ cional se alza, enlazando con aquella jornada de Londres, otra fecha de importancia: la de los conciertos en París. Todo, en esta hora tiene un alto valor político, y sobre España operan aún tinieblas, recelos e incomprensiones. El arte posee siempre un valor de misión y de embajada, que redunda, en definitiva, en crédito o descrédito del país en que ha nacido. Importa, a la hora española de 1950, que la Orquesta Nacional diga al mundo, con la voz de sus violines, sus chelos y sus trompas, la realidad de una tierra muy distinta a como el convencionalismo internacional quiere envolver a la patria. ${ }^{6}$

Por su parte, Iturbi ya en 1948 había dado sobradas muestras públicas de fidelidad política al régimen franquista, al declarar en Barcelona sentirse "orgulloso de ser español y que así lo proclama a los cuatro vientos por donde va", a la vez que al recordar "que en los últimos años ha sido objeto de campañas y boicots y difamaciones por parte de los comunistas norteamericanos, que le pidieron dos cosas que nunca podrán los marxistas conseguir: que se declarara hostil al actual Gobierno de España y que se afiliara al partido comunista". 7 Una fidelidad a la

4 CIFRA: "El pianista José Iturbi, en Valencia", $A B C, 6$ de diciembre de 1947, p. 15

5 Antonio FERNÁNDEZ-CID: "Adiós a un excepcional artista español", $A B C, 29$ de junio de 1980, p. 75. Una precisión: el mencionado concierto de Iturbi en Madrid tuvo lugar en 1948. Regino SAINZ LA MAZA: "Gran triunfo de José Iturbi con la Orquesta de Cámara", ABC, 23 de marzo de 1948.

6 José MONTERO ALONSO: Vida apasionada de Ataúlfo Argenta, Santander, Antología de Escritores y Artistas Montañeses, 1959, pp. CLXX y CLXXIV.

7 "La campaña contra Iturbi en Nueva York alcanzó caracteres serios, hasta el extremo de que nuestro compatriota lleva co nustantemente una guardias serios, hasta el extremo de que intentaban a cios contra Iturbi que pese a todo es cada vez más a usero no col público culto de a yuel país". CIFRA: "A pesar del veto comunista, Iturbi es admirado en Estados Unidos", $A B C$, 19 de mayo de 1948, p. 16. que se unía su inmensa popularidad, como demuestra el telegrama postal enviado en 1950 desde la Delegación Española en Turquía al ministro de Asuntos Exteriores:

Nuestro compatriota el maestro Don José Iturbi ha tenido en Istanbul donde ha dado dos conciertos un recibimiento sin precedentes. (...) Me ocupo del caso bajo el aspecto exclusivo de la propaganda de España en el extranjero. La presencia de Iturbi en Turquía ha dado ocasión a que se hable en términos elogiosos del grado cultural de España y de la alta cotización que se hace en el extranjero de sus valores. Iturbi se ha presentado como español ferviente quedando bien asentado su nacionalidad, patriotismo y los lazos que le une con su Patria. (...) Me congratulo en reiterar que el recibimiento a Iturbi no admite parangón con el dispensado a ninguna otra personalidad sea cualquiera el campo de su actividad. (...). ${ }^{8}$

Una popularidad cimentada en EEUU gracias a sus incursiones en los mundos de la radio, el cine, el jazz, las grabaciones discográficas y la divulgación musical televisiva, ${ }^{9}$ y que adquirió en la Valencia de finales de los años cuarenta, un carácter berlanguiano:

(...) Su fama de valenciano internacional llegará a tal punto que una confitería de la ciudad del Turia creará un pastel con su nombre. En 1948 da una serie de conciertos en el Teatro Principal de Valencia con llenos desbordantes. Un año más tarde vivirá el homenaje de toda la ciudad. Cientos de valencianos le reciben en la Estación del Norte. El clamor popular es tal que se ve obligado a salir al balcón del Hotel Inglés para dirigir unas palabras a sus paisanos. El Ayuntamiento le obsequia con una cena en los Viveros. Al final del banquete se le entregan las insignias de la Gran Cruz de Alfonso X El Sabio, que han sido costeadas por suscripción popular. Días después tiene lugar el concierto homenaje en el que es nombrado director honorario perpetuo de la Orquesta de Valencia, entonces Orquesta Municipal de Valencia, que le contrata para una gira. Esta se inicia en octubre de 1949 con conciertos en Alicante, Alcoy, Elche, Murcia, Zaragoza y Barcelona. Tras las fiestas de Navidad, se reemprende de nuevo por Francia e Inglaterra, siendo la primera vez que una orquesta española realiza una gira internacional. En Londres graban dos discos con la RCA Victor. A su regreso, el 26 de febrero de 1950, miles de valencianos salen a recibirlos. Unos días más tarde, el 19 de marzo, festividad de San José, Iturbi recibirá el homenaje de las Fallas. Desde el balcón del Ayuntamiento, y en una magna concentración, dirige todas las bandas de música que actúan ese día en la ciudad. ${ }^{\circ}$

Iturbi era sabedor del valor de embajada política que podía tener la música. Durante la Segunda Guerra Mundial había ofrecido conciertos para la United Service Organization y la Air

8 Telegrama postal enviado por Alfonso Fiscowich al ministro de Asuntos Exteriores (17 de marzo de 1950), AGMAE, Fondo de Cultura, Carpeta: “José Iturbi (pianista): 1941-1956", Legajo: R-5311, Expediente: 14

9 Alberto SALINAS: “Un español en Hollywood”, Audio Clásica, 108 (2006), pp. 72-73.

10 José DOMÉNECH PART y Manuel GIL DESCO: Iturbi en Hollywood, Valencia, Fundación Municipal de Cine-Mostra de Valencia, 2004 pp 14-15. El año anterior la prensa había recogido su visita de Cine-Mostra de Valencia, 2004, pp. 14-15. El año anterior, la prensa habia recogido su visita a y traslada para sus recitales el que está más próximo a la capital en que actúa Viaja siempre en avión y aunque ha vendido el suyo pronto compráá otro, pues tiene el título de piloto avia en En Norteamérica cobra por concierto unos 8 . ooo dólares. Por una película -y ha producido seisEn Norteamérica cobra por concierto unos 8.000 dólares. Por una pelicula $-y$ ha producido seis130.000 dólares. Las últimas tres peliculas las ha hecho con Jeannette MacDonald, Frank Sinatra y lo que gana”. CIFRA: “El pianista José...”, ABC, 6 de diciembre de 1947, p. 15 
Force Recruiting Service, dos asociaciones creadas con el fin de animar y ayudar económicamente a los soldados movilizados por EEUU," su país de adopción, en el que ya en 1943 había tomado parte en un "Festival Español" organizado por la Metropolitan Opera House de New York. ${ }^{12}$ Circunstancias determinantes de cara a su elección por parte de la Hollywood Bowl Association, entidad con la que además Iturbi venía colaborando desde la década de los treinta, para el mencionado festival musical angelino que el diario barcelonés La Vanguardia anunció así:

De nuevo los Coros y Danzas de la Sección Femenina llevan hasta América la belleza de nuestra música popular. La nueva gira, más breve que las anteriores y realizada solamente por tres grupos -Málaga, Zaragoza y Vigo- es a tierras de California. (...) al frente de la expedición la señorita María Luz Larios.

(...) actuarán en el 'Hollywood Bowl' de Los Angeles, el día 24, en un festival organizado con motivo de celebrar [en] dicha ciudad el 'Día de España'. En este festival también tomará parte José Iturbi. Días después irán los grupos de Coros y Danzas a la ciudad de Santa Bárbara, en la cual se celebra anualmente, siempre en el mes de agosto, la fiesta española paralela a las fiestas sevillanas. Por último, visitarán la ciudad de San Diego para actuar en el 'San Diego Bowl'. Su estancia en California será de unos veinte días.

Al aeropuerto de Barajas acudieron a despedir al grupo de Málaga la delegada nacional de la Sección Femenina, Pilar Primo de Rivera y otras jerarquías nacionales de la Sección. ${ }^{33}$

Dicho concierto-homenaje tuvo lugar el día 22 de agosto, con un programa integrado por Procesión del Rocio (J. Turina); Homenaje a Debussy y Marcha Burlesque (M. Palau); Landscape (J. Rodrigo); Tres Danzas de El Sombrero de Tres Picos (M. Falla); Concierto para piano $N^{\circ} 1$ (P. I. Tchaikovsky). ${ }^{14}$ Del éxito de la tourné californiana informó el diario $A B C$ al referenciar un concierto celebrado en el Colegio de Pasadena:

Los Coros y Danzas de España han terminado su gira por los Estados Unidos, en medio de un éxito apoteósico, en colaboración con el pianista y director de orquesta José Iturbi y la Orquesta Sinfónica de Hollywood, dirigida por Karl Wecker. Inició el programa Iturbi con la ejecución de varios números. (...) abarrotado de público, (...). Lo que más entusiasmó a público fue la jota. Las actuaciones fueron premiadas con ovaciones y acompañamiento de palmas, oyéndose algunas veces potentes 'oles'. 15

Artículo en el que también se daba a conocer una curiosa propuesta sobre la organización de festivales musicales en España: "El presidente de la institución norteamericana National

11 José DOMÉNECH PART y Manuel GIL DESCO, Iturbi en Hollywood, 2004, p. 13.

12 John MARTINO: "Spanish Festival stars argentinita; Jose Iturbi Conducts a Group from Philharmonic in event at Metropolitan Opera", The New York Times, 17 de mayo de 1943, p. 11.

13 En el primero de los viajes al exterior organizado por la Sección Femenina, el grupo de Málaga había visitado Argentina, Brasil y Portugal, tutelado por la regidora central de Cultura, Maruja Sampelayo. Esto explica que dicho grupo partiera unos días antes que los respectivos de Zaragoza y Vigo. En total, viajaron a EEUU cuarenta bailarinas jóvenes. "Los Coros y Danzas, de nuevo en América", La Vanguardia, 10 de agosto de 1950, p. 3.

14 Las obras españolas fueron interpretadas con el acompañamiento de la Hollywood Bowl Symphony, dirigida por el propio Iturbi, y la obra de Tchaikovsky corrió a cargo de Los Angeles Philharmonic Orchestra, dirigida por John Barnett. "José Iturbi: a mostly Spanish concert", Hollywood Bowl, Los Angeles, 22 de agosto de 1950. Información facilitada por Carol Merrill-Mirsky y Steven Lacoste, directora y archivero, respectivamente, del Hollywood Bowl Museum and Archives.

15 EFE/Cifra: “Coros y Danzas de España triunfan en California. Proyecto de festivales internacionales de música religiosa en Monserrat", $A B C, 15$ de septiembre de 1950, p. 19
Arts Foundation, de Nueva York, Mr. Smith, ha visitado Monserrat, donde estudió un proyecto de grandes festivales internacionales de música religiosa. Ha manifestado que la idea se la dio hace algún tiempo, el director de orquesta polaco Arthur Rozinski, que estuvo en España". Idea que, mutatis muntadi, el gobierno franquista no materializaría hasta 1962, al fundar la Semana de Música Religiosa de Cuenca. Entretanto, en 1952 vieron la luz los festivales internacionales de Granada y Santander, y en 1954 fue aprobado el Plan Nacional de los Festivales de España, inspirado, en no poca medida, en la fórmula de popularización artística del Hollywood Bowl, cuyo director, Karl Wecker, había emprendido en octubre de 1950 un viaje por España para "estudiar la posibilidad de establecer intercambios musicales" 17 entre ambos países:

Por mundialmente conocido, no hace falta que describamos el 'Hollywood Bowl', uno de los teatros más originales y famosos que funcionan en Los Angeles desde 1932.

(...) Karl Wecker, (...) ha venido a España con el propósito de que nuevos grupos de Coros y Danzas de la Sección Femenina actúen en los Estados Unidos en una gira que podría prolongarse a diez meses por todo el país. Tal es el entusiasmo que nuestros cantos y bailes populares, genuinamente españoles, produjeron en su reciente presentación en Norteamérica.

-Mr. Wecker, el honor de actuar en el 'Hollywood Bowl' está tradicionalmente reservado a las figuras artísticas de fama mundial. ¿Se trata de una generosa excepción lo que usted propone?

-Ni mucho menos. Ahora mismo podría darle una lista larguísima de las celebridades que han actuado en aquel teatro al aire libre. El criterio de selección de los espectáculos y audiciones no se quebrantará. Considero que los Coros y Danzas de la Sección Femenina son una atracción de excepcional calidad. El 'Hollywood Bowl' se creó precisamente para esto. Poner al alcance de grandes masas populares lo más selecto del arte mundial. Con una capacidad de veinte mil espectadores, desde su fundación el 'Hollywood Bowl' ha registrado ya la cifra de siete millones de entradas.

- ¿Se cumplirán sus propósitos de llevar los Coros y Danzas españoles a los Estados Unidos? -Ya he comenzado mis gestiones. En Norteamérica existe un interés extraordinario en presenciar esta embajada del arte español. Me ha dado un poco de confianza en que esto podría conseguirse el cónsul de España, don José Pérez del Arco. También quisiera llevar la Orquesta Nacional y los más destacados artistas de España. Lo español tiene cada día mayor interés en los Estados Unidos. ${ }^{18}$

Wecker recorrió la vida músico-institucional española durante el otoño-invierto de 1950/51, dentro de la operación orquestada desde el ICH a fin de contrarrestar el "aislamiento en que vivía la España de Franco al iniciarse la década de los cincuenta", el cual provocaba, entre otras cosas, "que nuestro país no fuera un lugar de visita habitual para los directivos de la industria

16 Ibid. La National Arts Foundation era una corporación privada neoyorquina sin ánimo de lucro dedicada a la promoción de las Bellas Artes, desde que en 1947 la fundara su presidente Robert Carleton Smith.

17 EFE: “Elogio a los Coros y Danzas de España”, $A B C, 27$ de septiembre de 1950, p. 8.

18 REDACCIÓN: “Un norteamericano en busca de arte español” La Vanguardia, 19 de octubre de 1950 p. 4. Aunque la primera actuación en el Hollywood Bowl tuvo lugar en 1922. Nathan MASTERS: p. 4. Aunque la primera actuacion en el Hollywood Bowl tuvo lugar en 1922. Nathan MASTERS: Recuperado de internet (http.//www.kcetorg/undaily/socal focus/history/la-as-subjoct/fromRecuperado de internet (http://www.kcet.org/updaily/socal_focus/history/la-as-subject/from-
daisy-dell-to-the-hollywood-bowl-34638.html\#); "The Hollywood Bowl", p. 26, en Hollywood daisy-dell-to-the-hollywood-bowl-34638.html\#); "The Hollywood Bowl”, p. 26, en Hollywood Bowl Orchestra-John Maceuri: Hollywood Dreams, (CD, Philips, 1991); "Hollywood Bowl History: dia/hollywod-bowl-history/symphonic-music-and-opa). 
musical de Estados Unidos". ${ }^{19}$ De hecho, el balance positivo de la visita cultural de Wecker a España se hizo público también en la ciudad angelina:

El importante diario de esta ciudad Los Angeles Times publica, en su número del pasado día 1, una información en la que, bajo el título a dos columnas, la 'Música en España',
recoge unas declaraciones del Dr. Karl Wecker, director del Hollywood Bowl, quien recientemente visitó España, invitado por el Instituto de Cultura Hispánica de Madrid. (...) al pasar revista al movimiento musical de España en la actualidad, señala la importancia dada a la música clásica en la mayoría de los programas sinfónicos que ha escuchado, y destaca la perfección de las orquestas sinfónicas, comenzando por la Orquesta Nacional. Afirma también que la Orquesta Ibérica de Madrid, formada por un conjunto de sesenta ejecutantes de instrumentos populares, es totalmente original y sin paralelo alguno en los Estados Unidos.

El Dr. Wecker considera la Agrupación Nacional de Música de Cámara -a la que escuchó en Madrid, en un concierto ejecutado con los instrumentos Stradivarius de la colección del Palacio Nacional- como el mejor cuarteto de música de cuerda del mundo, y afirma que tendría posibilidades de enorme éxito en los Estados Unidos..$^{20}$

Valoraciones artísticas al margen, lo que resulta evidente es la similitud entre el objetivo de popularización del arte mundial del "Hollywood Bowl" y el de los Festivales de España, esto es, la red de Festivales Artístico-Populares (pintura, teatro, música y danza) que el franquismo promovió por todo el territorio nacional como resultado de la creación, en octubre de 1953 (un mes después de firmar con EEUU el "Pacto de Madrid"), de un Patronato y de una Junta Técnica Información y Educación Popular que sería el paso previo del citado Plan Nacional de 1954. Se trató de una empresa política de carácter sociocultural que, partiendo de la exitosa experiencia festivalera previa de Santander, fue concebida para difundir determinadas manifestaciones artísticas por el mayor número de localidades españolas. La revista Documenta, editada por la Dirección General de Prensa del Ministerio de Información y Turismo, daba cuenta así de os comienzos del fenómeno:

Los antecedentes de los festivales artístico-populares (...), se remontan a las representaciones que en el año 1948 inició el Delegado de la entonces Subsecretaría de Educación Popular, en Santander, con la colaboración del Gobernador Civil y Jefe Provincial del Movimiento y con las que se dieron a conocer a centenares de alumnos extranjeros de la Universidad Internacional Menéndez Pelayo [UIMP], las más destacadas manifestaciones que integran la ejecutoria cultural de España.

En el año 1952, por iniciativa del Ministro de Información y Turismo señor Arias Salgado, y también con la entusiasta colaboración del Gobernador Civil y Jefe Provincial del Movimiento, señor Roldan Losada, el Ministro y su Delegación en Santander organizaron lo que podemos llamar Primeros Festivales Artístico-Populares propiamente dichos. Es decir, en ellos se perseguía ya la finalidad que después habían de encauzar el Patronato y la Junta Técnica de Información y Educación Popular: la de llevar una misión cultural y artística a todos los rincones de España. ${ }^{21}$

19 Victoria CAVIA NAYA: "Música y músicos españoles en Estados Unidos: 1950-1960", en Javier SUÁREZ-PAJARES (ed.): Joaquín Rodrigo y Federico Sopeña en la música española de los años cincuenta, Valladolid, SITEM-Glares, 2008, p. 56.

20 CIFRA: "El movimiento musical español, enjuiciado por el Dr. Wecker", $A B C$, 10 de enero de 1951, p. 16.

21 "Festivales artísticos-populares", Documenta 681 (1954) $p .3$ No se reconocia encambio, que esas representaciones que entre los años de 1948 y 1951 tuvieron lugar en la UIMP y que fueron deno-
Una política de Estado en la que se ahondó con la creación del Comisariado de Festivales (1957), un nuevo organismo más especializado vinculado al Patronato dependiente del Ministerio de Información y Turismo, entidad a la que se unieron, a partir de 1963, la Junta Coordinadora de Festivales y su órgano asesor, esto es, el Consejo Nacional de Festivales.22

Las razones que llevaron a la Dictadura a decidirse a crear una red de festivales por todo el país fueron la labor educativa ("elevación del nivel cultural del pueblo"), la dinamización de sector escénico-artístico, el beneficio turístico-económico ${ }^{23}$ y la inconfesada repercusión internacional, como se desprende de la carta que Esteban Pujals, director del Instituto de España en Londres, enviara en 1957 al Director General de Relaciones Culturales del Ministerio de Asuntos Exteriores:

Tengo la honra de enviar a V.I. un recorte de The Times del 5 de junio en el que el corresponsal de dicho periódico en nuestro país da noticia del comienzo de la temporada "Festivales de España", con la actuación de la compañía de Antonio en el jardín del Alcázar de Córdoba. También se da noticia de la representación de "El Alcalde de Zalamea" en Puertollano, Ciudad Real, y de la actuación en Oviedo de la compañía de ballet Sadler's Wells. Como escribe dicho corresponsal para información de sus lectores, estos festivales tienen lugar en sitios que ofrecen reconocida belleza natural o ambiente histórico, como las murallas romanas de Tarragona, los claustros de las antiguas catedrales, los patios de los palacios históricos, y los parques o jardines de las capitales, y su propósito es permitir que millares de trabajadores desfruten económicamente de escogidos programas de música y baile o de buenas representaciones dramáticas. (...). ${ }^{24}$

La cultura, en su vertiente artístico-escénica (esencial a la hora de configurar la imagen de un pueblo), fue protagonista de la estrategia legitimadora del régimen franquista allende sus fronteras. El informe solicitado en 1958 por el ministro de Asuntos Exteriores, con motivo de la polémica surgida en torno a la petición del Festival Internacional de Santander (FIS) de una subvención a la "Sección Exposiciones" del citado Ministerio, no deja lugar a dudas:

minadas como "Fiestas Universitarias", hundían sus raíces en una idea inspirada, sottovoce, en el proyecto de "Programa de fiestas universitarias" que Pedro Salinas, secretario general de la primigenia Universidad Internacional de Verano de Santander (U. I.), habia diseñado para esta en 1932. José Ramón SAIZ VIADERO: “Correspondencia inédita entre Salinas y Lastra: la Universidad Internacional de Santander", Historias de Cantabria, 7 (1994), pp. 110 y 112.

22 Jesús FERRER CAYÓN: La instrumentalización política de la cultura durante el primer franquismo: la Universidad Internacional Menéndez Pelayo (UIMP) y el Festival Internacional de Santan$\operatorname{der}(F / S), 1945-1957$, Tesis doctoral, Universidad de Cantabria, 2012, http://www.tdx.cat/handle/10803/80772.

23 "Festivales artísticos-populares", Documenta, 681 (1954), p. 2. Respecto al fenómeno del turismo, este "debe ser considerado no sólo como un asunto comercial, clave en el desarrollo económico de los años 5o, sino también como una pieza importante de las relaciones internacionales y diplomáticas en el proceso de construcción europea". De hecho, las gestiones diplomáticas de Luis Bolín, trajeron a nuestro pais en octubre de 1951 en misión turistica de gran lujo, a la caravana Fielding trajeron a nuestro pais en octubre de 1951 en misión turistica de gran lujo, a la caravana Fielding,
organizada por el editor de dicho nombre e integrada por multimillonarios americanos. Se trató organizada por el editor de dicho nombre e integrada por multimillonarios americanos. Se trató
de los primeros hombres de negocios que recorrieron el país (Barcelona, Palma, Formentor, Made los primeros hombres de negocios que recorrieron el pais (Barcelona, Palma, Formentor, Madrid, Toledo y El Escorial) y que allanaron el camino para el posterior pacto de Franco con los EEUU, GARRIDO: Historia del turismo en España en el siglo XX, Madrid, Síntesis, 2007, pp. 189-195.

24 Carta de Esteban Pujals al Director General de Relaciones Culturales del Ministerio de Asuntos Exteriores (Londres, 7 de junio de 1957), AGMAE, Fondo de Cultura, Carpeta: "Festivales de España ('The Times')", Legajo: R-4831, Expediente: 25. 
(...) En un momento de severo bloqueo diplomático con una casi nula actividad política tuvo España que realizar un considerable esfuerzo en materia cultural para estar presente en el mundo exterior. Por ello, se duplicaron algunas subvenciones o atenciones que Exteriores. Tal fue el caso del Festival de Granada que, en un principio, aparecía aislado como una posible ventana al exterior para ofrecer un testimonio de la vitalidad de España en el terreno artístico. Entonces tal vez fue acertado subvencionar dicho Festival, después se continuó por inercia y posteriormente el número de Festivales ha ido creciendo hasta el punto de que en el último verano se han realizado Festivales en lugares de muy escasa significación turística y con una importancia política inferior a veces a la categoría de Partido Judicial. (...)..$^{25}$

Ello era así porque los Festivales de España también debían "llevar una misión cultural y artística a todos los rincones del país", ${ }^{26}$ porque fueron el instrumento utilizado por la dictadura franquista para reeducar a unas masas necesitadas de cohesión interna tras el desgarro traumático de la Guerra Civil. O lo que es lo mismo, el modo de nacionalización tradicionalista-católico opuesto al modelo castellano-europeísta y cívico-republicano alentado desde $L a$ Barraca de Federico García Lorca y las Misiones Pedagógicas ideadas por Manuel Bartolomé Cossío. ${ }^{27}$ Un interés por "sacar la cultura a la calle" de filiación republicana que José Manue Riancho, primer director del Festival Internacional de Santander (FIS), reconocía en 1991 al relatar la vinculación inicial de este evento con la UIMP:

Las Fiestas Universitarias, en un planteamiento inicial, surgen de la colaboración de dos instituciones que en aquellos años dependían del Ministerio de Educación Nacional: la Universidad Internacional Menéndez Pelayo [UIMP] y la Delegación santanderina de Educación Popular, que yo venía desempeñando desde el 1 de julio de 1944. En conversación mantenida, en la primavera de 1948, con Ciriaco Pérez Bustamante, Rector Magnífico de la Universidad, e Ignacio Aguilera, Secretario General, esbozamos un proyecto de actividades artísticas -teatro, danza popular, cine y música- que quedó perfilado definitivamente después de que el Gobernador Civil, el inolvidable Joaquín Reguera Sevilla asumiera la financiación del proyecto. Así se puso en marcha un estilo de colaboración que haría posible más tarde la organización del Festival en la Plaza Porticada.

Desde un primer momento nuestro objetivo era hacer llegar al público universitario, en su mayoría extranjeros que seguían cursos de lengua española, mensajes nada tópicos del arte español a través de ejemplos vivos de obras dramáticas, música y danza popula de nuestras regiones. Al mismo tiempo, nos propusimos abrir estas manifestaciones culturales al público de la ciudad, que pronto desbordaría los marcos universitarios con un proyecto del que no había otros ejemplos en la España de la época.

En este propósito didáctico, en este objetivo de difusión cultural, está no sólo el origen de las Fiestas Universitarias, sino también la razón de ser del Festival, que en años próximos alcanzaría su internacionalidad.

La idea de 'sacar la cultura a la calle' recogía experiencias universitarias consagradas ya

en la preguerra española con La Barraca de García Lorca, que actuaría en la torre de la

25 "INFORME" [supuestamente de un funcionario del Ministerio de Asuntos Exteriores] (Madrid, 10 de noviembre de 1958), AGMAE, Fondo de Cultura, Carpeta: “Festival de Santander, 1958", Legajo: R-6192, Expediente: 5 .

26 "Festivales artísticos-populares", Documenta, 681 (1954), p. 3.

27 Sandie HOLGUÍN: República de ciudadanos. Cultura e identidad nacional en la España republicana,

Barcelona, Crítica, 2003, pp. 3-4
Plaza de las Caballerizas del Palacio de la Magdalena en los cursos estivales de 1933 y 1934 [y también, de 1935] de la Universidad Internacional de Verano de la República, a la que están tan unidas la figura señera de Don Ramón Menéndez Pidal, la sabiduría de Don Blas Cabrera y el puro acento poético de Don Pedro Salinas. A su vez, se inspiraba en una característica del teatro clásico español: su representación ante un auditorio de marcado carácter popular. Miembros de "La Barraca”, como Modesto Higueras, que fue su primer actor, y su hermano Jacinto, serían cualificados protagonistas de las Fiestas Universitarias -también del Festival en su primera andadura- en las veladas del Teatro Español Universitario, auténtica escuela dramática dirigida por Modesto, en el marco de las Caballerizas de La Magdalena.

La etapa de 1948 a 1951 determinará también las futuras características de la empresa artística: coordinación de las instituciones, creación de un equipo humano, estilo del futuro Festival e incorporación fiel de la ciudad.

La corta nómina de funcionarios de la Delegación Provincial asume la responsabilidad de la organización, el apoyo logístico y la dirección artística de estas veladas, con la asistencia técnica de los Servicios de Actos Públicos de la Subsecretaría de Educación Popular que realiza los montajes escénicos y los destinados al público. La Universidad incorpora a sus programas veraniegos estos actos culturales y les abre la pluralidad de sus marcos y escenarios, integrando como un protagonista excepcional a sus legiones universitarias en una adhesión expresada en rica variedad de lenguas.

Con la financiación económica necesaria del Gobernador Civil, Joaquín Reguera Sevilla, el equipo humano de la Delegación Provincial pudo adquirir una compleja experiencia que permitiría más tarde emprender la empresa cultural del Festival santanderino. ${ }^{28}$

Dentro del Plan Nacional de los Festivales de España fueron establecidas varias categorías atendiendo, fundamentalmente, a su ubicación geográfica y al objetivo principal que desde el Gobierno se esperaba de ellos: Festivales A (Santander y El Escorial) y A1 (Sevilla, San Sebastián Cádiz, Oviedo, Valencia, Vigo, Gijón y Elche), es decir, los dotados de proyección internacional; Festivales B (Palma de Mallorca, Zaragoza, La Coruña, Portugalete, Pontevedra, Málaga, Puertollano, Málaga, Vitoria, Tarragona, Salamanca, Cartagena, León, Segovia, Valladolid, Albacete y Cuenca), los que debían cumplir una función eminentemente turística; Festivales B1 (Almería, Lérida, Huesca, Córdoba, Torrevieja, Priego de Córdoba, Lugo, Badajoz, Algeciras, Tomelloso, Mataró y Ronda), aquellos que poseían un alto valor educativo; y, en una categoría clasificada aparte, Ceuta y Melilla: celebraciones de la soberanía española en plazas africanas. ${ }^{29} \mathrm{Y}$ en razón de esta clasificación eran establecidos sus contenidos: la música sinfónica y las compañías de danza de reconocido prestigio fueron el grueso de la programación de los festivales de categoría o proyección internacional y turístico; la música y la danza españolas, el teatro y las exposiciones de pintura, de los festivales de carácter local y educativo.

De entre todos, nos interesan los festivales internacionales de Granada y Santander, ya que ambos fueron muy pronto (1955 y 1956, respectivamente) admitidos en la European Festivals

28 José Manuel RIANCHO: “De la fundación a la internacionalidad (1952-1965)", en VV.AA.: Plaza Porticada. Festival de Santander (1952-1990), Madrid, Cicero, 1991, pp 83-84. La Universidad Internacional de Verano de Santander fue la primigenia institución universitaria de carácter cosmopolita y estival que la Segunda República creó en 1932 y que estuvo operativa entre 1933 y 1936 . Y su secretario general, el poeta y profesor Pedro Salinas, fue quien diseñó por vez primera un "Programa de fario general, el poeta y profesor Pedro Salinas, fue quien diseño por vez primera un "Programa de la Universidad Internacional de Santander", Historias de Cantabria, 7 (1994), pp. 110 y 112

29 "Distribución de Subvenciones para Festivales de España. Año 1963", Archivo General de la Administración (ACA) Sección: Cultura, Carpeta: "Documentación de Festivales", Caja Topogr.: 22/2. 
Association (EFA), una entidad creada en Ginebra en 1952 al amparo del Centre Européen de la Culture (CEC), institución fundada en la misma ciudad dos años antes en tanto rama cultural del Movimiento Europeo, es decir, el principal grupo de presión diseñado por la CIA para promover una Europa unida asociada a los Estados Unidos, mediante una serie de actividades subvencionadas a través de entidades tapadera como el Chase National Bank de Basilea o la Fundación Farfield y de mecenas como Julius Fleischman. De hecho, el CEC y la EFA fueron presididas por el escritor calvinista suizo Denis de Rougemont, quien procedía de la izquierda antifascista no marxista y que, tras la guerra, había trabajado para la Voz de América (como locutor) y la Unión Europea de Federalistas, organización para la que seguiría trabajando con la ayuda encubierta de la CIA desde el CEC..$^{30}$ Rougemont, un cuarto de siglo después, glosaba así los objetivos la EFA:

(...) La Asociación Europea de Festivales de Música ha reunido poco a poco todos los grandes festivales que manifiestan el deseo de cooperar en la unión cultural de Europa y que cumplían las condiciones siguientes: existencia de cinco años como mínimo, carácter específico de los programas, raíces nacionales y tradiciones locales, y asimismo irradiación y prestigio internacional bien establecido.

Al comienzo de 1951 se agrupan los festivales situados en el centro de Europa: los franceses con Aix-en-Provence, Besancon, Burdeos, Estrasburgo; los alemanes, con Bayreuth, Berlín, Munich y Wiesbaden; los italianos con Florencia, Perugia, Venecia; los suizos, en e centro, con Berna y Zurich; Viena al este y Holanda al norte. Durante los años siguientes, el círculo se amplió lentamente hasta llegar a todos los límites de la Europa tradicional. Así se adhieren sucesivamente: 1952, Helsinki; 1954, Granada; 1956, Santander y Dubrovnik; 1957, Estocolmo y Atenas; 1958, Praga; 1961, Edimburgo y Varsovia; (...)

(...) La Asociación proporciona así un ejemplo convincente de esta unión europea que debe operarse en los corazones antes de establecerse en los hechos. La música, la creación más típica de Europa, estaba destinada a manifestar, la primera, esta comunidad profunda de las reacciones de la sensibilidad y del espíritu. ${ }^{31}$

La admisión en la EFA suponía una manera de "ganar carta de ciudadanía con lo mejor de Europa", pues no había "rincón bello de Europa sin su festival".32 El Festival de Música y Danza Españolas de Granada fue impulsado expresamente para ello desde la Dirección General de Relaciones Culturales del Ministerio de Asuntos Exteriores. La pretensión de emular a los grandes festivales europeos (Bayreuth, Salzburgo, etc.) hizo que su carácter fuera elitista. En cambio, las Fiestas Artísticas y Populares de Santander nacieron dentro de la Delegación Provincial del recién creado Ministerio de Información y Turismo, como complemento cultural de la Universidad Internacional Menéndez Pelayo, cuya actividad académica estival otorgaba a la capital montañesa una relevancia político-intelectual que pronto aconsejó la proyección

30 EEUU centró su estrategia en apoyar la música vanguardista prohibida expresamente por Stalin, auspiciando, por ejemplo, la celebración en 1952 en Paris del Festival Obras Maestras del Siglo XX. Frances STONOR SAUNDERS: La CIA y la guerra fría cultural, Madrid, Editorial Debate, 2001, pp. 138 , 299-326 y 455-456. Rougemont también propició en 1950 la creación del grupo de científicos que en 1954 cristalizaría en el Centro Europeo de Investigaciones Nucleares (CERN). "Denis de Rougemont. Biografía ampliada", Editorial Veintisieteletras, http://www.veintisieteletras.com/autor. php?id=3.

31 Denis de ROUGEMONT: "El verdadero concierto europeo", XXV Años del Festival Internacional de Santander, [S. I.], FIS, 1977, pp. 8-9.

32 Federico SOPEÑA: "La ciudad y sus Festivales", Ideal (Granada), 12 de noviembre de 1952, citado en (1883-1952). Origenes del Festival Internacional de Música y Danza de Granada, Granada, Comares, 2000, p. 421. cosmopolita del evento hasta transformarlo en el Festival Internacional de Santander (FIS). Su ubicación en la Plaza de Velarde (conocida como "La Porticada"), acondicionada como teatro al aire libre para unos 6.000 espectadores, le asemejaba más al concepto popularizador de las artes del Hollywood Bowl. Por ello, su éxito marcó el camino del Plan Nacional de los Festivales de España. 33

La figura de Argenta fue decisiva a la hora de transformar las Fiestas Universitarias de la UIMP en los Festivales Artístico-Populares de la Plaza Porticada. De hecho, en agosto de 1951, el maestro castreño y la Orquesta Nacional de España (ONE), en compañía del prestigioso pianista húngaro Béla Siki, habían acudido a Santander para ofrecer dos conciertos en el Teatro María Lisarda Coliseum y uno (de música española) en la Residencia de Monte Corbán (sede de la UIMP); unas veladas, consideradas de antemano como "acontecimiento musical del verano", 34 a las que vino a sumarse, ante la enorme expectación suscitada y la demanda insatisfecha de entradas, un concierto extraordinario de carácter popular organizado por la Comisión de Festejos del Ayuntamiento en el Odeón, o Auditorium del Sardinero: 35 un escenario al aire libre ubicado en el corazón turístico de la ciudad, en dónde el éxito de Argenta y, sobre todo, el cosechado unos días antes por los Coros Montañeses hubo de ser definitivo para que las autoridades locales se decidieran a impulsar, un año después, en otro espacio similar del centro histórico urbano, el Primer Festival Artístico-Popular de Santander. ${ }^{36}$ Máxime si se tiene en cuenta que, en esos conciertos de 1951, la ONE había actuado en los tres ámbitos socioculturales que luego iban a confluir en La Porticada, a saber: el elitista, de las clases pudientes que acudían al Coliseum; el más ilustrado, de los profesores y estudiantes extranjeros que asistían a los cursos de verano de la UIMP; y el popular, de "las clases menos dotadas" 37 del Odeón, e cual, inaugurado el 23 de agosto de $1945{ }^{38}$ supuso para Santander un eslabón intermedio entre los kioscos de música o templetes tradicionales como el de la Plaza de Pombo (1886) y el del Festival de la Plaza Porticada (1952).

Llegado este punto, es casi imposible no pensar en el aludido Festival Español celebrado en 1950 en Los Angeles, durante la "estación musical" del icónico Hollywood Bowl,39 en cuyo

33 En 1953 asistieron a La Porticada 215.000 espectadores. "Festivales artísticos-populares", Documenta, 681 (1954), pp. 3-4

34 "El acontecimiento musical del verano", Alerta, 10 de agosto de 1951, p. 3.

35 Conciertos que tuvieron lugar los días 16,17, 18 y 19, respectivamente. El Diario Montañés, 4 de agosto de 1951, p. 4; 18de agosto de 1951, p. 2; y 19 de agosto de 1951, p. 4 .

36 "Anoche, en el Auditorium, actuaron con el mejor éxito los afamados Coros Montañeses, bajo la dirección de don Marcelo González. El público invadió aquel precioso lugar, siendo muy aplaudidos los moralistas, que tuvieron que bisar varios números. (...)". "Las grandes fiestas del Sardinero", El Diario Montañés, 15 de agosto de 1951, p. 2. “(...). Es de esperar que el público que asista a este acontecimiento musical acuda con la debida anticipación para evitar aglomeraciones que impidan a cada cual ocupar su sitito". "La Orquesta Nacional actuará esta noche en el Odeón del Sardinero", El Diario Montañés, 19 de agosto de 1951, p. 4.

37 "La Orquesta Nacional...", El Diario Montañés, 19 de agosto de 1951, p. 4.

38 El Odeón del Sardinero, también conocido como Auditorium de la Alameda de Cacho o de San Roque, era una concha acústica que había sido inaugurada el 23 de agosto de 1945 con un concierto de la Banda Municipal y la Coral de Educación y Descanso. Alerta, 24 de agosto de 1945, p. 4. 39 En Berlín existía un odeón similar, con capacidad para 22.000 espectadores, empleado como cine al aire libre y rebautizado, después de la II Guerra Mundial, como Teatro del Bosque o Berliner Waldbühne, el cual, inspirado en el Teatro de Epidauro (Policleto el Joven, finales del siglo IV a. C 15.000 espectadores), habia sido construido en 1936 dentro del Campo Deportivo Imperial y, tras los Juegos Olimpicos, en un seguidor del nacionalsocialismo. "Teatro del Bosque de Berlin", http://es. Wikipedia.org/wiki/ Teatro del Bosque de Berl\% C3\%ADn. Pero el interés por recrear el espíritu de los teatros de la dónde en 1903 se había construido el (William Randolph) Hearst Greek Theatre de Berkey, en 
escenario con forma concha de acústica parecía inspirarse, mutatis mutandi, el Odeón, o Auditorium santanderino; así como en el pianista y director José Iturbi, quien había apadrinado el debut internacional de Argenta en 1948 en el Festival de Música de Londres, en otro singular escenario como el del Harringay Arena, un pabellón polideportivo, ante 10.000 espectadores ${ }^{\circ}$

La actuación de Iturbi en La Porticada (días 11 y 13 de agosto de 1956) junto a la ONE y al maestro donostiarra Enrique Jordá (quien reaparecía en España después de once años de estancia en los Estados Unidos, donde desarrollaba con éxito su carrera al frente de la prestigiosa Orquesta Sinfónica de San Francisco), en la edición en que el FIS lograba su ansiada admisión en la EFA parecía cerrar una etapa de acercamiento e influencia entre la diplomacia cultural norteamericana y su homóloga española.

el cual, en 1906 fue instituido un festival de Teatro Griego conocido como las Cal Performances. Carol HYMAN: “UC Berkeley's Greek Theatre turns 100 years old this month", UC Berkeley Media Relations, 11 de septiembre de 2003, http://www.berkeley.edu/news/media/releases/2003/09/11 greek.shtml; "Founding and Early Expansion", http://calperformances.org/about/history.php. acústica, California, la ciudad de Los Angeles había instalado en 1929 una bandshell, o concha pectadores, en como Hollywood Bowl, un teatro al aire libre con capacidad para 20.000 espectadores, en donde la Filarmonica de Los Angeles" habia inaugurado en 1922 una suerte de de grandes masas populares lo más selecto del arte mundial". En 1950 estaban registrados ya de grandes masas populares lo mas selecto del arte mundial". En 1950 estaban registrados ya de octubre de 1950, p. 4; “Hollywood Bowl History", http://www.hollywoodbowl.com/philpedia/ de octubre de 1950, p. 4; "Hollywood Bowl History", http:// www.hollywoodbowl.com/philpedia/ propio en 1935 en uno de sus parques, para poder organizar todos los veranos un festival de música clásica conocido como Grant Park Music Festival; un evento gratuito nacido para dar trabajo a cantidad de músicos desempleados, a causa de la Gran Depresión, dentro de un programa de obras públicas que tuvo un impacto cultural generalizado. "The History of the Festival", http:// obras públicas que tuvo un impacto cultural generalizado. "The History of the Festival", http:// www.grantparkmusicfestival.com/about/history. Ese mismo año, la ciudad de Guatemala había un año después, una segunda ubicada en el Parque Central (Plaza de la Constitución), con el fin de albergar los conciertos de la Banda Marcial. "La concha acústica: origen, pasado y presente", MundoChapin.com, http://edngt.com/mundochapin/blog/2012/05/0g/la-concha y presente", MundoChapin.com, http://edngt.com/mundochapin/blog/2012/05/09/la-concha-acustica-origio Roberto Benzi dirigió a la Orquesta Sinfónica Nacional (OSN) del Perú un concierto extraordinario en el Auditorium del Campo de Marte, ante 30.000 personas. "El caso Benzi", https://www. facebook.com/media/set/?set=a.435705933173749.98567.111479752263037\&type =3\#1/photo. php?fbid=435706286507047\&set=a.435705933173749.98567.111479752263037\&type=3\&theater. 40 De hecho, en Londres ya existín desde 1895 los Proms (Henry Wood Promenade Concerts), un festival de verano destinado a divulgar la música clásica entre las clases populares.

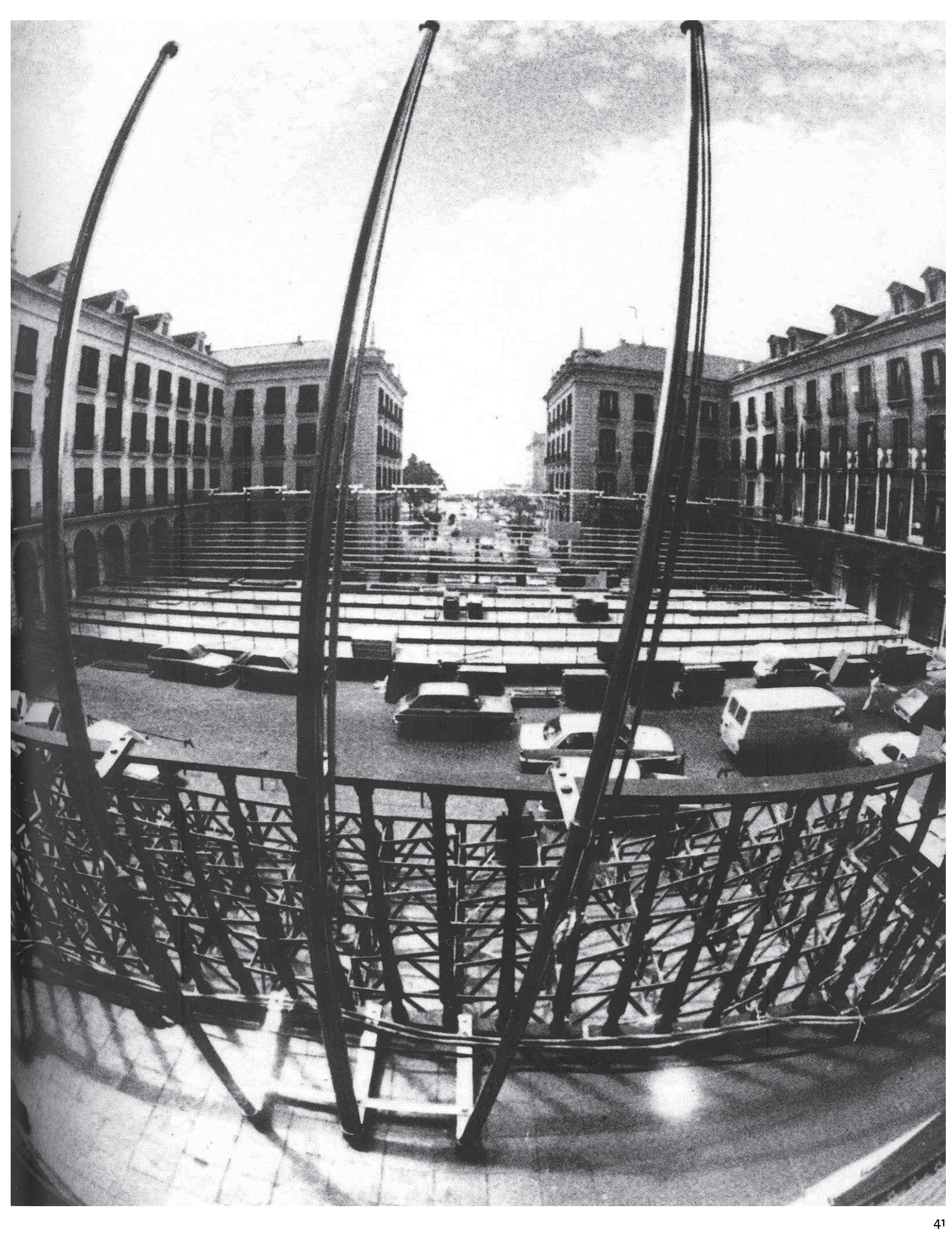

41 Montaje del graderío y escenario del Festival Internacional de Santander en la Plaza Porticada años sesenta (Fuente: VV.AA.: Plaza Porticada. Festival de Santander (1952-1990), Madrid, Cicero, 1991, p. 87). 


\section{Las asociaciones de amistad y la difusión de la propaganda soviética en el exterior}

La gestación de las asociaciones de amistad tuvo origen en movimientos como Hands off Soviet Rusia en oposición a la participación británica en la guerra civil rusa. Y tomó carta de naturaleza a través de la articulación del apoyo internacional a la URSS de los delegados asistentes al décimo aniversario de la Revolución de Octubre en la casa de los Sindicatos de Moscú, sede del I Congreso de los Amigos de la Unión Soviética. En la España de Primo de Rivera no puede constituirse como asociación de estas características.

En sus manifiestos, los Amigos de la Unión Soviética se muestran como agrupaciones antifascistas y valoran los logros del modelo soviético sintetizados en: el desarrollo económico, la mejora en las prestaciones sociales, la gigantesca revolución cultural puesta en marcha y su política internacional opuesta a la capitalista. Un año después se establece un comité internacional en Colonia que procuró una estructura coordinadora para compartir la defensa de la URSS.

De parte soviética contaban con todo un Estado y de sus instituciones habilitadas para la difusión de la propaganda del modelo soviético. Así, las publicaciones de la Sociedad para las Relaciones Culturales con el Exterior (VOKS) desde los años veinte y La Unión de Sociedades Soviéticas de Amistad y Relaciones Culturales con otros Países (SSOD), a partir de 1958, junto con las pertenecientes a los respectivos comités nacionales de Amigos de la Unión Soviética, son el mejor exponente de los discursos acorde con la política exterior soviética y una imagen favorable de la misma.

El boletín VOKS se corresponde con la etapa estalinista, destinaba amplios espacios para lo que constituía un logro en el afianzamiento de las relaciones internacionales de índole sociocultural a través de las Asociaciones de Amistad constituidas o reconstituidas tras la II Guerra Mundial y dedicó artículos a los daños ocasionados por los nazis. La revista Cultura y Vida y Novedades de Moscú, se corresponde con la etapa postestalinista, traducidas a múltiples idiomas, difundían principalmente la vida cultural, artística, y deportiva de la Unión Soviética a otros países. La SSOD fue encabezada por Y. Popov entre 1950 y 1975, Z. Kruglov de 1979 a 1987 y V. Tereshkova desde 1987 y en su nueva andadura postsoviética bajo otras siglas: la Asociación de Cooperación Internacional de Rusia, sucesora de derecho, desde el 4 de abril de 1992.

Las sedes de las asociaciones de amistad se convirtieron en sus plataformas de difusión propagandística en el exterior como se verá a través de los casos de Reino Unido y España.

A lo largo de la historia de las asociaciones de amistad de la Europa occidental con la URSS hubo momento álgidos como el auge de los comités pro-soviéticos con el aliado en tiempos de la segunda guerra mundial que dio paso a una 'paz fría' a la que era necesaria readecuar sus estrategias para frenar los estereotipos que pesaban contra la Unión Soviética y establecer puentes entre ambos modelos. La cultura se utilizó como medio de aproximación y vehículo de propaganda política a favor del modelo soviético. Una vez formulada la política de coexistencia, ésta se convertiría en el leitmotiv de las asociaciones de amistad y sus delegaciones hasta que la Perestroika subiera a la palestra internacional, lo que supondría una mayor apertura de la URSS y proyección exterior.

En el ámbito de la política internacional se organiza el grupo de trabajo sobre las relaciones Este-Oeste dentro de la OTAN. Una vez que desde finales de los cincuenta existían acuerdos culturales bilaterales entre estados miembros de la OTAN y la URSS, caso de Gran Bretaña y EEUU, procuraron coordinar la política cultural con la Unión Soviética. En un contexto marcado por la guerra fría, en el que la propaganda cultural jugaba un papel significativo como medio de influenciar a la opinión pública. Además, los estados del "mundo libre" estaban en contra de otras formas de contacto cultural al margen de las oficiales, es decir, de iniciativas particulares bajo el manto de la Unión Soviética, como las Asociaciones de Amistad con la URSS, y culares bajo el manto de la Union Sovietica, como las Asociaciones de Amistad con la URSS, y
otras organizaciones consideradas "compañeras de viaje del frente comunista". De esta manera ponían en común sus experiencias con la Unión Soviética, decidían la táctica y dificultaban el "tradicional juego" de atracción soviética."

La tendencia oficial de hostilidad hacia las asociaciones del "frente comunista" persistiría con el tiempo. No obstante, la URSS pasaría a ser una potencia redefinida en términos más amistosos cuando inicia su propio viraje durante la Perestroika, que se convierte en protagonista de la propaganda oficial soviética.

Reino Unido contó con varias asociaciones culturales ligadas a la Unión Soviética, a pesar de tener como fin el fomento y desarrollo de las relaciones con la URSS, guardan diferencias entre sí. La Asociación de Amistad Británico - Soviética es la heredera de los Amigos de la Unión Soviética, constituida en los años veinte, y adquiere tal denominación en 1946, cuando se aglutinan en su seno diversos organismos que habían trabajado para el fortalecimiento de la alianza contra las potencias del Eje en tiempos de guerra. En su seno aglutinaba a personas vinculadas con el Partido Comunista Británico. Su máxima era poner sentimiento sobre la base del conocimiento ${ }^{2}$ y, para difundir contenidos sobre la Unión Soviética y el propio asociacionismo, editaron Russia Today y desde 1956 British Soviet Friendship. En cambio, la Asociación Gran Bretaña - URSS se constituyó en 1959 y era la oficial en sus relaciones con los soviéticos para el gobierno británico.

En este contexto de guerra fría hay que insertar la imagen anticomunista de la dictadura franquista y la imagen antisoviética proyectada sobre la misma en las disposiciones oficiales represivas, los discursos y los escritos de diplomáticos, la literatura y prensa de la época, que al estar sujeta a censura, se corresponde, básicamente, con una visión acorde con la línea oficia del Régimen a pesar de que paulatinamente establecería contactos económicos con la URSS y un frustrado acuerdo cultural que no prosperó por los últimos asesinatos del franquismo. As pues, habría que esperar a la transición política española y al restablecimiento de relaciones diplomáticas con la URSS en 1977 para que el asociacionismo emergiera nuevamente.

En los primeros años, la tarea de la Asociación España - URSS fue ingente, pues debía contrarrestar la imagen estereotipada de una "Rusia culpable". Desde 1979 a mediados de los ochenta, la Asociación estuvo liderada por el científico Faustino Cordón. ${ }^{3}$ Los nexos culturales y científicos son los potenciados pero, más allá de los mismos, la Asociación se mostró como un bastión de apoyo de la coexistencia pacífica al considerar que ambos modelos podían complementarse. lucha antifranquista, como por otro lado también los que participaron en el exilio en el Congreso por la Libertad de la Cultura, pero con una diferencia de grado, ya que estaban enfrentados por

The National Archives (TNA). BW 64 /54. General Policy. 1954-1968

2 Russia Today, 1946 , p. 5

3 Contó con el apoyo de la asociación homóloga la URSS-España constituida previamente, la SSOD recogió en sus fondos el estudio de sus estatutos: Archivo Estatal de la Federación Rusa (GARF). F. 9576, Op. 20, d. 2252, 18 de julio de 1979 . 
la diplomacia cultural y popular de dos modelos antagónicos. Firmes defensores de este tipo de asociacionismo fueron militantes antifranquistas como Mariano Hormigón en Zaragoza, Miguel Ángel Pérez - Espejo en Murcia, y el citado científico Faustino Cordón al frente de la asociación estatal y su sucesor, el fiscal J. Vicente Chamorro. En los últimos años pasó a una dirección colegiada, que coincidieron con los años de cambio de la URSS. ${ }^{4}$ Desde la Gran Vía madrileña, la asociación estatal España -URSS proyectó la cultura soviética en distintas semanas culturales y jornadas específicas, donde las exhibiciones fotográficas, fílmicas (tanto del cine clásico soviético como producciones más recientes, distribuidas principalmente por Alta Films) y giras artísticas tuvieron cálida acogida. Los fondos de su biblioteca, repletos de editoriales soviéticas en ruso y traducidas al castellano, distribuidas por la librería Rubiños, apoyaron el aprendizaje del ruso y desde la Asociación se crearon becas de estudio que ayudaron a jóvenes españoles a conocer in situ el modelo soviético y a la formación de profesionales. De estas actividades y otras de programación propia se hacían eco las delegaciones territoriales.

Las relaciones de la URSS con los países de Europa Central y Oriental se habían intensificado desde el fin de la II Guerra Mundial y la integración en organismos internacionales como el COMECOM (1949) y el Pacto de Varsovia (1955), también se nutrían de las Asociaciones de Amistad. De hecho, era la expresión más acabada de los lazos de amistad con los llamados paí ses hermanos, es decir, con los países socialistas. Alemania resulta un ejemplo paradigmático puesto que tendría una experiencia dividida desde la segunda posguerra mundial. La Asociación de Amistad Germano - Soviética en la RDA había sido establecida bajo el nombre de Sociedad para la Cultura Soviética en 1947. Como la mayoría de las organizaciones en la antigua República Democrática Alemana experimentó un proceso de transformación en una asociación de carácter estalinista en los primeros años de existencia. ${ }^{5}$ En 1952, la Asociación contaba con tres millones de asociados, había conseguido extenderse entre los trabajadores industriales y campesinos, aparte de comprometerse activamente en el programa de rehabilitación de Berlín. ${ }^{6}$ La Asociación pervivió hasta 1990, y experimentó un auge durante la perestroika. La revista Die Neue Gesellschaft (Nueva Sociedad) fue el vehículo de expresión de la Asociación. Además, la Unión Soviética estableció tratados de amistad, colaboración y ayuda mutua con países socialistas, que procuraban el refrendo oficial de las estrechas relaciones en el bloque oriental Y defendió la idea de Europa como Casa común, que implicaba el reconocimiento de los Estados de diversos sistemas sociales, integrados en bloques político-militares opuestos, para tender puentes de colaboración. Por otro lado, los países comunistas contaron también con sus propias asociaciones de amistad con otros países como la Unión Soviética.

Al otro lado del Atlántico, en el continente Americano también contaban con asociaciones de amistad, a modo de ejemplo, Estados Unidos contó con su propia asociación, el Consejo Nacional de Amistad Soviético-Norteamericano, popular durante los años de la Segunda guerra mundial, que acabaría generando una estructura estable. Esta etapa se corresponde con la dirección de Corliss Lamont. ${ }^{7}$ Sin embargo en un clima de guerra fría, los integrantes de consejo estuvieron bajo sospecha e investigación, considerados como enemigos internos. En Argentina se formó en 1946 el Instituto Cultural-Argentino Ruso que vio interrumpida su labor tres años después por el arresto de integrantes del Partido Comunista. En 1953 resurgió como Instituto de Relaciones Culturales Argentina-URSS, beneficiándose de una coyuntura caracte-

4 Magdalena GARRIDO: La Guerra fría cultural...

5 Matthias KLINGENBERG: Kultur als Vehikel: zur Geschichte der Gesellschaft für Deutsch-Sowjetische Freundschaft (1947-1953) [Cultura como vehículo: La historia de la Asociación Germano - Soviética de Amistad], Heildeberg, 2001.

6 Herbert HUMMITSCH: “German-Soviet friendship in action”, VOKS Bulletin, 76 (1952), pp. 88-89.

7 Filósofo y activista de los derechos civiles estadounidense, autor de obras como The Peoples of the Soviet Union (1944). rizada por el acercamiento económico oficial con los soviéticos y por una política exterior que pretendía una mayor neutralidad en sus relaciones con los bloques antagónicos. ${ }^{8}$ Estos casos ilustran cómo la consideración gubernamental y sus políticas oficiales respecto a la URSS y los partidos comunistas influyen en el desarrollo del asociacionismo.

En los años ochenta, la crítica hacia Reagan y su política se hace sentir en las publicaciones de las asociaciones de amistad. Principalmente se manifestó un rechazo expreso a la Iniciativa de Defensa Estratégica, programa conocido como "guerra de las galaxias".9 Pero al mismo tiempo publicaciones soviéticas hicieron del peligro nuclear y el desarme una cuestión centra en las que exponían sus propuestas de pacificación frente al bloque liderado por EEUU, que fue representado como una amenaza para la paz en la propaganda y publicaciones de las asociaciones de amistad con la URSS. En este mismo sentido se pronunciaba Novedades de Moscú, periódico editado por la Agencia de Prensa Novosti y la SSOD que cubría las marchas por la paz celebradas en distintas ciudades europeas, ${ }^{10}$ al tiempo que se criticaba las pruebas nucleares."

En el cuadragésimo aniversario del fin de la II Guerra Mundial se organizó la I Conferencia de las Asociaciones Europeas de Amistad con la URSS. En la que participaron las delegaciones de treinta y siete países. Esta conferencia tuvo lugar en Viena. El tema principal tratado por los delegados fue la conmemoración de la derrota del fascismo y el rol de la Unión Soviética en la liberación de Europa que formaba parte del imaginario colectivo de las asociaciones y se convertía en elemento de conmemoración por parte de la propaganda pro-soviética. La presidenta de la Unión de las Sociedades Soviéticas de Amistad con los Países Extranjeros, Zinaida Kruglova valoró el asociacionismo con su país y respecto a la lucha antifascista comentó que las lecciones de la historia enseñaban a las gentes y a los Estados, independientemente de sus sistemas sociales, que debían y podían seguir un objetivo común ante una amenaza universal. De ahí la idoneidad de proyectar esa unidad, conseguida en la lucha antifascista, en unos tiempos amenazados por el peligro nuclear. ${ }^{12}$ Las actividades para frenar la carrera armamentística y la promoción del desarrollo de cooperación pacífica entre todos los países europeos fueron una prioridad, así como la intensificación de las relaciones. ${ }^{13}$

La necesidad de explicar la novoe myslenie (nueva mentalidad) aparejada a la Perestroika para que fuese comprendida dentro y fuera de sus fronteras hizo redoblar los esfuerzos propagandísticos. En este periodo los contactos Este-Oeste se intensificaron, ya no solo gracias a las asociaciones sino por la implicación occidental en el proceso de transformación económica y política de la Unión Soviética a través de fondos europeos y norteamericanos. No obstante el rechazo al modelo comunista persistía. En noviembre de 1988, Víctor Allen aborda este hecho en la delegación de la asociación británica de amistad de Newcastle considerando el antisovietismo una actitud normal en Occidente que saludaba la Perestroika como un rechazo al comunismo de la Unión Soviética a favor de los valores capitalistas, pero si aquélla quería resolver sus problemas colectivamente dentro del socialismo se podría ver una alternativa al propio capitalismo y una continuidad de la guerra fría. ${ }^{14}$

Magdalena GARRIDO:“Las relaciones político-culturales de Argentina y España con la Unión Soviética: la proyección internacional de las asociaciones de amistad", Avances del Cesor, 6 (2009), pp. 7-26. British Soviet Friednship, Julio de 1986, pp. 6-7. Desde las asociaciones de amistad se promovieron British Soviet Friednship, Julio de 1986, pp. 6-7. Desde las asociaciones de amistad se promovieron
conferencias de paz "Guerra Fría o detente" en distintas delegaciones sobre todo en el año internacional de la Paz aprobado en la ONU.

10 "La marcha de la Paz- 82. Una misión de la humanidad", Novedades de Moscú, 31, julio de 1982.

10 "La marcha de la Paz- 82. Una misión de la hur
11 British Soviet Friendship, Marzi de 1987, p. 2.

12 Pam MAISTER: "Soviet Union's European Friends Get Together", British Soviet Friendship, Mayo de 1985, p. 6.

13 Bristish Soviet Friendship, Junio de 1985, p. 3

14 British Soviet Friendship Magazine, Noviembre de 1988, p. 12. Victor L. ALLEN: The Russians Are Co- 
La Perestroika fue definida como el "gran giro de la historia contemporánea" y es valorada desde las asociaciones de amistad favorablemente. ${ }^{15}$ En la esfera internacional, el discurso an tibelicista soviético podía proporcionar importantes réditos en la proyección de una imagen positiva de la URSS en el exterior y las Asociaciones de Amistad eran conscientes de que, a su vez, era capaz de generar mayor consenso y apoyo en sus respectivas sociedades. De la misma manera que la proyección de su cultura, las manifestaciones artísticas, avances en la carrera espacial, las efemérides (Día Internacional de la Mujer, conmemoración de la Revolución de Octubre, entre otras) y el día a día de la Perestroika, presentando al líder soviético, Gorbachov como un hombre de Estado con visión, cubrían gran parte de los números de las revistas de las asociaciones de amistad como Minsk (boletín de la delegación de la Asociación España URSS de Zaragoza) y British Soviet Friendship (órgano de expresión de la asociación amistad británico-soviética).

Por su parte la asociación España - URSS tuvo boletines internos, donde comunicaban a los socios sus actividades, y también contaban con un espacio en otros medios para publicitar los actos culturales organizados.

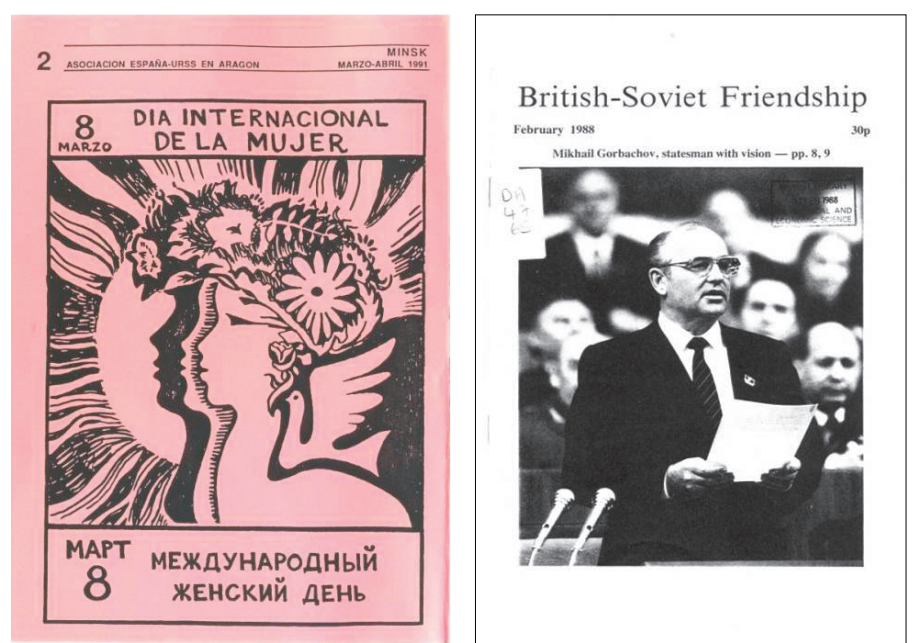

Fuente Garrido, M.: Las relaciones entre España y la Unión Soviética a través de las Asociaciones de Amistad en el siglo XX Fuentes y documentos. Murcia, Editum, 2008

1987 marca un año de tránsito hacia la consolidación de la Asociación España - URSS, tras una etapa inicial en la que todo estaba por hacer y en la que la imagen antisoviética había quedado como un cliché o apostilla de recelo con los asuntos relacionados con el país del Este. "Por la paz y la amistad" fue el lema del congreso celebrado en Zaragoza, donde asistieron las delegaciones territoriales y hubo mensajes de líderes comunistas e intelectuales significados con la URSS coincidía con el 70 aniversario de la Revolución de Octubre. ${ }^{16}$ El boletín Minsk de dicó artículos a la Perestroika firmados por S. Karamurzá, historiador de la ciencia que había acudido como conferenciante a distintas ciudades españolas y alertaba de los aspectos más controvertidos de la Perestroika. No obstante, la propaganda oficial, difundida por las editoriales soviéticas, señalaba que la crítica u oposición hacia este proyecto era muy limitada. ${ }^{7}$

ming: The Politics of Anti-Sovietism, Shipley, The Moor Press, 1987

15 A. ROTHSTEIN: “We are witnessing great turning point in history", British Soviet Friendship, Abril de 1987, pp. 8-9.

16 Documentación procedente de los Archivos particulares de la Asociación España - URSS (Madrid, Zaragoza y Murcia).

17 Desde Cultura y Vida, revista de la SSOD editada por Izvestia, aparecieron artículos en los que se destacaba el apoyo de los distintos sectores de la sociedad soviética en espacios destinados a tal
La glasnost implicó transparencia informativa y generó una desconfianza en los pasos dados por la URSS, cuyos ciudadanos sentían la pérdida de tutelaje. Por su parte publicaciones propagandísticas soviéticas como Novedades de Moscú generaron debate, se criticó desde el nes de su historia y señalaron los problemas latentes como los conflictos interétnicos, surcados por devastadores acontecimientos como Chernóbil (1986) y el terremoto de Armenia (1988), que generó una respuesta solidaria de la asociaciones de amistad. Entre las actividades culturales que generaban más expectación estaban las actuaciones de grupos de folklore soviético pero también las películas soviéticas, desde clásicos como "Acorazado Potemkin" a las más comprometidas con su tiempo, es el caso de "La pequeña Vera", propia de la apertura que propició en el ámbito cultural la Perestroika, en la que se realiza un retrato social principalmente de la juventud a través de la joven protagonista, precisamente el colectivo que sería utilizado en la propaganda soviética del cambio.

Los años de la Perestroika fueron también los años en los que una sociedad intentaba responder a las preguntas sobre cómo había sobrevenido la crisis del sistema que la propaganda arropaba. Debido al vertiginoso ritmo de los cambios y los problemas a resolver en la URSS, los socios se sentían desorientados. Los fondos soviéticos dejaron de destinarse a los programas culturales.

El British Soviet Friendship magazine, en la primavera de 1991, antes de la extinción de la URSS, comentaba los cambios que estaban aconteciendo y asistían como testigos del fin del sistema bipolar: la guerra fría ha terminado o eso nos dicen. En ese mismo año también se produce la debacle de la URSS, con la imagen simbólica del derrumbe de la estatua de Dzerzhinski que presidía la plaza Lubianka (sede del KGB) y comparte lugar con el Cementerio de los Monumentos Caídos. Se produce el final del modelo que habían defendido. Rusia regresa a la esfera internacional, se forma la Comunidad de Estados Independientes (CEI) y el encumbramiento del proyecto de Yeltsin. Sin embargo la emergencia de su figura no debe ocultar las movilizaciones de los soviéticos en tiempos de cambio a través de Frentes Populares y de Memorial. A partir de entonces se aplicó una terapia de choque con el beneplácito estadounidense, como documenta Stephen Cohen, que condujo a un drástico deterioro del nivel de vida, ${ }^{18}$ y tal y como el Libro blanco sobre las reformas neoliberales en Rusia ejemplifica en gráficos. ${ }^{19}$

En conclusión, estudiar el asociacionismo con la Unión Soviética permite calibrar su influencia exterior y la proyección de su propaganda a través de las actividades de las asociaciones, de sus congresos, revistas, periódicos, panfletos, dedicados a diversos aspectos de la vida en la URSS, fueron las huellas del activismo y servían de bastión frente a la propaganda anti-soviética. Grosso modo, la línea oficial de los gobiernos de Europa occidental era acorde con su vinculación al bloque liderado por Estados Unidos, el llamado "Mundo libre" los prejuicios y estereotipos hacia las asociaciones vinculadas con el frente comunista.

Los Amigos de la Unión Soviética y organismos afines proyectaron el discurso soviético y los beneficios de su modelo. Se amoldaron a los imperativos de cada época. De ahí el discurso de coexistencia pacífica y la necesidad de proyectar la Perestroika. Muchas delegaciones nacionales cuentan con un legado de activismo y dedicación muy prolongado en el tiempo, como ocurre para el caso británico, y otras, resurgirían tras un lapso de tiempo dictatorial como su-

efecto como "gentes de la perestroika", donde aparecen quienes mejor representan sus valores, y se reflejan a los jóvenes y sus gustos culturales (rock and roll, etc.), los artistas, etc.

18 Stephen F.COHEN: Failed Crusade. America and the tragedy of post-communist Russia, Nueva York, Londres, WW. Norton \& Company, 2001.

19 Sergei GLAZYEV, Sergei KARA.MURZA y Sergei BATCHIKOV: Belaya kniga: Economicheskie reformy

Rossii 1991-2002 [El libro blanco: reformas económicas en Rusia, 1991-2002], Moscú, IntelTekh, 1997. 
cede con la experiencia del asociacionismo español. Todas ellas expiraron con la debacle de la URSS aunque en algunos casos se readaptaron a los tiempos postsoviéticos.

No existe una historia global de las asociaciones de amistad. De ahí la conveniencia de estudios comparados para ahondar en la proyección soviética exterior en distintos países con el fin de lograr una mejor comprensión del fenómeno del asociacionismo con la URSS. En la línea de los trabajos realizados desde los cold war studies, que abordan la influencia cultural norteamericana en países beneficiarios del Plan Marshall, los American Studies y organismos como el Congreso por la Libertad de la Cultura.

Las asociaciones de amistad cumplieron su papel pero tuvieron sus límites. En los países de Europa del Este supuso un reforzamiento de la influencia soviética con los denominados 'países hermanos'y una historia común fundamentada en la lucha frente al nazismo, aunque bajo el tamiz de las organizaciones soviéticas se encontraba el rechazo a las mismas, la pluralidad y discrepancia frente a la uniformidad impuesta, es decir, se utilizaba como un instrumento de fidelidad o de proyección profesional. Las Asociaciones fueron más útiles en los países donde la URSS no contaba con representación diplomática y, con independencia del modelo político-social de los países a los que se aproximaba, utilizó la cultura, convertida en vehículo de su propaganda política para superar barreras, generar simpatías y difundir su imaginario 


\section{LOS REPATRIADOS ESPAÑOLES DE LA URSS EN EL} MARCO DE LA GUERRA FRÍA (1954-1960)

Luiza lordache Cârstea

ICPS-UAB

\section{Introducción}

Las consecuencias de la Guerra Civil española perduraron en el tiempo, más allá de su conclusión, lo que dio lugar a un régimen que condicionó los destinos de miles y miles personas alineadas con la legalidad republicana, obligadas a abandonar su patria entre 1936 y 1939. Además, las circunstancias políticas propias de la España franquista y en algunos casos del país de acogida, tal como fue el de la Unión Soviética, convirtieron unas estancias provisionales en un exilio prolongado, a veces para toda la vida. Unas décadas después, otras coyunturas políticas más favorables propiciaron la repatriación de los españoles procedentes del Gulag y de todos los sectores de la emigración republicana en la URSS.

Las repatriaciones oficiales se desarrollaron entre 1954 y 1959, periodo marcado por un lado por el «deshielo" y la «coexistencia pacífica», y por otro, por la firma del Pacto de Madrid entre España y EE.UU., el Concordato con la Santa Sede, el ingreso de España en la UNESCO y posteriormente en la ONU. También los españoles regresaban a casa en un momento complicado de la Guerra Fría, soportando algunos de los efectos negativos de la política internacional y nacional, ya que procedian del país del enemigo por antonomasia.

El objetivo de este texto es ahondar en una de las facetas negativas de la repatriación de los españoles, representada por el uso propagandístico de sus experiencias soviéticas, el seguimiento policial al que fueron sometidos por parte del régimen y los interrogatorios realizados por los servicios de inteligencia norteamericana (CIA). Mediante el análisis de documentos archivísticos, principalmente del Archivo del Ministerio de Asuntos Exteriores (AMAE), de las fuentes hemerográficas y de la bibliografía especializada, el presente trabajo pretende ampliar el panorama existente sobre este proceso configurado por la vigilancia y los interrogatorios, ilustrando a la vez la utilización de los repatriados dentro del bipolarismo mundial, en calidad de fuentes de información sobre la URSS.

\section{Aproximación a la repatriación de los españoles de la URSS}

Desde el final de la Guerra Civil, uno de los vectores que conectó de forma indirecta a la España franquista con la URSS fue la repatriación de algunos grupos de españoles sorprendidos por el desenlace de la contienda en el territorio soviético. Pese a la inexistencia de relaciones diplomáticas entre ambos países, ya que la URSS no reconoció al régimen franquista y éste a su vez adoptó desde un principio un posicionamiento anticomunista, los gobiernos soviético y franquista habían establecido contactos mediados por terceros países, que se manifestaron en los intentos de repatriación de los «niños de la guerra», los marinos y los pilotos españoles.

El lapso cronológico del proceso de repatriación y de las gestiones encaminadas al respecto queda enmarcado entre 1939 y 1959, conociendo distintas etapas. La primera fase (1939-1945) se caracterizó por las diligencias emprendidas por el Gobierno franquista con el fin de obtener la repatriación de los 2.895 «niños de la guerra» evacuados a la URSS durante la guerra, inten- tos que se prolongaron hasta 1956. La búsqueda y reclamación de los niños se canalizó a través de la Delegación Extraordinaria de Repatriación de Menores creada en 1938 y dependiente del MAE y desde 1941 hasta 1954 del Servicio Exterior de FET y de las JONS. Las diligencias emprendidas a través de las embajadas de España en Roma y Berlín, y de la diplomacia italiana en Moscú, tuvieron un desenlace negativo. No obstante, unos 18 jóvenes fueron repatriados a España durante la Segunda Guerra Mundial, al ser capturados en la URSS por las tropas nazis, y otros cuatro volvieron de de forma clandestina en $1948 .{ }^{1}$

Por otra parte, unos 190 pilotos que recibieron formación en la $20^{\mathrm{a}}$ Academia Militar de Kirovabad y cerca de 285 tripulantes de los buques españoles estacionados en puertos soviéticos desde finales de 1937, se hallaban en la URSS al finalizar la Guerra Civil. Parte de ellos solicitaron regresar a España, y en este sentido la política soviética fue de apertura, permitiéndoles la salida. En esta ocasión, el Ministerio de Asuntos Exteriores de Turquía y la diplomacia alemana en Moscú y Madrid actuaron como intermediarios entre ambos gobiernos. El resultado de este proceso de repatriación comenzado en julio de 1939 se saldó con 136 marinos y 3 pilotos repatriados, un número reducido de españoles comparado con el de los que habían obtenido el permiso de salida. Ello se debió a las dificultades para obtener el visado de tránsito por distintos países en guerra y a una política franquista que se movió entre la negativa y la mínima apertura en permitirles la entrada, en base a la revisión de expedientes por la Dirección General de Seguridad (DGS). ${ }^{2}$

La invasión de la URSS por las tropas del Tercer Reich cortó el proceso de repatriación ya iniciado y las posibilidades de unas futuras negociaciones. Finalizada la Segunda Guerra Mundial, la política franquista con respecto a las repatriaciones de españoles de la URSS se definió claramente. El Gobierno franquista seguía reclamando a los «niños de la guerra», junto a grupos de españoles enviados al Gulag: pilotos y marinos internados en el campo de Karagandá, a muchos de los cuales la DGS les había denegado anteriormente el permiso de entrada en España; prisioneros de la División Española de Voluntarios que participaron en la lucha contra la URSS; y productores que Franco envió a Alemania desde 1941, capturados por el Ejército Rojo en 1945 y recluidos en el Gulag. En esta segunda fase (1945-1953), las negociaciones se dirigieron por cauce diplomático, humanitario y supuestamente comercial. El Gobierno franquista acudió al arbitraje de la diplomacia de países europeos, latinoamericanos y árabes, y al Comité Internacional de la Cruz Roja (CICR). Las diligencias tuvieron un resultado negativo ante el silencio soviético, obstáculo también encontrado por otros gobiernos, cuyos ciudadanos purgaban condenas en los campos de trabajo forzados estalinistas. ${ }^{3}$

El fallecimiento de Stalin en 1953 desencadenó una serie de cambios en la estructura de poder, así como en la política nacional e internacional soviéticas. Por un lado, el «deshielo" benefició a los presos del Gulag, incluidos a los españoles, en virtud de la conocida «amnistía Vorochilov», que lleva el nombre de quien la firmó en 1953 como presidente del Presídium de Soviet Supremo. En este contexto de amnistía, seguido por edictos promulgados en los años venideros que abrieron las puertas del Gulag a millones de presos soviéticos y extranjeros, ${ }^{4}$

Alicia ALTED, Encarna NICOLÁS y Roger GONZÁLEZ: Los niños de la guerra de España en la Unión Soviética. De la evacuación al retorno (1937-1999), Madrid, Fundación Francisco Largo Caballero, 1999,
p. 175-182; Ángel VIÑNA y Fernando HERNÁNDEZ: El desplome de la República, Barcelona, Crítica,
2009. pp. 51-52. (O)

. Entre el acoso comunista, el glacis estalinista y el caparazón franquista, Tesis doctoral, UAB, 2011.

3 Ibid., pp. 353-382; Luis SUÁREZ FERNÁNDEZ: Franco y la URSS. La diplomacia secreta (1946-1970), Madrid, Rialp, 1987, pp. 118-132; Xavier MORENO JULIÁ: La División Azul. Sangre española en Rusia, 1941-1945, Barcelona, Crítica, 2006, pp. 51-470.

4 Elie MARC: Les anciens détenus du Goulag: libérations massives, réinsertions et réhabilitations dans I'URSS poststalinienne 1953-1964, Tesis doctoral, EHESS, 2007. 
debemos insertar el gesto soviético de liberar y repatriar a divisionarios, productores, marinos, pilotos y algunos «niños de la guerra». Con lo cual, estos prisioneros españoles regresaron en el Semíramis en abril de 1954, en virtud del decreto de amnistía y por vía de revisión de las causas incoadas por "crímenes cometidos". 5

Por otro lado, el «deshielo» propició algunos contactos soviético-franquistas marcados por la cautela de ambos bandos. Así, podemos subrayar que esta tercera fase (1953-1959) se caracteriza por un doble proceso de repatriación: el de los prisioneros españoles del Gulag, repatriados en el Semíramis; y el de "niños de la guerra", maestros que les acompañaron al ser evacuados en 1937 y 1938, marinos, pilotos y exiliados políticos. Junto a ellos volvieron también divisionarios que recuperaron su libertad después de 1954, productores y algunos miembros del grupo de republicanos enviados al Gulag desde Berlín, al ser liberado por el Ejército Rojo. El proceso de repatriación se desarrolló de forma escalonada en seis expediciones del buque Krym, entre septiembre de 1956 y mayo de 1957, y una más reducida y tardía, de mayo de 1959, en el Serguei Ordjonikidze. ${ }^{6}$ Las repatriaciones se negociaron de gobierno a gobierno en París, entre diplomáticos franquistas y soviéticos, con la colaboración de la Alianza de la Cruz Roja y Media Luna Roja soviéticas y la Cruz Roja española (CRE). Una vez más, la iniciativa perteneció al Kremlin, trasladada a Madrid por la Cruz Roja francesa (CRF), que actuó como mediador inicial. Cabe señalar que las repatriaciones determinaron algunos acercamientos soviético-franquistas, con visitas reciprocas en Madrid y Moscú, pero también algunos altibajos, como intentos de aplazamiento de expediciones, negación de recepción de algunos repatriados o negociaciones tensas mediadas por el CICR.

\section{El uso propagandístico de las vivencias de los repatriados por el régimen franquista}

El anticomunismo del régimen franquista, como uno de sus principios políticos e idea motriz en la justificación del "alzamiento", se hizo patente en la propaganda desplegada contra la URSS. Cualquier noticia relacionada con los españoles en la URSS, fuesen divisionarios, pilotos, marinos y «niños de la guerra», aparecía en la prensa. ${ }^{8} \mathrm{El}$ regreso en el Semíramis de los que sufrieron cautiverio en el Gulag fue una fuente de alimentación propagandistica con el trasfondo de la Guerra Fría. La utilización de las experiencias concentracionarias de los españoles en abril de 1954 como propaganda antisoviética no era nada nuevo. ${ }^{9}$ En 1948, periódicos como el $A B C$ explotaron las noticias publicadas por Solidaridad Obrera, La Batalla y otras publicaciones aparecidas en el extranjero que denunciaron el internamiento de antifascistas españoles en Karagandá. De hecho, estas informaciones le sirvieron como base a Eduardo Comín para narrar el periplo de los llamados "hombres arrepentidos", alzando "una enérgica protesta" contra el "esclavismo" en la URSS, autora también de una maniobra con "características netamente criminales" en cuanto al "secuestro" de menores españoles. ${ }^{10}$

5 Carta del Presidente de la Cruz Roja francesa al Presidente de la Cruz Roja española (París, 15 de enero de 1954), Archivo del Ministerio de la Presidencia del Gobierno, Jefatura del Estado, 19.1.

6 La relación de repatriados por expedición se halla en: "Llistat repatriacions", Arxiu Nacional de Catalunya, FCEM [AGE], Inventari S55, Codi 260-261, Núm. 106; Archives du Comité International de la Croix Rouge (ACICR), Service Ibérique, CG 2 IB B-036-045

7 Luiza IORDACHE CÂRSTEA: El exilio español... pp. 541-576.

8 A modo de ejemplo véase Francisco LUCIENTES: "Lo que el general rojo "El Campesino", dice de Rusia", y Luis G. de LINARES: "Aquellos niños españoles enviados a Rusia regresan de hombres políticos", La Vanguardia, 10 de febrero y 28 de septiembre de 1946.

9 Este tema, junto con algunas experiencias de jóvenes repatriados, fue parcialmente tratado debido a su magnitud en Magdalena GARRIDO CABALLERO:“Españoles repatriados de la URSS en la propaganda del régimen franquista" en Ángela CENARRO y Juan CARRERAS (eds.): VI Encuentro de investigadores sobre el franquismo, Zaragoza, Contexto Gráfico, 2006, pp. 117-130.

10 Eduardo COMÍN COLOMER: “Españoles esclavos en Rusia”, Temas españoles, 14 (1952), pp. 3-30.
El affaire Semiramis desencadenó una campaña propagandística con mensajes claros: el éxito de la repatriación se debía a las numerosas gestiones emprendidas por el régimen franquista" y la URSS era "una inmensa cárcel". Pese a lo que la prensa de la época había resaltado, la repatriación de los prisioneros se debió a la amnistía de 1953, sin la intervención de otros organismos o países, salvo la mediación en el proceso de la CRF. ${ }^{2}$ La campaña propagandística desencadenada tuvo una duración relativamente corta, desde finales de marzo hasta mediados de abril de 1954, pero fue intensa y minuciosa sobre las distintas facetas del proceso, la travesía en el barco, la acogida por las autoridades, el reencuentro con las familias, las peripecias de los retornados, etc. Entre la multitud de artículos que ocuparon las páginas principales de los periódicos, la serie de doce capítulos de Salvador López de la Torre fue la más representativa de lo que se publicó sobre las condiciones de vida en los "campos de exterminio" o los "campos de la muerte". ${ }^{3}$ Las vivencias de los presos españoles se convirtieron en un instrumento propagandístico más, en aras de preservar uno de los mitos del régimen, como el de «Rusia es culpable», que reafirmaba la política española en el marco de la Guerra Fría.

A partir de abril de 1954, la propaganda antisoviética relacionada con el Gulag se amplió a raíz de las entrevistas realizadas a bordo del Semiramis, presentando en una perspectiva comparada la vida de los divisionarios "mártires" y "la aleccionadora tragedia de los internados". También se recurrió a poemas rusos que sonaban "como una revelación":

Adiós impura y sucia Rusia,

país de esclavo, país de señores.

Adiós a vosotros uniformes azules.

Adiós a ti, servil pueblo que lo sirves. ${ }^{4}$

Igualmente, el sistema concentracionario estalinista generó publicaciones más amplias, como la memorias de los divisionarios que compaginaban el relato de sus experiencias soviéticas con la línea política anticomunista del régimen..$^{5}$ Las memorias del internado Fulgencio García Buendia distorsionadas por la pluma del policía Vicente Reguengo también fueron utilizadas por la propaganda franquista, al igual que las del piloto Francisco Aliaga Díaz. ${ }^{16} \mathrm{~A}$ éstas se suman otras memorias de antiguos republicanos represaliados en la URSS retornados posteriormente y que pasaron a engrosar las contribuciones de la época sobre el "paraíso soviético"."

Con diferencia, las repatriaciones posteriores no tuvieron tanto protagonismo en la prensa, que publicó las listas de los repatriados y de sus familias llegadas en las tres primeras expediciones. A medida que iban arribando más repatriados, las noticias disminuían en intensidad. Los detalles sobre la emoción del reencuentro, la composición del grupo, la comisión de recep-

11 "Incesantes gestiones del Gobierno español", $A B C, 28$ de marzo de 1954

12 "Telegramme" (Paris, 9 de enero de 1954), Centre des Archives Diplomatiques de Nantes, MD/AMB, F/418; E. ARBENZ: "Repatriación de españoles de la URSS" (Madrid, 2 de julio de 1954).ACICR, Archives Générales, B AG 210 218-008.

13 Salvador LÓPEZ DE LA TORRE: "Los años muertos", Arriba, 4-18 de abril de 1954

14 Adolfo PREGO: “Héroes españoles en Rusia”, Temas españoles, 85 (1954), pp. 22

15 Véase por ejemplo Teodoro PALACIOS CUETO y Torcuato LUCA DE TENA: Embajador en el Infierno. Memorias del Capitán Palacios. Once años de cautiverio en Rusia, Madrid, Sucesores de Rivandeneyra, 1956; Gerardo OROQUIETA ARBIOL y César GARCÍA SÁNCHEZ: De Leningrado a Odesa, BarceIona, AHR, 1958.

16 Vicente REGUENGO: Quince años en Rusia, Barcelona, AHR, 1955; "Yo fui piloto en la URSS. Memorias de un manchego en Rusia", Lanza, 4 de julio de 1956-21 de agosto de 1956.

17 Ramón MORENO HERNÁNDEZ: Rusia al desnudo, revelaciones del comisario comunista español Rafón Merayo de Hungria Rafael Pelayo de Hungria, comandante del ejército ruso, Madrid, Ediciones de Actualidad 
ción, la delegación soviética de a bordo, los artículos traídos por los repatriados, etc., patentes en las crónicas relacionadas con las primeras dos expediciones desaparecieron paulatinamente en las noticias de los siguientes viajes. De hecho, las informaciones sobre la cuarta y quinta expedición quedaron reducidas a breves párrafos que dejaban constancia del número de repatriados, la recepción del grupo, su traslado y los obsequios ofrecidos a la oficialidad del buque."

Tal vez el tono ponderado de las crónicas se debió a ruegos llegados desde Moscú, a través de una carta colectiva escrita por el exiliado político Francisco Ramos Molins, quien también conoció el Gulag. Ésta fue entregada al ministro secretario general del Movimiento Raimundo Fernández-Cuesta por un joven repatriado en la primera expedición y dejaba constancia del temor de algunos españoles ante un posible aplazamiento de las repatriaciones por las autoridades soviéticas como consecuencia de "la aparición de comunicados comprometedores para los que aun están en la URSS".19

\section{Vigilancia e interrogatorios}

La alegría del regreso, el reencuentro con la familia y el país natal después de años de exilio se vieron truncados por problemas de integración y adaptación a la España franquista. Se trata de un cúmulo de factores que influenciaron negativamente en los repatriados, especialmente en parte del colectivo de los «niños de la guerra», cuya repatriación y retorno fueron ampliamente analizados. ${ }^{20} \mathrm{En}$ base a testimonios orales, los autores citados señalan las dificultades afrontadas por este colectivo, como la vivienda, un trabajo acorde con la preparación profesional, la religión, la hostilidad de la sociedad española y la campaña propagandística a la que fueron sometidos a lo largo del tiempo, la ruptura de los lazos familiares, el conflicto de mentalidades y costumbres, etc. También ha habido casos que la adaptación no planteó problemas, pero como indica Alicia Alted, los factores negativos desencadenaron un segundo exilio, puesto que casi la mitad de los retornados, regresaron a la URSS tras su repatriación. ${ }^{21}$ No obstante, la mayoría de los autores coinciden en que uno de los elementos más negativos de las repatriaciones fue el proceso de acoso policial, la investigación, la vigilancia y los interrogatorios que afectaron a los repatriados. Se trata de una temática abordada previamente, ${ }^{22}$ pero que necesita ser tratada de manera más pormenorizada a la luz de nueva documentación, aunque parcial, debido a que todavía existen legajos clasificados.

La España franquista recibió con recelo a los repatriados, «niños de la guerra», marinos, pilotos y exiliados políticos que vivieron en la URSS. La puesta en marcha de las repatriaciones fue acompañada de instrucciones cursadas por el Servicio Exterior de Falange a las Jefaturas Provinciales para conocer la filiación política y recabar informaciones político-sociales sobre

18 Véase $A B C$ y La Vanguardia, 29 de septiembre, 23 de octubre, 24 de noviembre, 19 de diciembre de 1956 y 23 de enero de 1957.

9 Luiza IORDACHE: Francisco Ramos Molins. La inquebrantable voluntad de ser socialista, Barcelona, Fundació Rafael Campalans, 2010, pp. 152-154.

20 Jesús J. ALONSO CARBALLÉS: “El retorno de los niños exiliados en 1939: de la infancia a la edad tardía", en Josefina CUESTA BUSTILLO (coord.): Retornos: de exilios y migraciones, Madrid, Fundación Francisco Largo Caballero, 1999, pp. 306-318; Alicia ALTED VIGIL: "Jeunes filles évacuées vers I'URSS en 1937. Le retour", en Rose DUROUX y Alain MONTANDON (eds.): L'émigration: Le retour, Clermont-Ferrand, Université Blaise Pascal, 1999, pp. 545-559; Carmen GONZALEZ MARTÍNEZ: "El retorno a España de los "Niños de la Guerra civil»", Anales de Historia Contemporánea, 19 (2003), pp.75-100. Y desde una perspectiva comparada Magdalena GARRIDO CABALLERO: "Fracturas de guerra: los niños de la Guerra Civil española en el Reino Unido y la Unión Soviética", Bulletin of Spanish Studies, Vol. 89, 7-8 (2012), pp. 241-254.

21 Alicia ALTED: La voz de los vencidos. El exilio republicano de 1939, Madrid, Aguilar, 2005, pp. 368-369. 22 Alicia ALTED, Encarna NICOLÁS y Roger GONZÁLEZ: Los niños de la guerra..., pp. 205-207. las familias que solicitaron la repatriación de sus hijos y datos sobre éstos. ${ }^{23}$ Para tal fin, también se publicó un comunicado en la prensa, anunciando la preparación de la primera expedición, a la vez que se indicaba a las personas con familiares en la URSS que dejaran constancia ante la CRE de los datos personales de éstos y sus circunstancias de salida de España. ${ }^{24}$

Además, la DGS emitió la siguiente instrucción:

Cada vez que llega una expedición de Rusia, la Dirección General de Seguridad remite a los Srs. Gobernadores de las Provincias a que van a residir esta clase de elementos, hojas con la filiación, procedencia y noticias con la fotografía firma y reseña dactilar de cada uno. Y material similar es enviado a las Brigadas y Secciones Locales de la División de Investigación Social de la respectiva demarcación.

Otra colección de dichos documentos es facilitada a la Dirección General de la Guardia Civil y al Alto Estado Mayor.

Las dependencias del Cuerpo General de Policía comienzan a actuar con el material indicado, desde el mismo momento de llegada al destino de cada repatriado a quién se advierte de la obligación que tiene de presentarse a la policía.

De manera sistemática se realizarán confrontes al lugar de trabajo y domicilios a pretexto de conocer su situación si están conformes con sus medios de vida etc. Ello sin perjuicio de la constante observación, sobre todo a los que trabajan, que se realiza por dispositivos confidenciales. ${ }^{25}$

La práctica de la vigilancia y de los interrogatorios con respecto a los españoles que regresaban representó una constante en el régimen franquista. Los «niños de la guerra» capturados por las tropas alemanas en la URSS fueron sometidos a interrogatorios minuciosos en Berlín y después en España. La vigilancia para conocer "la actuación y el comportamiento del repatriado" también afectó a los que llegaron de forma clandestina a finales de los cuarenta. ${ }^{26} \mathrm{Con}$ anterioridad, a raíz de la repatriación de los marinos y pilotos entre 1939-1941, los diplomáticos franquistas en Estambul remitieron informes amplios sobre la estancia de los marinos en la URSS y las circunstancias políticas, sociales y económicas que les rodearon, así como declaraciones de los mismos, proceso que siguió en España, aunque para algunos en la cárcel, tal como ocurrió con los pilotos. ${ }^{27}$ Por lo tanto, la "política del informe» no era nueva, sino que siguió aplicándose primero con los presos repatriados y después con los que regresaron en las expediciones en masa.

El recelo de las autoridades franquistas se debió también a la posible infiltración de espías al servicio del comunismo, incluso en el seno de los que llevaban años en el cautiverio. Dentro de los miembros de la comisión que acompañó a los expedicionarios, algunos pertenecían al Ministerio del Ejército y a la DGS. Según un informe reservado, mientras duró la escala del Semiramis en Estambul, éstos junto a algunos diplomáticos alli presentes pasaron revista a los repatriados, confrontando sus nombres con la lista general que se había preparado en España en base a informes previos..$^{28}$ La revisión de los repatriados camuflada bajo un "aspecto sani-

23 lbid., pp. 197, 338

24 "Rusia accede a repatriar a 500 españoles internados", La Vanguardia, 28 de julio de 1956

25 "Disposiciones de la Dirección General de Seguridad para todos aquellos que inspiren sospechas por sus actividades de conducta, relación etc." (Madrid, s.f.), Archivo General de la Administración (AGA), (08)3.02Caja44/11062.

26 Alicia ALTED, Encarna NICOLÁS y Roger GONZALLZZ: Los niños de la guerra..., pp. 181-184.

27 Luiza IORDACHE CÂRSTEA: El exilio español...pp. 91-92; 169-205.

28 José Manuel ANIEL OUIROCA: “Repatriados españoles retenidos en Rusia” (Atenas, 31 de marzo de 1954), AMAE, R5165/1. 
tario" planificada con anterioridad siguió su curso, ${ }^{29}$ ya que en otra carta se alababa "la labor investigadora y altamente eficaz [...] con tacto, delicadeza y sigilo verdaderamente ejemplares" realizada por los interrogadores. ${ }^{\circ}$ Por otra parte, el delegado nacional de Excombatientes hizo un perfil de los repatriados, entre ellos considerados como más sospechosos los pilotos, dado que alguno podría regresar "como activista camuflado del comunismo". ${ }^{31}$ En este tema abunda un artículo de The New York Times, en el que se mencionaban los interrogatorios desarrollados por el Ministerio del Ejército para asegurarse de que el Kremlin no había enviado agentes camuflados y para comprobar las opiniones políticas de los pilotos y marinos que antaño habían servido a la República. ${ }^{32}$

En este contexto de investigación de los repatriados debemos aducir el interés manifestado por la CIA. Según Gregorio Morán, los servicios de inteligencia norteamericana interrogaron a los repatriados en aguas turcas, bajo la convicción de que algunos de ellos iban a trabajar para el espionaje soviético.33 Desconocemos si la información es veraz, pero un documento desclasificado de la CIA refiere los interrogatorios realizados a los divisionarios, cuyos conocimientos fueron considerados como una contribución mínima a la inteligencia sobre la URSS debido a su aislamiento en el Gulag. ${ }^{34}$ No se dio el mismo caso con los repatriados que regresaron en las expediciones del Krym.

Tal como se puede deducir de la documentación localizada, el perfil de repatriado y su ficha biográfica se dibujaba en el barco por la comisión española encargada de acompañarles a veces desde Estambul y otras desde Odessa. El método utilizado fue la entrevista en cadena que ayudó a establecer informes sobre la expedición en cuestión: los grupos que la componían, las informaciones políticas, sociales, económicas y religiosas sobre sus miembros, las características espirituales y políticas de la emigración española en la URSS y su censo aproximativo, las condiciones de vida y los trabajos practicados, la introducción en España de agentes con misiones específicas, etc. La siguiente etapa de investigación se desarrollaba en España, configurada por interrogatorios y fichajes en lugares destinados al respecto. Alli se realizaba la clasificación de los repatriados: los colaboradores y los «sospechosos».35

Los interrogatorios prosiguieron en los años siguientes en Madrid y en las provincias de residencia con el fin de obtener informaciones sobre la URSS y desenmascarar espías "activos» o «dormidos». La labor investigadora interesaba al Alto Estado Mayor, a la DGS y a la CIA. En este sentido, resulta interesante un informe de la DGS que denotaba satisfacción por los resultados obtenidos en base a los interrogatorios realizados:

Un buen número de repatriados han sido capaces de proporcionar datos muy interesan-

29 "Acta de la reunión de la Comisión" (Madrid, 11 de marzo de 1954), AMAE, R5165/93.

30 DUQUE DE HERNANI: “Carta al Director General de Seguridad", (Madrid, 27 de abril de 1954), Centro de Documentación de la Cruz Roja española, C/68z expte.2.

31 Magdalena GARRIDO CABALLERO: “Españoles repatriados...”, pp.124-125.

32 "Madrid Checking on the Repatriates. Army Starts an Investigation of 285 Former Prisoners Freed by Russians", The New York Times, 21 de abril de 1954

33 Gregorio MORÁN: "Otra mirada sobre el "Semíramis" (I)", La Vanguardia, 3 de abril de 2004

34 Lawrence E. ROGERS: "Project Niños" (12 de enero de 1963), CIA archives, Studies in Intelligence, CSI-2001-00018, http://www.foia.cia.gov/sites/default/files/document conversions/89801/ DOC_0000608384.pdf.

35 "Cuadro general de la segunda expedición de españoles repatriados de Rusia en el buque Crimea" (Madrid, 31 e octubre de 1956) "Inform de ención triados de Rusia” (Madrid, 30 de noviembre de 1956) “Nota para el Sr. Ministro" (Madrid, 26 de triados de Rusia" (Madid, 30 de noviembre de 1956), "Nota para el Sr. Ministro (Madrid, 26 de de Seguridad Segunda expedición de repatriados de Rusia" (Madrid, 29 de octubre de 1956).ACA (8)3.02Caja44/11062.

(2aja44/11062.

tes sobre la URSS. Algunos particularmente han vivido y se han formado en grandes centros de producción de armas modernas, equipos de aviación, submarinos, motores Diese etc., y han podido proporcionar a nuestros Servicios de Información datos de interés militar, cuya obtención por otros medios hubiera resultado muchas veces casi imposible y siempre extraordinariamente costosa.

Por otra parte, y a juicio de ciertos expertos en esta clase de información, el grado de confianza que merecen los datos obtenidos puede considerarse francamente satisfactorio, a menos en el campo técnico e industrial, pues es muy difícil preparar una falsa información sobre estas materias que engañe al personal especializado. [...]

Los servicios y organismos particularmente dedicados a la observación y estudio de los asuntos relacionados con los repatriados, están de acuerdo que muchos de éstos han sido cuidosamente educados y preparados en la URSS, bien para realizar una propaganda comunista en nuestra Patria, bien para servir de enlace con el interior, o para ser empleados en el futuro si fuere necesario; todo esto constituye un peligro constante en el aspecto político y social, que obliga a una permanente actividad policial". ${ }^{6}$

En cuanto a la $\mathrm{CIA}$, su interés por interrogar a los repatriados se remonta como mínimo a julio de 1956.37 Una nota posterior sobre la cuestión resulta relevante:

"Es evidente que el mundo gira alrededor de dos órbitas políticas que tienen como centro Washington y Moscú. España porque así lo ha decidido su gobierno trabaja en colaboración con los Estados Unidos en los planes defensivos del mundo occidental, contra una agresión soviética. En la actualidad España posee un campo informativo de primerísima importancia, constituido por los repatriados españoles de la URSS, de todos los aspectos políticos, militares, económicos etc., de la vida soviética. Estas informaciones interesan en grado sumo a los Estados Unidos y cuentan con la colaboración de los Organismos Oficiales españoles idóneos". ${ }^{38}$

Desde 1957 hasta 1960, la CIA desplegó un programa de interrogatorios por cuyo tamiz pasaron 1.800 repatriados y que tuvo como resultado más de 2.000 informes positivos en inteligencia. La operación del organismo, que se centró en campos prioritarios como la producción armamentística y el potencial militar la URSS, representó un avance en los conocimientos sobre el conjunto del sistema soviético en el marco de la Guerra Fría. El autor finalizaba su informe precisando que solo con las informaciones recabadas sobre los misiles soviéticos, el coste del proyecto podría considerarse como amortizado. ${ }^{39}$

\section{Conclusiones parciales}

La propaganda anticomunista del régimen franquista como forma de lucha contra el peligro soviético que había amenazado a España y después al mundo occidental, se alimentó a lo largo del tiempo con cualquier noticia relacionada con la URSS, mostrando especial predilección por las experiencias lúgubres de los «niños de la guerra» y los españoles recluidos dentro de las alambradas soviéticas. Esta propaganda de la que se benefició el régimen en e ambiente internacional de la Guerra Fría para su paulatina incorporación al bloque occidental, se complementó con la articulación de un sistema de investigación y control de aquellos re-

36 "Repatriación de españoles procedentes de Rusia" (Madrid), AMAE, R5520/41.

37 "Probable repatriación de españoles en Rusia" (Madrid, 21 de julio de 1956), AMAE, R4484/3.

38 "Muy confidencial. Nota para el Señor Ministro" (Madrid, 19 de febrero de 1957), AMAE, R4485/41.

39 Lawrence E. ROGERS, "Project Niños..." 
los retornados podría ser un posible "caballo de Troya", una fuente de infiltración ideológica comunista o un informador al servicio de la URSS.

No obstante, la historia de este sistema de control, su funcionamiento y colaboración con

la CIA, que también utilizó los conocimientos de los repatriados sobre la URSS, se merece un estudio más profundo. Quedan todavía muchas preguntas por responder como la reacción de aparato franquista ante las solicitudes de regreso, las razones por las que acogió a los repatriados o si el mismo régimen tomó algunas medidas represivas más allá de la investigación y vigilancia de las personas. 


\section{ESPAÑA Y LA GUERRA FRÍA CULTURAL: \\ LA INFLUENCIA ESTADOUNIDENSE EN EL CÓMIC \\ DURANTE EL FRANOUISMO}

María del Pilar Loranca de Castro

\section{Introducción}

El régimen franquista obtuvo el poder tras la victoria en la guerra civil y, desde un primer momento, pretendió por todos los medios posibles mantenerse en el mismo. Así, la política exterior, como no podía ser de otra manera, quedo subordinada al objetivo primordial de consolidar el régimen. Las principales características de esa política exterior fueron:

1. Política exterior personalista, es decir, la política exterior estaba dirigida por determinadas personas, principalmente Franco y en menor medida, por los diferentes Ministros de Asuntos Exteriores.

2. Es una política pasiva o de reacción, esto es, se toman las decisiones en respuesta a resoluciones adoptadas por los países extranjeros o las organizaciones internacionales.

3. Es una política continuista sobre todo en: el mantenimiento de España en el bloque occidental, su oposición a los regímenes comunistas, su relación con las grandes potencias y en algunas de las grandes cuestiones de política internacional como la descolonización.

4. La política exterior no estuvo supeditada a un control parlamentario y popular efectivo, convirtiendo a la sociedad española en un mero espectador.'

Los diferentes autores han recurrido a diversos criterios para establecer las diferentes etapas de la política exterior española: así Rafael Calduch establece cuatro etapas: la etapa de la condicionada aceptación internacional del régimen franquista (1939-1945), la etapa de aislamiento internacional (1945-1953), la etapa de la incompleta normalización de relaciones con la dictadura (1953-1975) y la etapa de la presión internacional para la desaparición del régimen (1975-1977); ${ }^{2}$ Ángel Viñas, en cambio, lo organiza en dos fases: fase autárquica (1939-1959) y la fase de apertura internacional (1960-1975); 3 Roberto Mesa que lo divide en tres períodos: período de "neutralidad benévola" (1939-1942), etapa de incorporación al mundo occidenta (1942-1957) y la fase de elaboración de una política exterior original (1957-1969)4 o las divisiones realizadas por el profesor Álvaro Soto Carmona en diversos trabajos, donde señala cuatro etapas: la primera de 1939 a 1943 de corte fascista, la segunda de 1945 a 1953 que corresponde a la fase de aislamiento, la tercera de 1957 a 1969 que es una etapa de dinamismo y, la última etapa de crisis en los últimos años de la dictadura 1973-1975.

1 Rafael CALDUCH: “Capítulo 2. La política exterior española (I): Ias relaciones exteriores durante el franquismo", en Rafael CALDUCH: Dinámica de la Sociedad Internacional, Madrid, Ed. CEURA, 1993. Recuperado de Internet (http://pendientedemigracion.ucm.es/info/sdrelint/libzcapz.pdf).

2 Rafael CALDUCH: “Capítulo IV. La política exterior española durante el franquismo" en Rafael CALDUCH et al. (coord.): La politica exterior española en el siglo XX, Madrid, Ediciones Ciencias Sociales, 1994, p. 108.

3 Ángel VIÑAS: “La política exterior española en el franquismo”, Cuenta y razón, 6 (1982), pp. 61-78.

4 Roberto MESA: Democracia y política exterior en España, Madrid, Ed. Eudema, 1988, pp. 23-31.
A pesar de estas diferentes divisiones, todas comparten rasgos en común: la etapa de aislamiento internacional, la etapa de decadencia o desaparición del régimen y, la que nos interesa la fase de cierto aperturismo o de incorporación en los mecanismos de relaciones internacionales, que en el tiempo se sitúa dentro del marco internacional de la Guerra Fría.

Con el estallido de la II Guerra Mundial, España se declara en la "más estricta neutralidad", pero este hecho no significó que cesasen las relaciones diplomáticas y comerciales con Alemania e Italia sino todo lo contrario y esta actitud se debe principalmente: a que hasta junio de 1940 el conflicto bélico se desarrolla entre Alemania y Francia, Polonia y Gran Bretaña y a la complicada situación que vivía España dentro de sus fronteras, incapaz de realizar un nuevo esfuerzo bélico, una situación económica complicada, problemas de abastecimiento de alimento... ${ }^{5}$ El cambio de actitud de España vendrá en mayo de 1940, fecha en la que Alemania viola la neutralidad de Holanda, Bélgica y Luxemburgo, Alemania entrará por el norte en Francia. Es cuando España se declara en "neutralidad vigilada o vigilante", esta proclamación va estar ligada a dos reivindicaciones: recuperar Gibraltar y mejorar las posiciones de España en el norte de África. Éste será un breve período de tiempo y en junio de 1940 a raíz de la ocupación alemana de Francia y la entrada en guerra de Italia, España evoluciona a una situación de "no beligerancia", que se traducía en simpatía hacia el Eje y en un política más activa y agresiva, dirigida por el Ministro Serrano Súñer.7 La nueva modificación en la política exterior española se dará en 1943 declarando oficialmente la "neutralidad", disolviendo la División Azul e intentando lavar su imagen frente a los EE. UU y Gran Bretaña tras los acontecimientos en la guerra. ${ }^{8}$ La posición española durante la guerra no fue doctrinal variando según sus intereses interiores, con una política exterior encaminada a sobrevivir y supeditada a los interés del régimen.

Tras la finalización del conflicto bélico, España pasa a una situación de aislamiento internacional. Se incorpora la "cuestión española" en los debates de la Asamblea General de Naciones Unidas, tomándose dos resoluciones importantes: la Resolución 32 (I) por la que se condenaba el régimen franquista y se pedía a los países miembros que no mantuviesen relaciones con el gobierno español y la Resolución 39 (I), que tras la misma, solo mantuvieron sus embajadores Argentina, Portugal, la República Dominicana y la Santa Sede. 9

Respecto al mundo del tebeo y del cómic español, éstos habían iniciado la década de los treinta teniendo las mismas insuficiencias expresivas del período anterior, pero según avanza la década pasaría a tener varios cambios, destacando las siguientes características: por fin se había convertido en un medio de entretenimiento y divertimento, dejando atrás su cometido moralizante y didáctico de tiempo atrás, empieza a emerger una escuela de dibujantes españoles, se generaliza los tebeos para un público adulto, las publicaciones bajan de precio, consolidación de los primeros editores especializados, la imagen comienza a ocupar un primer lugar en detrimento de los textos literarios y extensión del estilo americano en el cómic. ${ }^{10}$

Es también en esta década cuando se produce la tercera entrada de cómic norteamericano. La firma Opera Mundi adquirió los derechos de los cómics de Disney para Europa y de los nuevos cómics de aventuras que se llevaban editando en EE. UU desde 1929. La entrada del cómic norteamericano influye sobre todo en los gustos de los niños y en los dibujantes jóvenes, con

5 Rafael CALDUCH: “Capitulo IV. La política exterior...”, pp. 108-110.

6 Montserrat HUGUET: “Capítulo 26. La política exterior del franquismo (1939-1975)", en Juan Carlo PEREIRA et al. (coord.): La política exterior de España (1800-2003). Historia, condicionantes y escenarios, Barcelona, Ariel, 2003, p. 496

7 Rafael CALDUCH:“Capítulo IV. La política exterior...”, pp. 110-111.

8 Montserrat HUGUET: “Capítulo 26. La política exterior...", p. 499

9 Rafael CALDUCH: “Capítulo IV. La política exterior...", pp. 118-119.

10 Antonio MARTíN: Apuntes para una Historia de los Tebeos, Barcelona, Gléñat: Viñetas, 2002, p. 72. 
especial hincapié a partir de 1934. Mostraban nuevas historias, nuevas maneras de dibujar una nueva relación entre la imagen y el texto por medio del bocadillo."

Pero con la sublevación militar de 17 de julio de 1936 todo este panorama cambia al igual que la vida de todos los españoles y tras fracasar en su objetivo más inmediato que era la toma de Madrid, dio lugar a la guerra civil. La radicalización política, sumado a la máxima que tenían los dos bandos de eliminar al adversario y la durísima represión en la retaguardia de ambos contrincantes, originó un despliegue propagandístico enorme, pasando por carteles, prensa y los cómics y tebeos que jugaron un papel importante llegando a una "guerra de papel" que se desarrollaría paralelamente a la guerra de armas. ${ }^{12}$

En un primer momento, se tenía la idea de que el enfrentamiento militar iba a durar poco y, por ello, la actividad editorial continúo con normalidad en aquellos puntos que no existía un frente abierto. Así, en Barcelona continúan editándose los títulos de la etapa anterior y por los que estaba consiguiendo fama: TBO, Las revista de Tim Tyler, Pulgarcito, Pocholo... En Valencia aparecieron nuevos tebeos como El Muchacho o KKO-Perragorda, pero tuvieron poca vida. En Madrid, poco duraron las revistas de humor La Guindilla/El Straperlo y No Veas y tras su final, no aparecería en Madrid ninguna revista de este tipo y habría que esperar a la década de los 40 para que apareciese La Codorniz. En otras zonas ocupadas, la persecución acabó con cualquier indicio de oposición por parte de dibujantes y periodistas, como por ejemplo en Sevilla desde 1936 o en Málaga desde $1937 .^{13}$

La mayoría de las historietas de la guerra iban dirigidas al público infantil, aunque también surgieron algunas encaminadas a un público más adulto teniendo gran acogida en la zona republicana. Esos tebeos mostraban el ambiente de la guerra a través de los niños, siendo ellos mismos muchas veces los protagonistas de las propias historietas para plasmar arquetipos políticos, consignas... Además, desde esas páginas fueron sometidos a un adoctrinamiento sin limites que encuentra su mayor exponente en los tebeos editados en la zona "nacional". ${ }^{4}$ De esta manera, falangistas y carlistas crearon tebeos para esa instrucción, Flechas por parte de los falangistas, creado en Zaragoza en 1936 y Pelayos del lado de los carlistas, editado en San Sebastián a finales de 1936. En cambio, en la España republicana los tebeos infantiles continuaron con su función de entretenimiento. ${ }^{15}$

Según avanzaba el conflicto bélico, en el bando de los sublevados se decidió por parte de falange la edición de un único tebeo Flecha a partir de 1937, concentrando toda la actividad en San Sebastián, ciudad donde se encontraban los talleres de impresión offsset, los más importantes de España. Desde estos tebeos se creó el prototipo negativo del "rojo", imagen desde la que se proyectaba todos los males de España: democracia, ateísmo, masonería, marxismo... La representación de los milicianos rojos siempre era deforme, con características físicas bestiales, aparecían tuertos o con cicatrices, mal vestidos, sucios, con barba y desaliñados. Eran, en definitiva, la personificación del Mal frente a carlistas y falangistas que eran los representantes del Bien. En otoño de 1938 los tebeos Flecha y Pelayos se unieron creando uno nuevo bajo el título Flechas y Pelayos y en ese año también se incautó Chicos, que había aparecido en

11 Antonio MARTín: "La historieta española de 1900 a 1950", ARBOR Ciencia, Pensamiento y Cultura, CLXXXVII 2 EXTRA (2011), pp. 86-88.

2 lbid., p. 90

13 Manuel BARRERO: "Viñetas republicanas en la Guerra Civil española”, Tebeosfera $2^{a}$ Época, 8 (2011), (antes Tebeosfera (Astiberri, 2006), pp. 33-60). Recuperado de internet (http://www.tebeosfera. com/documentos/documentos/vinetas_republicanas_en_la_guerra_civil_espanola.html).

14 Antonio MARTín: "Los tebeos de la Guerra Civil española. Niños y propaganda", Tebeosfera $2^{a}$ Época, 2 (2008), http://www.tebeosfera.com/documentos/documentos/los tebeos de la guerra civil espanola ninos y propaganda.html.

15 Antonio MARTín: “La historieta española...”, p. 91. febrero de 1938, confirmando la dirección del tebeo a Consuelo Gil. En el bando republicano, la propaganda política recayó en las revistas de humor dirigidas al público adulto: L'Esquella de la Torratxa de Barcelona, La Traca de Valencia, No Veas de Madrid. Solo se publicarían dos tebeos beligerantes para los niños: El Pionero que surgió en 1937 en el País Vasco y editado por el Partido Comunista y que desaparecería al caer Bilbao y Pionero Rojo también de 1937 editado por la organización Juventud Comunista Ibérica. Se suspendería la edición de Mickey y a finales de 1938, se editaron en Barcelona los últimos números de Pulgarcito, En Patufet, Yumbo, Aventurero y la Revista de Tim Tyler, siendo los últimos tebeos republicanos. ${ }^{16}$

\section{Los Pactos con EE. UU: un cierto aperturismo}

El aislamiento internacional al que estaba sometido el gobierno español dará un giro en 1947. Fue el año en el que se anuncia oficialmente la Doctrina Truman o politica norteamericana de contención al comunismo. Un año después, en enero de 1948, el presidente Truman aprobaba la propuesta del Consejo de Seguridad Nacional que admitía la necesidad de normalizar y arreglar las relaciones económicas y políticas con España, hecho que favoreció que Francia reabriese su frontera. ${ }^{7}$ Con la resolución 386 (V) de 1950 se derogaba las resoluciones de 1946

Oue la Asamblea General, en la segunda parte de su periodo de sesiones, celebrado en 1946, aprobó varias recomendaciones concernientes a España, una de las cuales disponía que España fuera excluida de participar como miembro en los organismos internacionales establecidos por Naciones Unidas o vinculados con éstas, y otra de las cuales tendía a obtener el retiro de los embajadores y ministros acreditados en Madrid. (...) 1. Revocar la recomendación de retiro de embajadores y ministros de Madrid (...) 2. Revocar la recomendación encaminada a impedir que España sea miembro de los organismos internacionales establecidos por Naciones Unidas o vinculadas con ésta. ${ }^{18}$

Los años 1952 y 1953 serán claves en el rumbo de la política exterior española. El primero por ser cuando gana las elecciones Eisenhower y, el segundo, por ser el año cuando el embajador de EE. UU Chase Dunn y el ministro Martín Artajo firman los tratados entre ambos países. Éstos se componían de tres pactos: el de Asistencia Técnica era de carácter defensivo por el cual se construían las bases militares de Torrejón de Ardoz, Zaragoza, Morón de la Frontera y Rota el de Ayuda para la Defensa Mutua, de tipo económico principalmente, por el que EE. UU dotaba a España de materiales militares, de servicios de adiestramiento y mantenimiento a España para su defensa, no se especificaba la cantidad de dichos materiales pero sí que España no los podría utilizar si con ello interfería en los compromisos internacionales de EE. UU y el Convenio sobre ayuda económica supeditado a la ayuda militar, que pretendía que el gobierno español se abriese al comercio exterior.19

Con estos pactos se entiende que la opinión pública española no podría temer por la concesión de soberanía al gobierno estadounidense, pero el problema viene en el documento titulado Nota adicional al párrafo segundo del artículo III del convenio defensivo entre los gobiernos de España y los Estados Unidos por el que se establecía cuando podía hacer uso los EE. UU de las bases españolas: en el caso de una amenaza comunista a Occidente y podrían hacer uso esas bases ante cualquier amenaza, bajo la restricción de que ambos gobiernos tendrían que

16 Ibid., pp. 91-95.

17 Rafael CALDUCH: “Capítulo IV. La política exterior...", pp. 120-122.

18 Resolución 386 (V) Relaciones de los Estados Modernos y de los organismos especializados con España, 4 de noviembre de 1950, Asamblea General de Naciones Unidas. Recuperado en internet (http://www.un.org/spanish/documents/ga/res/5/ares5.htm).

19 Montserrat HUGUET: “Capítulo 26. La política exterior...”, pp. 502-506.

Antonio MARTín: “La historieta española...”, p. 91.


comunicarse para explicar sus objetivos. Así se establece como el gobierno estadounidense es el que tenía la capacidad autónoma y unilateral para decidir el uso de esas bases, bajo la única condición de la comunicación urgente. Pero la cosa no se quedo ahí, España además cedió soberanía en ámbitos como la jurisdicción penal o la legislación civil. Las contrapartidas que recibió España fueron beneficiosas sobre todo para el Régimen y no para la población: a través de estos pactos España pasa a formar parte de los aliados de EE. UU; supuso un apoyo no sólo político al régimen sino también militar ya que dotó a España de infraestructuras como la red de oleoductos entre Matagorda y Rota en Cádiz, entre San Cristóbal en Cádiz y Madrid y entre Madrid y Manises, además de las bases de Torrejón de Ardoz en Madrid y Zaragoza, la terminan aeronaval de Rota en Cádiz y los múltiples centros de información, control y aprovisionamiento extendidos por diferentes puntos del país, y un apoyo económico, que significó una serie de ayudas y préstamos oficiales colaborando a que el país saliese de la situación financiera y comercial tan grave que aún vivía. ${ }^{20}$

\section{La influencia norteamericana a través del tebeo}

La década de los cuarenta será recordada por la crueldad por la que estuvieron marcados. Además del hambre que se sufría, la falta de electricidad, medicinas, dinero..., hay que señala el destierro, la cárcel y la muerta que sacudió al país dentro de la dura represión que planteó el franquismo. Solo podían editar aquellas personas que se mantuvieron fieles durante la guerra civil y los que mantenían esa lealtad al régimen. La Ley de Prensa de 1938 significaba el control total sobre la prensa, supeditada al Estado como un servicio público. Establecía la censura previa a todas las ediciones antes de su publicación. Todo este control estatal también recaerá sobre las publicaciones infantiles, que quedará ratificado con el Decreto de 1940 por el que la infancia y la juventud españolas pasaban a ser jurisdicción de la Falange Española Tradicionalista (FET) y de las JONS. De acuerdo con toda la legislación de prensa, se configuran dos categorías para las publicaciones que no sean libros: una, las publicaciones periódicas, como revistas, con título propio, con periodicidad fija y contaban con la oportunidad de recibir de Estado cupos de papel "protegido" a precios más bajos que en el mercado, las nuevas licencias para este tipo de publicaciones se otorgarían a organismos oficiales y a empresas que hubiesen colaborado de alguna manera durante la guerra civil, algunos ejemplos serían Flechas $y$ Pelayos y Chicos; y dos, publicaciones periódicas autorizadas como publicaciones unitarias o folletos, pero se debería renovar el permiso de edición número a número, cada vez con título distinto, no tenían una periodicidad fija y el papel lo compraban a precios de mercado. ${ }^{2}$

Las dos formas de publicación que controlan el mercado durante estos años son la revista de contenido diverso, orientado en su mayoría hacia la historieta de humor y el cuaderno de aventuras, con un protagonista estático, que va a tener gran divulgación hasta su desaparición a partir de $1965 . .^{22}$

En 1951 se crea el Ministerio de Información y Turismo, del que a partir de este momento van a estar subordinadas todas las publicaciones infantiles y juveniles. Se deroga la prohibición de editar nuevas publicaciones periódicas y la reducción del proceso administrativo va a dar como resultado aumento de las publicaciones. Se crea un nuevo reglamento con unas normas de censura específicas para los tebeos: dividiendo las ediciones por edades y por sexos y precisando todo aquello que se prohibía. ${ }^{23}$

20 Rafael CALDUCH: “Capítulo IV. La política exterior...”, pp. 123-125.

21 Antonio MARTín: “La historieta española...", pp. 96-97.

22 Pedro PORCEL: "La historieta española de 1951 a 1970", ARBOR Ciencia, Pensamiento y Cultura,

CLXXXVII 2 EXTRA (2011), p.130.

23 Ibid., p. 130.
Y llegamos al tema de nuestra comunicación, va a ser a partir de este momento cuando se vislumbre esa influencia norteamericana en el tebeo español, principalmente por medio de tres temas: el anticomunismo, el apoyo al capitalismo y la defensa del "American Way Life".

El anticomunismo queda plasmado en mayor o menor medida en la mayoría de los tebeos de aventuras, fundamento impuesto por los órganos censores. En Dan Jensen, historieta realizada por Jesús Blasco y publicada en la revista Alcotán en 1951, es un buen ejemplo de esto. Se publica durante 12 números, estando en la portada a color y en otras tres páginas en blanco y negro en el interior. ${ }^{24}$ El protagonista es un norteamericano, que en plena II Guerra Mundial, cae en manos de los soviéticos, de los que va a escapar dirigiéndose a la Alemania Nazi ya que en manos de los comunistas su futuro es incierto. ${ }^{25}$

Probablemente sea en la serie de Hazañas Bélicas donde se expresa mejor esta idea del anticomunismo. Se comenzó a editar en 1948 y tuvo una primera serie de 29 números seguida de una segunda de 319, reeditados luego en álbum, llegando hasta 1971. Fueron historias con guión de Boixcar, con carácter moral, sin protagonista fijo y ambientado en la II Guerra Mundial y la Guerra de Corea. ${ }^{26}$ Destaca el realismo del dibujo, gran rigor documental y es de las pocas obras de aquella época en las que muestra al ejército alemán como un modelo de virtudes. Son ellos verdaderamente quienes combaten contra el comunismo, aunque perdiesen la guerra. El comunismo se presenta como algo que traspasa el tiempo y el espacio de la guerra, se extiendo por todos los sitios. ${ }^{27}$ Los comunistas son representados llenos de vicios, cobardes, mentirosos, como la personificación del Mal... En definitiva durante toda la serie se muestra la idea del anticomunismo, elogia la valentía y el coraje de los soldados americanos y se defiende a la Alemania nazi. ${ }^{28}$

Uno de los tebeos que tuvieron como tema central el anticomunismo fue Tras el Telón de Acero, fueron 20 números desde 1952 a $1953 .{ }^{29}$ Además de proliferar varias series policiales donde la trama giraba en torno a intrigas de los servicios secretos como Aventuras del FBI o Kit Boy. Pero va a ser la serie titulada Espionaje, donde la trama se centra en el Intelligence Service británico y la CIA americana quienes descubren que están pasando información a los países del lado comunista, quienes por no tener buenos ingenieros y técnicos necesitan los descubrimientos occidentales. Asi se resalta tanto la maldad y tiranía de los comunistas como el fracaso del proyecto comunista. El espionaje será la actividad predilecta de los comunistas para mantener a flote su sistema y utilizar los avances occidentales..$^{30}$

El otro tema fue el apoyo del capitalismo, que se entiende después de ver el sentimiento anticomunista que existía en España. La mayoría de los tebeos se sustentan sobre esta filosofía capitalista: los malos son los que violan la propiedad privada, los delitos tienen una base económica y el ansia de poder es lo que mueve a la mayoría de los personajes. Será el tebeo Roberto Alcázar el que ejemplifique ese sentimiento capitalista. Comienza su recorrido en 1940 y llegará en el tiempo hasta 1975. El protagonismo aquí será compartido entre Roberto Alcázar y Pedrín su joven compañero fiel. Son unos detectives privados, que poco a poco se llegarán a presenta como agentes de la Interpol y colaborarán con Scotland Yard, la prefectura del Sena y el FBI. Participarán en investigaciones en China, Canadá, selvas latinoamericanas... Se trata de detectives

24 Alcotán, Ediciones Clíper, Barcelona, 1951, http://www.tebeosfera.com/obras/publicaciones/ alcotan cliper 1951.html.

25 Salvador VÁZOUUZZ DE PARGA: Los cómics del franquismo, Barcelona, Planeta, 198o, p. 122.

26 Ibid., p. 123.

27 Antonio ALTARRIBA: La España del tebeo, Madrid, Espasa Calpe, 2001, pp. 267-289.

28 Salvador VÁZOUUEZ DE PARGA: Los cómics..., pp. 124-125.

29 Tras el Telón de Acero, Barcelona, Ediciones Toray, 1952-1953, http://www.tebeosfera.com/obras/

publicaciones/tras el telon de acero toray $1952 \mathrm{html}$.

30 Salvador VÁZOUEZ DE PARGA: Los cómics..., p. 126. 
de alto rango, que se desplazan en coches caros, se alojan en hoteles de primera, utilizan yates de lujo, leen las noticias de la Bolsa... Suelen ser contratos por grandes empresarios petrolíferos, grandes propietarios, condes... ${ }^{31}$ Es en definitiva, un detective rico que trabaja con ricos.

Por último, y conectado con los dos temas anteriores esta la defensa del "American Way Life". Pero esto no se limitó solo al mundo del tebeo, sino que el cine, la literatura y, en definitiva, casi todos los aspectos de la vida se vieron influenciados. En lo que respecta al cómic, los héroes norteamericanos recuperaron sus nombres originarios excepto aquellos que ya se habían hecho populares con su denominación española como El Hombre Enmascarado. Los héroes españoles ahora van a formar parte del FBI o del ejército americano como es el caso de Bravo Español creado por Alejandro Blasco, editado en la revista Alcotán. El protagonista, Juan Bravo (nombre que recibe de un famoso comunero) forma parte de las Fuerzas Armadas Americanas y la verdadera patria que defiende son los EE. UU. Los cuadernos de la serie Yanky Boys en sus portadas se podía leer "Tres muchachos americanos en lucha por su patria y po la justicia", y a continuación se lee una breve explicación sobre la historia de ese número. La serie es realizada en España y por españoles, pero a mediados de los cincuenta la patria ya no es España sino EE. UU como los galantes defensores de los valores occidentales. Donde mejor se expresa el mundo de los gángsters, tema recurrente también, es en la serie publicada en la revista El Coyote con el título Audaz, Detective Privado. Se intercalan aquí los paisajes urbanos, la música de jazz, vehículos, bares..., elementos que nos trasladan a los EE. UU.32

\section{Conclusiones}

A lo largo de esta ponencia, se ha realizado un repaso entre los tebeos más representativos y que mejor plasman esa influencia estadounidense. Hay que mencionar que tal predominio de lo norteamericano no solo se limito al cómic sino que va más allá, desde los años cincuenta los EE. UU incluyen a España en los circuitos de intercambio educativo, técnico y científico, ${ }^{33}$ en el cine, en el modo de vida...

Esta filtración estadounidense hay que entenderla dentro del conflicto de la Guerra Fría, la posición de los EE. UU obedece a captar a otro adepto más en su lucha contra el comunismo además de hacerse con la ayuda y beneficiarse de la posición geoestratégica de España en el caso de que se entrase en guerra.

Igualmente, fue el resultado de una "política de aceptación" de los Pactos de 1953. Era una forma también de control sobre la opinión pública y que ésta tolerase y consintiese las cláusulas de dichos pactos que beneficiaban en mayor medida a los norteamericanos.

Fue en definitiva, un respiro para la dictadura que se ve así de nuevo inserta en los circuitos de relaciones internacionales, responde a un cierto aperturismo del régimen y se encuadra en la búsqueda de partidarios de los EE. UU a su causa de lucha contra el comunismo.

31 Antonio ALTARRIBA: La España..., pp. 240-251.

32 Salvador VÁZOUUEZ DE PARGA: Los cómics..., pp. 132-137.

33 Véase Lorenzo DELGADO GÓMEZ-ESCALONILLA: “Las relaciones culturales entre España y los Estados Unidos, de la Cuerra Mundial a los Pactos de 1953", Cuadernos de Historia Contemporánea, 25 (2003), pp. 25-59. 


\section{DOS NO BAILAN SI UNO NO OUIERE.}

\section{LA SOCIALDEMOCRACIA ALEMANA Y EL SOCIALISMO}

\section{ESPAÑOL EN LOS AÑOS SESENTA}

Antonio Muñoz Sánchez

Instituto de Ciências Sociais - Universidade de Lisboa en los años centrales de la década por parte de los compañeros alemanes. $Y$ asistiremos al declinar de la dicha estrategia, apuntando a los factores que, en opinión del autor, la explicarían el rechazo furibundo que encontró en las organizaciones tradicionales del socialismo español, la resistencia del socialismo europeo a acompañar a los compañeros alemanes en una política posibilista hacia la España de Franco, y la propia inconsistencia de los socialistas del interior.

\section{La socialdemocracia alemana apoya al socialismo en España}

EI IG Metall, integrado en la Confederación Alemana de Sindicatos (DGB), fue pionero en la RFA y en Europa en el apoyo al antifranquismo en España. Su banco de pruebas lo tuvo en el trabajo con las decenas de miles de españoles que se establecieron en los grandes centros industriales alemanes a partir de la firma del convenio de emigración entre Bonn y Madrid en marzo de 1960. En estrecha colaboración con socialistas españoles como Manuel Fernández-Montesinos, Carlos Pardo o Santiago Rodríguez, los dirigentes del sindicato Max Diamant y Hans Matthöfer impulsaron una política de promoción de la socialización democrática entre y Hans Matthöfer impulsaron una política de promoción de la socialización democrática entre
los emigrantes, con medidas como la apertura de oficinas de asesoramiento, la edición de revistas y boletines, la organización de cursos de formación y el respaldo a los centros democráticos españoles. La respuesta de los metalúrgicos españoles a estas medidas fue extraordinariamente positiva y ya en 1965 más de un tercio de ellos (20.000) se habían afiliado al IG Metall. Por entonces, este sindicato alemán era probablemente en la organización demoIG Metall. Por entonces, este sindicato alemán era probablemente en la organización demo-
crática con mayor número de miembros españoles en cualquier lugar del mundo. De paso, el crática con mayor número de miembros españoles en cualquier lugar del mundo. De paso, el
sindicato se había convertido en la bestia negra de las autoridades españolas en la RFA, que se veían incapaces de contener el desarrollo del activismo antifranquista entre los emigrantes. ${ }^{3}$

A través de sus colaboradores españoles, el IG Metall conoció la realidad sindical en el interior de España, y simpatizó instantáneamente con los jóvenes activistas que trabajaban por reanimar el movimiento socialista a raíz de las masivas huelgas en Asturias y otras regiones durante la primavera de 1962. Con apoyo del IG Metall y de la Federación Internacional de Trabajadores de Industrias del Metal (FITIM), en octubre de aquel año se fundó en Barcelona y en Madrid la Alianza Sindical Obrera (ASO), en la que participaban anarquistas, activistas católicos y sobre todo ugetistas, entre ellos emigrantes como Josep Pallach y Manuel Fernáncatólicos y sobre todo ugetistas, entre ellos emigrantes como Josep Pallach y Manuel Fernández-Montesinos. La ASO defendía el entrismo en el Sindicato Vertical y participó en 1964 junto comisiones obreras legalmente elegidas. Convencido de que aquellas comisiones podían ser el germen de un sindicato unitario democrático español, el IG Metall redobló desde entonces su solidaridad con ASO. A finales de aquel año Manuel Fernández-Montesinos fue liberado de sus folidaridad con ASO. A finales de aquel año Manuel Fernandez-Montesinos fue liberado de su activistas se contaban ya algunos emigrantes retornados de Alemania. Además, el IG Metal intentó mover a los compañeros europeos y americanos a que apoyaran a esta organización para fortalecer el componente moderado en las nacientes comisiones obreras. 4

A la altura de 1964, la opinión generalizada en los círculos progresistas de la RFA era que, mediante su apoyo al movimiento democrático dentro de España, el IG Metall había abierto una vía por la que debía transitar el resto de organizaciones de la socialdemocracia alemana y

3 Antonio MUÑOZ SÁNCHEZ: “El Sindicato Vertical 'al servicio del emigrante': la Agregaduría Laboral de la Embajada de España en Bonn durante los años sesenta", Historia, Trabajo y Sociedad, 3 (2012), pp. 115-136.

4 Antonio MUÑOZ SÁNCHEZ: "Entre dos sindicalismos. La emigración española a la RFA, los sinAntonio MUNOZ SANCHEZ: "Entre dos sindicalismos. La emigración española a la RFA, los sinfundación $1^{\circ}$ de Mayo 1 (2008): Carlos SANZ:“Un sindicto Trabajadores y los trabajadores españoles en Alemania (1961-1976)", en Alicia ALTED (dir): UGT de reto de la emigración económica, 1957-1976, Madrid, Fundación Francisco Largo Caballero, 2010.
Sobre los conservadores alemanes y el franquismo, véanse Birgit ASCHMANN: "Treue Freunde...?" Westdeutschland und Spanien, 1945-1963, Stuttgart, Franz Steiner, 1999; y Carlos SANZ DÍAZ: Espana y la República Federal de Alemania (1949-1966). Política, economía y emigra
fría y la distensión, Tesis doctoral, Universidad Complutense de Madrid, 2005.

2 Hans APEL: "Spanien und die EWG", Pressemitteilungen und Informationen [boletín de información del SPD], 16 de enero de 1967. 
el conjunto de la izquierda moderada europea. Durante el juicio en el Tribunal de Orden Público en febrero de ese año a varios activistas del PSOE, entre ellos Antonio Amat, el corresponsa en Madrid del Süddeutsche Zeitung escribía: “qquién se ocupa en Europa de los [socialistas] en España? ¿Hay, por ejemplo en el SPD, una política constructiva hacia España que mire al futuro en lugar de a la guerra civil? Sin el apoyo de Europa aquí todo seguirá siendo igual. Y si algo cambia, como mucho será hacia la radicalización de la oposición en dirección al comunismo".5 Con la elección de Willy Brandt como presidente del SPD en aquellas mismas fechas, el partido pasó a hacer suyos estos puntos de vista y se puso manos a la obra para reorientar su política hacia el movimiento antifranquista, cuyo único interlocutor hasta el momento había sido la dirección del PSOE en Toulouse.

Especialmente activo se mostraría en este sentido el vicepresidente del SPD, Fritz Erler. Desde que conociera España durante unas vacaciones en 1962, Erler venía sosteniendo ante los compañeros de partido que el socialismo europeo debía acabar con el cordón sanitario que había impuesto al franquismo en los años cuarenta. Este paso era necesario para hacer llegar su mensaje a la sociedad española y para que en esta se asentase la identificación entre europeísmo y democracia, desmontando así la falacia publicitada por el gobierno de Madrid y organizaciones por él subvencionadas como el Centro Europeo de Documentación e Información (CEDI), de que no existían impedimentos políticos para la entrada de España en la CEE. Se trataba también de dar aliento al nuevo socialismo que estaba surgiendo en el interior y que trabajaba no ya como los exiliados por el utópico objetivo de derribar al régimen sino por el más realista de ensanchar las parcelas de libertad. ${ }^{6}$

Salvando no pocas reticencias y dudas dentro de su propio partido, en abril de 1965 Fitz Erler viajó a Madrid invitado por el Instituto Nacional de Estudios Políticos para impartir una conferencia. El vicepresidente del SPD quedó sorprendido por el ambiente distendido de las calles de Madrid, a años luz del que conoció en la Alemania del III Reich (que le había confinado durante años en un campo de concentración) y en aquellos países del Este por los que Fritz Erler había viajado últimamente. Durante su primer día en Madrid, Erler pronunció su conferencia en francés sobre Bad Godesberg, a la que siguió un largo debate con un público muy informado y participativo. A continuación cenó con sus anfitriones del Sindicato Vertical y departió algunos minutos con el ministro José Solís, quien se acercó al local para cumplimentarle. Al día siguiente, Fritz Erler se reunió con el representante del PSOE en la capital de España, con un grupo de activistas de ASO y con el profesor Enrique Tierno Galván, cuya inteligencia, talante y discurso moderado le cautivaron. Antes de abandonar el país, el vicepresidente del SPD dio una rueda de prensa en la que de forma inequívoca afirmó que España no podía ser miembro de la CEE mientras perdurase la dictadura de Franco. ${ }^{7}$ En la RFA, el viaje de Erler a Madrid tuvo un gran impacto mediático y fue unánimemente valorado como una contribución relevante a la evolución política española. La televisión alemana realizó incluso un programa especial sobre España en horario de máxima audiencia. En él se daba voz a miembros de la oposición y del régimen, como José Luis López Aranguren y Emilio Romero, quienes coincidieron en señalar que las dos Españas se estaban diluyendo y se avanzaba, a paso lento pero seguro, hacia un horizonte de democracia. ${ }^{8}$ Para el SPD, en fin, el viaje de Fritz Erler a Madrid constituyó un éxito, también en lo que se refiere al contacto con la oposición. A partir de entonces se abría, así

5 "Madrid: Sozialismus im Kreuzverhör", Süddeutsche Zeitung, 13 de febrero de 1964

6 Carta de Fritz Erler a Hans-Eberhard Dingels, secretario de relaciones internacionales del SPD (8 de mayo de 1963), Archiv der sozialen Demokratie (AdsD), Bonn, Legado de Fritz Erler, Carpeta 154.

Informe del embajador de la RFA, Helmut Allardt, al Auswärtiges Amt sobre la visita de Fritz Erler a Madrid (15 de abril de 1965), Politisches Archiv - Auswärtiges Amt, Berlín, Carpeta B26/318.

8 Transcripción del programa Report, emitido por la TV de la RFA el 12 de abril de 1965, AdsD, Legado de Fritz Erler, Carpeta 24A. lo creyó el partido en un alarde de optimismo, una nueva y luminosa etapa en las relaciones del socialismo europeo y el socialismo español.9

Para reforzar el incipiente movimiento socialista dentro de España, el SPD decidió invitar a su figura más destacada, Enrique Tierno, a realizar un viaje promocional a Alemania. Invitada por el partido a organizar esta visita, la Fundación Friedrich Ebert diseñó un programa amplísimo de tres semanas que permitiría a Enrique Tierno introducirse en los ambientes intelectuales de la RFA y conocer a la flor y la nata de la socialdemocracia alemana. La visita se inició en Berlín occidental a comienzos de febrero de 1966 Allí Tierno dio diversas conferencias y fue recibido por el alcalde-presidente de la ciudad, Willy Brandt. En la segunda semana, el viejo profesor se hospedó en Bonn, y se encontró entre otros con parlamentarios y dirigentes del SPD, de la DGB, de las Juventudes del SPD, de la Fundación Ebert y del Consejo Alemán del Movimiento Europeo. La tercera semana estuvo en Frankfurt, donde se reunió con el presidente del IG Metall Otto Brenner y conoció de la mano de Max Diamant y Hans Matthöfer la fructífera labor realizada por el sindicato entre los emigrantes. En Frankfurt, Tierno dio el primer mitin de su vida ante un público de cientos de obreros españoles. También debatió con el dirigente de ASO Josep Pallach y con el director del Centro de Documentación y de Estudios, Julián Gorkin, quienes a invitación del IG Metall habían venido desde Francia para tratar con e profesor sobre una posible colaboración. A todos sus interlocutores, Enrique Tierno expuso la idea de que el futuro del socialismo democrático español no estaba en los exiliados sino en los activistas del interior y era por tanto a estos a quienes debía apoyar masivamente la izquierda europea. El profesor dejó una excelente impresión en Willy Brandt, que a partir de entonces lo consideró como la personalidad con mayor proyección del socialismo español. ${ }^{10}$ Tierno no dejó tan buena impronta sin embargo en el IG Metall. El profesor desconfiaba de ASO porque, dijo, estaba manipulada por José Solís. En su opinión, las comisiones obreras -de las que entretanto ASO se había distanciado- era la única organización sindical seria y los socialistas debían cooperar con ella aunque algunos de sus líderes fueran comunistas. Tampoco sintonizó Tierno con Julián Gorkin y Josep Pallach." Días después de la visita de Tierno a la RFA, la Fundación Ebert organizó en su escuela de formación de Bergneustadt, cercana a Colonia, un seminario para activistas antifranquistas llegados directamente de España. En él participaron 28 activistas políticos, sindicales y culturales como el intelectual galleguista Ramón Piñeiro o el dirigente de Esquerra Republicana y futuro presidente del Parlamento de Cataluña Heribert Barrera. ${ }^{2}$ Otro seminario similar en el mismo centro de formación se celebró en verano de 1966. Tuvo una duración de dos semanas y los participantes eran en su mayoría estudiantes próximos a la Unión Sindical Obrera (USO), que por entonces colaboraba con la ASO; entre ellos se encontraba Enrique Barón.13

Con la organización de la visita de Enrique Tierno y de los seminarios en Bergneustadt, la Fundación Ebert había abierto horizontes desconocidos hasta entonces en la relación del socialismo europeo con el socialismo español. Por primera vez, un destacado antifranquista residente en España había sido invitado formalmente y a plena luz del día a reunirse con dirigentes de la izquierda de un país europeo, obteniendo así un enorme capital político. No menos relevantes habían sido los seminarios, donde participaban muchos jóvenes que conocían

9 "Spanien", Parlamentarisch-Politischer Pressedienst (boletín de la fracción del SPD en el Bundestag), 9 de abril de 1965.

10 Günter Grunwald, julio de 2010, Bonn, entrevista realizada por el autor. Grunwald fue director general de la Fundación Ebert entre finales de los años cincuenta y mediados de los años ochenta.

11 Informe de la Fundación Ebert sobre la visita de Tierno a la RFA (4 de marzo de 1966), AdsD, Legado Fritz Erler, Carpeta 95

12 Informe sobre el seminario (s.f.), AdsD, Fondo FES, Carpeta 1373.

13 Informe sobre el seminario (s.f.), AdsD, Fondo FES, Carpeta 1374. 
alli por vez primera la realidad europea y democrática. Si a estas actividades de la Fundación Ebert le unimos el respaldo del IG Metall a ASO y la visita del vicepresidente del SPD a Madrid comprenderemos por qué la socialdemocracia alemana llegó a convertirse en los años centrales de los sesenta en una esperanza para la izquierda moderada en España. Por entonces, el movimiento socialista ibérico no era más que un archipiélago de pequeños grupúsculos inconexos, carentes de infraestructura y con una línea ideológica muy poco definida. El apoyo de la poderosa socialdemocracia alemana, al que quizás seguiría el del resto de la izquierda europea, podía crear una dinámica constructiva que sirviera a la reconstrucción orgánica, la renovación ideológica y la inserción del socialismo en España en la red del socialismo europeo. Así lo había expuesto Enrique Tierno durante sus conversaciones con dirigentes socialdemócratas, a los que había propuesto que se diera un impulso a esa colaboración por medio de la edición de libros, la organización de seminarios de formación también en España, y la apertura de una línea de becas de estudio para universitarios en la RFA. Como medida estrella, Tierno había animado a la Fundación Ebert a establecer una delegación en Madrid con la cual, entendía el viejo profesor, los compañeros alemanes contribuirían a dar un poderoso impulso al movimiento socialista en España. ${ }^{14}$

Abrir una oficina de la Fundación Ebert en plena capital del franquismo para colaborar con los demócratas españoles no era por aquella altura una idea tan descabellada como pudiera parecer a primera vista. Desde la reciente promulgación de la Ley de Asociaciones, la oposición democrática estaba creando centros que le servían para realizar con cierta libertad actividades de carácter cultural con clara intencionalidad política. Algunos de estos centros estaban sostenidos desde el extranjero, como el Comité Español del Congreso por la Libertad de la Cultura, cuyo responsable era Pablo Martí-Zaro, participante en uno de los seminarios de la Fundación Ebert para españoles en la RFA ya referidos. Financiado por el gobierno de los Estados Unidos a través de diversas organizaciones y fundaciones, el Comité trabajaba por conectar internacionalmente a los sectores progresistas españoles y fomentar las tendencias moderadas dentro de la oposición a la dictadura, buscando así evitar el sobrepeso del comunismo en el movimiento antifranquista. El Congreso organizaba debates entre intelectuales, otorgaba becas de estudio en el extranjero y publicaba libros en su editorial Seminarios y Ediciones. Entre sus colaboradores se contaban Enrique Tierno Galván y su mano derecha Raúl Morodo. ${ }^{5}$

\section{PSOE y UGT se defienden de la "injerencia alemana"}

Las medidas desplegadas por los socialdemócratas alemanes en apoyo al movimiento antifranquista dentro de España a partir de comienzos de los años sesenta tenían como objetivo fundamental contribuir al fortalecimiento y la renovación del PSOE y la UGT. Por ello, irónicamente, estas iniciativas solidarias iban a encontrar la absoluta hostilidad y falta de colaboración de ambas organizaciones españolas, cuyas direcciones estaban en el exilio. Rodolfo Llopis y el resto de dirigentes del socialismo español habían renunciado tiempo atrás a la idea de reconstruir el partido y el sindicato en España hasta la muerte de Franco y hacían todo lo posible por desactivar y marginar a los activistas del interior que, como Antonio Amat, se oponían a esta línea de acción. El apoyo político, logístico y económico de los miembros de la IS y de la CIOSL constituía para el PSOE y la UGT en el exilio la piedra de toque de su supervivencia y estaban por ello dispuestas a defenderlo con uñas y dientes. Se entiende así que para Llopis y los suyos, los socialistas del interior que buscaban la solidaridad internacional fueran peligrosos

14 Informe de la Fundación Ebert sobre la visita de Tierno a la RFA (4 de marzo de 1966), AdsD, Legado Fritz Erler, Carpeta 95

15 Olga GLONDYS: La Guerra Fría cultural y el exilio republicano español. Cuadernos del Congreso por ismo, Congreso por la libertad de competidores contra los que debían defenderse a toda costa, sin importar el daño que pudieran causar con esta actitud al socialismo y a la causa antifranquista en su conjunto. La falta de interés del PSOE por el congreso de Munich en 1962, su permanente boicot a toda iniciativa de la UGT con los jóvenes emigrantes españoles en Europa y, en definitiva, la crisis profunda en la que el partido y del sindicato se fueron hundiendo durante los años sesenta encuentra en esa defensa intransigente por parte de Toulouse del monopolio de los contactos internacionales frente al socialismo del interior su principal causa. De cara a la galería, los dirigentes de PSOE y la UGT intentaban legitimar su postura con argumentos de escaso peso. Contra toda evidencia, defendían que la dictadura no había cambiado un ápice desde 1939 y que la represión seguía siendo brutal. En aquellas condiciones, no sería posible reconstruir el partido y el sindicato en España. Por ello, todos los que se decían renovadores del socialismo en el interior eran ilusos, aventureros e "idiotas útiles" del régimen, cuando no directamente colaboradores y policías infiltrados. ${ }^{16}$

La socialdemocracia alemana maduró su política de apoyo a los socialistas del interior no solo de espaldas a los intereses de los líderes del PSOE y de la UGT sino también al margen de los compañeros de la IS y la CIOSL. Los alemanes esperaban que los frutos positivos de sus iniciativas convencieran a unos y a otros de que aquella era la estrategia a seguir, pues en definitiva no buscaba otra cosa que promover en España un socialismo moderno capaz de hacer sombra a los comunistas y favorecer una transición pacífica tras la muerte de Franco. Una vez más, el cálculo de los compañeros alemanes estaba errado. La mayoría de partidos y sindicatos socialistas europeos no habían sufrido un proceso de total desideologización como en e caso del SPD después de su congreso de Bad Godesberg en 1959, y la mitificada guerra civil ofrecía para ellos enormes resistencias al desarrollo de actitudes que pudieran ser vistas por sus propias bases y por el conjunto de la izquierda europea como una concesión al régimen fascista español. Se explica así por ejemplo el estupor que la estancia de Fritz Erler en Madrid provocó entre los compañeros a uno y otro lado del Atlántico. Tras conocer por la prensa su viaje a la capital del franquismo, el secretario general de la CIOSL escribió a Fritz Erler una carta en la que lamentaba que el SPD hubiera tomado una iniciativa de tanto peso sin considerar los daños que esta suponía para la estrategia común de la izquierda europea en la cuestión española. Los colegas alemanes se debían preguntar qué sentido tenía que mientras la CIOSL rechazaba las repetidas invitaciones del Sindicato Vertical para que una delegación visitara España, el vicepresidente del SPD la aceptara sin más. Aquella falta de unidad en la estrategia de la izquierda europea sólo tenía un beneficiario: Franco. ${ }^{17}$ Similar fue la argumentación del poderoso sindicato norteamericano AFL/CIO. Para sus líderes no importaba lo más mínimo lo que Fritz Erler hubiera dicho o hecho en España, si había apoyado a los socialistas o había afirmado en público que España no entraría en la CEE hasta que no fuese un país democrático. Lo verdaderamente relevante era que, con su presencia en Madrid, Fritz Erler, una personalidad de primer orden de la izquierda europea, había contribuido al esfuerzo del régimen de Franco de presentarse ante el mundo como un sistema totalmente normalizado y aceptado. La visita había pues servido para que la dictadura se sintiera más segura y fuerte. ${ }^{18}$

16 Visiones complementarias sobre la decadencia socialista durante el franquismo las tenemos en Abdón MATEOS: EI PSOE contra Franco. Continuidad y renovación del socialismo español 1953-1974 Madrid, Editorial Pablo Iglesias, 1993; Santos JULLÁ: Los socialistas en la politica española, 18791982, Madrid, Taurus, 1997; y Luis Carlos HERNANDO: El PSOE y la monarquía. De la postguerra a la transición, Madrid, Eneida, 2013.

17 Carta de Hans Buiter a Fritz Erler (7 de abril de 1965), AdsD, Legado Fritz Erler, Carpeta 154

18 Carta de Jay Lovestone a Fritz Heine (SPD), reenviada por éste a Fritz Erler (14 de mayo de 1965), AdsD, Legado Fritz Erler, Carpeta 154 
Los únicos que estaban en situación de convencer a los líderes de las organizaciones políticas y sindicales miembros de la IS y de la CIOSL de que las posturas de los compañeros alemanes no estaban equivocadas sino que iban por el buen camino eran precisamente el PSOE y la UGT. Pero, como hemos visto, los exiliados no estaban precisamente por la labor. Desde que el IG Metall respaldase la creación de ASO a finales de 1962, Toulouse venía rechazando y boicoteando todas y cada una de las iniciativas de los socialdemócratas alemanes dirigidas a apoyar a los renovadores del interior y había convertido a Max Diamant y a Hans Matthöfer en sus enemigos jurados. Quien se atreviera a seguir los pasos del IG Metall, advertía Toulouse a los compañeros europeos, no haría otra cosa sino promover la normalización del régimen, traicionar a los mártires de la guerra civil y participar en una conspiración internacional dirigida a acabar con el único y verdadero socialismo español. ${ }^{19}$ Incapaz de convencer al SPD de que cancelara la visita de Fritz Erler a España, Rodolfo Llopis la presentó ante los compañeros europeos como un acto de gigantesca irresponsabilidad política además de una traición al PSOE y a la UGT por alimentar la propaganda franquista según la cual existía una oposición radical en el exilio y otra moderada en el interior. ${ }^{20}$ El encuentro de Fritz Erler con Enrique Tierno Galván publicitado en la prensa internacional encendió todas las alarmas en Toulouse. Ante el temor de que pudiera cuajar en España un núcleo socialista en torno al viejo profesor que focalizara la atención de la izquierda europea, el PSOE lanzó una campaña contra él y sus acólitos. En el verano de 1965, Enrique Tierno y su fiel compañero Raúl Morodo fueron expulsados del partido. ${ }^{21}$ Contemporáneamente, los miembros de la IS y de la CIOSL recibieron un venenoso dossier anónimo, aunque sin duda concebido por socialistas españoles, que presentaba al profesor como un oportunista que mantenía sospechosas relaciones con el régimen y que había pretendido controlar el PSOE para ponerlo al servicio de oscuros intereses. ${ }^{22} \mathrm{~A}$ partir de entonces ya no debía quedar ninguna duda para el socialismo europeo: quien siguiera respaldando a Enrique Tierno Galván estaba atacando al socialismo español y haciendo el juego al fascismo.

\section{Willy Brandt pliega velas}

Con su decisión de invitar a Enrique Tierno Galván a la RFA, el SPD fue consciente de que había llegado a un punto crítico en su relación con el socialismo español. ¿Debían mantener su estrategia de apoyo al interior y romper definitivamente con el exilio, o debían seguir las directivas de la IS y la CIOSL y volver a apoyar solo a Toulouse? Esta cuestión fue debatida por dirigentes del SPD, de la Fundación Ebert y del IG Metall en una reunión conjunta de marzo de 1966. Allí se defendieron las dos posturas que dentro de la familia socialdemócrata habían tomado forma en los últimos tiempos. Para un grupo, representado allí por el secretario de relaciones internacionales del SPD, Hans-Eberhard Dingels, lo determinante era que en España el panorama de la izquierda no comunista era terriblemente confuso, no había un solo grupo con un mínimo de solidez, y estos se ignoraban cuando no se combatían los unos a los otros. En aquella situación, los socialdemócratas alemanes no debían volcarse en un apoyo al interior que, además de un éxito improbable, iba a tener en frente a los exiliados. Ello aseguraba un conflicto nada deseable con la familia socialista europea, que ya había dejado claro tras la visita de Fritz Erler a Madrid su rechazo a aquellas iniciativas que no respetasen el catecismo

19 Abdón MATEOS: Exilio y clandestinidad. La reconstrucción de UGT 1939-1977, Madrid, UNED, 2002, pp. 158-167.

Carta de Pascual Tomás, secretario general de la UGT a Omer Bécu (16 de abril de 1965), Archivo de la Fundación Francisco Largo Caballero, Alcalá de Henares, Fondo UGT, Carpeta 372-1.

21 Carta de Rodolfo Llopis a Rolf Reventlow, dirigente del SPD de Munich y antiguo camarada en la guerra civil (29 de octubre de 1965), AdsD, Legado Rolf Reventlow, Carpeta 166.

22 Informe sobre Enrique Tierno Galván dirigido a Günter Grunwald (17 de septiembre de 1965) AdsD, Fondo FES, Carpeta 1364 antifranquista. Para el otro grupo, representado en la reunión por Max Diamant, la socialdemocracia alemana había roto el ensimismamiento de la izquierda europea respecto a España y debía perseverar en esa línea apoyando masivamente al interior e insistiendo ante la IS y la CIOSL para que siguieran su ejemplo. En aquella partida se jugaba nada menos que el futuro político de España. Diamant entendía que el aperturismo franquista iniciado en 1962 era la reacción del régimen a la presión social, política y sindical tanto interna como externa. $S$ esa presión se relajaba, el régimen se estabilizaría y no se abriría una transición democrática después de Franco. Tras exponerse y debatirse las dos posturas, Willy Brandt tomó la palabra y se decantó por la posición de Dingels. En opinión de Brandt, "no era asunto del SPD modifica sus relaciones con el PSOE y con los demás partidos de la IS y aparecer ante la opinión pública como el sabelotodo en lo referente a la cuestión española". EI SPD seguiría por tanto reconociendo únicamente al PSOE como su partner oficial en España, si bien no cortaría del todo el apoyo al interior, del que se haría responsable la Fundación Ebert. ${ }^{23}$

Con esta decisión, que pretendía contentar a todas las partes, Willy Brandt puso fin de facto a una estrategia original desarrollada por la socialdemocracia alemana para promover de forma activa desde Europa la renovación y crecimiento del socialismo español en pleno franquismo. Una estrategia que nunca llegó por tanto realmente a despegar, pero que sirve al menos de ilustración de los sinuosos caminos por los que discurrió la historia de la dimensión internacional del movimiento antifranquista. Muchos de esos caminos están todavía por descubrir por parte de la historiografía. 


\section{ARTURO BAREA, ¿UN BEVANISTA EN LA BBC?}

\section{EXILIO Y TERCERISMO EN LA GUERRA FRÍA*}

Eva Nieto McAvoy

Birkbeck College, University of London

Ni que decir tiene que la honorabilidad personal y profesional de Barea no están en causa ni para nada entran en las consideraciones que siguen. Considero su elección un grave error por parte de Vds. En este país [Gran Bretaña] está considerado (y poco importa que sea justa o injusta esta consideración para los fines prácticos que se proponen Vds.) como un bevanista, y en último término, un neutralista.

Estas palabras de Salvador de Madariaga sobre la posible incorporación de Arturo Barea (1897-1957) - autor de La forja de un rebelde y exiliado en Gran Bretaña - al Comité de Honor de la revista Ibérica en 1953 fueron escritas en el contexto de la campaña antineutralista defendida desde las páginas de Cuadernos del Congreso por la Libertad de la Cultura por los exiliados republicanos anticomunistas. Si como apunta Olga Glondys, el fragmento es un ejemplo de "cómo los parámetros de la Guerra Fría dictaban los valores de la izquierda antifranquista", esta comunicación pretende contribuir al estudio de las posturas políticas que desde el exilio republicano plantearon proyectos alternativos, no solo al Franquismo, sino a los discursos polarizados de este periodo. El fragmento de Madariaga nos permite por tanto iniciar una aproximación a la postura ideológica de Barea tanto dentro del mapa del pensamiento del exilio republicano español como en el contexto británico de producción y primera recepción de su obra; en concreto, nos permite profundizar en el significado de "neutralismo" en relación con el bevanismo (por el líder de la facción de izquierdas del Partido Laborista británico, Aneurin Bevan) y con la idea de Gran Bretaña como una "tercera fuerza" 3. Durante el Gobierno Laborista de 1945-1951, Gran Bretaña se presentó al mundo como una alternativa a los bloques americano y soviético con un socialismo democrático que, sobre los pilares de una sociedad justa e igualitaria, respetara las libertades individuales. Las medidas laboristas destacaron por e alcance de sus reformas en los inicios de la construcción del estado del bienestar en la Europa de posguerra, ${ }^{4}$ y los bevanistas -neutralistas y terceristas - fueron dentro del Partido Laborista quienes se mantuvieron fieles al proyecto socialista-democrático en el contexto de reorientación ideológica de la izquierda británica a consecuencia de las presiones de la Guerra Fría a

* Esta comunicación forma parte de la investigación de doctorado que en el departamento de lberian and Latin American Studies de Birkbeck, University of London, se desarrolla con subvención del Arts and Humanities Research Council (AHRC).

1 Carta de Salvador de Madariaga a Victoria Kent, de 29 de octubre de 1953. APSM; C101/1 y C101/2, citada en Olga GLONDYS: La Guerra Fría cultural y el exilio republicano español: Cuadernos del Congreso por la Libertad de la Cultura, 1953-1965, Madrid, CSIC, 2012, p.125.

2 Olga GLONDYS: La Guerra Fría..., p.125.

3 Jonathan SCHNEER: "Hopes Deferred or Shattered: The British Labour Left and the Third Force Movement, 1945-49", The Journal of Modern History, 56 (1984), pp.198-226 (p.198).

4 Tony JUDT: Postwar: A History of Europe since 1945, Penguin Books, 2006, pp. 74-75. finales de la década de los 40 . El tercerismo británico de la posguerra mundial constituyó para socialistas humanistas como Arturo Barea y Max Aub una esperanza ante la imposibilidad de proyecto republicano perdido en 1939 y definitivamente en $1945 .{ }^{5}$

Barea llegó a Plymouth en febrero de 1939, una de tantas víctimas de la Guerra Civil Española. Fue durante su exilio en Gran Bretaña cuando Barea se convirtió en escritor, en crítico literario y comentarista para el Servicio Latinoamericano de la BBC. ${ }^{6}$ Con esta colaboración radiofónica se convirtió en "Juan de Castilla" y se orientó al espacio transatlántico en el que sus ambiciones radiofónicas coincidieron con los intereses diplomáticos británicos. Desde 1940 hasta su muerte en 1957, Barea escribió más de 850 guiones de programas de radio en los que contaba en un registro coloquial anécdotas sobre su vida en un pueblecito de la campiña inglesa. ${ }^{7}$ Generalmente considerados por la crítica como descripciones sobre todo costumbristas con un cierto valor sociológico y ninguno literario, ${ }^{8}$ los guiones de Barea son textos con un componente ideológico que cobran nuevos significados al ser interpretados en relación con los discursos hegemónicos de la Segunda Guerra Mundial y después de la Guerra Fría, en el contexto de la estrategia general de la BBC de "broadcasting britishness" y "selling democracy" a través de su Servicio Mundial. ${ }^{9}$

En este estudio de caso, propongo leer una selección de los guiones que Barea escribió y radió para la $\mathrm{BBC}$, contrastándolos con documentos oficiales del Gobierno Laborista, con el objetivo de analizar las ideas con las que Barea participa en el discurso británico de la "tercera fuerza"; las formas en que contribuyó a construir la "iconografía sonora" de una Gran Bretaña de posguerra dirigida a los radioyentes de la BBC en Latino América durante los años cuarenta..$^{10}$ Estos guiones son además ejemplos del papel de la radio en la Guerra Fría cultural, poco estudiado hasta el momento pese a que

it is now widely recognised that the mass media played an unusually influential part in the battle between the "East" and the "West" between 1945 and 1991. The cold war was, after all, as much of a propaganda conflict - a battle of words, sounds and pictures as one fought between diplomats, soldiers and politicians. The BBC, as a broadcaster of news, comment and entertainment in Britain and large parts of the world throughout the cold war, stood at the very centre of this propaganda conflict."

5 Max AUB: Hablo Como Hombre ed por Manuel AZNAR SOLER, Sevilla, Renacimiento, 2003, pp. 105-108. 6 Para más información sobre la colaboración de Barea en la BBC, ver Luis MONFERRER CATALÁN: "La colaboración de Arturo Barea, 'Juan de Castilla', en la BBC", en El exilio literario español de 1939 "La colaboración de Arturo Barea, 'Juan de Castilla', en la BBC", en El exilio literario español de 1939,
Barcelona, Universitat Autonoma de Barcelona, 1998, pp.159-168; iD.: Odisea en Albión: Ios republiBarcelona, Universitat Autonoma de Barcelona, 1998, pp.159-168; iD.: Odisea en Albion: los republi-
canos españoles exiliados en Gran Bretaña 1936-1977, Ediciones de la Torre, 2007; Michael EAUDE: canos españoles exiliados en Gran Bretaña 1936-1977, Ediciones de la Torre, 2007; Michael EAUDE;
Triumph at Midnight of the Century: a Critical Biography of Arturo Barea: Explaining the Roots of the Spanish Civil War, Sussex, Sussex Academic Press, 20o9; Eva NIETO MCAVOY:"A Spaniard Disthe Spanish Civil War, Sussex, Sussex Academic Press, 2009; Eva NIETO MCAVOY: "A Spaniard D D
covers England: Arturo Barea and the Latin American Service", Wasafiri, 24 (2011), pp.8-10.

7 Archivo privado de Arturo Barea (APAB), Londres; British Broadcasting Corporation Written Archive Centre (WAC), Reading. Una selección de estos guiones ha sido publicada en Arturo BAREA: Palabras recobradas: textos inéditos, ed. por Nigel TOWNSON, Madrid, Debate, 2000.

8 Michael EAUDE: Arturo Barea: triunfo en la medianoche del siglo, Editora Regional de Extremadura, 2001, p.157.

9 Marie GILLESPIE, Alban WEBB y Gerd BAUMANN: "Broadcasting Britishness, Strategic Challenges and the Ecology of Overseas Broadcasting by the BBC", Historical Journal of Film, Radio and Television, 28 (2008), pp.453-458; Philip M. TAYLOR: British Propaganda in the 2oth Century: Selling Democracy, Edinburgh University Press, 1999.

10 Emma ROBERTSON: "I Get a Real Kick out of Big Ben: BBC Versions of Britishness on the Empire and General Overseas Service, 1932-1948", Historical Journal of Film, Radio and Television, 28 (2008), pp. 459-473.

11 Tony SHAW: “The BBC, the State and Cold War Culture: The Case of Television's The War Game 
Por último, el análisis de estos textos de Barea permite examinar el discurso "neutralista" del que es acusado, y redefinirlo proponiendo que la "tercera fuerza" no significó solo una posición equidistante entre la URSS y los EEUU, una neutralidad que favoreciera las posturas prosoviéticas, como la campaña antineutralista del CLC propugnaba, sino un proyecto político concreto materializado en las políticas laboristas británicas, sobre todo en aquellas defendidas por su facción más izquierdista, el movimiento de la "tercera fuerza" y los bevanistas. ${ }^{12}$ La naturaleza formalmente costumbrista de los guiones de Barea en los que describe al pueblo y a las instituciones británicas para una audiencia de habla española, sumada a la relación de interdependencia entre el gobierno británico y la BBC y entre esta y los intelectuales que trabajaban en sus servicios proporciona un contexto idóneo en el que explorar si la acusación de Madariaga es, como él mismo apunta, "justa o injusta". ${ }^{3}$

\section{Exilio, radio y la Segunda Guerra Mundial}

La BBC inauguró su Servicio Mundial'14 en 1932 con el objetivo de

'project' England overseas: to define 'Englishness' before other countries took the initiative. Such a projection of the nation, its politics, society, culture and belief systems, would be essential, [...] for the maintenance of 'peace itself'. ${ }^{5}$

Financiado por el Gobierno a partir de la creación de los servicios en lenguas extranjeras en 1938, el Servicio Mundial de la BBC entró a formar parte de la política exterior británica. El Servicio Latinoamericano comenzó a emitir ese mismo año, considerado imprescindible para combatir la vulnerabilidad política del continente ante la propaganda de regímenes totalitarios:

Countless Brazilians, Argentinians and Chileans, in position of influence and friendly towards our country, have told me how difficult it is to stand by and watch the effects of these activities and see Britain lift no finger to protect her name and interests. ${ }^{16}$

Durante la Segunda Guerra Mundial, la lucha antifascista "not by retaliation, but by the widespread dissemination of straightforward information and news" respondió tanto a la políti-

(1965)", The English Historical Review, 121 (2006), pp. 1351-1384 (p. 1353)

12 Los guiones analizados pertenecen al periodo de 1947 a 1951; desde los inicios de la Guerra Fría hasta el fin del Gobierno Laborista de posguerra. Pese a que la carta de Madariaga es de 1953, nos interesa destacar la posición de Barea con respecto al movimiento bevanista o tercerista, cuyo origen encontramos en el periodo seleccionado. Durante los años 1947-1949 el discurso de la "tercera fuerza" se convierte en hegemónico dentro del Partido Laborista y aparece con frecuencia en documentos oficiales. A su vez, los guiones de Barea contienen referencias explicitas a su posición tercerista, que va difuminándose a medida que entra en los 50.

13 En esta comunicación, destacaremos de los guiones de Barea tan solo las alusiones directas a la posición de Gran Bretaña como "tercera fuerza". Queda para otro estudio el análisis de algunos conceptos clave en la trayectoria ideológica de Barea y que matizan su interpretación de la "tercera fuerza", como su uso de las ideas de "libertad" o "socialismo". El estudio tampoco pretende abarcar los mecanismos de relación entre el Gobierno Laborista y la BBC, sino dar una visión general del contexto en el que explorar las ideas terceristas de los discursos oficiales y los textos de Barea.

14 El "BBC Imperial Service" pasó a llamarse "BBC Overseas Service" en 1939, que junto con el "BBC European Service" creado en 1941 formaban el External Services of the BBC. Se comenzó a llamar "BBC World Service" en 1988, pero usaré este término para facilitar la lectura.

15 Emma ROBERTSON: “' Get a Real Kick..."', p.459.

16 Feliz Greene (BBC) en gira por América Latina, citado en Asa BRIGGS: The BBC: The First Fifty Years,

Oxford, Oxford University Press, 1985, p. 143.

ca interna de la BBC como a la estrategia del gobierno británico. ${ }^{77}$ En esta difusión radiofónica internacional participaron no solo escritores e intelectuales británicos, sino también exiliados como Barea, por lo que a finales de los años 30 , el Servicio Mundial se había convertido en una "diasporic contact zone"; ${ }^{18}$ en un foco de refugiados europeos que usaron las ondas de la BBC para participar en la guerra de ideas desde su "puesto de batalla", ${ }^{9}$ negociando sus agendas particulares con las directrices de la emisora y la censura de guerra. ${ }^{20}$

A su llegada a Gran Bretaña, Barea rentabilizó su capital simbólico como protagonista y testigo de la Guerra Civil Española, que le proporcionó una audiencia en un contexto en el que la narrativa del conflicto español formaba parte de la memoria reciente de la izquierda británica. Su experiencia como censor, jefe del servicio de prensa extranjera del gobierno de la República y de la emisora de radio La Voz de España, así como su trabajo de locutor del programa La voz incógnita de Madrid ${ }^{21}$ tendrían que haber sido suficientes para ser reclutado por la BBC, pero resultaron ser un obstáculo inicial. Presionado por el Foreign Office, el Servicio Español de la BBC no empleaba exiliados republicanos, en un intento de mantener la supuesta neutralidad de la España Franquista. El Servicio Mundial evitó la confrontación contratando a los republicanos para su Servicio Latinoamericano - Madariaga, Luis Araquistáin o Esteban Salazar Chapela entre otros. ${ }^{22}$ Así, en octubre de 1940 "Juan de Castilla" comenzó a hablar por las ondas con el objetivo de contrarrestar la propaganda alemana e italiana en Latinoamérica. Las charlas de Barea durante la Segunda Guerra Mundial son narraciones sobre el heroísmo cotidiano de sus vecinos: un elogio aparentemente inocente al carácter nacional inglés representado por "el pueblo", que contribuyó a uno de los discursos más extendidos durante la Segunda Guerra Mundial en Gran Bretaña, conocida todavía hoy como "the people's war". ${ }^{23}$ Las descripciones de Barea transmitían una imagen de una Gran Bretaña amable, justa y libre en lucha por defender los valores democráticos, a través de una mezcla de temas tan anecdóticos como "Té a las cinco" o "La batalla de las patatas", acompañados de otros más universales como "Democracia". 24

\section{La "tercera fuerza": Gran Bretaña entre comunismo y capitalismo}

Con el fin de la Segunda Guerra Mundial, el Partido Laborista británico subió al poder con la difícil tarea de reconstruir el país. Durante la posguerra, desarrolló una política de socialismo democrático - socialista en lo económico y democrática en lo político. Encontramos entre los guiones de Barea de este periodo continuas referencias a los dos pilares del programa laborista de posguerra, base del Welfare State británico: "nationalization - notably of mines, railways, goods transportation and utilities - and the provision of medical services". ${ }^{25}$ La nacionalización de las minas, un "hecho histórico que un día tendrá su sitio en la historia de este pueblo y en la historia de todos los pueblos", ${ }^{6}$ compartió protagonismo con las charlas sobre

17 Asa BRIGGS: The BBC..., p. 142 .

18 Marie GILLESPIE: "Diasporic Creativity: Refugee Intellectuals, Exiled Poets and Corporate Cosmopolitanism at the BBC World Service", (2010) Recuperado de Internet (http://oro.open.ac.uk/26754/).

19 BAREA: Palabras Recobradas..., p. 469

20 Asa BRIGGS: The History of Broadcasting in the United Kingdom, vol. III, Oxford, Oxford University Press, 1995, p. 18 .

21 Arturo BAREA: La forja de un rebelde: Ia llama, Buenos Aires, Losada, 1954

22 Luis MONFERRER: Odisea En Albión..., pp.397-435; Asa BRIGGS, The History..., v. III, p. 434

23 Angus CALDER: The People's War: Britain 1939-1945, Pimlico, 1992.

24 Arturo BAREA: "La batalla de las patatas" (13-14 octubre de 1940), APAB, serie 2, caja 3; en Palabras..., pp. 221-224; ÍD.: "Té a las cinco" (3-4 agosto 1945), APAB, serie 2, caja 3; íD.: "Democracia inglesa” (7-8 de diciembre de 1941), APAB, serie 2, caja 3.

25 Tony JUDT: Postwar..., 69

26 Arturo BAREA: “Carbón” (5-6 de enero de 1947), APAB, serie 2, caja 3. 
el crudo invierno de 1947 que asoló Europa y que intensificó el hambre y las restricciones, pero que subrayó la importancia de que el Estado hubiera tomado "a su cargo los servicios de la comunidad que sería peligroso dejar en manos de los particulares". ${ }^{27}$

La reforma educativa, las políticas de vivienda y el Seguro Social fueron también tema de las charlas de Barea. El papel central del NHS (National Health Service) - logro del Ministro de Sanidad Aneurin Bevan - en la mejora de la calidad de vida de los británicos se debió, en palabras de Barea, a la posibilidad de que "cada ciudadano tenga derecho a un médico y a cada médico le pague el Estado, que es tanto como pagarle todos los ciudadanos." ${ }^{28}$ Como consecuencia, el NHS no trajo más que beneficios "rotundos": "En 1938 se morían 57 niños de cada mil que nacían antes de llegar a cumplir el año. El año pasado [1948], 31". El NHS, pero también el racionamiento y la reforma educativa, tuvieron para Barea el efecto de cerrar la brecha entre las clases sociales a consecuencia de su cobertura universal: "[p]obres y ricos en este país tienen derecho a asistencia médica y farmacéutica, incluidas operaciones quirúrgicas, completamente gratis. Al servicio dental, ortopédico y óptico".29

Al final de la legislatura laborista "income and wealth really were distributed as a result of the war legislation." En un discurso de enero de 1948, el Primer Ministro Clement Attlee resumía este objetivo:

The policy of democratic socialism which the Labour government is carrying out seeks to create conditions in which a good life will be attainable by every individual in the com munity, free form oppression whether by Governmental or by vested interests. Already great strides have been made towards a fairer distribution of wealth. Broad measures of social security have been passed. Basic industries are being steadily brought together under public ownership without scarifying any of the liberties which we all hold dear. ${ }^{30}$

En abril de 1948, Barea lo ratificó para una audiencia latinoamericana en estos términos:

Lo primero es que hoy Inglaterra tiene menos lujos que nunca tuvo, pero al mismo tiempo menos hambre y menos miseria que tuvo jamás. Hay menos ricos y hay muchísimos menos pobres; casi me atrevería a decir que no hay pobres. Hay trabajo para todos y trabajo decentemente pagado, el que más mal pagado está. Hay comida para todos, comida bajo decentemente pagado, el que más mal pagado está. Hay comida para todos, comida tegidos; los niños y las mujeres preñadas también. Y no protegidos con una limosna, sino con un derecho a cobrar de todos los sanos y de todos los útiles, lo que necesitan para vivir decentemente y no en la miseria ni en el asilo. No hay explotaciones ni jornales bajos, ni hay ya explotaciones de niños haciendo trabajo de hombres; hay en cambio escuelas abiertas y obligatorias hasta que los niños han cumplido quince años y hay vacaciones pagadas todos los años para todo el que trabaja en estas islas.3

27 Arturo BAREA: “Invierno" (16-17 de febrero de 1947); íD.: "Registro" (2-3 de marzo de 1947), APAB, serie 2, caja 3

28 Arturo BAREA: “Un doctor" (12-13 de diciembre de 1948), APAB, serie 2, caja 3.

29 Arturo BAREA: "Para las mujeres" (20-21 de noviembre de 1949), APAB, serie 2, caja 3; en Arturo BAREA: Palabras...,p. 263

30 "Britain and the Powers", Times, 5 de enero de 1948. Recuperado de Internet (http://find.galegroup com ezproxy lib. bbk ac uk/ttda/infomark, do?\& source=gale\&prodld=TTDA\&user-

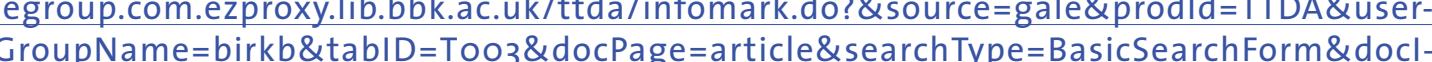
$d=C 570075941 \&$ type $=$ multipage\&contentSet $=$ LTO\&version $=1.0)$

31 Arturo BAREA: "Balance" (3-4 de abril de 1948), APAB, caja 3.
Si bien es verdad que tras el fin de la Segunda Guerra Mundial, medidas como el Seguro Social o el Servicio Nacional de Salud fueron tomadas por la mayoría de los países de la Europa occidental y democrática, Tony Judt señala cómo "nowhere outside Britain was comprehensive social coverage attempted on so generous a scale all at once". ${ }^{2}$ La idea de que una tercera fuerza europea era posible parecía materializarse en el ejemplo de Gran Bretaña. Defensores del tercerismo fueron los miembros de la rama izquierdista del Partido Laborista británico que bajo el nombre de Keep Left publicaron en 1947 un panfleto en el que además de insisti en la necesidad de continuar implementando medidas socialistas, criticaban las tendencias atlantistas del secretario del Foreign Office Ernst Bevin en relación con las crecientes tensiones internacionales en el contexto de la Guerra Fría. ${ }^{33} \mathrm{Abogaban}$ por la construcción de una Europa unida e independiente, liderada por Gran Bretaña, como una tercera fuerza que pudiera asegurar la paz y evitar la división del mundo en dos bloques dominados por la URSS y lo EEUU. 34 La "tercera fuerza" representó una alianza entre no solo los miembros del Partido Laborista, sino con los sindicatos e intelectuales de la izquierda no comunista que durante los primeros años de la posguerra hasta la década de los 50 compartieron "an unusual sense of optimism and idealism". 35 Así, pese a las discrepancias ideológicas dentro del Partido Laborista, la idea de presentarse al mundo como una alternativa tanto al estalinismo soviético como al capitalismo americano fue propuesta por el propio Ernst Bevin en enero de 1948 al Gabinete del Gobierno británico:

It is for us as Europeans and as a Social Democratic Government, and not the Americans, to give the lead in spiritual, moral and political sphere[s] to all the democratic elements in Western Europe which are anti-Communist and, at the same time, genuinely progressive and reformist, believing in freedom, planning and social justice - what one might call "The Third Force". ${ }^{36}$

La iniciativa pasó a formar parte de la política exterior británica y se hizo pública con el discurso radiofónico del Primer Ministro Clement Attlee en 1948:

At one end of the scale are the Communist countries; at the other end the United States of America stands for individual liberty in the political sphere and for the maintenance of human rights, but its economy is based on capitalism, with all the problems which it presents and with the characteristic extreme inequality of wealth in its citizens. [...] Great Britain, like the other countries of Western Europe, is placed, geographically and from the point of view of economic and political theory between these two great continental states. [...] Our task is to work out a system of a new and challenging kind, which combines individual freedom with a planned economy, democracy, with social justice. ${ }^{37}$

32 Tony JUDT: Postwar..., p. 75

33 John CALLAGHAN: The Labour Party and Foreign Policy: A History, Routledge, 2004, p. 198; Jonathan SCHNEER, "Hopes..

34 Walter LIPGENS y Wilfried LOTH: Documents on the History of European Integration: The Struggle for European Union by Political Parties and Pressure Groups in Western European Countries, 19451950, Walter de Gruyter, 1988, p. 673

35 Hugh WILFORD: The CIA, the British Left, and the Cold War: Calling the Tune?, Routledge, 2003, p. 17.

36 "Future Foreign Publicity", memorandum de Ernest BEVIN, (4 de enero de 1948), FO 1110/1/1; citado, entre otros, por Hugh WILFORD: “The Information Research Department: Britain's Secret Cold War Weapon Revealed", Review of International Studies, 24 (1998), pp.353-369 (p.356).

37 "Britain and the Powers..." 
Para Barea, las injusticias del sistema capitalista en relación con las ventajas del socialismo británico eran evidentes ya antes de que formaran parte de la estrategia tercerista. En 1947, Barea explicaba cómo el gobierno norteamericano permanecía indiferente al hecho de que sus ciudadanos pasaran hambre pese a tener una producción excedente de patatas que se exportaba al extranjero. Controlar el precio de las patatas como hacía Gran Bretaña redundaba en la riqueza de un país, que a juicio de Barea debía medirse por la ausencia "de sus mendigos y de sus hambrientos y de sus parados y estos tres grupos son tres grupos que no existen en Inglaterra"..$^{8}$

Pero su crítica no se centró solo en aspectos económicos. Durante 1948 las reflexiones de Barea sobre el papel internacional de Gran Bretaña en el creciente conflicto geopolítico fueron más explícitas. Como ejemplo, sobre las negociaciones diplomáticas secretas que se llevaron a cabo entre le URSS y los USA en mayo de 1948 escribió que los ciudadanos de los demás países del mundo no se interesaban por

ver cuál de los dos [la Casa Blanca o el Kremlin] es mejor y cuál es peor. Nosotros lo que quisiéramos es algo muy diferente. Ouisiéramos como ha dicho muy claramente el Ministro de Negocios extranjeros Mr Bevin: Paz. [...] No. No se resuelven así las cosas. Ni se resuelven de la manera que el Gobierno ruso ha pretendido hacer, ni se resuelven tampoco de la manera del gobierno norteamericano declarándose públicamente antiruso [sic] y tratando de llegar a un acuerdo con Rusia con las puertas cerradas. Las cosas se resuelven y se pueden resolver fácilmente a la clara luz del día. ${ }^{39}$

Ante las maniobras de ambas potencias, Barea alabó la libertad de expresión de que gozaba Gran Bretaña:

En Londres podéis oír cada semana a un orador comunista en plena vía pública tratando de convencer a los transeúntes. [...] En Nueva York no se puede predicar hoy el comunismo, ni en Moscú se puede predicar el sistema capitalista. [...] Vosotros, la mayoría, creéis en la fuerza, yo creo en el convencimiento. [...] En este país, donde el primer ciudadano es Rey y el segundo socialista. En este país, desde el cual me dejan hablar a mí. ${ }^{40}$

Barea no solo criticaba el capitalismo injusto de los Estados Unidos, sino que reprochaba al comunismo -por lo menos entre 1947 y 1949- su falta de libertad y su hermetismo. Como dijera Ernst Bevin en su memorándum, "[w] can fairly ask why the Communists, if life under Communist rule is so enviable, should shut themselves off so completely", en mayo de 1948 Barea también instó a la URSS a abrir las puertas de su país para mostrar al mundo "las excelencias de este régimen" y conseguir un "intercambio de ideas" con el que "veríamos todos, en paz, sobre todo en paz, las ventajas y los inconvenientes de una forma de vida y de otra y tal vez pudiéramos al fin ser capaces de seleccionar lo bueno, lo mejor, de cada lado y organizar un mundo de entendimiento y de tolerancia mutua". ${ }^{4}$

Como hemos visto, la sugerencia de Ernst Bevin en insistir en cómo "Social Democracy on the other hand, gives higher living standards for the masses and protects them against privilege and exploitation, whether Capitalist or Communist" fundamentaron los guiones de Barea de este periodo, destacando cómo la equidistancia no implicaba una ausencia de opinión ni de crítica; como ni la "tercera fuerza" ni Barea son "neutralistas". ${ }^{22}$ Es más, Barea consideraba

38 Arturo BAREA: "Decadencia" (27-28 de abril de 1947), APAB, serie 2, caja 3

39 Arturo BAREA: "Alta política" (15-16 de mayo de 1948), APAB, serie 2, caja 3.

$40 \mathrm{lbid}$.

41 lbid.

42 "Future Foreign Publicity", memorando de Ernest BEVIN, (4 de enero de 1948), FO 1110/1/1. que existía una relación de causa-consecuencia entre capitalismo y comunismo, de manera que las injusticias derivadas del capitalismo creaban las condiciones para que los trabajadores buscaran una solución en doctrinas totalitaristas como el comunismo o el fascismo. Sobre las elecciones italianas de 1948, argumentó Barea que el peligro de que hubiera ganado el Partido Comunista habría sido el mismo que hiciera arraigar el nazismo y el fascismo: el ansia de los que deseaban hacerse millonarios a costa de otros, auspiciados por "la libre competencia sin atenuantes de ninguna clase". ${ }^{43}$ En esta charla, Barea muestra cómo Estados Unidos representa el peor ejemplo de la libre competencia, no solo porque en el Sudoeste americano se estuvieran haciendo millonarios a costa de vender sus materias primas a un mundo necesitado de petróleo, algodón, trigo y carne; sino por aprovecharse de la mano de obra barata de otros países como Italia, creyendo alejarlos además del bolchevismo, pero con el efecto contrario:

Cuando los estómagos están vacíos y el pan cuesta más que se gana; cuando no hay lumbre en la cocina y los hijos lloran de frío; cuando en esta miseria se ve que hay gentes que ganan con ella millones, el convertirse en bolchevique o en nazi es muy simple; porque lo que se busca no es una solución ideológica, ni una solución política; lo que se busca es pan, es remedio a la desesperación. Y a cambio de una garantía mínima para uno y para la mujer y los hijos de uno se está dispuesto a ceder lo que se llama libertad. ${ }^{44}$

Ante la situación de crisis en Europa, Gran Bretaña parecía ofrecer una solución a la falta de justicia social americana y a la falta de libertad soviética:

Sí. En Inglaterra está organizado el trabajo, están regulados los jornales, están limitadas las ganancias, el pan está racionado y la mantequilla, el azúcar o las patatas; pero hay ganancia para todos y hay pan para todos. No hay una medida ancha para unos y estrecha para otros. Las gentes no hablan de revoluciones, ni de Mesías y cuando gritan algunos diciendo que no les dejan hacerse millonarios las gentes se sonrien. Cuando gritan otros ofreciendo el paraíso que Hitler ofrecía a los alemanes hambrientos, las gentes se sonríen también; y se sonrien por último cuando otros les ofrecen el paraíso de Moscú. [...] ¿Es que Inglaterra ha encontrado la solución? No, no lo creo, pero sí está en el mejor camino y que el mundo estaría en un camino mucho mejor si se siguiera su ejemplo, tratando de que no hubiera hambrientos y evitando que los millonarios surjan a centenares cuando hay millones que no comen. ${ }^{5}$

\section{El fin de la tercera fuerza y el bevanismo en los 50}

La "tercera fuerza" fue uno de los escenarios posibles de la posguerra que la Guerra Fría cercenó casi de raíz. Al final de la década de los cuarenta, la idea de la "tercera fuerza" fue abandonada en Gran Bretaña, como resultado de estrategias económicas y militares en el contexto de la Guerra Fría. El Plan Marshall y la reorientación atlantista, que se concretizó con la entrada de Gran Bretaña en la OTAN en 1949, fueron muestra de cómo para la mayoría del Gobierno Laborista, en comparación con las acciones hostiles de la URSS, "the US appeared, in contrast, humane". ${ }^{46}$ De este modo, los elementos más conservadores del Partido Laborista aplastaron "the positive, constructive intentions of those who retained a greater

43 Arturo BAREA: “Millonarios" (1-2 de mayo de 1948), APAB, serie 2, caja 3.

$44 \mathrm{lbid}$.

45 Arturo BAREA: Ibid.

46 Hugh WILFORD: The CIA..., p. 22. 
sense of leftist possibility", ${ }^{47}$ y en la década de los 50 el anticomunismo se acabó de posicionar como objetivo central de la política exterior laborista..$^{48}$

El alejamiento oficial de una postura tercerista en el Gobierno Laborista en 1949 fue parejo con su progresivo abandono de posturas anticapitalistas y la adopción de una economía keynesiana, pese a la resistencia de los miembros de Labour Left, entre los que se encontraba Aneurin Bevan, que se oponían a este revisionismo en favor de una defensa de un socialismo "as a planned, largely state-owned, economy". ${ }^{49}$ El tercerismo defendido por Bevan fue tema recurrente de sus editoriales en la revista laborista Tribune, de la que fue editor y en la que los Barea colaboraron con frecuencia. Sostenía que la solución para Gran Bretaña estaba efectivamente en una economía socialista que fuera complementada por un sistema democrático, incompatible a su juicio con el capitalismo. ${ }^{\circ}$ En 1951, el tercerismo resurgió entre las filas de la facción izquierdista de los laboristas en torno a la figura de Aneurin Bevan, como respuesta a la Guerra de Corea, el McCarthyismo y el rearmamento de Alemania. ${ }^{51}$ Durante la década de los 50, los ahora llamados bevanistas, herederos del Keep Left, mantuvieron una postura tercerista poco exitosa frente a la lógica de la Guerra Fría en contra de las posturas pro-americanas, revisionistas, Keynesianas, si no abiertamente capitalistas dentro del propio laborismo. Como Wilford explica:

Above all, it was the Cold War which wrecked the leftist possibilities of the period, confusing and demoralising those still trying to carve out a scene for humane socialism in between the great powers, and emboldening those whose main concern was fighting communism. ${ }^{52}$

La Guerra Fría acabó por influir en muchos intelectuales terceristas europeos - desde Steven Spender a Sartre - que se vieron obligados a tomar partido. ${ }^{3}$ Pese a su defensa de un socialismo humanista y la pertenencia de su mujer Ilsa a la facción bevanista del Partido Laborista - relevante por la documentada influencia de llsa en el trabajo de su marido -, los guiones de Barea de los años 50 se deslizan hacia una "retórica de la libertad" alejada de una política tercerista que merece un análisis detallado más allá de los límites de este estudio, para asegurarnos de que nuestra interpretación no sufre de la misma lógica maniquea impuesta por la Guerra Fría, que tuvo entre otras consecuencias intelectuales "a massive further appropriation of the term 'freedom"' de tal manera que "the term through which Sartre had

47 Hugh WILFORD: The CIA..., p. 18

48 Nótese que el anticomunismo ya formaba parte de la política del Gobierno Laborista, que en 1948 creó el Information Research Department, encargado de reunir y distribuir información crítica con el bloque comunista a medios, intelectuales y políticos. Descrito por primera vez en el mismo memorando en que Ernst Bevin anunciaba la idea de la "tercera fuerza", el apoyo inicial de Bevin al proyecto tercerista es a menudo interpretado como una estrategia para asegurar la creación del IRD, asociando el concepto de la tercera via de los radicales de las flas laboristas con el anticomunismo de muchos de los miembros del gobierno britanico, particularmente el suyo. Aunque (IRD naciera con el objetivo de reforzar la "tercera fuerza "británica, el anticomunismo estuvo en el centro de su politica desde sus inicios. Diane KIRBY: "Divinely Sanctioned: The Anglo American Cold War Alliance and the Defence of Western Civilization and Christianity, 1945-1948", Journal of Contemporary History, 35 (2000), pp. 402-403, citada por Hugh WILFORD: The CIA.., p. 53; ver

49 John CALLAGHAN: The Labour..., p. 198.

50 lbid., p. 198.

51 Hugh WILFORD: The CIA..., p. 26.

52 Ibid., The CIA..., p. 40.

53 Alan SINFIELD: Literature, Politics, and Culture in Postwar Britain, University of California Press, 1989, pp. 86-115. invoked a classless society, and Spender an independent individual stance, was constituted as the watchword of one side in the cold war".54

Asimismo, poco después de la observación de Madariaga con la que se iniciaba esta comunicación, Barea participó en ocasiones con el Congreso para la Libertad de la Cultura. En noviembre de 1953 dio una charla para el CLC en París, y colaboró con un artículo sobre Cela en Preuves y Cuadernos. ${ }^{55}$ En 1956, cuando la BBC lo envió de gira a América Latina, Barea coordinó con Julian Gorkin su participación en eventos patrocinados por el CLC. ${ }^{6}$ Pese a esta posible reorientación ideológica, ${ }^{57}$ con la presente comunicación se ha querido mostrar cómo Barea no perteneció, por lo menos en los primeros años de la Guerra Fría (1947-1949), a una oposición que desde el exilio se guiara por un "antifranquismo liberal en el contexto estadounidense", ${ }^{8}$ sino por un antifranquismo democrático socialista que en el contexto británico de posguerra laborista apoyó la opción de una "tercera fuerza": un "neutralismo" como opción y no solo omisión política. Ni la lucha antifranquista de los republicanos españoles, ni la "tercera fuerza" británica resultaron ser opciones políticas viables, pero la realidad histórica no deslegitima las posiciones de los que creyeron desde el exilio en proyectos de una modernidad, hasta cierto punto, alternativa. Aunque las charlas que Barea radiaba semanalmente en su programa del Servicio Latinoamericano de la BBC puedan estar sujetas a varias interpretaciones, son ejemplo de cómo las tensiones de la Guerra Fría se manifestaron en objetos culturales concretos, que en cualquier caso no pueden ser leídos como "apolíticos".

54 Ibid., pp. 93, 94

55 Arturo BAREA: "La obra de Camilo José Cela", Cuadernos para la libertad de la cultura, 7 (1954); íD. "L'œuvre de Camilo José Cela", Preuves, 58 (1955); íD.: “Una historia de tiempos futuros", Cuadernos para la libertad de la cultura, 23 (1957).

56 Correspondencia entre Julian Gorkin y Arturo Barea, (1956), APAB, serie 6, caja 8.

57 Queda para un futuro estudio el análisis de la relación de Barea con el comunismo y con el anticomunismo.

58 Olga GLONDYS: La Guerra Fría cultural .125 
“¿OTRO TENTÁCULO MÁS DEL IMPERIO?”

\section{SINDICATOS ESTADOUNIDENSES Y ESPAÑOLES}

DURANTE EL FRANOUUISMO*

Francisco Javier Rodríguez Jiménez

Universidad de Salamanca/Real Colegio Complutense de Harvard
Al fin y al cabo, las instituciones se componen de personas, con sus virtudes y sus defectos, sus fobias y sus filias, sus prejuicios y sus sentimientos. Últimamente, tales pulsiones están comenzando a recibir mayor atención como objeto de estudio histórico. ${ }^{3}$ No perderemos de vista este enfoque metodológico complementario, aun a sabiendas de que no siempre es fácil rastrear y localizar las pruebas documentales que permitan corroborar esas actuaciones "no estructurales" y cargadas de subjetividad.

Por otro lado, conviene advertir que existe un obstáculo añadido para comprender los entresijos de lo que fueron las relaciones entre la AFL-CIO y los sindicatos españoles: la proyección exterior del sindicalismo estadounidense durante la Guerra Fría ha recibido una escasísima atención historiográfica. ${ }^{4}$ No existe, por ejemplo, ningún monográfico que estudie con detalle la política exterior de la AFL-CIO.5 Una laguna que no deja ser llamativa teniendo en

\section{Introducción}

La historiografía española sobre las relaciones hispano-estadounidenses durante el franquismo ha prestado atención prioritaria a los juegos de poder, enfrentamientos y colaboraciones entre los distintos ejecutivos de un lado y otro del Atlántico.' Pero la conexión entre España y Estados Unidos en ese periodo no se limitó a los canales gubernamentales; también tuvieron su incidencia otros sujetos históricos, tales como fundaciones, empresas, universidades o sindicatos. Este texto tratará de cubrir parte de esa laguna historiográfica examinando lo que fueron las relaciones de la poderosa central sindical americana, AFL-CIO, con los sindicatos españoles, los clandestinos y el vertical vinculado al régimen franquista. Para ello analizaremos lo ocurrido desde la firma de los pactos de 1953 que permitieron la instalación de bases militares estadounidenses en territorio español al verano de 1971. El inicio de este marco cronológico responde a razones evidentes, el final se justifica porque a partir de ese año la renovación interna de UGT, el crecimiento de CC.OO y otros cambios que explicaremos a continuación dieron lugar a un escenario bien diferente que habrá que examinar en otra ocasión.

La elevada carga emocional y política de la Guerra Fría y de la guerra civil española actuaron a modo de "lentes" que desfiguraron el modo en el que los distintos actores implicados percibían lo que estaba realmente aconteciendo. Percepciones no siempre acertadas, estereotipos, fuerte ideologización que hicieron que, a veces, se distorsionase la realidad, que se exagerasen los peligros, etc. Y es que como ha señalado Michael Latham: "ideologies make it easier that it might otherwise be to cope with reality. They provide simple models for complex phenomena. They generate rhetorical justifications for action..."

* Una versión actualizada y ampliada de este texto será publicada en Hispania, vol. 74, nº 246 (Madrid, 2014) Ambos trabajaos han sido elaborados en el marco de los proyectos de investigación «Estados Unidos y la España del desarrollo (1959-1975): diplomacia pública, cambio social y transición política» (Ministerio de Ciencia e Innovación, HAR 2010-21694), y «Difusión y recepción de la cultura de Estados Unidos en España, 1959-1975» (Universidad de Alcalá).

1 Charles POWELL: El amigo americano. España y Estados Unidos: de la dictadura a la democracia, Barcelona Galaxia Gutenberg 2011. Lorenzo DELGADO y María Dolores ELIZALDE (eds): España y Estados Unidos en el siglo XX, Madrid, Biblioteca de Historia-CSIC, 2005; Rosa PARDO: "España y EE.UU. en el tardofranquismo: las relaciones bilaterales durante la presidencia de Nixon", Historia del Presente, 6 (2005), pp. 11-41. Ángel VIÑAS: En las garras del águila. Los pactos con Estados Unidos, de Francisco Franco a Felipe Gonzälez (1945-1995), Barcelona, Crítica, 2003.

2 Michael E. LATHAM: Modernization as Ideology: American Social Science and "nation Building" in the Kennedy Era, Chapel Hill, University of North Carolina Press, 2000, p. X.
3 Robert JERVIS se convirtió en obra de referencia en este sentido. Pero no tuvo mucho eco entre los historiadores, sí entre politólogos o sociólogos, véase Perception and Misperception in International Politics, Princeton, Princeton University Press, 1976. Últimamente, algunos autores sí han optado por ese novedoso enfoque. Frank COSTIGLIOLA: Roosevelt's lost alliances: how personal politics helped start the Cold War, Princeton, Princeton University Press, 2012 o Bárbara KEYS: “Henry Kissinger: The Emotional Statesman", Diplomatic History, vol. 35/4 (2011) pp. 587-609.

4 Por el momento, se ha priorizado el análisis de las cuestiones sindicales en clave interna Gloria SKURZYNSKI: Sweat and Blood: a History of US. Labor Unions. People's History, Minneapolis, Twenty-First Century Books, 2008; Robert CHERNY, William ISSEL y Kieran TAYLOR (eds.): American labor
and the Cold War: grassroots politics and postwar political culture, New Brunswick, Rutgers Univerand the Cold War: grassroots politics and postwar political culture, New Brunswick, Rutgers University Press, 2004; Robert ZIEGER y Gilbert GALL: American workers, American unions: the twentieth century, Baltimore, Johns Hopkins University Press, 2002 ; o el análisis de cuestiones de género o
raciales asociadas al mundo del trabajo, Dorothy COBBIE (ed): The Sex of Class: Women Transforraciales asociadas al mundo del trabajo, Dorothy COBBLE (ed): The Sex of Class: Women Transforming American Labor, Ithaca, ILR Press, 2007; Ronald KE
U.S. labor history, Westport Greenwood Press, 1993.

5 Carl GERSHMAN: The foreign policy of American labor, Center for Strategic and International Studies, RADOSH: American labor and United States foreign policy, New York, Vintage Books, 1969, fue publicado hace más de cuarenta años y presenta serias lagunas documentales. Roy GODSON: American American In the Intion of Labor and the Central Intelligence Agency. New York Peter Lang Between the tan an res datos inter Labor and the Cen

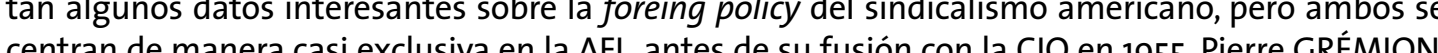

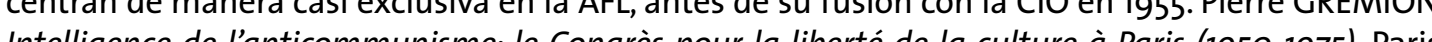
Intellis (1950-1975), Paris, Fayard, 1995, habla de pasada de la implicación de la AFL-CIO en el Congreso por la Libertad de la STROMOUIST (ed): Labor's cold war Urbana University of Illinois Press, 2008, pp. 257-273 si aborda cuál fue 1 (él. cuál fue el papel de la AFL-CIO en el extranjero, pero únicamente durante la guerra de Corea. La conCommitte the AFL-CIO and Central America", Diplomatic Histoyvol. 26, Issus: (2002), pp 419-451, es interesante, autue se limita es interesante, aunque se limita a Centroamerica en los años 80 . Existen algunos estudios sobre las centrados en los primeros años del conflicto bipolar, casi nada relativo los años sesenta y setenta y menos aún para caso españl Denis MacSHANE Internationallabour and the origins of the Cold y menos, Oxford para el caso español, Denis MacSHANE: International labour and the origins of the Cold Stato e Prospettive della Stry Press" Stato e Prospettive della Storiografia" en Maurizio ANTONOLI, Myriam BERGAMASCHI y Federico ton Edwin Mellen Press, 1998 . Cabos sueltos que podrian explicar la proliferación de otra literatura ton, Edwin Mrte impronta ideológica, con titulos tan llam extivos como Michael SUSSMAN: AIFID US. Trojan horse in Latin America and the Caribbean: a joint venture of the AFL-CIO, Department of State, Trojan horse in Latin America and the Caribbean: a joint venture of the AFL-CIO, Department of State, rican labor; the subversion of the AFL-CIO's foreign policy, New York, International Publishers, 1967. SKURZZYNSSKI: Sweat and Blood: a History of U.S. Labor Unions. People's History, Minneapolis, TwenWashington, 1975, ofrece alguna pista, pero es un trabajo muy reducido, apenas 80 páginas. Ronald HUGHES: In the Interest of Democracy: The Rise and Fall of the Early Crane, Russak, 1976 y Quenby American labour France and the politics of intervention 1945-1952: workers and the Cold War Lewis- 
cuenta que la influencia de este conglomerado de organizaciones sindicales fue considerable, por ejemplo, en el seno de la (CIOSL) o en la Organización Internacional del Trabajo (OIT). Laguna también acusada en lo relativo a los factores externos que afectaron a los sindicatos españoles. ${ }^{6}$ A continuación, trataremos de arrojar algo de luz a esas sombras historiográficas y a los interrogantes planteados.

\section{La alargada sombra de la guerra civil}

En 1953 se firmó un matrimonio de conveniencias que aportaba oxígeno y respetabilidad internacional a la dictadura franquista a cambio de una elevada cesión de soberanía para la instalación de bases militares estadounidenses. Tal alianza geo-estratégica fue denunciada duramente por parte de los sindicalistas españoles en el extranjero. A través de la Federación Sindical Mundial (FSM) o de la Confederación Internacional de Organizaciones Sindicales Libre (CIOSL), trataron de obstaculizar el reconocimiento del franquismo por parte de los países democráticos. Tanto la Internacional comunista como la socialista sirvieron de altavoz para aquellas críticas, pero no emprendieron ninguna medida contundente, decidida y prolongada en el tiempo para la reinstauración de las instituciones democráticas españolas. 7 Los distintos pareceres, el pragmatismo o un cierto seguidismo respecto a las políticas exteriores de los distintos países de donde procedían, imposibilitaron una acción conjunta y continuada de los sindicatos europeos contra el Caudillo.

Teniendo en cuenta que en los primeros años cincuenta la American Federation of Labor había colaborado con la CIA en actividades anticomunistas, podría pensarse que el celo con que Franco arremetía contra esa ideología era visto con buenos ojos por parte del sindicalismo estadounidense. De hecho, la manifiesta hostilidad del dictador español contra Moscú sirvió posteriormente de justificación al gobierno americano para tratar de vender a la opinión pública propia y a la extranjera los acuerdos de 1953. Empero, la AFL-CIO mantuvo una actitud de claro rechazo del régimen del 18 de Julio, distanciándose así de la realpolitik del presidente Einsenhower. The American Federationist-órgano de expresión primero de la AFL y después de la AFL-CIO- venía denunciado desde hacía años los abusos de la dictadura española contra los representantes de los trabajadores, la falta de libertades civiles, etc. ${ }^{8}$

En marzo de 1953, los ejecutivos estadounidense y español ultimaban los pormenores para la firma de los Pactos de Madrid. Simultáneamente, distintas organizaciones del mundo del trabajo norteamericanas organizaban por su parte un nuevo acto de apoyo al exilio republicano español en su denuncia contra el dictador español. Según un artículo publicado en $E$ Socialista, todos los oradores censuraron la política de Washington hacia el dictador español, al tiempo que "expresaron su mayor simpatía para el pueblo de España".9

Entretanto, la American Federation of Labor continuaba su particular "cruzada" de denuncias contra el régimen franquista. En julio de 1953, a tan sólo dos meses de la firma de los Pactos de Madrid, se publicaba un reportaje con el explícito título “Franco Still Tortures Spain's

6 José BABIANO: “El mundo del trabajo durante el franquismo. Algunos comentarios en relación con la historiografía", Ayer, 88 (2012, 4), pp. 235-36.

Denis MacSHANE: International labour...p. 50. En 1956, el sindicalismo vertical fue admitido oficialmente en la OIT. Aquella membresía traería bastantes quebraderos de cabeza al régimen, puesto que los sindicatos antifranquistas -aunque no representados oficialmente en dicho organismo- utilizaron aquella plataforma para denunciar a la dictadura, Abdón MATEOS: "El retorno de España a la Organización Internacional del Trabajo: la persistencia del ostracismo, 1956-196o", Historia Contemporánea, 16 (1997), pp. 203 y 211.

8 Dossier de prensa sobre noticias relativas a España, GMA, RG 98- 002, caja 57.

9 "Mitín antifranquista en Chicago", El Socialista, 5 de marzo de 1953. Véase asimismo "Europa y Estados Unidos" El Socialista 4 de marzo de/ 1954 y en el mismo número "Como ven a Franco y Estados Unidos. Inflación de Caudillo".
Trade Unionist". Asimismo se habrían ignorado varios intentos de la diplomacia franquista en la capital estadounidense para tender puentes de acercamiento. ${ }^{10}$ Censura que poco tiene que ver con las visiones un tanto maniqueas de la Guerra Fría en las que se define a los sindicatos estadounidenses como otro "tentáculo más del Imperio Americano".

¿Cómo entender pues la aparente contradicción de unos sindicalistas norteamericanos que rechazaban los cantos de sirena del franquismo, pero que en otros escenarios sí secundaban las políticas anticomunistas de su gobierno? ¿Por qué no acataban la hoja de ruta de Washington tendente a limar asperezas con Franco? En primer lugar, es evidente que en España no era necesario la misma cautela contra la expansión del comunismo que, por ejemplo, en Italia; el régimen franquista ya se empleaba con gran contundencia. Empero, eso no fue óbice para que Washington sí pactase con el dictador español. En el caso de la AFL-CIO, una posible respuesta reside en el hecho de que permanecía todavía vivo el recuerdo de la participación de muchos sindicalistas estadounidenses en las Brigadas Internacionales."

No obstante y a media que avanzaba la década de los cincuenta, esa especie de "sentimiento de culpabilidad" presente en amplios sectores de la izquierda europea y norteamericana "por su inhibición durante la II República y la Guerra Civil" fue perdiendo fuelle. Pero no ello no quiere decir que desapareciese por completo de la escena política estadounidense. ${ }^{12}$ Por lo que se refiere al sindicalismo internacional, esa pulsión ha sido definida como "sentimentalismo antifranquista" o "vinculaciones afectivas con el fracaso republicano".

Además de la progresiva desaparición de esa empatía en torno a la guerra civil por el mero distanciamiento temporal, en 1955 se produjo otro acontecimiento que haría aumentar la brecha entre sindicalistas americanos y españoles. ${ }^{14}$ En la contienda por hacerse con las riendas del sindicalismo estadounidense, George Meany, presidente de AFL -que aglutinaba fundamentalmente a trabajadores de "cuello blanco"- se impuso a Walter Reuther, presidente de la CIO, organismo más escorado a la izquierda y que representaba fundamentalmente a operarios industriales. Los dirigentes de UGT en el exilio habían apostado por el candidato que resultó derrotado. Desde entonces hasta 1976, la central española no mantuvo contactos oficiales con la confederación americana resultante, AFL-CIO.

Se generaba así una situación bastante particular. El sindicato español con más visibilidad y margen de maniobra internacional no tenía línea directa con la más poderosa coalición sindical de Estados Unidos. Aunque sí hubo contactos puntuales, e Irving Brown, representante de la AFL-CIO para Europa y agente de la CIA al menos en los años cincuenta, solio asistir como invitado a los congresos ugetistas en el exilio francés. ${ }^{15}$ Por su parte, los sindicalistas estadou-

10 "Franco Still Tortures Spain's Trade Unionist", The American Federationist, julio de 1953, GMA, RC 98- 002, caja 57

11 El que fuese Secretario General de Relaciones Internacionales de la UGT de 1976 a 1986 -desde 1971 lo había sido de Prensa y Propaganda- Manuel Simón, corrobora este particular. Manuel Simón, 16 de diciembre de 2010, entrevista realizada por Francisco Javier RODRÍGUEZ JIMÉNEZ.

12 Ángel VIÑAS: “Una política exterior para conseguir la absolución", Ayer, 68 (2007), p. 113. Véase en ese sentido el explicito Allen GUTTMANN: The wound in the heart; America and the Spanish Civil War, Nueva York, Free Press of Glencoe, 1962.

13 Abdón MATEOS: "El retorno...", p. 201 y Manuela AROCA: Internacionalismo en la historia reciente de la UGT, 1971-86, Madrid, Ediciones Cinca, 2011, p. 35

14 En esas mismas fechas, el cuerpo diplomático estadounidense mostraba su preocupación por la existencia de varias huelgas en España. El trasiego de maquinarias y militares estadounidenses en torno a las bases era señalado como un elemento coadyuvante de ese malestar. "USIS Inspection Report." 11 de abril de 1956, NR RG 306, caja 8. 15 Antes de representar a la AFL-CIO, Irving Brown había sido delegado de la AFL en Europa. También desde 1948. Hugh WILFORD. The CIA, the British left and the Cold War: calling the tune? Marshall Frank Cass, 2003, p. 104. 
nidenses continuaron apoyando varias campañas contra el régimen franquista, a veces con más celo que la propia CIOSL, o la OIT. Tales altibajos, tales contradicciones, responderían a los condicionantes que ya explicamos -Guerra Fría y recuerdo de la Guerra Civil.

\section{Transformaciones en los años sesenta}

Transcurridos veinte años del final de la Guerra civil, el sindicalismo internacional había desechado ya la idea de que fuese posible derrocar a Franco, sin una intervención militar. Por si cabía alguna duda, el presidente Eisenhower abrazaba al Caudillo en la base de Torrejón el 21 de diciembre de 1959. Meses antes, y para ir allanando el camino, el dictador realizó varias declaraciones elogiosas enfatizando su confianza en el presidente americano. La prensa afín las aireaba, al tiempo que situaba a George Meany con los sectores conservadores o "centrados" del Congreso estadounidense. ${ }^{16}$

Para la oposición antifranquista, aquella visita era una muestra más del cinismo norteamericano, puesto que iban de paladines de la libertad y la democracia pero pactaban con el tirano español. ${ }^{77}$ En la primera semana de 1960, El Socialista traía a su página de cabecera un extenso artículo firmado por el veterano líder socialista Indalecio Prieto. ${ }^{18}$ Entre otros asuntos, se narraba la iniciativa de un grupo de personalidades de la sociedad civil estadounidense que habían pedido a Eisenhower que se desmarcase públicamente del dictador español. Algunos de los firmantes fueron: Norman Thomas, religioso, líder del Partido socialista americano y pacifista; James A. Pike obispo de California, de la Iglesia Episcopal; o A. Knight, presidente del Comité de Asuntos Interamericanos de AFL-CIO. Un grupo heterogéneo, bastante ilustrativo por cierto de la compleja escena política y social estadounidense. La presencia de Knight como representante de la gran confederación del trabajo serviría para cuestionar los planteamientos de quienes consideran que los sindicatos americanos remaron siempre en la misma dirección que Washington.

Por aquellas mismas fechas, El Socialista volvía a ocuparse en sus páginas de Walter Reuther, el gran líder de la CIO antes de su fusión con la AFL. Pese a que su carrera quedó en parte frustrada al perder ante George Meany en 1955, continuó teniendo gran ascendente en el mundo de las relaciones laborales. No en vano mantuvo la presidencia de la United Auto Workers (UAW) del potente sector automovilístico desde 1946 hasta su muerte en 1970. ${ }^{19}$ Otra clave interesante en relación a su trayectoria y a la de otros líderes sindicales de Estados Unidos es que no solían ambicionar cargos políticos. Y es que en términos generales el sindicalismo estadounidense, a diferencia del europeo y máxime el español, dada su mayor politización, fue derivando en una suerte de market-unionism, técnico, privado y distanciado de los partidos. En otras palabras: reivindicación de mejoras salariales sí, que los sindicatos estuviese fuertemente politizados, no. ${ }^{20}$

16 "Franco considera a Eisenhower como portavoz de occidente", $A B C, 2$ de febrero de 1959. Esta percepción de George Meany como un líder "centrado políticamente" se mantuvo incluso más allá de la dictadura. "¿Qué izquierda queremos?", $A B C$, 24 de septiembre de 1978.

17 En mayo de 1959, un memorándum del gobierno americano alertaba del "growing anti-Americanism, particularly among students and workers". "USIS Inspection Report." 29 de mayo de 1959, NR RG 306 , caja 8.

18 Indalecio PRIETO: "Símbolos opuestos. Torrejón de Ardoz y Andrés Torrejón", El Socialista, 7 de enero de 1960 .

19 A la altura de los primeros años sesenta, Reuther estaba rodeada de un cierto halo de misterio. En unos pocos años había sufrido varias tentativas de asesinato."Walter Reuther reelegido por aclamación en el Congreso de la UAW", El Socialista, 7 de enero de1960. Bajo la politizada atmósfera del "Cold War Liberal Consensus," la UAW no tuvo demasiado margen de actuación dada su orientación más izquierdista. Martin HALPERN: UAW politics in the cold war era, Albany, State University of New York Press, 1988, p. 267.

20 El concepto de "market-unionism" en Pierre GRÉMION: Intelligence de l'anticommunisme...p. 347.
Durante el breve mandato del presidente demócrata Kennedy, la sociedad norteamericana parecía evolucionar hacia una mayor apertura política. Bajo esta nueva atmósfera, el socialista Norman Thomas fue invitado por el Departamento de Estado a participar como "U.S. specialist abroad", con la misión de conferenciar en universidades extranjeras y expresar su propia visión de Estados Unidos. Además de activista contra la proliferación armamentística, Thomas presidió el Iberian Council, organismo que aglutinaba a parte del exilio español en New York. Que este rojo fuese ahora invitado como "misionero" de Estados Unidos da cuenta de un tiempo distinto al de la viciada Caza de Brujas de apenas un lustro antes. ${ }^{21}$

En España y en la esfera de las relaciones laborales, una nueva realidad se fue abriendo pasó paulatinamente. La conflictividad social y las huelgas fueron en aumento. En 1963 se registraron un total de 600 huelgas, en 1966 "se alcanzaron ya el millón de horas perdidas por este motivo, llegándose en 1968 a los dos millones, que fueron 4,5 millones de horas perdidas en 1969 y más de 8 millones en 1970". ${ }^{22}$ Con el nuevo decenio, surgió un "Nuevo Sindicalismo", sin aparente vinculación directa con los partidos políticos en sus momentos iniciales; y con unas formas y señas de identidad diferentes a las de las históricas UGT, CNT o ELA-STV. Hablamos de las Comisiones Obreras, la Unión Sindical Obrera (USO), la Solidaridad de Obreros Cristianos (SOC) etc. Un despertar del sindicalismo democrático en el interior que a la larga actuaría como catalizador de la agonía del franquismo.

El régimen franquista también parecía evolucionar. En esos mismos años sesenta se implementó un cambio de imagen liberalizador. En el ámbito sindical, la creación del Congreso Sindical y del Consejo de Trabajadores o la institucionalización del 'conflicto colectivo' fueron acogidas favorablemente por una parte de los sindicatos de la AFL-CIO y de las Trade Union Británicas. Sin embargo, el objetivo prioritario de éstas era alentar la unidad de acción de las distintas facciones del sindicalismo democrático español no comunista. La UGT reaccionó con disparidad de criterios ante esa estrategia de frente amplio. Los líderes ugetistas del exilio "criticaron la presión de la AFL-CIO y de la CIOSL, defendiendo la fórmula de mero pacto sindical". Para el ugetista Manuel Muiño, "la acción internacional del sindicato norteamericano estaba subordinada a los planes de la CIA". ${ }^{23}$ Alfredo Grimaldos va incluso más allá y apunta a que la Alianza Sindical Obrera (ASO) había sido fundada por el impulso combinado, no solo de la CIA sino también de la Fundación Friedrich Ebert del Partido Socialdemócrata alemán. ${ }^{24}$

Más allá de estas lecturas, parece que un tanto exageradas, lo cierto es que la AFL-CIO mantenía su política de tolerancia cero con el sindicato "Vertical." No respondía a sus cantos de sirena y al mismo tiempo prestaba apoyo logístico a los disidentes españoles. Por ejemplo, en marzo de 1965, Jay Lovestone, Director del Departamento de Relaciones Internacionales de AFL-CIO, intermediaba con representantes de Naciones Unidas en España para denunciar las represalias sufridas por estudiantes vinculados a la CNT. ${ }^{25}$ Nuevamente emergen las contradicciones que ponen en cuestión las interpretaciones apriorísticas del estilo Grimaldos. Por aquel entonces, el ejecutivo estadounidense se cuidaba muy mucho de no verse involucrado con los manifestantes antifranquistas. Trataba de aproximarse a los miembros después calificados

21 "State Department to Norman Thomas", 20 de junio de 1961. “Thomas' report to JFK as president of the Iberian Council." 28 de junio de 1961. Thomas medió asimismo en las numerosas disputas habidas en el seno del exilio republicano español. "Alberto Uriarte to Victoria Kent" 25 de julio de 1961. Véase Norman THOMAS Papers, HUA, reel n 41 ; asimismo, Olga GLONDYS: «Victor Alba y la guerra fría encubierta", Laberintos. Revista de Estudios sobre los exilios culturales españoles, 13 (2011), pp. 49-67.

22 Nicolás SARTORIOUS: El resurgir del movimiento obrero, Barcelona, Laia, 1975, pp. 42 y ss.

23 Abdón MATEOS: UGT Contra la dictadura franquista, 1939-1975, Madrid, Siglo XXI, 2008, pp. $120-129$ 24 Alfredo GRIMALDOS: La CIA en España, La Habana, Editorial de Ciencias Sociales, 2007, p. 148.

25 "Students against Franco" y "Union Men are jailed and tortured in Spain", 7 de marzo de 1965 GMA, RG 18- 001, caja 6. 
como "aperturistas" del franquismo, y si acaso a algún socialdemócrata moderado, pero no a los más escorados a la izquierda, cenetistas. ${ }^{26}$ La AFL-CIO sí lo hacía, y además mantenía con más firmeza que otros sindicatos europeos la negativa a dialogar con la dictadura franquista.

A mediados de 1966, la ejecutiva de la UGT en el exilio discutía sobre la llamada "crisis de exclusividad" respecto a las relaciones con la CIOSL, puesto que en los últimos años la Internacional Socialista había comenzado a prestar atención también a la ASO, constituida, entre otros, por ugetistas disidentes del interior. ${ }^{27}$ Para Pascual Tomás, Secretario General de la central socialista aquel trasvase de apoyos desde el exilio al interior se debía a una "conjura internacional". ${ }^{2}$ Una teoría conspiratoria en la que además de sindicalistas europeos y estadounidenses no faltaría tampoco la CIA. Poco importaba que en septiembre de ese mismo año, la AFL-CIO hiciese caso omiso a un nuevo intento del Ministro del Movimiento, José Solís, para atraer a un representante americano al congreso anual de la Organización Sindical Española (OSE) Cónclave que según rezaba la invitación sería una "prueba democrática del Sindicalismo español". ${ }^{29}$

Pero más que declinar estas peticiones, lo que preocupaba a la AFL-CIO por entonces era el fraccionamiento del sindicalismo democrático español. En los primeros meses de 1967 , su Departamento de Relaciones Internacionales realizaba un interesante informe en el que se examinaba la situación laboral en la España franquista. Se veía con preocupación la división de la UGT en varias facciones y peor aún: el crecimiento de CC.OO., que parecía bien cimentando y $\sin$ visos de debilitarse. ${ }^{30}$

\section{De las revueltas de 1968 a los cambios del verano de 197}

El sindicalismo estadounidense no quedó al margen del clima de transformaciones experimentados en esos años. En julio de 1968 se produjo la salida de la United Auto Workers (UAW), que englobaba a los trabajadores del importante sector del automóvil, de la AFL-CIO. Las discrepancias entre George Meany y Walter Reuthers -líder de la UAW- venían de lejos, como ya explicamos.

En España, continuaba la pretensión de los ugetistas del exilio por mantener prietas las filas entre sus correligionarios. Si años antes eran bastantes renuentes a la unidad sindical, recordemos que para Pascual Tomás respondía a una conjura internacional- en El Socialista de marzo de 1968 se alababa una estrategia conjunta con CNT y la ELA-STV en el País Vasco. ${ }^{31}$ No sólo se ensalzaban las virtudes propias, también se volvía a repetir el rechazo más absoluto a colaborar con el régimen. Se acusaba a los comunistas de caer precisamente en esa tentación movidos por espurias intenciones.

En mayo de aquel año se celebró el IV Congreso de OSE. Como en ediciones anteriores, el ministro Solís se había esforzado en vano por atraer a representantes de la AFL-CIO. Es más, alguna organización sindical estadounidense contactó con el agregado laboral franquista en Washington, Enrique León, para denunciar aquella farsa, donde no existía verdadera libertad de elección. ${ }^{32}$ Por el contrario, el agregado laboral del gobierno estadounidense, Daniel Montenegro, sí asistió. La propaganda franquista ensalzó la (supuesta) presencia de numerosos

26 "Country program plans and priorities for FY-66 and 67", 24 de junio de 1965, NARA, RG 59, Country Files, caja 215.

27. Manuela AROCA: Internacionalismo p. 35

28 Abdón MATEOS: UGT contra...p. 131

29 El año anterior, 1965, el agregado laboral franquista en Washington también intentó en vano per-

suadir a Lovestone para que se entrevistase con Solís. Esta correspondencia en GMA, RG 18- 001

caja 6.

30 "Unions in Spain" 23 de febrero de 1967, GMA, RG 18-001, caja 6.

31 “¿Qué pasa ahora en España?", El Socialista, 1 de marzo de 1968.

32 "Lee W. Minton to Enrique León." o7 de agosto de 1968, GMA, RG 18- o01, caja 6. observadores extranjeros en dicho congreso, y también de Juan López, antiguo ministro cenetista, en lo que definía como el Espiritu de Tarragona. ${ }^{33} \mathrm{~A}$ pesar de que la AFL-CIO volvió a declinar la oferta del "Vertical”, el ugetista Manuel Muiño escribió a George Meany para cerciorarse de que efectivamente así era. ${ }^{34}$

Desde enero a marzo de 1969 se decretó un férreo estado de excepción, acompañado de una intensificación de la represión policial. Por entonces, representantes de la Organización Internacional del Trabajo barajaban la posibilidad de realizar un viaje al país ibérico. La gira había sido pospuesta ya en anteriores ocasiones. Esta vez, los dirigentes de la OIT querían seguir adelante y realizar la inspección. La CIOSL, por su parte, se posicionó en contra, denunciado las "whitewash maneuvres" y la aparente apertura que se quería vender al mundo, pero que no correspondía maneuvres" y la aparente apertura que se quería vender al mundo, pero que no correspondia Finalmente, y en contra de la opinión de la CIOSL, de la AFL-CIO, y de los ugetistas del exilio, varios miembros de la OIT viajaron a España. A las pocas semanas, hicieron público un "Informe Provisional" sobre la situación de las relaciones laborales y los derechos sindicales en España. El texto fue recibido con gran frialdad por parte de la oposición antifranquista y el sindicalismo internacional; pensaban que era demasiado complaciente con la dictadura..$^{36}$ Una de las voces más críticas fue la del propio George Meany. Conducta que casa mal con la idea que señalábamos con anterioridad de que una parte significativa de la izquierda española veía a los sindicatos estadounidenses como meras marionetas de la Casa Blanca.

Recordemos que en 1969 la atmósfera de las relaciones entre el gobierno franquista y la administración Nixon presentaba serias turbulencias. La renovación de los acuerdos de las bases venía posponiéndose desde hacía tiempo, los negociadores de una y otra nacionalidad mantenían un fuerte pulso. ${ }^{37}$ Bajo esas circunstancias, parece lógico pensar que el ejecutivo norteamericano no recibiría con gran entusiasmo las denuncias de Meany contra la tibieza del comunicado de la OIT, ni sus críticas contra el franquismo. En junio de aquel año se produjo algo poco habitual, las tres grandes confederaciones sindicales mundiales, la comunista FSM, la democristiana CMT y la socialdemócrata CIOSL elaboraron un escrito conjunto para expresar su preocupación por el agravamiento de la situación sindical en España.. ${ }^{88}$

Durante el curso político de 1970, el panorama sindical en España siguió experimentando una gran inestabilidad. Si en los años precedentes la mayoría de los conflictos laborales tuvieron su origen en la lucha por mejoras económicas, a partir de entonces las demandas políticas comenzaron a convertirse en motivo de manifestación per se. ${ }^{39}$ Entretanto, la UGT continuaba su particular batalla por mantener su exclusividad en las relaciones con la CIOSL. El ingreso de la Unión Sindical Obrera (USO) en la sectorial de la gran confederación socialdemócrata para las industrias metalúrgicas (FITIM) fue duramente criticado por los ugetistas en el exilio. Y es que la dirección de UGT no estaba por la labor de compartir el generoso paraguas económico y de visibilidad internacional que ofrecía la CIOSL, ni con USO, ni menos aún con CC.OO.

33 "Asamblea de dirigentes Sindicales", La Vanguardia, 18 de julio de 1968.“IV Trade Unions Congress, Tarragona, May 1968", GMA, RG 18- o01, caja 6.

34 "Manuel Muiño to George Meany, 7 de julio de1968, GMA, RG 18- o01, caja 6.Y "News from Spain." 7 de julio de 1968, GMA, RG 18- 001, caja 10.

35 "Study Group on Spain, February 1969", GMA, RG 18- o01, caja 6

36 "Manuel Muiño to George Meany." 29 de julio de 1969, GMA, RG 18- oo1, caja 6.

37 En agosto de 1970 concluía la negociación con la firma del “Non Military Agreement”, ACFE, caja 32. 38 "ICFTU report about ILO trip to Spain" d.s.f. GMA, RG 18- o01, caja 6.

39 Entre 1963 y 1969 sólo un $4 \%$ de los conflictos presentaba demandas políticas, en tanto que entre 1969 y 1974, este tipo de conflictos ascendió al 45,4\% del total. Además, "la politización del movimiento obrero incrementó la radicalidad de sus acciones". Manuel REDERO, Estudios de historia de Spanish Labor Outlook for 1976", 6 de abril de 1976, CMA, RG 18-010, caja 4. 
Según el órgano de prensa de AFL-CIO, las protestas de esta confederación por el estado de las relaciones laborales en España aumentaron en 1970. En ese sentido, el poderoso presidente Meany no sólo había exhortado al gobierno de su país a que aumentase la presión contra Franco, también volvía a insistir en la necesidad de la unidad sindical para apoyar a las fuerzas democráticas del interior. ${ }^{40}$ Empero, algunos ciudadanos estadounidenses pensaban que tal incrementó de la presión era digno de elogio, aunque no era suficiente. ${ }^{4}$

Durante la primera mitad de 1971, la AFL-CIO continúo denunciado la precariedad de los trabajadores españoles y la falta de verdadera libertad sindical. En mayo, el director de Relaciones Internacionales de la confederación, el controvertido Jay Lovestone, escribía a un representante del "la República española" en el exilio para que le facilitase material informativo. Lovestone aseguraba que podía mover sus contactos para que tal información fuese publicada en la prensa española, a pesar de la censura; y por supuesto aireada en las distintas publicaciones de la AFL-CIO.42

La influencia de los sindicatos democráticos en el tardofranquismo aumentó de manera considerable, actuaron como "instrumentos de deslegitimación de la dictadura incluso entre las clases medias y empresarial". 43 Por entonces, la central sindical española con más apoyos en el extranjero, UGT, necesitaba un golpe de timón frente a la expansiva presencia de CC.OO. Tenía que demostrar a la sociedad española que todavía tenía algo que decir en el mundo del trabajo. Los primeros días de agosto de 1971 se celebró el XI Congreso de la UGT, el de la "Renovación".

Un nuevo tempo comenzaba para la familia socialista-ugetista; en breve también para el sindicalismo democrático en su conjunto y para la propia AFL-CIO. Esta confederación tenía que responder al órdago de la reforma económica anunciada por Richard Nixon el 15 de agosto de aquel año. Cambio de rumbo que favoreció el aumento de la globalización financiera, las deslocalizaciones de empresas, etc.; para algunos autores, comenzó el estrangulamiento de las clases medias que se habían venido consolidando desde el final de la II GM. ${ }^{44} \mathrm{~A}$ partir de ese momento y temiendo una posible desestabilización cuando muriese el dictador, el gobierno estadounidense y la AFL-CIO aumentaron su interés por lo que acontecía en España. Lo sucedido posteriormente escapa a la limitación temporal de este texto.

40 "AFL-CIO News", 26 de diciembre de 1970, GMA, RG 18- o01, caja 6.

$41 \mathrm{lbid}$.

42 "Jay Lovestone to Julio Just", 17de mayo de 1971, GMA, RG 18- 010, caja 4.

43 Santos JULIÁ: "Sociedad y Política" en Manuel TUÑÓN DE LARA: Transición y Democracia, 1977-1985, Barcelona, Labor, 1991, p. 38

44 "Nixon's Grand Design for Recovery", Time, 30 de agosto de 1971. Thomas ZEILER: "Requiem for the Common Man.Class, the Nixon Economic Shock, agd the Perils of Globalization", Diplomatic History, 37:1 (Enero 2013), pp. 1-23; Bruce WESTERN and Jake ROSENFELD: “Workers of the World Divide:The Decline of Labor and the Future of the Middle Class", Foreign Affairs, 91:3 (Mayo/junio 2012). 
Parte 4.

LOS TEATROS DE LO BÉLICO 
REFLEXIONES EN TORNO A LOS TEATROS DE LO

\section{BÉLICO. UNA DISECCIÓN DEL ESTADO ACTUAL DE LOS}

\section{ESTUDIOS DE HISTORIA MILITAR}

David Alegre Lorenz

Alonso barra

El propósito de esta presentación es aportar una visión general del estado actual de los estudios de historia militar en la historiografía peninsular partiendo de nuestra experiencia como coordinadores de la mesa-taller Los teatros de lo bélico. En primer lugar, señalaremos los que a nuestro parecer son los principales referentes y piedras de toque en los análisis de la nueva historia militar, de los cuales nos hemos nutrido de forma directa o indirecta y, de mismo modo, trataremos de reflejar la recepción y plasmación que han tenido los principales avances historiográficos a nivel internacional en el seno de nuestra comunidad académica. De igual forma, llevaremos a cabo un análisis bibliométrico que, desde nuestro punto de vista, servirá para justificar el interés del propio taller y poner de manifiesto las inquietudes existentes en la actualidad entre los jóvenes investigadores dedicados al estudio de lo bélico. Finalmente, en relación con esto último desgranaremos los aspectos esenciales de los debates sostenidos a lo largo del encuentro y apuntaremos algunas de las líneas por las que, a nuestro juicio, debería transitar nuestra comunidad historiográfica a lo largo de los próximos años en lo referente a las investigaciones donde la historia militar tenga una presencia relevante.

\section{Arqueología de Los teatros de lo bélico. Violencia, memoria, identidad y sociedad de masas}

A nuestro parecer, tres son los hitos coincidentes en el tiempo que han marcado particularmente la comprensión de lo bélico entre los historiadores peninsulares, introduciendo en nuestra comunidad historiográfica algunos de los principales conceptos y avances metodológicos alumbrados allende nuestras fronteras y, a su vez, aportando categorías y conceptos propios. En primer lugar, podríamos señalar como un punto de inflexión esencial la obra de Xosé Manoel Núñez Seixas, quien ha trabajado in extenso la experiencia de combate, la conformación de identidades en el contexto bélico, el excombatentismo y las dinámicas inherentes a la movilización bélica, profundizando en las relaciones entre frente y retaguardia. De hecho, este último elemento fue el eje rector del congreso organizado por Javier Rodrigo, Retaguardia. Violencia, movilización y cultura de guerra, celebrado en Zaragoza en el año 2008 que posteriormente tendría plasmación en forma de dossier en la revista Ayer ${ }^{2}$ Precisamente, en dicho congreso participó Eduardo González Calleja, quien ese mismo año coordinó para la revista Historia Social el dossier Cultura de Guerra en España. Este trabajo indagaba en algunos aspectos clave hasta entonces poco atendidos por la historiografía, condensados todos ellos

1 Xosé Manoel NÚÑEZ SEIXAS: ;Fuera el invasor! Nacionalismos y movilización bélica en la Guerra Civil española (1936-1939), Madrid, Marcial Pons, 2006; Imperios de muerte. La guerra germano-soviética, 1941-1945, Madrid, Alianza Editorial, 2007; o, entre muchos otros, “'Eran los rusos culpables?: imagen del enemigo y políticas de ocupación de la División Azul en el frente del Este, 19411944", Hispania, Vol. LXVI, 223 (2006), pp. 695-750.

2 Javier RODRIGO (ed.): “Retaguardia y cultura de guerra, 1936-1939", en Ayer, 76 (2009). en una categoría con un fuerte componente interpretativo como es "cultura de guerra".3 De algún modo, estos tres historiadores han contribuido de forma muy activa a poner los análisis historiográficos peninsulares en la órbita de los principales trabajos y debates que se estaban tiva La Violence de guerre 1914-1945 o el rechazo de las teorías de la brutalización de la Gran Guerra por parte de Benjamin Zeimann. ${ }^{4}$ Sin lugar a dudas, sus esfuerzos han dado un impulso decisivo a la introducción de los renovadores paradigmas de la nueva historia militar en España. Por esta misma línea han discurrido otras muchas iniciativas que se han sucedido desde entonces, con trabajos desarrollados en paralelo o al calor de los de Núñez Seixas, Rodrigo y González Calleja, entre los que encontramos la obra de José Luis Ledesma, que tuvo su plasmación en el taller Violencia, memoria, trauma y experiencia -como parte del XI Congreso de la AHC celebrado en Granada en septiembre de 2012-. A lo largo de los debates que tuvieron lugar bajo su coordinación se pusieron de manifiesto pequeños conflictos generacionales en el modo de abordar el pasado y el presente, lo cual resulta significativo a la par que alentador. Concretamente, cabría destacar el momento en que varios jóvenes historiadores reivindicaron la vigencia de fenómenos o conceptos analíticos como "violencia estructural"-siempre acompañado de una complejización necesaria y un establecimiento de diferentes tipologías- ante el rechazo de otros colegas de una generación anterior. En cualquier caso, los diferentes aspectos tratados a lo largo de las sesiones del encuentro fueron de lo más variado, yendo desde las diferentes formas de codificación y vigencia del trauma a los nuevos enfoques sobre la naturaleza de la violencia en guerra, mostrando así la efervescencia y vitalidad de nuestra comunidad historiográfica. Precisamente, es justo y necesario reconocer que la iniciativa impulsada por Ledesma se convirtió para nosotros en un prolegómeno, una inspiración y un estímulo para la realización de Los teatros de lo bélico, tanto en su concepción como en su desarrollo.

Todas estas actividades se han enmarcado, sin lugar a dudas, en el amplio espectro de iniciativas y trabajos que se vienen desarrollando a nivel internacional. ${ }^{5}$ Como ya señalábamos, éstas han tenido un impacto muy significativo en el ámbito peninsular como producto del afán innovador de un creciente núcleo de investigadores y, por otro lado, la cada vez mayor movilidad de nuestra comunidad historiográfica, núcleo al que se ha ido sumando de forma muy representativa una nueva generación de jóvenes historiadores. Entre las iniciativas más relevantes que están teniendo lugar en la actualidad fuera de nuestras fronteras cabe destacar el creciente número de congresos y grupos específicos de investigación caracterizados por un predominio de la dimensión socio-cultural, sin la cual los estudios de lo bélico son poco menos que inconcebibles hoy en día. Así, por ejemplo, resultan muy significativo el gran volumen de actividades impulsadas desde la Universidade Nova de Lisboa y, más concretamente, desde su Instituto de História Contemporânea, gracias al trabajo de historiadoras como Maria Fernanda Rollo o Ana Paula Pires, quienes han conseguido con sus propuestas congregar regularmente en la capital lisboeta a investigadores procedentes de las más diversas proceden-

3 Eduardo GONZÁLEZ CALLEJA (ed.): Cultura de guerra en España, en Historia Social, 61 (2008).

4 Stéphane AUDOIN-ROUZEAU, et al. (ed.): La Violence de guerre 1914-1945, Bruselas, Éditions Complexe, 2002. Por su parte, Ziemann demostró a través del estudio de los soldados bávaros de origen rural que el ascenso del nazismo no fue una consecuencia directa derivada de la brutalización de los combatientes en el marco de la Gran Guerra, de hecho habría sido una generación posterior nacida después de 1900 la que habría nutrido las filas de las SA o las SS. Véase Benjamin posterior nacida despues de 1900 la que habria nutrido las filas de las SA o las SS. Vease Benjamin Klartext 1997 [disponible traducción al inglés: War Experiences in Rural Germany: 1914-1923] o, más recientemente, Contested Commemorations: Republican War Veterans and Weimar Political Culture, Cambridge, Cambridge University Press, 2013.

5 De hecho, es harto significativo que el propio Enzo Traverso fuese uno de los impulsores de la mesa-ta-

ller coordinada por Ledesma, a pesar de que finalmente no pudiese asistir por motivos personales. 
cias. Entre ellas podriamos subrayar por su importancia 'German Science' in Southern Europe, 1933-1945, celebrado en octubre de 2012, que contó con la participación del historiador de la tecnología Mikael Hård, el cual hizo especial hincapié en la importancia de la tecnología militar como fuente de intercambios y diálogos culturales y la guerra como instrumento potencial de transformación a todos los niveles. ${ }^{6}$ Más centrado en lo estrictamente bélico nos encontramos con el congreso War and Propaganda in the 2oth Century, celebrado en noviembre de 2013 , donde las dinámicas propias de las narrativas de la movilización y la relación entre frente y retaguardia constituyeron el eje de los debates. Su incansable actividad continuará en los próximos meses del 2014 con otros encuentros científicos como Resisting War in the 2oth Century, Europe between the World Wars, The Great War in Africa o, también, Prisoners of War in the Twentieth Century: Actors, Concepts, and Changes

A día de hoy, uno de los principales focos productores de estudios en torno a lo bélico radica en Dublín, concretamente en dos instituciones de referencia fundadas en el año 2008 y que a menudo colaboran entre sí: el Centre For War Studies del Trinity College, con John Horne a la cabeza, y su homónimo del University College, dirigido por Robert Gerwarth. Ambos están impulsando seminarios semanales, congresos, publicaciones y, al mismo tiempo, importantes proyectos de investigación a nivel internacional plenamente enmarcados en los paradigmas más punteros de la nueva historia militar, generando en su seno una constante circulación de jóvenes investigadores procedentes de toda Europa que contribuye a una renovación constante de los casos de estudio y los paradigmas. ${ }^{7}$ Con una tradición mucho más larga a sus espaldas, destaca la labor llevada a cabo en Le Centre de Recherche de l'Historial de la Grande Guerre de Péronne, presidido por el propio Audoin-Rouzeau. Fundado en 1992, ha sido capaz de convertirse en un centro referente a nivel mundial donde se congregan algunos de los principales expertos de la nueva historia militar, entre los cuales se encuentran John Horne, Sönke Neitzel, Henry Rousso, Vejas Liulevicius, Alan Kramer o Jovana Knežević, entre otros. ${ }^{8}$

En los últimos tiempos, en contacto con todas estas realidades, parece que se está desarrollando un interesante núcleo dentro de la historiografía peninsular en torno a los estudios de lo bélico donde confluyen tendencias que van desde lo más clásico a lo más renovador, desde lo estrictamente descriptivo a lo puramente interpretativo. De hecho, se han intensificado notablemente los contactos entre los diferentes ámbitos de esta emergente comunidad investigadora, generándose una red de intereses académicos que, a buen seguro, dará sus frutos en años próximos. Concretamente, a día de hoy, este intercambio de ideas ha hecho posible una miríada de propuestas entre las cuales cabe destacar la Revista Universitaria de Historia Militar, fundada en 2012 y dirigida por Félix Gil Feito desde la Universidad de Cádiz. Ésta se postula como un punto de confluencia abierto a las diferentes tendencias, metodologías y enfoques en torno a lo militar, dando lugar a un proyecto con múltiples posibilidades de cara

6 Una obra de referencia para las transformaciones en el ámbito de lo bélico, los equilibrios de

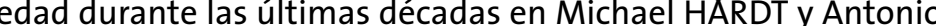
NEGRI: Multitude: War and Democracy in the Age of Empire, Nueva York, The Penguin Press, 2004.

7 Su trabajo ha quedado plasmado en obras colectivas recientes como John HORNE (ed.): A Companion to World War I, Chichester, John Wiley \& Sons, 2010; Heather JONES, Jennifer O'Brien y Christoph SCHMIDT-SUPPRIAN (ed.): Untold War: New Perspectives in First World War Studies, Leiden, Brill, 2008; Robert GERWARTH \& John HORNE: War in Peace: Paramilitary Violence in Europe after the Great War, Oxford, Oxford University Press, 2012; James MATTHEWS: Reluctant Warriors: Reputhe Great War, Oxford, Oxford University Press, 2012; James MATTHEWS: Reluctant Warriors: Republican Popular Army and Nationalist Army Conscripts in the Spanish Civil War, 1936-1939, Oxford,
Oxford University Press, 2012 [disponible en castellano con el titulo Soldados a la fuerza]. Precisamente, de forma completamente inesperada Matthews nos honró con su presencia en la segunda sesión de Los teatros de lo bélico.

8 Un resultado interesante de su trabajo se encuentra en John HORNE (ed.): Vers la guerre totale, le tournant de 1914-1915, París, Tallandier, 2010. al futuro dentro de la historiografía peninsular. De igual modo, otra iniciativa que ha puesto en contacto múltiples esferas de la comunidad investigadora dedicada al estudio de la guerra son las diferentes ediciones del Coloquio Internacional de Historia Bélica, impulsadas desde la Universidad de Cantabria. Concretamente, en el mes de diciembre de 2013 organizó su tercera edición, Los conflictos asimétricos en la contemporaneidad: Guerrilla, milicia, insurgencia e insurrección. Este encuentro centrado en las formas de guerra no convencionales no sólo propuso nuevas visiones y miradas sobre el pasado, iluminando cuestiones que habitualmente suelen quedar en los márgenes de la realidad histórica, sino que ofreció herramientas para una interpretación más compleja de los conflictos actuales. Todo este movimiento ha tenido su plasmación a finales de 2013 en la fundación de la Asociación Española de Historia Militar (ASEHISMI), que empieza ahora a dar sus primeros pasos y que reúne desde los más veteranos a los más jóvenes expertos de nuestro país. Por último, otras dos iniciativas que demuestran la pujanza de los estudios en torno a la guerra son, por un lado, el congreso organizado por el Grup d'Estudis República i Democràcia en la Universitat Autònoma de Barcelona, La Gran Guerra y sus consecuencias: las alternativas a la quiebra de la civilización liberal y, por otro lado el encuentro Posguerras: 75 aniversario de la Guerra Civil española, organizado por la Universidad Complutense de Madrid. En ambos casos, se hace un especial hincapié en los legados de la guerra, entendida ésta precisamente como un punto de inflexión en la vida de las comunidades enfrentadas y, por tanto, como el marco de profundas transformaciones en todos los ámbitos de lo humano.

En este sentido, como actividad desarrollada en el marco del IV Encuentro de Jóvenes Investigadores de la $A H C$, Los teatros de lo bélico es parte de esta creciente inquietud de la historiografía internacional por las cuestiones relacionadas con lo militar, que no es sino uno de los muchos caminos para analizar la naturaleza del ser humano y el lugar de la(s) violencia(s) en nuestra sociedades. Sin ir más lejos, la guerra, máxima expresión de lo militar, no es un acontecimiento residual, sino más bien todo lo contrario, hasta el punto de que podemos llegar a entenderla como la expresión del tiempo concreto en que tiene lugar. 9 Un referente esencia en su concepción fue la figura y obra de Raphael Samuel, de ahí el nombre de la iniciativa, que pretende ser un humilde homenaje al historiador británico..$^{\circ}$ Procedente de la historiografía marxista, Samuel fue alguien que en su carrera como historiador adquirió un compromiso permanente con la complejidad del pasado, manteniéndose siempre crítico respecto a su posición como historiador en el presente. Insaciable en su afán de conocimientos, el británico supo evolucionar intelectualmente y redefinir su enfoque hacia nuevas fuentes y perspectivas culturales que arrojaron luz sobre los márgenes de la realidad social y el escenario que la envolvía, algo que, hasta el momento, había resultado inaccesible partiendo de los paradigmas dominantes. De hecho, fue él quien nos mostró que el pasado nunca pasa, que siempre está en un eterno discurrir sobre el presente en que se recodifica y reintegra una y otra vez, ocupando diferentes sustratos de nuestra experiencia y nuestro modo de entender la realidad. Sin lugar a dudas, entendemos que esto es algo que se acentúa de forma evidente en todo lo que tiene que ver con lo bélico, siempre presente en la cotidianeidad como experiencia y como trauma, como memoria y como objeto de consumo, que no son sino algunas de las dimensiones que el taller pretendía recoger. Por lo que a nosotros se refiere, siempre hemos tenido bien presente en nuestro trabajo que el historiador es un producto de su tiempo y, por tanto, expresión viva de este, lo cual requiere mantener de forma permanente un enfoque crítico. De la misma for-

9 Al respecto es fundamental Thomas KÜHNE y Benjamin ZIEMANN: "La renovación de la historia militar. Coyunturas, interpretaciones, conceptos", SEMATA, Ciencias Sociais e Humanidades, 19 (2007), véase pp. 319-321. [El texto original fue publicado en 2000]

10 Fundamentalmente, nos inspiramos en Raphael SAMUEL: Theatres of Memory: Past and Present in Contemporary Culture, vol. I, Londres, Verso, 1994 
ma, constituye una suerte de deber moral para con nuestro oficio y condición de seres sociales el estar abiertos a todo aquello que discurre en torno a nosotros, pues de ello se nutrirán las investigaciones que pongamos en marcha. Precisamente, esta es una justificación más que suficiente para emprender una iniciativa como Los teatros de lo bélico.

Por todo lo dicho, el objetivo fundamental de nuestro trabajo ha sido y es enmarcarnos dentro de toda una ola de iniciativas y estudios orientados a la renovación de la historia militar, impulsada en muchos casos por jóvenes historiadores. De hecho, hablar de Los teatros de lo bélico es para nosotros hablar de nuestra voluntad por abrir un camino de largo recorrido más que poner una fecha concreta en el calendario o, dicho de otro modo, dar lugar a una impulso intelectual permanente abierto a la transformación, a la participación y construcción colectiva, al intercambio y producción de ideas. Precisamente, el taller constituía un primer intento de acercamiento a lo que se está haciendo tanto aquí como en otras comunidades historiográficas y, al mismo tiempo, una oportunidad para proponer nuevas aproximaciones para el estudio de lo bélico. Al fin y al cabo, creemos que muchos de los enfoques y propuestas vigentes en la historiografía peninsular deben ser seriamente repensados, y es aquí donde creemos que puede rendir un buen servicio la renovación historiográfica en curso a la cual hemos querido hacer nuestra pequeña y humilde contribución. Con Los teatros de lo bélico nuestra intención era pulsar las posibilidades interpretativas de esa nueva historia militar que, en muchos casos, ya es una realidad. Concretamente, nos referimos a una metodología capaz de integrar un amplio y variado número de voces en su discurso por medio de una firme apuesta social y cultural; de dar a lo local una dimensión global y una ambición teórica; de propiciar una vuelta historiográfica al sujeto individual como ente sufriente y codificador de la realidad de su tiempo; y, por supuesto, de conectar con marcos espacio-temporales situados más allá del ámbito local o nacional a través de perspectivas comparadas y transnacionales. En definitiva, una historia que aspira a servir como punto de confluencia de la complejidad inherente al pasado, huyendo del relleno de vacíos temáticos per se o de los enfoques puramente descriptivos que evitan el análisis y la interpretación, muy comunes en los modelos clásicos de historia militar.

\section{Análisis bibliométrico de Los teatros de lo bélico}

Con el fin de dar lugar a una visión lo más omnicomprensiva posible de las actividades que llevamos a cabo en el taller consideramos necesario realizar un análisis sintético de las líneas temáticas, tendencias historiográficas y categorías interpretativas que, a nuestro parecer, reflejan los contenidos más destacables del taller. De este modo, pretendemos ofrecer al lector un tanteo rápido a través de tres gráficas en torno a algunos de los objetos de interés dominantes entre los jóvenes investigadores dedicados al estudio de lo bélico y, a su vez, la forma en que abordan el pasado.

En primer lugar, entre los principales fenómenos objeto de investigación destacan por su primacía la guerra civil española y el franquismo, que por sí solos siguen justificando en la actualidad una gran cantidad de monografías, artículos, tesis doctorales y congresos. A pesa de que el call for papers del taller fue ampliamente difundido a nivel internacional, no debe sorprendernos el lugar preponderante de estas temáticas particularmente relacionadas con la historia de España. Esto no sólo tiene que ver con el hecho de que Los teatros de lo bélico se enmarcara en un congreso dirigido fundamentalmente a la comunidad académica peninsular, sino que además es un reflejo del interés existente por la guerra civil a nivel mundial, sólo superado en producción historiográfica por la Segunda Guerra Mundial. Sea como fuere, si bien la mayor parte de las investigaciones siguen teniendo como objeto de estudio aspectos relacionados con la historia de España, lo cierto es que, cada vez más, éstas son abordadas desde nuevas perspectivas, a menudo con la vista puesta en lo que ocurre más allá de los Pirineos. Precisamente, lo que muchos de los autores pretenden es conectar los procesos que tienen lugar en la península con las dinámicas europeas, tratando de romper con la largamente culti

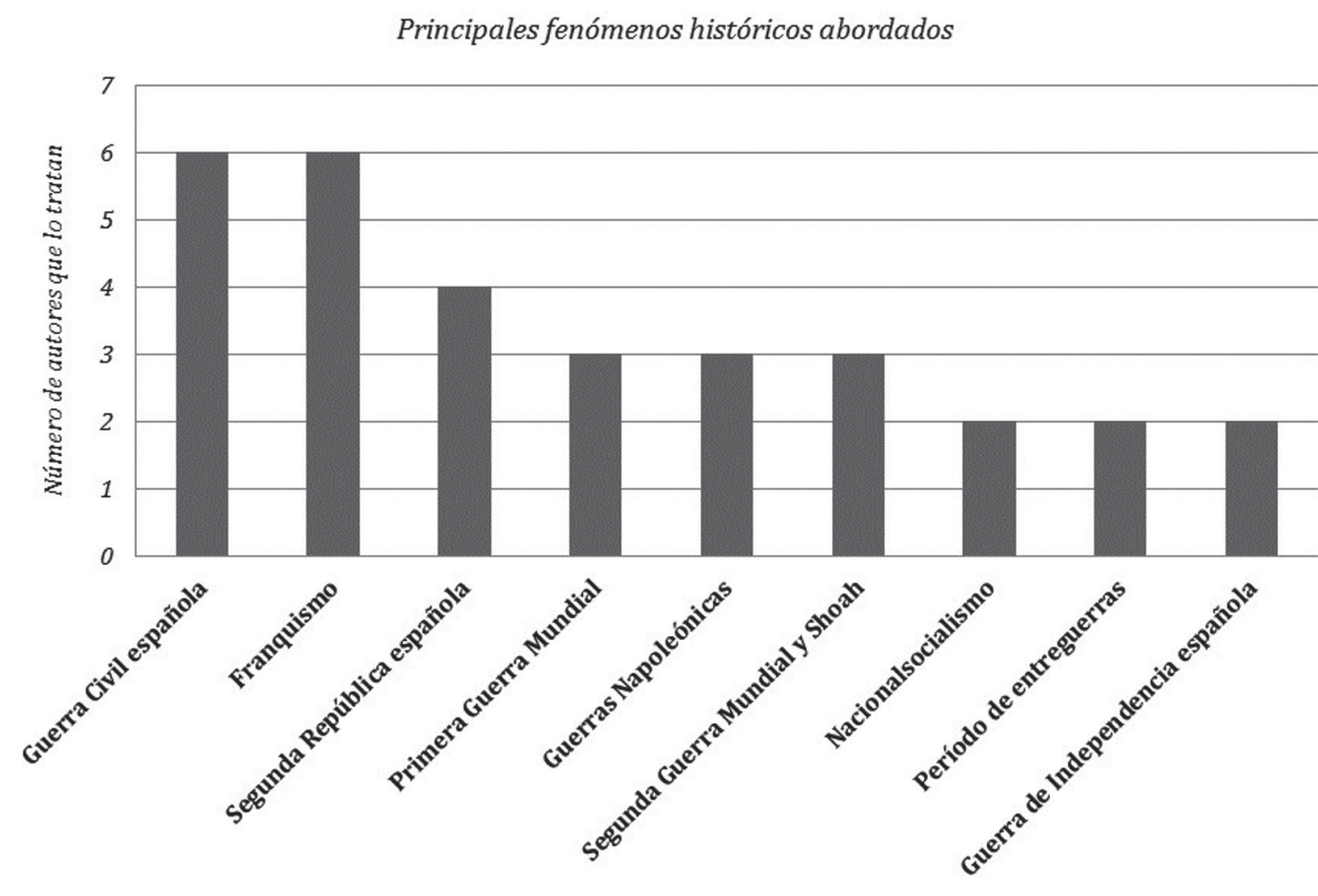

Gráf. 01 Principales fenómenos históricos abordados (fuente: elaboración propia)

vada visión de la supuesta anomalía española en la contemporaneidad, de ahí las referencias explícitas a acontecimientos como las dos guerras mundiales o el periodo de entreguerras. Asimismo, vemos cómo la dilatada tradición de historiadores hispanistas tiene continuidad en investigaciones como la de Florian Grafl (Universität Gießen), quien plantea una nueva aproximación al fenómeno del pistolerismo en la Barcelona de los años 20 a través de la influencia que tuvieron en la brutalización de la sociedad tanto la guerra colonial en Marruecos como la Gran Guerra. Por lo demás, cada vez en mayor medida, nos encontramos con jóvenes historiadores de nuestra comunidad académica interesados en fenómenos que tienen lugar más allá del ámbito peninsular, lo cual no sólo tiene un valor por sí mismo, sino que además contribuye a enriquecer significativamente nuestra mirada sobre lo acontecido en España y nos aporta nuevos puntos de referencia para el establecimiento de perspectivas comparadas. Un buen ejemplo es el trabajo de Ximena Machado (Universitat Autònoma de Barcelona), quien aborda un fenómeno poco conocido en la historiografía española como son los métodos de resistencia pasiva puestos en práctica por las comunidades judías recluidas en los guetos de Varsovia y Lodz. En cualquier caso, y esto es otra buena noticia, el trabajo de los jóvenes historiadores no se restringe al siglo $X X$, sino que pone de manifiesto los múltiples lazos existentes entre los diferentes acontecimientos bélicos de la contemporaneidad, decodificando narrativas legitimatorias basadas en conflictos decimonónicos como las guerras napoleónicas o los primeros conflictos coloniales. En este sentido, dos casos destacables son los trabajos de María del Pilar Loranca (Universidad Autónoma de Madrid) y Torben lbs (Universität Leipzig)

En segundo lugar, entre las tendencias historiográficas que han guiado los trabajos que componen Los teatros de lo bélico destacan por su peso la historia local y la historia cultural, si bien los estudios centrados de uno u otro modo en el análisis del lenguaje tienen un peso suficientemente significativo como para ser considerados aquí como una categoría aparte. En este sentido, hay que destacar el trabajo de José Manuel Lafoz (Universitat Autònoma de Barcelona), quien lleva a cabo un análisis centrado en el proyecto revolucionario libertario y la sublimación de la violencia en su discurso durante la guerra civil, todo ello a través de la prensa de la época y la literatura memorialística. De cualquier forma, como ya apuntábamos más arriba, nos encontramos con una importancia fundamental de los estudios locales que, por lo 
historia
comparada; $\quad$ Tendencias historiográficas

6,45

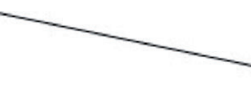

historia social;

9,67

vuelta

historiográfic

a al sujeto;

16,12
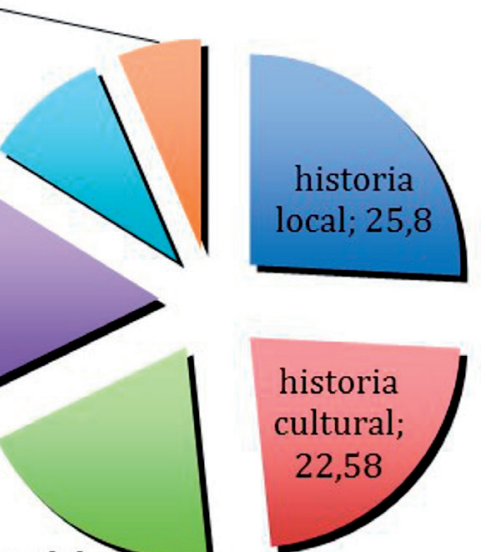

análisis del

Gráf. 02 Tendencias historiográficas (fuente: elaboración propia)

demás, tratan de ir un paso más allá al conectar con las realidades globales en las que se enmarcan, es decir, una "historia desde lo local" que potencia sus posibilidades interpretativas y presenta casos paradigmáticos de estudio que pueden ser extrapolados a otros contextos. Los trabajos de Miguel Ángel Melero (Universidad de Málaga) y David Veiga (Universidade de Santiago de Compostela) constituyen buenas muestras de ello. A través del caso de Antequera, Melero observa las dinámicas propias de la movilización total, la implicación de la población civil en el esfuerzo de guerra y, en consecuencia, la estrecha relación entre frente y retaguardia. Por su parte, Veiga se centra en las redes de sociabilidad y solidaridad de los excombatientes de la División Azul en la provincia de Alicante, así como en los grupos de influencia y presión política tejidos en torno a aquéllas, haciendo un especial hincapié en el caso de la capital provincial. Como no podía ser de otro modo, la historia cultural ocupa un lugar esencial en Los teatros de lo bélico. Así, nos encontramos con estudios como el de Nelly Álvarez (Universidad de Valladolid), quien aborda el teatro de urgencia nacido en la retaguardia rebelde durante la guerra civil como un medio para diseccionar la cultura de guerra de los sublevados y los límites de la movilización total.

En tercer lugar, la última de las gráficas nos presenta una detallada muestra de las principales categorías analíticas presentes entre los textos que componen los teatros de lo bélico. Así, como viene siendo habitual en los últimos años, la violencia tiene un lugar preponderante entre las preocupaciones de la comunidad historiográfica europea, un interés que ha dado lugar a innumerables congresos, artículos y monografías; al fin y al cabo, con sus diferentes tipologías, actores y víctimas ésta se ha convertido en una dimensión o fenómeno inexcusable en múltiples investigaciones, ya sea con una posición central o subsidiaria, dado que en no pocas ocasiones caracteriza, refleja y traspasa todos los ámbitos de la realidad social, política, cultural y económica de la contemporáneidad. Esto tiene su reflejo en el taller, donde se exploran diferentes encarnaciones de lo violento. Por un lado, el trabajo de Pablo Gómez (Universidad de Zaragoza), enmarcado en lo que se conoce como "guerra civil europea"-categoría analítica resignificada en los últimos tiempos por Enzo Traverso-" "aborda la apropiación y codificación violenta de la realidad por parte de los sublevados en la construcción de una particular cultura de guerra basada, en buena parte, en una imagen movilizadora de la amenaza revolucionaria.

11 Enzo TRAVERSO: A sangre y fuego. De la guerra civil europea (1914-1945), València, PUV, 2009 [2007].
Categorías analíticas

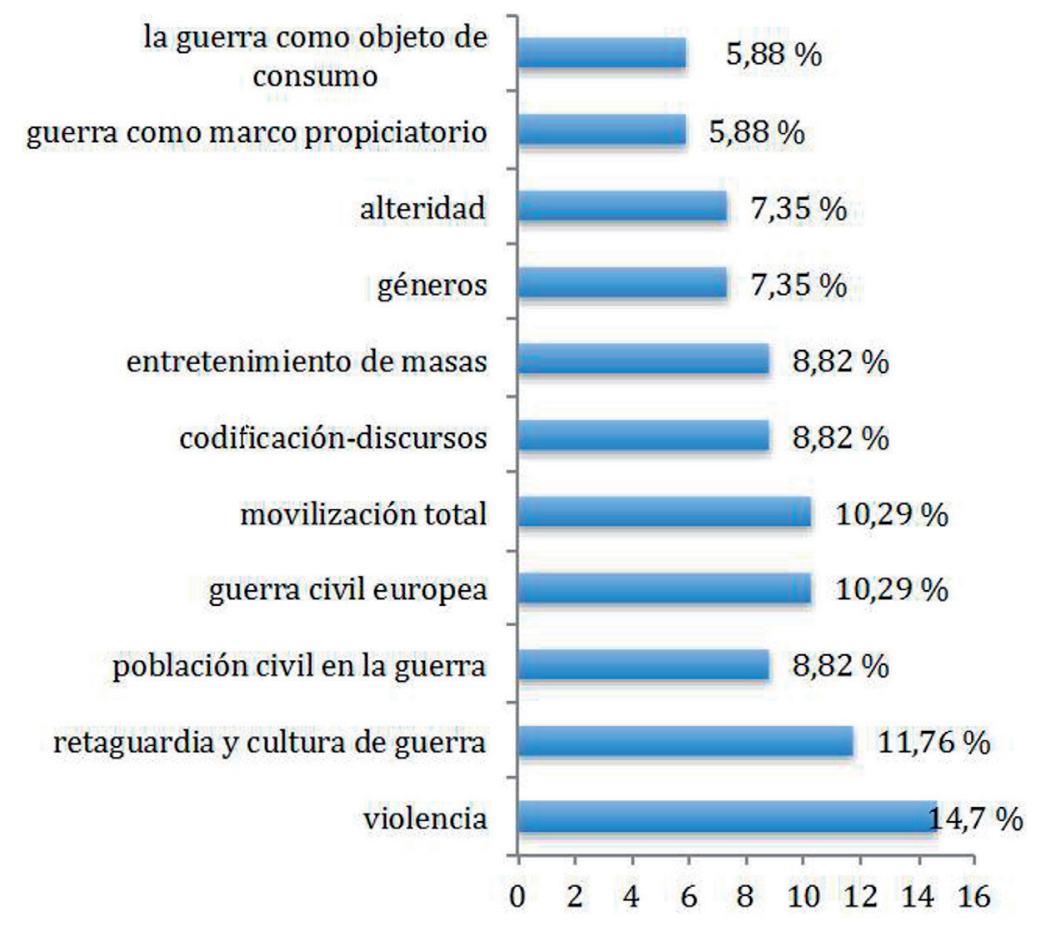

Gráf. 03 Categorías analíticas (fuente: elaboración propia)

Por otro lado, Francisco J. Leira (Universidade de Santiago de Compostela) ahonda de forma implícita en lo que podríamos identificar como la violencia estructural inherente al proceso de movilización total en la retaguardia gallega durante la guerra civil, algo que sirve al autor para poner en tela de juicio el supuesto apoyo incuestionable de la población al golpe de estado. Precisamente, el papel jugado por la población civil en el curso de la guerra -lo cual pone de manifiesto el recurso a la Alltagsgeschichte y un retorno al sujeto individual como objeto de estudio- es otro de los elementos esenciales entre los diferentes trabajos que componen el taller, una dimensión que se aborda in extenso en el texto de Leira. Por último, podríamos decir que las dinámicas e instrumentos que actúan en la codificación y comprensión de la realidad generando diferentes discursos conforman otra de las grandes categorías analíticas de Los teatros de lo bélico. Esto queda patente en el trabajo de Eloísa Zamorano (Universidad Autónoma de Madrid), quien aborda la construcción de una alteridad cimentada en la vulgarización y deformación de la figura de Nicolás II como forma de legitimar la necesidad de la Revolución rusa, mostrando una imagen frivola y extremadamente belicista del zar por medio del cine documental soviético.

\section{Los espejos de lo bélico. Debates, paradigmas y futuro de la nueva historia militar}

A lo largo de las dos sesiones del 11 y 12 de septiembre en las que se desarrolló Los teatros de lo bélico se plantearon múltiples debates que, por lo general, dejaron algunas cuestiones abiertas, sobre todo dada la profundidad y amplitud de los temas abordados y los diferentes enfoques de los participantes. Precisamente, creemos que el valor del taller residió en su condición de punto de partida para ulteriores trabajos y reflexiones, así como en su capacidad para tejer una red historiográfica de sociabilidad y poner a los asistentes en la órbita de nuevas preguntas, debates e intereses, abriendo su trabajo a perspectivas e inquietudes de lo más diverso.

Sin ir más lejos, una de las cuestiones candentes en los principales debates historiográficos actuales se centra en la validez y la maleabilidad de los límites por los que las categorías analíticas se definen. De hecho, en pleno siglo XXI, cuando la idea tradicional de conflicto parece 
no ofrecer respuestas satisfactorias a la multiplicidad de fenómenos violentos que acontecen bajo el paraguas del concepto "guerra", resulta de vital importancia extremar las precauciones del historiador en el despliegue de sus instrumentos de análisis. Por ello, en Los teatros de lo bélico se discutió sobre lo que caracteriza los conflictos, es decir, si éstos han de ser definidos cualitativa, cuantitativa, temporal o territorialmente y, por otro lado, se señalaron los múltiples intereses y percepciones de todo tipo que se superponen en la codificación y narración de éstos. Dicha realidad se ha puesto de manifiesto muy particularmente en la denominada War on Terror o guerra contra el terrorismo, la campaña promovida y puesta en marcha desde el año 2001 por el gobierno de los Estados Unidos en colaboración con sus aliados para combatir e auge de los grupos armados islamistas a nivel mundial. ${ }^{12}$ Este conjunto de políticas, medidas y operaciones militares escapan claramente a los contornos de la guerra tal y como la hemos entendido hasta finales del siglo XX: no hay unos frentes definidos excepto en ciertos momentos puntuales, como por ejemplo la invasión de Afganistán e Irak o la intervención francesa en Malí; a menudo no se da un combate cuerpo a cuerpo entre los contendientes, como vemos en las operaciones con drones dirigidas a miles de kilómetros de distancia, que no es sino la encarnación del videojuego hecho realidad; o, por lo demás, como conflicto no tiene un final claramente definido por su propia naturaleza, sino que muta y se adapta a la evolución y desarrollo de los acontecimientos. Sin embargo, en otras muchas facetas sí muestra las características propias de un enfrentamiento convencional, como por ejemplo en el caso de los discursos legitimatorios y movilizadores que actúan como aglutinantes frente al enemigo común. Precisamente, el hecho de darle la denominación de "guerra" al uso supone una revalorización del concepto como tal, revistiéndolo con un componente de justicia y legalidad: la idea de la "guerra civilizada" portadora de los valores de la democracia frente a un "terrorismo irracional" que reniega de los supuestos beneficios del progreso occidenta|' ${ }^{13}$ No obstante, es obvio que lejos de las connotaciones negativas que caracterizan el concepto "terrorismo", los grupos armados islamistas perciben su propia lucha como una guerra legítima al tiempo que, precisamente, califican las acciones de los gobiernos occidentales como una agresión terrorista en toda regla. Por tanto, lo que ocurre en la actualidad nos obliga a repensarnos como historiadores acercándonos a las zonas del pasado en sombra y ampliando nuestros objetos de análisis por medio de nuevos prismas.

La noción de víctima es otra de las cuestiones que afloró con mayor intensidad a lo largo de los debates, especialmente poniendo en discusión lo que, a nuestro parecer, ha impuesto unos límites más que claros a la hora de aprehender la realidad: su absolutización en algunos de los relatos historiográiicos, una tendencia que parece estar revirtiéndose en los últimos años. Precisamente, quién puede ser considerado como víctima fue uno de los ejes en torno a los que giraron las discusiones, una cuestión que a pesar de conducirnos a un punto muerto por su naturaleza casi etérea -en lo que a la concepción de víctima se refiere- puso sobre la palestra otros objetos de interés. Uno de ellos abordó el papel de la mujer en la guerra, discutiendo a menudo la noción de ésta como víctima por antonomasia y, por tanto, sujeto pasivo sin margen de maniobra real cuando lo cierto es que en todos los casos se constata una implicación activa de ésta en múltiples facetas de lo bélico: formas de resistencia, colaboracionismos, con-

12 Somos plenamente conscientes de las dificultades y riesgos que entraña definir terminológicamente a estos grupos de las más diversas procedencias y naturalezas sin resultar tendenciosos, sobre todo dado que no somos expertos en la materia.

13 Hasta cierto punto se trata de pautas discursivas relacionales o construcciones identitarias presentes en todas las guerras, como se pone de manifiesto en la unión entre fascismo y religión dusentes en todas las guerras, como se pone de manifiesto en la unión entre fascismo y religión du-

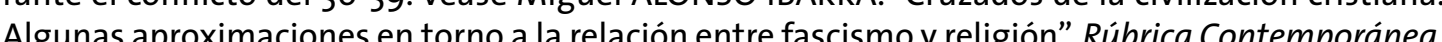
$3 / 5$ (2014), en prensa. tribuciones al esfuerzo de guerra en la retaguardia, delaciones e, incluso, participación directa en las operaciones militares como parte activa de los ejércitos en conflicto. Sea como fuere, si existió un acuerdo en torno a la necesidad de considerar la violencia ejercida contra la mujer como un caso específico de estudio e interés, sobre todo por la dimensión sexual y de género que esta adquiere en la mayor parte de los casos. ${ }^{14}$ De algún modo, esto nos pone en la línea de otro de los grandes ejes discursivos de Los teatros de lo bélico: el habitual solapamiento de la condición de víctima y perpetrador en un mismo individuo, lo cual no es sino un reflejo de la complejidad inherente a los contextos de guerra, una de las cuestiones en las que se hizo más hincapié a lo largo del debate. Precisamente, el compromiso del historiador con la complejidad es una de las principales apuestas de la nueva historia militar, y creemos que debe ser uno de los ejes rectores esenciales por los que discurra la historiografía en los próximos años. De hecho, concluimos en los debates que no es sino el perpetrador y la naturaleza de la violencia ejercida por éste lo que da contenido y razón de ser a la víctima como tal, de forma que obviando esta dimensión fundamental seremos incapaces de aprehender la realidad de un modo omnicomprensivo. Así pues, huir de esa absolutización de la víctima per se parece una buena salida frente al impasse en que han caído algunas interpretaciones, para lo cual parece fundamental entender las motivaciones del perpetrador y las direcciones o formas adoptadas por la violencia. Quizás, dicho de otro modo, se trataría de acometer el esfuerzo de establecer un vínculo empático con éste que nos permita ahondar en su realidad emocional, es decir, superar la barrera moral, política, cultural o social que nos separa de él, algo que en otras historiografías se viene haciendo de forma sistemática desde hace casi dos décadas..$^{15}$ De este modo, podríamos aspirar a entender cómo un individuo llega a ejercer violencia sobre otros superando de forma gradual esos puntos de no retorno impuestos por la ética y la moral y, al mismo tiempo, propiciando una transformación radical sobre sí mismo y su entorno.

Entroncando con esto último, se impone como una necesidad perentoria hacer referencia al problema de la periodización de los conflictos, es decir, qué criterios se observan en su conformación, qué realidades delimitan, así como por qué y de qué modo condicionan e, incluso limitan nuestra percepción y estudio del pasado. Precisamente, decimos que entronca con lo anterior porque a menudo un periodo de guerra convencional-delimitado por la apertura de hostilidades y la firma de una rendición o un tratado de paz-abre paso a un tiempo de desagravios y ajustes de cuentas, en muchas ocasiones caracterizado por tasas de violencia y fracturas del cuerpo social propias de una guerra civil. Por lo que a Los teatros de lo bélico se refiere, constatamos en el curso de los debates cómo los conflictos se extienden más allá de los marcos temporales normativos, haciendo referencia a casos concretos como el de la guerra civil griega (1946-1949), donde existe un amplio consenso historiográfico en torno a la tesis de que las dinámicas que caracterizaron este enfrentamiento fueron abiertas y establecidas por y durante la Segunda Guerra Mundial. Algo similar ocurre en el caso de las grandes expulsiones y desplazamientos forzosos de poblaciones alemanas, polacas y ucranianas, entre otras, que tuvieron lugar en Europa centro-oriental al término de la guerra para el reordenamiento fronterizo y la homogeneización étnica del continente europeo, todo ello marcada por altos

14 En este sentido, es de gran interés Dagmar HERZOG (ed.): Brutality and Desire: War and Sexuality in Europe's Twentieth Century, Londres, Macmillan, 2009. 15 En el caso alemán fueron decisivos la Wehrmachtausstellung y los debates que giraron en torno a su puesta en marcha y desarrollo, una polémica exposición que demostraba la implicación de la por el Hamburger Institut für Sozialforschung y recorrió muchos puntos centrales de la geografia por el Hamburger Institut für Sozialforschung y recorrió muchos puntos centrales de la geografía alemana y austriaca, con un tremendo impacto en ambas sociedades. El evento puso en cuestion
el mito de la saubere Werhmacht [limpia Wehrmacht], según el cual los soldados alemanes estarían libres de toda culpa en los crimenes del Tercer Reich y, edemás, como hom alemanes eshabrian sido una víctima más de la guerra. 
niveles de mortalidad y variadas formas de violencia. ${ }^{16}$ Evidentemente, esto exige por parte del historiador extremar las precauciones en lo que a los orígenes de las políticas de la violencia se refiere y, por ello, hay que poner mucho cuidado frente a una posible equiparación de las víctimas que pudiera ser entendida a modo de exculpación. No es ésta la tarea de historiador. Sin embargo, sí lo es entender que la masividad y el carácter irreversible de los fenómenos de violencia étnico-política acontecidos al final de la guerra en Polonia, los Países Bálticos, Checoslovaquia o las fronteras occidentales de la URSS fueron concebibles y realizables gracias al proyecto racial del nacionalsocialismo y las diversas políticas implementadas para su realización, sufridas precisamente por los habitantes de estos mismos territorios. En este sentido, creemos que la Segunda Guerra Mundial o, al menos, las dinámicas abiertas por ésta-lo que podríamos denominar “legado del nacionalsocialismo"-se extenderían de forma muy clara hasta los años 1948-1950, determinando en buena medida la configuración actual del continente europeo.

En último lugar, un punto de especial interés en el taller fue el debate en torno a la percepción y recepción de lo bélico por parte de la sociedad, tanto en época de guerra como a posteriori, fenómeno que, constatamos, se vehicularía por medio de una serie de ideas-fuerza presentes en todo espacio de circulación ideológica, a modo de collage. De alguna manera, se hizo presente el viejo debate historiográfico muchas veces abordado por Peter Burke sobre el origen y el proceso de configuración de las culturas y relatos imperantes en la sociedad, en nuestro caso sobre la idea de comunidad en guerra y los diferentes discursos movilizadores. Tal y como defendiera el historiador británico, los debates apuntaron hacia la hipótesis de que dichos discursos se configuran desde arriba y desde abajo, con la participación activa de una sociedad que se implica de múltiples formas en su construcción llegando a modificarlos. ${ }^{17}$ Por ejemplo, esto se constata en múltiples aspectos como la construcción mediante suscripción popular de monumentos conmemorativos y, a menudo, sublimadores de la guerra como motivo de orgullo comunitario; la contribución al esfuerzo de guerra a través del envío de ropas de abrigo a los combatientes en el marco de campañas impulsadas por el estado; o la legitimación del racionamiento en la retaguardia como forma de solidarización con los soldados en el frente. ${ }^{18}$ Sea como fuere, gran parte del interés se centró en el papel clave jugado por el estado en la conformación de los discursos movilizadores, rol que se ve notablemente intensificado por el impacto de lo que Benjamin denominó la "era de la reproductibilidad técnica" o, dicho de otro modo, la modernidad, que hace posible una difusión masiva de dichos discursos. De hecho, constatamos que el concepto "retaguardia" tiene un componente claramente proac tivo en alemán e inglés, Heimatfront o Home Front, algo que pretende transmitir una visión muy concreta de la realidad destinada precisamente a implicar a la población civil como parte activa y crucial en el esfuerzo de guerra. ${ }^{19}$

16 Véase, por ejemplo, David ALEGRE LORENZ: "«Un mundo desplomado y devenido ceniza». Violende la 'cuestión alemana' en la Europa centro-oriental cia y trauma en la emergencia y resolucio
(1945-1948)", Historia Actual, en prensa.

17 Para el caso del franquismo y la guerra civil española vease Javier RODRIGO: Cruzada, Paz, Memoria. La guerra civil en sus relatos, Granada, Comares, 2013 y, por otro lado, para el caso del Tercer Reich y la Segunda Guerra Mundial véase Victor KLEMPERER: LTI. Apuntes de unfilólogo, Barcelona, Minúscula, 2007 [1946].

18 Algunos de estos aspectos en David ALEGRE LORENZ: “Formas de participación y experiencia política en el primer franquismo: la pugna por los principios ordenadores de la vida en comunidad durante el periodo de entreguerras (1936-1948)", Rúbrica Contemporánea, $3 / 5$ (2014), en prensa.

Heimatfront y Home Front serion en cierto modo equivalentes, pues ambos tienen unas implica9 ciones emocionales muy fuertes que hacen referencia al lugar donde uno se reconoce a si mismo so crió y donde cons "frente interno", aunque de este modo pierde ese componente emocionaly casi familiar que ex-
Así pues, creemos que nuestro futuro como comunidad historiográfica pasa por convertirnos en algo más que meros receptores y aplicadores de los principales avances metodológicos y conceptuales que se generan más allá de nuestras fronteras -algo que seguirá siendo fundamental, por otra parte-. Más allá de ello, el objetivo debe ser situarnos como productores y exportadores de instrumentos de análisis y conocimientos de interés para el conjunto de la comunidad académica internacional. Así pues, el camino ha de partir de la consolidación difusión y potenciación de los principales avances conseguidos hasta el momento, y dirigirse hacia la construcción de una red más tupida de afinidades e intereses en torno a lo bélico; el desarrollo de iniciativas abiertas y transversales como los seminarios y workshops; y, finalmente, la integración en los principales circuitos internacionales mediante la participación en congresos en el extranjero y la publicación de artículos de investigación en otras lenguas. ${ }^{20}$

Finalmente, creemos que la idea de teatros de lo bélico es por sí misma una declaración de principios metodológicos que apunta en el sentido de evitar cómodas explicaciones estructurales en el estudio de lo militar, la violencia y la guerra y, al mismo tiempo, nos invita a analizar estas cuestiones desde la perspectiva del escenario o el contexto. Por ello, defendemos la necesidad de entender los espacios socio-culturales en movimiento y no como estructuras anquilosadas que poco o nada contribuyen al conocimiento del pasado en toda su complejidad. Cada experiencia individual y colectiva es hasta cierto punto irrepetible en tanto que pasa por una serie de trances concretos que las determina en los más variados sentidos, de tal forma que aprehender la experiencia de la guerra es algo extremadamente difícil. No obstante, como historiadores interesados en la historia militar debemos exigirnos tres cosas fundamentales para conseguir avanzar y alcanzar buenos resultados: una búsqueda permanente de nuevas fuentes y una crítica impecable de aquéllas utilizadas, siendo conscientes de la múltiple información que ocultan tras su, en ocasiones, aparente opacidad; la necesidad de la conceptualización y reflexión teórica en torno al objeto de estudio, siendo permeables a otras disciplinas para abordar lo militar en toda su extensión; y, por último, el reconocimiento de los límites que se plantean a lo largo de nuestra investigación, lo cual no sólo es un necesario ejercicio de humildad, sino que además hará más sólidos y fiables nuestros trabajos

presa en alemán y en inglés. En cualquier caso, se trata de una idea que pretende extender el frente de combate al interior de los propios hogares en la retaguardia, apelando a los lugares a los que se sienten vinculados cotidiana y existencialmente todos y cada uno de los miembros de una sociedad dada: un barrio, un pueblo o una región concretas.

20 Antonio Cazorla apuntaba cuestiones interesantes al respecto en "Las historias que no escribimos. Una reflexión" en Óscar RODRÍCUEZ BARREIRA (coord): Franquismo desde los márgenes. Campesinos, mujeres, delatores, menores... Espai/Temps, 62 (2013), pp. 45-56. 


\section{EL TEATRO COMO ARMA DE COMBATE DURANTE \\ LA GUERRA CIVILEN LAESPAÑA SUBLEVADA \\ (VALLADOLID, 1936-1939)*}

Nelly Álvarez González

Universidad de Valladolid

\section{Introducción}

El drama político-social “R.I.", del valiente escritor nacionalista José Martín Villapecellín, es una pieza magnífica, reveladora del inmenso desprecio que la España auténtica y gloriosa siente por la barbarie "renovadora" del mandil masónico, impuesta por analfabetos del arroyo, incendiarios presidiables, profesores maricas y otros "intelectuales" de perra gorda, que solo pueden respirar, como las ratas, el ambiente nauseabundo de letrinas y albañales.'

Estas palabras, escritas por el político monárquico José María Albiñana, corresponden al prólogo de presentación a la obra antirrepublicana R.I.: "comedia dramática político-social", de José Martín Villapecellín, estrenada en los teatros vallisoletanos en pleno ecuador de la Guerra Civil. ${ }^{2}$ Debido a su implacable ataque a la República y a sus dirigentes, la obra, creada en 1933 había sido censurada en dos ocasiones por Manuel Azaña. Pero una vez iniciado el conflicto bélico, la polémica pieza teatral encontró dentro de la España sublevada el escenario idóneo para su representación, como discurso amparador del alzamiento. El lenguaje combativo y de absoluto desprecio hacia el adversario utilizado por Albiñana ${ }^{3}$-y reproducido con agudeza en la propia comedia-sirve como muestra de la utilización que se hizo del teatro como arma ideológica de combate durante la contienda española.

Con el presente artículo pretendo demostrar cómo, a lo largo de la Guerra Civil, el teatro fue utilizado en la España insurrecta -al igual que en la republicana-como herramienta de cultura de guerra para propagar el discurso hegemónico de los sublevados, adoctrinar a la población y articular una identidad colectiva basada en la contraposición de un "nosotros"-defensor de unos valores modélicos, justos y redentores-frente a un "ellos" que aunaba todos los males de la sociedad. ${ }^{4}$ Para realizar este estudio me apoyo en un análisis de fuentes primarias referentes a la actividad teatral desarrollada en la capital vallisoletana.

- Este artículo se ha ampliado posteriormente y publicado en la Revista Universitaria de Historia Militar, $n^{\circ}$ 4, pp. 64-87. http://www.revista-historiamilitar.org. Forma parte del dossier «Los teatros de lo bélico. Violencia, memoria, identidad y sociedad de masas", coordinado por David ALEGRE LORENZ y Miguel ALONSO IBARRA, a quienes agradezco su apoyo en mi investigación y su gran profesionalidad. José María ALBIÑANA: "Prólogo", en José MARTíN VILLAPECELLÍN: “R.I." Comedia dramática de carácter político-social situada en un pais imaginario, con un prólogo y tres actos, Madrid, Gráficas España, 1933. La obra fue estrenada el 14 de diciembre de 1937, por la compañía de Sagi-Vela, en un festival a favor de la causa nacional.

El doctor Albiñana no pudo ver en vida la representación de la obra al morir fusilado en agosto de 1936.

4. Tomo elconepto de "ultura de guerr" déngel Alcalde, quien la define como "el conjunto de discursos, prácticas, sistemas simbólicos y representaciones producidos por un grupo social, en relación a la experiencia de guerra" a fin de "construir una identidad grupal frente a un enemigo y empujar al conjunto de la sociedad a participar en el esfuerzo de guerra". Ángel ALCALE FERNÁNDEZ: "1 conjun " "Culturas de guerra", excombatientes y fascismos en Francia y España durante el periodo de entreguerras", Ammis. Revue de civilisation contemporaine Europes/Amériques, 10 (2011) http://amnis, revues.org/1251.
Teatro al servicio de la propaganda

El golpe militar del 17 de julio de 1936 obligó a las autoridades sublevadas a utilizar un discurso legitimador que sirviese para glorificar su lucha armada y presentar sus acciones como necesarias para el bien común, frente al amenazante enemigo. ${ }^{5}$ Con el fin de adoctrinar a la ciudadanía, se sirvieron de todos los canales posibles para difundir sus ideas, y el teatro -principal medio de entretenimiento de las masas junto al cine- no fue una excepción.

La capital vallisoletana, adherida desde el mismo arranque de la guerra a la retaguardia de bando golpista, ${ }^{6}$ presentó una intensa actividad teatral a lo largo de la contienda. A finales de verano de 1936 los teatros vallisoletanos ya funcionaban con plena normalidad. Gran parte de la oferta de la cartelera se aferró a la reposición de obras que gozaban del agrado del público desde años atrás y que, asimismo, garantizaban un éxito de taquilla. Pero, además de los títulos comerciales, surgió otro tipo de obras que, nacidas o rescatadas para la ocasión, formaron parte de un teatro militante, "de circunstancias", "de compromiso", o también denominado "de urgencia", que se utilizó como arenga legitimadora de la causa sublevada. ${ }^{7}$

Desde el bando republicano, Alberti utilizó el término de "teatro de urgencia" para definir un tipo de "obritas rápidas, intensas-dramáticas, satíricas, didácticas", adecuadas a los pocos medios existentes, y de breve duración, que era obligado crear ante las circunstancias marcadas por la Guerra Civil. ${ }^{8}$ Señala José Montelón que la urgencia venía dictada por la "necesidad de operar a tiempo", ya que, una vez resuelto el conflicto, su función sería "anacrónica e inútil". Dada la exigencia de escribirlas de forma rápida, descuidando consecuentemente el lenguaje, estas manifestaciones teatrales cumplían más una función política que estética, siendo su principal propósito influir en el público por medio de la "palabra viva y directa", como afirma Mundi Pedret. ${ }^{10}$ El objetivo era desprestigiar al enemigo y contraponerlo a personajes ejemplares cuya conducta heroica y patriótica debía servir de modelo a los espectadores.

En los teatros vallisoletanos se estrenó una veintena de obras (véase cuadro final) que se amoldaron a las principales características del teatro de urgencia, especialmente por su prioritaria finalidad adoctrinadora; no obstante, no todas se ajustaron a la extrema brevedad. Se representaron en dos tipos de espectáculos diferentes: bien como parte de la programación de las funciones ordinarias de las compañías, o insertas en los festivales benéficos organizados para recaudar fondos a favor de la "causa nacional". En dichos festivales, las obritas teatrales "de circunstancias" eran un ingrediente más de un espectáculo ecléctico diseñado para exaltar el patriotismo. ${ }^{2}$

Casi todas fueron escritas durante el periodo bélico y, ciñéndose a la actualidad, recreaban historias contextualizadas en la propia Guerra Civil. Se salen de este molde tres obras creadas

5 Cuando la legitimidad se cuestiona, señala van Dijk, el grupo que maneja el poder se marca como objetivo inmediato demostrar que sus principios básicos son justos, e incluso universales, frente a la incorrección de los principios defendidos por el rival. Teun A. van DIJK: Ideología: un enfoque multidisciplinario, Barcelona, Gedisa, 1998, p. 320 .

6 El 18 de julio de 1936 se proclamó en Valladolid el alzamiento militar por el general Saliquet.

7 Véase: Berta MUÑOZ CÁLIZ: “EI 'teatro de urgencia': la brevedad al servicio de la eficacia”, Cuadernos del Ateneo, 21 (2006), pp. 17-22.

8 Rafael ALBERTI: “Teatro de urgencia”, en Prosas, Madrid, Alianza, 1980, pp. 79-80.

9 José MONTELÓN: "El mono azul". Teatro de urgencia y Romancero de la Guerra civil, Madrid, Ayuso, 1979

10 Francisco MUNDI PEDRET: El teatro de la guerra civil, Barcelona, Promociones y Publicaciones Universitarias, 1987, p. 18.

1 Nigel DENNIS y Emilio PERAL VEGA (eds.): Teatro de la Guerra Civil: el bando nacional, Madrid, Fundamentos, 2010, p.55

12 En los festivales se podía intercalar arengas, obritas de teatro de urgencia, recitales de poesía patriótica, himnos y diversos números musicales. 
antes de estallar el conflicto, ${ }^{13}$ pero cuya lectura resultaba también muy idónea a los fines instructivos perseguidos. Se aprecia especialmente en la ya mencionada R.I.: ambientada no en la guerra sino en la Segunda República, el retrato tan depravado que se hace de ésta servía para justificar ante el espectador la necesidad de emprender medidas radicales para derrocar al Gobierno legítimo. De hecho, la obra finaliza con un golpe militar de un "doctor, caudillo de las derechas, salvador de la patria". ${ }^{4}$

Que la finalidad moralizante del teatro de urgencia estuviera por encima de la calidad se evidenciaba en la autoría de las obras. Salvo excepciones -como la de José María Pemán quien también contribuyó con su pluma a este teatro de propaganda- ${ }^{15}$ la mayor parte de los estrenos correspondieron a escritores inexpertos, o apenas conocidos, que quisieron contribui con la causa o bien aprovecharse de las circunstancias para promocionarse. El hecho de ser falangista, militar o sacerdote era motivo de elogio, aunque su experiencia en el campo teatral fuese inexistente. Así mismo, la limitada riqueza dramatúrgica -de la que eran conscientes, además de la crítica, los propios autores y sus abanderados- quedaba recompensada por el "elevado espíritu patriótico" de la obra. Como ejemplo de esta permisividad, obsérvese la advertencia de Albiñana sobre R.I.:

Cualquier escrupuloso crítico, hallará seguramente en la obra desaliños literarios, falta de técnica, descuidos de bulto. El drama no ha sido escrito por su autor con el propósito de pasar a la inmortalidad. Responde a un momento angustioso que abruma a la Patria, y a muchas otras. Patrias, amenazadas de destrucción por los explotadores malvados de la brutal ignorancia populachera, cuna de todas las maldades y origen de todas las desenfrenadas tiranías. ${ }^{16}$

\section{Los relatos del teatro de guerra}

La trama patriótica de estas obras se apoyaba en retóricas maniqueas diseñadas desde el bando sublevado para retratar la depravación del enemigo (identificado con el marxismo ateísmo, masonería y judaísmo), frente a la rectitud de los defensores de la "España reconquistada". Véase por ejemplo la reseña de la comedia dramática España inmortal, del autor vallisoletano Otero del Pozo:

De la guerra actual de la reconquista nacional en la que España mantiene una lucha épica por defender la plenitud de su independencia territorial y espiritual, sus tradiciones seculares, su civilización cristiana y sus valores históricos contra los enemigos interiores y exteriores, dirigidos por los poderes judaico-masónicos y soviéticos, internacionales, ha sacado el señor Otero del Pozo una trama, que proyecta en el decurso de tres actos, una condenación acerba de la ideología marxista y de sus planes inhumanos, una exaltación ardorosa del amor a la Patria y una loa entusiástica del Ejército español, y de la milicias ciudadanas que con él tan brillantemente cooperan en esta gloriosa cruzada. ${ }^{17}$

13 Más leal que galante, Almoneda y $R$.I.

4 José MARTIN VILLAPECELLÍN: "R.I." Comedia dramática de carácter político-social situada en un país imaginario, con un prólogo y tres actos, Madrid, Gráficas España, 1933.

15 Pemán estreno durante el periodo bélico Almoneda y De ellos es el mundo. La primera, comedia en la que critica la decadencia moral motivada por la modernidad, fue escrita en los meses previos a la guerra y se aleja más del estilo del teatro de urgencia. Diferente es el caso de la segunda a la que el propio Pemán la consideró como "de ocasión” y, de hecho, prohibió su reposición una vez concluido el conflicto.

16 José María ALBIÑANA: “Prólogo"...p. 7.

17 “España inmortal! Comedia dramática en tres actos y en verso, original de Otero del Pozo”, Diario
La misma finalidad de concienciar al ciudadano sobre la colisión extrema de valores se observa en Todo por la patria, del periodista Gallardo -obra dramática que resalta "la conducta traicionera y cobarde de los marxistas" frente al "amor patrio del pueblo español, sano de ideas y creyente"18 - y en La polilla, de los autores vallisoletanos Negueruela y Fernández Cadarso, comedia condenatoria del marxismo por su "engaño" de los trabajadores:

Es esta una obra de circunstancias, en la que se trata de impugnar y satirizarlo que era esencia de la vieja política, principalmente de los partidos marxistas, con sus procedimientos de captación, de falacia y de engaño para reclutar adeptos, para explotar los cargos directivos en los sindicatos y para medrar a costa de la ignorancia de los trabajadores. Esa vieja política es la polilla que ha traído las cosas de España a la guerra actual. Merced a esa vieja política pudo crecer y desarrollarse el comunismo. ${ }^{19}$

A la hora de elaborar las tramas, un importante corpus de obras recurría al humor para ridiculizar, humillar y mofarse del adversario y, a su vez, provocar la risa en el espectador. A esta finalidad responden claramente Felipe el de las FAl, de Merino y Córcega y EI miliciano Pomperosa, de Sánchez Arjona y Leal, que narra la historia de un miliciano que, sin saberlo, se convierte en confidente de las tropas "nacionales".

Tampoco faltaron obras, también muy patrióticas pero menos críticas y más sensibleras, diseñadas para emocionar y provocar la lágrima fácil del espectador. En sus relatos, basados más en loar al "nosotros" que en agraviar al "otro", cobraba un gran peso el ingrediente del amor. Muchachas de blanco, de Hernández Pino, comedia escrita como homenaje a las "virtuosas" enfermeras de los hospitales, constituye un claro ejemplo.

\section{Los personajes del teatro de guerra: "héroes" y "villanos"}

Dado que el teatro de urgencia buscaba la eficacia inmediata a la hora de impactar al espectador, dichas narrativas moralizantes se presentaban a través de personajes dicotómicos, y claramente definidos, a fin de que el público pudiera identificarse al momento con el modelo que debía seguirse o repudiar, tanto masculino como femenino.

El principal estereotipo de modelo masculino a imitar se retrataba en el personaje del aguerrido combatiente del bando sublevado. Su figura aparece en cada una de las obras ambientadas en la Guerra Civil,y casi siempre con un papel principal. De todas ellas, el apropósito lírico ¡Viva España!, ${ }^{20}$ de Bermejo, por su brevedad (1 acto), limitado número de personajes, inmediatez en la ambientación (recrea un hospital de sangre) y extremo didactismo moral, se ajusta a todas las características del prototípico teatro de urgencia. Protagonizan el relato un falangista que ha resultado gravemente herido tras luchar en el Alto de los Leones y una enfermera que le cuida. Es muy significativa la elección de los nombres: León, el soldado y Piedad, la enfermera. A través del dialogo entre ambos, Bermejo subraya la proeza de los soldados "nacionales" frente a la vileza, inferioridad y cobardía del enemigo:

Regional, 14 de noviembre de 1936. (La mayor parte de las noticias que presento en el artículo son anónimas).

18 "Brillante función a beneficio del hospital de guerra de R.E. en el Teatro Calderón", Diario Regional, 29 de enero de 1937.

19 "La polilla, comedia de los señores Negueruela y Fernández Cadalso", Diario Regional, 19 de marzo de 1937. 20 Antonio BERMEJO: Viva España!: dedicado al glorioso ejército español y milicias: cuadro dramático
en verso; letra de Antonio Bermejo y música de Gregorio del Valle, Vall ladolid, Casa Martín, 1936, p. 7 . Se estrenó en el teatro Candéón de Valladolid en el festival benéfico de "El aguinaldo del combatiente", el 17 de diciembre de 1936 . 
Las narrativas del teatro de guerra también construían modelos paradigmáticos de mujer

Al fin entre aquella turba fiera

se inició la desbandada,

y ondeó nuestra bandera

en el "Alto del León"

sobre un picacho clavada. ${ }^{21}$

El soldado finalmente fallece y esta muerte, por amor y defensa de la patria, le convierte en héroe, permitiéndole morir en paz. Otorgar un rango de héroe, no sólo a los fallecidos en el frente de batalla, sino también a los mutilados, formaba parte del desenlace de muchas de las historias recreadas. Con ello, además de ofrecer cierta recompensa moral a heridos y familiares de las víctimas, se subrayaba el deber patriota de anteponer la defensa de la "causa nacional" a la propia vida. Sirva como ejemplo, en Muchachas de Blanco, el consuelo que transmite un teniente coronel a su soldado cuando éste pierde la vista en el frente:

-Esté tranquilo muchacho. Pase lo que pase, siempre tendrás la gloria de ser un caballero mutilado. Piensa que te ha tocado hacer de héroe.

-iHe tenido esa suerte, mi Teniente Coronel! ¡A sus órdenes!22

Además del combatiente, otro personaje elogiado en las narrativas era la del piadoso sacerdote, presentado como una víctima del odio enemigo y defensor de la lucha sublevada. De todas las obras estrenadas, el mejor ejemplo lo constituye el drama ¡Arriba España-Viva España!, escrita por el clérigo Luis Alonso. Cuenta la historia de un humilde párroco que, al estallar la guerra, es capturado por "la barbarie de las hordas" rojas que se "ceban" sobre él. A pesar de todo, mantiene hasta su liberación "un elevado espíritu patriótico con abnegación, firmeza y heroísmo". ${ }^{23}$ La convivencia de personajes políticos y religiosos, identificados ambos con un mismo fin ideológico, resultaba acorde a la politización de lo religioso y sacralización de lo político, propia de retórica de la España franquista, y cuyo fin era otorgar a la causa sublevada el epíteto de "santa". ${ }^{24}$ Se producía en este sentido un apoderamiento de las imágenes religiosas para otorgarlas una misión protectora a los combatientes del bando rebelde. Sirvan de ejemplo los siguientes versos cantados a la Virgen del Pilar con los que arranca iViva España!:

\section{Aunque el rojo a mí me tire}

nunca me podrá matar

llevo en mi pecho grabada

21 Ibid., pp.7-8.

22 Emilio HERNÁNDEZ PINO: Muchachas de blanco. Comedia en tres actos, Zaragoza, Talleres Gráficos La Editorial, 1938, p. 83 .

23 El Norte de Castilla, 2 de marzo de 1937

24 Véase: Giuliana di FEBO: Ritos de guerra y de victoria en la España franquista, Bilbao, Desclee de Brouwer, 2002.
Se podrían destacar principalmente tres personajes: el de la madre, calificada como "santa" por su estoico sufrimiento, devoción religiosa y absoluta dedicación a la familia; el colectivo de jóvenes enfermeras, entregadas con fervor a la causa y renegando de la vida superficial de pasado; y, en un escalón más alto, monjas y hermanas de la caridad que aunaban todas las virtudes por su comprensión, inteligencia y piedad.

La introducción de estos personajes servía a los autores para inculcar al público lecciones de moralidad. La estrategia seguida era reprochar la degeneración de valores causada por la modernidad -proyectada en mujeres frívolas, vanidosas, consentidas, caprichosas e independientes- y contraponerla a un modelo de feminidad diseñado por el nuevo orden -mujer recatada, sumisa, generosa y devota. Un recurso utilizado en algunas de las obras consistía en presentar al inicio del argumento un prototipo de mujer "viciada" por las "malas costumbres", la cual, arrepentida de sus actos, encuentra en la vocación religiosa una salida idónea para reconducir su vida y redimirse de todo su pasado. ${ }^{26}$

A la ejemplaridad, que identificaba a las protagonistas de la España insurrecta, se contraponía la bajeza moral y crueldad de los personajes representativos del bando rival, calificados también de ignorantes, ladrones y cobardes.

De todas las obras de guerra representadas en los teatros vallisoletanos, R.I. es una de las más mordaces en su crítica al adversario. Martín Villapecellín construye un retrato depravado de los males de la República a través del personaje de Carlos, al que se contraponen su hermano sacerdote (Jesús) y su "santa madre", quien fallece debido a los disgustos de su propio hijo. Carlos procede de una familia humilde que se ha sacrificado por darle unos estudios, pero él, influido por las "malas compañías", malgasta los ahorros, sin trabajar ni estudiar. Es un personaje vengativo que odia a las clases acomodadas y se marca como objetivo "la exterminación de la clase azul". Cuando se proclama la República, pese a su carencia de estudios, asciende al puesto de subsecretario de la Presidencia y, una vez alcanzado el poder, renuncia a todos sus principios -desprecia a las clases inferiores e impone que le agasajense deja llevar por la ambición, la traición, el rencor, el odio y la falta de compasión (incluso condena a su propio hermano). Al final muere asesinado. En plena agonía siente miedo por la muerte, pero no consigue arrepentirse.

A lo largo de la trama, el autor, en su particular retrato de la República -identificada con el amor libre, la quema de iglesias, la persecución de órdenes religiosas, los confinamientos y las deportaciones- hace un especial hincapié en destacar la corruptela de los dirigentes de izquierdas. Obsérvese el siguiente diálogo entre un joven aristócrata (Vicent) cuando solicita al subsecretario de Presidencia (Carlos) una recomendación para un amigo en las Cortes:

Vicent: A ver si le podéis dar un enchufe en donde no haga nada

Carlos: Le presentaré una vacante de diputado a Cortes por mi partido.

Vicente: iPero si él no es orador!

25 Antonio BERMEJO: jViva España!... p. 5

26 Es el caso, por ejemplo, de la protagonista R.I.: la joven aristócrata Teresa Ouinloney, se transforma en Sor Adoración señal el autor "por amor en Dios y el arrepentimiento sincero de su vida frivo- 
Carlos: No hace falta. No tiene más que ir alguna tarde al Congreso, como quien va a los toros o al cine, e insultar a los "cavernícolas".27

En España Inmoral, Otero del Pozo aprovecha su relato de la Guerra Civil para ofrecer a espectador un discurso atroz sobre las barbaries cometidas por el enemigo. El personaje más perverso, Eugenio, representa a un dirigente sindicalista, cruel y vengativo, dispuesto a asesinar a toda la población enemiga, sin compadecerse de nadie. Obsérvese el siguiente parlamento:

Vamos a dar la batalla,

nada de simples camelos,

que sobra ya mucha gente

y hay que terminar con ellos.

Matar a todos es poco.

En cachos así, pequeños,

y después así quemados

que no quede ni el recuerdo [...]

Cuando matemos a todos

mucho mejor estaremos

Pero, no a los hombre sólos [sic]

y a las familias, jmostrencos!.

Que no queden ni los rabos.

Las mujeres, sin recelos;

sus hijos, como hizo Herodes,

en dos pedazos lo menos.

Y si alguno queda vivo,

no dudar, lo cogeremos. ${ }^{28}$

Al final de la trama, el autor se mofa de la cobardía y la falta de dignidad de este protagonista cuando, al ser arrestado, afirma con tal de preservar su vida: "yo no soy ya comunista, yo quiero hacerme fascista"; aunque no le sirve para salvarse.

A la hora de retratar al "otro" se observa, en la mayoría de las narrativas, dos tipos de categorías de enemigos. En un escalafón más alto, en cuanto a crueldad, estarían los personajes (como los descritos de Carlos e Eugenio) que actúan de cabecillas, o desempeñan puestos de responsabilidad, presentados como asesinos, corruptos, inmorales, capaces de engañar y aprovecharse incluso de los suyos. Pero, por debajo de ellos, se presenta otro tipo de personaje -generalmente personificado en humildes obreros sin cultura- representativo de una masa popular que, fruto de su ignorancia, sigue a los líderes de izquierdas sin darse cuenta de que está siendo manipulada. Únicamente sobre este segundo modelo de enemigo se contempla la posibilidad de redención, siempre que exista un arrepentimiento sincero. En España inmortal se reencarna a la perfección este papel en Blas, obrero comunista "envenenado por las falsas doctrinas", que encuentra en Doña Concha (mujer de derechas, culta y de buena posición) su guía para hacerle ver que aquellos líderes a los que admira son en realidad "vividores de ocasión", capaces de explotar la ignorancia de los obreros para su propio provecho y "llenar su panza"29. Blas, consciente de la crueldad y el engaño de sus superiores,

27 José MARTÍN VILLAPECELLÍN: “R.I.”..., p. 41.

28 Sotero OTERO DEL POZO: España inmortal. Comedia dramática en tres actos y en verso, Valladolid, Artes Gráficas Afrodisio Aguado, 1937, pp. 40-42.

29 lbid., pp. 21,22 y 34 se arrepiente y se pasa al bando "nacional" para, como señala el propio autor, volver a encauzarse en el "civismo español" de la "nueva España".30

\section{El escaso éxito del teatro de guerra}

Dada la finalidad patriótica del teatro de propaganda, el juicio de la prensa no podía se muy ecuánime al estar al servicio del poder, y esto se hacía más evidente en las obras estrenadas en festivales benéficos: como el fin era recaudar fondos para la causa, las crónicas de dichas veladas se limitaban a relatar el éxito de taquilla, el maravilloso espectáculo ofrecido y el patriotismo mostrado por todos los alli presentes. Consecuentemente, al hacer referencia a las obras de teatro de guerra estrenadas se solía subrayar el éxito obtenido por los autores, que casi siempre estaban presentes en los estrenos, hasta el punto de verse obligados a salir al final de la obra al escenario para saludar al entregado público.

Sin embargo, en las críticas referentes a las obras presentadas en las funciones ordinarias, cuya recaudación ya no era para la causa, si se aprecia un tono menos lisonjero. Con mucha sutileza, los críticos hacían referencia a la limitada calidad, la carencia de medios o la falta de ensayos; no obstante, apenas se hacía mención a la respuesta del público. Se sale de esta tendencia de cauteloso silencio una crítica del cronista del Diario Regional, Oretos, quien, a raíz del fracaso de taquilla del estreno de El miliciano Pomperosa, arremete con sarcasmo contra el público, compañías y empresarios por su poco apoyo al teatro de guerra. Su juicio sirve para atestiguar la escasa atracción que despertaban en el público estas obras y, por ello, empresarios y compañías las evitaban para no perder dinero:

El miliciano Pomperosa no se repite hoy, ni acaso en días sucesivos. ¿Por qué? ¡Ah, señores! Porque se trata de una obra de guerra. Y las obras de guerra quieren hacer patria y se nutren, en la parte humorística, de lo grotesco, de lo arbitrario, de lo ridículo de nuestros enemigos; y lo primero ¡todavía! ni es firme deseo de mucha gente, ni lo segundo hace reír a muchas personas. Por eso las obras de guerra no llenan los teatros y por la misma razón los empresarios, que ceden sus locales para fines benéficos o patrióticos, consienten la total pérdida de la nómina y no transigen con una escasa entrada cuando, en un derecho legítimo, abren sus taquillas para ganar dinero. Como en la actualidad los cómicos hacen sus contratos con participación en los beneficios, se resisten, como los empresarios, a montar, propagar y representar obras de guerra. ${ }^{31}$

Continúa su crítica reconociendo la baja calidad de muchas de las obras, pero aun así justifica su existencia y propagación dada la finalidad patriótica de éstas:

Es cierto que hay público qué ha sufrido estrenos de esta clase poco afortunados; pero esto no puede ser ni parcial disculpa de un sistema impropio de una sociedad que avanza por los comienzos de una ruta imperial. Si los primeros pasos fuesen fáciles, claros y felices, el destino no captaría la poderosa ilusión del premio a nuestro sacrificio y a nuestra constancia. En los nuevos caminos de España todo lo bueno está empezando y todo debe merecer apoyo, atención, contribución y estímulo. ${ }^{32}$

La crítica de Oretos sobre el fracaso del teatro de circunstancias cobra mucho sentido $s$ tenemos en cuenta el escaso número de veces que éstas obras fueron representadas (véase

30 Ibid., p. 6.

31 ORETOS: "El miliciano Pomperosa”, Diario Regional, 23 de marzo de 1938

32 lbid. 
cuadro). A excepción de las de Pemán, quien ya venía avalado por un nombre, y de España inmortal, de Otero del Pozo, de cuya comedia se editó además un libro que circuló con éxito por la España sublevada, ${ }^{33}$ el resto apenas superó las seis representaciones y, en la mayoría de los casos, se limitó a una o dos. El hecho que los empresarios y compañías buscaran el máximo rendimiento económico, me hace interpretar, para concluir, que estas obras, de haber obtenido el respaldo del público, habrían pasado a sus repertorios habituales, como de hecho ocurría con otras obras muy divulgadas. De esta forma, si comparamos los resultados del teatro de guerra con otros títulos mucho más comerciales, como el popular sainete de Federico Chueca La del manojo de rosas, que alcanzó en los escenarios vallisoletanos casi las cuarenta representaciones durante la contienda, resulta evidente que los espectadores se sentían mucho más atraídos por espectáculos puramente de evasión que les permitiesen escaparse, al menos momentáneamente, de las duras condiciones de la guerra. Y es que, tal y como señalaba Oretos en otra de sus críticas, el público, cuando acudía al teatro, solo quería reir.

\begin{tabular}{|l|c|c|c|}
\hline \multirow{2}{*}{ Título de la obra } & \multicolumn{2}{|c|}{ No $^{\circ}$ total funciones } & \multirow{2}{*}{ Compañia } \\
\cline { 2 - 3 } & Ordinarias & $\begin{array}{c}\text { Festivales } \\
\text { benéficos }\end{array}$ & Carmen Díaz \\
\hline $\begin{array}{l}\text { Almoneda. Comedia en tres actos y un intermedio de José } \\
\text { María Pemán. }\end{array}$ & 2 & & Florencio Medrano \\
\hline $\begin{array}{l}\text { Amor, sobre todo amor. Tragedia heroica en tres actos y en } \\
\text { verso, de Regino Martínez (capellán de Renovación Española). }\end{array}$ & - & 1 & $\begin{array}{c}\text { Compañía } \\
\text { pro-patria }\end{array}$ \\
\hline $\begin{array}{l}\text { Amor y espionaje. Comedia musical patriótica de Emilio Fer- } \\
\text { nández Cadarso y música de V. Serrano. }\end{array}$ & - & 2 & Florencio Medrano \\
\hline $\begin{array}{l}\text { Arriba España-Viva España. Drama patriótico en tres estam- } \\
\text { pas del sacerdote riojano Luis Alonso. }\end{array}$ & 2 & - & Carmen Díaz \\
\hline $\begin{array}{l}\text { De ellos es el mundo. Película representable en un acto y cin- } \\
\text { co cuadros de José María Pemán. }\end{array}$ & 10 & - & Juan Calvo \\
\hline $\begin{array}{l}\text { El miliciano Pomperosa. Comedia asainetada en tres actos del } \\
\text { Santander Rojo, de Manuel Sánchez Arjona y Roberto Leal. }\end{array}$ & 6 & - & Carmen Díaz \\
\hline $\begin{array}{l}\text { Embajada. Comedia patriótica en tres actos Jesús María } \\
\text { Arozamena y J.V. Puente. }\end{array}$ & 4 & - & $\begin{array}{c}\text { Sagi Vela (7) } \\
\text { Carmen Díaz (2) }\end{array}$ \\
\hline $\begin{array}{l}\text { España inmortal. Comedia dramática en tres actos y en ver- } \\
\text { so, de Sotero Otero del Pozo. }\end{array}$ & 8 & 1 & Carmen Díaz \\
\hline $\begin{array}{l}\text { Felipe el de la FAl. Sainete en } 3 \text { actos sobre escenas cómicas } \\
\text { madrileñas vividas durante los meses revolucionarios del } \\
\text { año 1937, de Merino y Córcega. }\end{array}$ & 3 & - & Florencio Medrano \\
\hline $\begin{array}{l}\text { La polilla. Comedia en tres actos de Dionisio Negueruela y } \\
\text { Emilio Fernández Cadarso. }\end{array}$ & 2 & - & Arias-Cuevas \\
\hline $\begin{array}{l}\text { La Sirrena. Sainete en tres cuadros de Luis Tejedor, música de } \\
\text { los maestros Ochoa y Galán. }\end{array}$ & 3 & - & Carmen Díaz \\
\hline $\begin{array}{l}\text { Las cinco rosas. Comedia dramática en } 3 \text { actos y prosa; de } \\
\text { José Escudero y Jesús Paz Aveleira (afiliados a Falange). }\end{array}$ & 2 & 1 & \\
\hline
\end{tabular}

33 Después de su estreno en Valladolid inició una gira por toda la zona sublevada; incluso se editó un libro de la obra que, según señala el diario $A B C$ de Sevilla fue un éxito de ventas “.España un libro de la obra que, según señala el unilı a

\begin{tabular}{|l|c|c|c|}
\hline \multirow{2}{*}{ Título de la obra } & No total funciones & \multirow{2}{*}{ Compañia } \\
\cline { 2 - 4 } & Ordinarias & $\begin{array}{c}\text { Festivales } \\
\text { benéficos }\end{array}$ & \\
\hline $\begin{array}{l}\text { Más leal que galante. Drama carlista en dos actos y en verso } \\
\text { de A. Pérez de Olaguer y B. Torralba de Damas. }\end{array}$ & - & 1 & Carmen Díaz \\
\hline $\begin{array}{l}\text { Muchachas de blanco. Comedia en tres actos de Emilio Her- } \\
\text { nández Pino. }\end{array}$ & 6 & - & Carmen Díaz \\
\hline $\begin{array}{l}\text { Por esta noche ná más. Comprimido de sainete de ambiente } \\
\text { madrileño en un acto y en prosa, de Tomás Seseña Palacios }\end{array}$ & 6 & 1 & Carmen Díaz \\
\hline $\begin{array}{l}\text { R.I. Comedia dramática política social situada en un país } \\
\text { imaginario, con un prólogo y tres actos, de José María Mar- } \\
\text { tín Villapecellín. }\end{array}$ & - & 2 & $\begin{array}{c}\text { Sagi Vela (1) } \\
\text { Aficionada con el } \\
\text { autor (1) }\end{array}$ \\
\hline $\begin{array}{l}\text { Si te dicen que caí. Diálogo escenificado, en prosa y verso, } \\
\text { original de Adolfo de la Calle (Comisario-Jefe del Cuerpo de } \\
\text { Investigación y Vigilancia). }\end{array}$ & - & 1 & $\begin{array}{c}\text { Cuerpo de Investi- } \\
\text { gación y Vigilancia }\end{array}$ \\
\hline $\begin{array}{l}\text { Sigue con tu cruz. Comedia dramática de costumbres en tres } \\
\text { actos del comandante Luis Turón Morales. }\end{array}$ & - & 1 & Sagi-Vela \\
\hline $\begin{array}{l}\text { Todo por la patria. Obra dramática en prosa del periodista } \\
\text { José Gallardo con ilustraciones musicales de Ángel Juan } \\
\text { Quesada. }\end{array}$ & - & 1 & Sagi-Vela \\
\hline $\begin{array}{l}\text { iViva España! Apropósito lírico en un acto de Antonio Ber- } \\
\text { mejo y música de Gregorio del Valle Villalba. }\end{array}$ & 1 & 1 & Florencio Medrano \\
\hline
\end{tabular}




\section{ESPAÑA EN LUCHA CONTRA LA REVOLUCIÓN}

Pablo Gómez Nogales

Universidad de Zaragoza

Introducción

El conflicto bélico que sacudió España entre 1936 y 1939 se enmarca en la llamada guerra civil europea que tuvo inicio con la Primera Guerra Mundial. Durante los treinta años que van de 1914 a 1945, final de la Segunda Guerra Mundial, por toda Europa se buscaron soluciones más o menos violentas a los conflictos provocados o agudizados por la modernización capitalista. En el primer tercio del siglo XX, la entrada de las denominadas "masas" en el juego político produjo un cuestionamiento de las relaciones de poder y el país se sumió en una crisis política y social, agudizada en los años treinta por la coyuntura de recesión económica. El régimen republicano inaugurado en abril de 1931 intentó canalizar estos conflictos a través de la política parlamentaria y de la reforma del sistema para ensanchar sus bases sociales. Sus cinco años de duración representaron un periodo de intensa movilización política sin precedentes en la historia española y, en muchos aspectos, sentaron las bases de la guerra civil.

Para los sectores privilegiados que vieron amenaza su posición de privilegio se hizo necesaria una operación de disciplinación de la sociedad que buscaba acabar con los desafíos a su situación. La derecha contrarrevolucionaria en sus distintas vertientes, nacional-católica y falangista, configuró un discurso defensivo dirigido a las clases medias urbanas y rurales, a las que se pretendía movilizar contra el proyecto democratizador. Estos sectores tenían una experiencia de la modernidad marcada por la sensación cambio acelerado y la amenaza a su identidad formada por una amalgama de nociones de clase, de género, religiosas y nacionales, que se tradujo en reacciones de miedo y ansiedad por la pérdida de un mundo conocido y en la búsqueda de valores estables apelando a una "tradición inventada" que presentaba los valores que conformaban su identidad. En otras palabras, mientras se mantenía un sistema de producción que estaba en la base de las transformaciones frente a las que se reaccionó, se produjo un rechazo de la modernidad cultural, señalada como el origen de todo mal. ${ }^{2}$

Una de las piedras angulares de este discurso fue el concepto de revolución, que fue objeto de una constante redefinición. En este proceso que culminó con la Guerra Civil, el término se estiró para englobar distintas realidades que fueron asimiladas dentro de un mismo esquema

Enzo TRAVERSO: A sangre y fuego. De la guerra civil europea (1914-1945), València, Publicacions de la Universitat de València, 2009.

2 Helen GRAHAM: "Gender and the State: Women in the 1940s", en Helen GRAHAM, Jo LABANYI (eds.): Spanish Cultural Studies. An introduction: The struggle for modernity, Nueva York, Oxford University Press, 1995, pp. 183; 183-184. El proyecto contrarrevolucionario como medio de petrificación de las relaciones sociales y productivas del capitalismo en Antoni DOMÉNECH: El eclipse de la fraternidad: una revisión republicana de la tradición socialista, Barcelona Crítica, El eclipse expresión de tradición inventada en Eric HOBSBAWM, Terence RANGER (eds.): La invención de la tradición, Barcelona, Crítica, 2002 mental. ${ }^{3}$ Este discurso enlazaba con el pensamiento contrarrevolucionario europeo iniciado con la Revolución francesa de 1789 y su objetivo era ocultar/desplazar los conflictos que dividían la sociedad. Desde la perspectiva contrarrevolucionaria, tales conflictos no serían productos de una

Esta continuidad en el discurso anterior y posterior al 17 de julio cumplió un papel fundamental en el esfuerzo de guerra. Enlazando las nuevas realidades con un pasado reconocible se asignaron significados a una situación que cambiaba con gran rapidez y, en ocasiones, en una dirección totalmente inesperada, facilitando la "naturalización" de la situación. Así se inició un proceso de construcción de lo que denominaremos cultura de guerra - entendida como un conjunto de elementos culturales y discursivos puestos en marcha para la adaptación de la población a una situación de guerra y violencia de masa - incluyó la formación de la opinión pública y de los imaginarios sociales, la construcción del enemigo, la gestión del sufrimiento, de la muerte y del duelo y, por su puesto, su memoria. ${ }^{4}$ Desde el 17 de julio, como venían haciendo a lo largo de los últimos cinco años, los distintos actores individuales y colectivos que se desenvolvían en el territorio controlado por los golpistas desarrollaron una competición política por imponer significados y reforzar una identidad común. Los partidos políticos a través de sus líderes, los ciudadanos, el ejército y la Iglesia fueron los protagonistas de este proceso improvisado de negociación. ${ }^{5}$ Por lo tanto, el resultado del mismo no se puede entender como una imposición desde arriba sino como una interacción, bidireccional. ${ }^{6}$

\section{La guerra civil española: orden y caos frente a frente}

La iniciación roja: 18 de julio de 1936, una fecha funesta para la civilización, una fecha magnífica para la civilización. Una fecha paradójica. Funesta y gloriosa. Sombra y luz...7

Esta frase, extraída del relato de Joaquín Romero Marchent sobre la revolución en Madrid nos habla sobre la división que se produjo en España como consecuencia de la sublevación militar que comenzó el 17 de julio. Ese día, una parte del ejército se levantó contra el gobierno legal de la República con el objetivo de hacerse con el poder político y frenar la política reformista impulsada por la izquierda republicana. Los militares y sus apoyos civiles fracasaron en su objetivo de hacerse con el poder central, sin embargo, su fuerza les permitió sustituir a las autoridades republicanas en buena parte del territorio español. En cuestión de pocas semanas, lo que había comenzado como un golpe de Estado se convirtió en una guerra civil. El país quedó dividido en dos mundos irreconciliables divididos por el frente, y en cada uno de estos mundos se inició un proceso social, político y cultural mediante el cual se buscaba dar una salida a la situación de crisis de los años treinta.

3 Una obra que muestra cómo los conceptos de revolución y de contrarrevolución se van definiendo en consonancia con la propia dinámica política de la revolución francesa tanto por sus protagonistas como por sus antagonistas es Jean-Clément MARTIN: Contre-Révolution, Révolu tion e Nation en France, 1789-1799, Paris, Seuil, 1998.

4 Stéphane AUDOIN-ROUZEAU y Annette BECKER: 14-18, Retrouver la Guerre, Paris, Galimard, 2003. 5 Este enfoque de la movilización colectiva se encuentra en Rafael CRUZ: En el nombre del pueblo. República, rebelión y guerra en la España de 1936, Madrid, Siglo XXI, 2006, pp. 261-320.

6 José Luis LEDESMA VERA:" ¿Cuchillos afilados?. De violencias, Guerra Civil y cultura bélicas en la España del Primer siglo XX", en Eduardo GONZÁLEZ CALLEJA y Jordi CANAL (coord.): Guerras Civiles. Una clave para entender la Europa de los siglos XIX Y XX, Madrid, Casa de Velázquez, 2012, pp. 89-104.

7 Joaquín ROMERO-MARCHENT, (Alejandro de España): Soy un fugitivo. (Historia de un evadido de Madrid), Valladolid, Librería Santarén, 1937, p. 28. 
En la retaguardia rebelde, la acción de los militares tuvo eco entre una buena parte de la población que reaccionó con gran entusiasmo a los acontecimientos de verano de 1936. Cas paralelamente a la sucesión de una serie de hechos inesperados se fue asignando significados a los mismos recurriendo a un repertorio cultural previo. Un numeroso grupo de pequeños y medianos propietarios rurales y urbanos y de profesionales liberales profundamente católicos y conservadores interpretaron los acontecimientos como un despertar de la nación española entendida ésta como una entidad católica - esta idea quedó reforzada tras el bombardeo de Pilar en Zaragoza y el fusilamiento de Cristo Rey en el Cerro de los Ángeles -. Muy pronto la jerarquía eclesiástica sancionó esta visión de los hechos y los líderes militares, viendo el apoyo popular que suscitaba la noción de Cruzada, la tomaron como propia para justificar su operación de reimposición del orden. ${ }^{8}$ Según este discurso, lo que se vivía en la retaguardia rebelde era un acto de la verdadera España, iniciadora de una Cruzada en defensa del orden social, religioso y nacional en peligro por el alejamiento de las tradiciones españolas. A través de este mecanismo discursivo las nuevas realidades de la retaguardia rebelde quedaron enmarcadas en una continuidad de lucha por este orden sancionado por Dios, única fuente de la autoridad y de la Justicia garantes del bien común. 9 Y no nos referimos sólo a la identificación de la nación con la religión católica o la negación de identidades nacionales alternativas a la española. Los conceptos jerarquía, autoridad y familia, íntimamente ligados entre si, daban cobertura a unas relaciones económicas y de género que no tenían nada de naturales ni de necesarias. Bajo la apariencia de armonía social se ocultaba la violencia producida por una serie de relaciones desiguales que eran presentadas como naturales. Formas de movilización muy diferentes quedaron ligadas por una línea de continuidad; si durante los años de paz las formas de lucha contra la revolución eran fundamentalmente la participación en manifestaciones, la asistencia a mítines y, sobre todo, la participación electoral; el fracaso en la elecciones de febrero de 1936 dejó el golpe de estado como única solución frente al desorden. Esta opción requirió la colaboración civil en los trabajos de policía, en la violencia política y, a medida que se hizo evidente que era necesaria una guerra larga, la movilización de los hombres para el frente y de las mujeres para la producción, para los trabajos de asistencia y de ayuda al frente. Esto fue posible porque, aunque la violencia política desencadenada en el verano de 1936 era cualitativa y cuantitativamente distinta de la producida con anterioridad, los conflictos de fondo a los que respondía eran en muchas ocasiones los mismos: las relaciones de subordinación entre los géneros y las clases sociales que convivían en el país, las disputas territoriales entre el centro y la periferia y, finalmente, la posición ocupada en la sociedad por la Iglesia y el ejército. ${ }^{10}$

Pero como da a entender la frase que abre este artículo, la situación no quedaba completa sin atender a lo que sucedía al otro lado del frente, donde se estaba produciendo la temida revolución, antítesis de todo lo que España representaba. La sombra de la revolución era una amenaza que había estado siempre latente y que en ese preciso momento tomó unos contornos definitivos. Como venimos señalando, cuando descendemos a los relatos de la revolución sorprende la cantidad de líneas de continuidad existentes entre el discurso contrarrevolucionario anterior y posterior a la guerra. Resulta evidente que los ingredientes fundamentales que conformaban el discurso contrarrevolucionario se habían combinado con cierto éxito durante

8 Mary VINCENT: "La Guerra Civil española como guerra de religión", Alcores, 4 (2007), pp. 57-73 y Rafael CRUZ: En el nombre del pueblo,..., pp. 261-320. Aunque estas obras no tienen en cuenta la dimensión de clase que en este artículo apuntamos.

9 Isidro GOMA: “Carta colectiva del episcopado español" en ÍD.: Pastorales de la guerra de España, Madrid, Rialp, 1955, p. 158. La carta colectiva se publicó el 1 de julio de 1937 y fue firmada por la mayoría de los obispos españoles. Alcanzó una gran difusión tanto a nivel nacional como internacional.

10 El aspecto rupturista de la violencia desencadenada en el verano de 1936 en José Luis LEDESMA VERA:“¿Cuchillos afilados?. De violencias, Guerra Civil...”, p. 101. el periodo republicano: durante el periodo de cinco años que va de abril de 1931 a julio de 1936 se había estado hablando del carácter revolucionario de la República. El concepto Revolución se vio ampliado con la huelga revolucionaria de octubre de 1934 y la primavera de 1936. Ahora bien, cuando el golpe de Estado y la fractura de los mecanismos de coerción posibilitaron el estallido de la revolución social el significado del concepto en el discurso contrarrevolucionario se transformó de nuevo. Los cinco años anteriores no habían sido sino una preparación para la verdadera revolución. Si durante la República se había considerado revolucionario el matrimonio civil, el divorcio, los jurados mixtos y toda una serie de medidas legislativas adoptadas por los gobiernos de izquierdas, tras el 17 de julio pasaron a formar parte de la revolución las colectivizaciones, la violencia masiva, la toma del poder por las organizaciones obreras o la participación de las mujeres en la guerra." Como veremos, estos acontecimientos se presentaron como un resultado necesario de las medidas de los gobiernos del primer bienio y del Frente Popular. Este discurso permitía dar una imagen homogénea de los distintos enemigos políticos, borrando las distinciones entre la izquierda republicana y las diferentes organizaciones obreras. El relato de la guerra como una Cruzada quedaba cerrado presentando dos bandos bien definidos que defendian valores absolutos enfrentados.

Pero aunque los elementos de continuidad fuesen muy importantes, es innegable que la fuerza de los nuevos acontecimientos reforzó la presencia de este discurso que durante la guerra llegó a impregnar todas las manifestaciones culturales de la retaguardia rebelde. El contenido definitivo del concepto de Revolución se alimentó de las experiencias de la retaguardia republicana; las nuevas experiencias de miles de españoles fueron rápidamente integradas en los marcos cognitivos anteriores que quedaron modificados. Desde una fecha muy temprana se buscó el testimonio de evadidos de la retaguardia republicana. ${ }^{2}$ En poco tiempo comenzaron a aparecer libros de testigos de la revolución, novelas sobre el Madrid rojo, poemas, artículos de prensa, colecciones de fotografías, carteles y programas de radio que se ocuparon de transmiti la experiencia de la revolución de una forma fuertemente estereotipada. La aterrorizada burguesía consumió estos productos, algunos de los cuales se convirtieron en auténticos éxitos. ${ }^{13}$

Sin excepción, los autores contrarrevolucionarios responsabilizaron a los gobiernos republicanos de izquierdas de la descomposición social que según ellos tuvo lugar tras el golpe de Estado. Dicho de otro modo, los políticos republicanos habían posibilitado la situación alcanzada al alejarse de la religión y fomentar la pérdida del respeto hacia las jerarquías. Especialmente Azaña, "El hombre fatídico que en su loca osadía, y soberbia sin límites, se propuso destruir España". ${ }^{14}$ La posición de estos políticos al frente del Estado no se correspondía con la existencia de un proyecto social apoyado por una parte importante de la sociedad española movilizada durante la Segunda República. Al contrario, era la consecuencia de fuerzas ocultas que conspiraban contra la Nación española, era "la actuación callada, sorda, misteriosa de la masonería". ${ }^{15}$ Esta acción corrosiva de los intelectuales, "disfrazada de momento con todos los

1 Advertir de que algunos de estos cambios encuentran una fuerte oposición entre los propios revolucionarios como es el caso de la subversión de los roles de género.

12 La primera entrevista a un evadido de la parte oriental de Aragón fue publicada en Heraldo de Aragón el 25 de julio de 1936.

13 Sobre la producción, publicación y difusion de las obras literarias en la retaguardia rebelde José María MARTÍNEZ CACHERO: Liras entre Lanzas. Historia de la Literatura "Nacional" en la Guerra Civil, Madrid, Castalia, 2009. Especialmente: pp. 87-108; 275-341. José Carlos MAINER: "De Madrid a Madridgrado (1936-1939): La Capital vista por sus sitiadores", en Albert MECHTHILD (ed.): Vencer no es convencer. Literatura e ideología del fascismo español, Madrid, Vervuet, 1998, pp. 181-198, habla del éxito de las novelas sobre la revolución entre la burguesía.

14 Ángel GOLLONET MEGÍAS y José MORALES LÓPEZ: José, Rojo y azul en Granada, Granada, Ed. “Imperio", 1937, p. 21.

15 Antonio PÉREZ DE OLAGER: Lágrimas y Sonrisas, Burgos, Ed. Antisectarias, 1938, p. 97 
requisitos y burocracia del capitalismo o economía de la burguesía, y bajo el pabellón y la comedia de hacer creer que se sostenía y defendía a la República, a la democracia", por lo tanto, había sido casi imperceptible para muchos buenos españoles que se habían dejado engañar durante un tiempo. Pero pronto dio paso a algo mucho más terrible: desde febrero de 1936 en toda España se preparaba un complot marxista en el que lo más bajo de la sociedad se sacudiría la tutela de sus líderes naturales y pondría en peligro a toda la sociedad en su conjunto. ${ }^{16}$ Este contexto era la oportunidad esperada por los irresponsables políticos demagógicos de la izquierda para llenarse los bolsillos con todas las riquezas que pudiesen recoger y abandonar el país antes de que la violencia de la revolución les alcanzase a ellos mismos. ${ }^{17}$ A través de esta argumentación se buscaba desacreditar cualquier intento de cambio por moderado que fuese. Según los contrarrevolucionarios, al poner en cuestión los pilares del orden se había liberado el potencial destructivo de unas masas que debían estar tuteladas en todo momento por los más dotados de la sociedad.

Con el objetivo de ilustrar este razonamiento se retomó toda una batería de imágenes que presentaban a los revolucionarios como los habitantes de un mundo inferior, en ocasiones subterráneo, imposible de controlar y que ascendía sin pedir permiso para inundar el mundo ordenado de la superficie. Agustín de Foxá, en su novela Madrid, de corte a checa describió como "el enemigo nos surgía de las plantas de los pie; ascendía, vertical e implacable, de las porterías, de los sotabancos, de las alcantarillas". La metáfora del conde falangista, como tantas otras antes y después, identificaba directamente a ese temido submundo con la clase obrera. De una forma todavía más concreta nos decía que "el enemigo era la criada de nuestro cuarto, nuestro portero, el lavacoches de nuestro automóvil, el guarda del Retiro de nuestra niñez, el lechero, el panadero, el maquinista del tren de nuestros veraneos".18

Pero si no había ninguna injusticia en la situación anterior iqué impulsó a esta gente extraña a conquistar todo lo que no les pertenecía por derecho? ¿Por qué atacaron un orden que, según los obispos españoles, garantizaba la justicia y el bien común? ${ }^{19}$ Las causas de la revolución estaban muy claras para aquel que siguiera atento el discurso contrarrevolucionario. Ya hemos visto cómo la actuación de políticos e intelectuales había socavado de manera irresponsable la posición de la religión, freno de las pasiones, y de los líderes naturales de la comunidad. La argumentación seguía con una curiosa mezcla de paternalismo y desprecio hacia la clase obrera, explicando que "lo que fue pueblo, clase trabajadora, había sido transformado por los "delincuentes" que gobernaban, en instrumento". ${ }^{\circ}$ Llenos de un odio y una envidia inoculada por agentes corruptores, los revolucionarios se lanzaron contra los garantes de la moralidad, Dios y sus representantes, los sacerdotes; contra aquellos que habían triunfado por sus propios méritos y dirigían a la comunidad con el objetivo del bienestar colectivo, la clase media y la aristocracia; $y$ contra los encargados de mantener el orden, el ejército y la guardia civil. El marxismo era señalado como un "grano purulento", un "virus monstruoso" que había infectado a una parte de la sociedad. Una metáfora médica que apoyaba la idea de su origen externo. Bajo su influencia:

16 E. PUIG MORA: (El ciudadano desconocido), La Tragedia Roja en Barcelona. Memorias de un evadido, Zaragoza, Librería General, 1937, p. 41

17 La venalidad de los dirigentes socialistas en uno de los temas favoritos del general Gonzalo Quipo de Llano y lo explotó reiteradamente en sus célebres charlas radiofónicas, por ejemplo en $L a$ Unión, 22 de julio de 1936 se reproducían las palabras del general respecto a el afán de riquezas de Indalecio Prieto, citado en lan GIBSON: Queipo de Llano. Sevilla, verano de 1936, Barcelona, Grijalbo, 1986, p. 155

18 Agustín de FOXA: Madrid, de corte a cheka, Madrid, Ciudadela, 2008 (3a edición) [1938].

19 Ver cita 9 del artículo.

20 Joaquín ROMERO.MARCHENT: (Alejandro de España), Soy un fugitivo..., p. 55
No tiunfó la República, no triunfó la democracia, no triunfaron siquiera los hombres de la República, el éxito era de las malas pasiones, de los apetitos apremiantes, de todas las codicias, de todas las más bellacas ansias, metidas en los cuerpos de los más audaces, de

los más incultos, de todo el bajo fondo que una sociedad tiene. ${ }^{21}$

Llegados a este punto del razonamiento contrarrevolucionario encontramos ya formuladas las ideas por medio de las cuales, en primer lugar se operó el desplazamiento de los conflictos que fracturaban la sociedad. Se negaba que dentro del orden establecido hubiera relaciones desiguales e injustas entre patronos y obreros, entre propietarios y jornaleros, entre hombres y mujeres, etc. Al contrario, la oposición a un orden justo era consecuencia de la ponzoña vertida en la sociedad por determinados intelectuales. Y, en segundo lugar, se describía a las clases populares como seres inferiores incapaces de analizar y comprender por si mismos el mundo en el que vivían y proponer una forma de organización alternativa. Instrumentalizados por oscuros intereses se encaminaban al desastre y arrastraban al conjunto de la sociedad con ellos. A partir de aquí, los relatos de la revolución constituyen una colección de hechos y explicaciones que ilustran y apoyan estas dos ideas.

Los primeros momentos de la revolución fueron descritos como un auténtico descenso a los infiernos. Empezando por Madrid, que fue el lugar que produjo una literatura más amplia prácticamente todas las ciudades que vivieron la revolución encontraron testigos dispuestos a narrar los horrores producidos por ésta. ${ }^{22}$ Los testimonios de los supervivientes dibujaron una situación que mezclaba la alegría descontrolada, totalmente irracional, de los revolucionarios, producto de la entrega completa a los instintos más primarios; junto con el desbordamiento de la violencia. Esto contribuyó a extender la imagen de la revolución como una fiesta macabra, un auténtico carnaval en el que todas las reglas de comportamiento fueron subvertidas y las relaciones de un mundo ordenado resultaron alteradas. Así describió Gabriel Araceli, un huido de la Valencia revolucionaria, su experiencia en la capital del Turia: tras el asalto a los cuarteles de infantería "el carnaval se extendió por toda Valencia. Todo un día del mes de Agosto, con un casco de campaña, arrastrando un sable de Caballería, gritando y berreando dio en tierra con más de un esforzado defensor de la "causa del pueblo". ${ }^{23}$

Este carnaval comenzó con la ocupación del centro de las distintas ciudades por miles de obreros. Algo que los testigos procedentes de las clases media y alta vivieron como la invasión de un espacio que les pertenecía por naturaleza, como la inversión de unas relaciones que siempre habían seguido la única lógica posible. Esta sensación la reflejó bien Remigio Moreno González, miembro de la Audiencia provincial de Málaga, en la narración que hizo de su primer encuentro con las "hordas" en la calle Larios, el corazón de la Málaga burguesa, nada más comenzar la revolución: hombres y mujeres de aspecto diferente a los que normalmente frecuentaban esta calle, procedentes de los barrios obreros situados al oeste del río Guadalmedina, se dedicaban a saquear e incendiar las casas y los comercios y se paseaban con los "trofeos de sus rapiñas", sables, macetas o, incluso, unas cortinas de Damasco a modo de mantón. ${ }^{24}$

21 Entrecomillados en E. PUIG MORA (El ciudadano desconocido): La Tragedia Roja en Barcelona..., p. 45; Remigio MORENO GONZÁLEZ: Yo acuso... Ciento treinta y tres días al servicio del Gobierno de Madrid, Tánger, 1938, p. 76 .

22 La principal novela sobre la revolución en Madrid es Agustin de FOXA: Madrid, de corte a cheka,.. Aunque existen muchas otras. La revolución en Barcelona fue narrada por ejemplo por E. PUIC MORA (El ciudadano desconocido): La Tragedia Roja en Barcelona... El caso de Málaga en Remigio MORENO GONZÁLEZ: Yo acuso.... Valgan de ejemplo de una larguísima lista de obras.

23 Gabriel ARACELI: Valencia, 1936, Zaragoza, Talleres editoriales de "El Noticiero", 1939, p. 31

24 Remigio MORENO GONZÁLEZ: Yo acuso..., p. 55. La información sobre los barrios obreros y la calle Remigio MORENO GONZALEZ: Yo acuso..., p. 55. La información sobre los barrios obreros y la calle La ios en RICHARDS, Mich ael. "Presentando armas al santisimo sacramento: Guerra Civil y Sema- 
Como ha señalado Chris Ealham, los cambios que sufrieron las ciudades estaban cargados de significado. Sin embargo, este significado resultaba oscurecido y se hacía prácticamente desentrañable por la apariencia de descontrol que invadía todo. Los revolucionarios seguían una lógica propia que enlazaba con las experiencias de movilización y protesta popular acumuladas durante años, sus protagonistas intentaron plasmar un "proyecto urbanístico revolucionario" que buscaba transformar las ciudades en un sentido anticapitalista. Dirigidos por comités revolucionarios se ocuparon los barrios ricos y los edificios que representaban el privilegio, el poder y la influencia social de la elite - Iglesias, oficinas, hoteles, casas de los ricos, cuarteles,...- - devolviéndolos a la comunidad, además se sustituyeron otros símbolos de poder de la élite por otros nuevos que expresaban el poder recién adquirido de las organizaciones obreras. ${ }^{25}$ Ajenos a estas lógicas, los relatos de carácter contrarrevolucionario presentan estos actos desprovistos de su contenido político, y por lo tanto, los hacían impenetrables para la razón. El ambiente de carnaval envolvía la "tragicomedia de la incautación de edificios" en la que los milicianos de las numerosas organizaciones competían por apropiarse de los mejores edificios, donde "vivaqueaban salvajemente" después de haber expulsado a sus legítimos habitantes. Las iglesias fueron asaltadas, saqueadas y finalmente quemadas; los elementos del culto católico eran profanados y las imágenes destruidas. El asesinato de los miembros del clero, las parodias de misas y la exhibición de las momias desenterradas de los cementerios de los conventos acentuaban, a ojos de los católicos, la interpretación de la revolución como una fiesta de carácter satánico. Paralelamente, las diferencias entre los sexos se difuminaban, las mujeres se vestían con monos azules de obrero y se paseaban con fusiles, actuando como hombres, mientras que los hombres no cumplían con sus deberes hacia las mujeres y la familia. Todo ello estaba redondeado por el más absoluto libertinaje sexual. Finalmente, se describía un proceso de igualación por lo bajo. Las formas de vestir se homogeneizaron, una vez desaparecidos los distintivos de la clase media, sombreros y corbatas, sólo se veían hombres "despechugados" y "calzados con alpargatas"; las normas de comportamiento desaparecieron y nadie respetaba el trato reservado a las jerarquías anteriores. ${ }^{26}$

Como consecuencia de todos estos cambios, los "espectadores" de la revolución declaraban tener la sensación de vivir en ciudades desconocidas, situadas en un país diferente a España, en el que incluso las personas habían cambiado de aspecto. ${ }^{27}$ En muchos relatos, como en el de Foxá, este sentimiento de extrañeza iba acompañado de una intensa nostalgia por la ciudad tradicional perdida, en su caso Madrid. El impacto de la modernidad, origen de todos los males, había roto la armonía de clases, y una nueva ciudad "hosca, de taxis y huelguistas con monos azules, y rascacielos" se volvía contra su pasado, "las leyendas, los recuerdos, la nostagia. (...). Y la ciudad se quedaba sin historia, (...), sin engarce con el pasado". ${ }^{28}$

cultural y Guerra Civil española, Granada, Comares, 2005, pp. 253-286.

25 Chris EALHAM, "El mito de la muchedumbre enloquecida: clase, cultura y espacio en el proyecto urbanistico revolucionario de Barcelona, 1936-1937, en Chris EALHAM y Michael RICHARDS (eds.) España fragmentada..., pp. 153-186. Entrecomillado en la p. 154

26 Lo aquí descrito se puede encontrar en casi todas las obras sobre la revolución, valgan como ejemplos sobre la incautación de edificios Jacinto MIOUELARENA (El Fugitivo): Cómo fui ejecutado en Madrid, Ávila, s.n., 1937, p. 36; sobre la violencia anticlerical Niceto CASTRO ALBARRÁN: La gran victima. La Iglesia española, mártir de la revolución roja. Salamanca, 1940; la subversión de las relaciones de género en Emilio CARRERE: La ciudad de los siete puñales, La novela del Sábado, nº 20, Madrid, Ediciones Española, 1939, p. 31; el tema de los cambios en el vestuario recibe mucha atención en Marqués de la Cadena: Entre rojos y entre azules, Zaragoza, Heraldo de Aragón, 1939, p. 174.

27 E. PUIG MORA (El ciudadano desconocido): La Tragedia Roja en Barcelona..., p. 52 sobre Barcelona. 28 José Carlos MAINER: "De Madrid a Madridgrado (1936-1939)...; Agustín de FOXÁ: Madrid, de corte a checa,..., pp. 154 y $246-247$
Pero la revolución aún tenía un aspecto más terrible que hemos dejado para el final. El grotesco carnaval estaba completado por la presencia de los temidos milicianos. Éstos, organizados en comités y patrullas de vigilancia se paseaban en coches incautados exhibiendo sus armas, la verdadera fuente de poder de los obreros. A falta de una autoridad que se impusiese a los caprichos de cada uno de los distintos comités, patrullas, etc., se vivía en una situación de absoluta arbitrariedad. En cualquier momento la voluntad de un miliciano podía ser fatal para cualquier ciudadano decente. Las bases de la sociedad, religión, propiedad y familia, quedaron a merced del odio y resentimiento de los revolucionarios.

Metáforas de distinto tipo jugaban un papel importante para reforzar la percepción de la revolución como un estallido de irracionalidad. Se utilizaron profusamente los símiles naturales: las masas revolucionarias podían ser descritas como una fuerza natural fuera de control, como una riada que había roto los diques de contención y se precipitaba sobre el resto de la sociedad arrasando todo a su paso. Igualmente, todavía dentro de las semejanzas naturales, era recurrente asociar a los milicianos con animales, como hacía en este pequeño poema de dudosa calidad literaria Felix Cuquerella: "No repican las campanas / a fiesta; pero ya salen hombres, mujeres y niños / de las casas. jLoco enjambre / que avanza, con rumor ronco, / para dar al auto alcance! / Que corren como manada / de hienas y de chacales / hambrientos, que por la selva / van olfateando la sangre".29

Otro argumento utilizado una y otra vez, en particular por el carlista catalán Pérez de Olaguer era el de la ebriedad. Para este autor, huido de Barcelona tras las primeras semanas de la revolución y que escribió varios libros sobre la Revolución en Cataluña y en Andalucía, la intensa violencia sólo era comprensible como el resultado de una borrachera de odio que había convertido a personas normales en bestias despiadadas. ${ }^{\circ}$ Para intensificar esta imagen, muchos relatos del "Terror rojo" presentaban, entre el variado elenco de personajes que se daban cita en sus páginas, al revolucionario arrepentido. Éste, después de haber participado activamente en la orgía de sangre de la revolución, había tomado conciencia de sus faltas y buscaba apaciguar su alma atormentada revelando sus crimenes a un aterrorizado oyente. El antiguo revolucionario, como despertado de un mal sueño, daba cuenta de su participación en la espiral de violencia, en la que habría actuado fuera de sí, movido por fuerzas ajenas a su propio ser. ${ }^{31}$

Estas fueron las estrategias discursivas a través de las cuales se intentó vaciar de su lógica político-social a la revolución. El impacto de la violencia revolucionaria y su posterior interpretación en clave contrarrevolucionaria tuvo como uno de sus principales efectos el que la frontera que separaba la revolución del orden se hiciera más visible para amplios sectores de la población - en especial una parte de la clase media - que habían dado su apoyo al republicanismo de izquierdas pero que miraba con recelo la movilización de las masas obreras. Buena parte del heterogéneo grupo formado por profesionales liberales y pequeños propietarios urbanos y, en menor medida, rurales, al hacerse clara la distinción entre revolución y contrarrevolución se vieron en el lado incorrecto y decidieron saltar la frontera y unirse a aquellos que mejor podían asegurar su mundo. ${ }^{32}$ Los militares rebeldes fueron sensibles al miedo que despertaba la movilización obrera entre estas personas y fueron capaces de ganarse su apoyo asegurando su posición social.

29 Félix CUQUERELLA: Romances y episodios de la revolución “roja”, Zaragoza, Librería General, 1940 p. 24

30 Antonio PÉREZ DE OLAGUER: El Terror rojo en Cataluña, Burgos, Ediciones Antisectarias, 1937, pp. 29 y 69 y ÍD.: El Terror rojo en Andalucía, Burgos, Ediciones Antisectarias, 1938, pp. $27 ; 36$.

31 Joaquín PÉREZ MADRIGAL: Tipos y sombras de la Tragedia. Mártires y Héroes. Bestias y farsantes, Ávila, Imprenta católica Sigiriano Diaz, 1937.

32 Los pequeños propietarios rurales estuvieron siempre del lado de la contrarrevolución. 
Evidentemente estos grupos no tenían una identidad propia homogénea y fue necesario un proceso de reapropiación de los discursos por los distintos grupos sociales para adaptarlos a su forma de autorrepresentarse. En este empeño su condición de propietarios frente a la amenaza de los desposeídos resultó clave. Para muchos de los antiguos liberales que se echaron en brazos del franquismo como medio de salvaguardar sus intereses materiales la violencia contra las organizaciones obreras y republicanas, la dictadura militar y la preeminencia de la Iglesia católica y de FET y de las JONS se convirtieron en el precio a pagar por la eliminación de cualquier amenaza. Y si dentro de los apoyos sociales de los rebeldes hubo quien aplaudió y alentó la violencia, otros tuvieron que reprimir los aspectos más traumáticos del régimen para adaptarse a éste. La imagen del caos y la violencia revolucionaria facilitó la explicación de su toma de partido. La violencia sufrida se convirtió en una fuerza de cohesión en torno a la cual se reformuló la identidad de la comunidad nacional y en uno de los principales argumentos para excluir de ella al movimiento obrero y a los republicanos de izquierdas; en definitiva, fue la base de la cultura de guerra franquista que se convertiría en la interpretación oficial de la guerra. Esta cultura de guerra impregnó la sociedad de posguerra en España y justificó la perpetuación de las prácticas violentas contra los vencidos durante las primeras décadas de la dictadura.

\section{Conclusión}

Como han señalado muchos historiadores, la guerra se presentó como un enfrentamiento maniqueo entre principios absolutos como el bien y el mal o el orden y la revolución, la Patria y la anti-patria. Pero esto no se trataba de mera retórica, estos conceptos no eran nociones generales vacías de contenido. A través de las imágenes que hemos analizado el discurso contrarrevolucionario, como había hecho otras veces en el pasado, operó un desplazamiento de los distintos conflictos que desgarraban la sociedad española y que alimentan la propia guerra civil: bajo la noción de orden se negaba que los conflictos encontrasen sus causas en situaciones de injusticia y desigualdad entre trabajadores y patronos, entre hombres y mujeres, y en la implicación de instituciones como la Iglesia y el Ejército en el mantenimiento de los privilegios de un grupo reducido de la población. Por el contrario, la revolución era el producto de una influencia exterior corruptora, allí donde ésta triunfaba el orden era destruido y la sociedad se disgregaba en innumerables elementos dispersos que buscaban satisfacer sus caprichos sin importarles el destino común. El único efecto posible de la revolución era la destrucción las bases de la civilización religión, propiedad y familia, que quedaban unidas en la Nación Española.

Este discurso no fue una creación original para interpretar la situación de guerra. Existía una larga tradición contrarrevolucionaria europea que se remontaba a la revolución francesa o, incluso, a la revolución inglesa. En el caso español, este discurso se había revitalizado desde la proclamación de la Segunda República. En este sentido, como en otros, el enfrentamiento bélico no supuso un punto y aparte sino que fue, más bien, un punto y seguido. Sin embargo la dinámica de polarización extrema propia de la guerra y la experiencia de la violencia masiva en la retaguardia republicana afectaron al discurso. En este sentido, por un lado se produjo un cambio en la intensidad de las exclusiones en las que se basaba, la oposición revolución-contrarrevolución, identificadas con cada uno de los bandos en liza, no dejó espacio para posiciones intermedias, forzando a muchos a elegir Y, por otro lado, la violencia sufrida por aqueIlos que vivieron la revolución se reveló como un increíble aglutinante de nuevas identidades, construidas sobre bases previas pero transformadas por la guerra: la condición de víctima de la revolución permitía ocupar una posición tan importante como la de excombatiente en la retaguardia franquista. Sobre estas dos figuras, opuestas a la del “rojo", se construyó la cultura de guerra del conflicto. 


\section{A NEW APPROACH TO THE PISTOLERISMO? \\ THE INFLUENCE OF WARS ON 'EXPERTS OF VIOLENCE' \\ IN $1920 S$ BARCELONA}

Florian Grafl

University of Giessen

\section{Introduction}

Between 1917 and 1923, in the course of the struggles between entrepreneurs and workers, more than 800 people were gunned down in the streets of Barcelona. Those years, which became known as Pistolerismo, not surprisingly constitute one of the most thoroughly researched period of time in the history of the Catalan city. The main theme of the countless works on that most violent aspect of the history of Barcelona focused on the question whether either the upper class or the working class have to be blamed for initiating the mutual aggressions. Since it seems that room for innovative new research is rather restricted here, maybe it is time to try a new approach.

Thinking the case of Barcelona in a more global perspective, comparisons can easily be drawn to the events in the capitals and metropolis in other European countries during the post war years from 1918 onwards. Historians working on these issues in order to explain the high amount of violence mainly refer to the brutalization of the society due to the experience during the First World War. True, Spain was only affected indirectly by the military conflicts which turned most of the European continent into a slaughterhouse. However, recent research on war experience does not focus exclusively on the First World War anymore, but also had turned its intention to violence which the European soldiers experienced in the colonies abroad.

This new direction of research could be promising for the Spanish case as well, given the fact that on one side, many young men of the working class had to fulfill their military service at the turn of the century in one of the remaining colonies, Puerto Rico, the Philippines, Cuba and later Morocco while on the other hand, many highly-decorated army officers who as civi governor had a deep impact on the politics in Barcelona had as well served abroad. In order to develop a new approach on the Pistolerismo, based on the experience of what could be called 'experts on violence' of either side of the social conflict in Barcelona, firstly it seems sensible to describe Barcelona's history of violence leading to the Pistolerismo. Secondly, the focus will be turned to the European context. Thirdly, the relation between the Spanish army and violence will be highlighted in general terms in order to conclude by turning the focus on single persons and show on their biography in which way the experience in the Colonial Wars lead to their radicalization in the time of the Pistolerismo.

\section{Barcelona at the turn of the 2oth century - A history of violence}

In 1888 Barcelona staged its first Great Exhibition in order to overshadow the then dominant capital Madrid.' It was not so much this event, but rather the anarchist terror starting

1 For a recent article on the Great Exhibitions and its impact on Barcelona see: Martin BAUMEISTER: titäten in Barcelona und Turin 1884 bis 1929", Historische Anthropologie, 10 (2002), pp. 449-463. five years later for which the Catalan city for the first time gained attention across the borders of the Iberian Peninsula. ${ }^{2}$ At that time, Barcelona as the industrial centre of Spain, was struck by the first wave of terrorism in the $1890{ }^{3}{ }^{3}$ According to the dogma of "propaganda by deed" the anarchists started a series of determined bomb attacks. ${ }^{4}$ The first major upset was caused on 24 September 1893, when a bomb exploded during a military parade on the occasion of the on 24 September 1893, when a bomb exploded during a military parade on the occasion of the
Fiesta de Merced. Paulino Pallás was made responsible and executed. His prediction, that his death would be revenged by further acts of terror, soon came true. On 7 November, not much more than one month later, Santiago Salvador dropped a bomb in the Liceo opera house, a popular meeting point of Barcelona's upper class, killing 20 people. Another spectacular bomb attack occurred in the Calle de Cambios Nuevos during a religious procession on 7 June 1896.5 attack occurred in the Calle de Cambios Nuevos during a religious procession on 7 June 1896.5
Already the first terror attacks in 1893 evoked a strong reaction by the state starting with "La Campaña de Montjuich", in which many innocent anarchists were tortured and executed. This policy of countering violence with violence remained the preferred method to deal with terrorism for the next thirty years to come. ${ }^{6}$

The second phase of terrorism in Barcelona lasted until 1907 and was rather different. In the 1890s, the terror attacks had been directed against clearly defined targets, as the military, the upper class and the church. In the first decade of the new century, the anarchists opted for a new strategy: bombs exploded randomly at various places in the city in order to create fear among the citizens. The case of Joan Rull, a well-paid police confident who nevertheless planted many of the bombs in order to "stay in business" showed two tendencies which gained even more relevance later: the helplessness of the police as well as the economic aspect of terrorism. ${ }^{7}$

In 1909, the authorities for the first time completely lost control in Barcelona. During the 25th July and the 2th August, which became known as "Tragic Week", many religious buildings were set on fire. When finally the order in the city was restored with the help of the army once again the punishment by the Spanish state was severe. ${ }^{8}$ The executions which followed especially the one of Francisco Ferrer, the founding father of the "Escuela Moderna", were seen by most of the contemporaries as even more violent than the events in the Tragic Week and

2 Angel SMITH: "Barcelona through the European mirror. From red and black to claret and blue", in Angel SMITH: "Barcelona through the European mirror. From red and black to claret and blue", in
Angel SMITH (ed.): Red Barcelona. Social protest and labour mobilization in the twentieth century, Angel SMITH (ed.): Red Barcelon.

3 For a more comprehensive picture of this period of terrorism see the recent article by Heinz-Gerhard HAUPT Y Klaus WEINHAUER: “Terrorism and the state", in David BLOXHAM \& RobertGERWAR$\mathrm{TH}$ (eds.): Political violence in twentieth-century Europe, Cambridge, University Press, 2011.

4 For "propaganda by deed" as well as the specifics of violence in Spanish anarchism see the article of Werner BERNECKER: "Strategien der , direkten Aktion“ und Gewaltanwendung im spanischen Anarchismus" in Wolfgang MOMMSEN (ed.): Sozialprotest, Gewalt, Terror. Gewaltanwendung durch politische und gesellschaftliche Randgruppen, Stuttgart, Klett, 1982.

5 For the most recent overview on the bomb attacks at the end of the nineteenth century in Barcelona see: Rafael NÚÑEZ FLORENCIO: “El terrorismo”, en Julián CASANOVA (ed.): Tierra y libertad, Cien años de anarquismo en España, Barcelona, Crítica, 2010, as well as Teresa ABELLÒ: "Anarchism in the Catalan-speaking countries. Between syndicalism and propaganda (1868-1931)", Catalan Historical Review, 3 (2010), pp. 87-102.

6 For the Montjuich trials, see the extensive work by Antoni DALMAU: El Procés de Montjuïc. Barcelona al final del segle XIX, Barcelona, Ajuntament de Barcelona, 2010.

7 The case of Juan Rull was recently fully examined by Antoni DALMAU: EI Cas Rull. Viure del terror a la ciutat de les bombes (1901-1908), Barcelona, Columna edicions, 2008.

8 In the course of the 1ooth anniversary of the Tragic Week, many new works have been published, for example: Alexia DOMÍNGUEZ ÀLVAREZ: La Setmana Tràgica de Barcelona 1909, Valls, Cossetània, 2009, as well as: Dolors MARIN: La Semana Trágica. Barcelona en llamas, la revuelta popular Tràgica, Barcelona, Pòrtic, 2009. 
provoked a massive protest not only in Spain..$^{9}$ After this culmination of violence, the second decade of the twentieth century in Barcelona started rather peacefully. ${ }^{10}$

Nevertheless, a new source of conflict was already established. In 1910, the CNT (Confederación Nacional del Trabajo) was founded, which rapidly became the most important trade union with more than 700,000 members in 1919. This new organization was created by a variety of different political fractions, which also included some of the leading anarchists." Therefore, the new wave of violence starting at the end of the 1910 s was not only politically motivated but also had social reasons, such as the poor conditions of the working class. The two general strikes in 1917 and 1919 as well as a lock-out by the factory owners created an atmosphere of mutual distrust and hate among the upper class and the workers, and the stage was set for the most violent episode in the history of Barcelona. Representatives of both sides of the social conflicts fell victim to assassinations. When the period of the "pistolerismo" came to an end in 1923 with the beginning of the dictatorship of Primo de Rivera, more than 800 people had been attacked in the streets. ${ }^{12}$

\section{The brutalization of the society in Europe during the Interwar Period (1918-1939)}

Due to the extraordinary amount of collective violence and its singularity concerning other Spanish cities during that time, it is not surprising that the Pistolerismo in Barcelona together with the period of the first anarchist bomb attacks and the time of the Civil War is probably the most well-researched period of time in the history of the city.13 As a result, we have a very detailed knowledge about the events going on in Barcelona from 1918 to 1923. When it comes to reveal the causes of the bloodshed, however, it is quite surpring that not only the local, but also national and international historians only focused on the regional context, and therefore mainly came up with the rising conflicts between entrepreneurs and workers to explain the high frequency of violence. Following the innovations of the recent turn of histography to a more global approach, it seems sensible not so see the Barcelona case on ist own or only in its regional or national context, but to have a look on the situation across Europe during that time. ${ }^{14}$

It immediately becomes obvious that political violence was a common phenomena in almost all European states during that period and many of the nations in the years after the First 9 Although it cannot be denied that Ferrer was an innocent victim of the events following the Tra-
gic Week, the recent work on his life by Juan AVILÉS FARRÉ: Francisco Ferrer y Guardia. Pedagogo, gic Week, the recent work on his life by Juan AVILÉS FARRÉ: Francisco Ferrer y Guardia. Pedagogo,
anarquista y mártir, Madrid, Marcial Pons Ediciones de Historia, 2006, makes clear that Ferrer at anarquista y mártir, Madrid, Marcial Pons Ediciones de

10 Julián CASANOVA remarked in his article: "Terror and Violence: The Dark Face of Spanish Anarchism", International Labor and Working-Class History, 67 (2005), p. 87, that in 1910, only one bomb exploded while the following five years were completely free of any act of terro

11 For a recent article on the CNT, see: Katharina BIBERAUER: "Anarchismus mit oder versus Syndikalismus. Die ideologische Entwicklung der CNT (1910-1936)", in Friedrich EDELMAYER (ed.): Anarchismus in Spanien. Anarquismo en España, Wien, Verlag für Politik und Geschichte, 2008.

12 For detailed statistics of the victims, see: Albert BALCELLS: El pistolerisme. Barcelona (1917-1923), Barcelona, Pòrtic, 2009, p. 56

13 The most recent works incude for example: Francisco ROMERO SALVADÓ: The foundations of Civil War. Revolution, social conflict and reaction in liberal Spain 1916-1923, London, Routledge, 2008, Eduardo GONZÁLEZ CALLEJA: El máuser y el sufragio. Orden público, subversión y violencia politica en la crisis de la Restauración 1917-1931, Madrid, Consejo Superior de Investigaciones Cientificas, 1999. María PRADAS BAENA: LAnarquisme i les lluites socials a Barcelona 1918-1923. La repressió obrera i la violència, Barcelona, Publicacions de l'Abadia de Montserrat, 2003

14 For an overview of the concepts of Global history, see:Christopher BAYLY: “Eine globale Geschichte der Moderne", von Voltaire bis zur Gegenwart, München, Beck, 2011.
World War were on the verge of revolution. ${ }^{15}$ The late Eric Hobsbawm, in his remarkable book on the history of the 2oth century refers to the period between 1914 and 1945 as the „Thir ty-one Years' War with the obvious intention to make up a comparion to the bloody conflict which as the Thirty Years' War effected almost the whol European continent between 1618 and $1648 .{ }^{16}$ In the Interwar Period of the 2oth century, the violent climate was most strongly felt in the big European cities. Mainly paramilitary groups were responible for this considerable raise in conflicts and clashes. ${ }^{7}$ In regards to urban violence, the most striking and thorou ghly investigated example is probably the German capital Berlin, where in the course of Adolf Hitler's rise to power young men affected to his fascist NSDAP continously were engaged in street fighting with the communist KPD supporters, leading to numerous violent incidentes. ${ }^{18}$ In recent comparative studies, Andreas Wirsching and Sven Reichhard have shown as well that similar events took place both in the French capital Paris and in Italian cities as Bologna. ${ }^{9}$

In search for an explanation for this phenomena, historians came up with what became known as the Brutalisierungsthese, the thesis that the civil societies in the European states had undergone a process of brutalization due to the experience by most of the population during their service in the First World War. ${ }^{20}$ Given the fact that nations as Finland or Spain, which were effected to a comparatively smaller extent by the war's atrocities, underwent process of radicalization during the post war years as well, this theory seems to have its limitation and does not suffice to explain the high amount of violence in Europe after 1918 to full extent. Therefore, a new wave of historians started to extend this theory by exploring the experience of the soldiers during their service in the colonies at the turn of the century. ${ }^{21}$

This new approach might be productive for the Spanish case as well, given the fact that at the end of the 19th century as well as at the beginning of the 2oth century, Spanish soldiers who were sent out to perform their military service in one of the remaining Spanish colonies Puerto Rico, the Philippines, Cuba and later Morocco experienced a fair share of violence during the uprisings in the course of the struggle for independence. Therefore, by turning the attention from the European context back to the Spanish case again, firstly the connections between the Spanish military and collective violence should be outlined in order to focus more closely to specific ,experts on violence ' which became the protagonists of the Pistolerismo in Barcelona.

15 Martin CONWAY y Robert GERWARTH: "Revolution and counter-revolution", in David Bloxham \& Robert Gerwarth (ed.): Political Violence in Twentieth-Century Europe, Cambridge, University Press, 2011.

16 Eric HOBSBAWM: Age of Extremes. The Short Twentieth Century 1914-1991, London, Abacus, 1994, p.

17 A recent overview on paramilitary violence in Europe after the First World War is given by Robert GERWARTH (ed.): War in Peace. Paramilitary Violence in Europe after the Great War, Oxford, University Press, 2012.

18 Dirk SCHUMANN: Politische Gewalt in der Weimarer Republik 1918-1933. Kampf um die Straße und Furcht vor dem Bürgerkrieg, Essen, Klartext-Verlag, 2001.

19 Andreas WIRSCHING: Vom Weltkrieg zum Bürgerkrieg? Politischer Extremismus in Deutschland und Frankreich 1918-1933/39, München, Oldenbourg, 1999; Sven REICHARDT, Faschistische Kampfbünde. Gewalt und Gemeinschaft im italienischen Squadrismus und in der deutschen SA, Köln, Böhlau, 2002.

20 See for example the First issue of the Journal of Modern European History (2003), which focused on Violence and Society after the First World War.

21 Recent examples would be Susanne KUSS: Deutsches Militär auf kolonialen Kriegsschauplätzen. Eskalation von Gewalt zu Beginn des 20. Jahrhunderts, Berlin, Ch. Links Verlag, 2010 and Christian Schöningh, 2013. 


\section{Spain and its Military}

Stanley Payne, in his pioneer study on politics and the military in Spain dates back the foundations of the modern Spanish army to the War of Independence when Spain was occupied by the troops of Napoleon at the beginning of the 19th century. Its impact on politics soon became obvious, when Spanish generals began to initiate military coups in order to overcome the ruling government. ${ }^{22}$ During the Carlist uprisings, which the army under the command of the Bourbon monarchy suppressed, the military lay the foundation of its future role not only as a guarantor of the state and the nation against external enemies, but also to insure law and order in the interior. ${ }^{23}$ When the threat of a Carlist insurrection was averted for the time being, the main function of the army towards the end of the 19th century became the preservation of what had remained of the Spanish Empire of Early Modern Times, the last colonies Cuba, the Philippines and Puerto Rico.

As Payne states, the army's role was fundamental in the government in Havana, San Juan and Manila, because the Captain General of the city also held the ultimate civil authority in his territory. In Cuba, Spain's most important colony, from the middle of the 19th century onwards, the Spanish military leaders often took a tolerant approach to the political problems. For example, a Captain General of Havana, Juan de la Pezuela, ordered the closure of the Cuban slave trade in the $1850 \mathrm{~s}$. But this humane behavior caused strong protests from the Cuban oligarchy which lead to his dismissal. The climate definitely became more violent in the course of the Cuban Independence War of 1868-1878. . $^{4}$ This struggle according to Payne cannot be compared to armed conflicts in colonies of other European states but instead was the first of the "dirty wars" of colonial emancipation. The insurgents applying a kind of guerilla tactic made it difficult for the Spanish army to achieve victory by purely military means. ${ }^{25}$ The conflict came to an end in 1878 due to the interference of Martinez Campos, the general who later suffered an assassination attack in Barcelona in 1893. He had to make large concessions to the Cuban nationalists. But in the next years, his policy proved completely ineffective, since the rebels increased their actions by every passing month. ${ }^{26}$ Martinez Campos was replaces by Valeriano Weyler, which was the descendant of German immigrants. Payne described him as:

A men with steel-blue eyes, full of energy and endurance who had a reputation for efficiency and ruthlessness gained in action on nearly every front where Spanish troops had been engaged during the past generation. He neither drank nor smoked, and when on campaign he shared the lot of the men, sleeping on regular infantry field cots and living for days on bread and canned sardines.

During his reign in Cuba, atrocities were reported both by the Spanish army as well as by the Cuban nationalists. ${ }^{27}$

Spain's other major colony, the Philippines were not easy to rule either. In the late 1880 os rebellions frequently occurred ${ }^{28}$ At the end of 1896 , General Camilo Polavieja was send to the Philippines to restore law and order with a firm hand. However, the severity of his command,

22 Stanley PAYNE: Politics and the Military in Modern Spain, Stanford, University Press, 1967, p. 5-7

23 Sebastian BALFOUR: "The Making of an Interventionalist Army 1898-1923" in Francisco ROMERO

SALVADÓ \& Angel SMITH (eds.): The agony of Spanish liberalism. From revolution to dictatorship 1913-1923, London, Palgrave Macmillan, 2010, p. 257.

24 Stanley PAYNE: Politics and the Military in Modern Spain..., p. 66

25 lbid., p. 67

26 Ibid., p. 71 .

27 Ibid., p. 74 shown most obviously by the judicial murder of the Philippine patriot Jose Rizal, provoked loud anti-Spanish propaganda and as a response, Spanish troops captured by the rebels were now regularly tortured and mutilated. Only after a few months, Polavieja had to return to Spain, and his predecessor, Fernando Primo de Rivera, seemingly was able to restore full control by the summer of 1897.29 Nevertheless, only one year later, Spain, due to the defeat in the Spanish-American War, had to resign his last colonies, which produced a huge crisis in Spain.

In order to overcome this defeat, the Spanish government tried to extend its influence in Morocco in the first years of the new century. La Porte identified four main effects on Spanish public opinion during the last years of the regime: First, it widened the gap between people and the institutions of the Restoration. Second, it became a catalyst for other social tensions which erupted in the context of the hostility towards the Moroccan campaigns. Third, it discredited the regime more than any other issue in its last turbulent years. Ultimately, the impact of the African venture deprived the Spanish Liberal monarchy of any remnants of social support at a time when it was absolutely essential for its survival. ${ }^{30}$ Concerning the war experience of the soldiers sent to the African continent, Balfour emphasized "the brutality of that war and the extreme conditions in which it was fought widened the sense of alienation from the broader dominant cultures of Spain among many colonial officers" and stated that the service in the Moroccan War provided opportunities for celebrity, drink and extra-marital sex or sometimes rape, male bonding or machism. ${ }^{31}$

\section{'Experts of Violence' in Barcelona and their experience of armed conflict}

After having examined the urban violence in Barcelona and the violence caused by military conflict in interwar Europe as well as in contemporary Spain, in the final paragraph this two phenomena should be brought together questioning the contribution of the military to the high amount of violence in Barcelona during ist history up to the Pistolerismo. The Catalan metropolis for the time had to suffer from military violence when it was bombed by franco-castilian troups in 1714. After the surrender of the city, Catalonia lost most of its priviledges and a military garnison was errected on the Monjuich, from where in the course of the first half of the 19th century the city twice was bombed in order to calm down urban uprisings.

It was during that time when the image of the Spanish army as an occuping force took shape. The tensions became more imminent when at the end of the 19th century, Catalan nationalism began to rise and in 1905 this conflict produced the first violent incident, when about 200 officers entered the two leading catalan newspapers ¡Cu-Cut! and La Veu de Catalunya, and destroying furniture and wounding several employees with their saves as an act of revenge for the constant mocking of the army in the Catalan press..$^{32}$ But the army was not only seen as a tool of the detested Spanish central state, but also broadened the social tensions between the upper and lower classes, because the rich could free their sons from army service by paying the "redención metálica", while the workers could not. This injustice was emphasized when in the course of the ongoing conflict in Morocco, Catalan reservist troops in July 1909 were supposed to be sent to Africa. The protests led to the famous Semana Trágica, one week of rioting in which course almost all churches in the city were burned.

Since this is all very vague, a prosopographic approach seems more sensible. Indeed, in

29 Ibid., p. 74-75.

30 Pablo LA PORTE : "The Moroccan Quagmire and the Crisis of Spain's Liberal System 1917-1923" en Francisco ROMERO SALVADO y Angel SMITH (eds), The agony of Spanish liberalism. From revolution to dictatorship 1913-1923, London, Palgrave Macmillan, 2010, p. 246.

31 Sebastian BALFOUR: The Making of an Interventionalist Army 1898-1923..., p. 270.

32 See for example: Jordi CASSASAS Y YMBERT: Els fets del Cu-Cut!, cent anys després, Barcelona, L'Avenc, 2006 
this way some connections can be drawn by the engagement in the colonial wars and the contribution to the high extent to violence in Barcelona. For the period of the anarchist terror attacks and the severe repression by the state in the 1890s, Payne gave the example of General Valeriano Weyler. As it was already pointed out, Weyler became infamous for his rectless treatment of the rebels during his service on Cuba. Later, he was civil gouvernour in Barcelona and during his reign anarchism was brutally surpressed..$^{33} \mathrm{~A}$ more relevant example for the time of the Pistolerismo was Severiano Martinez Anido, who became the civil gouvernour of Barcelona on the 8th November 1920. He made it obvious that in order to solve to conflicts between the entrepreneurs and the workers he would apply the same measures he had adopted during his service in the colonies. A famous quotation by him goes as follows: "I have worked in Cuba and the Philippines. I should have been send to Africa. The government decided to send me to Barcelona and I will act as though I were on active service". ${ }^{34}$ It would be interesting to find out whether some of the Pistoleros did service in any of the Spanish colonies before they became 'experts of violence' during the struggles in Barcelona. Unfortunately, it seems there is only one, not very reliable source reporting on a man who served in Morocco and later was incorporated in the grupos de afinidad of the anarchistic trade union CNT, where he also committed assassinations. ${ }^{35}$

\section{Conclusion}

The approach to put the Pistolerismo in a wider European context and focusing more on the previous war experience of the perpetratrors seems quite interesting and promising. In doing so, it was noted that the brutalization of the civil society as a result of the First World War is already a well-established theory in order to explain the high amount especially of paramilitary violence in the 1920 s and early 1930 s. Since recent studies have convincingly shown that the brutalization through war experience actually already started in the colonial wars which where fought at the turn of the 2oth century, it seems quite natural to try to imply this new concept on the Spanish case as well, given the fact that without doubt the wars in Cuba, the Philippines and later in Morocco were very bloody and must have been a traumatic experience for both the soldiers and the officers. However, as it was shown in the last part of this paper, the problem might be that there are few sources to make a connection between the service in the colonies and the involvement in the violent acts in Barcelona. In order to proof this, more personal documents especially from working class families are needed, but the question is whether such material still exists.

33 Stanley PAYNE, Politics and the Military in Modern Spain..., p. 61.

34 Angel SMITH: Anarchism, Revolution and Reaction. Catalan Labour and the Crisis of the Spanish Central State 1898-1923, London, Berghahn Books, 2007, p. 331. 
REMEMBERING THE VÖLKERSCHLACHT (BATTLE OF

THE NATIONS) 1813 AND ITS MONUMENT FROM 1913

IN THE 21TH CENTURY. THE LEIPZIG COMMEMORATION

ACTIVITIES IN 2013

Torben lbs

Universität Leipzig
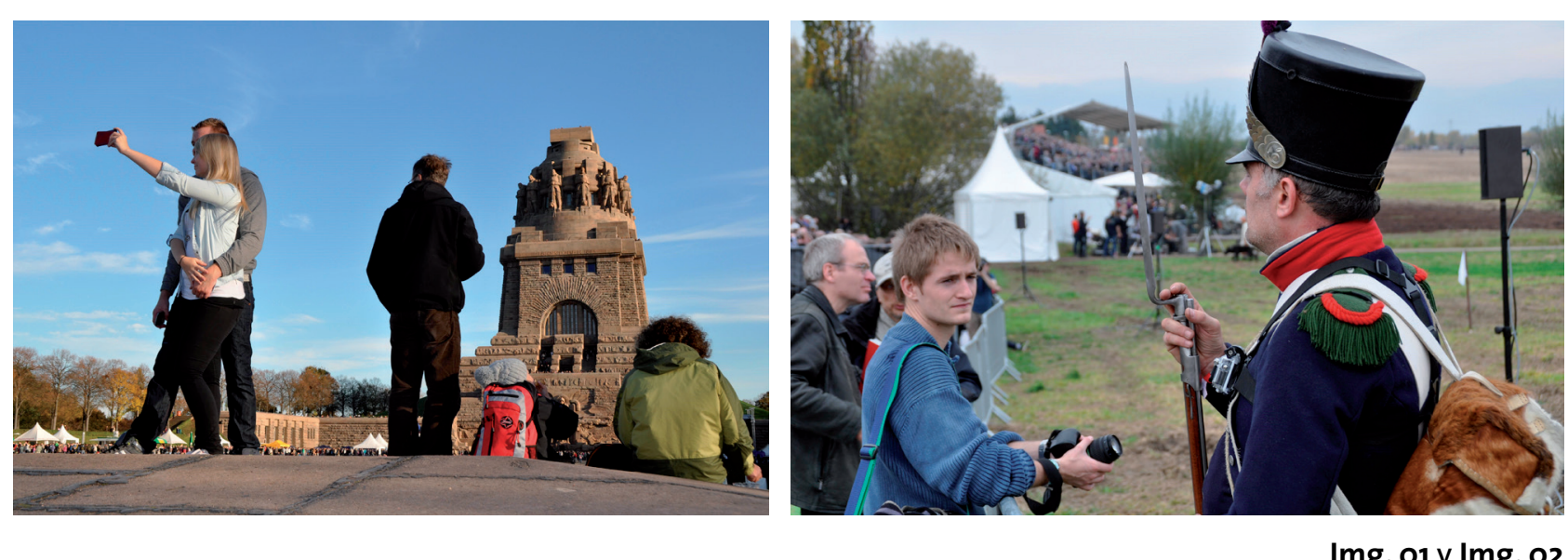

Img. 01 y Img. 02

\section{Panorama 1813-1913-2013}

Between the 16th and 19th October 1813 the biggest battle in European history - up to this point - took place in and around Leipzig. Over half a million of soldiers from several nations - Russians, French, Austrians, Prussians etc. - fought for several days and ended Napoleon's military plans of ruling Europe Over 100.000 soldiers died during those days and with them the same number of civilians due to the following famine, plagues etc.. Even today rests of ammunition and other relicts can be found on the former battlefields which nowadays have the status of a landscape monument and are mainly used as crop fields. The battle meant a big defeat of Napoleon's forces which had to retreat behind the Rhine river.

The victory over Napoleon did not only lead to the Congress of Vienna in 1815 which redefined the political landscape all over Europe but also started a strong nationalist movement, especially in the German states. The idea of a unified nationality became more and more popular among German intellectuals and bourgeois forces and in the revolution of 1848 with its center in Frankfurt the national assembly even tried to convince the Prussian King Friedrich Wilhelm IV to take the title as German Kaiser, which he neglected. With the Prussian-Austrian war in 1866 and the German-French war in 1970/71 the unification of the German Reich was achieved with military strength and not being given from the hands of civilians. But the national spirit remained strong and the citizens of Leipzig decided to build a national monument in remembrance of the 1813-battle. The plans delivered Freemason Bruno Schmitz, and the nationalist civil association Deutscher Patriotenbund (German Patriots' Alliance) organized building and funding. It was not a state owned monument. The dimensions are huge. The height is 91 meters, and its basis is $80 \times 70$ meters. The material is mostly concrete. The erection took 15 years and it was opened in 1913 by the German Kaiser and Prussian King Wilhelm II. He did not like monumental style and even left the celebrations of the monument to attend the paralle commemoration activities of the Russian and Austrian monarchs.
From its beginning the Völkerschlachtdenkmal was part of nationalist and völkisch discourses. Also it was at first a civil opposition to the monarchy, which included mainly bourgeois and nationalist forces. The workers' movements had no connection with the monument, and denying any respect the social-democrats just called it a "pile of stones"..

During World War I the monument was a prominent spot for patriotic acts but finally became the main commemorative point for the fallen German soldiers in the war. This function was kept throughout the republic of Weimar and preserved the installation as national monument and kept it connected to military forces. So it was no wonder the national-socialist movement was attracted by this symbol. In the 1932 commemoration activities, one year before Hitler came to power, SA forces rallied even together with choirs and nationalistic student re Hitler came to power, SA forces
organizations at the monument.

With the turn to the nation-socialist regime the meaning of the monument changed again slightly. The nationalism was now stronger militarized and the tune in speeches at events got more and more aggressive in the pre-war time. The Nazis used the impressive ambient frequently for mass events and interpreted the monument as symbol of the invincibility of the Germans. Hitler's first speech there took place in may 1933 where he drew a line between the victorious forces of 1813 and the new nationalistic movement. ${ }^{4}$ During the war the current interpretations emphasized on German strength and loyalty but after the air raid on Leipzig in December 1943 it was also used as place to commemorate the civil victims.

During the following socialist regime the monument's meaning changed fundamental. It served as a symbol for the German-Russian alliance and brotherhood in arms with the other socialistic states and and, especially in the early years, to define the new regime as the heir of the progressive line of German history. In 1950, one year after the GDR was officially founded, the inner space of the monument was used to celebrate the first anniversary of the first socialist state in Germany. It was also used as a spectacular scenery for mass events especially for its youth organizations. The socialists applied the same esthetic use of the monument when they summoned for examples thousands of people with torches as did their predecessors.

As seen, during all its existence the monument served as a legitimating political monuments with changing messages. The political discourse just integrated the monument in the current models. It always worked as a symbol for dominating and hegemonic political ideas. It was never a neutral political space at least not until 1989.

With the disappearance of the GDR the new democratic city government had no idea what to do with the monument. Due to the air pollution during the socialist period it was in a bad shape, the brown sandstone-fassade had turned black and also the surrounding areas had substantially suffered. But parts of civil society demanded the reconstruction. In 2002 the monument was given to a public foundation, the Stiftung Völkerschlachtdenkmal Leipzig ${ }^{5}$, and the reconstruction was given in the hands of a civil association Förderverein Völkerschlachtdenk-

1 Völkisch is difficult to translate. As grammar would put it, it is an adjective to Volk (people). It uses an ethnical definition of people and derives in this case from German romanticism and was strongly used by the National-Socialists which connected it with the idea of a superiority of the Aryan or German race, so the adjective völkisch has a racial component as wel.

2 Quoted after: Peter Hutter: "Die feinste Barbarei". Das Völkerschlachtdenkmal bei Leipzig, Mainz am Rhein, Philipp von Zabern, 1990, p. 185

3 Steffen Poser: "Zur Rezeptionsgeschichte des Völkerschlachtdenkmals zwischen 1914 und 1989", in Katrin Keller and Hans-Dieter Schmid (eds.): Vom Kult zur Kulisse. Das Völkerschlachtdenkmal als Gegenstand der Geschichtskultur, Leipzig, Leipziger Universitätsverlag, 1995, pp. 78-104; 85.

4 Ibid., p. 87

5 http://www.leipzig.de/de/buerger/satzungen/4 11.PDF 
mal. ${ }^{6}$ The association did fund-raising and planned the reconstruction and cleansing-process which successfully ended in 2012

Also first voices arose about the question what to do with the monument in the future In 1993, with the 18oth anniversary of the battle, which was widely celebrated, the novelist Wolfgang Loest proposed to name the Völkerschlachtdenkmal as a monument for European peace and unification. ${ }^{7} \mathrm{He}$ is also the author of the 1984 published novel "Völkerschlachtdenkmal" in which he tells the story of the monument and a blaster who wants to disrupt it. A new intent of a political intended re-interpretation of the monument was started with his intervention.

Nowadays the monument and its surrounding are a merely a touristic point and since 1993 once a year a sociocultural center has used it for a sportive fun event, called Badewannenren $n^{9} n^{9}$ (bath-tube-race), where the participants enter the water basin in front of the monument with self build boats and do some fun oriented challenges. This event is offensively disrespecting all historical bounds and attracts year by year over 10.000 spectators. The surroundings are also used for open air concerts, wine or beer markets and other events in a more entertaining context in which the Völkerschlachtdenkmal is reduced to pure scenery with no connection whatsoever to any historical events. The monument has been transferred from the political and societal sphere to consumerism's one. However, this does not to support a political ideology to create some sort of community but shall attract the individual to spend his money there to fulfill the commercial circle. If there is an ideology working this is a neo-liberal one with its own marketing scheme and characterized by the idea of total commodification. The subjects use the aura inherent to the monument to do their business which is clearly based in the contemporary need for events. But this does not apply a new interpretation to the monument but really uses it as an empty space, a signifier without any significant. The net of commodification lies around the Völkerschlachtdenkmal without really tangling it.

Only Neo-Nazi movements and their party the national democrats (NPD) are using the monument for political rallying and have tried repeatedly to hold manifestations in front of the national monument, seeking for impressive pictures and of course reformulate their nationalistic and racist discourses with the power of the traditions the monument is providing to their cause. The city government and civil society are always trying to defend the place and to keep the right wing manifestations away from such points. There is a big consensus in the city that the monument may not be used for such propagandist uses and the Förderverein even produced a big banner, saying: "Nazis raus", which is only shown, when the Nazis have declared their presence. ${ }^{0}$

In the look back every time has produced its echo over the Battle of Nations and with its 2ooth anniversary the time has come to give a new echo, a new interpretation. The pile of stones is accompanied by a pile of interpretations and this chain of interpretations cannot be smashed. It's like a maelstrom which goes over the past destroying and reconstructing it at the same time.

\section{The discursive field}

The events of the battle in 1813 , the erected monument and its history of reception and political interpretation let appear a framework, or discursive formation in which the utterances about battle and function of the monument can be organized. I follow thereby the discourse

6 http://www.voelkerschlachtdenkmal.de.

7 Erich Loest: "Vom Totenmal zum europäischen Friedensmal", in: Katrin Keller and Hans-Dieter Schmid (eds.): Vom Kult zur Kulisse. Das Völkerschlachtdenkmal als Gegenstand der Geschichtskultur, Leipzig, Leipziger Universitätsverlag, 1995, S. 211-212; S. 212.

8 Erich Loest: Völkerschlachtdenkmal, Hamburg, Hoffmann und Campe, 1984

9 http://natobadewanne.wordpress.com/; all online cites from 26-06-13.

10 http://commons wikimedia.org/wiki/File:V\%C3\%B6/kerschlachtdenkmal/Leipzig,Anti-Nazi-Plakat 2.JPG theory of Michel Foucault and the implications to it formulated by Achim Landwehr's term of the 'history of the say-able'." It is based on the assumption that utterances in the discourse are always framed by historical context which means that not all utterances in a given discourse can appear at any time. This limitation derives from the changing rules of the say-able. As Sarasin puts it: "An utterance is 'rare', it is historical unique, it appears and disappears again. The interest for an analyst of discourse is to explain why utterance $X$ appears at time-point $Y$ ". ${ }^{2}$

The emergence of an utterance relies on the discursive fights about legitimation and truth Every utterance, as states Michel Foucault, has primary followed the discourse rules which produce a regime of truth. ${ }^{3}$ Only within this regime an utterance is valid and true. And the truth is bigger than the hegemonic discourse position, but it derives from the underlying patterns. To make a true utterance in a discourse (assuming that the subject has the power to speak and being heard) the subject has to make a formulation on the basis of those underlying structures. Its validity relies on the limits of the defined truth, the current discursive rules, and the underlying patterns. For example nowadays an utterance which relies on a bloodand-soil ideology would be rejected because it is outside the regime of truth but a reference to a German nation can still be made. I want to examine the historical interpretations and attributions attached to battle and monument to see what are those underlying concepts on which subjects still rely on. I would not define them as universal but they prove a certain stability in their base throughout the years. However, of course, the details of their interpretation change constantly. The nationalistic notion has always been there but is nowadays obviously framed differently than in the Third Reich. The field of possible utterances can be visualized for the Battle of Nations and the Völkerschlachtdenkmal as one of its biggest echoes as follow:

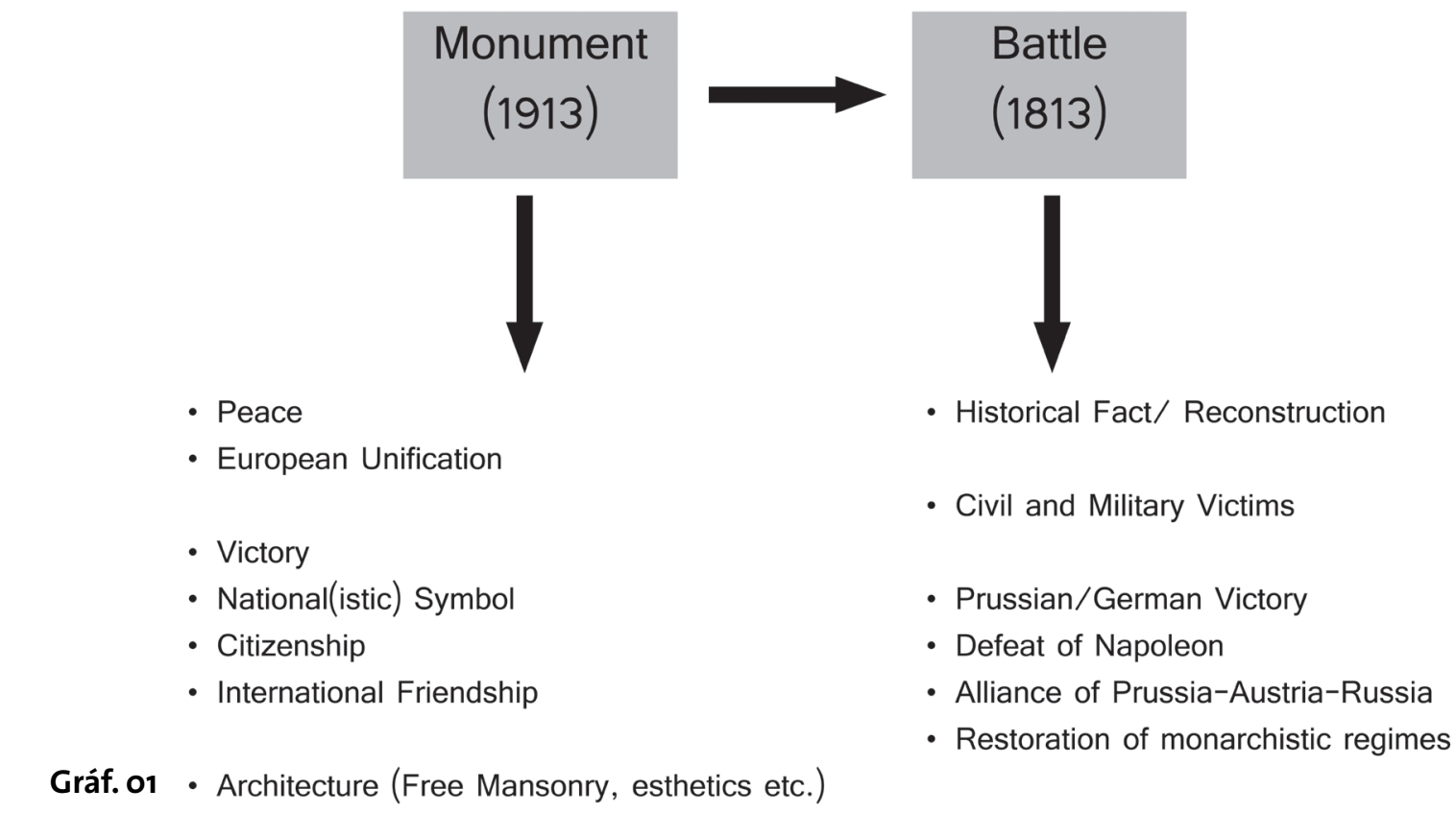

11 Achim Landwehr: Geschichte des Sagbaren. Einführung in die historische Diskursanalyse, Tübingen Edition diskord, 2001 .

12 Philipp Sarasin: Wie weiter mit Michel Foucault, in: Hamburger Institut für Sozialforschung (ed.): Wie weiter mit...? Wie weiter mit Hannah Arendt? /Wie weiter mit Niklas Luhmann? /Wie weiter mit Michael Foucault? /Wie weiter mit Karl Marx? /Wie weiter mit Max Weber? /Wie weiter mit sigmund Freud? Wie weiter mit Ėmile Durkheim? /Wie weiter mit Theodor W. Adorno?, Vol. 4 (8 vols.), Hamburg, Verlag Hamburger Edition, 2008, p. 18

13 Michel Foucault: Die Ordnung des Diskurses, Frankfurt am Main, Fischer, 1991, p. 25. 
All of those fields, especially the questions of esthetics, could be laid out more detailed but as an approach this scheme seems sufficient. In a semiotic perspective the monument of 1913 is the signifier for the battle of 1813 , but this representation is already an interpretation of the battle and its aftermath. There is no pure or innocent representation of the past. Its interpretation, seen as the nationalist ideal of a unified Germany forged by wars, is already inscribed in the stone monument. On an esthetic level it abandons the then dominant neo-classicism (the art of monarchy) and uses a style which is thought to be more archaic and closer to the German roots and mass symbols, which Elias Canetti defines as forest (Wald) and army (Heer). ${ }^{14}$ The construction itself could therefore stand as an example for the modern renaissance of the nation, which can be seen as ideology. The monument is constructed with concrete, but the facade is 100 per cent sandstone. The modernity is covered by an archaic element which rebounds to the past. The imagined past is a mask to hide (before) the impositions of the modern world, leaving that behind shining concrete becomes the favorite material in later postmodern architecture.

Also historical facts are not just there but organized as story line which in the given case lead to German unity. The storytelling follows the rules of 19th century historians. In this case the narrative model of the romantic comedy applies perfectly, and tells the story of a hero (the German people) who fights and finally gets his right (the German nation-state). ${ }^{15}$ The Battle of the Nations is here not the final point but the starting one.

All those narrative and ideological patterns shown in the graphic are inscribed in the monument and cannot be erased but taken into account in new interpretations. With our little walk through the history of reception we have seen how different aspects have shown up in the utterances. The founder highlighted the marks of citizenship, nationalism and the military victims. With the Weimar Republic, especially the military victim narrative was emphasized but took a turn from the 1813 memory to World War I. Also the nationalistic and militaristic approaches were strong, the part of citizenship faded away. The upcoming national-socialist focused on nationalistic ideas which were interpreted as völkisch, and especially during World War II the militaristic message grew stronger and stronger but later it was accompanied by the commemoration of war victims, especially contemporary ones. In the GDR the nationalism was re-interpretated and the Russian-German comradeship reinitialized, while a certain amount of militarism always stuck to the monument, here in a more para-military way.

\section{Mapping the discourses - the remembrance activities in 2013}

Even in 2013 it can be shown how these fields of meaning are still part of the actualized narratives. The emerged patterns are still in use and only a new interpretation in discourse is applied by the speakers. The discursive fights are not only about the remembrance discourse as a whole but also about the sub-topics which are used as anchors of legitimation for the speakers position. We will see who throws his anchors at which part of the remembrance-reef

I want to focus on some of the main events in the commemoration week taking place from October 16th to October 20th. 2013. Based on the outlined discursive basis the main question is how these groups interact in the discursive schemes and what topics they apply to strengthen their interpretations and discursive position. But since these positions are relative it is first needed to define the hegemonic position given by the city government and establish the contemporary official political interpretation of the 1813 events and the 1913 monument.

14 Elias Canetti: Masse und Macht, Frankfurt am Main, Fischer, 1980, p. 190.

15 See: Hayden White: Metahistory: The Historical Imagination in 19th-century Europe, Baltimore,

John Hopkins University Press, 1973, p. 22

\section{Official discursive framing}

The approach of Loest's "moument for peace" in 1993 has nowadays become the officia political standpoint not only but city officials but also on a European scale Mayor Burkhard Jung for example writes on behalf of the two anniversaries:"Begehen wir das Doppeljubiläum [...] zukunftgewandt als ein europaweites Signal für Frieden, Völkerverständigung, Demokratie und Selbstsbestimmung, das von Leipzig, der Stadt der Friedlichen Revolution ausgeht". ${ }^{6}$ In this rhetoric figure the monument is cut off from the instances in the past. It is on the first sight depleted of any earlier meaning and put in a context of European peace. Kant's never ending peace between republics which he formulated in 1795 comes to mind. This European peace idea is then connected to the peaceful revolutions against the socialist regimes in 1989 in which the population Leipzig took a big part with weekly mass demonstrations. Those are annually celebrated in Leipzig with an event called festival of lights at 7 th of October, one week before the commemoration events of the Battle of the People. ${ }^{77} 1989$ is especially important for the city's identity and the connection between the peaceful revolution and the Battle of the Nations is not coincidental. It tries to establish Leipzig, a city in the center of Europe, as a center also for European history with the two historical main events of 1813 and 1989. Again an official narrative which does not neglect certain teleological views is established.

But this discourse about European freedom and peace is not only the city's discourse but generally assumed by actors of the political sphere. For example, the prime minister of Saxony, Stanislaw Tillich, pledges to give to the Völkerschlachtdenkmal "which was founded as a national monument a truly European dimension". ${ }^{8}$ Martin Schulz, president of the European Parliament points out that "the battle of nations is for long not only a German point of memory but a European one". ${ }^{19}$ In effect people from all over Europe come together to talk about "our common future". He also points out the events of 1989 and declares the necessity to put "this disturbing monument in a new context".20 That proves that "we" learned from the errors of the past (earlier he mentions not only the Napoleonic wars but also world war I and II) to overcome "wars, racism and anti-Semitism". 21

All three reformulate a new political idea for interpretation and using the monument anew. The history delivers on a first sight the legitimation to do so but on a second look the artifact is cut off its historical bounds in favor of a Kantian idea of a never ending peaceful future in the frame of a common Europe. Any militaristic approach towards the monument is wiped off (a parade of the re-enactment groups was even forbidden by the mayor). Nevertheless the bounds to its historical meanings have not be cut but shifted as the nationalist symbol now appears as European symbol. Once again the battle of 1813 has become the origin of a political community's unification, but this time it is not about the German nation but the nation of Europe. The European Union, one could imply, is the new nation in the 21st century. The bloodshed of the 2oth century is filled with a teleological meaning of what Europe has overcome and left behind: racism, fascism, etc. This vision ignores obviously current discussions all over

16 Leipzig Tourismus und Marketing (LTM) (eds.): Leipzig 1813-1913-2013. Eine europäische Geschichte, p. 9, (http://www.voelkerschlacht-jubilaeum.de/tl files/voelkerschlacht/download/Voelki_Programmheft2013 Web.pdf) Translation: "Let's make this double anniversary [...] headed to the fusend out by Leipzig the city of the Peaceful Revolution, to all Europe".

17 Torben IBS: “Rituale der Erinnerung. Lichtfest Leipzig". in: Heeg, Günther et al. (eds.): Reenacting History: Theater \& Geschichte, Berlin, Theater der Zeit, 2014, PP. 106-115.

18 Ibid., p. 8.

19 lbid., p. 7 .

20 lbid.

21 lbid. 
the continent from the fortress Europe at the southern borders to the problems of European minorities such as the Roma, the ongoing nationalist tendencies in regions like Catalonia or Scotland and a strong right-wing-populism all over Europe. But discursively these topics disappear in a shiny cloud of goodness inside the commemoration. It is noteworthy that only one month after the celebrations the publication of plans for a new mosque in Leipzig gives room for a strong anti-muslim movement which is based on racist arguments. Peace is not only the absence of war.

The Völkerschlachtdenkmal has once again become a symbol for a current policy or ideology in a sense that ideology is nothing else than a dominating discourse, which legitimate political actions. The monument has to serve again, but its history is reduced to a minimal impact, and a far shadow. The national (war) monument becomes an European (peace) monument. In the proposed scheme the hegemonic discursive position uses the following aspects:
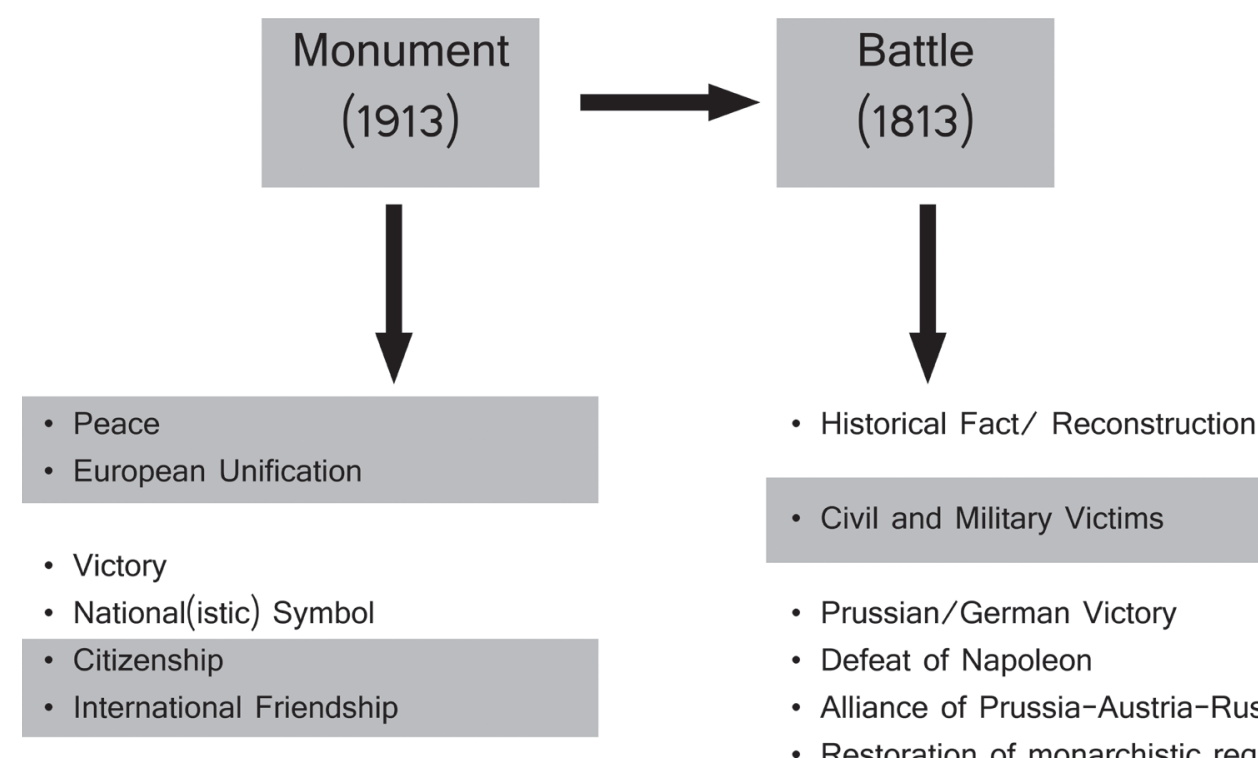

- Civil and Military Victims

- Prussian/German Victory

- Defeat of Napoleon

Alliance of Prussia-Austria-Russia

Gráf. 02 - Architecture (Free Mansonry, esthetics etc.)

- Restoration of monarchistic regime

The victims are the legitimation of the new processes. It is a common figure to build a community upon those who died for it and by this operation, giving to their deaths a deeper sense. In the rhetoric patterns, as seen, this status of victim is also widened and not only includes In the rhetoric patterns, as seen, this status of victim is also widened and not only includes
the victims of 1813 but all victims of what some historians nowadays call the European civil wars. But the legitimation of the present on the bones of the dead is still in force and also the nationalist forces in the 19th century used this scheme. The monument stands for cruelties which shall never happen again as if there would be a lesson learned in all this bloody history.

\section{Re-enactment: trying to connect with the past}

"We want to bring to life in an authentic way what happened 200 years ago", explains Michél Kothe ${ }^{22} \mathrm{He}$ is the president of the Verband Jahrfeier Völkerschlacht bei Leipzig 1813 and since the late 1980 s they are organizing re-enactments of the battle. For the 200-year-commemoration 6000 participants from all over the world come to Leipzig to live for three days in historical bivouacs, which are also open to public. It is not only the re-enactment of the battle of 1813 but also of the daily life an routine at this time. More than 30.000 spectators visit the spectacle. It is staged on original grounds. Besides the battle reconstruction the association organizes educational events in schools with history lessons in reconstructed uniforms with the aim that the pupils can literally get in touch with history. Authenticity is a key concept in all those activities. Another key concept is the will of going back to the origin ("Ursprung") of the battle. As Foucault points out such an origin is impossible to find because it's only the construction of history, and its writing that produces history. History cannot be thought as an origin but is only thinkable as a look back and with all inscriptions in work, life and language. ${ }^{23}$ The re-enactment therefore must be seen as an actualization of our picture of what happened in 1813 . It is, as Wolgang Hochbruck and Judith Schlehe write, "an enactment, implying a mise-en-scène quality few of the original event that have become subject to reenactment ever had". ${ }^{24}$ The organizer try to give an insight in how a part of the battle could have taken place. The used acting techniques are based on a strategy of embodiment and overcoming the distance between now and then allowing a total identification:

This is an attempt to feel sympathy for the subjects of bygone events by imagining oneself in their position. By eliminating the safe distance between abstract knowledge and personal experience, between then and now, between the others and oneself, re-enactments maker personal experience of abstract history possible. ${ }^{25}$

That has consequences for the event:

It is not history, however, which is passing before their eyes but a (re-)constructed past for which a stage has been prepared on which the same willing suspension of disbelief is operative which already informed Samuel Taylor Coleridges's theory of the theatre, an which is largely based on the credibility of the presented past's pastness. ${ }^{26}$

It's the credibility or authenticity which is so appealing and its conversion into a stage which takes away obstacles for the spectator. The presented events must not be true in a strong sense but the show must be credible. The re-enactment is not about the monument or its ideals but refers to the battle itself, with authenticity as the key argument. In his discursive interventions Kothe is not happy with the reformulation of the Völkerschlachtdenkmal as a monument for Europe and peace. In his opinion such a new interpretation cannot be done without damaging the "spirit of the monument" which should only "stand for the time it represents." It's a call for purity but also the intent to depoliticize the monument making it a pure artifact with no discursive content since the old idea of a national monument cannot be transferred in the 21st century easily. At the same time Kothe assigns himself to some part of the official paradigm, since he argues that this event is an international one and brings together the foes of the past in the name of peace and international dialogue. Again Kothe discards the discursive role of the monument to strengthen the focus on the battle itself. His discursive position can be visualized as this:

23 Michel Foucault: Die Ordnung der Dinge, Frankfurt, Suhrkamp, 1974, p. 397.

24 Judith Schlehe and Wolfgang Hochbruck: "Introduction: 'Staging the Past", in: Judith Schlehe $e$ al. (eds.): Staging the Past. Themed Environments in Transcultural Perspectives, Bielefeld, Transcript 2010, pp. 7-22; 14 .

25 Inke Arns: "Strategies of Re-enactment", in: Inke Arns, Gabriele Horn and KW Institute for Contemporary Art (eds.): History will repeat itself. Strategies of re-enactment in contemporary (media) art and performance, Frankfurt am Main, Revolver-Archiv für aktuelle Kunst, pp. 38-63; 61.

26 Judith Schlehe and Wolfgang Hochbruck: "Introduction: 'Staging the Past"'..,p. 15 


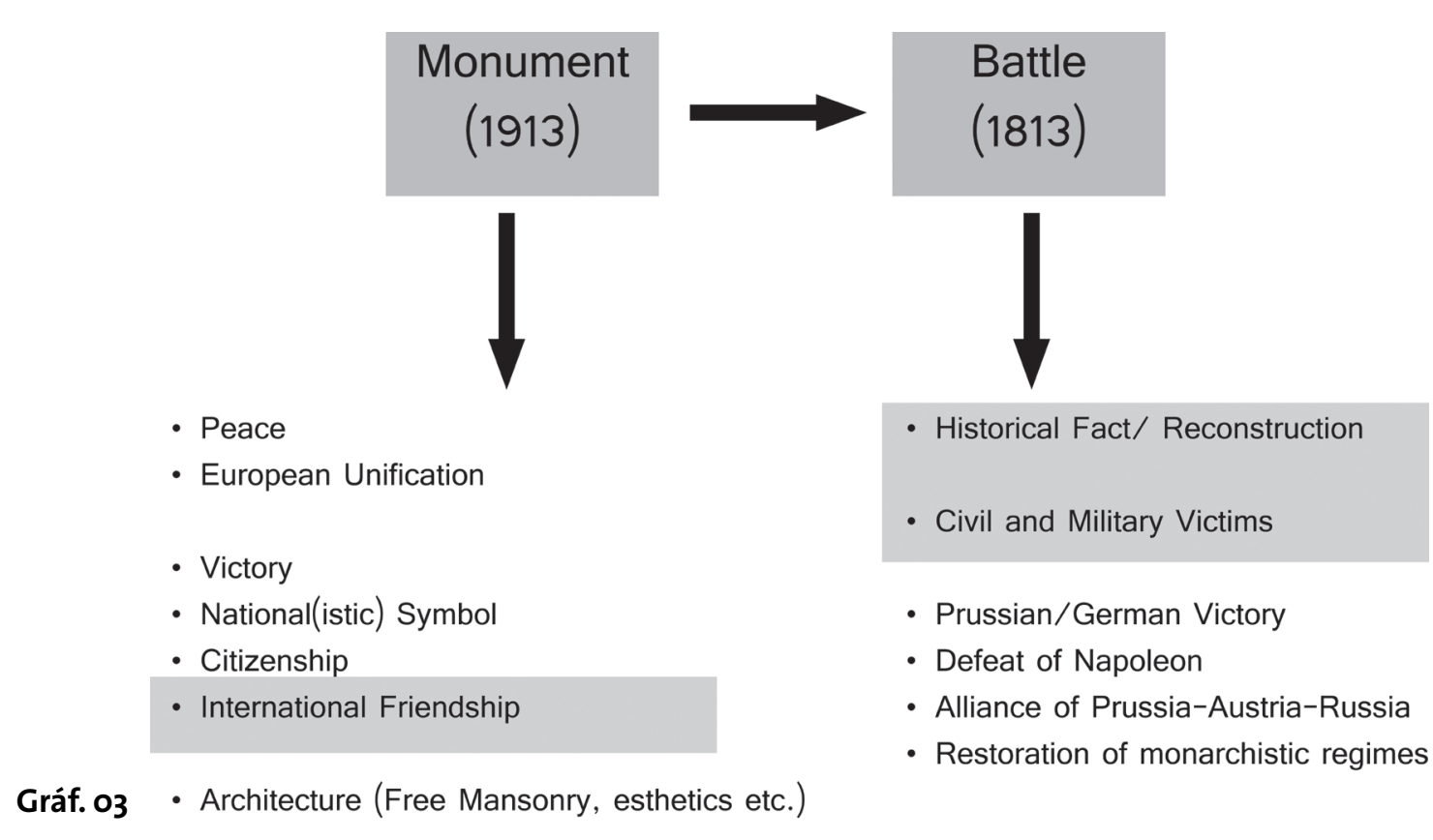

His group is in general a friend of the idea to use the commemoration events as an international peace festival with cultural exchange and global contacts. A special focus lies on the historical events and a gaining for accuracy at least with the costumes and props, not so much in the ongoing re-enactment of the battle itself which is merely symbolic. They demand that the monument shall be politically neutral and oppose themselves to new interpretations, but they also tend to ignore such built manifestations or they try to use them for their action (as scene for a parade for example). Nevertheless they don't deliver a view which goes furthe than the acknowledgment of the battle they stage, a position which is coherent with their stand opposed to re-interpretation and an interesting attempt to ignore contemporary struggles as well as the given history of reception and all their traps. The claim for neutrality also hides their own political position in contemporary discourses, so their whole endeavor seems more likely as part of the event-culture and co-modification, stabilizing and not intervening in the struggles of meaning but certainly demanding for a voice. The intention to keep the monument out of political and discursive struggles appears naive since discussions about the question what the monument is all about have always been part of the monument and its reception from the very beginnings. There is no neutral ground.

\section{Historical events as entertainment}

The two theater projects "Ein einzig langes Donnergebrüll” (One long thunder roar) by Maya Chrenko and "Krieg und Frieden" (War and peace) by Konsortium Luft und Tiefe work with a strong will to create a connection with past, and try to explain, in a way, what happened by mixing authentic elements with artifical ones. This is really clear with the work of Maya Chenko. It's a small play with three actors and the several scenes are taken from historical sources as well as literature pieces as a collage. It delivers no own position to the nowadays event around the commemoration. The same can be said about the production of "Krieg und Frieden," based on Leo Tolstoy's novel "War and Peace". Director Stefan Ebeling produces a nicely entertaining piece of work, which fits in the scenery and has a certain wil to bring the text alive. A classical work for summer season where many groups play rather comedies. In this context a topic like Tolstoy is quite an effort and an economic risk for but it does not claim to be a political intervention at all. Both plays can therefore be seen as entertaining and l'art pour l'art which are stabilizing the official discourses but give a special emphasis on the victims' side.

\section{Searching for the ignored}

As part of the official ceremony the city of Leipzig hired the theater group Titanick, based in Leipzig and Münster but working international. For the commemoration the group creates an open air theater space in front of (but not within the area) the Völkerschlachtdenkmal. The title of the performance is "Imagine Europe/TraumWelten". It is a theater installation with several stages and different performances including lots of bizarre objects, big puppetry, visual effects and fireworks. It takes place on 19th of October, one day after the official speeches and one day before the battle re-enactment. Robert Schiller, technical director, explains that the idea was an artistic comment on the ongoing crisis as a symptom that the Battle of the Nations is not over. ${ }^{27}$ The result is a installation with performances The theater work therefore does not consist of one homogenous narrative but is divides into different sections. The esthetics used by the group derive from modern avant-garde and street theater with big machines, industrial alike costumes and a grotesque body work with a similarity to puppets similar to the early works of La Fura dels Baus. It takes place in a park in front of the monument but not part of the monument. In the presentation Titanick starts with a march of soldiers in the central paved part of the park, but then let the audience stroll through the park where several installations and little scenes are going to happen There is no narrative but a strong artistic will. Fantasy and nightmares stand against the disciplinary machine represented by the military forces.

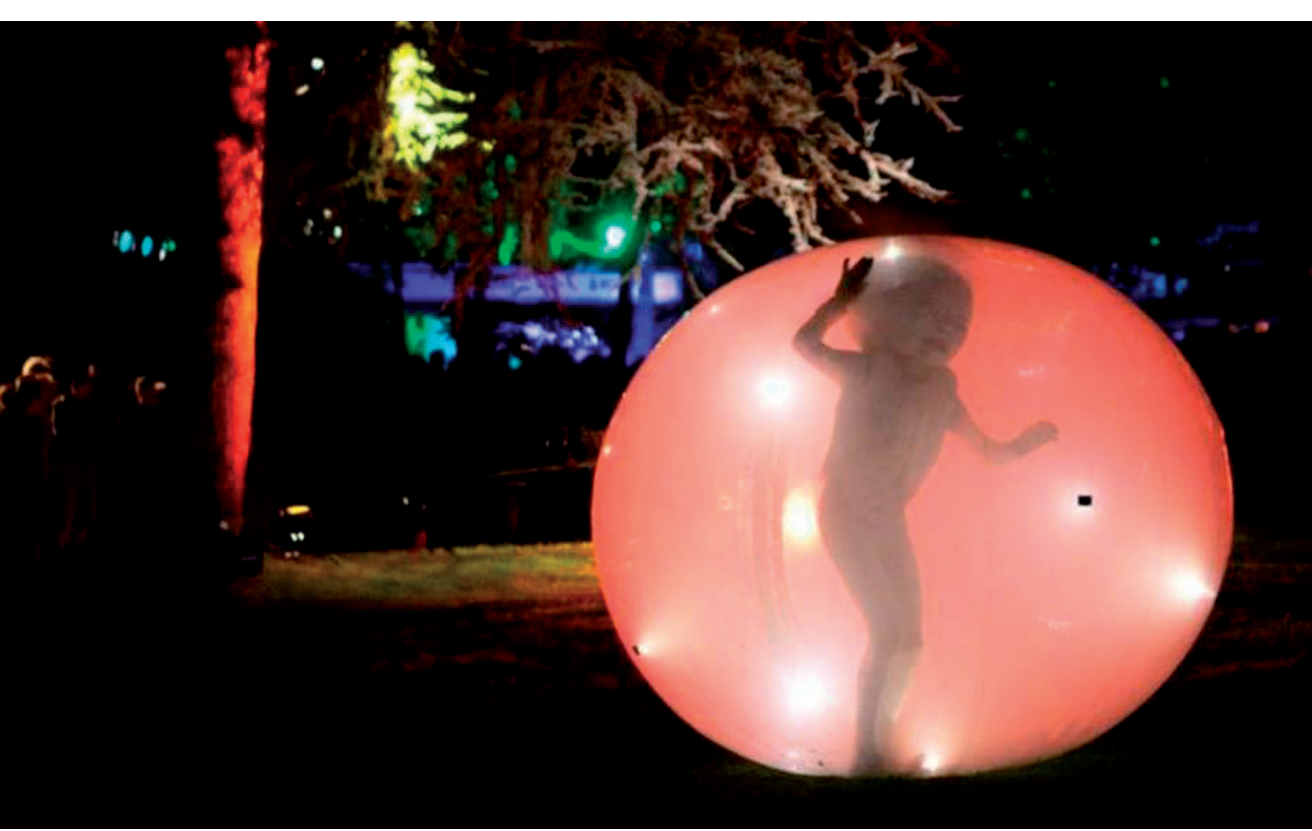

By focusing on the inactivity in wartime and disobedience Titanick tries to break up the classical inscriptions and narrations of history, installing a space in between, trying to bring the war movements to an end. This operation is not only a comment against the dominant storytelling but searches for cracks in the closed circuit which seems to be the future. By focusing on the Not-Doer, Titanick also connects in a political sense to heterogeneity, denying one central political thesis but referring to the "utopia of the other life". ${ }^{28}$ The new political sense in this kind of productions, as Lehmann puts it, is not the representation of the oppressed but a practice of this heterogeneity in life and work. ${ }^{29}$ It's a suspension of the current political dis-

27 Robert Schiller: 14th may 2013, interview by the author, Leipzig.

28 Hans-Thies Lehmann: Postdramatisches Theater, Frankfurt, Verlag der Autoren, 1999, p. 457.

29 lbid., pp. 455-457. 
courses and this interruption can be seen as a contemporary political approach to theater. ${ }^{30}$ It is a theater which not only looks for a dialectic confrontation with hegemonic political discourses but undermines its patterns and contents by escaping them. It opens a third space in which military expressions are defiled and devalued, which is accompanied by a high emphasis to a whatsoever other. Creativity washes the soldiers away. It is a call for heterogenity.

A similar approach can be seen in "Millenium Front Theater" (MFT) which takes place from May 28th to June 15th 2013 in Leipzig. The project is part of a two year cooperation between the theater group fringe ensemble, situated in Bonn, and the theater Schaubühne Lindenfels in Leipzig. For three weeks they install a workshop on an open field which had the camouflage of a military camp. Several authors and actors live and work there together and in the nights the just produced texts are presented in stand up performances. This procedure can be seen as a comment on the re-enactment process which uses similar strategies but in the spirit of reconstruction and not, as it is the case of MFT, to produce new texts, theate performances, and insights. At the same time it is comment, persiflage, and something quite different. MFT is looking for the creative potential in this camp situation, doing a research as a classical form of independent theater groups in Germany. What seems a connecting point between re-enactment and art appears as a breaking point in a closer look.

The leading question is: "Where is the front line?" The MFT thus uses the events of 1813 and 1914 to decipher in an artistic project the layers of battlefields which have been inscribed in places and thinking throughout the time. The camp site is situated on the place of an old fabric, which produced war machinery during both world wars and even the sleeping place of Napoleon during the 1813 events is near that location. Everything is connected and disconnected at the same time. The texts, produced instantly, mostly ignore these main events or took them only as a starting point to perform a re-sampling with today events For example Russian author Alexander Malchonov connects in his play "The Stone" Russian war remembrance culture with the currents events about Pussy Riot by telling a fictitious interrogation of a protester who vandalized against a monument of the Russian-French war. Other works focus on military patterns in contemporary society or seem on the first view quite apart from the topic. In the panorama of texts a great variety and a connection to heterogeneous aspects is visible which also had the potential to undermine political discourses, giving voice to new historical connections and alternation of historical as well as current events. In this way the project gives voice to subaltern discursive speeches - not only in order to oppose hegemonic assaults but to undermine them as well and show how fragile the construction of a hegemonic discourses always is.

Both projects try to establish a counter-discourse by either oppose the official discourse paradigms or by the tactics of evasion to promote a different approach to the topic Völkerschlacht and its remembrance. But in contrast to re-enactment they do not propose a clear alternative of how the monument could be used in a way of an alternative policy of me mory. They evade the monument and in a way the ongoing activities but nevertheless perform a subaltern discourse which answers and echoes the official one. Both approaches emphasize with the victims, especially the civil ones, to tell a counter-history which would basically be a history from the bottom. This process is an attempt to de-legitimate the official positions and to diffuse the concentration. The main character of the historical events is its heterogenity which shall overcome the official ideological line. This is the discursive struggle that these artistic projects try to establish in order to crack the hegemony in favor of a much wider focus, which makes a historical narrative with teleological aspects impossible. In such a discourse the victims would not be ignored but waived with grief without any sense-making. The question which arises here is not only about war and peace but about the meaning of killing. The humanist approach here is strongly pacifist, stating that there is no sense in such killings and victims. This is the great difference between the official discourse and the artistic one, as it can be called. But even this discourse approach is based on the same discursive pattern mapped below and their actions are not independent from the official celebrations but need them as antithetic counterparts:

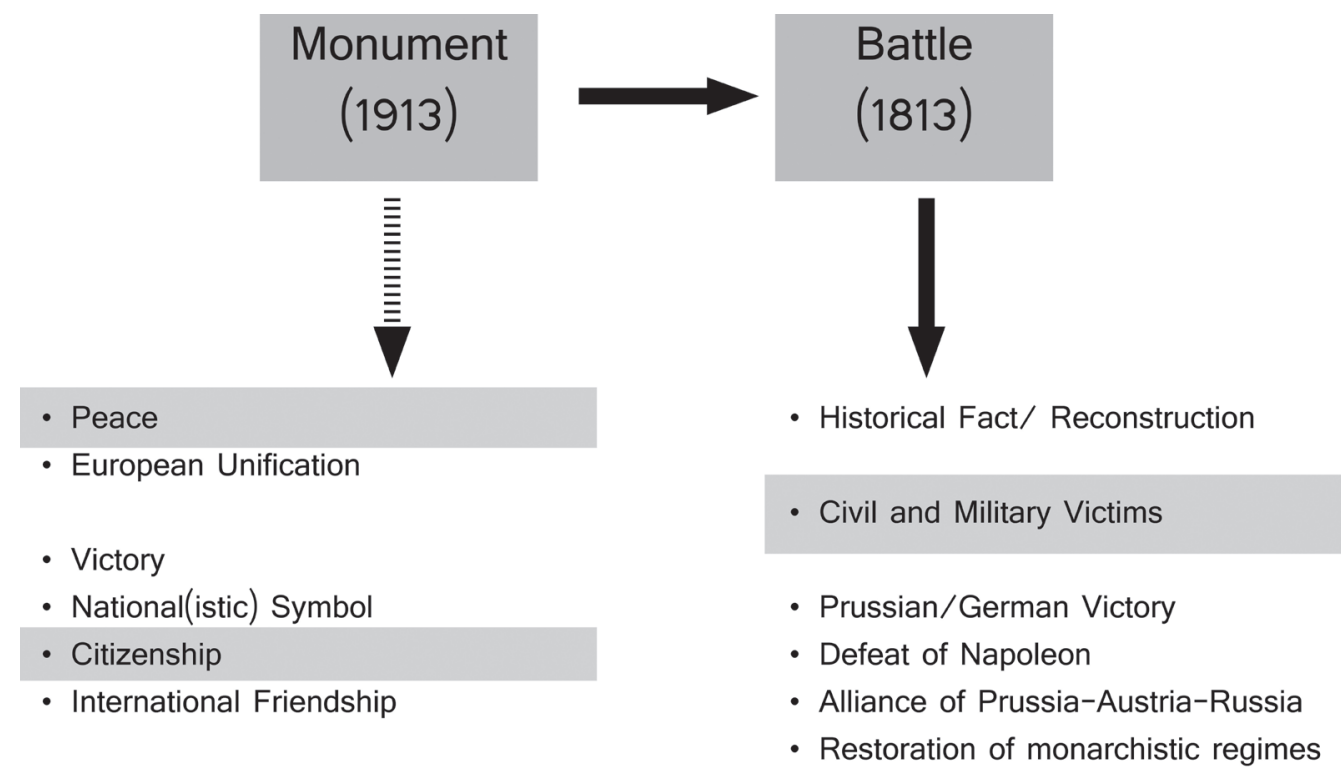

Gráf. 04 - Architecture (Free Mansonry, esthetics etc.)

Conclusions

It has become clear that a monument such as the Völkerschlachdenkmal (but it's true for all other monuments as well) does not have a clear defined meaning throughout all times as structures like this are always part of current political interpretations which are framed and formulated in an official discourse. This discourse is searching through past legitimacy for ac tions in present and future, however these legitimation discourses are not random but built on a certain set of rules and objects which are open for continuing re-interpretation. Besides this changing political meanings sites like the Völkerschlachtdenkmal are under a steady consumerist pressure which intends to use the monument as depoliticized facade for certain events.

Today the official discourse proclaims the remembrance stone of the Battle of Nations as a European monument for peace and unity, fostering a new quasi-teleological view of history and once again defining the victims as a worthy sacrifice, even though this impetus is connected with a never again. The nationalist idea originally represented in the monuments has been transferred to the idea of Europe as an ersatz nation.

Civil society does not provide an alternative reading of the monument but nevertheless oppose itself against the official discursive framing. The theater artist articulate an alternative view on history by ignoring the monument and its battle to search for the ignored facts of history which does not automatically fit in the big narrative and focus on a history from above. They devalue the monument and its inherent pathos. On the contrary, the re-enactment group is against any new argumentative framing and seeks for the neutrality of the facts which, as seen, can only be called a naïve myth. Telling history is always interpretation.

All different discursive and artistic approaches can be seen in its relation to a set official, hegemonic discourse. Also many other events hold by other actors such as the churches or groups of civil society could be included in this pattern to create a discursive map of civil society and its interventions in the anniversaries. The infinity of utterances regarding the commemoration of 
the battle and its monument also show that history is never over. A final statement what the Völkerschlachtdenkmal meant or means, cannot be made, and every criticism to a given interpretation just leads to another signification. There is no basic ground or origin which could be reached by that strategies. But there is an ongoing struggle for hegemonic ideas.

In a pluralistic society the discursive battle about such symbols like the massive monument of the Battle of the Nations is an never ending imperative to subaltern and hegemonic groups. As definitions of the meaning of this stone block are never final, they are always part of the discursive play and every utterance should be welcomed. But these utterances organize in a specific social field which I tried to measure. Subjects organize themselves within those fields and its layers and historians are just one more part in this field delivering more utterances plays and language games.

This analysis shows how discursive actors are trying to shape or to frame the interpretation not only of the monument and its history in a whole but referring to certain key-variables and deliver an interpretation of their specific value in the framework - in accordance with the today needs and not the intentions in the past. These emphasized or ignored aspects shape the nowadays signification of the monument as a monument for peace or of the victims. The interpretations are not exclusive but emerge from the same discursive pattern and can therefore be seen merely as fluent variations than radical counterparts.

The ironic outcome is that the stone made form of remembrance produces a true flexibility in the remembrance throughout the years. And that is valid for all monuments. It's is not the history that lays frozen in a monument but the monuments enables the present forces to perform their discursive jumps. 


\section{LA IMAGEN DE LA GUERRA DE INDEPENDENCIA ESPAÑOLA DURANTE EL FRANOUISMO}

María del Pilar Loranca de Castro

\section{Introducción}

Durante los años que duró la dictadura franquista, ésta utilizó una serie de mitos para elaborar y transmitir a la sociedad una determinada imagen de España. Uno de esos mitos será la Guerra de Independencia Española, creando una verdadera "cultura del tiempo".' Dentro de su nuevo discurso, el franquismo va a señalar que elementos del pasado de España hay que prestar atención y a cuáles no, para confeccionar la imagen de la "Nueva España", analizando esos hechos y dando una visión de los mismos que colaborase a consolidar y defender el régimen Los libros de texto, la educación, los espacios públicos, el cine y la prensa en general fueron soportes idóneos para la transmisión de esta idea.

La política cinematográfica franquista se va a caracterizar por la represión y el control. Toda esta política se caracterizaba por la compleja red burocrática que daba como resultado la pluralidad de decisiones e intervenciones, en donde colaboraban ministerios, sindicatos y organismos del Movimiento, del Ejército o de la Iglesia. ${ }^{3}$

Del mismo modo que va a suceder con el tebeo, de los mecanismos de control más visibles que el régimen estableció fue el de la censura, orientada siempre a que cualquier creación "artística", ya fuese el cine o el tebeo, a consolidar la ideología del nuevo régimen. Asimismo, el cine también introdujo el doblaje obligatorio y, dentro de esta política de control, nos encontramos por último con la instauración del noticiario NO-DO.4

Será en 1951 cuando se produzcan cambios sustanciales en el cine y en la industria cinematográfica en España. Es en esa fecha cuando se crea el Ministerio de Información y Turismo y la Dirección General de Cinematografía y Teatro que se encargarían de lo relativo al cine pero también tuvieron competencias sobre el cine otros ministerios como el de Industria. Más importante aún que la creación del Ministerio será el nombramiento de García Escudero, al año siguiente, como el primer director general de Cinematografía y Teatro. Quiso realizar una verdadera política cinematográfica, pero no pudo por su dimisión, aunque volvería al cargo en 1962. Los criterios de censura no sufren modificaciones importantes y la protección del medio siguió siendo los pilares básicos. Los cambios se produjeron en el tema de las subvenciones que no irían vinculadas a los permisos de importación y de doblaje.5

Claudio HERNÁNDEZ: “La "cultura del tiempo" en España: la Guerra de Independencia en el discurso franquista", Historia Actual Online, 25, (Primavera 2011), pp. 145-158. Recuperado de internet. http://www.historia-actual.org/Publicaciones/index.php/haol/article/view/56g/486.

2 Ibid., pp. 146-147.

3 Roman GUBERN (coord.): Historia del cine español, Madrid, Cátedra, 1995, p. 188.

4 Ibid., pp. 189-195.

5 Ibid., pp. 246-252.
En 1962 vuelve García Escudero a la Dirección General de Cinematografía, se crearían nuevas normas de censura y una nueva metodología para el proteccionismo: uno, para las películas "comerciales y, otro, para películas artísticas. Dependía ahora de la recaudación en taquilla y por el "interés especial", es decir, las que el Estado creyese oportuno, bien por argumentos políticos, sociales o morales o bien por razones artísticas. ${ }^{6}$

Los puntos principales de la nueva política cinematográfica llevada a cabo por García Escudero fueron:

- Protección económica, sustituyendo el modelo anterior

- Una legislación única, recogida en un texto unitario.

- Se fomentaban las ayudas a realizadores jóvenes que procediesen de la Escuela Oficial de Cinematografía, que también era ayudada económicamente.

- Nuevas normas de censura y publicación de las mismas.

- Potenciar el cine infantil.

Poco a poco el cine español comienza a realizar otro tipo de películas, se comienzan a crear verdaderas "escuelas", como la Escuela de Barcelona, y grandes cineastas como Berlanga, Fernán-Gómez...

Respecto al tebeo, fue un medio que vino bien al régimen, tanto por las posibilidades técnicas, como por las infraestructuras industriales y a los niveles económicos de España. ${ }^{8}$ Con la Ley de Prensa de 1938 se imponía la censura previa a todas las publicaciones y el Estado pasaba a ostentar todo el control de la prensa. Además, con el Decreto de diciembre de 1940, todas las publicaciones infantiles estarían supeditadas a la FET y de las JONS. 9

Al igual que en la industria cinematográfica, el año 1951 con la creación del Ministerio de Información y Turismo, del que va a depender desde ese momento todas las publicaciones infantiles y juveniles. Asimismo, la normativa también cambiará con respecto a la década anterior, sobre todo hay que subrayar la simplificación administrativa, provocando el aumento de nuevos títulos, secundados además por la eliminación de la prohibición de incluir nuevas publicaciones periódicas en el mercado y nuevas normas de censura, dividiendo las ediciones por edades y por sexos y precisando todo aquello que se prohibía. ${ }^{10}$

\section{La imagen en el cine}

Vamos a centrarnos en el cine histórico, que no se entendería sin explicar la concepción de la Historia que postuló el régimen y que creó un género propio en el cine: dominio de lo político sobre lo económico y sociológico, va a mostrar multitud de biografías de los personajes más relevantes, aparecerán los acontecimientos más importantes, glorificación del héroe-caudillo como motor de la Historia y el padre de la nación, se eligen ciertos marcos cronológicos los más gloriosos, la concepción teológico de que hay una misión nacional, no hay cabida a la crítica..."

A este cine histórico, se le conocía como el cine "de barbas", según expresión popular y también con el nombre de "la fazaña".12 Este tipo de cine manipulará el pasado para reescribirlo

6 José María CAPARRÓS: Historia crítica del cine español. (Desde 1897 hasta hoy)", Barcelona, Ariel Historia, 1999, p. 127.

7 lbid., pp. 125-126.

8 Antonio ALTARRIBA: La España del tebeo, Madrid, Espasa Calpe, 2001, p. 12.

9 Antonio MARTín: "La historieta española de 1900 a 1950", ARBOR Ciencia, Pensamiento y Cultura, CLXXXVII 2 Extra (2011), p. 97.

10 Pedro PORCEL: "La historieta española de 1951 a 1970", ARBOR Ciencia, Pensamiento y Cultura, CLXXXVII 2 Extra (2011), p. 130.

11 Roman GUBERN (coord.): Historia del cine español..., pp. 235-237.

12 Doménec FONT: Del azul al verde. (El cine español durante el franquismo), Barcelona, Editorial Avance S. A., 1976, p. 81. 
de la manera que el régimen franquista quería, se centrará sobre todo en el individuo-héroe, en el afianzamiento del mito guerrero y del "culto por el jefe". ${ }^{13}$ Se trataba pues, como explica Doménec Font “(...) de legitimar históricamente lo narrado en base a adaptarlo a los moldes verosímiles del drama y/o del film de aventuras estructurado de acuerdo con la virginidad ideológica del "héroe positivo"'.".

Las películas que vamos a comentar las hemos agrupado según la temática a la que hacen referencia, siguiendo la división propuesta por Ama Kouassi:15 "El Dos de Mayo", "Agustina de Aragón y el sitio de Zaragoza”, "Los guerrilleros", “La leyenda de Bruch” y temática general en la que entraría las historias de ficción, de combates, de amor..

\section{El Dos de Mayo}

La película de Eusebio Fernández Ardavín, El Abanderado, de 1943, la trama nos remite al Madrid de comienzos de 1808 , donde el teniente Javier Torrealta es nombrado abanderado de su regimiento y prometido con Renata hija de un general francés. Sus compañeros Luis Daoíz y Pedro Velarde están planeando una conspiración contra los franceses, en la que Torrealta no quiere participar por su compromiso. Es cuando se produce la sublevación de Madrid, se producen las primeras luchas con los franceses donde mueren Daoíz y Velarde. Torrealta se dirige a una misión secreta que al ser descubierto por los sublevados le tachan de traidor, pero su intervención en un ataque sorpresa de los franceses le permite seguir con su historia de amor.

La película comienza con el siguiente aviso:

Cualquier capítulo de la historia de España está lleno de fechas gloriosas pero entre ellas destaca por la trascendencia que tuvo en la historia del mundo, la gesta heroica de 1808. El abanderado es un relato que muy bien pudo ser cierto, en el cual, los personajes creados por la imaginación del autor se mezclan y conviven con los de aquella época que, por sus hechos de acendrado patriotismo han sido elevados a la categoría de héroes.

Ya desde el principio, se muestra el claro mensaje propagandístico que va a dar la película. Además, hay que recordar que la película se estrena cuando la Guerra Civil española ha terminado hace 4 años, se evidencia en los continuos mensajes patrióticos y la exaltación nacional que muestra el film por medio de las gestas militares..$^{16}$ La recreación del Levantamiento del Dos de Mayo es bastante buena pero la película se convierte en un folleto propagandístico. Se trata de una conspiración entre unos oficiales y la nobleza la que lidera la revuelta popular para "promover un alzamiento nacional". ${ }^{7}$

Agustina de Aragón y el sitio de Zaragoza

a película de Juan de Orduña Agustina de Aragón de 1950 nos muestra uno de los episodios más importantes de la guerra, que fue la defensa de Zaragoza. Esta película combina ficción con realidad, mostrándonos personajes reales como Agustina o el general Palafox.

3 Ibid., pp. 81-82.

14 lbid., p. 83

15 Ama KOUASSI: Representación del tema de la Guerra de Independencia en la novela histórica española reciente, Tesis doctoral, Universidad Complutense de Madrid, 2011.

6 Gonzalo SANZ: El Dos de Mayo y la Guerra de la Independencia (1808-1814) en el cine, Madrid, Comunidad de Madrid, Consejería de Cultura y Turismo, 2008, p. 45.

17 Josefina MARTÍNEZ: "La pervivencia de los mitos: la Guerra de Independencia en el cine", Cuadernos de Historia Moderna, Anejos, IX (2010), p. 200.
Agustina de Aragón es la personificación de una heroína que se inserta en la España autárquica y del racionamiento. Desde el poder se alaba el sacrificio y generosidad de la mujer española elevándola a la categoría de "Reina Santa". ${ }^{8}$

Agustina es portadora de todo esto, que además no duda en aventurarse para entregar un mensaje al general Palafox o en dejar a su prometido por afrancesado (hecho que se evidencia porque tiene libros de Voltaire). Es capaz de enfrentarse a la gente por defender al general $\mathrm{Pa}$ lafox “iSi derribáis a este hombre, derribáis lo único que le queda a España!”. Evidenciando así, su respeto por la jerarquía militar y su nacionalismo. ${ }^{19}$

El otro film que utiliza como su argumento central este tema es Sueños de Historia de José Hernández Gan de 1967. Se divide en dos partes y la trama se sitúa en época actual y la protagoniza un niño que sueña que está en ciertos sucesos históricos. Una parte está dedicada a la conquista de América y otra al sitio de Zaragoza. La historia comienza en las afueras de la ciudad, donde los soldados franceses avanzan pero interrumpidos por la defensa de los españoles. Aparece el "Tío Jorge" y Agustina es quien recoge al niño y lo lleva a su casa. Mientras se suceden las batallas y el avance de los franceses una voz en "off" va contando la historia de la defensa y resistencia de Zaragoza. ${ }^{20}$

\section{Los guerrilleros}

La película Aventuras de Juan Lucas de 1949 dirigida por Rafael Gil trata de un bandido, Juan Lucas, quien se une junto a sus hombres a los soldados y campesinos para luchar contra la invasión francesa. El escenario es la preparación y desarrollo de la batalla de Mengíbar y de las tropas españolas que vencen a los franceses dirigidas por el general Castaños.

En la película también llama la atención el personaje de la condesa Ana, quién paga a los contrabandistas para armar una partida que combata junto al general Castaños en Bailén, mostrando asi de nuevo la figura de una mujer valiente como en el caso de Agustina de Aragón. ${ }^{21}$

También observamos en este film como los guerrilleros se unen a las tropas regulares intentando alcanzar el objetivo final de la victoria.

Asimismo hay que destacar la aparición de la partida de los garrochistas de Jerez, basándose en la novela homónima de Manuel Halcón. Es importante porque este grupo fueron los primeros en vencer a los coraceros. ${ }^{22}$

No hay que olvidar que el protagonista es un bandolero y se une a la lucha para poder casarse con su amada, pero termina siendo el paradigma de prototipo.

Por último, otro detalle que nos muestra esta película es que al igual que sucedía entre la oficialidad militar del ejército franquista de la época que se alejaba de la tropa, la película muestra este mensaje clasista representado por el general Castaños cuando hablando con su amigo Don Martín, le comenta que él estaba lejos de tratar con su tropa y que no había pretendido el liderazgo. ${ }^{23}$

El director Pedro L. Ramírez estrenará en 1963 Los guerrilleros, cuyo argumento nos traslada a los preparativos de la batalla de Bailén. Un destacamento francés tras saquear Córdoba se dirige hacia Andújar para unirse al general Dupont e intentar derrotar al general Castaños. Mientras por toda España se están formando grupos de guerrilleros para luchar contra la ocupación francesa.

18 Doménec FONT: Del azul al verde..., p. 83.

19 Josefina MARTÍNEZ: “La pervivencia de los mitos...”, p. 202.

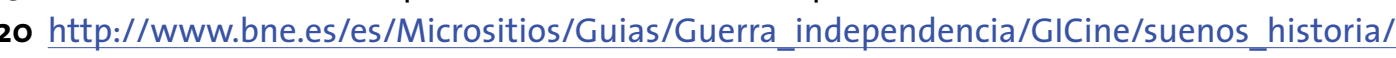

21 Josefina MARTÍNEZ: “La pervivencia de los mitos...", p. 203.

22 Ibid., pp. 206-07.

23 Gonzalo SANZ: El Dos de Mayo..., pp.114-115. 
Esta película cuyo protagonista es Manolo Escobar, se aproxima a la Guerra de Independencia en un tono más desmitificador y folclórico, repleta de canciones populares. ${ }^{24}$

El film La guerrilla, de coproducción española-francesa y de nuevo del director Rafael Gil estrenada en 1972, durante los últimos años del franquismo. Basada en la novela de José Martínez Ruiz, Azorín, del mismo nombre, está ambientada en un pueblo situado entre Madrid y la Sierra y nos cuenta como se forma una guerrilla para luchar contra el enemigo extranjero.

Nos muestra la implicación de los habitantes con los guerrilleros, con acciones como que cada vecino debe matar y tirar al pozo a los franceses que lleguen a la venta. ${ }^{25}$

Nos presenta asimismo, las desavenencias que se produjeron en la población rural, y como en muchas películas que estamos comentando, hay un francés que enamora a una española para crear aún más conflicto si cabe.

\section{La leyenda de Bruch}

El tambor de Bruch dirigida por Ignacio F. Iquino y estrenada en 1947, nos cuenta la historia que sucedió en las montañas catalanas cuando los somatenes se enfrentan a las tropas francesas. Se dice que un niño al tocar su tambor provocaba la huida de las tropas francesas, debido al eco provocaba que el sonido fuera como el de un gran ejército aproximándose, y por esta razón este hecho fue mitificado ${ }^{26}$

\section{Temática general}

Realizaremos una recorrida por las películas que nos parecen más interesantes y las comentaremos por orden cronológico.

La película de Enrique Gómez Bascuas El Verdugo de 1947 nos transporta a dos momentos históricos muy distintos: por un lado, a 1940 cuando unas jóvenes franceses huyen del régimen nazi hacia España alojándose en la casa del marqués de Leganés, hay que recordar que España se encuentra en esos momentos fuera de los circuitos de relaciones internacionales y se quiere dar una imagen de un país seguro y unido; de otro lado, a la Guerra de Independencia cuando el protagonista relata la historia de un antepasado suyo, "el verdugo", quien es elegido por las tropas franceses para ejercer de tal de sus familiares como represalia al asesinato de un soldado francés. Luna de Sangre de Rovira Beleta de 1950 está ambientada en Andalucía donde los jóvenes del pueblo se unen para luchar contra los franceses, aunque la batalla no tiene lugar porque se había firmado por parte del general Ballestero un tratado en 1812 para la liberación de Andalucía. El film combina amor, crimen y el tema de los bandoleros.

Lola la Piconera data de 1951 de Luis Lucía, trata del sitio y de las Cortes de Cádiz. Plagada de folclore y canciones, hay también el triángulo amoroso que aparece en tantas películas de una española enamorada de un español y un francés. El tema de las Cortes de Cádiz esta tratado muy sutilmente ya que no era un aspecto histórico que agradase a la ideología oficial. ${ }^{27}$

El director Cahen Salaberry estrenó en 1958 el film Ventas de Vargas, al igual que la película anterior está llena de folclore y canciones que nos remite a los preparativos de la Batalla de Bailén. Relata la historia de amor entre una cantante y un soldado francés.

24 Josefina MARTíNEZ: “La pervivencia de los mitos...", p. 205.

25 Ibid., p. 206.

26 David BRAVO: “Un conflicto en imágenes. La Guerra de Independencia a través del cine y la televisión", en Leandro MARTíNEZ y Manuela FERNÁNDEZ (coords.): De las Navas de Tolosa a la Constitución de Cádiz. El Ejército y la guerra en la construcción del Estado, Valladolid, Asociación Veritas para el Estudio de la Historia, el Derecho y las Instituciones, 2012, p. 416

27 KOUASSI: Representación del tema..., p. 178.
Carmen de la Ronda de Tulio Demicheli de 1959 nos cuenta la historia de Carmen enamorada de un guerrillero y de un soldado francés. En la película, una historia de amor, se muestra a los guerrilleros como auténticos patriotas y no como bandoleros o ladrones.

\section{La imagen en el tebeo}

Al igual que el cine, el tebeo, en su condición de medio de comunicación de masas, también se hará eco de la Guerra de la Independencia como una temática más, pero apenas lo cultivó interesándose más por otros temas. Los cómics se centrará sobre todo en el Dos de Mayo y el sitio de Zaragoza, las batallas serán escasamente tratadas y tan solo habrá referencias a la Batalla de Bailén. Lo que sí será un argumento insistente será lo relacionado con los guerrilleros. Veamos los títulos más significativos.

El primer título que aparece es El Caballero sin Nombre en 1942 firmado por Emilio Freixas. Se trata de una serie de tres aventuras que aparecieron en el semanario Chicos, tituladas El Caballe ro sin Nombre, Guerrilleros Españoles y La Partida del Chambergo. La Guerra de la Independencia no es el tema central, sino que sirve como telón de fondo para contar las aventuras del protagonista, de la aristocracia, que lucha contra un pariente suyo para recuperar a su amada. ${ }^{28}$

Hay que destacar, que durante nueve números, del 214 al 223, se muestra los acontecimientos del Dos de Mayo, en el que el protagonista participa activamente junto a Daoiz y Velarde. En cambio, Guerrilleros Españoles, que se inicia en el número 224 y concluye en el 240 , la trama se sitúa en el sitio de Zaragoza aunque no hace referencia a hechos históricos y tan solo una breve referencia a Agustina de Aragón. ${ }^{29}$

La última serie, La Patria del Chambergo, nos traslada a Tauste y al Madrid ocupado, centrando el argumento ahora en intrigas entre la corte aristocrática afrancesada.

Se puede afirmar que este título es el antecedente de los que vendrán después que traten la Guerra de la Independencia, aunque no es el argumento principal y no constituye un tebeo propio, sino que inserta como una historieta dentro del semanario Chicos, lo hemos mencionado aqui por ser el primero que, de algún modo, utilizó este tema.

El siguiente título es Aventuras de Capa Negra, de 1953, dibujado por Ángel Badía y con guión de Salvador Dulcet, esta historieta nos cuenta la historia de un justiciero enmascarado que luchará contra los franceses en Madrid. Tras esa máscara se esconde Diego Miranda, un aristócrata español, observando aquí la influencia de El Zorro o El Coyote.

En esta historia se atribuye a los franceses toda clase de vicios, defectos y brutalidad solo por el hecho de ser franceses, en contraposición de cómo presenta los españoles, portadores de integridad, honradez y moralidad que solo luchan por obtener su libertad y buscando como fin último la unidad de la patria. ${ }^{\circ}$

Un año después, en 1954, aparecerá El Tambor de Granaderos, ocho episodios de 15 páginas en las que el protagonista es un joven tambor del ejército español en Cataluña. Al joven Marti la sublevación le ha pillado separado de su regimiento por lo que deberá unirse a la guerrilla de Mataró.

Los franceses son más violentos y brutales que los títulos comentados anteriormente, donde podemos observar viñetas donde las mujeres son azotadas o el fusilamiento de españoles. ${ }^{31}$

28 Jesús Ma MAROTO: "La Guerra de la Independencia en los tebeos", $R$ \& D, Reseearching \& Dragona 6 (Agosto, 1998), p. 22

29 Ibid., pp. 24-25.

30 Salvador VÁZOUEZ DE PARGA: Los cómics del franquismo, Barcelona, Planeta, 1980, p. 105.

31 Jesús Ma MAROTO: “La Guerra de la Independencia...”, p. 27. 
En ese mismo año, se publicará Juan León que nos traslada a Sierra Morena y a pueblos cercanos de Sevilla. No tuvo mucho éxito y como personajes históricos aparecen el mariscal Dupont, el general Castaños o el general Navarro.

Luis Valiente surge en 1957, como la anterior trata de entretener al público infantil mostrando persecuciones entre el protagonista y su adversario francés. La Guerra de la Independencia solo es aludida en la Batalla de Bailén, el resto de la historia transcurre en África.

El Guerrillero Audaz de Manuel Gago se publicó en 1962 y contaron con 26 números. El protagonista, Diego, es el hijo de un agricultor, vive cerca de Madrid y se verá implicado en los sucesos del Dos de Mayo. A partir de ese momento, se moverá por venganza ya que los franceses han matado a su padre.

Este tebeo también nos muestra el sitio de Zaragoza y acaba con la Batalla de Bailén. Aparecen personajes históricos como el general Murat o el general Lefevre. La historia es violenta y aunque de ella se desprenda esa defensa a ultranza de la patria, el verdadero motor de la historia es las ansias de venganza del protagonista. ${ }^{22}$

Por último, hay que mencionar la historieta titulada El Sargento Furia de 1962 también. La violencia abunda en esta serie y el protagonista siempre aparece con uniforme militar. La única referencia histórica que hay es al general Lapisse y su ejército por el Guadarrama. ${ }^{33}$

\section{Conclusiones}

Como hemos podido observar a lo largo de esta comunicación, el franquismo utilizó unas etapas históricas determinadas como un arma más dentro de su aparato de propaganda para crear una conciencia nueva. Esto queda patente desde un primer momento, en el que el Ministerio de Educación Nacional, creado en 1938, entendió la enseñanza de la Historia como un elemento terminante a la hora de difundir los nuevos valores tanto políticos y culturales y como un instrumento de adoctrinamiento. Esto queda plasmado en el texto de septiembre de 1938

El depósito sagrado de la genuina cultura de España, a costa de tanto heroísmo salvado, exige de aquellos que han sido llamados a custodiarlo y a transmitirlo, los ciudadanos más abnegados y, las más hondas, preocupaciones, que han de traducirse, sin vacilar, en primer término, en aquellas reformas radicales que el porvenir de la Enseñanza española primer término, en aquellas reformas radicales que el porvenir de la Enseñanza española salmente como la base insuperable y fecunda para el desarrollo de las jóvenes inteligencias. (...) Consecuentemente, la formación clásica y humanística ha de ser acompañada por un contenido eminentemente católico y patriótico. El Catolicismo es la médula de la Historia de España. (...) La revalorización de lo español, la definitiva extirpación del pesimismo antihispánico y extranjerizante, hijo de la apostasía y de la odiosa y mendaz leyenda negra, se ha de conseguir mediante la enseñanza de la Historia Universal (acompañada de la Geografía), principalmente en sus relaciones con la de España, se trata así de poner de manifiesto la pureza moral de la nacionalidad española; la categoría superior universalista, de nuestro espíritu imperial, de la Hispanidad, según el concepto felicísimo de Ramiro de Maeztu, defensora y misionera de la verdadera civilización, que es la Cristiandad. ${ }^{34}$

32 Ibid., p. 29.

33 Ibid., pp. 30-31

34 Boletín Oficial del Estado, Ley de la Jefatura del Estado Español 20-IX-1938, Sobre reforma de la

Enseñanza Media.
El cine y, en menor medida, el tebeo sirvieron como vehículo para mostrar la Guerra de la Independencia como se pretendía desde el poder. Como hemos comentado, la recreación de conflicto bélico es escasamente fidedigna y lo que se busca es crear mitos y mostrar la concep ción histórica que desde el Estado se quería. Los episodios más repetidos son: los sucesos del Dos de Mayo -representando así un pueblo en armas que se levanta y se defiende contra el enemigo exterior, que en el caso del franquismo, ese enemigo era el comunismo al que habían vencido en la Guerra Civil-; los guerrilleros, no se les representan como bandoleros que lo son, sino como a personas llenas de valor y coraje dispuestos a todo por defender la patria y la unidad de España; la Batalla de Bailén, como la gran victoria del ejército español sobre el francés; asimismo, los personajes históricos más representados serán el general Castaños y el general Dupont, adversarios en la Batalla de Bailén y Pedro Velarde y Luis Daoíz, ambos participes en el levantamiento del Dos de Mayo; por último, el sitio de Aragón y el personaje de Agustina de Aragón, representado a esa mujer, defensora y madre de la patria, que sabe sacrificarse por la misma. Es una alusión clara a los momentos críticos que pasaba la España autárquica y de las cartillas de racionamiento.

Finalmente, cabe destacar como en muchas películas, aparece un triángulo amoroso entre española-español-francés o simplemente una española enamorada de un militar francés. Es un juego al estilo de la historia de Romeo y Julieta, dos familias enfrentadas, dos bandos enfrentados, un amor romántico que, en muchos casos, o acaba con la vida de los dos amantes 0 incluso el militar francés es capaz de traicionar a su patria por el amor. 


\section{¿COMO OVEJAS AL MATADERO? FORMAS DE RESISTENCIA PASIVA DE LOS JUDIOOS EN LOS GUETOS DE VARSOVIA Y DE LODZ (1939-1942)*}

Ximena Machado

CEFID/UAB

\section{Introducción}

En las últimas dos décadas, la historiografía israelí sobre el Holocausto ha desarrollado un gran interés por el estudio de la denominada resistencia "espiritual" -más conocida en Europa como resistencia pasiva- de los judíos víctimas de la persecución y el exterminio nazi. Esta categoría es definida por los investigadores de Yad Vashem como el intento de las personas de mantener su humanidad, integridad personal, dignidad y sentido de la civilización frente a los intentos nazis de deshumanizarlos y degradarlos.' La resistencia pasiva hace referencia entonces al rechazo a permitir que se quiebre el espíritu de la persona en medio de la degradación más horrible. Con este tipo de resistencia, los judíos no intentaban poner en peligro el régimen nazi, sino que buscaban preservar su espíritu, su identidad y su organización comunitaria, en un contexto de extrema persecución y, posteriormente, de exterminio.

Si bien el interés de los investigadores por este campo de estudio ha ido en aumento, aún no está plenamente consolidado en la historiografía europea y americana sobre el Holocausto, debido a que solo se considera resistencia aquella acción activa y, en general, violenta, orientada a ralentizar o frenar los objetivos del enemigo opresor. Es por esta concepción generalizada que las actividades de preservación de la cultura judía y de ayuda social desarrolladas en los guetos no son aún plenamente reconocidas como formas de resistencia, ya que no representaron la ralentización o el freno de los objetivos nazis de exterminar físicamente a toda la comunidad judía europea. Estas actividades, en cambio, suelen ser consideradas o bien comportamientos orientados a confrontar la vida, o bien son objeto de critica por su naturaleza irresponsable y superficial, cuando no se consideran un esfuerzo completamente inútil. Paralelamente, las acciones de resistencia pasiva de los judíos en los guetos de Polonia fueron distorsionadas e instrumentalizadas para alimentar prejuicios antisemitas, según los cuales los judíos reaccionaron ante el opresor nazi con sumisión y cobardía, ya que fueron a la muerte sin resistir, "como ovejas al matadero", ${ }^{2}$ haciéndolos así responsables de su propia aniquilación.

Una versión extendida y mejorada del texto ha sido publicada posteriormente al Encuentro en la Revista Universitaria de Historia Militar, $\mathrm{N}^{\circ} 4$, volumen 2, 2014. http://www.revista-historiamilitar. org/2014/01/revista-universitaria-de-historia.html

Yad Vashem es el centro israelí de conmemoración, documentación, investigación y educación del Holocausto. 2 Esta extendida y malinterpretada expresión fue empleada por primera vez por el jefe de los com1941 llan g los habitantes del gueto a resistencia armada. En una apelación al orgulo y sentimientos de los judios sometidos a lo a ris nazi expréó “No vamos a ir como ovejas al mataderol Es cierto que somos débiles e indefensos, pero la única respuesta ante el asesino es la rebelión! i Hermanos! Más vale caer como luchodores libres que vivir conforme a merced de los asesinos.j jevartaost , Mevántate con tu último alientol". Con esta metáfora, Kovner intentaba inducir a los judios a
El debate sobre la resistencia pasiva o "espiritual" de los judíos durante el Holocausto sigue abierto. El objetivo de esta comunicación es demostrar que las actividades educativas, culturales y de ayuda social que se desarrollaron en los guetos de Varsovia y de Lodz entre 1939 y 1942 fueron vividas como formas de resistencia pasiva por quienes las llevaron a cabo. Es a través del análisis de las experiencias narradas por las propias víctimas que es posible concluir que sus acciones respondian de forma plenamente consciente al objetivo de afirmar la vida desde su identidad judía frente a la opresión y el exterminio nazi.

\section{La resistencia pasiva en la historiografía sobre el Holocausto}

A partir de la década del sesenta del pasado siglo, y más concretamente a partir del juicio a Adolf Eichmann, se inició un polémico debate sobre la actitud que adoptaron los judíos europeos a la hora de enfrentarse a la persecución y el exterminio. Una idea comenzó a extenderse y afianzarse tanto entre los historiadores como entre en la opinión pública, y es que los judíos no ejercieron prácticamente resistencia ante la muerte. Fue durante el juicio a Adolf Eichmann en 1961 cuando esta idea salió a la luz y se extendió entre la opinión pública, concretamente a partir de las preguntas que el abogado defensor del burócrata nazi formuló a prácticamente todos los testigos judios: “¿por qué no protestó?”, “ipor qué se subió al tren?”,“¿por qué no se defendió?", ¿por qué no resistió?”. Durante este juicio estuvo presente Hannah Arendt, quien realizó un informe titulado, "Eichmann en Jerusalén. Un estudio sobre la banalidad del mal", en el que reflejó lo que vio y escucho durante el juicio, es decir, que la resistencia judía fue "lastimosamente pequeña", "increíblemente débil"y "especialmente inocente" en su asalto a la máquina de guerra nazi. También hizo referencia en su informe a los combatientes judíos señalando que "únicamente los más jóvenes fueron capaces de decidir que no podían aceptar ir a la muerte como corderos" y que "quienes resistieron de forma violenta a los nazis fueron héroes". En relación al levantamiento del gueto de Varsovia, Arendt declaró, "La gloria de la revuelta del gueto de Varsovia y el heroísmo de los otros, pocos, que supieron resistir radicó precisamente en que los judíos renunciaron a la muerte relativamente fácil que los nazis les ofrecían, a la muerte en la cámara de gas o ante las ametralladoras".3 Desafortunadamente sus palabras fueron malinterpretadas como una expresión de sus propias ideas y tesis, siendo por ello duramente criticada por una parte importante de la comunidad judía.

El mismo año, el historiador austríaco Raul Hilberg publicó su extensa obra titulada "La destrucción de los judíos europeos". En las conclusiones, el autor expuso que los judíos no ejercieron resistencia al extermino y que cuando finalmente lo hicieron esta resultó insignificante. ${ }^{4}$ Años después, en 1968, se celebró en Yad Vashem la conferencia: "Manifestations of Jewish resistance". En ella participaron ponentes que trataron por primera vez el tema de la resistencia pasiva o "espiritual" como una forma válida y legítima de luchar contra el opresor nazi. El historiador israelí Saul Esh fue pionero en el estudio de la resistencia espiritual al introducir y analizar en sus investigaciones el concepto kiddush ha-hayyim (santificación de la vida). Según Esh, en los guetos y, en menor medida, en los campos de concentración, los judíos tuvieron comportamientos orientados a preservar la cultura y la identidad judía y estos fueron actos de resistencia tan válidos como las acciones de resistencia armada contra los nazis. Es posible entonces entender los actos de kiddush ha-hayyim como formas de resistencia, porque de lo que se trata es de preservar la vida espiritual judía en el medio de la opresión y la barbarie.

rebelarse, sin por ello asumir que se habían mostrado pasivos ante la muerte. "Abba Kovner: Partisan \& Poet", recuperado de Internet (http://www.holocaustresearchproject.org/revolt/kovner.html)

3 Hannah ARENDT: Eichmann en Jerusalén, Barcelona, Lumen, 2001, pp. 25-26.

4 Raul HILBERG: La destrucción de los judios europeos, Madrid, Akal, 2005, pp. 1094-1097. 
Los judios encontraron finalmente la muerte, pero ello fue después de una dura lucha por sobrevivir y muchas veces como resultado de la misma.

En esta conferencia participó también el excombatiente del gueto de Vilna e historiador Meir Dworzecki. En su ponencia titulada: "The day to day stand of the Jews" puso de relieve la idea de "mantenerse en pie". Este término engloba todas las expresiones de no-conformismo y resistencia de los judios destinadas a contrarrestar la deshumanización a las que los nazis los sometían día a día. Entre ellas señaló los actos de preservación de la identidad judía, la resistencia religiosa la resistencia cultural y la ayuda colectiva, entre otras. En esta misma línea hizo su intervención como ponente la investigadora de Yad Vashem Leni Yahil, quién presentó una ponencia titulada: "Jewish resistance. An examination of active and passive forms of Jewish survival in the holocaust period". En ella planteó que a pesar del fracaso del pueblo judío en salvar millones de vidas, hubo una resistencia considerable y una fuerte voluntad de sobrevivir manteniendo la identidad judía en circunstancias tan terribles como las impuestas por los asesinos nazis. ${ }^{6}$

En la actualidad, el más reconocido exponente de esta línea de investigación es el historiador israelí Yehuda Bauer, uno de los más destacados investigadores del Holocausto. Según Bauer hasta el año 1942, año en que la verdad sobre las deportaciones y los campos de exterminio fue una certeza, el tipo de resistencia que mayormente se ejerció fue "espiritual". El objetivo de la misma fue conservar la mayor cantidad de vidas y hacerlas lo más llevaderas y significativas posible. Continuando el legado del profesor Saul Esh, Bauer analizó el posicionamiento de los líderes de la comunidad judía que decidieron tomar como lema las palabras de Isaac Nissenbaum -rabino de Varsovia- quién escribió: "Es tiempo de Kiddush ha-hayyim, de santificar la vida y no de Kidush Hashem, de martirologio". Por su parte, las autoridades de los Consejos Judíos adoptaron la consigna: "Mantener el cuerpo y el alma juntos". Ambas consignas confluyen en una idea básica que resume el objetivo de la resistencia "espiritual" de los judíos durante la persecución nazi: si el ataque se daba contra todas y cada una de las dimensiones del ser judío, los mismos contraatacarían celebrando la vida como tales y sobreviviendo como tales.

En contraposición con esta línea de investigación, hay historiadores que defienden que los actos considerados como resistencia pasiva o "espiritual" no son más que actos de confrontación de la vida. En este sentido el estudio más reciente es el de Shirli Gilbert. Esta historiadora británica argumentó en su libro titulado La música en el Holocausto. Una manera de confrontar la vida en los guetos y en los campos nazis, que la retórica de la resistencia espiritual tiene buenas intenciones en la medida que busca contrarrestar la imagen de las víctimas como seres pasivos, atribuirles cierta dignidad retrospectiva a sus actos y otorgarles significado a su sufrimiento. Sin embargo también conlleva una tendencia a caer en el sentimentalismo y la mistificación. Para Gilbert, la mayor parte de las veces, las víctimas no tenían una clara comprensión de lo que estaba sucediendo debido a una estrategia de engaño cuidadosamente planeada y con la que los nazis contaban. Frente a la incertidumbre las comunidades hacían lo que podian para seguir funcionando: mantenían algunas formas de vida religiosa, organizaban reuniones clandestinas, contrabandeaban alimentos y compartían raciones, establecían grupos de ayuda social e intentaban preservar algunas de sus prácticas culturales de preguerra. Estos proyectos revelan un instinto de conservación más allá de si era realista o no tener esperanzas, un instinto tan poderoso que no puede interpretarse solo en términos de heroís-

5 El artículo original de Saul Esh está disponible únicamente en hebreo. Para un comentario en inglés del articulo vease, Michael MARRUS: "Jewish resistance to the Holocaust", Journal of Contemporary History, vol. 30, 1 (enero de 1995), pp. 83-110.

6 Leni YAHIL: "An examination of active and passive forms of Jewish survival in the holocaust period" en Meir GRUBSZTEIN (ed.): Jewish resistance during the Holocaust. Proceedings of the Conference on Manifestations of Jewish Resistance, Jerusalén, Yad Vashem, 1971, pp. 35-45.

7 Yehuda BAUER: Jewish reactions to the Holocaust, Tel Aviv, Mod books, 1989, pp. 86-95. mo. La gente le temía a la muerte, por más inconcebible que fuera la inminencia de la propia, y buscaba puntos de referencia para restablecer el orden en medio del caos de los guetos o de los campos. Argumentó además, en referencia concreta al caso de la música, que mientras la palabra "resistencia" apunta a una decisión y a una actividad, parecería más bien que la música era solo una parte del marco en que se sobrellevaba la situación. ${ }^{8}$

En la actualidad, el debate sobre la validez de la resistencia pasiva o "espiritual" de los judíos durante el Holocausto aún sigue abierto. El objetivo de esta comunicación es insistir en la afirmación de esta validez, ya que se reconocen en las acciones educativas, culturales y de ayuda social llevadas a cabo por los judíos en los guetos de Polonia una clara intención de resistir y de mantener la identidad judía frente a la barbarie nazi.

\section{Resistió quién describió los acontecimientos y los enterró en la arena}

"Schreibt un farschreibt", escriban y registren, fueron las palabras que - en su lengua natal, el yídish - dijo a los judíos del gueto de Riga el historiador Simon Dubnov antes de mori ejecutado por los nazis. En lo que ha registro clandestino de acontecimientos ocurridos en una comunidad judia durante la ocupación nazi se refiere, uno de los más completos e importantes fue "Oneg Shabat" (los que festejan el Sabat). Su ideólogo y creador fue el historiador y activista político judio, Emanuel Ringelblum. ${ }^{9}$ Él y su equipo de colaboradores se reunían los sábados -de ahí el nombre del archivo- para poner en común los registros que habían recogido a lo largo de la semana: crónicas de los acontecimientos ocurridos en el gueto, entradas de diarios personales, trabajos literarios, letras de canciones cantadas por mendigos en las calles, cartas, folletos, prensa clandestina, comunicados del Consejo Judío, decretos de las autoridades de ocupación, actas de reuniones de varias organizaciones, tarjetas de identidad, papel de carta oficial, tickets de tranvías, brazaletes con la estrella de David, invitaciones a los eventos culturales, envoltorios de los famosos dulces que se fabricaban en el gueto, etc. El alcance de la actividad de este archivo clandestino y el esfuerzo llevado a cabo por los colaboradores fue realmente impresionante, más aún teniendo en cuenta las terribles condiciones de vida del gueto y el riesgo que implicaba ser descubiertos por las autoridades alemanas..$^{10}$

Con el inicio de las deportaciones a campos de exterminio en julio de 1942, los colaboradores del archivo decidieron guardar los registros y la documentación en recipientes de estaño y enterrarlos en diferentes lugares del gueto. Durante las acciones de deportación, y bajo un clima de violencia extrema, el archivo siguió funcionando para documentar el crimen que los nazis estaban perpetrando, hasta que uno a uno los colaboradores fueron asesinados, como fue el caso del propio Ringelblum, o tuvieron que luchar por sobrevivir entre las ruinas del gueto.

En el gueto de Lodz, también se hizo un notable esfuerzo por documentar detalladamente la vida de los judíos. En este caso se hizo desde una institución, el Consejo Judío. Su fundador fue el polémico presidente Chaim Rumkowski, quien lo inauguró el 17 de noviembre de 1940. El objetivo del archivo, explicó su responsable Henryk Neftalin, era reunir un conjunto de materiales que sirvieran para que en el futuro los investigadores estudiaran la vida de la sociedad judía en uno de sus períodos más difíciles. Los trabajadores del archivo tenían el permiso de Rumkowski para obtener información, datos y documentos de cualquier agencia de la administración judía del gueto. En casi cuatro años de actividad, el archivo logró reunir material de la administración

8 Shirli GILBERT: La música en el Holocausto, Buenos Aires, Eterna Cadencia, 2010, pp. 31-32.

9 Emanuel Ringelblum fue miembro del partido de izquierdas Poale Zion. En setiembre de 1939 mientras co-organizaba la defensa civil en el barrio judío de Varsovia, comenzó a escribir una crónica de los eventos que ocurrían en la ciudad.

10 Para un análisis detallado y documentado de la organización y funcionamiento del archivo clandestino de Ringelblum vé perished city, New Haven, Yale University Press, 2009, pp. 659-672. 
alemana y la administración judía del gueto, incluyendo órdenes, textos de discursos, correspondencia oficial de cualquier tipo, datos estadísticos, fotografías, etc. A su vez, recogieron valiosos libros y manuscritos dejados atrás por los intelectuales, académicos y rabinos que murieron o fueron reasentados. Después de la deportación de los judios provenientes de Alemania Luxemburgo, Austria y Checoslovaquia -que previamente habían sido reasentados en el gueto de Lodz-el archivo estableció una sección especial con los documentos que estos judios dejaron atrás. Uno de los trabajos más valiosos desarrollados desde el archivo fue la Crónica, que involucró a muchos colaboradores de diferentes perfiles. Los mismos fueron contratados como empleados permanentes cuyos salarios fueron determinados y pagados por la administración judía del gueto. También recibían una asignación alimentaria suplementaria. Desafortunadamente, solo uno de los trabajadores del archivo del gueto sobrevivió a la guerra."

El primer boletín de la crónica del gueto fue escrito el 12 de enero de 1941. Se llegaron a escribir dos versiones, una en alemán y otra en polaco. Los temas que abordaba la crónica eran: nacimientos y defunciones, asesinatos por parte de los guardias y suicidios, llegada de alimentos y su racionamiento, precios del mercado negro e incidentes con los contrabandistas, asuntos relacionados con la sanidad y las enfermedades, órdenes de las autoridades alemanas e inspecciones al gueto por parte de varias comisiones externas, acciones tomadas por la administración judía y sus diferentes departamentos y talleres, actividades culturales, fiestas judías y costumbres del gueto, rumores, asentamiento en el gueto de judíos polacos y extranjeros, etc. La crónica finalizó el 30 de julio de 1944, cuando los alemanes ordenaron la liquidación del gueto de Lodz.

\section{Resistió quien dio clases clandestinas}

Hasta el año 1941, las autoridades alemanas del Gobierno General prohibieron las escuelas judías bajo la excusa de riesgo de epidemias. Durante el tiempo de la prohibición, y a pesar de la misma, se había extendido en el gueto de Varsovia la enseñanza en escuelas clandestinas llevadas a cabo por organizaciones y profesores particulares que impartían lecciones en sus casas. Las dificultades eran numerosas y variadas, pero tal vez el mayor obstáculo era el hambre que padecían los niños y que les impedía concentrarse. En el gueto de Varsovia este problema intentó paliarse en diciembre de 1940 con la organización de clases clandestinas en las cocinas públicas. El riesgo de desobedecer el decreto llevando a cabo actividades educativas clandestinas era muy alto, ya que las autoridades alemanas eran implacables si se trataba de la desobediencia de un decreto oficial. Mary Berg, habitante del gueto de Varsovia, recogió en una entrada de su diario personal que en junio de 1940, "[...] dos escuelas clandestinas fueron descubiertas por los alemanes; más tarde supimos que los maestros fueron fusilados en el acto y que los alumnos han sido enviados a un campo de concentración cerca de Lublin"..$^{2}$ Asimismo, Berg señaló que los habitantes del gueto que decidian arriesgarse a impartir o recibir clases lo hacían como un acto de rebelión contra el opresor alemán, “[...] el carácter ilegal de la enseñanza y el peligro que nos amenaza minuto a minuto nos reviste de una rara seriedad. La antigua distancia entre maestros y alumnos ha desaparecido: somos camaradas de armas mutuamente responsables". ${ }^{3}$ Con el inicio de las deportaciones hacia Treblinka las clases clandestinas prácticamente desaparecieron, ya que los jóvenes dejaron sus estudios y comenzaron a preparase para la resistencia armada.

Paralelamente a las clases clandestinas, durante la ocupación alemana de Polonia se dio en los guetos una gran importancia al desarrollo de la cultura. Sus habitantes se entregaron a la

11 Isaiah TRUNK: Lodz ghetto. A history, Bloomington, Indiana University Press, 2008, pp. 39-62.

12 Mary BERG: El gueto de Varsovia. Diario, 1939-1944, Barcelona, Sefarad, 2010, p. 31.

13 lbid. promoción de la lectura y al desarrollo de actividades culturales clandestinas de todo tipo, ya que generalmente las mismas estaba prohibidas por las autoridades alemanas. Los judíos de Varsovia, señala Emanuel Ringelblum, no tenían derecho a utilizar la biblioteca pública, que fue construida por filántropos judíos, por lo que las bibliotecas encubiertas atraían a una gran cantidad de lectores. Se crearon numerosas bibliotecas móviles de las que no se conocía su dirección, ya que los libros se entregaban en la dirección de los suscriptores. La demanda de libros era muy elevada por lo que se llegaron a introducir libros de contrabando desde la zona aria junto con la comida.

También se llevaron a cabo numerosas actividades artísticas clandestinas por parte de grupos que organizaron espectáculos de todo tipo por cuenta propia. Orquestas de jóvenes que tocaban en las calles, conciertos de solistas en los patios de los edificios, cantantes que componían y cantaban canciones cuya letra ridiculizaba a las autoridades judías, actores que hacían representaciones breves en los pasillos de los edificios, etc. Destacable era la presencia en el gueto de músicos judíos de la Radio, la Filarmónica y la Ópera de Varsovia, que se encontraban sin trabajo y que formaron sus propias orquestas. Se dieron también casos de grupos de jóvenes que organizaban conciertos discográficos clandestinos en pisos, como fue el caso del crítico literario alemán Marcel Reich-Ranicki. En sus memorias relató que:

[...] Nos reuníamos en pisos estrechos de quince y hasta dieciocho personas, tantas como cupieran en una habitación. En realidad, aquellas reuniones estaban prohibidas. Pero éramos bastante audaces como para no preocuparnos por ello [...]. Tengo la impresión de que la música no tuvo en ningún momento de nuestras vidas una importancia tan grande como en aquella época tan tenebrosa. ${ }^{14}$

Existía también en el gueto de Varsovia una intensa actividad teatral clandestina. Era muy común que los actores que se habían quedado sin posibilidad alguna de ejercer su oficio, al igual que los actores amateurs, improvisaran representaciones en los desvanes o en los sótanos. Para que los asistentes supieran donde se hallaba el "teatro" se habían colocado en diferentes lugares "oficiales de enlace" que, por un lado, indicaban a la gente la ruta a seguir y, por el otro, se aseguraban de que si aparecía algún guardia alemán o polaco daban la señal convenida para que todas las personas reunidas pudieran escapar. De todos los teatros y cabarets, el "Fémina" era el más popular, porque allí se representaban operetas en polaco que satirizaban el soborno y la corrupción que imperaba en el Consejo Judío y denunciaba la dura y difícil vida de los judíos en el gueto. Con frecuencia las obras se representaban en condiciones difíciles, como cuando fallaba el gas o la electricidad. Aún así, las salas estaban llenas y los asistentes se quedaban hasta el final de la función, a pesar del frío y de que se actuaba a la luz de las lámparas de carburo o de velas. Janina Bauman, habitante del gueto, recogió en la entrada de su diario del 21 de julio de 1942 la profunda impresión que le causó la función de un cabaret al que asistió con un amigo:

El programa estaba bien. Aparte de los viejos éxitos cantados por artistas de antes de la guerra, trataba sobre la vida cotidiana en el gueto. Ácidos y mordaces, los números y canciones azotaban sin piedad la corrupción y la indiferencia, ironizaban sobre la vacuidad de nuestra 'acogedora estabilidad' y hacían reír y también llorar al público. Nos fuimos profundamente conmovidos. ${ }^{15}$

14 Ibid., pp. 215-216.

15 Janina BAUMAN: Más allá de estos muros, Madrid, Kailas, 2008, p. 101 
La creación de una vida cultural en el gueto fue vivida como una manifestación de resistencia pasiva, ya que los judíos estaban combatiendo la imposición del ocupante alemán de excluirlos de todo aquello que representara un valor cultural. Antes de acabar físicamente con sus vidas, el opresor nazi decidió exterminar su vida espiritual, prohibiéndoles toda manifestación cultural y artística. Si bien en lo que respecta al exterminio físico lograron su objetivo, no fueron igual de exitosos a la hora de exterminar la capacidad cultural y artística de la comunidad judía europea, que siguió desarrollándose de forma clandestina en los guetos de Polonia.

\section{Resistió quien ayudó a los más necesitados}

En el gueto de Varsovia se llevó a cabo una intensa actividad de ayuda social a los más necesitados (ancianos, enfermos, niños) a partir de dos vías independientes y muchas veces en tensión: los Comités de Vecinos y el Consejo Judío. Entre ambas organizaciones se dieron numerosas disputas, ya que cada una tenía su propia visión de a qué colectivo ayudar y de qué forma debía otorgarse la ayuda. Los Comités de Vecinos veían en el Consejo Judío a una institución representante de los intereses de los alemanes -que al fin y al cabo eran quienes los habían designado- y no de los intereses judíos como ellos mismos se presentaban. Estos comités surgieron tras la invasión alemana de Polonia como un movimiento de defensa sociopolítico. Se organizaban por barrios y su unidad básica era el patio o edificio de vecinos. Estos últimos elegían a sus representantes para un Comité Central. Ringelblum, uno de los organizadores de estos comités, los describió de la siguiente manera:

No hubo ni una cuestión en la vida de los judíos durante la ocupación alemana en la que los Comités de Vecinos no se involucraran. Estos organismos se ocupaban de los refugiados, de las personas que volvían de los campos de trabajo, patrocinaban diferentes instituciones infantiles, cuidaban de la limpieza de la finca, ofrecían ayuda a los vecinos, mediaban en los altercados y disputas entre vecinos; pero antes que nada, los Comités de Vecinos se interesaban por los inquilinos que sufrían hambre y que se dirigían a ellos con una necesidad imperiosa. ${ }^{16}$

En setiembre de 1940 se contabilizaron unos dos mil Comités bajo la dirección de Ringelblum. Estos tenían a su vez un claro perfil sociopolítico que invitaba a no respetar las decisiones tomadas por el Consejo Judío. Una habitante del gueto (cuyo nombre se desconoce) que formaba parte de uno de los comités describió en una entrada de diario que los mismos:

[...] Además de cumplir un papel importante al ofrecer ayuda a la población empobrecida, se dedicaban también con frecuencia a despertar la conciencia política de la gente. Al frente de estos comités había personas que estaban en contacto con las masas de tra-

bajadores. El Consejo Judío estaba en contra de los comités porque las actividades de la mayoría de ellos le ponían en evidencia. ${ }^{17}$

Una de las funciones más importantes de estos comités consistía en paliar el hambre en el gueto, principalmente entre los niños huérfanos. Así crearon la llamada "Comisión de la cuchara", que recolectaba dos veces por semana una cucharada de azúcar o dos cucharadas de harina y avena cocida de cada inquilino. También se recolectaban durante todo el año patatas, zanahorias, remolachas, repollos y otros productos alimentarios. Durante las fiestas judías, los Comités de Vecinos repartían todo tipo de comidas preparadas o bien ingredientes para

16 Emanuel RINGELBLUM: Crónica..., p. 452

17 Michal GRYNBERG: Voces del gueto de Varsovia, Barcelona, Alba, 2004, p. 36 cocinar los platos especiales de la cocina judía. Hubo momentos en que las acciones de los Comités de Vecinos eran más importantes y abarcaban a más personas que las actividades del Consejo Judío en este ámbito. Los representantes de los Comités de Vecinos hicieron numerosas propuestas al Consejo para mejorar las raciones alimentarias de los más pobres, pero ninguna se llevó a cabo. Aún así, a pesar del gran esfuerzo que realizaron todos los voluntarios, el programa de alimentación de los Comités de Vecinos no dio los resultados esperados. Desafortunadamente, la lucha contra el hambre en el gueto fue una batalla perdida.

En el gueto de Lodz, el Consejo Judío contaba con un área de bienestar social. Esta se dividía en diez departamentos que se encargaban de cuestiones como el subsidio de desempleo, hogares de infancia, orfanatos, guarderías, hogares de ancianos, albergues para los sin techo y para los refugiados, etc. El "Departamento de Ayuda Social" estuvo activo desde el 15 de octubre de 1939 hasta el 27 de setiembre de 1940. Al igual que en Varsovia, el principal problema era la alimentación de la población más pobre del gueto, por lo que el departamento organizó comedores públicos donde se llegaron a repartir un promedio de 7825 sopas diarias. El 22 de julio de 1940, las autoridades alemanas llevaron a cabo una inspección de estos comedores públicos y como resultado arrestaron a todos sus empleados y funcionarios. ${ }^{18}$

La ayuda social en el gueto de Lodz fue decayendo hasta casi desaparecer en enero de 1942 cuando comenzaron las deportaciones al campo de exterminio de Chelmno. El esfuerzo y la constancia de los organizadores y trabajadores que llevaron a cabo actividades de ayuda social en los guetos de Varsovia y de Lodz es un claro ejemplo de resistencia a la deshumanización, la pobreza, el hambre y la muerte impuesta por el opresor alemán.

\section{Conclusiones}

Desde la década de los sesenta del pasado siglo, y debido a la repercusión del juicio de Adolf Eichmann en Israel, se ha extendido la idea de que los judios no ejercieron resistencia al opresor nazi y fueron al exterminio "como ovejas al matadero". Los testimonios aquí citados muestran que los judíos confinados en guetos emplearon todas sus energías en construir un nuevo tejido social con otras reglas, otras prioridades y otros objetivos muy diferentes a los existentes antes de la invasión alemana de Polonia. Para miles de judíos la continuidad de su comunidad se convirtió en un reto y en un objetivo central, pero no estaban dispuestos a continuar a cualquier precio, sobrevivir como judíos era una condición necesaria y lo llevarían adelante hasta las últimas consecuencias. Unos decidieron registrar los acontecimientos del gueto y reunir documentación para la posteridad, otros participaron en actividades educativas, otros en actividades culturales y otros muchos en actividades de ayuda social. Todos ellos actuaron de forma clandestina, poniendo en riesgo su propia vida y la de su círculo más próximo. Con estas acciones, todos ellos demostraron que a pesar de vivir bajo una situación de ocupación extremadamente violenta e inhumana, se esforzaron por pensar y trabajar en favor del futuro de la comunidad judía en una Polonia libre. Difícilmente un colectivo que supuestamente actúa de forma pasiva, sumisa y cobarde se esfuerza por pensar y actuar bajo un gran riesgo en favor del futuro de su comunidad. Es posible concluir entonces que los judios opusieron resistencia al opresor alemán y definitivamente no fueron al exterminio "como ovejas al matadero". 
TOMANDO LA PALABRA... Y EMPUÑANDO EL FUSIL:

LA PARTICIPACIÓN CIUDADANA EN LA GUERRA CIVIL.

LA OCUPACIÓN SUBLEVADA Y LA REPRESIÓN.

UN CASO ANDALUZ, ANTEQUERA

Miguel Ángel Melero Vargas'

Universidad de Málaga

\section{Introducción}

La Historia de la guerra civil ha sido narrada fundamentalmente desde una perspectiva "militar". Las operaciones de guerra, la progresiva ocupación de la zona gubernamental por parte del Ejército sublevado, o el proceso represivo desarrollado, a partir de los bandos de guerra primero -desde agosto de 1936-y por los tribunales militares posteriormente -a partir de marzo de 1937- constituyen el grueso de una ingente cantidad de trabajos en los que quizás no se había valorado en su justa medida el protagonismo fundamental de una población civil que participa "desde abajo", 2 de forma directa, en una etapa como es la de la guerra y el primer franquismo.

Un colectivo social que siempre estuvo ahí, participando de forma activa en el proceso de construcción y consolidación del Nuevo Estado que se inicie desde la progresiva conquista territorial sublevada, sufragando económicamente una nueva coyuntura militar, dando alojamiento y manutención a los principales mandos del Ejército sublevado y que permanecen en la ciudad de forma estable, o bien en su tránsito hacia nuevos escenarios militares. También, formando parte de las milicias populares, de carácter paramilitar, conformadas en los municipios tras la ocupación rebelde, y que desarrollarían una actuación, tanto interna -asumiendo competencias y atribuciones que eran propias de las fuerzas públicas que se mantuvieron leales a la República, y que habían sido desmanteladas o reorganizadas-como auxiliar de las fuerzas sublevadas en las operaciones militares posteriores a la ocupación de Antequera. Del mismo modo, participó en un plano que no solo contemplaba el apoyo material, sino también el anímico y moral, y protagonizado en gran parte por la mujer antequerana; y por supuesto en el voraz proceso represivo desarrollado en la zona a partir de agosto de 1936, bien como pertenecientes a estas fuerzas paramilitares, como de forma personal a través de las delaciones de que se nutran los procesos surgidos al amparo de los bandos de guerra, así como las que formen parte fundamental de los procesos incoados por los tribunales militares. E incluso más allá, por ejemplo para la elaboración del probablemente más importante instrumento propagandístico del que se valió el Régimen Franquista, y de paso justificar la ejecución de su barbarie: la Causa General.

Todos estos factores se vislumbran en el caso de la comarca andaluza de Antequera, en una comunicación que pretende contribuir a arrojar luz a una etapa en que en muchos casos se ha tenido olvidada a una parte de sus protagonistas; a reflejar las formas y manifestaciones en que esta participación va a producirse, las fuerzas motrices que motivan estas actitudes de participacion, como su resultado.

1 Cualquiera de los aspectos tratados en esta comunicación, como del origen de las fuentes para su construcción, puede ser consultado más extensamente en Miguel Ángel MELERO: De la Esperanzo al Sometimiento. Frente Popular, Guerra Civil y Primer Franquismo en una comarca andaluza. El caso de Antequera, Tesis doctoral, Universidad de Málaga, 2013.

2 Ronald FRASER: “La Historia Oral como historia desde abajo”, Ayer, 12 (1993), pp. 79-92.
La ocupación de Antequera el 12 de agosto de 1936, supone el inicio de un proceso de evolución desde una ciudad de retaguardia republicana a otra de retaguardia sublevada temprana, ocupada militarmente, supeditada a la presencia militar, y convertida en una ciudad de trinchera, línea de frente, y centro distribuidor de tropas a otros sectores en guerra, en plena acción militar.

Una evolución en el rol de la ciudad, y que implica también un progreso en el papel de la población en el proceso, pero siempre desde una perspectiva de patriotismo en múltiples vertientes como de agradecimiento por la "salvación", como señales inequívocas de adhesión, pero en los que serán también una constante las actitudes coercitivas de las autoridades, mostradas cuando el entusiasmo inicial degenere hacia tácticas de evasión de una población a la que este patriotismo estaba afectando seriamente su economía.

Por tanto una adhesión que, desde lo voluntario, innato y espontáneo, e incluso lo aquiescente, involucionaba hacia otra fundada, controlada y dirigida a través de la recomendación que no encerraba sino la amenaza velada y la incitación al miedo: "La Alcaldía espera que nadie se excuse ni se retraiga porque será tachado de antipatriota y se expondrá a la censura de sus conciudadanos".

\section{El sostén de un aparato militar rebelde. Aportación económica y de infraestructura. Un patrio-} tismo "caro"

Antequera es, desde su ocupación sublevada en agosto de 1936, una ciudad fuertemente militarizada, que alberga la cabecera de una División, así como la Plana Mayor de su oficialidad, de la misma forma que pasará a convertirse en sede de la Comandancia Militar y del Gobierno Civil de la provincia, en este último caso desde noviembre de 1936.

El caso es que la ciudad se había convertido desde este verano del 36 en una plaza fundamental para el Ejército sublevado, y no solo por posibilitar el enlace con una desde julio aislada capital de Granada, sino sobre todo y a partir de este momento, por las aspiraciones rebeldes sobre Málaga; un hecho que indudablemente tiene un peso específico en el hecho de que la vida cotidiana de Antequera desde su ocupación y durante el desarrollo de la guerra civil, quedara supeditada y totalmente condicionada por la presencia militar en la ciudad, y dentro de esta, por una constante labor de asistencia al Ejército, a través de numerosas y variadas manifestaciones, pero entre las que van a destacar aquellas relacionadas con el sostenimiento económico del aparato militar rebelde, como sobre los antequeranos movilizados en el Ejército sublevado y de manera subsidiaria sobre sus familias, y que van a encontrar además en la población a uno de sus múltiples baluartes.

A mediados de agosto de 1936, se crea en Antequera una Comisión Financiera con el objetivo de destinar partidas económicas hacia la recuperación de la normalidad económica de la ciudad, pero que no es sino el punto de partida de un largo y costoso proceso de aportación económica de Antequera al Ejército rebelde, fundamentalmente a través de una contribución ciudadana, como la primera y más importante de ellas, y por la que se obtenga del Banco de España, y con el aval de sesenta de las principales familias de la ciudad, un crédito de trescientas mil pesetas, con destino al Ejército de Andalucía.

A ellas se unirían las cien mil pesetas que pocos días más tarde recibiera Varela, el general conquistador de la ciudad, para sufragar las actuaciones militares posteriores, y que suponían el inicio de la llamada Aportación Pro Glorioso Ejército Salvador, que se desarrollaría entre agosto de 1936 y agosto de 1939, y en la que el sufragio económico del pueblo, tanto de forma directa a través de suscripciones -bien en metálico como en oro y joyas-como en progresivos y variados gravámenes y derramas especiales contributivas, va a convertirse en un recurso cotidiano como costoso. 
De hecho, y a pesar de que la gestión del Ayuntamiento de Antequera durante la guerra civil, y en especial en la etapa que comprende el gobierno de la primera de las tres gestoras que desarrollen su labor durante la guerra -así pues la Gestora Vidaurreta entre agosto de 1936 y marzo de 1937- aparece nítidamente marcada por la coyuntura bélica, y por ello supeditadas sus funciones a las necesidades excepcionales derivadas del conflicto, el sostenimiento económico de este aparato militar en la ciudad va a provenir en buena parte de la aportación popular, y hasta más allá del final de la guerra.

Así por ejemplo los industriales que contaban con empleados voluntarios ${ }^{4}$ que desarrollaban labores en la ciudad como miembros de las fuerzas paramilitares creadas en ésta a los pocos días de su ocupación, continuarían satisfaciendo a éstos sus haberes como si continuaran trabajando, a través de las derramas especiales establecidas por la Junta Administrativa del Recargo sobre la Contribución Industrial con destino a los obreros y empleados adscritos a las Milicias Voluntarias, y que en el caso de Antequera afectaría a veintisiete empleados.

De la misma forma, los antequeranos movilizados en el Ejército sublevado, como sus familias, serían destinatarios de ayudas económicas en las que sería fundamental la aportación ciudadana. Así, la Orden de Queipo de Llano por la que en diciembre de 1936 instaba a la creación en los municipios ocupados de Andalucía, de comisiones "de hombres solventes y honrados", que se encargaran del suministro de alimentos y ropa de abrigo para aquellas familias que, por tener algún miembro en el frente, sufrieran de situaciones de penuria y escasez, ${ }^{5}$ se vería progresivamente acompañada por una sucesión de recargos y gravámenes y que paulatinamente irían aumentando su porcentaje como el número de servicios y productos a los que afectaba, como la venta de tabaco, los billetes de entrada a espectáculos públicos, consumiciones en cafés, bares y confiterías, servicios extraordinarios en hospedaje y venta de perfumes, venta y licencias de aparato de radio, el producto íntegro de lo recaudado en concepto de Día Sin Postre, el $50 \%$ de la recaudación obtenida del Plato Único, o una parte de las tasas especiales por licencia de caza, expedición de salvoconductos, donativos varios y multas. También las consumiciones en bares y restaurantes, gastos extraordinarios en hoteles y pensiones, entradas a espectáculos públicos, Perfumería y servicios de lujo en peluquerías, ropa lujosa, joyas, obras de arte y antigüedades, juego recreativos, sobre entradas a corridas de toros, espectáculos deportivos o de circo, artículos comestibles que no fueran de primera necesidad así como te, cacao, vinos y licores, servicios de venta de coches, muebles e incluso juguetes cuyo importe superara las veinticinco pesetas. ${ }^{6}$

Esta asfixia económica a la población posibilitará por otro lado que entre febrero de 1937 y diciembre de 1944, la Junta Local Pro Combatientes, la Comisión Local de Subsidio al Combatiente y la Comisión Local de Subsidio al Ex combatiente atendiera seis mil setenta y un subsidios de combatientes y ex combatientes del término, con una inversión que rondará las ochocientas mil pesetas

De forma paralela surgirían otras medidas específicas, destinadas fundamentalmente a requerir a la población civil sobre la necesidad de colaboración con los soldados en el frente como a los que permanecían enfermos y heridos en los hospitales militares, sobre todo en época navideña e invernal. Así se establece en la ciudad el Aguinaldo del Combatiente, cuya suscripción, y en la que incluso participaban los aproximadamente doscientos encarcelados

4 En el caso de los que marcharan al frente forzosamente, es decir, por reemplazo, los patronos no tenían que pagar por ellos, solo respetar su puesto hasta que volvieran de la guerra. Francisco ESPINOSA: Contra el olvido: Historia y memoria de la guerra civil, Barcelona, Crítica, 2006.

5 El Sol de Antequera, 3 de enero de 1937.

6 Respectivamente, Gaceta, 12 de enero de 1937, BOE, 11 de enero de 1937, BOPM, 3 de marzo de 1937, $B O E, 26$ de nero de 1937, BOPM, 8 de febremode $1938, B O E, 5$ de agosto de 1938 e bid 21 de noviembre de 1939 . que en diciembre de 1936 saturaban la Prisión del Partido, se desarrollará en los tres inviernos de la guerra, alcanzado una cifra cercana a las cincuenta y cuatro mil pesetas.

Si importante era la ayuda al combatiente o al ex combatiente, no menos lo era la de aquellos que habían dejado de serlo por heridas irreversibles y que los convertirían en Mutilados de Guerra. En este caso la ayuda procedería entro otras de la respuesta de la Administración local como de determinadas empresas privadas del término, ante las órdenes de la Comisión Inspectora Comarcal del Benemérito Cuerpo de Mutilados y Heridos de Guerra de Antequera, y por las que se establecía la prioridad de éstos en cuanto al acceso a un trabajo.

En total aparecen registrados noventa y seis mutilados de guerra, de los que la gran mayoría obtendrán colocación en la principal empresa antequerana del momento, la Sociedad Azucarera Antequerana, seguida del propio Ayuntamiento.

Por otro lado, las ayudas a las familias de los combatientes cristalizan también en el Decreto $\mathrm{N}^{\circ} 264$ de 1 de mayo de 1937,7 creado con la finalidad de aliviar en alguna medida la precaria situación económica de combatientes, en el frente o convalecientes por causa de guerra, e incluso las viudas y huérfanos de éstos en algunos casos, a través de la condonación del alquiler de aquellos que vivieran en este régimen, así como los gastos de luz y agua que de ella se derivaran. Un pago cuyos fondos van a obtenerse de la aplicación de una derrama especial sobre la contribución urbana. Desde la publicación del Decreto y hasta finales de 1940, se tramitaron y aprobaron ciento sesenta y ocho expedientes, cuyo importe total condonado ascendió a poco más de sesenta y dos mil pesetas.

Al margen también se desarrollarán otras medidas con un carácter excepcional en cuanto vienen a coincidir en la mayoría de los casos con fechas señeras para la celebración de eventos y rememoración de hechos relacionados con el Ejército y las efemérides militares, y que van a desarrollarse desde agosto de 1936 y hasta mucho más allá del final de la guerra -así, y por citar algunas, las relacionadas con la Fiesta de la Raza, los regalos a Varela con motivo de los aniversarios de la ocupación de la ciudad, las suscripciones para la adquisición de un buque de guerra que sustituyera al hundido acorazado "España", las destinadas a los monumentos de Mola y Calvo Sotelo, o de la derribada imagen del Sagrado Corazón de Jesús, o el obsequio a Franco de la "Espada del Caudillo".

Más escasas, aunque también importantes, serán otro tipo de aportaciones en especies, a través de Acción Católica Femenina y Falange, al margen de las aportaciones en plata, destinada al laboratorio farmacéutico del Ejército del Sur, mientras que las donaciones en oro se llevarán a cabo fundamentalmente en los primeros meses tras la ocupación de la ciudad, y hasta enero de 1937, fecha a partir de la cual la aportación será casi exclusivamente económicå:

Para reconstruir el Tesoro Nacional, robado por el Gobierno marxista, es necesario mucho oro. Las alhajas guardadas no sirven para nada, es un valor muerto, y quién las luzca de aquí en adelante, además de ir haciendo una ostentación censurable y provocativa en estos tiempos de austeridad y sacrificio, pregonará su falta de patriotismo y un sentimiento egoísta vituperable. ${ }^{9}$

La respuesta de la población, no exenta de la ya mencionada presión de las autoridades civiles y militares, no se hará esperar, y semanalmente serán entregadas cantidades destinadas a la suscripción en favor del Ejército, en efectivo, en forma de descuentos de días de sueldo po parte de trabajadores, así como de importes condonados por facturas por servicios hechos al

7 BOE, 1 de mayo de 1937.

8 Archivo Histórico Municipal de Antequera. Fondo Municipal. Secretaría.

9 El Sol de Antequera, 31 de enero de 1937. 
Ejército. Una iniciativa que va a conseguir que en poco más de un año, no solo hubiera sido recuperado el préstamo de trescientas mil pesetas obtenido con aval popular en agosto de 1936 sino que incluso se consiguiera un importante superávit, igualmente destinado al Ejército

Junto a estas medidas e iniciativas que vienen a probar la importancia de la contribución económica popular como principal pilar de sostenimiento del Ejército durante la guerra, van a tener lugar otro tipo de aportaciones, destinadas también al sostenimiento del entramado benéfico establecido en la ciudad, como las promovidas a través de la Junta Local de Beneficencia, la Junta de Asistencia Social, el Auxilio de Invierno y el Auxilio Social, ${ }^{\circ}$ los ya mencionados Plato Único y Día sin Postre, la Subcomisión Pro-Auxilio a Poblaciones Liberadas," o las destinadas de forma concreta a los huérfanos de guerra. ${ }^{22}$

Pero la participación y aportación ciudadana al Ejército traspasa lo meramente económico, y cristaliza también en otras labores como la del alojamiento de militares. Tras la ocupación del anejo antequerano de Cartaojal, el 26 de agosto de 1936, y con ello ocupada totalmente la zona Norte del término antequerano, el general Varela establece una guarnición fija para Antequera y sus alrededores, compuesta por tropas de Marinería y de Regulares de Ceuta; unos ochocientos efectivos, a los que se unirán posteriormente cincuenta guardias civiles, una Centuria de Falange -cien hombres- una Sección de ametralladoras, así como sesenta regulares más, llegados en octubre y procedentes de Tetuán.

Una situación que inapelablemente va a generar una notable demanda de espacios e infraestructuras para el albergue de estas fuerzas, máxime por el aumento de una presencia de militares en Antequera, ligada a hechos como la preparatoria para las operaciones para la ocupación de Málaga, o la movilización de tropas con destino a los diferentes frentes de la provincia de Córdoba, y que motiva que a pesar de la reutilización de edificios públicos para el albergue de las tropas, o del empleo de los hoteles de la ciudad para el hospedaje de oficiales y suboficiales, ello resulte insuficiente, ${ }^{13}$ y sea de nuevo la ayuda prestada por la población civil la que resulte decisiva para solventar un serio problema de sobrepoblación en este caso para los oficiales y suboficiales. Y se hará a través de una medida ya establecida en el Antiguo Régimen, el Servicio de Alojamientos, por el cual el Estado obligaba a la población civil al hospedaje de tropas; un aspecto que, al menos en los primeros momentos difería para el caso de Antequera, donde en un principio la ayuda será prestada de forma voluntaria, en un nuevo ejercicio de patriotismo, pero que irá tornándose progresivamente en impositivo, cuando no exista una excesiva buena acogida entre la población antequerana.

El caso es que, mientras los soldados permanecían en los cuarteles habilitados, doscientos sesenta y siete oficiales y suboficiales fueron alojados en Antequera durante la guerra, por doscientas cuarenta y tres familias de las de mayor solvencia económica y reconocimiento social de la ciudad, resaltando el hecho del establecimiento de lo que hemos denominado como una jerarquización en el acogimiento, y por el que dentro de éstas, aquellas familias de mayor raigambre social, acogerán a su vez a los oficiales de mayor rango.

10 Archivo Histórico Municipal de Antequera. Fondo Municipal. Beneficencia.

11 Bando del Alcalde Diego López Priego de 11 de mayo de 1938 y publicado en El Sol de Antequera, 15 de mayo de 1938.

12 Todos los expedientes referentes al censo de huérfanos de la Revolución y de la Guerra correspondientes a Antequera, se conservan en Archivo Histórico Provincial de Málaga. Fondo Gobierno Civil. Legajos $7,8,9,10,11$ y 183 .

13 En este sentido, se impone a pensiones, hoteles y fondas, la obligatoriedad de conceder una bonificación del $25 \%$ del importe de la factura generada por oficiales y subofician conceder una botablecimiento para estos de un "cubierto económico" en restaurantes de capitales de provincia y municipios de más de 15000 habitantes. BOE, 11 de marzo de 1938.

\section{De la paramilitarización a la "caricia de la Retaguardia"}

Pero la participación ciudadana en el proceso de conformación de la nueva realidad antequerana desde agosto de 1936, fue mucho más allá del sostenimiento económico e infraestructural, y se vinculó también, y de manera muy estrecha, a otras acciones en las que la cooperación de la población se produce de una forma involucrativa más física, como en la conformación de las fuerzas paramilitares que de manera omnipresente desarrollen una labor tanto dentro como fuera de la población, en la participación de antequeranos como combatientes en el Ejército Sublevado, o en la asistencia laboral, material y moral, en este caso copada de forma exclusiva por la mujer antequerana.

El apoyo que fuerzas de orden como la Guardia Municipal, Guardia de Asalto, Carabineros, e incluso la más sorprendente de la Guardia Civil, prestaron a la legalidad republicana, va a provocar su profunda reorganización, e incluso su desmantelamiento tras la ocupación de la ciudad, así como la asunción de sus competencias por nuevos cuerpos de carácter cívico y función paramilitar -originarios en la Europa de entreguerras-y parapolicial, cuya esencia va a recordar al originario y antiguo somatén catalán y que, gozando de la absoluta confianza de las nuevas autoridades, cubrieran los servicios y atribuciones desarrolladas por los anteriores, así como otras nuevas condicionadas por la nueva situación de excepcionalidad, de mantenimiento de un Orden Público, como de la necesidad de controla a una población que, no por reprimida, era necesariamente adepta, al margen de la ya mencionada auxiliar de las fuerzas de ocupación sublevadas en sus empresas militares.

En Antequera, y con esta esencia, el 26 de agosto el Alcalde, Santiago Vidaurreta, anunciaba la organización de las Milicias Voluntarias de Antequera:

¡Antequeranos! Rescatada esta ciudad por el glorioso y abnegado Ejército Español de las hordas marxistas... para prevenir la contingencia de que éstos intenten un golpe de mano cuando la columna del general Varela nos deje... deben organizarse milicias de carácter puramente local, como son el Batallón de Voluntarios y las escuadras de Falange Españo-

la, que tendrán a su cargo la defensa del orden en nuestra ciudad... ${ }^{14}$

Cristalizaba así la idea de constituir un grupo de milicias voluntarias con la finalidad de que "Antequera no quede desguarnecida una vez que las fuerzas del Glorioso Ejército Español hayan de marcharse de ella, para continuar con su labor liberadora...", así como que, mientras estas permanecieran en la ciudad, prestasen servicios auxiliares de vigilancia interior y exterior de la población, sobre todo después de que fuera suprimida la Guardia Municipal, al ser considerada "ineficaz así como de actuación revolucionaria y criminal". 15

Así, desde el mismo 13 de agosto comienza a organizarse el Grupo de Voluntarios de Antequera, pionero en la provincia, cuya respuesta entre la población será verdaderamente entusiasta, llegando a integrarlo derechistas, miembros de asociaciones católicas, patronos, señoritos, miembros de clases medias acomodadas, incluso considerados apolíticos, y en definitiva aquellos que aparecían vistos por las autoridades como "personas de orden", pero donde de nuevo se vislumbra la presión procedente de las Autoridades para el sostenimiento físico y económico de estos grupos: "Si usted no es emboscado, ni un canalla marxista con disfraz y aún no está en activo militando, inscríbase enseguida porque si no después tendrá usted que pasar la afrenta de ser llamado sinvergüenza, aprovechado y parásito profesional". ${ }^{16}$

14 Archivo Histórico Municipal de Antequera. Fondo Municipal. Secretaría. Bandos, edictos...

15 Archivo Histórico Municipal de Antequera. Fondo Municipal. Actas Capitulares.

$16 \mathrm{El} \mathrm{Sol} \mathrm{de} \mathrm{Antequera,} 27$ de septiembre de 1936. 
En todo caso una respuesta sin paliativos ${ }^{17}$ de Antequera al llamamiento, y que había posibilitado que en la primera semana de septiembre ya prestaran servicio dos compañías, ins truidas, armadas y equipadas, mientras una tercera se encontraba igualmente preparada en la tercera semana de este mes.

En total, mil doscientos voluntarios llegarán a engrosar las filas del Grupo en los dos primeros de los cuatro Escalones en que se dividía, y de los que el Primero constituirá la Vanguardia, desempeñando la gran mayoría de las funciones de Seguridad, Vigilancia e Investigación, sobre todo en la línea de frente, así como desempeñando una importante labor en la protección de convoyes, mientras que el Segundo y Tercero conformarán las Fuerzas Cívicas donde, actuando generalmente por parejas y desarrollando su actividad en puntos estratégicos de la ciudad, a tenor de la paradigmática situación de Antequera como ciudad de primera línea, de frontera con la zona republicana, hasta febrero de 1937, llevarán a cabo una amalgama de funciones internas centradas en el control de la normalización y reorganización de la ciudad, así como en registros domiciliarios y detención de sospechosos, recuperación e incautación de bienes, control del abastecimiento, así como de representación social.

Por último, el Cuarto Escalón de Cooperadores, con un papel fundamental en tanto recaerá sobre él el sostenimiento económico del Grupo de Voluntarios, como de labor de recaudación entre el resto de la población civil. Todos desarrollarán su actividad hasta su absorción, a partir de noviembre de 1936, por Falange; una Falange que bifurcaría su cometido entre el Frente Primera Línea-y la Retaguardia-Segunda Línea-.

En primer lugar, las funciones desarrolladas por Falange en la Retaguardia, suponen una mescolanza entre las competencias que le habían sido conferidas, pero sobre todo las que ésta se atribuiría a sí misma, por ese carácter de garantía de supervivencia, que suponía la pertenencia a la organización falangista, así como la consideración de la camisa azul, como salvavidas.

Y todo ello, magnificado cuando tras la disolución del Grupo de Voluntarios, quedara como única representante de las milicias locales, añadiendo a las atribuciones ya conocidas, una fundamental de participación en el proceso represivo iniciado en la ciudad tras la ocupación sublevada, exhibiendo su prepotencia y despotismo a través de la ley de las armas y la cultura de la violencia. Y todo ello además con una controvertida relación con el resto de autoridades y fuerzas que conformaban el heterogéneo grupo de apoyos en la construcción y consolidación del Nuevo Régimen.

Por su parte, la Falange Combativa, de Primera Línea, iniciaría su labor a partir de la ocupación de Antequera, en las operaciones desarrolladas con posterioridad en los municipios vecinos, y hasta conformarse, también a partir de noviembre de 1936 en la Bandera de Antequera, con un importante protagonismo en las operaciones para la ocupación de la zona Sur del término antequerano como de la propia capital malagueña, e incluso más allá de ésta, en otros frentes, como el cordobés de Peñarroya, destino principal de los combatientes antequeranos en el Ejército sublevado, unos aproximadamente mil quinientos en total, y de los que un 10\% perderían la vida.

Unos combatientes para los que en el caso de Antequera, y al margen de las ayudas económicas, existirán otras atenciones, producto de otra manifestación de la participación ciudadana, y muy concretamente por parte de la mujer antequerana, como en la asistencia hospitalaria, donde, a través de la Junta de Enfermeras hasta sesenta y cinco mujeres abandonarán el confinamiento del hogar para desarrollar una labor, fundamentalmente como enfermeras voluntarias, limpieza e higiene, como de compañía a los hospitalizados, tanto en el Hospital Municipal de San Juan de Dios, como en el habilitado como Hospital de Sangre, en el Colegio de las Recoletas, a partir de 1937.

17 El papel de la ciudadanía como activo soporte económico y moral del Nuevo Estado en formación aparece reflejado en Antonio BAHAMONDE: Un año con Queipo de Llano: memorias de un nacionalista, Sevilla, Espuela de Plata, 2005.
A ellas se unirán otras dos figuras, la Madrina de Guerra ${ }^{18}$ y la Madrina de Cama, encargadas más de una labor de asistencia moral del soldado, tanto de los antequeranos que permane cían en el frente como integrantes del Ejército sublevado, como de los convalecientes en los hospitales de la ciudad.

En el primero de los casos, la participación de la mujer a través de una figura mucho más ligada a la zona sublevada que a la gubernamental, y que en el caso español ya aparece históricamente ligada a la Guerra de África, consiste en el establecimiento de una correspondencia regular entre mujeres antequeranas con soldados de la ciudad en el frente; una relación epistolar que para el caso antequerano, parece encontrar su impulsora en la propia espontaneidad de los combatientes, y con el inestimable papel como intermediaria de la prensa escrita.

En Antequera, las peticiones de madrinas de guerra colapsarán el diario El Sol de Antequera desde septiembre de 1936, y hasta febrero de 1939, con casi mil cuatrocientas peticiones de madrinazgo, y en las que tengan cabida consejos, oraciones, apoyo, e incluso la oportunidad de entablar una relación amorosa, pero donde chocarán con una respuesta casi nula de la mujer antequerana, y que irá siendo progresivamente sustituida por un nuevo llamamiento generalizado al patriotismo de la población, y no ya solo de esta.

Por su parte, la función de la Madrina de Cama, supone de alguna forma la extrapolación del papel de la Madrina de Guerra, con una función similar de apoyo moral y sufragio económico y de bienes, aunque obviando naturalmente la relación epistolar que se establecía en el primer caso.

Una relación que, si bien se desarrolla por un corto espacio de tiempo, sí que parece contar con una acogida notablemente mayor que la de las madrinas de guerra-noventa y dos mujeres responderán a este llamamiento en los casi dos meses y medio en que se mantenga esta iniciativa- al ser la propia mujer antequerana la que respalde decididamente la iniciativa de la Autoridad, a través de la creación de la conocida como Junta de Damas, formada por viudas y esposas de destacados miembros de la sociedad antequerana encargada de encabezar y coordinar la acción, así como de ampliarla al conjunto de mujeres antequeranas: "No es cuestión de hacer donativos ni regalos, sino de algo más elevado y espiritual, de sentirse como la madre del herido... algo que el Caudillo pide y la Patria nos exige". ${ }^{9}$

Esta Junta de Damas, como la ya mencionada Junta de Enfermeras, se encargará igualmente de la conformación de colectas para la recaudación de dinero y bienes para los soldados, reafirmando el hecho de que "no se gana únicamente la guerra en el frente, sino en retaguardia a la vez, cumpliendo la misión de amor y ternura a que se obliga y da derecho, a un tiempo mismo, su condición de mujer española...", ${ }^{20}$ y por el que todas ellas serían elevadas por Franco al rango de combatientes.

\section{Miedo y adhesión de una población en guerra}

La represión franquista, como un instrumento más del proceso de establecimiento del Nuevo Régimen, generó miedo, ${ }^{21}$ pero también fue resultado de alguna forma de él, convirtiéndose en piedra angular sobre la que iban a establecerse las relaciones entre los agentes de la represión y sus destinatarios, y desde luego una de las bases sobre las que el Franquismo iba a

18 Carmen ORTIZ y Manuel DE RAMÓN: “Las madrinas de guerra en la historia”, en Cuadernos republicanos, 56 (2004), pp. 77-109. De estos mismos autores es la más actualizada y completa obra sobre la figura de la madrina de guerra. Véase Carmen ORTIZ y Manuel DE RAMÓN: Madrina de guerra. Cartas desde el frente, Madrid, La esfera de los libros, 2003.

19 El Sol de Antequera, 6 de marzo de 1938.

20 Ibid., 17 de octubre de 1937.

21 Manuel CHAVES: A sangre y fuego. Héroes, bestias y mártires de España, Santiago de Chile, Ediciones Ercilla, 1937; Bertrand RUSSELL: Por qué no soy cristiano, Barcelona, Edhasa, 2007. 
Efectivamente el reformismo republicano genera el miedo de una oligarquía terrateniente en univilegiada situación forjada y enriquecida un hecho que discurre paralelo al aumento del poder obrero, a través de los sindicatos agrícolas, que aumentan su potencial reivindicativo, y que son generadores en parte de una conflictividad laboral que genera pérdida de riqueza entre esta oligarquía.

La República genera miedo también entre un estamento religioso que igualmente ve peligrar su situación privilegiada, por el desarrollo de medidas que pretenden minimizar el poder de la Iglesia como su control social.

En todo caso, estos colectivos, a los que se une otro de naturaleza fascista, forman parte de una población que va a desarrollar un consenso reaccionario ${ }^{23}$ contra este reformismo republicano, y que alcanzará trágicas dimensiones en el posterior proceso represivo.

Junto a ellos existe otro colectivo sobre el que se despliega un proceso represivo como fórmula de control social a través de la violencia, y que en el caso español genera por un lado el rechazo de una parte de la población sobre la que el Régimen desarrolla sus planes de aniquilamiento, y el apoyo de otra a la que éste va a mostrar la necesidad de llevar a cabo esta represión, y que de alguna forma se convierte en agente de la represión, y por ello partícipe activa de esta.

$Y$ en esta última variante nos detenemos, en la de la población convertida en agente de la represión en potencia, tanto para aquellos que pasan a formar parte de la disciplina falangista, como de los que -junto a Guardia Civil, Falange, Alcaldía o la propia Iglesia-conviertan las acusaciones y delaciones vertidas sobre los acusados de responsabilidad republicana, en cualquiera de sus grados, y sobre todo como parte de los procesos incoados por los tribunales militares en la ciudad, a partir de marzo de 1937 -aunque también en la represión de "día a día", en la materialización de su venganza por el daño físico o económico anteriormente sufrido, o como inmejorable forma de mostrar adhesión al Nuevo Estado, lo que no deja de ser de alguna forma, otra derivación del miedo.

22 Gutmaro GÓMEZ y Jorge MARCO: La obra del miedo. Violencia y sociedad en la España franquista (1936-1952), Barcelona, Península, 2011.

23 Francisco $\mathrm{COBO}$ (coord.): La represión franquista en Andalucía. Balance historiográfico, perspectivas teóricas y análisis de resultados, Sevilla, Centro de Estudios Andaluces, 2012 


\section{LA HERMANDAD PROVINCIAL DE LA DIVISIÓN AZUL DE ALICANTE: UN ANÁLISIS A TRAVÉS DE SU BOLETÍN \\ BLAU DIVISION}

David Veiga Chousa

Universidade de Santiago de Compostela do con estos años están en su nivel de mayor apogeo. En el caso del año 1956 los donativos de la Diputación Provincial de Alicante, Ayuntamiento de la capital y distintas cámaras municipales de la provincia, ascienden a casi a un total de 60.000 pesetas, de un total de 78.000 brepasan las 10.000 pesetas en el presente año. Por lo que como vemos el apoyo instituciona es absolutamente fundamental para la asociación. Para hacernos una idea más cercana de significado de estas cifras, el salario mínimo establecido en el Decreto del 16 de octubre de 1956 y en diversas órdenes ministeriales del mismo mes que afectaban a la industria y a los servicios, quedará fijado en 36 pesetas. ${ }^{6}$

En el apartado correspondiente a los gastos de la Hermandad es donde podemos analizar las actividades y proyectos que realizan, los cuales son bastante heterogéneos. Desde donativos a camaradas de la Hermandad Provincial y a madres y huérfanos de los caídos, al pago de viviendas a madres de los caídos -tanto alquileres como gastos de luz y agua-, diferentes obras sociales como la compra de juguetes a huérfanos de caídos o a hijos de los divisionarios más pobres, o incluso el reparto de cestas de Navidad. Finalmente, existe también otra actividad que sólo se va a contemplar en estos primeros años de bonanza económica y que supera con creces esa idea casi única de 'sociedad de socorro' que a menudo se tiene de estas asociaciones. Uno de los gastos más altos se destina a lo que ellos denominan Prestamos reintegrables a camaradas o lo que es lo mismo, la Hermandad de Alicante se revela como una especie de banco de préstamo para los divisionarios que necesiten un adelanto monetario con unas funciones similares a la de un banco corriente, en las que la Hermandad presta un montante al excombatiente de turno que necesita liquidez para que éste después de un tiempo, haga efectiva su devolución por lo que parece a un interés muy bajo o directamente nulo.

Pero antes de profundizar más en los aspectos económicos y en los proyectos de la asociación, hagamos un breve repaso a la estructura y organización del grupo.

\section{Estructura y organización}

La Junta de Gobierno de la Hermandad sufrirá poca o casi ninguna variación a lo largo de los primeros veinticinco años de vida de la asociación, claro que el núcleo en sí de los miembros activos tampoco es que sea demasiado numeroso, para ser más exactos podríamos decir que los cuarenta o cincuenta afiliados que realmente colaboran de una manera regular en la organización de la asociación, forman en sí el grupo de la Junta de Gobierno, aunque sólo poco más de diez divisionarios tengan un puesto formal. Esto lo podemos ver claramente en la exigua cantidad de veces que se presentan candidaturas alternativas a la dirección de la Hermandad. De todas de veces que se presentan candidaturas alternativas a la dirección de la Hermandad. De toya que siempre tratan de redondearlas, aunque sí se puede saber si la concentración fue mayor o menor de la esperada teniendo en cuenta los comentarios de indignación que casi siempre hará el motor fundamental de esta organización, el divisionario Manuel Salvador Gironés.

Así, los puestos que permanecerán inamovibles a lo largo de estos años tienen nombres fijos: José Gil Alpañés como Presidente de la Hermandad y su mano derecha, principal impulsor de Blau División y segundo al mando, Manuel Salvador Gironés como Secretario de la organización. Otros como Joaquín Miralles Guill, Vicente Más Martínez, Juan Tato, José Antonio Vidal y Gadea o José $M^{a}$ Bueno Ferrer,7 éste último como Vocal para Familiares de los Caídos, cierran la lista de los nombres más relevantes y que más veces aparecen ligados a la Junta de Gobierno. ${ }^{8}$

6 Domingo Antonio MANZANARES MARTINEZ: "Determinación de los salarios de hombres y mujeres en la industria de conservas vegetales, 1939-1975", Universidad de Huelva, $2009 \mathrm{http} / / / \mathrm{rabida}$ uhu.es/dspace/bitstream/handle/10272/2482/b15148889.pdf?sequence =1

7 "Barómetro de la actualidad", Blau División, 65 (enero de 1965).
8 "Junta de Gobierno de la Hermandad de la División Azul de Alicante", Blau División, 234 (enero de 1979).
2 Estatutos de la H.D.A.A., 1956, p. 3.

3 "Nuestro saludo", Blau división, 1 (febrero de 1957)

4 Publicado por primera vez en febrero de 1957.

5 “Tesorería”, Blau División, 1 (febrero de 1957). 
En cuanto a la infraestructura física, ni con el buen momento financiero que atravesaban en ese momento lograrían conseguir un cuartel general propio, un ansiado objetivo de la asociación, siendo su local permanente el facilitado por la Jefatura Provincial del Movimiento. ${ }^{9}$ La Hermandad tendrá un domicilio fijo en la calle Sevilla de la capital alicantina. Las pretensiones de los divisionarios a la hora de elegir una sede propia pudieron jugar en su contra, su idea era la de un local céntrico y amplio para constituir un bar, un salón de lectura y habitaciones para los divisionarios que pasaran temporalmente por Alicante ${ }^{10}$ aunque como vemos, tendrían que conformarse con un local dentro de las instalaciones de la Jefatura."

La Hermandad comenzó entonces a extender su organización territorialmente. De hecho no sólo contaba con el núcleo de la capital, existían varias delegaciones locales en toda la provincia en poblaciones como Alcoy, Elche, ${ }^{12}$ Elda, Ibi o Crevillente. Estas cinco fueron sin duda las más representativas de la provincia y las que definitivamente poseen una actividad considerable, siendo en varias ocasiones los motores de la asociación provincial.

Las delegaciones funcionaban como 'franquicias' de la entidad superior provincial en sus respectivos municipios, realizando incluso reuniones entre ellas sin la presencia del ente provincial. ${ }^{13}$ Algunos de los delegados de los enclaves municipales más fuertes serán Jaime Fuster Cortés en Alcoy, Antonio Gras Maciá en Elche o Vicente Mas Martínez en Crevillente. ${ }^{14}$

Las localidades nombradas eran las que muestran una actividad más pronunciada, pero no podemos olvidar que los veteranos de la asociación estaban desperdigados por toda la provincia teniendo también cierta relevancia en lugares como Petrel o Novelda. ${ }^{15}$ Por encima de esta red provincial los dos núcleos de autoridad de la asociación serán las Asambleas Generales de la Hermandad Provincial y la Junta de Gobierno.

La presencia de las delegaciones dentro de la provincia de Alicante es un buen indicador para conocer su nivel real de incidencia, a este respecto nos encontramos incluso con la existencia de otro boletín, concretamente en la localidad alicantina de lbi llamado Inquietud, de duración efímera. Como señalábamos anteriormente lbi será un punto de bastante actividad de veteranos de la División en la provincia y sin duda una buena muestra de ello es esta publicación que nace en $1965 .{ }^{16}$

No hay duda de que la Hermandad contaba con una buena organización interna, en este sentido su red de delegaciones locales es una buena muestra de una estructura más que aceptable. Al igual que la presencia de Blau División, uno de los pocos boletines informativos por no decir el único, que consiguió una continuidad regular a lo largo de los años sin enfrentarse a su desaparición. Sin embargo, esto no nos puede hacer obviar que estamos hablando de una asociación relativamente escueta en cuanto a miembros se refiere, al menos los que podemos considerar como afiliados verdaderamente activos. Oficialmente la Hermandad de Alicante según los datos que hemos encontrado, cuenta a comienzos de 1973 con unos cuatrocientos miembros, ${ }^{77}$ un número nada desdeñable, aunque solo un $10 \%$ de ellos colabora de manera participativa en la asociación.

Lo cierto es que existe un buen número de divisionarios que se acercan a las Hermandades en los años cincuenta buscando colocaciones laborales o ayudas económicas. Cuando esto

9 Juan MARCO GARCÍA:"Pensando en subsistir", Blau División, 3 (febrero de 1962).

10 "Hogar para la Hermandad", Blau División, 3 (octubre de 1957).

11 "Pensiones", Blau División, 70 (junio 1965)

12 "Delegaciones locales de Alcoy y Elche", Blau División, 12 (marzo de 1959).

13 Manuel SALVADOR GIRONÉS: “Barómetro de la actualidad: 'Reuniones en Elche, Elda y Alcoy”, Blau División, 161 (diciembre de 1972).

14 "Actos del 10 de Febrero", Blau División, 30 (febrero de 1962).

15 "Sobre la Cena de Hermandad", Blau División, 192 (julio de 1975).

16 "Mi saludo a INOUIETUD de Ibi", Blau División, 55 (marzo de 1964).

17 Manuel SALVADOR GIRONÉS, “Asamblea General”, Blau División, 162 (enero de 1973). se va consiguiendo, los motores de la Hermandad siguen siendo el reducido grupo de origen Aunque los afiliados aumenten en algunos períodos de tiempo, éstos no se manifiestan como tal y no es difícil pensar que simplemente se aprovechan de la situación y las oportunidades que la Hermandad puede ofrecerles, pero sin tener el más mínimo interés en la marcha de la misma. Aún con todo como vemos, se puede afirmar con rotundidad que la organización era bastante más que aceptable y la estructura tanto de la célula provincial como la de las restantes delegaciones locales estaba más que consolidada.

En cuanto a Blau División, con el paso del tiempo también llegará a tener sus problemas. A comienzos de los setenta alcanzaba una tirada de más de 600 ejemplares, ${ }^{18}$ por lo que rebasaba con mucho la capacidad divisionaria alicantina, y aunque no tenemos datos concretos para asegurar que esta cifra aumentara a finales de esta década no sería una locura pensarlo, teniendo en cuenta que a comienzos de los ochenta Blau División es casi la única publicación sólida de toda la geografía española para estos veteranos y como tal, excombatientes de todas partes del país comienzan a colaborar en ella y a recibirla.

\section{Financiación y donativos: origen y destino del capital económico de la Hermandad}

Desde la instauración de la asociación hasta el fin del régimen franquista la Hermandad va a contar con bastantes ingresos de las instituciones y administraciones públicas, unos ingresos que casi siempre irán por delante de los ingresos de las cuotas de afiliados. Los años cincuenta y sesenta serán la mejor época económica para el grupo y por consiguiente es la época en la que más actividades financian. Esta 'época dorada' no sólo responde a la nueva concepción del régimen para con los divisionarios, sino a los altos cargos públicos con pasado en la División Azul que existen en la época y en especial, en la provincia alicantina.

Las actividades que la Hermandad Provincial financiaba en este período de bonanza van desde numerosas ayudas a veteranos en precario estado económico, al pago de viviendas y gastos de las mismas a viudas y madres de caídos, e incluso hasta el préstamo directo de distintas cantidades a divisionarios que necesitaban una inyección de liquidez. ${ }^{19}$ Claro que este proyecto de la Hermandad de posicionarse casi como si de un 'banco de crédito divisionario' se tratase, al final traerá más de un disgusto a la tesorería de la asociación tratando de que se les devolviese el dinero prestado. ${ }^{20}$

La Hermandad comenzó también a extender sus actividades en las donaciones, y durante años se repartieron decenas de cestas de Navidad entre los veteranos o familiares de caídos más desfavorecidos, asi como centenares de juguetes entre los huérfanos de los soldados caídos en combate. Incluso durante estos años la Hermandad decide comenzar a otorgar becas de estudio para los hijos de divisionarios afiliados a la asociación, en las cuales se dará preferencia a los huérfanos de los caídos, realizándoles para este objetivo hasta una prueba de aptitud. ${ }^{21}$ Por ejemplo, para el curso 1958-195922 la asociación ofrecerá hasta cinco becas completas a niños de entre ocho y diez años, las cuales cubrirán el año escolar íntegro.

Además, el grupo provincial, organizará varios concursos literarios con premios en metálico tanto para niños como para adultos, ambos dotados con premios en metálico. ${ }^{23}$

Todos estos gastos entre los que también se encuentra la publicación de Blau División, uno de los mayores gastos de la Hermandad, estaban totalmente supeditados a las subvenciones

18 "A nuestro Lectores", Blau División, 137-38 (enero-febrero de 1971).

19 "Tesorería", Blau División, 1 (febrero de 1957).

20 "Morosos", Blau División, 1 (febrero de 1957)

21 "Becas de Estudios", Blau División, 3 (octubre de 1957)

22 "Becas de Estudio", Blau División, 7 (septiembre de 1957)

23 "La Hermandad convoca dos concursos", Blau División, 83 (julio de 1966). 
de la administración. De hecho resulta sencillo trazar una línea comparativa en la que viésemos cómo paralelamente al mismo tiempo que el régimen encara su recta final y la democracia comienza a hacer acto de presencia, los ingresos de la Hermandad caen estrepitosamente. Pero lejos de esos tiempos el régimen era un escenario positivo para su economía, y casi más que ningún otro la provincia de Alicante.

En 1955, fecha en la que arrancó la Hermandad alicantina, todos los altos cargos públicos de la provincia o habían sido divisionarios o estaban totalmente dispuestos a ayudar a la asociación de veteranos con los medios que fuesen necesarios. Como alcalde de la capital nos encontramos a Agatángelo Soler Llora.

Soler Llorca que había sido divisionario, sería alcalde de esta localidad durante casi diez años (1954-1963), coincidiendo con el máximo esplendor de la organización, más tarde sería nombrado Consejero Nacional del Movimiento. Como Presidente de la Diputación de Alicante, Lamberto García Atance sería uno de los mayores patrocinadores en toda la trayectoria de la asociación. ${ }^{24}$ Atance era notario en Madrid, y estaba muy relacionado con el entorno de la ultraderecha hasta el punto de que Blas Piñar fue el testigo en la boda de su hijo.

Como Gobernador Civil de la provincia, nos encontramos a Evaristo Martín Freire, de 1954 a $1958,{ }^{25}$ el que tal vez es el más importante de esta 'tríada' y el que a largo plazo supondría sin duda el mayor beneficio para la Hermandad, aunque no tuviera pasado divisionario. En su breve estancia como gobernador civil alicantino, -en 1958 se le trasladaría al Gobierno Civil de A Coruña hasta 1966-, va a llevar a cabo la gestión diplomática necesaria para asegurar unos ingresos estables para la Hermandad por parte de las instituciones públicas. Martín Freire será él quien inste a los ayuntamientos de la provincia a comenzar con la distribución de donativos hacia la asociación de excombatientes. ${ }^{26}$ Lamentablemente para los divisionarios, la falta de relación de Martín Freire con los poderes empresariales alicantinos e incluso con algunos sectores políticos, acabarán por modificar su destino. ${ }^{27}$

A esta primera tríada de altos cargos 'prodivisionarios' que supondrán el despegue definitivo y los años de mayor apogeo de la agrupación, les sucederán en ocasiones otros nombres que también van a estar ligados a la División Azul, caso del antiguo divisionario Alejo Bonmat Gonzálvez, Presidente de la Diputación de Alicante entre los años 1964 y 1966, ${ }^{28}$ y que será el anfitrión y patrocinador de la IV Asamblea Nacional de la Hermandad, la cuál se celebró en Alicante por segunda vez consecutiva. ${ }^{29}$ Así como también el sucesor del Gobernador Civil Martín Freire, que esta vez sí será divisionario, Miguel Moscardó, y que les brindará su ayuda en la colocación laboral de varios excombatientes sin trabajo como veremos seguidamente.

Otros grandes colaboradores de la Hermandad Provincial que llegaron a ser gobernadores civiles de la provincia de Alicante fueron Felipe Arche Hermosa $3^{30} \mathrm{o}$ el ex divisionario Benito Sáez González, quien poco después de su nombramiento acudió al local de la asociación para

24 "Homenaje de adhesión y despedida al camarada Lamberto García Atance", Blau División, 13 (mayo de 1960).

25 Damián-Alberto GONZÁLEZ MADRID, “Evaristo Martín Freire (1904-1972). Semblanza biográfica de un poncio manchego", en F. ALÍA MIRANDA y P. SÁNCHEZ FERNÁNDEZ (coord.): Piedrabuena y su entorno. Arte, antropologit buena, 2006, pp. 515-543.

26 Manuel SALVADOR GIRONÉS: “En homenaje y memoria de Evaristo Martín Freire”, Blau División, 60 (noviembre de 1972).

27 Damián-Alberto GONZÁLEZ MADRID: “Evaristo Martín Freire (1904-1972)..."

28 Manuel SALVADOR GIRONÉS: "Barómetro de la actualidad", Blau División, 55 (marzo de 1964).

29 Manuel SALVADOR GIRONÉS: "Nuestra Asamblea Nacional de la Hermandad de la División Azul", Blau División, 64 (diciembre de 1964).

30 Manuel SALVADOR GIRONÉS: “Un divisionario alicantino, a Felipe Arche”, Blau División, 81 (mayo saludar a sus antiguos compañeros de armas amistosamente. ${ }^{31}$ Sáez González era abogado y fue nombrado Gobernador Civil de Alicante en agosto de $1973^{32}$

En todo este ambiente de actividades, la Hermandad de Alicante será también una de las organizaciones que acuda en apoyo de la Hermandad de Valencia tras unas inundaciones que sufre la capital valenciana en 1957, en la que los divisionarios alicantinos no sólo se movilizan para donar ropa y enseres que puedan servir de ayuda a los afectados, entre los cuales se señala que hay divisionarios, sino que se compra ropa nueva para enviársela y se les cursan envíos de dinero en efectivo. ${ }^{33}$

Pero esta etapa de bonanza comienza a decrecer antes incluso de que el régimen franquista toque a su fin. Las instituciones van cambiando de cargos y cada vez la Hermandad va teniendo menos apoyo en los donativos y subvenciones públicas. El precedente que sentó Martín Freire como Gobernador Civil, las donaciones de los ayuntamientos de la provincia, parecen mermar con el paso de los años. Ni que decir tiene que la lista de concejales divisionarios que la Hermandad posee por toda la provincia es bastante considerable, como el caso de Francisco Montesinos y Manuel Díaz Lancho, elegidos concejales de Alicante en 1967,34 que relevaban a los cinco divisionarios que había en la cámara municipal desde 1963.35 Pero los cargos van cambiando y algunos ayuntamientos dejan de pagar. La Hermandad regularmente 'recordaba' a los ayuntamientos el pago de sus donaciones, que más que voluntarias, a principios de los setenta parecían ciertamente un poco coaccionadas. El divisionario Salvador Gironés cuenta que desde la Junta de Gobierno se enviaban regularmente cartas pidiendo y recordando las cifras que la cámara municipal de turno debía donar. ${ }^{36}$

Desde luego, para 1975 el capital de la Hermandad ya no es lo que era años atrás y se mantiene absolutamente bajo mínimos, aunque siguen recibiendo donaciones de algún ayuntamiento provincial. Pero a partir de aquí, el Blau División como el gasto más pronunciado de la organización, se encontrará en un limbo casi eterno por la falta de financiación externa.

Actividades de la Hermandad: de los actos conmemorativos a la colocación de los divisionarios

Como ya comentamos anteriormente, existen algunas fechas clave para la Hermandad que implican obligatoriamente un acto a la medida. Primeramente, tres son las grandes fechas conmemorativas relativas directamente a la División Azul: el 10 de febrero en honor a la Batalla de Kransy Bor, el 13 de julio para conmemorar la partida de los voluntarios y el cruce de fronteras, y el 12 de octubre día en el que se celebra el bautizo de fuego de la División.

Estas fechas suelen ser celebradas y recordadas con misas casi siempre en el mismo lugar, la Iglesia de los Padres Franciscanos de Alicante, un centro espiritual que es elegido por la Hermandad debido a que serán los Franciscanos los únicos religiosos que acepten la celebración de estas misas en la 'etapa oscura' de los veteranos es decir, de 1944 a 1952-53,37 por lo que como gesto a éstos siempre se elegirá este mismo lugar.

Sin duda la misa del 10 de febrero y la 'Cena de Hermandad', que suele coincidir con el bautismo de fuego, son las dos fechas principales en la que los divisionarios tienen la oportunidad de reunirse y charlar, puesto que las asambleas generales no tienen una concurrencia dema-

31 "Nuevo Gobernador Civil y Jefe Provincial del Movimiento", Blau División, 171 (octubre de 1973).

32 Francisco MORENO SÁEZ: Partidos, sindicatos y organizaciones ciudadanas en la provincia de Alicante

durante la transición (1974-1982), Alicante, Archivo de la Democracia-Universidad de Alicante, 2008.

33 "Pro-Damnificados de Valencia", Blau División, 4 (noviembre de 1957).

34 "Divisionarios en el Ayuntamiento", Blau División, 89, (enero de 1967)

35 Manuel SALVADOR GIRONÉS: "Barómetro de la actualidad", Blau División, 44, (marzo de 1963)

36 Manuel SALVADOR GIRONÉS: "Barómetro de la actualidad-"Subvenciones de los ayuntamientos",

Blau División, 150 (febrero de 1972).

37 Manuel SALVADOR GIRONÉS: "Barómetro de la actualidad", Blau División, 67 (marzo de 1965). de 1966).

.


siado significativa y se suelen celebrar cada dos años. Aún así el principal festejo para ellos será la cena de octubre, en las que no en pocas ocasiones superarán el centenar de comensales. Hay que tener en cuenta que solían acudir con sus esposas e hijos, algo que sin duda tiene también su relevancia ya que se intenta introducir a sus familiares, concretamente a sus hijos, en la sintonía divisionaria.

Un ejemplo que nos puede dar buena cuenta de esto es lo sucedido en la reunión de 1964, año en el que en la tradicional cena de la Hermandad se decide 'condecorar' a los hijos varones de los divisionarios que fuesen mayores de diez años con la imposición del Emblema de la División Azul. Hasta treinta niños participarán en estas condecoraciones delante de sus progenitores. ${ }^{38}$ El lugar de la reunión en este caso es otro elemento bastante típico en estos actos, el Salón de Actos de la Casa Prisión José Antonio, algo que también nos da buena cuenta de la falangistización de la memoria divisionaria. Como vemos la integración de los familiares en la 'disciplina' divisionaria es algo que está muy presente. Con el tiempo serán muchos de estos hijos los que van a recoger el testigo de sus padres, con el fin de mantener viva su particular memoria sobre la División Azul.

Es bastante común que a estos actos, digamos los de mayor importancia como la misa del 10 de febrero, acudan también todo tipo de autoridades, desde alcaldes, concejales, Presidente de la Diputación, Gobernador Civil, Gobernador militar, altos cargos de la Guardia Civil... para mostrar su respeto a estos hombres, lo que también puede darnos buena cuenta del tamaño y repercusión de estas celebraciones en la ciudad. ${ }^{39}$

Además de estos actos conmemorativos hay que destacar que existe al menos una parte de estos veteranos que, si bien no organizaban una misa explícitamente en su ciudad con el siguiente motivo, sí lo apoyaban. Nos referimos con esto a las ásperas críticas con que el divisionario José Antonio Vidal y Gadea, se refiere a la prohibición por parte del Arzobispado de Madrid a la celebración de una misa-funeral en honor a Hitler y a Mussolini, una crítica que extiende también al Obispo de Murcia, quién ha realizado la misma prohibición..$^{40}$

Vistas ya las actividades conmemorativas que tienen más regularidad en el día a día de la agrupación, entraremos ahora en la actividad que la Hermandad va a llevar a cabo en la colocación laboral de no pocos afiliados en la provincia alicantina. Unas colocaciones que en su inmensa mayoría suelen estar dirigidas hacia instituciones públicas y que no cesarán hasta que exista paro cero entre los excombatientes 'azules'.

En este punto resulta importante señalar el hecho de que en estas colocaciones laborales vamos a encontrar un patrón casi general, en el cual la Hermandad va a hacer de intermediario entre los divisionarios demandantes de empleo y las instituciones, incluso se llega a censurar a aquellos veteranos que por su propia cuenta acudan a pedir trabajo sin pasar antes por los locales de la Hermandad. En los primeros años incluso podríamos decir que una de las funciones más relevantes de ésta es sencillamente, ser una oficina de intermediación laboral privada para todos estos hombres. ${ }^{41} Y$ no solamente vamos a encontrarnos con este circuito de 'ayudas' por parte de las instituciones del régimen, sino que habrá ocasiones en las que los que tiendan la mano serán divisionarios en puestos importantes de empresas privadas o adinerados que ayudan a otros ex compañeros de armas. En este hilo encontramos casos como el de la hija de un divisionario que es aceptada en la academia que dirige Martínez Beresaluce, otro veterano del frente ruso, quién costeará los estudios en su centro de la hija de su compañero. As

38 "Asamblea, Comida de Hermandad e Imposición de Emblemas", Blau División, 58 (junio de 1964) 39 "Actos del 10 de Febrero", Blau División, 103 (marzo de 1968).

40 José Antonio VIDAL Y GADEA: “Rogar a Dios por los vivos y los difuntos", Blau División, 94 (junio de 1967).

41 "Muchas Gracias", Blau División, 4 (noviembre de 1957). como también el caso del 'guripa'42 Barreres, quién pondrá a disposición de la Hermandad una ambulancia para trasladar a un divisionario enfermo de Madrid a Orihuela sin ningún coste. ${ }^{43}$

Ya en el primer número de Blau División se agrega una nota informativa en la que se pide abiertamente trabajo para algunos afiliados que se encuentran en situación de "paro forzoso", 44 sin determinar la cantidad de puestos que persiguen ni el destinatario del aviso, digamos que la petición se hace de un modo generalista. A partir del primer número Blau División va plasmando en los siguientes meses lo que ellos denominan 'ayudas recibidas', en donde dan las gracias a la autoridad competente por la colocación del divisionario de turno y detallan brevemente dos aspectos importantes, qué organismo lo contrata y qué función va a desempeñar.

Con estas variables encontramos muchísima colaboración de los ayuntamientos de la provincia como Elche, Crevillente, Novelda, Alicante... en la contratación de los desempleados divisionarios, que principalmente serán contratados como policías municipales, empleados en la Playa de Postiguet, vigilantes nocturnos, en profesiones relacionadas con la construcción... ${ }^{45}$ aunque también encontramos contratos en hospitales, bancos o incluso en CAMPSA. ${ }^{46}$ Pero también la Diputación de Alicante va a ayudar a dar trabajo a algún que otro excombatiente, e incluso hasta el mismo Esteban Infantes les llega a gestionar la contratación de un divisionario en el Banco de España. ${ }^{47}$ A comienzos de los sesenta se vanagloriarán de haber "colocado" hasta cinco 'guripas' en empresas alemanas, una gestión que agradecen al Jefe de la Oficina de Colocación de la Delegación Provincial de Sindicatos, José Sánchez Díaz, también exdivisionario $4^{8}$

Para hacernos una idea de la rapidez de todas estas gestiones, estas contrataciones que acaban a finales de la década de los cincuenta, solamente en dos años, de 1957 a 1958, una treintena de divisionarios alicantinos son contratados por instituciones públicas bajo la intermediación de la Hermandad, una cifra nada desdeñable. Estas gestiones no acaban aquí, también va a existir mucha disposición por parte de las autoridades en la adquisición de viviendas protegidas para estos excombatientes, caso de la localidad de Crevillente. ${ }^{49}$ Más sonado aún será el caso de las Mil viviendas en donde de 37 peticiones para conseguir una vivienda protegida, hasta 21 divisionarios o viudas de caídos se les adjudicó una de ellas. En este último trámite desde su boletín agradecen públicamente al Gobernador Civil y divisionario Miguel Moscardó la ayuda prestada, asi como al secretario de éste, Carlos Pascual, que también era divisionario ${ }^{50}$

Como podemos observar las redes clientelares que poseen son verdaderamente efectivas, tanto es así que a finales de los sesenta desde la Hermandad Nacional emana un importante aviso para las células provinciales, el cual tiene como objeto comunicarles que no den más trabajo en sus respectivas provincias a ningún 'guripa' que no sea oriundo o residente de la misma, a no ser que lleve consigo una autorización de su Hermandad de origen. La concesión de un trabajo o que se les facilitase una vivienda comienza ser una tónica general que llegaba

42 Es común que entre los divisionarios se llamen entre ellos 'guripas', una especie de calificativos que viene a significar, soldado o compañero de armas.

43 "Ayudas Recibidas", Blau División, 1 (febrero de 1957).

44 "Nota Informativa", Blau División, 1 (febrero de 1957).

45 "Ayudas Recibidas", Blau División, 2 (julio de 1957).

46 "Muchas Gracias", Blau División, 3 (octubre de 1957).

47 "Nuestro agradecimiento", Blau División, 6 (julio de 1958).

48 "Barómetro de la actualidad - 'Emigración para trabajar en el extranjero", Blau División, 34 (julio de 1962)

49 "Ayudas Recibidas", Blau División, 2 (julio de 1957).

50 "Adjudicación de Viviendas", Blau División, 10 (noviembre de 1959). 
a complicarse demasiado. ${ }^{5152}$ Para principios de 1970 la Hermandad asegura tener a todos los divisionarios colocados en algún puesto de trabajo, algo que usan para justificar un poco la disminución de las ayudas, 53 una mentira a medias.

Aún así no siempre están totalmente satisfechos con todas estas ayudas y si tienen la oportunidad, dejan caer alguna crítica pidiendo trabajos mejor remunerados ${ }^{54}$. Claro que son críticas más orientadas al gobierno estatal y lógicamente no a los círculos de poder provinciales en donde como vemos, la línea que separa a los altos cargos públicos y los divisionarios se hace tan estrecha que en ocasiones ni siquiera podemos afirmar que exista.

51 Manuel SALVADOR GIRONÉS: "Barómetro de la actualidad - 'Transeúntes, Blau División, 107 (julio 1968).

52 Martínez Mena, comentará unos años más tarde, que es consciente de que muchos divisionarios "de boquilla" se aprovecharon de esta condición, quedándose en la retaguardia, para luego ascender rapidamente en la escala social, a éstos se les achaca que no comparten con el grupo ningún ideal falangista.

53 "La Hermandad de la División Azul Alicantina durante el año 1969", Blau División, 125-26 (enero-febrero de 1970).

54 “'Por qué...?”, Blau División, 28 (febrero de 1962). 


\section{IMAGEN Y CASTIGO. DOCUMENTOS GRÁFICOS DE NICOLÁS II. LO OUE EL CINE GRABÓ Y EL}

\section{VIENTO NO SE LLEVÓ}

María Eloísa Zamorano Rodríguez

Universidad Autónoma de Madrid
[Sfir SHUB (Padenie dinastii Romanovykh,) URSS, 1927] incluida en una trilogía sobre la historia de Rusia que hizo la realizadora Sfir Shub. Lo que sí podemos decir es que nos movemos en los albores del cine documental y que, en nuestro caso, estamos frente a películas de compilación.

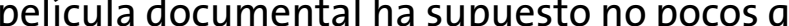
riadores y especialistas en cine. En general, fue más fácil definir las características del cine de ficción que las del documental. El ideario documentalista que intentó ser teórico terminó siendo ambiguo y en la práctica fue más fácil, para los realizadores, no seguir lo establecido y dejar que la improvisación y creatividad definiera su estilo. Las primeras grabaciones de los Lumiere ya contaban con ciertos matices documentales al tratarse de cortometrajes sobre la realidad más inmediata. Sin una intención legitimadora se convirtieron en captadores de una verdad más inmediata. Sin una intención legitimadora se convirtieron en captadores de una verdad y formal de cine lo permitió, se constituyó un grupo de realizadores que se distinguieron por lo que querían grabar y por cómo querían grabarlo. Ya en la primera década del siglo XX empezó a haber diferencias entre los noticiarios, los travelogues, las panorámicas y vistas y los primeros documentales, aunque compartieran propósitos, aspectos artísticos y hasta directores. Lo ros documentales, aunque compartieran propósitos, aspectos artisticos y hasta directores. estéticas y técnicas con el cine de ficción. Éste usa el guión, actores, crea y recrea historias, se vale de los mecanismos de ilusión, utiliza los avances técnicos y mecánicos y los pone sin reparos al servicio de la historia fílmica. Y, en términos generales, las características del cine de ficción definen el tipo de público que acude a las salas a ver las estas películas. También hay un público específico que ve documentales pero que las características de uno y otro no suelen ser compartidas lo determina el hecho de que, por ejemplo, hay un trasvase indiscutible de aficionados al documental que acuden a las salas convencionales a ver películas de ficción, no es igual en sentido inverso. Solemos recordar sin ninguna dificultad el Oscar al mejor filme, al mejor actor, sin duda... otra cosa es recordar (o saber siquiera) que también hay un Oscar para la mejor película documental. Y lo que desde luego no queda más remedio que aclarar es la diferencia que existe entre lo que es el cine documental y lo que hoy, de forma contaminada entendemos por documentales. Termino televisivo que abarca pseudo documentales, falsos documentales y seriales informativos, por muy de exploración que pueden parecer y por mucho que de aquellos deriven parte del concepto de estos. No el soporte, ni el medio, ni el fin, ni la concepción fílmica es igual en ambos formatos, unos se subrogaron la veracidad de lo que graban aunque solo sean compendios de información más o menos desmedida, sea esta sobre la sabana africana o los aborígenes australianos o sobre el sorprendente encadenamiento de ADN o las galaxias remotas. En esa voracidad informativa reside una de las grandes diferencias con el cine documental, una cosa es informar, anunciar, dar noticia de algo, otra: documentar, probar o justificar la verdad con documentos.

La institucionalización del término y del concepto documental, la realizó John Grierson no solo con su análisis del filme Moana (Moana, Robert Flaherty, 1926) al que definió como "a documentary" sino que con la escuela documental británica que creó elaboró unas reglas y normas con las sentó las bases que siguieron muchos otros realizadores. ${ }^{2}$ El mismo Flaherty unos años antes también había contribuido al estilo, al formato o al género documental, si se prefiere, creando una forma de grabar y entender la realidad que generó de un estilo y un modelo que habrían de ser pioneros en la historia cinematográfica. Con su Nanuk, el esquimal, [Robert FALHERTY (Nanook of the Noth, EE.UU, 1922] marcó un hito y convirtiéndose, en cierto sentido, en el padre del documental.

Apenas unos años antes los Lumiere habían estado enviando, por todo el mundo, a un centenar de sus camarógrafos para captar, grabar y después emitir las imágenes grabadas. Con lucionarias. De las primeras no suele haber información del autor, rara vez en los programas se imprimía el nombre del operador. De las segundas destaco La caída de la dinastía Romanov 
ellas querían sorprender al público "creándoles sentimientos sin precedentes al ver el mundo". ${ }^{3}$ A Rusia fueron tanto Feliz Mesgish como Francois Doublier quien junto a Charles Moisson atravesó, en 1898, parte del territorio grabando, sobre todo, donde había población judía. Estas películas marcan el inicio del cine de viajes y de compilación, una especie de subgénero del cine documental o más bien un precedente. 4 Una de las grabaciones más antiguas que se conservan es, precisamente, la realizada durante los actos de coronación de Zar Nicolás II en Mayo 1896, no ha pasado ni un año de la primera exhibición pública cinematográfica en París. En los dos minutos escasos de imágenes que se conservan, a través de estáticos planos generales, podemos distinguir parte del ceremonial de la entronización, desde la salida del palacio, el desfile oficial de miembros de la corte, nobles, militares y eclesiásticos, y, sobre todo, una imagen definitiva y descriptiva del sentido de la monarquía imperial rusa que otorgaba al Zar un rango divino. 5 Un plano largo muestra el majestuoso palio que protege y dignifica al hombre y lo eleva a Zar y Padre de todas Las Rusias, con una estética que recuerda las procesiones religiosas. El Zar tenía potestad en el Sagrado Concilio de la Iglesia Ortodoxa aunando en su persona un poder terrenal y celestial propio del antiguo régimen. Era así desde el ascenso al trono del primer Romanov, Pedro I El Grande que dentro de las grandes reformas políticas que llevó a cabo, sustituyó el antiguo patriarcado de la iglesia ortodoxa por una especie de consejo ministerial, presidido por el Zar. De este modo el poder de intervención religiosa en asuntos imperiales quedó mermado y bajo control del Zar. La indumentaria: corona, capa de armiño, el cetro y el orbe imperial, heredados a lo largo de siglos o elaborados siguiendo la estricta tradición, no solo son joyas de exquisita ejecución, son las insignias imperiales y simbolizan una concepción del poder milenaria. ${ }^{6}$ En los trescientos años de la dinastía Romanov se realizaron hasta siete Álbumes de Coronaciones en los que podemos estudiar los detalles de esta ceremonia y por extensión la idea que la casa imperial tenía de sí misma.7

Paradójicamente, la censura que habría de ejercerse sobre las imágenes del Zar, se aplicó sobre lo que Doublier pudo grabar ese día. Mientras se celebraba el acto oficial hubo un accidente fatal al derrumbarse parte de las tribunas. No solo fallecieron parte de las personas que se precipitaron sino que la avalancha siguiente produjo la estampida y el aplastamiento de unos miles de asistentes. La policía a instancias gubernamentales "cuando recobramos el conocimiento nos arrestó junto con los demás corresponsales y testigos. Confiscaron nuestro equipo y no volvimos a ver nuestra preciosa cámara". ${ }^{8}$ De este modo podemos ver las incongruencias que tiene la historia universal, historia de hombres, al fin, en la que víctimas y verdugos pueden jugar a intercambiar sus papeles. Solo un poco de tiempo y un cambio político pueden llevar al ejecutor al otro lado de la línea. En el caso que analizamos, este intercambio se produjo en apenas 34 años que es lo que duró el reinado de Nicolás II, pasando de ser el sanguinario a morir ejecutado junto a toda su familia y parte de su séquito en la oscuridad de una madrugada y de un sótano. El apodo con que lo definieron sus adversarios e incluso los más críticos en su gobierno le fue puesto por acontecimientos como el arriba citado. El pueblo

3 Erik BARNOUW: El documental..., p. 19.

4 Jean Lup PASSEK: Diccionario de Historia del Cine, Madrid, Larousse, 2001. p. 125

5 Incidiendo en las diferencias entre cine y documentales televisivos, la facilidad de acceso que hoy tenemos a cualquier filme, ha hecho que nuestra forma de ver el cine sea totalmente opuesta al concepto y forma inicial. Sin duda se abren nuevas y enormes posibilidades, pero también se pierden parte de los modos del entendimiento cinematográfico.

6 Paola RAPELLI: Diccionario de Arte. Grandes dinastías y simbolos de poder, Milán, Electa, 2005.

7 La exposición realizada entre febrero y junio de 2013, en el Hillwood museum \& gardens de Washington ha recopilado, con motivo de los 400 años de la dinastía Romanov, los diferentes álbumes que se conservan de las coronaciones de los zares pertenecientes a dicha dinastía. Véase http:// www.hillwoodmuseum.org/, consultado el 15/06/2014.

8 Jay LEYDA: Kino. A history of Russian and Soviet film, Londres, Allen, 1960, pp. 18-19. nunca perdono al Zar que el mismo día que morían miles de súbditos al acudir a su coronación no interrumpiera los actos protocolarios e incluso brindara en la recepción oficial con Cham pagne. Tampoco olvidarían el Domingo Sangriento, verdadero punto de inflexión en el futuro de la dinastía Romanov, cuando más o menos organizados y más o menos manipulados y con el sacerdote Georgí Gapón a la cabeza acudían, eso sí, desarmados y entregados a su Zar, a pedirle que tuviera en cuenta aquellas peticiones lógicas de mínimos cambios necesarios para poder sobreponerse a tanta miseria y pobreza. Decenas de mujeres y ancianos, niños y por supuesto hombres formaban el contingente de la manifestación que fue recibida con tiros a las puertas del Palacio de Invierno, en donde ni siquiera se encontraba el Zar. El choque no fue solo contra la institución imperial, que fracturó la relación de confianza centenaria, sino que la fracción afectó a la milenaria relación entre pueblo y ejército.

Entre los mencionados testigos del acto oficial y luctuoso, también hubo fotógrafos. Las películas de los Lumiere, formaban un catálogo con el que viajaban los camarógrafos que hacían sesiones cinematográficas en los grandes teatros o salas de las ciudades a las que viajaban. 9 Las fotografías se difundían en los periódicos y revistas de la época. Con estas imágenes además de con los grabados y pinturas oficiales, se fue creando un imaginario que, a diferencia de épocas anteriores, contó con una difusión casi mundial. Así como había habido pintores de la corte, las monarquías se acostumbraron a tener fotógrafos y camarógrafos oficiales. De ese modo las diferentes ceremonias públicas a las que el emperador y su familia acudían fueron siendo documentadas. Nacimientos, bodas, onomásticas, misas solemnes, etc., pero la evolución técnica de las propias cámaras permitía no solo a los fotógrafos oficiales, sino al propio Zar acostumbrarse a retratar escenas menos solemnes y de ese modo empezamos a tener constancia de actividades familiares privadas y lúdicas.

Estas fotografías familiares, junto con algunas películas realizadas en vida del Zar, fueron utilizadas según criterios bolcheviques de un modo parcial. Por un lado, mostrar el lado más íntimo y familiar de Nicolás y su esposa la emperatriz Alexia suponía crear vínculos psicológicos de empatía que la revolución no solo no podía permitirse sino que tenía que evitar. La relación del pueblo ruso con sus zares era ancestral y aunque complicada y ambivalente estaba profundamente arraigada en el sentir popular. Nicolás II no era un hombre de estricta personalidad imperial y vivió en un periodo cambiante y convulso para el que no estaba preparado ni personal ni políticamente, él mismo escribió y declaró "no saber nada del arte de gobernar".10 Ni por formación, era militar sobre todo, ni por tiempo ya que accedió al trono mucho antes de lo que se esperaba, a raíz del agravamiento de la enfermedad de su padre Alejandro III, se encontraba Nicolás educado para su futuro destino. Los cambios sociopolíticos habían infligido a la familia duros golpes, varios de sus antecesores fueron asesinados en actos terroristas lo que generó represalias y un endurecimiento de la gestión imperial. No solo su abuelo y también su tío paterno, murieron de forma violenta. Salvando acontecimientos más que desafortunados es incuestionable que la gente vivía de modo muy cercano la vida de sus emperadores, aún hoy, los acontecimientos públicos y privados reales se siguen con especial interés por millones de personas, de tal modo que las fronteras se desdibujan. Esto con los Romanov se hizo evidente cuando apareció en la corte el personaje controvertido de Rasputín. Las intrigas y la influencia nefasta que llegó a ejercer sobre Alexia fueron conocidas, divulgadas y criticadas por todo el pueblo ruso. Algunas caricaturas de la época, muestran imágenes soeces del monje con la

Entre otras, en el catalogo figuraban La guerra de los bóer; La salida de misa de doce del Pilar de Zaragoza; Paseo en Góndola por Venecia o Carreras de caballos en el Derby australiano..

10 El Zar Nicolás que fue instruido por tutores y hermanos de su padre, recibió la educación que el protocolo de un heredero presuponía, en su caso estricta formación militar, varios idiomas, y como la En ellos pueden leerse muchas de sus angustias y temores, confirmando su timidez y devoción. 
emperatriz, dando veracidad a las hipotéticas relaciones que se decía había habido entre ellos. Las fotografías y los hechos demuestran, sin embargo, que se trata de una madre angustiada, acomplejada y llena de dolor por haber trasmitido al ansiado hijo varón la hemofilia.

Alejandra Hesse-Darmstadt era nieta de la Reina Victoria de Inglaterra y como miembro de esta dinastía, portadora de la hemofilia. Había sido testigo de la muerte de su tío y de dos de sus sobrinos y, lo que es peor, de la de su hermano Federico a causa de un accidente fatal que la enfermedad genética le impidió superar. Lo que supuso para ella la enfermedad del Zarévich Alexis puede verse físicamente y hasta rastrearse psicológicamente en las fotografías posteriores a su nacimiento, en las que observamos a una mujer abatida y prematuramente envejecida. La aparición de un personaje cuanto menos curioso y controvertido como el de Rasputín, capaz de conseguir la ansiada mejoría del niño, durante alguna de sus terribles crisis, llenó el hueco que la angustia y la desesperación provocaban en la zarina. Pero también puso al descubierto las intrigas e influencias palaciegas y conyugales y que la personalidad de Nicolás permitía a Alexia dominar algunas situaciones no solo familiares, ya que la vida personal y la política del Zar eran, lógicamente, compartida con su familia.

Por otro lado, desde que se produjo la apertura de los archivos del Kremlin y la democratización de Rusia, muchos documentos han revelado y descubierto facetas de la familia Romanov que fueron ocultados intencionadamente durante el periodo bolchevique, especialmente en los años inmediatos al asesinato de la familia. Los diarios de Zar y las cartas personales entre La Zarina y Nicolás nos muestran una relación amorosa poco usual entre los monarcas de esa época, cuyos matrimonios seguían siendo una cuestión de estado que nada tenían que ver con las emociones. Las fotografías de los últimos meses, especialmente las tomadas semanas antes de su asesinato, muestran una imagen muy diferente de la que podemos ver, por ejem plo, en la película compilatoria de Sfir Shub La caída del imperio Romanov." En la campaña de desprestigio que se llevó a cabo por el gobierno bolchevique, figuran no solo las fotografías de la familia siempre lúdicas, siempre en fiestas sino que se potencia la visión desenfadada e inconsciente de la familia, utilizando, entre otras cosas, las declaraciones de sus empleados más directos para confirmar la mediocridad de sus personalidades..$^{12}$ Además, como veremos, de incidir especialmente, en las actividades militares de Zar. En las últimas semanas, la imagen oficial y protocolaria de la familia fue desapareciendo para dar paso a otras en la que se puede observar el deterioro físico de todos los miembros, muy especialmente el del ya ex-emperador Nicolás, de la Zarina, como hemos dicho, pero también de las propias hijas del Zar, a quienes una enfermedad infecto-contagiosa obligó a cortarles el pelo. La obsesión de permanecer unidos que siempre tuvo la emperatriz, una idea familiar y dependiente propia del pueblo llano y desde luego de una idea monárquica-democrática posterior, es probablemente, muy en contra de lo que ella y el Zar debieron pensar, lo que propició el asesinato de todos sus miembros.

El interesante y parcial relato que escribió Alekxander Kerenski, sobre el asesinato de la familia imperial, nos muestra desde el estamento oficial lo que sucedió los últimos meses de mandato imperial. Kerenski inició su carrera política a la vez que sus estudios de derecho, formándose en grupos revolucionarios de izquierda. Tras pasar por diferentes cargos en la Duma, parlamento ruso que se creó después de la revolución de 1905, su socialismo moderado y su oratoria contenida le hicieron ganarse, merecidamente, la fama de hombre y político con gran capacidad mediadora. Finalmente, tras ser ministro de Justicia y de la guerra, fue llamado a suceder a Lvoff en la jefatura del gobierno, debido a su amplio apoyo popular y a su influencia sobre el Soviet de Petrogrado. Será entonces cuando realice las diferentes gestiones para sacar

11 Para entender las conclusiones a las que llego en mi investigación es necesario visionar el filme: http://www.youtube.com/watch?v=XN99P3WVUjw, consultado el 15/06/2014

12 Alejandro KERENSKI: La verdad sobre la matanza de la familia imperial rusa, Guadalajara, Nos, 1936, p. 21. a la familia del país, cuando se obliga personalmente a protegerlos, salvaguardando su integridad física, fracasando en su empeño, una vez llegados al poder los bolcheviques. Su gran capacidad política e intermediadora no puedo controlar el deterioro social que llevó a los socialistas a conseguir el apoyo casi general de la casi totalidad de la población. Entre las diferentes fuerzas parlamentarias: monárquicos, socialistas, liberales sus posibilidades de continuar gobernando perdieron toda eficacia, y tras el intento de golpe de Estado del general Kornilov, quedó sin autoridad política. Ese es el momento en que los revolucionarios con Lenin a la cabeza convocan el Congreso de los Soviets y se alzan con el poder definitivo. Kerenski no tuvo más remedio que huir del país, dejando a los Romanov definitivamente entregados a la suerte bolchevique. El texto es un canto a la imposibilidad que proclama su inocencia. La comisión que se creó para explicar la matanza de Ekaterimburgo, dirigida por Nikolai Sokolov, en la que se entrevistaron a diferentes personalidades del gobierno provisional, contó con declaraciones de algunas de las doncellas de la emperatriz, de la hija de Eugeni Botkin, médico personal del Zar, asesinado junto a la familia, incluso declaró la hija de Rasputín. Igualmente prestaron declaración prisioneros que habían compartido celda y confidencias con algunos de los carceleros de la familia imperial, especialmente del grupo revolucionario-civil que se encargó inicialmente de su custodia antes de la entrada del grupo ejecutor bajo el mando de Yakov Yurovsky. Asimismo declaró Pierre Gilliard, instructor del heredero y de las duquesas con quienes tenía una profunda y sincera relación hasta tal punto que de forma voluntaria les acompañó en su exilio de Tobolsk. Se le prohibió oficialmente y contra su voluntad, viajar a Ekaterimburgo, es muy probable que fuera su origen suizo lo que le salvó de morir, también, en la casa Ypatía. ${ }^{13}$

Una vez en el poder y dentro de las instituciones que el gobierno soviético creó para la estructuración de la nueva sociedad revolucionaria destacaron aquellas que, sobre todo, tenían en la instrucción del pueblo su cometido principal. Y el cine, aún a medio camino entre arte y mecánica, se convertía en un instrumento fundamental para la propaganda del ideario revolucionario. Pronto se creó un comité cinematográfico que con delegaciones en las principales ciudades de la republica, recabó a un nutrido grupo de artistas que habrían de convertirse en referencia de la cinematografía internacional. Dziga Vertov con su innovadora y futurista visión de la verdad soviética, el cine-ojo que todo lo ve y que graba la vida al improviso. ${ }^{14}$ Eisenstein, personalidad y artista de indiscutible calidad cinematográfica, creador de uno de los filmes propagandísticos más emblemáticos de la historia del cine El acorazado Potemkin [Serguei EISENSTEIN. (Bronenósets Potiomkin) URSS, 1925]. Kuleshov, que comenzó grabando documentales en 1916 y creó la primera escuela de cine, en Moscú, donde terminaría siendo profesor años después. Y, finalmente, Sfir Shub que formó parte de este grupo de artistas de los que Lenin supo sacar provecho a favor de la revolución y de lo que habría de ser, más teóricamente que en la práctica, la novi bit soviética. Una nueva forma de vida en la que se trataba de transformar todos los órdenes, lo público y lo privado y para la que el ímpetu y la creatividad de los jóvenes artistas fue fundamental ya que no solo sus ideas revolucionarias, sino todo su interés y talento se pusieron a disposición de las instituciones leninistas.

La realizadora ucraniana entró a trabajar en la Goskino después de relacionarse con los futuristas soviéticos en la editorial LEF, donde el poeta Mayakovsky, el matrimonio Brick, Osip y Lili, y el fotógrafo Rodchenko, entre otros, desarrollaron sus creaciones artísticas y sobre todo donde sentaban las bases teóricas de los diferentes movimientos artísticos soviéticos: cubo-futurismo, suprematismo, y definitivamente constructivismo y productivismo. Términos con lo que se conocen las distintas corrientes artísticas que de forma desigual tratan de expli-

13 Pierre Gilliard que aparece en fotografías tomadas en Tobolsk, cortando leña con el Zar, no solo permaneció en Siberia después de la muerte de la familia imperial colaborando con la citada comisión sino que es autor de un libro que describe los años que vivió con los Romanov.

14 Dziga VERTOV: Memorias de un cineasta bolchevique, Madrid, Labor, 1974, p. 14 
car y resumir en un estética fuertemente innovadora, que rompe con el pasado representativo y objetivo del arte, que trae la esencia de las formas, los colores, el dinamismo y la mecánica al centro de la actividad artística y hace de la abstracción, lo no figurativo, lo dinámico, el volucomo término integrador que es capaz de llevar esta concepción a una dimensión pública y popular como destino último de todo trabajo social. A veces fue de forma más idealista que real, ya que no siempre el pueblo, último destinatario del arte de ese periodo pudo entender los mensajes artísticos. El trabajo, aparentemente más profano, de la realizadora, era la recopilación de miles de metros de películas extranjeras y nacionales, el montaje de noticiarios y el almacenamiento de imágenes en archivos reutilizables lo que le proporcionó una destreza inusitada en la compilación fílmica. Rigurosa y disciplinada, pionera en el trabajo femenino cinematográfico recibió el encargo de hacer una serie de películas que fueran testimonio de la revolución de octubre y de lo que la dinastía Romanov había supuesto en la situación social que la propició. A diferencia de los documentales innovadores y creativos de Vertov, en los que las teorías del montaje futurista y el compromiso estético y ético del autor, pueden verse y reconocerse, las películas de Shub, son un compendio de imágenes de las que ella, probablemente no grabó ni una sola. El filme La caída del imperio Romanov encadena de forma magistral las imágenes de archivo que la realizadora manejaba, pero deja entrever una idea intencionadamente torticera de los últimos Romanov. La visión de la película nos muestra que el Zar y su familia, son las personas y la institución directamente responsable de la situación del pueblo oprimido, engarzando todo ello en el entorno europeo y mundial de codicia capitalista. Sin embargo el propio análisis documental e histórico-cinematográfico del filme me permite asegurar que la utilización ideológica posterior que sufrió influyó negativamente en el papel que la propia realizadora habría de ocupar dentro de la historiografía cinematográfica soviética y mundial que en la pretendida criminalización del periodo histórico-político que reseña el documental. Algo que curiosa y paradójicamente (una vez más) se asemeja al olvido y castigo al que fue sometida Leni Riefensthal cuyas obras cinematográficas son de excelente factura, sorprendente perspicacia e innegable cualidad artística. Su condición de mujer, de mujer adscrita al régimen nazi, condenó su brillante carrera, como Sfir Shub fue intencionadamente olvidada durante el periodo estalinista.

La reducción de la imagen del Zar a intervenciones condicionadas por intertítulos, a imágenes que suceden otras imágenes introductorias y definitorias y, sobre todo, la imagen unificada y permanente del hombre y emperador como militar, rebajan su personalidad histórica a la faceta, sin duda, más nefasta de Nicolás II. La vida militar del Zar es su vida pública, social, cortesana y, sobre es su vida política, ya que el gobierno estaba tradicionalmente compuesto por militares de origen nobiliario. ${ }^{15}$ Una de las imposiciones que más costó asumir al Zar y a su corte fue la intromisión en el gobierno de miembros no militares, de civiles. Tener que dar la mano, oficialmente, a médicos, abogados, etc., fue algo que incomodaba por igual al Zar y su esposa. ${ }^{16}$

La guerra contra Japón, cuya declaración, en Febrero de 1904, también está testimoniada en imágenes y cuyo edicto se inserta en el filme, sumió al pueblo ruso en una contienda de la que salieron muy mal parados y en muy pocos años de hecho, sin haber conseguido recuperarse ni

15 En la película de Shub, la primera aparición del Zar, en un plano general de una recepción, es con uniforme militar recibiendo una representación oficial en la que recibe un presente mientras es reverenciado compulsivamente. En los intertítulos, de enorme eficacia inductiva podemos ver cómo se explica que el zar aparece entre su camarilla de nobles militares.

16 Alejandro KERENSKI: Memorias, Barcelona, Luis de Caralt, 1967, pp. 353-355. Podemos ver la rigidez del protoco imperial y nueva visión que los revolucionarios. $353-355$. Podenos ver la rigidez del protocolo imperial y la nueva visión que los revolucionarios, en ese momento, un grupo que incluye distintas posiciones politicas querian imponer al discurso gubernamital. Habla también mano, siendo "tan solo" un abogado de reconocido prestigio. económica, ni militar ni estratégicamente, se vieron inmersos en otra guerra de dimensiones y características peores: La Gran Guerra, calificativo sorprendente y esclarecedor de cómo se ha vivido e interiorizado durante años, en la historiografía, la primera guerra mundial. $Y$ todo ello para finalmente caer en una guerra civil que terminó de devastar lo poco que quedaba en pie, no solo oficialmente sino a ras de suelo, entre el pueblo, entre la gente de a pie, a quién el gobierno había llevado al desánimo sesgando "el lazo espiritual existente entre el Zar y su pueblo"."7

La Rusia zarista ya estaba inmersa en revueltas y diferentes manifestaciones revolucionarias que habían minado, como hemos dicho, la popularidad del imperio considerablemente. Y que no solo fue la desastrosa intervención del domingo sangriento o la, también violenta, represión en la cuenca minera de Lena, sino que hubo que salir al paso de las acusaciones contra la Zarina cuya situación había quedado en entredicho a raíz de la presencia de Rasputín en la corte, que también era acusado de ser espía alemán. Alexia, por su parte siempre se identificó con su procedencia inglesa, ese era el idioma en sus cartas oficiales y en su círculo familiar más que el alemán, país en donde nació, o el ruso su país de destino. Ni llegó a integrarse en la familia Romanov ni en la corte en general, ni entre el pueblo, donde se la consideró, siempre, una intrusa, de tal modo que la extraña relación con el extraño personaje de Rasputín fue una excusa más para agrandar la distancia de la Zarina y por extensión de toda la familia de pueblo. Y es el pueblo, eso sí, quien puede marcar sus predilecciones históricas y hacer ostentación popular de ello, de ese modo hasta muy al final de su reinado, la aparición de Nicolás II en cualquier actividad pública y popular (re)generaba la cercanía milenaria de sus súbditos. Como la paradoja histórica sigue demostrando, la victima del filme, victima real la noche del 17 de Julio de 1918, Nicolás Romanov durante los últimos meses de su mandato, sumiso una vez más a los consejos de gobierno, decidió llevar a cabo una limpieza de su imagen y con intención claramente manipuladora y ciertamente propagandística se decidió a visita el frente, a donde se enviaron pertinentemente los fotógrafos y también por primera vez un cámara oficial para grabar las diferentes actividades del emperador. El Zar detentaba el alto mando militar y con el encadenado de imágenes no solo de Nicolás sino del Zarévich pasando revista, saludando a los altos mandos, se reduce la responsabilidad del gobierno, errónea y desacertada, que se fija a su figura. De un lado se utilizan las imágenes de ambos para limpiar y fijar la cercanía con el pueblo que lucha por y para la causa imperial y en 1927, año del estreno del filme, esas mismas imágenes se manipulan y se cambia el significado de tal modo que la responsabilidad de todos los males militares de la nación es del Zar. Esta misma intención reflejada en imágenes reiteradas del Zar, sobre cualquier otro miembro de la familia, permitió que durante el gobierno de Stalin, no solo hubiera un interés oficial en borrar toda visión posible de la vieja dinastía, sino que el olvido cayó sobre los filmes de Shub y de todos un elenco de realizadores de gran talento que tardaron décadas en ser recuperados para bien de la historiografía contemporánea. Es esa danza macabra que bailan víctimas y verdugos en donde el paso dominante puede y es, muchas veces, alternante.

\section{Conclusiones}

El valor documental de fotografías y filmes nos permite utilizar estos documentos en soportes mecánicos, como fuente para la investigación histórica de este momento tan extraordinario de la historia contemporánea. Por un lado la imagen de la familia imperial, mientras aún estaban con vida fue utilizada para su difusión y acercamiento al pueblo que dominaban. Por otro, esas mismas imágenes fueron utilizadas con intenciones contrarias. Alejar y justificar el asesinato de los Romanov.

17 Alejandro KERENSKI:Memorias..., p. 66. 
Para terminar, una vez llegados al poder los revolucionarios, el cine pasó a ser un medio de propaganda y divulgación del ideario bolchevique y la censura de determinadas imágenes contribuyó a dejar en el lado oscuro de la propia revolución el incompresible hecho de partida de un gobierno legitimado. Gobierno que sin embargo permitió la injusta ejecución del Zar Nicolás II, 50 años; de la Zarina Alexandra Fiodorovna Románova, 46 años; De Olga Nikoláyevna, Gran Duquesa de Rusia, de 22 años; De Tatiana Nikoláyevna, Gran Duquesa de Rusia de 21 años; de María Nikoláyevna, Gran Duquesa de Rusia, de 19 años; de Anastasia Nikoláyevna, Gran duquesa, de 17 años. Del zarévich y heredero, Alexei Nikoláyevich de 13 años. Junto a ellos, fueron ejecutados además: el médico de la familia, Eugeni Botkin, de 52 años, Anna Demídova, doncella o dama de la zarina, de 39 años. El cocinero Iván Jaritonov y el ayudante de cámara Aleksandr Trupp. Entre los restos que encontraron los investigadores, que citábamos al comienzo de esta comunicación, también estaban los huesos de un perro.... 
Parte 5.

HISTORIA MILITAR 


\section{ALGUNA NOVEDAD EN EL FRENTE:}

\section{LA HISTORIA MILITAR HOY}

Hernán Rodríguez Velasco

La Historia Militar ha sido tradicionalmente entendida como un "cajón de sastre" donde cabían las historias de batallas y hechos de armas contenidos en una guerra. También servía de receptáculo de biografías de grandes personajes y valerosos militares curtidos en mil encuentros bélicos; y de las armas y maniobras que habían utilizado aquéllos para doblegar a su enemigo. Sin embargo, durante las últimas décadas se ha conocido una sustancial renovación de los contenidos y de las formas de hacer este tipo de historia. Es cierto que quizá no son nuevas para el público anglosajón, para quien ya desde los años cincuenta comenzó a entender este tipo de historia de una forma diferente, en opinión de Peter Paret.' Según este autor, hace distinción entre una nueva y una vieja historia militar no tiene mucho sentido, pero sí que la renovación puede entenderse como una apertura interdisciplinar hacia la historia social, a la economía o a la cultura.

En general, como apunta Félix Gil, la historia militar debería ser una "ciencia multidisciplinar que no solo aglutine el estudio de hechos bélicos, sino que profundice y combine otras disciplinas que tienen una estrecha vinculación con la historia militar, como por ejemplo la psicología, la arquitectura y el arte, la economía, la geopolítica o la arqueología".

Está claro que, especialmente, un acercamiento social y cultural al fenómeno bélico enriquece el debate $y$, de hecho, plantea nuevas preguntas e interrogantes que desafían la mera narración de hechos de armas. La descripción y vivencias de individuos y su relación con la violencia, de alguna manera reinterpreta visiones clásicas que mejoran con ese toque social. ${ }^{3}$

En España, este tipo de historia, donde se prioriza un estudio de las experiencias y las motivaciones de los individuos en guerra, se ha dado sólo en las últimas décadas. Hasta ese momento, la Historia Militar parecía haber estado vinculada al carácter militar de la dictadura franquista, y de ahí su rechazo por los historiadores civiles, entre otros factores. ${ }^{4}$ De manera que, como ya comentó hace años Pablo González-Pola de la Granja, "estamos incorporándonos a las nuevas tendencias con cierto retraso".

1 Peter PARET: “The New Military History”, Parameters. The US Army War College Quarterly, Autumn (1991), pp. 10-18

2 Félix GIL FEITO: "Historia militar y universidad", Revista Universitaria de Historia Militar-On line, 1 (2012), http://www.revista-historiamilitar.org/, p. 6

3 Mark MOYAR: "The Current State of Military History", The Historical Journal, 50 (2007), pp. 225-240 y Jeremy BLACK: Rethinking Military History, New York, Routledge, 2004.

Hernán RODRÍGUEZ VELASCO: “La Historia Militar y la Guerra Civil Española: una aproximación crítica a sus fuentes", Studia Historica. Historia Contemporánea, 24 (2006), p. 60

5 Pablo GÓNZALEZ-POLA DE LA GRANJA: "Perspectivas actuales de investigación sobre la historia tar, Sevilla, 6-10 mayo de 1996, Cátedra "General Castaños", Madrid, Deimos, p. 548.
De la preocupación por conocer si ya nos habíamos incorporado definitivamente y si esta nueva historia militar había calado verdaderamente en nuestro país, y había permeado las no siempre porosas instancias académicas, surgió la idea de proponer a la dirección del congreso la creación de una mesa dedicada a este tipo de historia. La intención no sólo era conocer lo que se estaba haciendo en las universidades españolas sobre Historia Militar, sino entablar con sus creadores un debate sobre el estado actual de dicha materia.

Una vez determinadas las bases del congreso, mi miedo era que muy pocos o casi nadie acudiera a la llamada. ¿Ouién iba a molestarse en escribir sobre batallas, generales y tácticas? ¿A quién le interesaría un mundo reservado a un cuerpo muy cerrado o a freaks de la militaria?

Sorprendentemente, desde que se hizo el llamamiento para recibir propuestas de ponencias el goteo de resúmenes fue creciendo de manera sustancial, hasta alcanzar un número de catorce. Tras dar el visto bueno, los meses siguientes se fueron cribando los distintos proyectos y, en el camino, se quedaron interesantísimas ideas que abarcaban desde biografías, estudios sobre el desembarco de Alhucemas, la doctrina militar, la guerra de 1898 hasta acercamientos arqueológicos de la Guerra Civil o nuevas historias de la Primera Guerra Mundial. Por diversos motivos, sólo acabaron concretándose ocho ponencias, de las que, finalmente, seis verán la luz en estas actas.

Entre ellas está el trabajo de Julián Paniagua, El contrabando de armas durante la guerra de Riff, 1921-1927, que ofrece un novedoso acercamiento a uno de los más desconocidos aspectos de esta guerra colonial. Julián rebuscó en archivos un material olvidado que ahora sale a luz y que descubre interesantes secretos sobre los siempre oscuros manejos que hay detrás de cada conflicto. Destaca la figura de un inglés, Charles Alfred Percy Gardiner, que demuestra la importancia de los sujetos individuales en el desarrollo de las acciones colectivas.

Otro trabajo es el de Víctor Sánchez, que nos transporta al siglo XIX para explicarnos en su De rebeldes derrotados y revoluciones triunfantes. La sublevación del Ejército Expedicionario en 1820: del fracaso militar al éxito político, las peripecias del famoso golpe del coronel Riego. En este caso, un conocido evento de nuestra historia es analizado de manera pormenorizada a la luz de documentación primaria y una visión panorámica e interrelacionada de la historia militar y la historia política.

Alejando Muñoz debuta en el mundo académico con este trabajo sobre La Segunda guerra Sino-Japonesa. El conflicto olvidado 1937-1945. Aunque basado en bibliografía secundaria, tiene el mérito de rescatar un aspecto no muy conocido de la Segunda Guerra Mundial y abre la puerta futuras investigaciones en campos alejados de nuestra geografía.

Sergio Cañas es otro de los que mira hacia el siglo XIX para traernos las impresiones de los Militares españoles en la Unificación de Italia: los diarios de operaciones como fuentes historiográficas. El interés de esta ponencia es doble, ya que, por un lado, nos enfrenta a la disyuntiva de cribar unas fuentes primarias muy particulares, al tiempo que nos conduce a un momento histórico desvinculado aparentemente de nuestra historia, para demostrarnos cómo los conflictos internos de carlistas y liberales trascienden nuestras fronteras.

Artitz Ipiña descubre con su ponencia, De la institución al frente. Participación del funcionariado municipal y provincial vizcaíno en el esfuerzo bélico republicano: 1936-1937, otro aspecto desconocido de la Guerra Civil de 1936-1939, lo que viene a confirmar que aún quedan temas ignorados de aquella contienda. El acercamiento de Aritz a un foco local y con una mirada hacia sujetos desconocidos demuestra una tendencia con una doble vertiente: el análisis "social" de la guerra mezclado con la visión política.

Por último, Germán Ruiz apunta en esa misma dirección con La Milicia alavesa de Acción Popular durante la Guerra Civil Española (1936-1939). Las características de un grupo muy concreto en un conflicto tan popular habían pasado desapercibidas por la historiografía hasta que han sido rescatadas en esta ponencia. Su mérito no es sólo el descubrimiento de un nuevo tema sino su tratamiento muy permeado de historia social. 
En el debate que se abrió a continuación de las ponencias, se pusieron en común una serie de opiniones que trataban no sólo de comentar lo específico de cada una de ellas, sino de buscar también un consenso sobre el estado actual de la Historia Militar en las universidades españolas y las posibles coincidencias de enfoque de los temas expuestos, a pesar de la aparentemente desconexión temporal y temática de cada una.

Por un lado, es llamativo que la mayoría de las ponencias respondan a esta nueva visión de la Historia Militar que vindicábamos al comienzo. La visión social, "desde abajo", que pone el foco sobre el sujeto particular y que relaciona el devenir de los acontecimientos con los vaivenes de los personajes o de un conjunto de ellos, ayuda a trascender la rígida visión "desde arriba" en la que sólo los líderes parecían hacer historia. Las historias de múltiples y pequeños soldados o civiles que se involucran, voluntaria o involuntariamente, en una guerra, es parte de una nueva y diferente manera de entender la Historia Militar. También creo que este enfoque ayuda a transmitir una visión más "sucia" y realista de lo que fue cada conflicto. Las grandes heroicidades quedan supeditadas a la proeza de sobrevivir. Además, la narración de estos hechos, tal vez ayude a acercar al gran público este tipo de historia, por parecer más cercana y humana. ${ }^{6}$

Otro de los consensos del debate fue sobre la importancia de la Historia Militar como una parte fundamental de la Historia en general. En un país donde se han luchado tantas guerras y han muerto tantos hombres, resulta indispensable este tipo de historia. Ahora bien, ¿dónde buscar y encontrar la materia prima para fundamentar los hechos? Sobre el tema de las fuentes, coincidimos en que el estado actual de los archivos militares ha mejorado sustancialmente en los últimos años y que son raras las restricciones y muy comunes la ayuda desinteresada de los funcionarios (militares).

Teniendo en cuenta que todos los presentes éramos civiles, jóvenes y, por lo tanto, no habíamos realizado el servicio militar obligatorio (salvo Julián), nos preguntamos hasta qué punto pesaba o condicionaba el no conocer el estamento sobre el que hablábamos desde dentro. Obviamente, la respuesta es que cualquiera puede hacerlo. ¿Acaso hace falta ser diplomático para hablar de relaciones internacionales o mujer para hacer historia de género?

Precisamente, se abrió un curioso debate en la sala al comprobar que ya no sólo el 100\% de los ponentes eran hombres sino que entre todos los asistentes a la mesa, sólo había una mujer. ¿Es la historia militar una cosa de hombres? Evidentemente, no. De hecho, unas de las propuestas y ponencias que finalmente no han podido publicarse fue la de una mujer, Chiara Maria Pulvirenti. Pero encontramos más féminas relacionadas con la literatura bélica, sólo aquí en España podemos mencionar a Cristina Borreguero, María Dolores Herrero Fernández Quesada o Josefina Martínez Álvarez.

La conclusión final de todo este cruce de puntos de vista fue que la Historia Militar en España goza de buena salud y, sobre todo, que su desarrollo se ha normalizado en las últimas décadas gracias a una nueva visión más social pero también enriquecida por un relevo generacional. Del mismo modo, también los centros docentes están dando cabida a asignaturas o medios que fomentan el estudio de este tipo de historia, como por ejemplo, el Instituto Universitario General Gutiérrez Mellado, que fue pionero en aproximar la milicia y temas de seguridad al ámbito civil, o la Revista Universitaria de Historia Militar On-line, editada desde 2012.

De aún más reciente creación es la Asociación Española de Historia Militar (ASEHISMI), fundada en octubre de 2013, cuyos fines son, entre otros, promover y difundir investigaciones sobre este tipo de historia, o crear un espacio multidisciplinar para investigadores de diferentes áreas interesados en el desarrollo histórico de la milicia y la historia bélica.

6 El ejemplo más reciente de este tipo de historia es la obra de James MATTHEWS. Soldados a la fuerza Reclutamiento obligatorio durante la Guerra Civil, 1936-1939. Madrid, Alianza, 2013. Por cierto quiero agrecr a Matthews su presencia en Valencia, donde aportó interesantísimas sugerrencias y comentarios.
Esperamos que estas ponencias que aquí se presentan sirvan no sólo de reflejo de esta ilusionante situación actual sino también de estímulo para nuevas aportaciones y consideraciones en el ámbito de la Historia Militar. 
DE LA INSTITUCIÓN AL FRENTE.

\section{PARTICIPACIÓN DEL FUNCIONARIADO MUNICIPAL \\ Y PROVINCIAL VÍZCAINO EN EL ESFUERZO BÉLICO \\ REPUBLICANO: 1936-1937.}

Aritz Ipiña Bidaurrazaga

UPV/EHU

\section{Introducción}

El papel desempeñado por el funcionariado municipal y provincial vizcaíno en el esfuerzo bélico del bando republicano y su relevancia en el Gobierno Provisional de Euzkadi no ha sido estudiado ni analizado por la historiografía vasca, por lo que en este campo carecemos de estudios rigurosos y metodológicos que nos permitan siquiera acercarnos brevemente a conocer cuál fue y cómo fue dicha participación.

El objetivo de esta comunicación no es únicamente el de analizar brevemente cual y como fue la participación de varios cuerpos municipales y provinciales durante la Guerra Civil en el frente vizcaíno, sino que también analizaré la participación de dichos funcionarios y los cargos que ocuparon en el Gobierno Provisional de Euzkadi, creado el 7 de octubre de 1936.

Esta comunicación se enmarca en la tesis doctoral que estoy realizando sobre la depuración administrativa y represión física que sufrieron dichos funcionarios y personal laboral tras la victoria del Ejército Nacional comandado por el General Franco, tras la caída de Bizkaia en su poder. Para comprender mejor las sanciones administrativas y las condenas militares que les fueron impuestas es necesario analizar cuál fue su participación en la guerra.

Esta participación constituye uno de los motivos por los que fueron castigados posteriormente. Incurriríamos en un gran error si relacionásemos únicamente el papel desempeñado durante la guerra con las razones que motivaron sus destituciones laborales, ya que muchos de los sancionados no tuvieron una participación destacada, sino que se limitaron a seguir en sus puestos desempeñando su trabajo. Los juicios sumarios a los que fueron sometidos y por los que fueron condenados a penas de muerte o a años de privación de libertad, en cambio, sí están más relacionados con dicha actuación durante la guerra.

\section{Características del funcionariado en Bizkaia}

Al inicio de la Guerra Civil de 1936 el número de funcionarios en Bizkaia sobrepasaba los 5.500 efectivos y estaban repartidos en cuatro grandes grupos.

El primero de ellos era el dependiente del Estado español y estaba compuesto entre otros por Guardias Civiles, el Cuerpo de Asalto, el Cuerpo de Investigación y Vigilancia, el personal de Correos, maestros nacionales... A pesar de depender del Estado no era el grupo más numeroso de funcionarios en Bizkaia, ya que suponían alrededor del $20 \%$ del total.

El segundo grupo lo componía el personal dependiente de la Diputación Provincial de Vizcaya, que contaba con unos 1.150 trabajadores en activo al inicio de la Guerra Civil. La Diputación, gracias al Concierto Económico', disponía de un sistema de financiación propio con el consi-

1 Eduardo J. ALONSO OLEA: EI Concierto Económico (1878-1937). Orígenes y Formación de un Derecho Histórico, Oñati, IVAP, 1995. guiente riesgo que ello conllevaba, en virtud del cual se establecían y regulaban las relaciones tributarias entre la Diputación y el Estado español. La Diputación Provincial de Vizcaya disponía de un amplio staff técnico de Hacienda, de ingenieros de caminos, y peritos agrónomos, pero Vizcaya, además de los maestros y maestras de Barriada y el Cuerpo de Arbitrios Provinciales.

El grupo más numeroso de funcionarios era el dependiente de los municipios vizcaínos y al frente de ellos se encontraba el Ayuntamiento de Bilbao, con más de 1.600 funcionarios y alrededor de 600 trabajadores temporales. Las plantillas municipales estaban compuestas, entre otros, por miembros de las guardias municipales, celadores de arbitrios, personal técnico del ayuntamiento, maestros, limpiadoras y médicos municipales. Estos últimos desempeña-
ron una amplia labor durante la guerra y la práctica mayoría de todos ellos fueron juzgados sumariamente por dicha labor.

El último grupo estaba compuesto por lo que podríamos llamar personal mixto. Este personal estaba pagado por varias instituciones, por lo que es muy difícil identificar a que institución pertenecían realmente. Dentro de este grupo podemos agrupar al personal que trabajaba en los museos de Bilbao, el personal de limpieza $u$ ordenanzas de los institutos de $2^{\mathrm{a}}$ enseñanza, los manicomios, el Sanatorio de Górliz e incluso en el Depósito Franco.

Una de las características principales de los trabajadores era su edad, ya que la amplísima mayoría de ellos sobrepasaba los 30 años, por lo que no se encontraban en lo que podríamos denominar una edad óptima para el combate. Los datos recogidos y analizados a través de sus expedientes de depuración, juicios sumarios y plantillas de funcionarios de cada institución nos demuestran que los grupos de mayor edad eran los de 41 a 50 años, con 1.210 trabajadores, y los de 31 a 40 años, con 944 .

\begin{tabular}{|l|c|}
\hline $15-20$ años & 14 \\
\hline $21-30$ años & 390 \\
\hline $31-40$ años & 944 \\
\hline $41-50$ años & 1.210 \\
\hline $51-60$ años & 699 \\
\hline $61-70$ años & 212 \\
\hline $71-80$ años & 27 \\
\hline Total & 3.493 \\
\hline
\end{tabular}

Cuad. 01 Edad de los trabajadores municipales y provinciales de Bizkaia a fecha 19 de junio de $1937^{2}$ día de la conquista de Bilbao por parte del ejército sublevado. (Fuente: Elaboración propia a través de expedientes de depuración, juicios sumarios y plantillas de funcionarios.)

A pesar de que muchos de ellos sobrepasaban la edad de movilización impuesta por el Gobierno Vasco para acudir a la primera línea, no impidió que se alistasen voluntariamente para combatir o que fueran requeridos para ocupar cargos de responsabilidad en el frente o en el Gobierno Vasco, por lo que la participación durante la Guerra Civil no puede analizarse únicamente contabilizando el número de movilizados ni voluntarios, sino que debe abarcar un amplio espectro de casos, que en esta comunicación por motivos de espacio me es imposible detallar

La segunda característica es la antigüedad en sus puestos de trabajo y la vinculación con la institución. La mayoría llevaba más de 6 años desempeñando sus cargos, por lo que fueron nombrados antes de la constitución de la República. En 1931 se producen por lo menos 250 nuevas incorporaciones laborales, por lo que debemos analizar este dato con cautela, ya que

2 Estos datos no los podemos dar por definitivos, ya que no se dispone de información sobre el $25 \%$ de ellos, pero aun asi podemos utilizarlas para dar una aproximación bastante exacta.

ti, IVAP, 1995. 
en ningún otro año se producen tantos nuevos nombramientos. Esto puede deberse a la iniciativa de los nuevos gestores republicanos de intentar introducir personal afín en las nuevas instituciones, pero también coincide con el aumento de la demanda de mayores y mejores servicios municipales y provinciales que venía dándose desde años atrás. Estos datos reafirman el anterior, personal mayor de 30 con más de 6 años de vinculación laboral.

\begin{tabular}{|l|c|}
\hline $1-6$ años & 958 \\
\hline $7-10$ años & 494 \\
\hline $11-20$ años & 1.522 \\
\hline $21-30$ años & 496 \\
\hline $31-52$ años & 179 \\
\hline Total & 3.649 \\
\hline
\end{tabular}

Cuad. 02 Años de vinculación laboral de los trabajadores municipales y provinciales de Bizkaia a fecha 19 de junio de $1937^{3}$, día de la conquista de Bilbao por parte del ejército sublevado. (Fuente: Elaboración propia a través de expedientes de depuración, juicios sumarios y plantillas de funcionarios.)

\section{Personal técnico al servicio de la Junta de Defensa de Vizcaya y del Gobierno Vasco}

La sublevación militar desarrollada por parte del ejército español apoyado por elementos civiles destruyó completamente el orden republicano en todo el Estado español, tal y como apunta Jiménez Vallejo4. El Golpe de Estado no triunfó en Bizkaia, pero sus instituciones sufrieron una rápida transformación, porque en un principio desempeñó un mayor papel el Gobierno Civil de Vizcaya y posteriormente se creó la Junta de Defensa de Vizcaya ${ }^{5}$. Los Ayuntamientos fueron sustituidos por Comités de Defensa de la República, en los que los concejales derechistas y tradicionalistas fueron apartados y fueron sustituidos por personal afín a los postulados del Frente Popular y del Partido Nacionalista Vasco. En estos comités menores, encontramos funcionarios tanto de la Diputación como municipales que desempeñaron varios cargos, como delegados de abastos.

Uno de los funcionarios más destacados en la Junta de Defensa de Vizcaya fue el jefe de Servicio Agrícola de la Diputación Provincial de Vizcaya, Andrés Arzadun, militante de Izquierda Republicana de 65 años y con 18 años de experiencia laboral en la Diputación. Su participación como jefe de la Comisaría de Abastos y Alojamiento Civil comenzó el 20 de julio de 1936 y tras la disolución de la Junta pasó a trabajar en la Delegación del Gobierno Vasco en París ${ }^{6}$.

Con la creación del Gobierno Vasco el 7 de octubre de 1936, comenzó una avalancha de nombramientos para desempeñar cargos técnicos que eran esenciales, tanto para el devenir de la guerra como para el funcionamiento de la vida administrativa.

El primer Consejero de Asistencia Social del Gobierno de José Antonio Aguirre y Lecube fue Juan Gracia Colas, militante del Partido Socialista, funcionario del Ayuntamiento de Bilbao desde 1934 en el cuerpo de hacienda municipal como investigador de contribuciones directas. En 1907

3 Estos datos no los podemos dar por definitivos, ya que no se dispone de información sobre el $20 \%$ de ellos, pero aun así podemos utilizarlas para dar una aproximación bastante exacta.

4 Carlos JIMENÉZ VALLEJO: "La destrucción del orden republicano (apuntes jurídicos)", Hispania Nova, 7 (2007). http://hispanianova.rediris.es/7/dossier/o7doo6.pdf

5 La Junta de Defensa de Vizcaya se creó inmediatamente tras el Golpe de Estado y desapareció tras la proclamación del Gobierno Vasco. En la actualidad no hay ninguna monografía sobre dicha Junta de Defensa de Vizcaya que analice su trabajo y quiénes fueron los hombres que alli desempeñaron los cargos.

6 Expediente de depuración de Andrés Arzadun Zabala, Archivo Histórico Foral de Bizkaia. Sección

\begin{abstract}
Administrativa, AJ-02551/003.
\end{abstract}
desempeñó el cargo de concejal de dicho Ayuntamiento, por lo que tenía un completo conocimiento de la administración?. El 9 de octubre de 1936 fue nombrado como Secretario General de Asistencia Social del Gobierno Vasco Joaquín Bustos, ordenanza de primera del Ayuntamiento de Bilbao y también militante socialista, con 19 años de experiencia laboral en la institución8.

Cuatro de los Directores Generales de los distintos departamentos del Gobierno Vasco, fueron funcionarios de la Diputación Provincial de Vizcaya. Francisco Arregui Fernández, de 46 años y afiliado al Partido Nacionalista Vasco y uno de los socios fundadores de Solidaridad de Obreros Vascos, estuvo al frente de la Dirección General de Seguridad.

Santiago Alonso Izaguirre, de 45 años, fue nombrado Director General de Industria. Además de ingeniero industrial era militante de Izquierda Republicana y llevaba 17 años trabajando en la Hacienda de la Diputación de Vizcaya.

El 14 de octubre de 1936, Juan Elorrieta Artaza, Ingeniero-Director del Servicio de Montes de la Diputación Provincial de Vizcaya, de 44 años y con 19 años de servicio en el Cuerpo de Guardia Forestal, fue nombrado Ingeniero Jefe de los Servicios Forestales de Euzkadi9. La Diputación era la mayor propietaria de montes de todo Bizkaia y disponía de un cuerpo de guardas forestales compuesto por 42 hombres que estaban distribuidos por todo el territorio, siendo su función cuidar y vigilar los montes.

Andrés Perea Gallaga, Inspector Técnico de impuestos de la Diputación Provincial de Vizcaya, militante de Acción Nacionalista Vasca, de 38 años y con 10 años de experiencia, fue nombrado Interventor General de Hacienda el 10 de octubre de 1936. El 15 de enero el cargo se desdobló y fue nombrado Director General de Operaciones del Departamento de Hacienda del Gobierno Vasco ${ }^{10}$

La Consejería de Hacienda del Gobierno Vasco dirigida por Heliodoro de la Torre, se nutrió de un buen número de funcionarios de la Diputación Provincial de Vizcaya que trabajaban también en la Hacienda Provincial. Esta consejería fue clave para el Gobierno Vasco, ya que las necesidades requeridas por la guerra y por los miles de refugiados que se desplazaron a Bizkaia desde Gipuzkoa y Araba, en menor medida, hicieron indispensable contar con un staff técnico óptimo que asesorase al Gobierno Vasco en materia económica y fiscal.

Nicolás Gaminde Guimón, Jefe de la Oficina de Inspección Técnica de Impuestos de la Diputación, afiliado al Partido Nacionalista Vasco, de 39 años y con más de10 años de servicio en la Diputación, fue nombrado Asesor Técnico de la Consejería de Hacienda".

Enrique Dueñas Zaballa, Oficial $1^{\circ}$ de Depositaría del Ayuntamiento de Bilbao, de 49 años y con 23 de servicio en el Ayuntamiento, fue nombrado Jefe de la Oficina de Pagos de Hacienda del Gobierno Vasco.

Para la debida preparación de las disposiciones que hubiera de adoptar el Gobierno Vasco, en las que se requería un estudio técnico-jurídico detenido, por su carácter de normas generales que regulasen la vida pública se creó el 8 de octubre de 1936 una comisión jurídica asesora. Entre sus componentes encontramos a Alberto de Otaduy, secretario del Ayuntamiento de Bilbao, Ju-

http://www.fpabloiglesias.es/archivo-y-biblioteca/diccionario-biografico. Juan Gracia Colas. Recuperado de internet (http://www.fpabloiglesias.es/archivo-y-biblioteca/diccionario-biografico/ biografias/9486_gracia-colas-juan)

8 http://www.fpabloiglesias.es/archivo-y-biblioteca/diccionario-biografico. Joaquín Bustos. Recuperado de internet (http://www.fpabloiglesias.es/archivo-y-biblioteca/diccionario-biografico/ biografias/3139_bustos-apoitia-joaquin)

9 Archivo Administrativo de la Diputación Foral de Bizkaia. Sección Personal. Signatura 0203066 expediente 15 .

10 Eduardo RENOBALES: ANV, el otro nacionalismo: Historia de Acción Nacionalista Vasca - Eusko Abertzale Ekintza, Tafalla, Txalaparta, 2005, p. 388.

11 Archivo Administrativo de la Diputación Foral de Bizkaia. Sección Personal. Signatura 0203152, expediente 2 . , AJ-02551/003. 
lián de Arrién, abogado asesor del Ayuntamiento de Erandio, Jacinto Daniel Montellano, jefe letrado de la Diputación de Vizcaya y Jesús de Arenzana jefe letrado del Ayuntamiento de Bilbao ${ }^{12}$

Estos nombramientos, que son un simple muestreo ya que la extensión del texto no me permite analizarlos más profundamente, demuestran que los nuevos cargos técnicos del Gobierno Vasco, no fueron nombrados únicamente por ser afines a sus postulados políticos, requisito muy importante en época de guerra, sino que fueron empleados institucionales con una amplia y dilatada experiencia profesional en sus respectivos trabajos, por lo que conocían de primera mano el nuevo trabajo que debían desempeñar.

\section{El personal sanitario al servicio del Gobierno Vasco}

El personal sanitario municipal y provincial, en el que englobamos a médicos, practicantes, farmacéuticos, matronas y veterinarios, desempeñó un papel fundamental durante la Guerra Civil, ya que mientras muchos de ellos acudieron al frente voluntariamente desde el comienzo del Golpe de Estado, otros se hicieron cargo de los hospitales de retaguardia instalados por el Gobierno Vasco en las principales villas de Bizkaia.

El Ayuntamiento de Bilbao, debido a su población, a su presupuesto y a que disponía de un Cuerpo Médico Municipal desde $1897^{13}$, era la institución con más personal sanitario. Contaba con 74 médicos, 28 practicantes y 12 veterinarios, por lo que también fue el municipio vizcaíno que más personal sanitario aportó a la guerra.

Las autoridades republicanas, conscientes de lo importante que era organizar una eficiente red de sanidad militar en el frente y hospitales de retaguardia en las villas cercanas a él, no escatimaron en esfuerzos materiales y económicos para su creación, por lo que no dudaron en movilizar al personal capacitado para hacerse cargo de los nuevos hospitales de retaguardia creados en Bilbao, Durango, Otxandiano, Portugalate, Getxo, Barakaldo, Amurrio... ${ }^{14}$

La movilización de la gran mayoría de los médicos municipales se produjo en los mismos pueblos en las que trabajaban, para evitar el desabastecimiento sanitario de las localidades en los que anteriormente trabajaban, por lo que se prohibió a los médicos que ejercían en un determinado pueblo abandonar éste sin la pertinente autorización del Colegio Oficial de Médicos de Vizcaya ${ }^{15}$

Los servicios médicos necesarios para la guerra se configuraron nada más producirse el Golpe de Estado. En las primeras columnas que salieron desde Bilbao y sus alrededores hacia Ubidea y otros puntos de la provincia también se enroló voluntariamente personal sanitario.

Como ejemplo tenemos a José Luis Arenillas Ojinaga, médico municipal de Bilbao destinado en el barrio de las Cortes, de 34 años. Militante del POUM y con seis años de experiencia médica en el Ayuntamiento de Bilbao. El 19 de julio de 1936 partió hacia el frente de Otxandio, pueblo limítrofe con Araba. Alli fue nombrado jefe sanitario de la columna, pasando después

12 Federico ZABALLA ALLENDE: El Gobierno de Euzkadi y su labor legislativa, 1936 - 1937, Oñati IVAP, 2006, p. 50 .

13 Juan GONDRA y Antón ERKOREKA: "El Cuerpo médico municipal (1897-1937) y la pandemia de la Gripe Española en Bilbao (1918-1920)", Bidebarrieta: Revista de humanidades y ciencias sociales de Bilbao, 21 (2010), pp. 139-152.

14 Para conocer en profundidad la labor desarrollada por el Departamento de Sanidad del Gobierno Vasco véase: GOBIERNO VASCO: La Sanidad Militar de Euzkadi. Gobierno Vasco. Bilbao, 1937. En este libro, realizado en plena guerra, se analiza cada característica de los hospitales, además de figurar quiénes eran los médicos responsables de cada centro hospitalario. También aparecen citados todos los miembros de la Sanidad del Gobierno Vasco, tanto civil como militar, por lo que tras la pérdida de Bilbao este libro sirvió de referencia a las tropas sublevadas para realizar la posterior represión sobre dicho personal.

15 Federico ZABALLA ALLENDE: El Gobierno de Euzkadi y su labor legislativa, 1936 - 1937, Oñati, IVAP, 2006, p. 187 a desempeñar el cargo de inspector de sanidad de los frentes de combate. Por último fue ascendido a Jefe de Sanidad Militar del Gobierno Vasco, perteneciente al Estado Mayor. Fue cap turado mientras huía en barco junto con otros responsables militares, juzgado sumariamente en Santander y fusilado el 18 de abril de 1937 en Derio, Bizkaia. La tragedia familiar no termino allí, ya que dejó un bebé recién nacido en Francia, porque su mujer se encontraba allí exiliada, y su madre fue destituida como profesora del Ayuntamiento de Bilbao ${ }^{16}$.

José Luis Arenillas no fue el único médico que desempeñó un importante cargo dentro de Gobierno Vasco. También tenemos los ejemplos de Julio Calle Cabieces, al servicio del Ayuntamiento de Bilbao desde 1918 y de adscripción nacionalista vasco, que fue nombrado jefe técnico de la sección de información del Gobierno Vasco. O el de José Luis Aransolo Bilbao, también nacionalista y funcionario del Ayuntamiento de Bilbao, que fue nombrado el 31 de diciembre secretario técnico sanitario del Departamento de Sanidad del Gobierno Vasco.

El personal sanitario dependiente de la Diputación Provincial de Vizcaya también colaboró en el esfuerzo de guerra, aunque su número era inferior al del Ayuntamiento de Bilbao y a otros ayuntamientos, como el de Barakaldo. El director del Sanatorio de Górliz, Luis Larrinaga Maurolagoitia, y uno de los médicos del sanatario, Luis Goiri Eizaga, fueron los responsables de la evacuación médica a Francia de los niños allí hospitalizados. Los dos, junto con enfermeras y varias maestras de barriada, viajaron con los enfermos a Francia para supervisar, asesorar y atender a los niños. Los dos médicos, al igual que las maestras fueron destituidos por la Diputación.

Tras la derrota republicana en Bizkaia, un gran número de médicos optó por huir al extranjero, empezando por Francia y terminando algunos de ellos en el continente americano, como fue el caso de: Román Pereiro Echevarria, médico de Getxo y delegado de hospitales de retaguardia del Gobierno Vasco, José Luis Aransolo, José María Aguirreche, Jesús Arrese Axpe, Julio Calle Cabieces o Jesús Lartitegui Arenaza, médico de Barakaldo perteneciente al Estado Mayor del Ejército Vasco, detenido en Santander y canjeado como prisionero ${ }^{17}$.

\section{Los cuerpos de seguridad provinciales y municipales durante la Guerra}

Además de las fuerzas y cuerpos de seguridad del Estado, en Bizkaia existía el Cuerpo de Miñones de Vizcaya, dependiente y pagado íntegramente por la Diputación. Los miembros del Cuerpo disponían de fuero militar, siendo imprescindible haber estado en el Ejército para poder ser miñón. A 19 de junio de 1937, el Cuerpo estaba compuesto por 124 hombres de tropa además de un 1 teniente coronel y 3 capitanes, todos ellos también militares.

Desde el mismo 18 de julio de 1936 el Cuerpo de Miñones de Vizcaya quedó a las órdenes de la Diputación, colaborando en el mantenimiento del orden en Bilbao y en todos los pueblos en los que había cuarteles. La actuación colectiva del Cuerpo fue muy desigual, ya que mientras los miñones de izquierdas y nacionalistas vascos actuaron como instructores de milicias o como tenientes en los batallones, por su condición de militares, otra parte del Cuerpo, de adscripción derechista, se limitó a mantener el orden y al cuidado de los presos de los barcos prisión situados en la Ría de Bilbao. Estos barcos fueron asaltados en septiembre y octubre de 1936 por marineros republicanos y civiles que asesinaron a multitud de presos. Tras estos sucesos se decidió poner al frente de la custodia de presos al Cuerpo de Miñones, militares disciplinados de tendencia derechista que protegieron en todo momento a los presos custodiados.

16 Su Consejo de Guerra en el Archivo Intermedio Militar Noroeste, Ferrol. Causa 4/37 de Santander. Su expediente de depuración en el Archivo Histórico Foral de Bizkaia. Sección Archivo Municipal de Bilbao, Bilbao decimosexta 0003/210. Y su carta antes de ser fusilado en VVAA. Como mueren los vascos: Testimonios póstumos de fusilados en Euzkadi por los invasores franquistas. Vitoria-Gasteiz, Gobierno Vasco, 2009

17 Antón ERKOREKA: Médicos vascos exiliados en América en 1937.XXV años de nutrición Comunitaria

en Bilbao y Euskadi, Memorial J.M. Bengoa Lecanda, Bilbao, 2010. 
La actitud de los cuatro oficiales también fue totalmente distinta en cada caso, ya que mientras Casiano Guerricaechevarria, uno de los capitanes del Cuerpo, ascendió hasta ser el Jefe de Artillería del Ejército Vasco y participó en combates, Luis Montaner y Canet, Teniente Coronel y Jefe del Cuerpo huyó a las líneas enemigas tras el bombardeo de Gernika ${ }^{18}$, posiblemente moralmente hundido al conocer de primera mano el poder destructivo de la aviación alemana, ya que tuvo que desplazarse a Gernika a recoger a otro oficial del Cuerpo, Ignacio Anitua, que allí residía.

El Ayuntamiento con mayor número de guardias municipales era Bilbao, que contaba con 256 hombres, mientras que localidades como Getxo, Portugalete y Basauri contaban con 37, 16 y 13 respectivamente.

El intento de mantener constantemente el orden público fue una de las principales señas de identidad del Gobierno Vasco, aunque no siempre se consiguió, ya que el 4 de enero de 1937 las cárceles de Bilbao fueron asaltadas y alrededor de 200 presos derechistas fueron asesinados $^{19}$. A pesar de este asalto, en Bizkaia no se produjeron tantos asesinatos como en otras provincias leales al orden constitucional, en parte debido a los medios humanos y materiales que las autoridades dispusieron para este servicio.

Tras la formación del Gobierno Vasco, desde la Dirección General de Seguridad se creó el Cuerpo de Orden Público, compuesto de unos 460 hombres, bajo las órdenes de un teniente coronel, cuatro capitanes y siete tenientes. Entre los componentes del Cuerpo de Orden Público encontramos 85 funcionarios municipales y provinciales, siendo 2 de ellos tenientes. De estos 85 funcionarios la amplia mayoría pertenecían a la Guardia Municipal de Bilbao, que aportó 72 miembros. A consecuencia del traspaso de personal a dicho cuerpo, la Guardia $\mathrm{Mu}$ nicipal quedó un tanto desmantelada ${ }^{20}$, ya que muchos de sus efectivos se encontraban en el frente de forma voluntaria o movilizados.

El Jefe de la Guardia Municipal de Bilbao, el capitán Modesto de Arambarri Gallastegui, pasó a desempeñar el cargo de Jefe de Operaciones del Ejército Vasco, siendo más tarde sustituido y nombrado asesor técnico militar del Gobierno Vasco. Modesto Arambarri contaba con 35 años y 5 años de servicio en el Ayuntamiento de Bilbao cuando embarcó a Francia exiliado ${ }^{21}$.

Además del Cuerpo de Orden Público, el Gobierno Vasco creó otra nueva policía, la Ertzaina. Esta policía disponía de dos secciones, una de infantería y otra motorizada, llamada Ertzain Igilatua, cuyo creador y jefe fue el funcionario de Hacienda de la Diputación Provincial de Vizcaya José María Picaza Andrés, de 36 años, afiliado al Partido Nacionalista Vasco y con 17 años de experiencia en la Diputación.

Las condiciones exigidas para el ingreso en la Ertzaina eran poseer por lo menos los idiomas de euskera y castellano, talla mínima de 1,75 , y disponer de un certificado de buena conducta y adscripción al Gobierno Vasco ${ }^{22}$. Por lo menos cuatro funcionarios sirvieron en la sección de in-

18 Uno de los objetivos del bombardeo además de la completa destrucción de la Villa de Gernika y de demostrar su poder aniquilador era el de destrozar moralmente a los defensores republicanos. Para conocer más profundamente las razones, objetivos y consecuencias del bombardeo vid. Xabier IRUJO AMEZAGA: El Gernika de Richthofen. Un ensayo de bombardeo de terror, Museo de la Paz de Gernika, 2012.

19 Carmelo LANDA MONTENEGRO: "Bilbao, 4 de enero de 1937. Memoria de una matanza en la Euskadi autónoma durante la Guerra Civil española", Bidebarrieta: Revista de humanidades y ciencias sociales de Bilbao, 18 (2007), pp. 79-115.

o Andoni VERGARA y Félix CUADRADO: Bilbao y su Guardia Municipal. Más de 100 años de historia, Bilbao, Ayuntamiento de Bilbao, 2003.

21 Andoni VERGARA: Modesto Arambarri Gallastegui (1902-1988). Biografía, Bilbao, Ayuntamiento de Bilbao, 2006

22 Federico ZABALLA ALLENDE: El Gobierno de Euzkadi y su labor legislativa, 1936 - 1937, Oñati, IVAP, $2006,08$. fantería, mientras que otros tres lo hicieron en la Ertzain Igilatua, siendo el médico municipal de Bilbao, José Escudero Pascual, el sanitario de esta sección.

Los miembros de las guardias municipales de las distintas localidades vizcaínas también sufrieron las consecuencias de la Guerra, ya que al disponer de conocimientos del manejo de las armas y al estar muchos de ellos comprendidos en edad militar fueron movilizados o partieron como voluntarios durante los primeros días a milicias.

Los cuerpos de seguridad municipales y provinciales fueron los más castigados por la represión física franquista y la depuración administrativa llevada acabo por los nuevos ayuntamientos, además de partir hacia el exilio en un gran número. Esta represión fue debida a su participación en el frente o al mantenimiento del orden público en retaguardia, a su militancia política y al peligro que representaban para el Nuevo Estado.

\begin{tabular}{|l|c|}
\hline Cuerpo de seguridad & Miembros fusilados \\
\hline Cuerpo de Miñones de Vizcaya & 9 \\
\hline Guardia Municipal de Portugalete & 4 \\
\hline Guardia Municipal de Bilbao & 3 \\
\hline Guardia Municipal de Sestao & 3 \\
\hline Guardia Municipal de Barakaldo & 1 \\
\hline Guardia Municipal de Bermeo & 1 \\
\hline Guardia Municipal de Berriz & 1 \\
\hline Total & 22 \\
\hline
\end{tabular}

Cuad. 03 Miembros de los cuerpos de seguridad provinciales y municipales fusilados por las aujuicios sumarios y plantillas de funcionarios.)

\section{Funcionarios voluntarios en milicias y movilizados por el Gobierno Vasco}

Como hemos visto a lo largo del presente texto, desde el comienzo de la sublevación grupos de funcionarios dejaron sus puestos de trabajo y contribuyeron al esfuerzo bélico republicano de forma voluntaria en puestos técnicos. Realizar una aproximación cuantitativa sobre cuántos acudieron de forma voluntaria a las milicias que se organizaron después del 18 de julio de 1936 es complicado, ya que lo primero que es necesario analizar y definir es el término "voluntario".

Por "voluntario" aceptamos una de las definiciones que ofrece la RAE "que nace por espontánea voluntad y no por obligación o deber", por lo que ciñéndonos a este concepto hemos identificado como mínimo a 78 funcionarios que acudieron por voluntad propia a las milicias que se constituyeron en un primer momento o a trabajos de fortificaciones. Otro factor que imposibilita un cálculo más preciso sobre la participación voluntaria es la gran cantidad de funcionarios que abandonaron su puesto laboral y huyeron a Santander, Asturias o fuera de Estado español. El estudio de sus expedientes de depuración, si es que dispusiesen de ellos ya que instituciones como el Ayuntamiento de Bilbao cesó al personal que no solicitó su reingreso sin la apertura de dicho expediente, no suele reflejar el motivo de su marcha, limitándose a apuntar que "ha abandonado su puesto laboral".

El cálculo sobre el funcionariado movilizado también conlleva las mismas dificultades cuantitativas, pero dicho personal en muchos casos cayó prisionero del ejército sublevado o solicitó su reingreso en la institución; analizando la documentación conservada en los juicios sumarios y en sus expedientes de depuración podemos obtener un cálculo aproximado.

Tras la constitución del Gobierno Vasco, éste decretó una progresiva pero lenta movilización de hombres en edad de combatir. 


\begin{tabular}{|l|c|}
\hline Quintas movilizadas & Decreto \\
\hline $1932,1933,1934$ y 1935 & $16 / 10 / 36$ \\
\hline 1931 y 1936 & $08 / 12 / 36$ \\
\hline 1929,1930 y 1937 & $07 / 04 / 37$ \\
\hline 1928,1938 y 1939 & $07 / 05 / 37$ \\
\hline 1925,1926 y 1927 & $21 / 05 / 37$ \\
\hline
\end{tabular}

Cuad. 04 Ouintas movilizadas por el Gobierno Vasco y decretos de movilización. (Fuente: Federico ZABALLA ALLENDE: El Gobierno de Euzkadi y su labor legislativa, 1936 - 1937 Oñati, IVAP, 2006, p. 76.)

La movilización entre octubre de 1936 y mayo de 1937 afectó por lo menos a 292 funcionarios que se dividieron en distintas unidades. Los movilizados a raíz del último decreto se incorporaron a sus batallones sobre el 13014 de junio de 1937, cuando los combates se encontraban sobre Bilbao, por lo que más de una decena de ellos se escondieron para no acudir a sus respectivos cuarteles.

\section{Conclusiones}

El esfuerzo bélico de los funcionarios municipales y provinciales de Bizkaia en el bando republicano puede ser calificado de desigual por distintos motivos. La actitud pasiva de muchos de ellos fue debido a su avanzada edad, ya que muchos sobrepasaban la edad de combatir, tenían familia, llevaban varios años trabajando en la misma institución, sus puestos no eran técnicos y muchos eran claramente contrarios a la causa republicana y nacionalista vasca.

Otros muchos de ellos no mostraron ninguna actitud pasiva y colaboraron activamente con el Gobierno Vasco y las autoridades republicanas, tal y como apuntan los juicios sumarios y los expedientes de depuración que les fueron instruidos tras su captura.

La participación del personal técnico fue fundamental ya que encontramos funcionarios muy capacitados y con amplia experiencia laboral adjuntos a los distintos departamentos del Gobierno Vasco, ya fuese en sanidad, en defensa o en fortificaciones, como es el caso de José Martín González de Langarica, jefe de obras públicas de la Diputación que fue uno de los máximos responsables de las obras de fortificación.

El Gobierno Vasco, institución creada en plena Guerra Civil y con autoridad legítima sobre un territorio acechado por un ejército sublevado, se sustentó sobre personal técnico capacitado que hasta ahora ha permanecido en el más completo anonimato, tal vez por la dificultad que conlleva el rastreo y análisis de las fuentes documentales o por el deslumbramiento que provocan sus líderes más carismáticos. 


\section{MILITARES ESPAÑOLES EN LA UNIFICACIÓN DE ITALIA: LOS DIARIOS DE OPERACIONES COMO FUENTES HISTORIOGRÁFICAS}

Sergio Cañas Díez ${ }^{1}$

Universidad de La Rioja

\section{Introducción}

En este trabajo se analizarán las memorias y los diarios de operaciones de los distintos líderes militares españoles, tanto liberales -como el general Fernández de Córdova-, como carlistas, -en el caso del general Borges y el teniente coronel Tristany-, quienes participaron en las luchas civiles italianas en el contexto de la Unificación de Italia cuya cronología es 1848-1870. Para ajustarme al espacio dado para exponer los resultados de esta investigación, de la que esta comunicación es una parte de un todo más voluminoso, fundamentalmente nos vamos a basar en el caso de aquellos oficiales que tomaron parte en las luchas desarrolladas en la península itálica contra la unidad de Italia y a favor del legitimismo borbónico, o bien, paradójicamente para el caso español, contra la unidad de Italia y a favor de los intereses de Pío IX.

Tal vez esta primera idea parezca un oxímoron, pero realmente es parte de la peculiaridad de la España bajo el reinado liberal-modernado y con tintes neocatólicos de Isabel II, y de su posicionamiento contra la idea unificadora en Italia y a favor de los intereses del catolicismo mundial representado por Pío IX. Tal vez sean estas acciones unas de las pocas cuestiones en que ambos encarnizados enemigos patrios coincidian, así como lo hicieron a la hora de expulsar a Napoleón de España liberales y absolutistas antes de enfrentarse entre ellos por dirigi el destino del reino. Porque lo cierto es que, aunque carlistas y liberales lucharon entre sí en España hasta los límites que la crueldad humana permite en las acciones de guerra en lo que fue la primera Guerra Civil de la contemporaneidad española, en un primer momento tanto las tropas de Isabel II como las del pretendiente al trono Carlos, apoyaron unánimes la causa del papado en distintas épocas, y de manera sustancialmente diferente: los primeros como ejército y los segundos como guerrilla. ${ }^{2}$ No así los voluntarios que se pusieron prestos a las órdenes de Garibaldi los cuales no entran en este estudio. Más que hablar de dos Españas, en este caso al menos podemos hablar de tres. ${ }^{3}$

1 sergio.canas@unirioja.es. Esta investigación de temática militar debe enmarcarse de manera global en el seminario permanente sulle guerre civili nell Italia contemporanea, coordinado por el doctor $\mathrm{C}$ Pinto en la Universidad de Salerno, en cuyo marco se presentó una primera versión más reducida y distinta de este trabajo, en el Seminari di Studio: Patriottismo, Conflitto civile e Rivoluzione nel Mezzogiorno Risorgimentale, celebrado el 30-31 de mayo de 2012 en la Universidad de Salerno (Italia).

2 Para entender mejor esta idea en toda su complejidad y desarrollo, véase: Sergio CAÑAS: "El catolicismo español frente a la Unidad de Italia", en Eugenia GRANITO (coord.): Un popolo uno Stato. Conquiste e problematiche dell'unificazione italiana viste da una provincia meridionale, Salerno, Conquiste e problematiche dell' unificazione italiana viste da una provincia meridionale, Salerno,
Plectica, 2012, pp. 189-222; ID. "La Iglesia de Calahorra frente a la unificación italiana (1848-1870). Tensión entre catolicismo y liberalismo en España", en Alejandra IBARRA (coord.): Actas del III Encuentro de Jóvenes Investigadores de la AHC.

3 Jordi CANALS: "Voluntarios españoles en guerras ajenas. Liberales y papistas frente al espejo de Italia", La aventura de la Historia, 161 (2012), pp. 60-63.
Es por ello por lo que me ceñiré al caso del general José Borges ${ }^{4}$ y del teniente coronel Rafael Tristany, ${ }^{5}$ famosos personajes carlistas en el sur de Italia que en España pasan académica y socialmente, por lo común, desapercibidos. De igual manera, del lado isabelino estudiaremos el caso del general Fernando Fernández de Córdova. Un protagonista mucho más conocido para la historiografía hispana, asi como italiana, y que también quiso dejar su testimonio, su granito de arena, para que sus contemporáneos conociesen de su mano los hechos que acaecieron en suelo meridional italiano. ${ }^{6}$ También es necesario y complementario para nuestro trabajo manejar memorias de militares italianos, liberales en este caso, pero ello nos obligaría a alargar bastante el relato historiográfico y por tal razón decidimos excluirlas voluntariamente a pesar de que pueden enriquecer la investigación. ${ }^{7}$

Además de basarnos en estudios generales de las historiografías española e italiana sobre el tema de la intervención militar española en Italia, los cuales nos ayudan a conformar una perspectiva sólida y fundamentada sobre esta cuestión, o por el contrario, a darnos cuenta de los errores que algunos autores han tenido a la hora de valorar las intervenciones militares españolas en suelo itálico, pondremos encima de la mesa el análisis y la explicación de las distintas crónicas autobiográficas de aquellos protagonistas que nos legaron en forma de escritos sus experiencias, así como su visión particular de la contrarrevolución europea en general y de los casos de Italia y España en particular. Desde luego, en el ejemplo concreto del general Fernández de Córdova, cuyo liberalismo no es sospechoso tras su activo papel en el primer levantamiento carlista, no podemos hablar de reacción sino de liberalismo "moderadamente conservador", muy apegado al neocatolicismo según denunciaban los progresistas y republicanos de la época, que regía España tras el final de bienio progresista y antes de la revolución de 1868 , y que caracterizó a todas luces los distintos gobiernos de Isabel II.

Mediante unas consideraciones previas al objeto de esta comunicación quiero acercarme también a repasar brevemente, con la ayuda de un sintético estado de la cuestión, la atención mostrada al marco temático general que nos ocupa desde ambos países hacia los estudios comparativos de la contemporaneidad de estas dos naciones mediterráneas que configuran la Europa meridional. Con todo, será grosso modo el análisis de las relaciones entre brigantes italianos y carlistas españoles dentro del proceso unionista italiano, y el de las fuentes utilizadas para su estudio, nuestro segundo y principal objetivo.

Es preciso adelantar que pese a no tratarse de un primer acercamiento al tema, resulta sensato señalar las limitaciones del presente estudio, el cual necesita de próximas y pormenorizadas investigaciones, así como de mayor espacio para desarrollarlas en toda su extensión si queremos analizar todos los datos que las memorias nos aportan para el conocimiento tanto de los temas narrados, como de los personajes que participan en los hechos y los escribieron en forma de diarios o libros. De todas formas esta idea deberá evaluarse de forma más precisa en el apartado final de las conclusiones, dadas las diferentes perspectivas que estas voluminosas fuentes históricas nos abren. Ya ha habido otros trabajos anteriores que las han usado de manera bastante satisfactoria en el caso de la historiografía italiana, si

4 Para consultar las memorias de Borges, Juan MANEE Y FLAQUER y Joaquín MOLA Y MARTINNEZ: Historia del bandolerismo y de la camorra en la Italia meridional, Barcelona, Imprenta de Salvador Manero, 1864

5 Ibid.

6 Fernando FERNÁNDEZ DE CÓRDOVA: Mis memorias intimas, Madrid, Imprenta de Manuel G. Fernández, 1882

7 Es el caso de Giuseppe BOURELLY: Il brigantaggio delle zonbe militari si Melfi e Lacedonia dal 1860 al 1865 , Os na carta de poco valor perteneciente a Tristany y opiniones sobre la conducta de Borges y sus 
bien nosotros simplemente ahondamos en ellas desde una nueva perspectiva y las recuperamos para la historia española para hacerlas visibles en otro espacio cultural parcialmente distinto como el mundo hispano. ${ }^{8}$

\section{Contextualización historiográfica}

Una interpretación exhaustiva del envío de tropas españolas para defender a Pío IX y sus posesiones terrenales, así como del complejo fenómeno del carlismo español y de su relación con los brigantes y legitimistas borbónicos del sur de Italia, debe partir de la base de que la oposición armada fue "sólamente" uno de los aspectos más espectaculares, conocidos y evidentes, de las resistencias a la creación del Reino de Italia por parte del Reino de España y de buena parte de la población meridional italiana. Bien fuese un antagonismo total o parcia en España, puesto que si bien el ánimo popular apoyaba las disposiciones eclesiales puestas al servicio de Roma los progresistas con Sagasta al frente junto a republicanos y demócratas como Castelar sí que apoyaron en el parlamento la ayuda y la defensa de la unidad nacional italiana, lo cierto es que caló en algunas de las poblaciones meridionales italianas donde todavía hoy pervive el movimiento neoborbónico como parte del folclore cultural de la Italia de sur'. Tampoco olvidemos que a la postre, y con bastante retraso en contraste con el panorama europeo, con la oposición de la propia Isabel II ante la decisión de un poder ejecutivo español presionado desde varios frentes internos y externos, fue un gobierno moderado el que en 1865 finalmente reconociese la legitimidad del reino y de la nación italiana de 1861. Otro símbolo más del retraso español del siglo XIX.

Lo cierto es que si miramos más allá de los testimonios periodísticos, más propios de la literatura de viaje, ${ }^{10}$ y de los diarios de operaciones militares, donde la fidelidad y subjetividad de lo escrito se mezcla en ocasiones con el uso de ciertas ficciones que tratan de engrandecer y maquillar los hechos realmente sucedidos, comprobamos que fueron movimientos que tuvieron unas características y unas articulaciones más amplias y profundas que las que caracterizaron la insurgencia de la época napoleónica en ambos territorios, donde podemos establecer sus orígenes contemporáneos y el inicio de las guerras de guerrillas contra ejércitos regulares de ocupación si usamos terminología moderna. Centrándonos más en el periodo propuesto, debemos tener claro que la contienda no era solo entre unionistas y legitimistas en Italia, y el enfrentamiento no era únicamente entre los partidarios de Carlos de Borbón y los partidarios de Isabel II en España: dos configuraciones distintas del territorio y dos modelos sociopolíticos distintos chocaban en ambos países durante el siglo XIX: el antiguorregimental y el liberal. Así como hubo simpatías y apoyos entre liberales de uno y otro espacio, parece lógico que se dieran casos parecidos entre los movimiento contrarios surgidos a raíz de los cambios geopolíticos y diplomáticos acaecidos en Europa durante la centuria decimonónica, y que rompieron el "equilibrio reaccionario europeo" pactado en Viena en 1815

8 Aldo ALBÒNICO: La Mobilitazione legittimista contro il regno d'Italia : la Spagna e il brigantaggio meridionale postunitario, Milán, Giuffrè, 1979. Pese a ser una obra clásica y contener a nuestro juicio algunas afirmaciones que pueden y deben ser matizadas y corregidas, verdaderamente es clave para conocer este tema desde un punto de vista global.

9 Sergio CAÑAS:"El catolicismo... Aclaro que lejos de querer hacer un juicio de valor para el que no estoy cualificado ni es motivo de este trabajo, esta pugna por la verdad histórica hace correr ríos de tinta en la prensa, en las revistas especializadas y en distintas asociaciones culturales del sur de Italia.

10 Es el caso de José GUTIÉRREZ DE LA VEGA: periodista que acompañó al general Fernández Córdova, y publicó sus viajes por Italia en un relato cercano a la literatura de viaje típica del momento.
Jaume Vicens Vives ya lo vio claro a mediados del siglo XIX:

A despecho de las diferencias en su respectiva evolución histórica, un mismo pensamiento reunía entonces el intento de las minorías activas de ambos pueblos, no solamente de los elementos liberales, sino también de los grupos prepotentes en ciertos sectores sociales de los absolutistas. Liberales y absolutistas italianos y españoles buscaron recíproca ayuda, moral y material, estrechando vínculos más firmes y participando de las mismas vicisitudes."

Otro de los puntos a tratar en este epígrafe es el de la recepción por parte de los historiadores de la presencia isabelina o carlista en la Italia meridional del siglo XIX. Pese a ser un tema en constante renovación, prácticamente acapara tantos estudios rigurosos en España como en Italia, donde el estudio de este fenómeno tiene más tradición durante el siglo XX, y en otras naciones europeas. ${ }^{12}$ Con todo, por mi parte todavía es un tema en pleno desarrollo y que necesita de mayor difusión fuera de la academia, ya que gran parte de los trabajos precedentes se han ocupado de otras cuestiones colaterales. Necesarias para entender el contexto y ampliar las miras del historiador del siglo XXI, pero que no han llegado a centrar la cuestión militar como nos proponemos con esta investigación. ${ }^{13}$ Como siempre suele suceder, hay excepciones muy recientes que nos han sido muy valiosas para entender mejor el objeto de nuestro estudio y establecer un debate interesante e intenso con estudios anteriores. ${ }^{14}$

Una de las características más importantes para entender la presencia de militares liberales en la guerra civil italiana del siglo XIX, así como el compromiso de distintos líderes militares carlistas contra el Risorgimento, es la vocación continental de la complicada y dinámica situación política española cuando se debatía entre caer del lado liberal o reaccionario. Desde luego que estos enfrentamientos internacionales tuvieron mucha relevancia en el mediodía italiano y en los Estados del papado, tal vez una característica que complicaba aún más las cosas,

11 Jaume VICENS VIVES: "Relaciones entre Italia y España durante el Risorgimento", Obra Dispersa, vol. 2,1967, p. 336.

12 Por lo menos en el caso inglés, contamos con obras tan clásicas como la de Count MAFFEl: Brigan t life in Italy: an History of bourbonist reaction, Londres, Hurst and Blackett, 1865, hasta otras más cercanas a nuestro presente donde se pone el punto de mira en este hecho, como en Eric HOBSBAWN: Rebeldes primitivos, Barcelona, Crítica, 2010. Del resto de obras hemos dado cuenta, o daremos, a continuación cuando sea preciso.

13 Sin tratar de pormenorizar el total de títulos consultados, podemos resaltar varios de los títulos más significativos: Manuel GONZÁLEZ: La Italia del siglo XIX, Madrid, Imprenta de Manuel Rojas, 1861; Jaume VICENS VIVES, op. cit.; Francesco MOLFESE: Storia del brigantaggio dopo I'Unità, Milán, Feltrinelli, 1976; Fernando JIMÉNEZ: Los gobiernos de Isabel II y la cuestión de Italia, Madrid, lán, Feltrinelli, 1976; Fernando IMENEZ: Los gobiernos de Isabel IIy la cuestion de Italia, Madrid, Ministerio de Asuntos Exteriores, 1988; Alfonso BULLON DE MENDOZA y Joaquim VERISSIMO: La
contrarrevolución legitimista (1688-1876), Madrid, Editorial Complutense, 1995; Alfonso BULLÓN contrarrevolución legitimista (1688-1876), Madrid, Editorial Complutense, 1995; Alfonso BULLON DE MENDOZA: "El legitimismo europeo, 1688-1876", en Stanley G. PAYNE (dir.): Identidad y nacionalismo en la España contemporánea, el Carlismo, 1833-1975, Madrid, Colección Luis Hernando de

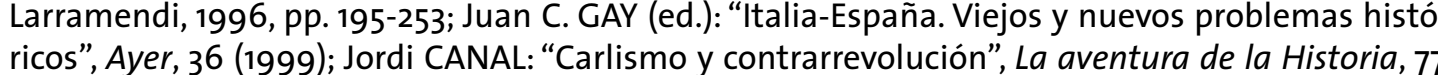
ricos", Ayer, 36 (1999); Jordi CANAL: "Carlismo y contrarrevolución", La aventura de la Historia, 77,
(2005), pp. 46-52; ID: "La guerra civil en el siglo XIX (España, Portugal, Francia e Italia)", Violencias (2005), pp. 46-52; ID.: "La guerra civil en el siglo XIX (España, Portugal, Francia e Italia)", Violencias
fratricidas. Carlistas y liberales en el siglo XIX, Pamplona, Gobierno de Navarra, 2008, pp. 187-213: ID, fratricidas. Carlistas y liberales en el siglo XIX, Pamplona, Gobierno de Navarra, 2008, pp. 187-213.: ID,
"Guerra civil y contrarrevolución en la Europa del sur en el siglo XIX: reflexiones a partir del caso "Guerra civil y contrarrevolución en la Europa del sur en el siglo XIX: reflexiones a partir del caso español", Ayer, 55 (2004), pp. 37-60.; José Ramón UROUIJO: "Los estados italianos y España durante la primera guerra carlista (1833-1840), Hispania, 182 (1992), pp. 947-997; Isabel María PASCUAL: La
Italia del Resorgimento y la España del sexenio democrático (1868-1974), Madrid, CSIC, 2002; Simon SARLIN: “Los carlistas en Italia en el siglo XIX”, Violencias fratricidas. Carlistas y liberales en el siglo XIX, Pamplona, Gobierno de Navarra, 2008, pp. 223-239.

14 Vid. Vicente PUCHOL: Diario de operaciones del cuerpo expedicionario a los Estados Pontificios (1849-50) Madrid, Ministerio de Defensa, 2011 ID "1849. La expedición a los Estados Pontifios Atenea, $35,(\mathrm{~V})$, pp. $78-82$ 
pero también en España. Baste pensar en las distintas alianzas internacionales para derrocar a Napoleón o terminar con el Trienio Liberal, por citar dos ejemplos meridianos. Es decir, cuando en casi todos los países de la Europa occidental se asistirá al nacimiento de una voluntad contrarrevolucionaria, que fracasa en origen en su lucha contra la revolución liberal a partir de la tercera y cuarta década del siglo XIX, se están sentando las bases para su cohesión a nivel europeo mediante la internacional blanca. Lo mismo podría decirse de la internacional liberal aunque venciese en sus luchas nacionales. Así se explica que estos movimientos sean al mismo tiempo guerra civilistas en su génesis pero continentales e intercontinentales, como en los casos de Espoz y Mina o el propio Garibaldi en Latinoamèrica, en su desarrollo posterior. $O$ tal vez se pueda plantear algo distinto al entender que desde sus inicios el conflicto era internacional y simplemente en cada espacio se manifestaba de acuerdo con las lógicas propias de cada lugar. En palabras del profesor Jordi Canal estos conflictos fueron nacionales en apariencia, pues: "La larga guerra civil europea del siglo XIX constituía el inevitable telón de fondo".15

Finalizando este punto y retomando la idea de guerra civil que apuntamos antes, si bien la idea de Canal es clave para avanzar más allá de las historiografías nacionales, en donde la parte española parece haber estado menos abierta al exterior en lo referente al siglo XIX que la italiana en este tema, parece también claro que ni las guerras carlistas ni el legitimismo borbónico pueden entenderse sin el contexto de una guerra interna. Una idea expresada sintética y poéticamente por Octavio Paz en una bella metáfora: la guerra civil como fraterno "abrazo mortal", ${ }^{16}$ y que ha sido tomada para contextualizar las grandes revoluciones contemporáneas a nivel internacional por otros historiadores. ${ }^{17}$

\section{Intervención militar española en 1848: de Nápoles a Gaeta}

La primera característica de este punto es el hecho de que un estado oficialmente libera como el del reino de España de 1848-1850, se decantase por apoyar antes la causa de Pío IX que la causa del liberalismo nacionalista italiano. Este factor además de explicarse por la enorme influencia del clero en la política isabelina, aún tras sonados enfrentamientos con el Gobierno por el contenido constitucional en materia de política religiosa, el apoyo de ciertos sectores clericales al carlismo y la desamortización eclesiástica, hay que enfocarlo en el hecho de que una misma dinastía, la borbónica, regía en España y en el Reino de las Dos Sicilias, y en el incuestionable apoyo de gran parte de la población a la causa del catolicismo, o la causa de la jerarquía católica según el ideario liberal del sector progresista. Así al menos, aclaramos sucintamente la susodicha paradoja del caso español.

Por otro lado, las razones que llevaron a Fernández de Córdova como protagonista de la primera acción bèlica a redactar estas memorias fueron combatir los errores de algunas obras historiográficas del siglo XIX que habían tratado ese hecho. ${ }^{8}$ Asimismo, también se infiere un gusto personal por la escritura y la narración tanto de su periplo vital como el de el resto de su familia, ya que pertenecía a una antiquísima saga militar. Algo que no tiene mucho que ver con las intenciones de los líderes carlistas como veremos después. Si bien esto es lo que se desprende del texto original, lo cierto es que también en su motivación hubo factores mucho más personales e individuales y menos científicos o académicos. Por ejemplo esto puede verse en las partes en que se trata de dibujar unos hechos que dejan al general y a la tropa española en un lugar más elevado del que realmente tuvieron, al parecer, como en el episodio donde

15 Jordi CANAL: "Voluntarios españoles en guerras ajenas. Liberales y papistas frente al espejo de Italia", La aventura de la Historia, 161 (2012), p. 60.

16 Octavio PAZ: El laberinto de la soledad, Madrid, Cátedra, 1993, p. 294.

17 Jordi CANAL: "Guerra civil y contrarrevolución en la Europa del sur", Ayer, 55 (2004), p. 47

18 Alfonso BALLEYDIER: Historia de la Revolución de Roma, Barcelona, Imprenta de Tomás Gorchs, 1856. se asegura que Fernando II de Nápoles quiso poner tropas napolitanas al mando del general español y así unificar el mando de ambos ejércitos bajo liderazgo español, idea que le fue expresada en una reunión privada entre ambos caballeros pero del que no consta ninguna clase de documentación que avalen esa propuesta que en ningún caso se llevó a la práctica ${ }^{19}$. En cambio, es una cuestión que autores autorizados de Italia dan como cierta aunque tampoco aportan más noticias para su comprobación. ${ }^{\circ}$

Por otro lado, también en ciertos autores italianos se recrudece la crítica a Fernández de Córdova, e incluso se confunden datos estadísticos o de movimientos tácticos en aras de minusvalorar aspectos de la intervención española contra las tropas de Garibaldi, o al revés, exaltar el ingenio militar del italiano, si bien, quizás sea más sensato señalar que cuanto menos hay una controversia entre lo señalado por las fuentes originales y su recepción por parte de la historiografía italiana de principios del siglo XX con la española del siglo XXI. ${ }^{21}$ Con todo, y con el objeto de valorar estos debates, no podemos olvidar que se trata de un personaje famoso en España por su autoritarismo y extrema ortodoxia militar, y por ser el blanco, merecida o inmerecidamente, de distintos periódicos nacionales y extranjeros a lo largo de su carrera. En todas esas ocasiones no dudaba en defenderse y aportar su visión de los hechos y menoscabar las críticas, y la cuestión italiana no iba a ser una excepción. ${ }^{22}$

Aquel mismo día presentóseme la ocasión de conocer el estado en que encontraba el $2^{\circ}$ de Ligeros, así como de dar a entender a sus individuos bajo que pie empezaba yo a mandarles (...) Estaba el batallón formado en masa por compañías, (...) cuando vi a un granadero que, llamado por el teniente que le mandaba, háblabale sin respeto y sin llevarse la mano al chacil para saludarle (...) y dando la espalda a su oficial, púsose a hacer una diligencia con ademanes descompuestos e insubordinados. Indignado como era consiguiente de semejante falta (...) mandé en el acto al batallón poner armas al hombro, y haciendo salir al granadero (...) hícele despojar de sus armas y equipo y aplicar sesenta palos (...). Cumplido el castigo, arengué victoriosamente al batallón, asegurando a sus soldados que les mataría a palos por cualquier falta que cometieran. (...) Yo era entonces, como lo he sido siempre, contrario al palo; pero entonces como después, lo usé excepcionalmente como el mejor medio para hacer entrar a una tropa insubordinada en la línea del deber. ${ }^{23}$

Lo cierto es que como la expedición española no tomó parte finalmente en ninguna acción militar de primer orden, salvo en la de perseguir a un derrotado Garibaldi y sus tropas infructuosamente ya que no era materialmente posible alcanzarlas dadas las posiciones defensivas a

9 Fernando FERNÁNDEZ DE CÓRDOVA: Mis memorias..., pp. 174-175. El desarrollo historiográfico de los acontecimientos que niegan esta idea y matizan otras del mismo calado en Vicente PUCHOL, op.cit., pp. 83-89. Podemos resumirlos en la falta de documentación para una propuesta de semejante magnitud, y en la falta de información que sobre el mismo hecho tuvieron tanto la embajada como el gobierno de España.

20 Aldo ALBòNICO: La Mobilitazione..., pp. 2-3.

21 Por ejemplo, tenemos el caso de Eugenio DE ROSSI y Luigi GRITTI: "La Marcia di Garibaldi da Roma a S. Marino", Revista de Caballería, 9 (1902), pp. 10-13, autores que a la postre han marcado el camino para la historiografía posterior, como ha estudiado de forma exhaustiva e internacional Vicente PUCHOL: Diario de operaciones..., pp. 170-171. Incluso se le achacaba una crueldad y unos fusilamientos bastante indecorosos que no ha sido demostrado hasta la fecha.

22 Autor prolifico entre el elemento militar donde los haya, ya con anterioridad a publicar sus memorias íntimas, había publicado, Memoria del teniente general Fernando Fernández de Córdova, sobre los sucesos políticos ocurridos en Madrid en los días 17, 18 y 19 de julio de 1854, Madrid, Imprenta de M. Rivadeneyra, 1855

23 Vid. Fernando FERNÁNDEZ DE CÓRDOVA: Mis memorias..., pp. 203-206 
las que estuvieron destinadas las tropas, y su número fue menor que el que se esperaba del Reino de España, aún pese a los esfuerzos e intentos de su general por hacerlas aumentar, lo cierto es que fueron las tropas de Francia y Austria quienes llevaron el peso de las acciones militares en la defensa de Roma y de Pío IX. En marzo de 1850 las últimos soldados de la división del general Córdova con su jefe militar al frente llegaron a Barcelona. El único beneficio que el gobierno español obtuvo de esta acción militar que duró once meses, fue mantener buenas relaciones con la Iglesia en vistas de las desavenencias entre Iglesia y Estado derivadas del propio desarrollo del liberalismo nacional, y del futuro Concordato con la Santa Sede, firmado en 1851. También permitió al país seguir teniendo presencia y cierta influencia en la política militar continental e internacional, que progresivamente iba menoscabándose en la centuria decimonónica por las luchas independentistas coloniales. Sería discutible si también pudo armonizar más el gobierno nacional frente al pueblo que mayoritariamente defendía los intereses del papado, porque lo cierto es que la desafección política de esta parte de la historia era, en global, muy alta. A nivel militar y de política exterior española, podemos ver en esta intervención una manera de desviar la atención de problemas de índole interna así como un vano e infructuoso intento de devolver a la idea imperial de Espanna el lustre que tuvo durante las centurias anteriores y que poco a poco perdió hasta el conocido desastre finisecular del siglo XIX.

\section{La internacional blanca entre España e Italia: los casos de Borges y Tristany}

Para empezar a entender el hecho de la colaboración entre el carlismo y el legitimismo absolutista italiano, debemos tener en cuenta que la transición unitaria de Italia y la creación del reino italiano coincide con un periodo de entreguerras carlistas, y que desde 1840 un carlismo derrotado por las armas y conquistado por la diplomacia cristina, consiste efectivamente en unas redes de fidelidad y solidaridad legitimista de las cuales una parte está en el exilio. Ese es el caso de los oficiales carlistas catalanes José Borges y Rafael Tristany, ${ }^{24}$ si bien antes de 1848 regresaron a España para participar en infructuosos intentos de reanudar el conflicto en la misma extensión e importancia que tuviera en 1833-1840. Una empresa que como sabemos nunca llegó a representar una verdadera amenaza, una alternativa poderosa y real, frente a la hegemonía liberal en España la cual desde entonces fue la base de todos sus gobiernos hasta la segunda década del siglo XX. A diferencia del legitimismo italiano y de otros movimientos contrarrevolucionarios europeos, el carlismo contó a nivel regional con el apoyo directo de grupos sociales que le permitieron sobrevivir periódicamente en sus alzamientos armados, si bien, no será hasta la revolución española de 1868 cuando esté en condiciones de provocar una nueva guerra civil de grandes dimensiones provocando la III Guerra Carlista entre 1872 y 1876 En este caso que acabamos de comentar, debemos destacar la presencia de borbones italianos que, ya perdida prácticamente la lucha contra la unidad italiana, y destronados de sus cargos nobiliarios, apoyaron la coronación carlista. Nos referimos al duque de Parma, el conde de Caserta y el duque de Bardi. Ello nos demuestra la férrea unión y solidaridad que se daba entre ambos movimientos absolutistas y reaccionarios europeos.

Las razones para la participación del carlismo en Italia pueden concretarse en el alejamiento del teatro bélico del suelo español, la propia crisis interna del movimiento en distintas opciones

24 Cuyas memorias están recogidas y publicadas en Juan MAÑÉ Y FLAQUER y Joaquín MOLA Y MARTíNEZ: Historia..., y se complementan con información archivistica obtenida de la bibliografía itade distinto material archivistico publicado en Italia al que gracias a la inestimable ayuda, generosidad y profesionalidad de Franco Manzione, del Archivo estatal de Salerno he tenido, generosidad y profesionalidad de Franco Manzione, del Archivo estatal de Salerno, he tenido acceso. degli Stato. Tribunalli militari straordinari, Roma, Ministerio de Bienes Culturales y Ambientales, 1998, y Rento DENTONO: Guida alle fonti per la storia del brigantaggio postunitario conservate negli Archivi di Stato, Roma, Ministerio de Bienes Culturales y Ambientales, 1999. más o menos reaccionarias, más o menos reformistas, en donde el conocido caso del general Maroto y la firma del tratato de Paz con el general Espartero en Vergara da buena cuenta de ello. También hay que añadir a esta lista de causas, la propia disgregación del movimiento producida por el exilio, así como las malas condiciones del mismo para quienes no se encontraban en la cúspide del movimiento. ${ }^{25}$ Todo ello sin menoscabo de su apoyo incondicional a la causa del monarca legítimo, el apoyo al catolicismo ultramontano impulsado por Pío IX y exagerado por buena parte del clero español, lo cual, raya en una especie de fanatismo romántico, ${ }^{26}$ no carente de venganzas político-personales por el fusilamiento de ancestros, y una voluntad tenaz ante los ideales defendidos en suma. No teniendo como causa principal del trabajo desentrañar las razones principales y las motivaciones, creemos sensato exponerlas todas como un conjunto de explicaciones que razonen la conexión entre el carlismo y el legitimismo italiano.

Sea como fuere, lo cierto es que entre 1840-1859 Italia fue un destino para los soberanos que fueron víctimas de la revolución y para una parte de sus seguidores, como ya comentamos. Además de los lazos de filiación dinástica o ideológica -denpendiendo de los casosque pueden explicar esta recepción, pensamos que a la sazón era una de las zonas más ricas de la "península italiana" y una de las regiones más grandes de lo que luego fue el reino de Italia, por lo que no obstante parecía un destino lógico de acogida. Es destacable saber que en el caso del exilio español de esta época mientras la mayoría de los exiliados se inscriben dentro de la población pobre, empobrecida más bien, en sus países de bienvenida por el abandono de sus riquezas españolas, fueron los elementos de la oficialidad carlista los únicos que pudieron elegir otro destino distinto al francés y a su mercado laboral, destino de muchos exiliados puesto que los subsidios otorgados por el Estado vecino no eran suficientes para la subsistencia como vimos en el caso de Borges.

Algunos ejemplos de este primer exilio, llamémosle elitista, los hallamos en el caso napolitano del conde de Montemolín en 1850. Este hijo del pretendiente Carlos María Isidro y por ende pretendiente al trono español desde la renuncia de su padre en 1845 , se casó con una hermana del rey de Nápoles Francisco II, el cual para intentar buscar una solución al conflicto creado con España a raíz de esta unión familiar y política e intentar mantener su reino al margen de las guerras europeas que tenían al liberalismo revolucionario como protagonista y inevitable telón de fondo continental y occidental, comprometió a su yerno a renunciar a toda actividad política en sus territorios. Un hecho del que el embajador Bermúdez de Castro tuvo más que sospechas, evidentes pruebas de su incumplimiento, como las posteriores intentonas golpistas del pretendiente prueban fehacientemente. Sin embargo no podemos dudar de las verdaderas intenciones de la corona napolitana, si consideramos que al general Cabrera se le prohibió directamente la entrada en el reino del sur de Italia, por ser uno de los líderes carlistas más temidos por los liberales españoles, aunque fuera una censura que no afectó a otros personajes secundarios como veremos a continuación si bien no era fácil su control pues lo normal era que viajasen con una falsa identidad. ${ }^{27}$ En suma, parece que la política napolitana

25 Pensemos que un militar de carrera como Borges, famoso por su ardor en el campo de batalla, terminó trabajando como restaurador de libros en Francia antes de viajar a Italia. Véase Francesco MOLFESE, op. cit, p. 101. Por otro lado, parece que se empeñó tanto en esta labor que con la ayuda de algunos legitimistas franceses puso su propio taller donde pudo dar empleo a otros colegas. Juan MAÑÉ Y FLAQUER y Joaquín MOLA Y MARTÍNEZ: Historia..., p. 355.

26 Como indica Alfonso BULLÓN DE MENDOZA: "El legitimismo europeo, 1688-1876", en Stanley G. PAYNE (dir.): Identidad y nacionalismo en la España contemporánea, el Carlismo, 1833-1975. Madrid, Colección Luis Hernando de Larramendi, 1996, p. 196, y autores que están en otras líneas de planColección Luis Hernando de Larramendi, 1996, p. 196, y autores que estan en otras lineas de plan-
teamiento han constatado como el caso de Eric HOBSBAWN: Rebeldes primitivos: estudio sobre las formas arcaicas de los movimientos sociales en los siglos XIX X XX, Barcelona, Crítica, 2001.

27 Por ejemplo, José Borges tomó el seudónimo de José Granollers, si bien el cónsul español controló

Por ejemplo, Jose Borges tomó el seudonimo de Jose Granollers, si bien el consul español controló 
no fue monocorde en todo el periodo tratado y quiso en todo momento nadar y guardar la ropa, como se suele decir popularmente, frente a sus intereses como reino independiente y frente a la alianza con la monarquía isabelina y el legitimismo carlista.

Antes de referirnos a los casos de Borges y Tristany, tal vez los dos líderes carlistas más destacados en la defensa del legitimismo borbónico italiano y en la defensa del papado aunque no fueran los únicos "facciosos", como se les denomina en la documentaciòn liberal del momento, involucrados, debemos tener en cuenta que la fragilidad del poder pontifical frente a las revoluciones liberales italianas fueron el motivo de una serie de operaciones militares europeas en suelo itálico. Bien se tratase de movimientos oficiales como en el caso de España en 1849, donde curiosamente el líder de esa expedición era el general liberal Fernández de Córdova, el mismo que resultó vencedor en la primera contienda carlista, o bien se tratase de una serie de proyectos de legiones extranjeras integradas por voluntarios católicos españoles, que nunca llegaron a crearse en la práctica y por cuyo motivo se concluyó con la inclusión del carlismo en el bandolerismo legitimista del sur de Italia, lo cierto es que todas las experiencias investigadas tuvieron un denominador común: la defensa de los intereses de la Iglesia catòlica bajo el mandato de Pío IX.

Partiendo ahora de esta segunda intervención de la década de 1860, una vez que el gobierno moderado de España se declarase neutral en las contiendas que asolaban el territorio italiano, destacaría el papel del general carlista y catalán José Borges, quien exiliado en Francia no dudó en ir a Roma con un proyecto para crear un cuerpo de voluntarios españoles basado en el modelo ya seguido por el batallón franco-belga y los irlandeses de San Patricio. Su oferta fue recibida con buenos modos y sin recelos pero igualmente rechazada, pues no se quiso alertar al gobierno español permitiendo el rearme y la composición de un cuerpo de voluntarios carlistas en el Estado pontifical, que a todas luces era lo que hubiera sucedido. Además hay que considerar la importancia que este hecho hubiera tenido en las relaciones entre Roma y Madrid, pues de haberse validado y originado sin duda alguna se hubiera puesto en jaque lo acordado entre Pío IX e Isabel II en 1851 quienes habían restablecido la normalidad y el buen entendimiento entre el jefe del catolicismo y el liberalismo español en el gobierno. Lo que más sorprende, incluso teniendo en cuenta este hecho, es el escaso número de españoles en general, y de carlistas en particular, que formaron parte del ejército de Pío IX, el cual se estima en el total del periodo en unos 100 voluntarios; menos de un $1 \%$ del total de soldados. Tal fue el exiguo número de combatientes carlistas bajo el mando de Borges, que por momentos ocho hombres le parecieron "igual de valiosos"-la exageración es nuestra para mostrar la poca capacidad militar- que un millar de soldados, aunque esperarlos supusiera poder ser capturados por los guardias nacionales o adentrarse en terrenos naturales desconocidos:

Los hombres que me habían ofrecido no llegan, voy creyendo que sean imaginarios o que desconfían de nosotros. (...), los ocho hombres que yo esperaba no han llegado (...) S yo hubiese desembarcado tres semanas antes hubiera encontrado 1.067 hombres y 200 caballos (...) y esta fuerza bastaba para hacerles comprender lo que valen. (...) Por mi mala suerte cuando lleguè a aquel punto estaban desbandados. ${ }^{28}$

punto esta información escapaba al gobierno meridional italiano. Por otro lado, Borges paso un año junto a Montemolín en Nápoles en 1850, si bien su actuación militar narrada en su diario es de 1861. 28 Es una constante de Borges lamentarse de ser pocos en número para imponerse, no solo a las fuerzas italians sino también a los lideres brigantes como Crocco. Incluso por momentos suspiraba por tener "trescientos hombres a su mando para dar la vuelta a la patética situación en que se haba por sus tropas". Hay varios y distintos momentos en que podemos conocer sus deseos en esta materia. Las citas ". Juy vañ y distintos momentos en quepodemos conocer sus
Pese a ello, no cabe duda de que dentro de la relación entre el carlismo y la resistencia armada contra el reino de Italia en el mezzogiorno, el movimiento nacionalista italiano movilizó en su contra a los carlistas en tanto en cuanto la afirmación de dicho nacionalismo resultó incompatible con el legitimismo tradicional y rápidamente se asoció a una empresa secularizadora de la política, la economía y la sociedad. De este modo, el ideal de solidaridad al que apelamos al inicio se mostró a favor de la causa del rey de Nápoles y de la Iglesia católica en su lucha contra las tropas revolucionarias de Garibaldi. Por un lado mediante ofertas de alistamientos como la de los hermanos Tristany quienes en febrero de 1861 creían "posible y aún fácil reunir en el mediodía de Francia 500, 800 o 1.000 españoles que nos seguirán si se ofreciera el reconocimiento de sus grados y empleos". En esta misma carta se justifica su compromiso. Dice así:

Ya sabes cuántos sacrificios hemos hecho hasta aquí; sólo anhelemos continuarlos hasta dar la vida, si hubiera sido menester, en defensa de la causa de nuestro rey. La espada que empuñamos en España, volveremos a tomarla para combatir la legitimidad en dónde convenga: los revolucionarios son en todas partes los mismos, y sus planes siempre inicuos. La usurpación cometida contra el Augusto Rey de Nápoles pide una justa venganza, y tendremos a grande honor el cooperar por nuestra parte a ella. ${ }^{29}$

El hecho de haber cambiado el destino de Roma por el de Nápoles deriva de la cronología particular del carlismo español en donde las actividades conspirativas que terminan en fracasos, como la expedición liderada por el conde de Montemolín de la que ya dimos cuenta, y la muerte de su hermano y tercer pretendiente, aleja la idea de una acción inmediata en España y deja a numerosos carlistas sin objetivos propios por los que luchar. También sabemos que en el caso de Borges, las distintas comunicaciones entre los pretendientes con su prima Isabel I buscando mejorar las relaciones le causaron un profundo malestar. Así, el compromiso con otro soberano legitimista aparece como la única manera honrosa de defender y continuar el combate por sus ideas contrarrevolucionarias. Este es también el argumento del general Borges antes de dirigirse tras su experiencia como brigante, sin éxito, a Roma y ser prendido y fusilado:

Yo seguiré marchando ínterin pueda hacerlo, pero si la voluntad de Dios es que muera, dejaré estos apuntes a Capdevila, (...) y si Capdevila también muriese, deberá dejarlos a comandante Landet para que éste haga lo que Capdevila debió hacer. Me interesa mucho que este escrito llegue a manos del rey para que sepa Su Majestad que muero sin llorar la pérdida de mi vida, que tengo la honra de ofrecer sirviendo a la causa de la legitimidad. ${ }^{30}$

Por otro lado, y buscando razones más positivas, hay que tener en cuenta que así como la figura y el mito popular de Garibaldi hizo que algunos españoles se insertaran en las filas de los camisas rojas, jóvenes aventureros, demócratas y republicanos en su mayoría, que veían en Garibaldi a un ilustre jefe revolucionario, tuvo el efecto contrario en las filas carlistas, que veían en la resistencia napolitana el combate decisivo entre el Antiguo Régimen y la nueva era revolucionaria. De hecho Borges anotó en su diario que su mala fortuna en lo rerefrente a sus estrategias y tácticas, su circunstancia -como escribió Ortega y Gasset- "me roba una gloria, que hubiese constituido la felicidad de toda mi vida".3

Las insurrecciones populares del sur de Italia contra el nuevo gobierno alentaron, más si cabe, estas ideas. Según Benedetto Croce se trataba de un romanticismo legitimista. ${ }^{32}$ Además desde

29 Carta de Tristany a su hermano mandada desde Francia en febrero de 1861. Archivio di Stato di Napoli, Archivio Borbone, b. 1135, f. 300 .

30 Juan MANE Y FLAQUER y Joaquín MOLA Y MARTÍNEZ: Historia..., pp. 390.

31 Ibid, pp. 385 .

32 "Uno dei più rinomati cabecillas delle guerre carliste, coraggioso esperto di guerra, sincero e devo-

to uomo", Benedetto CROCE: Uomini e cose della vecchia Italia, Bari, G. Laterza, 1956., pp. 307 y ss. 
un punto de vista más materialista, los carlistas eran buenos y viejos soldados más que jóvenes aventureros inexpertos, y en palabras de agentes borbónicos: "la sobriedad y la discreción de los españoles, hacen que su alistamiento sea preferible bajo muchos aspectos frente al de los franceses", pese a que en la pràctica el jefe brigante Crocco prefirió siempre al general francés Langlois por encima de Borges, quien por su parte opinaba de éste superior que "se da los aires de un general pero obra como un imbécil"y que actuaba de manera "muy intrigante". ${ }^{3}$

La publicidad dada en España a esta expedición de Borges hizo que incluso tras su muerte junto a nueve compañeros, no se pusiera inmediatamente fin al reclutamiento de voluntarios y solo la falta de recursos hicieron fracasar el esperado desembarco de tropas que mantenía esperanzada a la guerrilla bajo el mando de Rafael Tristany quien en 1862 comandaba las tropas en el norte del extinto reino napolitano. Vista la nulidad de la victoria legitimista, regresó tras su captura en 1863 a su patria para continuar desde alli la lucha y la resistencia. Para ajustarme al espacio dado para radactar este texto, terminaré este punto haciendo un balance general de la participación carlista en el brigantaggio y señalando las conclusiones generales de los propios voluntarios con sus jefes a la cabeza. El diario de operaciones de Borges durante su campaña en el Mediodía, pretendía, además de lo ya señalado, abrir los ojos de la opinión pública europea ante las diferencias entre el ideario carlista de la realidad del bandolerismo local, que en todo momento tacha de ladrón, inmoral y desordenado. El general español describe en sus memorias el aislamiento que notó tras llegar a Calabria, la desconfianza de las partidas autóctonas preocupadas por conservar su botín, las miserias de su refugio en las montañas siempre huyendo de la persecución enemiga, la actitud de los campesinos en Basilicata que por un lado le daban comida y por el otro le denunciaban ante la guardia nacional, que al mismo tiempo lo recibían amistosamente como le intentaban robar sin pudor. Unas gentes que, para el general carlista, son legitimistas de corazón pero no quieren terminar encarcelados, muertos, o reprimidos psicológicamente al ver arder sus casas y heridas a sus familias por la represión de las tropas italianas.

Al unirse a la partida del famoso, y autotitulado general, Crocco, quien también en sus memorias critica abiertamente al general español llegando a decir que le causó problemas incluso después de muerto, Borges le reprocha su falta de organización militar y la desobediencia de sus consejos u órdenes, así como denuncia la cobardía de los bandidos que huyen en cuanto ven soldados enemigos y que cometen injusticias en las localidades conquistadas teniendo una actitud y un comportamiento más tipico de ladrones que de soldados y caballeros. Sin embargo, Borges ve nexos de unión claros entre sus aspiraciones y las del pueblo meridional italiano, pues su idealismo estuvo intacto en todo momento: el pueblo llano aparece como bueno y monárquico así como enemigo absoluto de los piamonteses y de los ricos, que son finalmente los malos de su relato. Lo único que lamenta es la falta de más fuerza militar que animara a los campesinos y les hiciera perder el miedo al fracaso del mismo modo que le hubiera permitido ajustar las cuentas con los brigantes que le ignoraban o despreciaban militarmente hablando. Al tenor de estas informaciones y con la amplia perspectiva que nos da el tiempo pasado, no resulta raro que Crocco dijera que Borges era "un pobre iluso venido de su país lejano", y que cuando se dio cuenta de que no iban a llegar más tropas en auxilio del español le abandonara a su suerte y aconsejara al resto de la banda hacer lo mismo. ${ }^{34}$

Tristany se enfrentó con unos problemas parecidos y con la misma idea peregrina de cómo moralizar y disciplinar a la tropa que pretendía liderar. Sobre todo en su rivalidad con el jefe brigante Chiavone en los Abruzos, lo que llevó al catalán al fusilamiento de todos los que se negaran a seguir sus órdenes, Chiavone incluido, un hecho que le enemistó con los bandidos

33 Juan MAÑÉ Y FLAQUER y Joaquín MOLA Y MARTÍNEZ: Historia..., pp. 395-400.

34 Carmine CROCCO: Autobiografia, 1889 , editada por Eugenio MASSA, Gli ulitimi briganti della Basi-

licata. Carmine Donatelli Crocco e Giuseppe Caruso, Melfi, 1903, pp. 655 y ss. e hizo imposible la unión de fuerzas contra el Piamonte, pero que evitó desórdenes innecesarios y la temida relajación de la conducta ${ }^{35}$. Borges parece que quiso hacer lo mismo pero no le era posible. En definitiva, las visiones son muy parecidas entre sendos compatriotas, porque ambos dibujan con palabras un pueblo fiel a Francisco II pero que necesita de oficiales que lideren su insurrección más o menos latente. Sin embargo, sobre el terreno Tristany limitó mucho más sus operaciones a pequeños asaltos contra destacamentos aislados de la frontera dando muestras de un idealismo más pragmático que el de Borges. Tristany dejó claro que se retiró de la lucha italiana tras haber estado un año entero esperando más apoyos que nunca llegaron ni iban a llegar. Su salida arrastró a la del resto de carlistas restantes en el sur de Italia hasta 1869, y como Sarlin ha estudiado buscando "una salida airosa" y con ella firmando el punto y final del apoyo exterior a las revueltas meridionales, pero no así de la rebelión antiunitaria, que siguió activa más tiempo ${ }^{36}$. Además, Tristany y sus acólitos participarían en la III Guerra Carlista donde aparecieron famosos personajes de la aristocracia borbónica italiana como ya quedó dicho.

\section{Conclusiones}

Posiblemente haya dejado en el tintero más aspectos que los que hubiese querido analizar dada la extensión del problema histórico presentado y la amplitud de la fuentes estudiadas, los cuales tendrán que ser solventados en otras investigaciones futuras, si bien confío en haber explicado bien los ejes temáticos que apunté en la introducción. Así, que repasaré en este apartado final de las conclusiones, las ideas motrices de mi estudio y sus resultados principales. Como parece razonable dada la magnitud del tema propuesto y su complejidad esta cuestión necesita de más investigaciones ya que es mucho el material para su estudio, y debe abrirse a una historiografía internacional para escapar de la rigidez de las historiografías nacionales de España y de Italia, intentando conjugar en todo momento aspectos e informaciones complementarias. Pero también a veces contrarias por el distinto uso de las fuentes militares analizadas. Por eso no se trata en ningún momento de hacer afirmaciones contundentes y definitivas, sino al contrario, ofrecer argumentos útiles y elementos novedosos para la discusión científica de nuestro siglo XXI, donde igualmente que hubo debate entre las razones del fracaso legitimista postunitario entre Crocco y Borges, distintos historiadores pergeñamos distintas explicaciones para un mismo hecho. Por ejemplo, como hecho más evidente y que refleja la disparidad de criterios, dependiendo del autor estudiado vemos que cambia la forma de referirse a los brigantes, bien como guerrilleros, bien como bandoleros, o simplemente como criminales, siendo la categorización de este fenómeno un asunto controvertido en sí mismo y que encierra algo más que una denominación tradicional o neutra. Como cuando la historiografía y la documentación liberal denomina facciosos a los carlistas. Tambièn autores como Puchol Sancho, son màs optitmistas y positivos que quien suscribe este trabajo a la hora de valorar la actuación española de mitad del siglo XIX.37

En el caso del general Fernández de Córdova, parece evidente que no podemos seguir al pie de la letra sus escritos, un error que comete en parte Aldo Albònico, bien sea por la distancia del momento de vivirlos, de recordarlos y escribirlos, ya que normalmente las memorias se escribían en años próximos a la vejez salvo excepciones, o bien porque trata de darse más relevancia que la que realmente tuvo. Por otro lado, tampoco podemos seguir a pies

35 Alessandro BIANCO DI SAINT-JORIOZ: Il brigantaggio alla frontiera pontificia dal 1860 al 1863 . Studio storico-politico-statistico morale-militare, Milán, 1864, pp. 187 y ss.

36 Simon SARLIN, pp. 237.

37 Agradezco a la UPC que me hayan prestado amablemente la tesis doctoral de dicho historiador para su consulta y estudio. Vid. Vicente PUCHOL SANCHO: La intervención militar española en la restauración de Pio IX (1848-50), Tesis doctoral, UPC, 2009. 
juntillas todo lo que se dice sobre él por parte de la historiografía más tradicional italiana,ya que le achacaron muchos más fallos operativos que los que realmente parece tuvo tras haber analizado fuentes, memorias e historias, que hacen más brillante la táctica de Garibaldi en sus movimientos militares.

En el caso de las crónicas carlistas, parece claro que se trata de unas memorias que quieren relatar y registrar los hechos sin muchos más objetivos que planear un levantamiento que nunca ocurrió, la penetración de refuerzos, y dejar testimonio y constancia de lo que pasó visto desde su subjetividad. Desde luego la influencia formal y estilistica de Julio César, autor de cabecera para Borges, es evidente. En todo caso, de la lectura y estudio del diario de Borges se comprende que fue incapaz de entender la rebelión del pueblo meridional y a sus jefes, esos "bandidos reaccionarios", la cuestión de la terminología no es baladí como dijimos, tanto o más que las élites italianas unitarias que sólo vieron en este hecho una manifestación de la delincuencia común y del pillaje meriodional tradicional. Aún así, no sin acierto autores consagrados como Albònico dejan claro que el fracaso no puede achacarse a la falta de entendimiento y cooperación entre los líderes brigantes y los militares carlistas, porque materialmente era imposible que pocos hombres desorganizados y con tan pocos recursos de todo tipo pudieran vencer militarmente a un ejercito nacional. ${ }^{8}$ La realidad es tozuda a este respecto.

Pese a que cuantitativamente la participación carlista en Italia es muy pequeña lo cierto es que cualitativamente nos da ejemplo del alto grado de compromiso entre los contrarrevolucionarios y al mantenimiento de una solidaridad internacional, como comentamos en la introducción. Visto de esta manera, la categoría de guerra civil en torno a la tensión interna y externa de revolución-contrarrevolución puede constituir en los países de la Europa del sur España, Portugal, Italia y Francia, así como en naciones de otras latitudes, una clave para analizar y volver a pensar en otros términos la historia del siglo XIX. La longevidad del carlismo es una marca singular dentro del conjunto de movimientos que compusieron la internacional blanca, lo cual puede explicarse por su poca firmeza programática, capacidad de adaptación a los hechos consumados, las adhesiones recibidas por distintos extractos sociales -sobre todo por el catolicismo ortodoxo-y su capacidad de reproducción cultural. Unas señas de identidad vistas por Marx hace dos siglos:

El tradicionalismo carlista tenía unas bases auténticamente populares y nacionales de campesinos, pequeños hidalgos y clero, en tanto que el liberalismo estaba encarnado en el militarismo, el capitalismo (las nuevas clases de comerciantes y agiotistas), la aristocracia latifundista y los intelectuales secularizados. ${ }^{39}$

En lo relativo a las fuentes, parece claro que la historiografía y la archivistica italiana han desarrollado mucho más este tema que la española, a pesar de que los diarios de Borges y Tristany no pueden encontrarse en lengua itálica. Seguramente, este hecho ha facilitado sobremanera que la escasa bibliografía que se ha ocupado de la cuestión de las fuentes hayan prescindido de ellas, basándose más en estudios clásicos y en la propia investigación de otro tipo de documentos militares. A ese respecto debemos entender que la participación carlista en las luchas italianas no abarcaron ni todo el espacio ni mucho menos el tiempo, ya que el movimiento "antiunitario" pervivió, al menos, hasta el siglo XX, y todavía hay asociaciones y partidos políticos minoritarios que ponen en tela de juicio dicho proceso político, pero también historiográfico y de memoria colectiva nacional. Por otro lado, los diarios nos ofrecen una información mucho más rica, amplia y en cierto modo detallista sin ser extensa, que la que ca- bría esperar en un principio cuando propuse este tema para participar en la mesa de historia militar. Pues al mismo tiempo en que se narran las aventuras y desventuras de los brigantes por las montañas meridionales de Italia, cuyos recorridos pueden seguirse más o menos en la actualidad, se nos ofrece un panorama descriptivo del territorio, de sus gentes, de los hechos que suceden diariamente entre los bandos y los pensamientos de los autores.

En último lugar, destaco que de la misma forma en que contrastar el contenido de los diarios de operaciones con la documentación ad hoc para el tema propuesto es muy útil y necesario de cara a entender mejor la veracidad de los hechos narrados y recogidos por la historiografía, del mismo modo, y a la inversa, los trabajos ya publicados tienen que apoyarse en este tipo de fuentes para analizar mejor los hechos y no caer en errores anteriores "arrastrados" de autor en autor. Sin duda alguna, si yo mismo tuviera que reescribir algún trabajo anterior, de los cuales ya he dado la referencia pertinente, matizaría más algunos aspectos de los que he aprendido a lo largo de esta investigación. Por eso, valga este articulo para corregir esos posibles desajustes y complementar de forma mas concreta aspectos que en otras ocasiones no he podido incluir en mis primeros estudios, si bien, la base global de textos anteriores sobre el tema de España frente a la Unificación de Italia, son piezas sustentantes claves para poder continuar haciendo aportaciones más amplias como la presente, y así profundizar más y mejor en el estudio de esta cuestión. 


\section{LA SEGUNDA GUERRA SINO-JAPONESA.}

\section{EL CONFLICTO OLVIDADO 1937-1945*}

Alejandro Muñoz Rumbero

Universidad Autónoma de Madrid

\section{Antecedentes}

El interés de Japón sobre China estaba presente desde 1868, momento en que los japoneses buscaron impulsar una nación poderosa en diversos aspectos como la economía, el ámbito militar o la influencia política lejos de sus fronteras.' Japón unió a los anteriores intereses mencionados la búsqueda de una seguridad en todos los ámbitos que se configuraría como clave para fomentar su expansionismo cultural y territorial. Las primeras operaciones militares que permitieron tomar las islas más próximas (las islas Kuriles al norte y las Ryukyu al sur) contaron con el beneplácito del gobierno y los nacionalistas radicales. Desde su conquista los principales objetivos japoneses viraron hacia el continente asiático, para ser exactos en Korea y el territorio chino.

Japón buscó convertirse en una potencia hegemónica, tratando de convertirse en un país colonial aplicando un modelo que había dado resultado en el mundo occidental. Según Jansen, a finales del XIX Japón necesitaba convertirse en una potencia imperialista para poder, tanto emular a Occidente, como competir con él. ${ }^{2}$ La motivación de marchar sobre China se justificó por la superioridad que observaban frente a los chinos, estos eran más débiles, parecían más atrasados y qué mejor que alguien inferior para redondear la idea del imperio japonés. La forma de expansión y de creación de un imperio no albergaba ningún tipo de opción, sólo se podría ejecutar mediante el expansionismo militar.

Esta superioridad nipona sobre el pueblo chino impulsó la creación de un modelo económico colonial, de carácter teórico, donde China y otros territorios adyacentes serían esenciales para obtener recursos materiales y económicos, necesarios para que Japón llevase a cabo su desarrollo industrial, económico, militar y político. Por ello, el nuevo gigante asiático, no dudó en disputar por las armas cualquier territorio sobre el que tuviera interés, como se demostró un prime enfrentamiento bélico: la Primera Guerra Sino-Japonesa 1894-1895, donde la victoria le otorgó unos acuerdos de paz favorables, ratificados en la Paz de Shimonoseki. La Paz equiparó a Japón en todos los sectores, respecto a las potencias europeas. Del segundo conflicto bélico del perioen todos los sectores, respecto a las potencias europeas. Del segundo conflicto bélico del perio-
do, la Guerra Ruso-Japonesa, también salió victorioso ya que demostró su desarrollo técnico a nivel militar, a la par que su capacidad de combate frente a cualquier ejército occidental. La guerra quedó resuelta por el Tratado de Portsmouth, por el cual Japón adquirió beneficios territoriales en la región de Manchuria y las concesiones del ferrocarril Surmanchuriano.

En líneas generales, Japón vivía una época de auge gracias a la Restauración Showa. Asistía al desarrollo industrial, demográfico y se veía capacitado para llevar a cabo su expansión por el noroeste asiático, situándose en el plano internacional como el hegemón asiático.

Mis agradecimientos a la Profesora Angeles Hijano Pérez y a Sara Pardo Corral por la ayuda prestada en la corrección y adecuación del texto y por mostrar sus discrepancias y acuerdos que sin duda han ayudado a la mejora de la comunicación.

Paul. J. BAILEY: China en el Siglo XX, Barcelona, Ariel, 2002. pp.132.

2 JANSEN cf en Ibid., pp.132.
El país del sol naciente buscó hacerse con el control económico, político y militar de la región de Manchuria aplicándolo con un carácter monopolístico. El territorio de Manchuria, asociado las pretensiones que también se cernían sobre Mongolia, representaba casi 120.000 kilómetros de extensión y casi 28 millones de habitantes. ${ }^{3}$ Este territorio daría el espacio necesario para la población rural nipona que no tenía tierras y además ofrecía riquezas forestales, mineras y agrícolas. Por esos motivos, las inversiones japonesas en dicho territorio llegaron a representa un $82 \%$ del total de las inversiones en el extranjero. Con estos dos territorios, Japón organizaría un imperio continental, necesario para el desarrollo de la gloria y prosperidad nacional. ${ }^{4} \mathrm{~A}$ los motivos económicos se unió que Manchuria serviría para garantizar la seguridad geoestratégica japonesa poniendo punto y final a los problemas de Asia Occidental. ${ }^{5}$ Por último, estos territorios continentales servirían, bajo el pretexto de un interés comercial, para lanzar la invasión total de China. ${ }^{6}$ Peattie demostró que en 1930 Ishiwara Kanji, General del Ejército Imperial Japonés, predijo que Manchuria sería crucial para cualquier futuro esfuerzo bélico, en especial en esfuerzos hacia posibles enfrentamientos contra la URSS y Estados Unidos. 7

En China la situación era diferente. La inestabilidad política marcaba al país asiático. Los nacionalistas y sus adversarios, los comunistas, buscaban el relanzamiento de una nueva China, de un país poderoso desde todos los puntos de vista, tanto económico, como político y militar a la par que buscaba ganarse el respeto internacional. ${ }^{8}$ Pese a buscar un mismo ideal, sus mecanismos de obtención eran diferentes, como quedó demostrado a lo largo de la guerra contra la invasión japonesa. China fue testigo de La Larga Marcha Comunista y de la persecución de sus participantes por parte de los seguidores de Chiang Kai-shek, provocando múltiples enfrentamientos armados. Los acontecimientos mostraban de antemano el poco entendimiento entre las diferentes posturas y como ambas mantenían la ambición de regir un país con población eminentemente rural y donde los señores de la guerra aún tenían altas cuotas de poder.

Los problemas surgirían en la región de Manchuria, una región que cómo antes hemos comentado era de vital interés para Japón. Las tropas japonesas acantonadas en dicha región tendrían un papel fundamental en la creación o gestión de un incidente, el casus belli, que diera paso y justificara la invasión japonesa del territorio. El primer incidente sucedió en 1928; Zhang Zoolin, militar chino de corte comunista y que se hallaba de vuelta hacia su base, moría asesinado. Este acto provocó la inquietud en las fuerzas japonesas como en las del Guomindang, ya que no quedaba claro quien había ejecutado el asesinato, y dando paso a las especulaciones y cruce de acusaciones. La segunda crisis que sacudió la región sucedió en 1931. En esta ocasión la crisis fue creada por los oficiales de rango inferior japoneses que buscaron poder lanzar una gran ofensiva sobre el territorio todavía en manos chinas. ${ }^{9}$ La crisis vino provocada porque la línea de ferrocarri Surmanchuriano había sido objeto de un sabotaje. Ante el incidente el ejército japonés ejecutó una operación de castigo que permitió ampliar la esfera de operaciones e influencia en la región de Manchuria. En el mismo año establecieron el Reino del Manchukuo gobernado por un monarca títere, Puyi. Este acto confirmaba que Japón actuaba a partir de hechos consumados y que su interés por Manchuria no iba a desaparecer. Además demostraba la fuerte influencia y poder que tenían las tropas acantonadas en el continente respecto al gobierno de Tokyo.

Franz SCHURMANN y Oliver SCHELL: China Republicana. El nacionalismo, la guerra y el advenimiento del comunismo 1911-1949, México, Fondo de Cultura Económica, 1971. pp. 250.

4 Ibid., pp.249.

5 Peter ZARROW: China in War and Revolution 1895-1949, New York, Routledge, 2005. pp. 304.

6 Franz SCHURMANN y Oliver SCHELL: China Republicana ... pp. 256.

7 Paul. J. BAILEY: China en... pp.136.

8 Conrad SCHIROKAUER y Miranda BROWN: Breve Historia de la Civilización China. Barcelona, Bellaterra, 2011. pp. 368

9 Paul. J. BAILEY: China en ...., pp.137 
A partir de esa proclamación Tokyo se vio sometido a los designios del ejército de Kwantung que movió al régimen prácticamente a su antojo y tomando sus propias decisiones. Un año después de los hechos, y de ver como ni Estados Unidos ni Gran Bretaña respondían a las agresiones japonesas, Tokyo dio un paso más; en 1933 el ejército japonés lanzó otro ataque aumentando su poder a costa del Guomindang. ${ }^{10}$

A las acciones directas se sumó la acción diplomática del ministro de Exteriores que exigió a China que reconociese la preeminencia de Japón en el norte de China y que ambos colaboraran contra el comunismo. La acción diplomática se redondeó con los acuerdos de Pacto Anti-Komintern.

Pese a todos estos incidentes, la relación sino-japonesa siempre fue ambigua, ya que en muchos instantes de los años 30 y en décadas previas, habían sido buenas. Si bien hubo enfrentamientos bélicos o bien tensiones diplomáticas, algunos sectores japoneses, al margen en la mayoría de los casos de lo público, impulsaron la renovación de China, defendiendo una China moderna y democrática. Pese a estos movimientos, entre bambalinas el gobierno japonés enviaba mensajes oficiales de carácter arrogante, despreciativo e intentaba aumentar el poder y los privilegios en el continente.

Las bases para un posible conflicto armado estaban sentadas y en él, se enfrentarían dos modelos antagonistas.

\section{La guerra}

El porqué de la guerra ha sido planteado desde varios enfoques: Jansen planteó que Japón combatió para conservar sus derechos políticos y económicos en China; preservándolos contra el nacionalismo chino y contra una creciente influencia del Partido Comunista Chino." Storry propuso que la Segunda Guerra Sino-Japonesa fue el primer paso para crear un nuevo orden mundial asiático, que de la mano de China lucharía contra lo soviético y contra el modelo democrático anglosajón. ${ }^{12}$ Por último, Hsiung y Levine interpretaron el conflicto como un desarrollo bélico que trascendería la influencia asiática, y que tendría una incidencia plena en la Segunda Guerra Mundial. ${ }^{13}$

La tensión entre ambos países estuvo presente a lo largo de la década de los treinta y en 1937 explotó con el enfrentamiento del 7 de julio en el Puente de Marco Polo, situado en las cercanías de Pekín. Esta escaramuza se inscribía dentro de una serie de enfrentamientos comunes durante los años previos y que normalmente se produjeron en los alrededores de Beijing. ${ }^{14}$ Sin embargo, fue la chispa para encender el conflicto. Japón diseñó una estrategia para llevar a cabo una guerra dinámica basada en una conquista ágil y rápida, gracias a la acción de infantería y caballería combinada y, una vez obtenida la victoria, buscar la negociación posterior con el gobierno chino. Pero todo sucedió por otros derroteros, la guerra se dilató y enquistó. Hubo, es innegable, una conquista territorial rápida del ejército nipón frenada a duras penas por el ejército chino cumpliéndose el primer axioma, pero el segundo principio, el de la negociación nunca se cumplió.

La guerra se inició tras dos rearmes, el japonés llevado a cabo en 1936, y el del ejército chino durante 1934, relacionado con el proceso de eliminación de la resistencia comunista. Durante el proceso de rearme, los japoneses habían reforzado sus guarniciones en China enviando otras tres divisiones poco antes del incidente, como refuerzo para la guerra que se fraguaba.

10 Ibid., pp.137

1 JANSEN cf Paul. J. BAILEY: China en ... pp.131.

12 STORRY cf Ibid., pp.131.

13 HSIUNG y LEVINE cf Ibid., pp.131.

14 Peter ZARROW: China in ...., pp. 305.

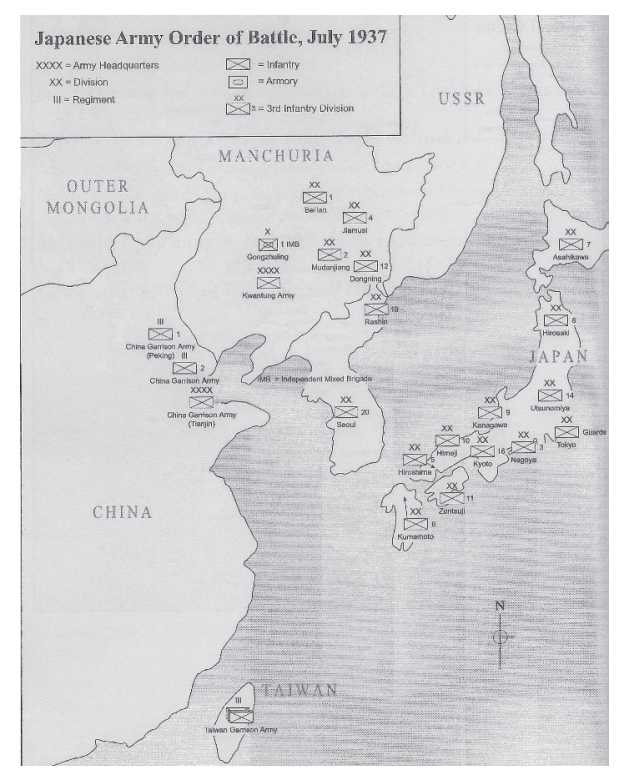

Map. 01 Disposición de las tropas japonesas en el momento inmediatamente posterior al incidente del Puente de Marco Polo. (Fuente: Mark PEATTIE, Edward DREA Y Hans VANDEVEN (coords):The Battle for China: Essays on the Military History of the Sino-Japanese War of 1937-1945. Stanford, Stanford University Press, 2010.)

Ambos ejércitos plantearon la guerra con dos tácticas muy diferentes, Japón buscaba movilizar rápidamente a sus tropas y llevar a cabo maniobras ágiles mientras que las tropas chinas confiaban en la posibilidad de aguantar a la defensiva y que el conflicto se dilatara en el tiempo permitiendo la entrada de actores occidentales. Por este motivo Chiang Kai-shek, encargado de la defensa de China, envió como primera fuerza de choque a tropas entrenadas por oficiales alemanes, haciendo entender que unas tropas cualificadas mantendrían mejor el combate ante un ejército profesional. La región de Xuzhou fue la elegida para el despliegue de este ejército.

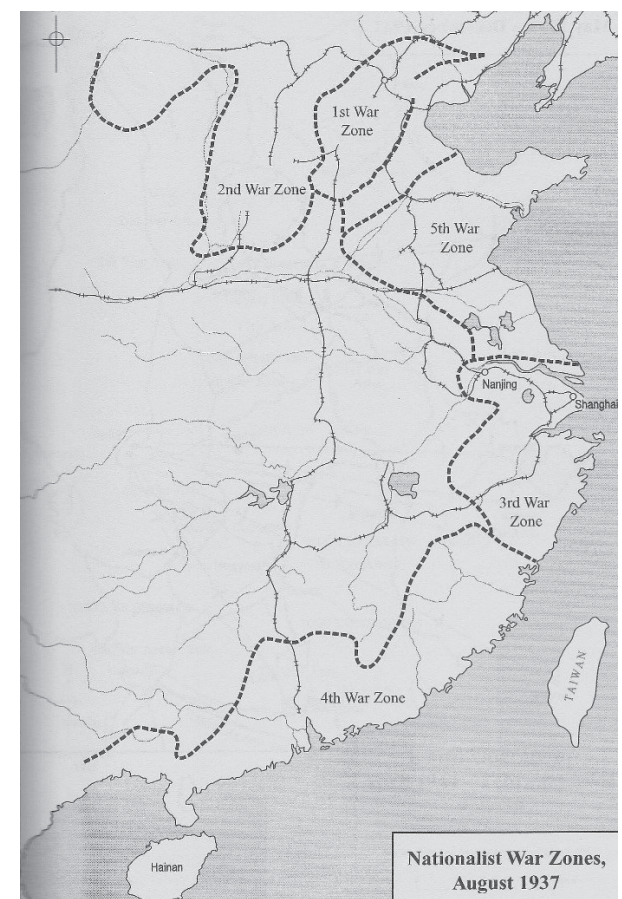

Map. 02 Distribución de las zonas de guerra chinas, lugares donde se llevaría a cabo la defensa. (Fuente: Mark PEATTIE, Edward DREA y Hans VAN DE VEN (coords.):The Battle for China: Essays on the Military History of the Sino-Japanese War of 1937-1945. Stanford, Stanford University Press, 2010.) 


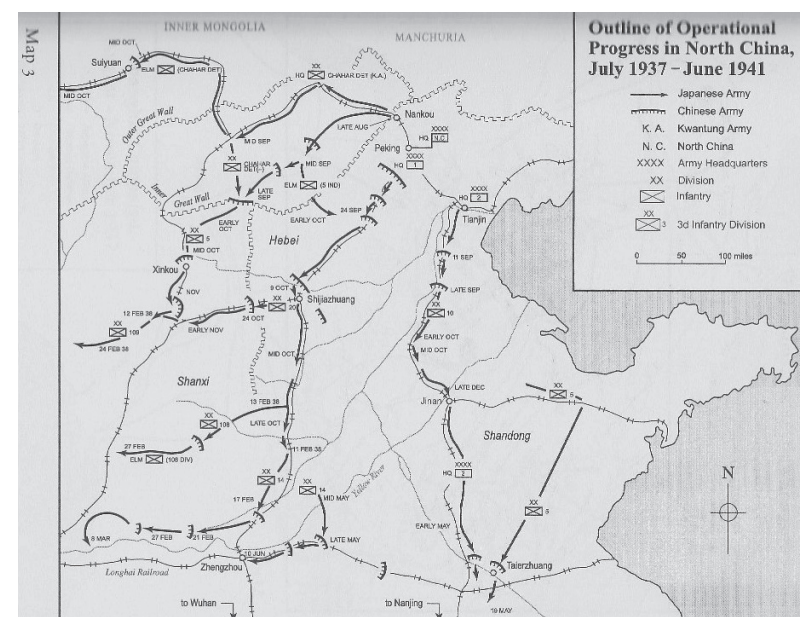

Map. 03 Principales rutas de penetración y operaciones japonesas 1937-1941. (Fuente: Mark PEATTIE, Edward DREA y Hans VAN DE VEN (coords.):The Battle for China: Essays on the Military His-
tory of the Sino-Japanese War of 1937-1945. Stanford, Stanford University Press, 2010.)

Pero la táctica de alejar y contener al ejército japonés lejos de las principales bases chinas, fue inútil, ya que los japoneses obtuvieron victorias fáciles sobre las tropas del ejército chino. Ante esta primera derrota los chinos volvieron a intentar frenar a los japoneses, lejos de sus principales ciudades, sosteniendo el frente pese a las bajas que tuvieron. La defensa de sus centros de poder era clave y cuanto más lejos se instalasen los frentes de batalla, más beneficiosa sería para la estrategia china.

Para la táctica japonesa eran vitales las líneas de ferrocarriles como la línea Tianjin-Pukou, y la línea Peking-Wuhan, ya que les permitirían cubrir las rutas de despliegue y sus maniobras podrían dirigirse hacia el este y al oeste de manera rápida. La toma del ferrocarril también formaba parte de la estrategia de un rápido despliegue de sus ejércitos en territorio continental. El Primer Ejército del Japón comenzó su movilización hacia el sur y el Segundo Ejército haría lo mismo, girando posteriormente hacia el oeste para ejecutar una maniobra de pinza. Estas operaciones fueron gestionadas por la NCAA (North China Area Army). ${ }^{15}$

Estos primeros movimientos y, en general, toda la guerra estuvieron marcados por la geografía china, que se presentó como favorable para el ejército japonés. Esta ventaja permitio grandes avances de los cuerpos de infantería y caballería que optarían por eliminar las tropas chinas, realizar grandes maniobras de flanqueo y, en último lugar, movimientos de pinza. Pero la geografía también perjudicó a los ejércitos japoneses debido a que, por su número limitado de soldados, eran poco eficaces en la creación de bolsas y aislamiento de los ejércitos chinos en los grandes llanos, permitiendo por ello que muchas retiradas chinas fuesen altamente exitosas. Por este motivo, se exigió desde el gobierno al IGHO ${ }^{16}$ que las maniobras fueran de penetración profunda, quedando en segundo lugar la creación de bolsas y aislamiento. ${ }^{17}$

La guerra del lado japonés quedó, en los primeros instantes, en manos de la fuerza aérea que actuaría en el norte de China, mientras que las fuerzas navales actuarían en el centro y sur. ${ }^{18}$ Novedoso fue el castigo del territorio chino mediante bombardeos selectivos ejecutados por las fuerzas aéreas. La superioridad aérea japonesa estuvo presente a lo largo de todo el

15 Edward J. DREA y Hans VAN DE VEN: " An overview of Major Military Campaigns during the Sino-Japanese War, 1937-1945" en Mark PEATTIE, Edward DREA y Hans VAN DE VEN (coords.):The Battle for China: Essays on the Military History of the Sino-Japanese War of 1937-1945. Stanford, Stanford University Press, 2010. pp. 28

16 Las siglas significan Imperial General Headquarters.

17 Edward J. DREA y Hans VAN DE VEN: “ An overview of Major Military Campaigns during...,pp.29.

18 Ibid., pp.29. conflicto otorgando una ventaja estratégica al ejército japonés, ya que permitió ataques tanto de corto como de largo alcance y cubrió los avances de la infantería nipona. Los ataques llegaron desde bases en el Mar del Este, Japon, Taiwan y Manchuria. Pese a todo y a lo sofisticado de la táctica en su mayoría los bombardeos fueron poco eficaces y poco resolutivos por falta de organización y tácticas de combate aéreo deficientes.

Mientras, la infantería japonesa emprendía una ofensiva de larga duración hacia el sur, ejecutada por tropas del Kwantung Army y reservas del NCAA. Paralelamente la Quinta División ocupaba la provincia de Chahon dirigiéndose hacia el norte y el oeste de Peking. El avance contó con el apoyo de la caballería y las fuerzas aéreas que abrirían la brecha completada por la infantería. La Ouinta División, sufriría un duro revés en la región montañosa de Pin-Xianguan donde el Ejército Central Chino y la 115 División de Partido Comunista Chino la frenaron y obligaron a retirarse tras inflingirle un severo correctivo, causando múltiples bajas.

Estas operaciones, de las que Drea da sobrada cuenta, demuestran como en los primeros compases la iniciativa fue japonesa y combinó todos los medios a su alcance para llevar a cabo grandes penetraciones en el territorio chino. ${ }^{19}$ Sus objetivos serían las principales ciudades y puntos neurálgicos del Estado Chino.

Una de las operaciones más cruentas de la guerra fue la operación sobre Shanghai. La operación se desarrolló a mediados de agosto y para el ejército chino supondría el diseño y puesta en marcha de una maniobra para liberar la presión de otras regiones. Chiang Kai-shek inició la ofensiva hacia los muelles y su decisión se convirtió en una de las mayores operaciones de la guerra, debido al número de tropas que implicó en la operación, ya que supuso la participación de setenta divisiones chinas. La Batalla de Shanghai se desarrolló en el norte de la ciudad y, aparte de aliviar el frente del Norte, Chiang Kai-shek percibió que era esencial para mantener la ciudad por su importante puerto y su carácter simbólico. La ofensiva se caracterizó por las densas fortificaciones chinas que dilataron la duración de la batalla hasta límites insospechados. ${ }^{20}$ Frente a este despliegue, Japón envió dos divisiones, formándose la Shanghai Expeditionary Force. El estancamiento de la batalla incomodó fundamentalmente a Tokyo, ya que le era necesario seguir avanzando para lograr sus objetivos, por ello, para desatascar la operación, a mediados de septiembre, el gobierno envió tres divisiones más buscando obtener la victoria en la ciudad portuaria y contrarrestar las divisiones chinas dispuestas sobre el terreno.

19 Mark PEATTIE, Edward DREA y Hans VAN DE VEN (coords.):The Battle for China: Essays on the Military History of the Sino-Japanese War of 1937-1945. Stanford, Stanford University Press, 2010.

20 Edward J. DREA y Hans VAN DE VEN:" An overview of Major Military..." y Franz SCHURMANN y Oliver SCHELL: China Republicana ... 


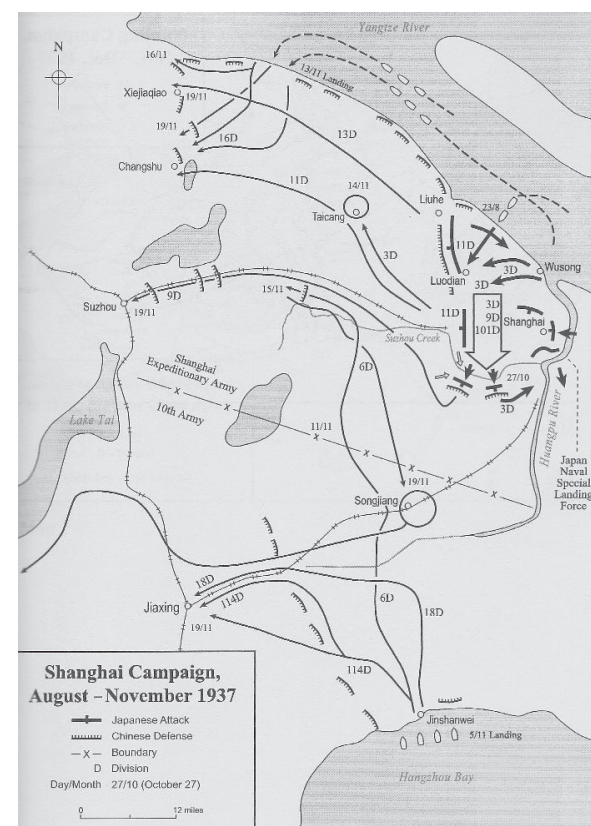

Map. 04 Batalla de Shanghai. (Fuente: Mark PEATTIE, Edward DREA y Hans VAN DE VEN (coords.):The Battle for China: Essays on the Military History of the Sino-Japanese War of 1937-1945 The Battle for China: Essays on the Military
Stanford, Stanford University Press, 2010.)

Los corresponsales extranjeros recogieron en sus diarios cómo la geografía y las fortificaciones dispuestas por los soldados chinos convirtieron la batalla en una masacre, donde se combatió por centímetros de tierra. ${ }^{21} \mathrm{El}$ saldo de la batalla fueron cuarenta mil bajas japonesas y para China doscientos mil soldados muertos y una derrota en un punto que consideraban clave. ${ }^{22}$ La Batalla de Shanghai alivió el frente del Norte, distrajo la atención japonesa hacia otro punto y enmarañó la guerra de tal modo que cambio el signo de la guerra hacia una posición en la que China obtenía cierta ventaja estratégica, aspecto que hasta entonces no se había producido.

Pese a las bajas de Shanghai, Tokyo dio órdenes de atacar y seguir con la ofensiva en la región de Shanxi. Con dicha estrategia buscaba proteger los flancos del avance y a la par eliminar las bases del Ejército Nacional y del Ejército Comunista en el noroeste chino. A la ofensiva se unieron dos divisiones que ejecutaron operaciones anfibias constituyendo al $X$ Ejército japonés. Las operaciones fueron un éxito porque rompieron las últimas defensas de Suzhou Creek, y dieron acceso al sur de la ciudad. ${ }^{23}$

Si bien es cierto que los avances se produjeron en la región de Shanxi, la Batalla de Shanghai fue un punto y aparte en la estrategia japonesa. A partir de ahí, sus frentes se enmarañaron y sus avances se volvieron más lentos. Para China supuso constatar que su estrategia era válida, pese al alto coste de vidas y al alto coste monetario, enfangar la guerra, atacar, retirarse y hacer que Japón se distrajera de sus grandes penetraciones sería positivo para ganar tiempo, esperar el apoyo de fuera y en último caso obtener la victoria.

De nuevo en el frente abierto en Shanxi, donde se habían roto las defensas de Suzhou Creek, el X Ejército reemprendió su marcha encontrado resistencia en los alrededores de Taiyuan y de Xinkou. La resistencia frenó el avance japonés durante los meses de octubre y noviembre. Al mismo tiempo que el X Ejército llevaba a cabo sus operaciones, el I y II Ejército trataban de

21 Franz SCHURMANN y Oliver SCHELL China Republicana ... pp.258.

22 Edward J. DREA y Hans VAN DE VEN “ An overview of Major Military...” pp. 30.

23 Peter ZARROW. China in..., pp. 306. atrapar y eliminar a las tropas chinas en la zona de Shijiazhuang que tenía en sus proximidades la línea Peking-Wuhan.

La iniciativa de las operaciones militares siguió del lado japonés, el X Ejército hostigó a las tropas de Chiang Kai-shek a través de un ataque a la ciudad de Nanjing que era de vital importancia tanto desde el punto de vista estratégico como simbólico. La movilidad fue la clave para ejecutar estas operaciones ya que gracias a las ventajas técnicas y a las buenas líneas de abastecimiento, flanqueaban las defensas chinas evitando el conflicto hasta el momento deseado. Con estas tácticas de combate las tropas del X Ejército se presentaron el 10 de diciembre a las puertas de Nanjing.

La batalla de Shanghai estaba reciente, y las bondades de su estrategia también. Chiang Kai-shek ordenó que Nanjing se mantuviera con todas las fuerzas, al igual que se había mantenido la ciudad de Shanghai hasta el último hombre en pie. Su mantenimiento era vital tanto por motivos económicos como intelectuales, ya que allí se hallaba la tumba del teórico Sun Yat-sen. Pese a las órdenes Nanjing cayó en un breve lapso de tiempo. La retirada desordenada del ejército chino provocó una entrada japonesa alborotada y desordenada. Tras los combates, los desmanes del ejército japonés tuvieron una alta repercusión siendo duramente criticados por las atrocidades cometidas que fueron desde la violación sistemática hasta el asesinato selectivo de manera arbitraria.

Nanjing pasó a la historia como uno de los episodios más deplorables de la guerra, pero no fue el único episodio cruento, Zarrow demostró que miembros del ejército chino cometieron una matanza indiscriminada en la ciudad de Dongzhou. ${ }^{24}$

Todas estas maniobras militares convirtieron el avance japonés en una realidad. 1937 fue un año exitoso para los ejércitos japoneses y nefasto para los chinos. A las victorias de la infantería que avanzaban sin excesiva oposición salvo casos excepcionales se asistió al desarrollo de las técnicas de bombardeo y a las técnicas de combate que darían aún una mayor ventaja técnica en futuros combates.

En 1938 la mayoría de las ciudades chinas estaban en manos japonesas y su estrategia pese a batallas como la de Shanghai, no había cambiado sustancialmente, las líneas de comunicación y transporte seguían siendo primordiales para llevar a cabo grandes marchas y maniobras hacia el interior. 25 Para China 1938 supuso la resistencia del ejército comunista y el nacionalista resistiendo frente a los envites y bombardeos japoneses, mientras desdeñaban nacionalista resistiendo frente a los envites y bombardeos japoneses, mientras desdeñaban rales lo aplicaron sin casi ninguna oposición. Muestra de esta táctica de combate fueron las maniobras del general Li Zongren que atacaba constantemente las líneas de comunicación japonesas para posteriormente replegarse. Los ataques se centraron en las líneas de ferrocarril Tianjin-Pukou y Peking-Wuhan mientras buscaban enmarañar y ralentizar el avance japonés.

En 1938 la geografía se volvió contra los ejércitos japoneses favorecidos debido a la escasez de hombres y a la incapacidad para grandes penetraciones lo que condujo al estancamiento de la guerra. ${ }^{26}$ Japón contaba sobre el terreno con dieciséis Divisiones formadas por seiscientos mil soldados que necesitaban grandes líneas de suministro, una remodelación y renovación de sus efectivos tras un año de combate y profundos avances en materia de abastecimiento militar y progreso técnico. Por ello, Tokyo movilizó nuevas divisiones y buscó poner punto y final a la guerra mediante el desarrollo de una guerra total, donde el país entero se volcaría hacia la victoria.

Las operaciones de 1938 seguirían a cargo de los cuerpos de las NCAA que, con nuevos refuerzos, mandos más enérgicos y decididos, apostaron por avanzar hacia el sur. Por ello se lan-

4 Peter ZARROW: China in..., pp. 310.

25 Ibid., pp. 310.

26 Edward J. DREA y Hans VAN DE VEN:“ An overview of Major Military..." pp. 32. 
zó una nueva ofensiva sobre la región de Shandon ejecutada por el II Ejército y cuyo objetivo fue limpiar de resistencia china la orilla norte del Rio Amarillo. Dos grandes columnas se desplazaron hacia el norte y este, generando un movimiento de pinza cuyo punto de encuentro sería Taienzhuang. La operación encontró la oposición del Il y XX⿳0 Cuerpo de Ejércitos del Kuomintang. Al mismo tiempo la Va División llegó al punto de encuentro previamente acordado con el II Ejército, pero tuvo que retirarse por temor a caer emboscados. ${ }^{27}$ Esta retirada supuso la pérdida de miles de soldados para el $V$ y $X$ Ejército japonés. El fracaso del $V$ y $X$ Ejército demostró que los ejércitos japoneses avanzaban con más dificultad y que, en muchas ocasiones, los retrasos provocados por los ejércitos chinos impedían el desarrollo de las estrategias planteadas por los altos mandos japoneses.

El fracaso supuso la puesta en marcha de una maniobra envolvente iniciada el 14 de febrero de 1938. Las fuerzas del NCAA y del CCEA (Central China Expeditionary Army) desplegarían siete divisiones formadas por doscientos mil soldados con el objetivo de destruir a cincuenta divisiones chinas. Durante la operación la ciudad de Xuzhou cayó, lo que supuso la huida de las tropas que la defendían. Con la toma de la ciudad comenzaba a ponerse de manifiesto otro problema, las tropas japonesas estiraban mucho sus líneas de abastecimiento dejando mucho espacio detrás de sus vanguardias, lo que les exponía a ataques chinos.

Para asegurar las líneas, a mediados de mayo, los japoneses avanzaron hacia el Rio Amarillo y continuaron por el ferrocarril de Longhai, intentado unir la línea norte con la sur, representada por el ferrocarril Peking-Wuhan a la altura Zhenzhou. Los chinos se retiraron de nuevo, pero ordenaron romper los diques del río provocando graves inconvenientes al avance japonés. Dos divisiones quedaron aisladas y se produjo el estancamiento del ejército a ochenta kilómetros del objetivo. ${ }^{28}$

Las operaciones se reanudaron en el Yangtze, pero el temor de los altos mandos se hizo realidad: las conexiones y líneas de abastecimiento se colapsaron. Esto provocó falta de víveres y de suministros que dieron paso a enfermedades contagiosas que provocaron los primeros estragos en el XI Ejército. Mientras esto ocurría en China los japoneses tenían sus primeras escaramuzas a lo largo de su frontera con la URSS, a la altura de Changkuopeng.

EI XI Ejército tomó, tras superar sus problemas de abastecimiento, el 21 de octubre la ciudad de Guangzhou, ciudad destacada por su actividad financiera y administrativa. El 26 de octubre caía una de las ciudades de las líneas ferroviarias, Wuhan culminando una operación de diez meses. Para los chinos suponía perder uno de los frentes de su ejército, el frente del centro y muchos de sus mejores oficiales. La caída de este frente provocó que la capital se trasladase a la ciudad Chongquing.

Esta nueva derrota supuso que el ejército chino replantease su estrategia, su huida se dirigió hacia el sur buscando evitar el enfrentamiento y poder reorganizarse; a estos presupuestos se unían la creencia, parte de los dirigentes chinos, de un desplazamiento de los enfrentamientos al sur provocaría una reacción en las potencias occidentales y éstas se decidirían a intervenir. El control de Sichuan sería esencial para sus objetivos, al igual que la dispersión de los ejércitos japoneses. La dispersión permitiría utilizar la estrategia de las guerrillas, acosar a las unidades, aislarlas, hostigarlas y luego retirarse, todo ello ejecutado tras las líneas enemigas.

Para el ejército japonés la batalla de Wuhan supondría la pérdida de flexibilidad en las operaciones militares y la pérdida de capacidad para llevar a cabo movimientos de larga duración. ${ }^{29} \mathrm{El}$ ejército japonés se dedicó a estabilizar las zonas conquistadas y a comenzar un proceso de reducción de las tropas en casi cuatrocientos mil soldados. Buscaron organizar

27 Edward J. DREA y Hans VAN DE VEN:" An overview of Major Military..." pp. 33 28 Ibid., pp. 34

29 Edward J. DREA y Hans VAN DE VEN:" An overview of Major Military...” pp. 35. gobiernos títeres, mientras que el IGHO ocupaba la ciudad de Nanchang en la provincia de Jiangxi. Su ocupación se encuadraba dentro de los planes de estabilización ya que supondría la merma de suministros para la resistencia china.

Entre 1938-1940 el combate de las guerrillas fue esencial, y este provocó la fortificación parte del ejército japonés, de varios puntos a lo largo de las líneas ferroviarias y de comunicación. Se trataba con ello evitar los ataques guerrilleros, poniendo las mejores tropas en los puntos más calientes.

Tras el refuerzo de ciertos sectores, la salida de tropas japonesas y un clima de intento de pacificación de territorio conquistado por los japoneses, las ofensivas pasaron ahora a manos del ejército chino. Buscaban recuperar la ciudad de Nanchang, viéndose de nuevo implicado en el XI Ejército japonés que debía repeler la ofensiva. Mientras, al mismo tiempo, se llevaba a cabo otra operación liderada por el General Li-Zongren, que de nuevo hostigaba la línea de ferrocarril Peking-Wuhan. La pérdida de la iniciativa por parte de Japón supuso un cambio en su estrategia. Ahora ejecutarían ataques rápidos y después se replegarían con el objetivo de desgastar al Ejército del Kuomintang.

Para conseguir ese objetivo se pusieron en marcha las Operaciones 100 y 101. Éstas se basaron en grandes bombardeos sobre las principales ciudades chinas, buscando desmoralizar a la población y forzar la negociación. Ambas operaciones fracasaron en sus objetivos, aunque la operación 101 mostró al mundo un nuevo tipo de avión, el Zero japonés. Al mismo tiempo, el XI Ejército comandado por el General Okamura trató en una operación militar de carácter ofensivo y que implicaba a un alto número de tropas, el cerco de treinta divisiones chinas, fracasando la operación por falta de efectivos.

La ofensiva nipona fue respondida por una contraofensiva china que movilizó a setenta divisiones y obtuvo victorias en las ciudades de Nomonhan y Changsha. De nuevo los chinos tomaban la iniciativa y emprendían una ofensiva en invierno de 1940. Ésta fue un éxito pero su impulso quedó roto por las desavenencias entre comunistas y nacionales. ${ }^{30}$ La ofensiva de invierno provocó que el XI Ejército quedase diseminado e incapaz de reagruparse. Pese a triunfo de la ofensiva, y la dispersión de las tropas, las batallas se saldaron con los japoneses ocupando sus antiguas oposiciones. A pesar de que el cambio estratégico fue mínimo, China demostró poder llevar a cabo grandes operaciones militares mientras que Japón demostraba que no era capaz de sostener una guerra de defensa. ${ }^{31}$

Varias operaciones japonesas buscaron desatascar la situación; una de estas maniobras estuvo encabezada por el XI Ejército sobre Yichang, cuyo objetivo era buscar un paso hacia Chonquing. En una operación combinada de los diferentes cuerpos del Ejército, capturaron la ciudad. Los objetivos cambiaron y al igual que la Segunda Guerra Mundial se decantaba del bando alemán que obtenía victorias sobre los principales países occidentales, Japón centró sus ataques sobre las colonias de dichos países en el territorio asiático mientras, que ante una inminente guerra contra la URSS, reorganizaba sus ejércitos.

Los chinos volvieron a llevar el peso de una operación ofensiva, la Ofensiva de los Cien Regimientos, con las líneas de abastecimientos y los almacenes como objetivos principales. Ata caron los principales puntos débiles pillando por sorpresa a las tropas niponas. La contraofensiva japonesa se llevó a cabo en noviembre, obteniendo una gran victoria pese al alto coste humano. ${ }^{2}$ Un año después de la ofensiva de los Cien Regimientos, el General Okamura ponía en marcha la "Política de los Tres Todos", su principal característica era la destrucción de todo

30 El Segundo Frente Unido, movimiento político por el cual comunistas y nacionalistas buscaron un entendimiento se resquebrajaba a consecuencia de la diferencia de opiniones y por el incidente denominado "el del Nuevo IV Ejército" Paul. J. BAILEY: China en ... pp.136.

31 Edward J. DREA y Hans VAN DE VEN:" An overview of Major Military..." pp. 37.

32 Ibid., pp. 39 
aquello que se encontrase al paso de las tropas, incluyendo bienes materiales y humanos. Las principales ofensivas de 1941 tuvieron como objetivo cortar los suministros como el ataque combinado desde Guangzhou hasta Hong Kong. Pese a todo, no se obtuvieron grandes victorias y tampoco acabaron con el Trigésimo Ejército Chino.

Las ofensivas japonesas de 1941 se centraron de nuevo en Changsa. El Teniente General Anami buscó destruir con esta ofensiva al ejército del Kuomintang, que en dicha región estaba formado por trescientos mil soldados. La ciudad cedió pero la contraofensiva ejecutada por e $X$ Ejército Chino obligó, a la rendición de dos divisiones japonesas en 1942 y supuso para Japón la pérdida definitiva de la ciudad.

En 1941 Japón atacaba Pearl Harbor, y la guerra se encaminó hacía un punto de no retorno. Desde entonces las fuerzas armadas japonesas atacaron cualquier aeródromo que se hallase en pie en el territorio chino, destacando en dichos ataques las zonas de Zhejiang y Jiangxi por ser las que mayor grado de virulencia recibieron.

A partir de esa ofensiva, las tropas en China fueron las de segunda línea, tropas de reemplazo japonés, cuyas instrucciones eran que las operaciones que ejecutasen pusieran punto y final a la guerra continental. De este modo Japón podría centrarse en su enfrentamiento con los aliados en el frente del Mar Pacífico. Una de las últimas operaciones japonesas de gran envergadura se produjo en 1943. Seis divisiones atacaron Changde y posteriormente se dirigieron hacia el Río Amarillo atacando la zona ente Shashi y el Lago Dongting. Changde sería recuperada el 9 de diciembre por las tropas chinas teniendo un coste de cuarenta mil soldados fallecidos durante la batalla. En el intercambio de golpes, desatado desde 1943, Japón lanzó una ofensiva para recuperar una de las ciudades próximas a Chonquing y que le daría la llave para cerrar los suministros a una ciudad de vital importancia para el desarrollo de la estrategia china. Pero el contexto en el continente asiático ya no le era tan favorable, Burma sufría las embestidas de China y sus aliados occidentales y la guerra en el Pacífico parecía perdida. En este contexto Japón llevó a cabo la última maniobra se produjo con la ofensiva de Ichigo, donde participarían medio millón de hombres de los diferentes ejércitos imperiales y otros seiscientos veinte mil pertenecientes a la China Expedicinary Army. La operación fue un éxito pasajero ya que si bien es cierto que las tropas del XI Ejército de los CEA y el Vigésimo Tercer Ejército tomaron bases americanas y ciudades como Changsa y Henyang. Esta sería la última operación que lograría posicionar en una situación ventajosa a los ejércitos japoneses. Desde entonces las tropas niponas sufrirían derrotas a manos del ejército del KMT, mientras que en el Pacífico los Estados Unidos y sus aliados también daban cuenta de los nipones derrotándolos en diferentes ocasiones. Podemos decir que Japón quedó atrapado en los territorios chinos sin capacidad de reacción y que esto le penalizaría en el desarrollo de otros esfuerzos de guerra.

El punto y final llegaría con los bombardeos de Nagasaki e Hiroshima, que obligaron a Japón a firmar la rendición sin condiciones. La guerra se saldó con pérdidas entorno a los diez millones de soldados chinos y otras tantas víctimas civiles chinas, mientras que Japón contabilizó pérdidas entorno a los cuatrocientos diez mil soldados, y casi novecientos treinta mil heridos como saldo de su guerra contra China. ${ }^{33}$

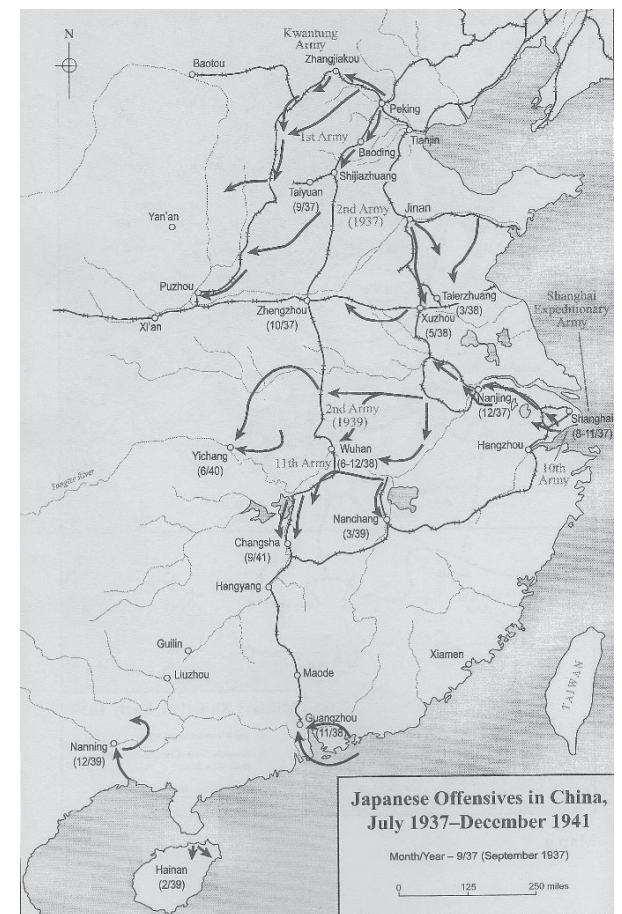

Map. 05 Resumen de operaciones ofensivas japonesas. (Fuente: Mark PEATTIE, Edward DREA y Hans VAN DE VEN (coords.):The Battle for China: Essays on the Military History of the Sino-Japanese War of 1937-1945. Stanford, Stanford University Press, 2010.)

\section{Conclusiones}

Con este breve trabajo he querido manifestar la importancia que tuvo la Segunda Guerra Sino-Japonesa para el continente asiático así como su influencia en el mundo Occidental. Japón iniciaba en 1937 una guerra con el objetivo de convertirse en una potencia colonial, tomando como modelo a las potencias occidentales y basando sus acciones en la superioridad sobre el país colonizado. Frente a él se situaba China, que veía en el impulso del nacionalismo la única vía de crecimiento y de obtención del respeto internacional. La guerra sirvió como zona de pruebas para un ejército japonés que posteriormente lucharía en el Pacífico contra las tropas estadounidense, a la par que sirvió para fortalecer a los dos ejércitos chinos que se enfrentarían en la Guerra Civil de 1946. Ambos pagaron un alto coste monetario y humano que llevó a la derrota final japonesa y a la ruptura del proyecto imperial, mientras que permitió obtener a China el papel en el mundo internacional que había deseado, todo ello gracias a su resistencia militar. La importancia del contexto internacional fue vital, ya que mientras Japón pudo disponer de la ventaja de que Occidente se mantuviera al margen del conflicto, o de que sus aliados obtenían victorias sobre potenciales enemigos en el continente asiático, e país del Sol Naciente obtuvo victorias militares y avances territoriales. Cuando el contexto in ternacional cambió, y dejó de ser favorable para los aliados de los japoneses las circunstancias obligaron a Japón a replegarse en todos sus frentes, al contrario de lo que sucedió con China que pudo sacudirse la presión militar y territorial.

A mi juicio la Segunda Guerra Sino-Japonesa supuso una rémora para un país, Japón, que de otro modo podría haber influido de manera más directa en la Segunda Guerra Mundial, y que a la par demostró ser un Imperio con los pies de barro al no poder mantener sus conquistas territoriales. Recordando un comentario en clase, la principal obsesión de todos los ejércitos expansionistas era mantener dos grandes frentes: el que le ocupaba en el territorio chino y el que tenía en el Mar del Pacífico cosa que Japón no pudo hacer. Como consecuencia salió derrotado de China y del conflicto internacional en el cual quedó inmerso tras el ataque a Pearl Harbor y las provocaciones a la URSS. 


\section{LA MILICIA ALAVESA DE ACCIÓN POPULAR DURANTE LA GUERRA CIVIL ESPAÑOLA (1936-1939)*}

Germán Ruiz Llano

Universidad Complutense de Madrid

El estudio del fenómeno miliciano derechista durante la Guerra Civil ha sido uno de los que menos atención ha suscitado en los investigadores de la contienda ya que, por un lado, la mayoría han centrado su atención en la zona republicana y, por otro, la historia militar ha sido relativamente dejada de lado por la historiografía española. Sin embargo, sin este fenómeno no se puede entender la propia Guerra Civil ya que fueron precisamente los milicianos de uno y otro bando los elementos decisivos para que un golpe de estado parcialmente fallido pasara a ser una contienda militar en toda regla, engrosando por un lado los escasos efectivos del ejército sublevado y por otro posibilitando al gobierno republicano y a las fuerzas que le permanecieron leales la defensa de la legalidad alli donde se produjo la sublevación militar (aunque una vez sofocada ésta propugnaran sus propios objetivos políticos, como la defensa de la revolución social). ${ }^{2}$ Si bien el estudio de las milicias derechistas y la movilización contrarrevolucionaria durante la II República y la Guerra Civil ha ido avanzando con nuevas e intere-

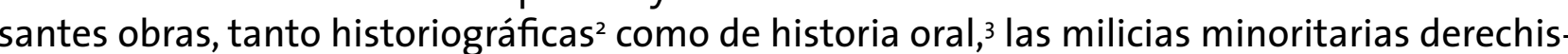
tas, como la de Acción Popular, Renovación Española o los Legionarios de Albiñana han sido mucho menos estudiadas. En el presente caso tratamos, en parte, de rellenar ese hueco en el estudio de la contienda y explicar cómo el partido derechista y católico mayoritario durante la II República fracasó a la hora de movilizar a sus apoyos tras el inicio de la guerra y cómo fue superado por las otras organizaciones más extremistas, en una provincia como Álava en la que, a pesar de ser dominada políticamente por el tradicionalismo, el peso de Acción Popular no era en absoluto desdeñable.

La marca electoral de la Confederación Española de Derechas Autónomas (CEDA) en Álava era Acción Popular Alavesa (AP) y sus juventudes se agrupaban en la Juventud de Acción Popular (JAP). La CEDA se fundó a principios de 1933 y nació como una coalición de partidos de

* Esta comunicación se inscribe dentro de la beca Predoctoral del Gobierno Vasco que financia el proyecto "El voluntariado alavés durante la Guerra Civil" de la que es beneficiario el autor.

1 Julio ARÓSTEGUI: "Sociedad y milicias en la guerra civil española, 1936-1939, una reflexión metodológica", En Santiago CASTILLO (coor.): Estudios de Historia de España: homenaje a Manuel Tuñón de Lara. Vol. 2, Santander, Universidad Menéndez Pelayo, 1981, pp. 307-326.

2 Sobre las milicias derechistas durante la II República ver Eduardo GONZÁLEZ CALLEJA: Contrarrevolucionarios. Radicalización violenta de las derechas durante la Segunda República, 1931-1936, Madrid, Alianza, 2011. Sobre el Requeté durante la Guerra Julio ARÓSTEGUI: Los combatientes carlistas en la guerra civil española. Vols. 1 y 2, Madrid, Aportes, 1991; Javier UGARTE TELLERIA: La Nueva Covadonga Insurgente. Orígenes sociales y culturales de la sublevación de 1936 en Navarra y el País Covadonga Insurgente. Origenes sociales y culturales de la sublevación de 1936 en Navarra y el País
Vasco, Madrid, Biblioteca Nueva, 1998; sobre Falange José Antonio PAREJO FERNÁNDEZ: Señoritos, Jornaleros y Falangistas. Sevilla, Bosque de Palabras, 20o8; e İD.: Las piezas perdidas de la Falange: El sur de España, Sevilla, Universidad de Sevilla, 2008.

3 Pablo LARRAZ ANDIA y Víctor SIERRA-SESÚMAGA: Requetés de las trincheras al olvido, Madrid, La Esfera de los Libros, 2011 centro-derecha católica, convirtiéndose en el partido derechista con mayor apoyo electoral durante la II República y llegando a formar parte de varios gobiernos del período 1934-1935. Como es bien sabido, su líder era el abogado salmantino José María Gil Robles y su militancia estaba formada por católicos accidentalistas en cuanto al régimen establecido, partidarios de la vía electoral para conseguir el poder y descontentos por la política laicista y de izquierdas de los primeros gobiernos republicanos. ${ }^{4}$

En Álava, este partido fue fundado en 1934 por los derechistas independientes de la provincia escindidos de Hermandad Alavesa, que hasta entonces había sido la organización política que agrupaba y unificaba a todos los derechistas alaveses, pero que estaba controlada por los tradicionalistas. ${ }^{5}$ Aunque minoritario, la CEDA tuvo un gran auge en Álava, al contrario que en Vizcaya y Guipúzcoa, ${ }^{6}$ entre 1934 y 1936, nutriéndose sus buenos resultados electorales de una parte del electorado nacionalista vasco y del católico no tradicionalista. ${ }^{7}$ En este sentido es muy ilustrativo el hecho de que el lema de su sección de Araya, único lugar fuera de Vitoria donde el partido se organizó, fuera "Religión, Patria, Familia, Orden, Trabajo y Propiedad" " frente al "Dios, Patria, Fueros y Rey" 9 de los Círculos Tradicionalistas. Una peculiaridad de la CEDA en Álava fue que tenía una base social urbana, mientras que en el resto de España era rural ${ }^{10}$. La relación de Acción Popular con el resto de fuerzas derechistas de la provincia fue tensa, debido a su estrategia posibilista con respecto a la República. Aunque el partido siempre se movió "dentro de ese mismo molde de ambigüedad doctrinal y semilealtad que habían caracterizado a la organización desde 1933"," esa actitud chocaba con la intransigencia del tradicionalismo hacia el régimen republicano. Ello hizo que la CEDA fuera atacada desde las columnas del diario carlista Pensamiento Alavés ${ }^{12}$ y que en febrero de 1936 se rompiera el

4 José Ramón MONTERO: La CEDA. El catolicismo social y politico en la II República. Vol 1, Madrid, Ediciones de la Revista de Trabajo, 1977 pp. 245-306; Alfonso ROJAS OUINTANA: José María Gil Robles. Historia de un injusto fracaso, Madrid, Síntesis, 2010, pp. 80-94; Eduardo GONZÁLEZ CALLEJA: Contrarrevolucionarios..., pp.106-108; José Luis RODRIGUEZ JIMÉNEZ: La extrema derecha española en el siglo XX, Madrid, Alianza, 1997, pp. 115-118.

5 Durante la II República fue la marca electoral de la Comunión Tradicionalista en Álava, aunque nació en 1931 como agrupación de todas las derechas alavesas estuvo dominada por José Luis Oriol y los tradicionalistas. El arquitecto y financiero bilbaíno José Luis Oriol era diputado tradicionay los tradicionalistas. El arquitecto y financiero bilbaíno José Luis Oriol era diputado tradiciona-
lista por Álava y uno de los principales dirigentes de la Comunión Tradicionalista en todo España lista por Álava y uno de los principales dirigentes de la Comunion Tradicionalista en todo España Partidos y Vida Politica, Bilbao, Universidad del País Vasco, 1989, pp. 56-65

6 Gabriel PLATA PARGA: La derecha vasca y la crisis de la democracia española (1931-1936), Bilbao, Gabriel PLATA PARGA: La derecha vasca y la crisis de la democracia española (1931-1936), Bilbao, Diputación Foral de Vizcaya, 1991; Jose Antonio RODRíGUEZ: Guipúzco

7 Los resultados electorales y porcentajes en la $1^{\text {a }}$ vuelta de las elecciones de febrero de 1936 en Álava fueron los siguientes: Comunión Tradicionalista Frente Popular Frente Popular

16.020

8 Esta sección se fundó bajo la protección de la familia Ajuria, dueña de la empresa metalúrgica del pueblo. Archivo Histórico Provincial de Álava. (AHPA). Caja. (C.) 1573, Expediente (Exp.) 16; DE PABLO, Santiago: La Segunda República..., p.67

9 AHPA. C. 27466-B y C. 1573, 1574 y 1575.

10 DE PABLO, Santiago: La Segunda República ..., pp. 67-68.

11 Manuel ÁlVAREZ TARDío: “La CEDA y la democracia republicana", en Fernando DEL REY (Coor.): Palabras como puños. La intransigencia política en la Segunda República española, Madrid, Tecnos, 2011, p. 412.

12 Este periódico era propiedad de José Luis Oriol y actuaba como portavoz del tradicionalismo alavés. DE PABLO, Santiago: La Segunda República..., p. 16. Para las críticas del tradicionalismo a la 
pacto electoral con Hermandad Alavesa para presentar por consenso un candidato de cada formación política (José Luis Oriol por aquella y el abogado Luis Pérez Flórez-Estrada por AP), repartiéndose los votos derechistas de la provincia para conseguir que los dos fueran elegidos. La tensión entre ambas candidaturas llegó al extremo de producirse incidentes entre partidarios de ambos durante la campaña electoral. A pesar de la estrategia posibilista del partido, de su respeto a la legalidad y de la no implicación de sus afiliados en la violencia política que produjo en la provincia en la primavera-verano de 1936, AP fue tachada de enemiga del régimen republicano y equiparada con los tradicionalistas y falangistas por las organizaciones de izquierda alavesas. ${ }^{13}$ Éstas llegaron a pedir a las autoridades republicanas su disolución tras los incidentes registrados entre izquierdistas y derechistas durante la celebración del aniversario de la República en Vitoria, el 14 de abril de 1936. En ellos murió de un infarto un obrero, debido a la tensión producida por los gritos de Viva España propalados por un afiliado al partido monárquico Renovación Española, que fueron contestados por los Vivas a la República de los elementos republicanos al paso del desfile militar. ${ }^{14}$

Una vez triunfante la sublevación militar's en la provincia, AP formó su milicia el día 20 de julio de 1936, tras el ofrecimiento del partido a las autoridades militares, formándose un primer grupo con 50 voluntarios que marcharon el día 26 al frente de Somosierra. ${ }^{16} \mathrm{~A}$ estos primeros voluntarios se les irían uniendo progresivamente nuevos contingentes hasta alcanzar la cifra de 96 milicianos, que estuvieron combatiendo toda la guerra en el frente de Somosierra-Guadalajara, encuadrados en la $1^{\text {a }}$ Centuria de Falange de Álava. ${ }^{17}$ En el siguiente gráfico podemos comprobar cómo se repartieron los combatientes voluntarios alaveses y el carácter absolutamente minoritario de la milicia de AP:

CEDA ver Martin BUNKHORN: Carlismo y contrarrevolución en España 1931-1939, Barcelona, Crítica, 1979, pp. 174-197.

13 Hay que tener en cuenta que en el partido convivían varias sensibilidades que iban desde un sector demócrata-cristiano, minoritario, que era partidario del reconocimiento del régimen republicano y el respeto a la legalidad a otros sectores más radicales y partidarios de apoyar un golpe militar en caso de peligro revolucionario. Sobre la implicación de la CEDA en la conspiración militar ver Eduardo GONZÁLEZ CALLEJA: Contrarrevolucionarios..., pp. 358-361; Sobre los cedistas contrarios a la sublevación militar ver Vicent COMES: En el filo de la navaja: biografía política de Luis Lucía Lucia (1888-1943), Madrid, Biblioteca Nueva, 2002; Javier TUSSELL y José CALVO: Giménez Fernández, precursor de la democracia española, Sevilla, Diputación de Sevilla, 1990.

14 Días antes, el 11 de abril, el diario comunista Euzkadi Roja también había pedido la disolución de la CEDA en Álava con los mismos argumentos. En el resto de España militantes de la CEDA y JAP también fueron objeto de persecución y violencia política por parte de la fuerzas de izquierda. Manuel ÁlVAREZ TARDíO: “La CEDA...”, pp. 412-18.

15 En el caso de Álava no hemos encontrado en las fuentes referencia a que el partido participara en la conspiración contra la República, aunque es muy posible que sus dirigentes alaveses estuvieran al tanto de la conjura y recibieran instrucciones al respecto ya que Gil Robles pasó por Vitoria camino de Francia el 15 de julio de 1936 entrevistándose con los líderes locales de AP y con el teniente coronel Camilo Alonso Vega, uno de los cabecillas de la sublevación militar en Alava y jefe del Batallón Flandes de guarnición en la ciudad. Y Aunque Gil Robles lo niegue en sus memorias resulta inverosímil que no hablaran sobre la inminente sublevación. José María GIL ROBLES: No fue posible la paz. Barcelona, Planeta, 1998, p. 820.

16 Archivo del Territorio Histórico de Álava. (ATHA). DAIC. C. 12692-A; Archivo General Militar de Ávila. (AGMAV). Jefatura de Milicias de Vitoria. Legajo. 25. Exp. 2485. Felipe GARCÍA DE ALBÉNIZ: Álava por Dios y por España, Vitoria, Editorial Social Católica, 1936, p. 100.

17 Otra expedición de milicianos se envió el 24 de agosto de 1936 y posteriormente algunos más aisladamente. ATHA. DAIC. C. 12692 A-B

\begin{tabular}{|c|c|c|c|c|c|c|c|}
\hline Requeté & $\%$ & Falange & $\%$ & Voluntarios Ejército & $\%$ & Acción Popular & $\%$ \\
\hline 2.128 & 70,7 & 516 & 17,1 & 270 & 8,9 & 96 & 3,3 \\
\hline
\end{tabular}

Gráf. 01 Voluntariado combatiente alavés durante la guerra civil. (Fuente: Elaboración propia a partir de Archivos Municipales de Álava; ATHA. DAIC. C. 12692-A-B; Archivo General Milita de Guadalajara. Zona de Reclutamiento/Álava; AGMAV. Jefatura de Milicias de Vitoria.)

Política y asociativamente la milicia de AP se nutrió sobre todo por personas jóvenes afiliadas al partido o sus juventudes y de las organizaciones de corte católico afines, como el Sindicato Católico de Estudiantes Alaveses o que no tenían corte partidista como los Congregantes Marianos, ${ }^{18}$ mientras que los militantes y simpatizantes de edad se enrolaron en la Milicia Ciudadana de Vitoria, realizando tareas de retaguardia. ${ }^{9}$ También, al igual que en las otras milicias o en el Ejército, se alistaron personas para escapar de la represión, como el industrial Carmelo Álvarez de Arcaya, afiliado a Izquierda Republicana, ${ }^{20}$ y algunos nacionalistas, sobresaliendo el caso de Ignacio Mués, perteneciente al grupo radical nacionalista Jagi-Jagi. ${ }^{21}$

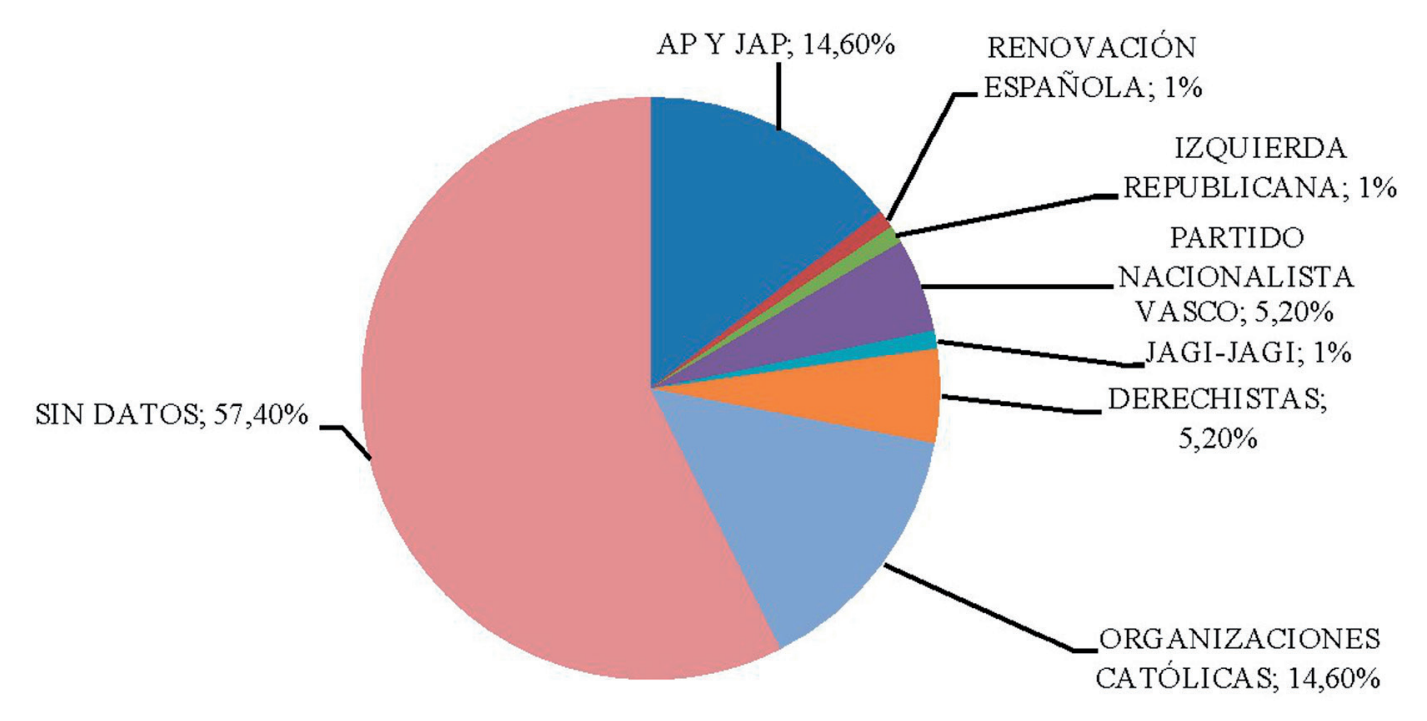

Gráf. 02 Filiación política y asociativa de los milicianos alaveses de ap. (Fuente: Elaboración propia a partir de ATHA; AGA; Base de datos de Santiago de Pablo de afiliados y simpatizantes de organizaciones politicas y sindicales de Alava durante la ll República. Las organizaciones nas, Mutualidad Catequística y Federación Alavesa de Estudiantes Católicos.)

18 Las Congregaciones Marianas son asociaciones de católicos que aspiran a mejorar su formación cristiana y a divulgar su fe.

19 Germán RUIZ LLANO: “La Milicia Ciudadana de Vitoria”, en Alejandra IBARRA AGUIRREGABIRIA (coord.), No es pais para jóvenes. Actas del III Congreso de jóvenes investigadores de la AHC, Vitoria, 2011, CD-ROM.

20 Iñaki GIL BASTERRA: Jurisdicción especial y represión franquista en Álava: 1936-1942: documentación del Tribunal de Responsabilidades Políticas para Álava, Vitoria, Gobierno Vasco, 2006, p. 17.

11 El Jagi-agi era un grupo escindido del PNV que defendí la independencia det Pais Vasco. Este El Jagi-Jagi era un grupo escindido del PNV que defendia la independencia del Pais Vasco. Este grupo llegó a tener alguna importancia en Vizcaya pero en Alava apenas una docena de naciona-
listas seguía sus consignas. DE PABLO, Santiago. La Segunda República..., p. 52. Una vez comenzada lis contienda una parte del nacionalismo alavés se alineó con los sublevados tanto para escapar la contienda una parte del nacionalismo alaves se alineó con los sublevados tanto para escapar cuestión ver SantiagO DE PABLO: En tierra de nadie. Los nacionalistas vascos en Álava, Vobre esta sager, 2008 , pp. $236-261$ 
Geográficamente los milicianos de AP provenían de las zonas donde la CEDA había tenido mayor éxito electoral y organizativo. Vitoria, con un $83 \%$, copaba los orígenes de los milicianos, mientras que eran marginales los provenientes de la Llanada, circundante a Vitoria, y la Montaña Alavesa, e inexistentes en el resto de la provincia.22 Para establecer una estructura socioprofesional de los milicianos vamos a seguir el esquema propuesto por Pedro María Sanz en su obra Elecciones Municipales de 1931 en Vitoria. ${ }^{23}$ Sobre aquella podemos decir que presenta los caracteres urbanos de la mayoría de los milicianos y del partido. La mayoría de éstos son jóvenes estudiantes, lo que hace que, unidos a los pertenecientes a profesiones liberales, patronos y empleados, podamos decir que la milicia de AP se nutrió sobre todo de personas provenientes de las clases medias y altas, seguidos en importancia por miembros del proletariado católico, mientras que labradores y jornaleros agrícolas eran muy escasos. Esto último nos indica que AP, a pesar de sus buenos resultados electorales en 1936, no tuvo el tiempo suficiente para arraigar en la zona rural alavesa ${ }^{24}$ y que la mayoría de los labradores de ideas católicas y derechistas prefirieron alistarse en el Requeté, ${ }^{25}$ a través de las antiguas redes sociales y vínculos de dependencia existentes de antemano en el mundo agrario tradicional alavés. ${ }^{26}$ En este sentido resulta muy significativo el hecho de que muy pocos de los militantes de su sección de Araya se dedicaran a la labranza y que nadie del pueblo se alistara en su milicia. ${ }^{27}$

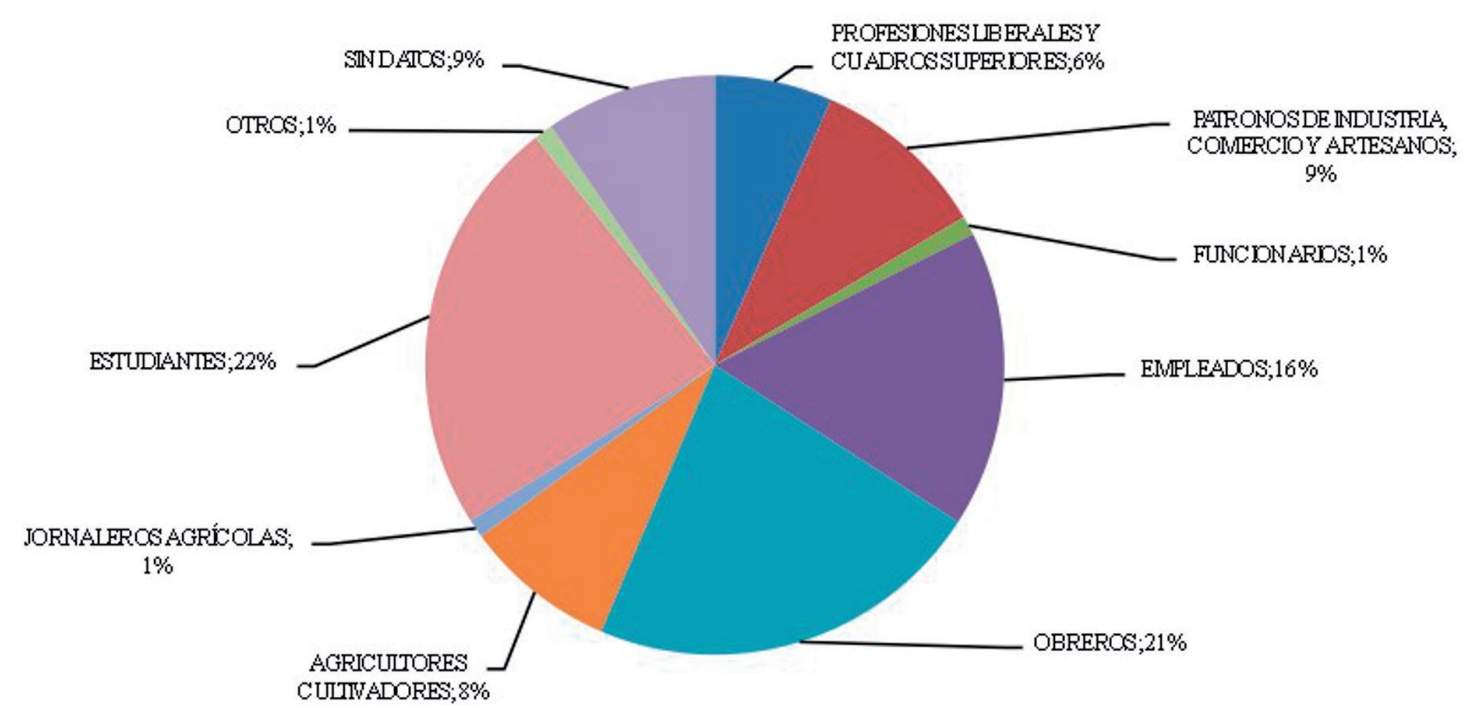

Gráf. 03 Origen socio-profesional de los milicianos alaveses de ap. (Fuente: Elaboración propia a partir de ATHA DAIC. C. 12692-A-B; AGMAV. Jefatura de Milicias de Vitoria.)

22 Aparte de Vitoria hemos encontrado milicianos aislados en los municipios de Santa Cruz de Campezo, Salvatierra, Alegría, Peñacerrada, Los Huetos, Arlucea, Bernedo y Foronda.

23 Pedro María SANZ LEGARISTI: Elecciones Municipales de 1931 en Vitoria, Vitoria, Diputación Foral de Álava, 1985, p. 72. A la clasificación original hemos suprimido "Personal de servicio" ya que se refiere mayoritariamente al servicio femenino en casas y también "Cuadros Medios" ya que es un tanto confusa y la hemos sustituido por "Funcionarios". También hemos añadido "Estudiantes" debido a la importancia que tienen éstos como grupo independiente por la juventud de la mayoría de los milicianos.

24 De sus 8.681 votos, 4.390 los obtuvo en el municipio de Vitoria.

25 La milicia falangista también obtuvo un notable porcentaje de voluntarios en Vitoria, un $38,5 \%$ por un $11,5 \%$ del Requeté. Sin embargo un alto número de milicianos falangistas, tanto del campo como de Vitoria, eran nacionalistas, izquierdistas o prisioneros de guerra alistados para escapar de la represión.

26 Javier UGARTE TELLERIA. La Nueva Covadonga..., pp. 9-142

27 AHPA.C. 1573, Exp. 16; ATHA. Censo electoral de 1936.
Una vez comenzada la guerra, AP renunció a continuar su actividad política y dedicó sus esfuerzos a apoyar a sus milicianos alaveses o a los de su organización que combatían en la provincia. ${ }^{28}$ Sin embargo, la hostilidad de los principales grupos antirrepublicanos de Álava (falangistas y tradicionalistas) contra AP y su líder, José María Gil Robles, se recrudeció, arreciando las críticas y los ataques por su anterior implicación con los gobiernos republicanos durante 1934-35. ${ }^{29}$ También debido a ello una pequeña parte de su militancia, más radicalizada y decepcionada por el fracaso electoral de febrero de 1936, se alistó en las milicias de Falange y Requeté, ${ }^{30}$ mientras que los afiliados y milicianos que se habían mantenido en la organización defendían en la prensa su actuación y se quejaban de la injusticia de los ataques de que eran objeto, ${ }^{31}$ a la par que respondían con hostilidad a los falangistas con los que estaban encuadrados en el frente de Guadalajara, barajándose incluso la posibilidad de separar a ambos grupos..$^{32}$ Frente a estas acusaciones, es muy revelador (obviando la exageración de su fuerza de movilización en la provincia) lo que escribió el jefe de AP de Álava, Adolfo Monreal, en el libro del periodista Felipe García de Albéniz, Álava por Dios y por España, en el capítulo dedicado a la contribución de AP a la sublevación militar: ${ }^{33}$

En la pugna abiertamente violenta entre España y la Anti-España, en la lucha sorda y definitiva, que se planteaba en el terreno de la sangre y del valor entre las dos aspiraciones fundamentales, y al mismo tiempo diametralmente opuestas, de un Pueblo el cristianismo y e comunismo, "Acción Popular Alavesa", con sus Juventudes, con sus cuadros, con su fe y con su aliento, sólidamente tradicionalista y español, profundamente cristiano, con su Organización en pie de guerra, se puso desde el primer momento en la vanguardia de este Movimiento Nacional, de este Movimiento que no es ni puede catalogarse entre castas ni de partidos, sino que entraña el hondo sentir colectivo de un Pueblo, harto de consunciones estériles, de gobernantes sin sentido nacional, ni orientación constructiva.

"Acción Popular Alavesa", teniendo presente todo el contenido nacional y antipartidista del Movimiento, contenido nacional y antipartidista que sería un crimen no llevarlo hasta sus últimas consecuencias, quiso exteriorizar una vez más su sobriedad, su desprendimiento, su sacrificio -divisa perenne de la J.A.P- siguiendo el criterio del Jefe: no extender en más fracciones las Milicias Voluntarias: si es posible al Ejército Nacional, bajo una guerrera militar... Y nuestros jóvenes, disciplinados, trocaron en todo el territorio nacional, desde el primer instante, su traje manual por el uniforme militar, que era la más bella sintetización de un pensamiento político nacional, rectilíneo siempre. Y también, con hermandad, con entusiasmo, sin recelo -porque la J.A.P. no admite rencores ni envidias- se enrolaron otros en las Milicias Nacionales que por las circunstancias de todos conocidas, tenían más motivos de preparación bélica; y así la J.A.P. de

8 Archivo Histórico Nacional. Fondos Contemporáneos. Ministerio del Interior. $810 \mathrm{H}$

29 Alfonso ROJAS QUINTANA: José María Gil Robles..., pp. 255-262. E

30 Antes de la guerra sólo hemos encontrado dos casos de militantes o simpatizantes de AP que se afiliaran a Falange y una vez comenzada la guerra se alistaron en las milicias falangistas de $1^{\mathrm{a}}$ y $2^{\mathrm{a}}$ Línea otros seis. Con respecto al Requeté, tres se alistaron en el de $1^{\mathrm{a}}$ Línea mientras que unos 16 lo hicieron en el Requeté Auxiliar por lo que podemos afirmar que hubo un trasvase mínimo a otras organizaciones.

31 LL. 5 de septiembre de 1936, 12 de septiembre de 1936, 17 de septiembre de 1936, 6 de octubre de 1936,13 de octubre de 1936. En otros lugares los ataques fueron $\tan$ virulentos que, por ejemplo, para el caso de Orense, Julio Prada lo define como un via crucis para AP. También hubo incidentes entre falangistas y cedistas en Valladolid. Julio PRADA: A dereita política ourensá: monárquicos, católicos e fascistas (1934-1937), Vigo, Universidad de Vigo, 2007, pp. 111-118; Jesús María PALOMARES: La Guerra Civil en Valladolid. Entusiasmo y represión en la "Capital del Alzamiento", Valladolid, Ayuntamiento de Valladolid, 2001, p. 42.

32 AGMAV.C. 5703, Carpeta. 4

33 Felipe GARCÍA DE ALBÉNIZ: Álava por Dios...,pp. 98-102. 
Álava cumplió doblemente con sus deberes ciudadanos y patrióticos: imponiéndose su propio sacrificio de no mantener por sí misma una fracción de Milicias que le hubiera permitido una posible hegemonía por su formidable potencia juvenil y por lo tanto pronto y fácil camino para las suspicacias que en aquellos momentos hubiera sido criminales: $y$ el haber cooperado por el contrario, en el anónimo, calladamente, aportando su esfuerzo para la salvación de España, con todo su aliento, con todas su energías, con todo su nervio nacional y españolista... (...).

"Acción Popular Alavesa", toda íntegra, está laborando silenciosamente al servicio del Movimiento Nacional. En las Oficinas de Abastecimiento y Alistamiento de Milicias, hay una Juventud que trabaja febrilmente en retaguardia, porque imperiosas y especiales circunstancias le han impedido incorporarse al frente. Sin espectacularismos ni gallardías, trabajando veladamente por la Patria cumpliendo sus deberes cívicos en las Milicias Ciudadanas. Aportando todos, su acervo de oro al acervo de la Patria.

En estas líneas se puede observar la hostilidad de AP frente a sus compañeros en la sublevación, la Comunión Tradicionalista y Falange, postulándose como una fuerza que sacrificaba su actividad política en aras del apoyo a la sublevación y defendiendo una "apoliticidad" conservadora, más eficaz que el afán de protagonismo de aquellas y sus luchas partidistas por conseguir la supremacía política en la zona sublevada. ${ }^{34}$ En este sentido se puede afirmar que AP nació como un grupo partidario de la lucha electoral legal y sin pretensiones subversivas frente al régimen republicano. Por lo tanto sus nutridas juventudes, al contrario que las tradicionalistas y falangistas, no estaban encuadradas en milicias ni preparadas para la acción violenta, a pesar de su agresiva retórica y su progresiva imitación de las maneras fascistas. ${ }^{35}$ Sólo podían desempeñar un papel de movilización civil en caso de situaciones revolucionarias, tal y como ocurrió durante la intentona revolucionaria de octubre de $1934 . .^{36}$ La lucha política violenta se reservaba para las opciones más marginales del espectro político de la extrema derecha, mientras que la CEDA, en caso de peligro revolucionario, siempre podía acudir al tradicional recurso del Ejército. ${ }^{37} \mathrm{De}$ ahí los ataques de que era objeto, el éxito de sus rivales más extremistas y la marginalidad de AP y sus milicias en el esfuerzo de reclutamiento en Álava y el resto de España, una vez comenzada la contienda, hasta su final disolución con el Decreto de Unificación del 19 abril de $1937 . .^{8}$ La historia de las Milicias de AP en Álava puede definirse por

34 Sobre las luchas políticas por el control de las instituciones alavesas durante la Guerra Civil y la posguerra entre las fuerzas partidarias de la sublevación ver Virginia LÓPEZ DE MATURANA: Vitoria: Poder local y política simbólica durante el franquismo (1936-1975), Tesis Doctoral, Universidad de País Vasco, 2013, pp. 18-97; Iker CANTABRANA: “Lo viejo y lo nuevo: Diputación-FET de las JONS. La convulsa dinámica de la ¿leal? Álava. (Primera parte: 1936-1938), Sancho el Sabio, 21 (2004), pp. 149-80; e Íd.: "Lo viejo y lo nuevo: Diputación-FET de las JONS. La convulsa dinámica de la ¿leal? Álava. (Segunda parte: 1938-1943)", Sancho el Sabio, 22 (2005), pp. 139-172.

35 José María BÁEZ Y PÉREZ DE TUDELA: “El ruido y las nueces: la Juventud de Acción Popular y la movilización "cívica" católica durante la Segunda República", Ayer, 59 (2005), pp. 132-34; e İd.: "Movilización juvenil y la radicalización verbalista: La Juventud de Acción Popular", Historia Contemporánea, 11 (1994), p. 96.

36 En este sentido, por ejemplo, tenemos constancia de que la sección de Araya, y seguramente la de Vitoria, se puso en contacto en octubre de 1934 con el alcalde del municipio para ponerse a su disposición en caso de que hubiera desordenes debido a los sucesos revolucionarios que estaban ocurriendo en Asturias, Cataluña y País Vasco. AHPA. C. 1573, Exp.16; sobre la actuación de los jóvenes de AP como grupos de acción civil durante la Revolución de Octubre de 1934 ver Eduardo GONZÁLEZ CALLEJA: Contrarrevolucionarios..., pp. 230-33; sobre la movilización civil de JAP y su justificación en José Ramón MONTERO: La CEDA..., p. 616.

37 Julio ARÓSTEGUI: “Conflicto social e ideología de la violencia”, en José Luis GARCIA DELGADO (ed), España, 1898-1936: Estructuras y cambio, Madrid, Universidad Complutense, 1984, p. 340.

38 César BAEZ PEREZ DE TUDELA: “Movilización juvenil...”, pp. 104-5; Eduardo GONZÁLEZ CALLEJA: Contrarrevolucionarios pp. $230-33$ y 285-89; id. "La violencia y sus discursos: los limites de la "fascistización" de la derecha española durante el régimen de la Segunda República", Ayer, 71 tanto como la crónica de una muerte anunciada: de cómo un partido pensado para tiempos de paz y la lucha electoral se vio sobrepasado por sus rivales más extremistas cuando la guerra sustituyó a las urnas por el campo de batalla como lugar para dirimir las disputas políticas.
(2008), pp. 103-109. Tenemos constancia de que Acción Popular consiguió formar milicias propias (2008), pp. 103-109. Tenemos constancia de que Acción Popular consiguió formar milicias propias Civil Española. El 18 de julio La sublevación paso a paso, Barcelona, Ediciones Folio 1996, Gp. $80-81 ;$ Rafael CASAS DE LA VEGA: Las Milicias Nacionales. Vol. 1 Madid, Editora Nacional, 1977, Pp. 228, $233-34$ y 256 
DE REBELDES DERROTADOS Y REVOLUCIONES

\section{TRIUNFANTES. LA SUBLEVACIÓN DEL EJÉRCITO}

EXPEDICIONARIO EN 1820: DEL FRACASO MILITAR

AL ÉXITO POLÍTICO

Victor Sánchez Martín

Universidad de Alicante

\section{La conquista de Cádiz y las primeras informaciones}

¿Cómo los pronunciados en 1820 contra el absolutismo, confinados en San Fernando, pudieron conseguir el triunfo de la revolución que permitió el restablecimiento de la Constitución de Cádiz y la inauguración del Trienio Liberal? ¿Cómo pudo una clara derrota militar convertirse en un éxito político que derivó en una revolución triunfante? Sucintamente, podemos avanzar que la propia dinámica del pronunciamiento permitió que pese a no haberse conseguido los objetivos militares planteados sí se consiguieran los objetivos políticos tras apelar a la opinión pública mediante un despliegue de fuerzas que no necesitó una confrontación seria para obtener un cambio de régimen al sumar apoyos en el resto del país.

¿Cuáles habían sido los objetivos militares del pronunciamiento de 1 de enero de 1820 ? Reunido en torno a Cádiz el Ejército Expedicionario que debía marchar a las colonias americanas, los batallones de Asturias y Sevilla, mandados por Rafael del Riego, debían tomar el cuarte general de las fuerzas expedicionarias, situado en Arcos. Por su parte, los batallones de España y Corona mandados por Quiroga debían tomar Cádiz, ciudad que se convertiría en el punto de apoyo de la revolución. Sólo el primero de ambos objetivos se consiguió en los primeros días de enero, pues Ouiroga tomó San Fernando, pero no pudo entrar en Cádiz. ${ }^{2}$

1 Sobre las particularidades del pronunciamiento, veáse Miguel ALONSO BAOUER: El modelo español de pronunciamiento. Madrid, Rialp. 1983. José CEPEDA GÓMEZ: El Ejército en la política española (1787-1843). Conspiraciones y pronunciamientos en los comienzos de la España liberal, Madrid, ñola (1787-1843). Conspiraciones y pronunciamientos en los comienzos de la España liberal, Madrid, Fundación Universitaria Española, 1990; Irene CASTELLS: La utopia insurreccional del liberalismo. Torrijos y las conspiraciones liberales de la década ominosa, Barcelona, Crítica, 1989. Para un análisis general sin carácter exhaustivo de la clase y mentalidad militar a principios del siglo XIX, veáse
Fernando FERNÁNDEZ BASTARRECHE: El Ejército Español en el siglo XIX, Madrid, Siglo XXI, Estudios de Historia Contemporánea, 1978; Stanley G. PAYNE: Ejército y sociedad en la España liberal dios de Historia Contemporanea, 1978; Stanley G. PAYNE: Ejercito y sociedad en la España liberal 1808-1936, Madrid, Akal Editor, 1976, Eric CHRISTIANSEN: Los origenes del poder militar en España
(1800-1854), Madrid, Aguilar, 1974 y Francisco ANDÚJAR CASTILLO: Los militares en la España del siglo XVIII: un estudio social, Granada, Universidad de Granada, 1991. 2 Para los avatares militares y políticos del pronunciamiento siguen siendo esenciales las memorias vil de las tropas nacionales al mando del Comandante General de la Primera División D Rafael del vilego, desde su salida de la ciudad de S. Fernando el 27 de Enero de la Primera Division D. Rafael del Riego, desde su salida de la ciudad de S. Fernando el 27 de Enero de 1820, hasta su total disolución en Memoria de las operaciones de la columna móvil de las tropas nacionales, al mando del mariscal de campo Don Rafael del Riego. Publicada anteriormente por el jefe de estado mayor de la misma. Nuevamente corregida y aumentada. Madrid, Imprenta de Collado, 1820; Fernando MIRANDA: Memoria sobre el levantamiento y opraciones le la Primera División del Ejército Nacional al mando del Comandante General D. Rafael del Riego, desde $1^{\circ}$ hasta 26 de enero de 1820 . Sevill a mando del Comand Ejército Nacional de San Fernando, desde su alzamiento en $1^{\circ}$ de enero de 1820 hasta el restableci-
Para el día 5 ya se conocía vagamente lo sucedido en Madrid. A partir de entonces, fue abundante el interés por conseguir información acerca del alzamiento, obtenida en "las agitadas reuniones, los comentarios a que todos se entregaban, apoyados en cartas y documentos contradictorios que iban recibiendo", según un conocido testigo del momento. Si los de mayor edad pronosticaban el rápido fin del alzamiento, difundiendo las derrotas de los sublevados, los más jóvenes "abultaban las noticias que de público corrían, citaban nombres y regimientos insurreccionados, plazas tomadas, triunfos y sucesos engrandecidos por su deseo". ${ }^{3}$

La documentación de la embajada francesa dirigida por el duque de Montmorency resulta fundamental para conocer la respuesta oficial del gobierno absoluto de Fernando VII a la vez que el control y gestión de la información que realizó, constatando tanto su sorpresa e incapacidad de reacción como sus frecuentes e inquietantes silencios. El embajador francés señalaba cidad de reacción como sus frecuentes e inquietantes silencios. El embajador francés señalaba enero, indicando además al embajador inglés el día 10 que los problemas de Andalucía estaban calmados. Sin embargo, el embajador galo era tajante: "personne, Monseigneur (je n'en excepte pas le Gouvernement) en connait exactement l'etat des choses". ${ }^{4}$

Sin embargo, la situación no parecía halagüeña para los rebeldes. Tras una semana de alzamiento no se había tomado Cádiz ni la mayor parte del Ejército se había sublevado, objetivos esenciales del plan militar. Las tropas pronunciadas se reunieron el 7 de enero en San Fernando, donde Riego había entrado con unos 1.700 hombres y ni un sólo soldado de caballería, al mando de los batallones de Asturias, Sevilla, segundo de Aragón y Guías. Allí unificó sus fuerzas con los batallones de España, Corona y el del Depósito mandados por Quiroga, para un total de más de 5.000 efectivos, que se verían reducidos por las deserciones. Cuando los pronunciados parecía que no recabarían más apoyos, el pronunciamiento en Osuna del bataIlón ligero de Canarias, mandado por el Brigadier O'Daly, y el escuadrón y brigada de Artillería dirigida por su comandante López Baños, supuso una inyección de moral para los sublevados, pues eran parte de los mandos comprometidos inicialmente. Unos 100 hombres de Canarias y 80 artilleros montados llegaron el día 10, resultando un refuerzo esencial para servir las baterías de la Isla y contar con artillería ligera a caballo. Además de ser una oficialidad muy comprometida con la conjuración, el espíritu de unión del arma de artillería y las circunstancias facilitaron que se pensara que toda ella estaba con la causa de los pronunciados, lo que a la postre tendría unos efectos propagandísticos de importancia. 5

Pese al escaso éxito inicial de los rebeldes, la lealtad del ejército absolutista no ofrecía confianza a sus mandos, aunque eso no se tradujo en un apoyo a los pronunciados. Un observador del momento como Ramón Santillán, poco amigo de la tentativa rebelde, reconocía que "ninguno de los demás Cuerpos de que se componía el Ejército Expedicionario dejaba de encerrar más o menos elementos de sublevación", pero la tropa habría creído alejado el embarque, "único sentimiento que por entonces podía arrastrar al soldado a la desobediencia al gobierno". Para Miraflores, ir a América era algo "a lo que el soldado Español ha tenido siempre y conserva una gran repugnancia, y no menos el oficial". Coincidía el embajador francés señalando que "la Constitution, marotte des officiers, n'est rien pour eux: mais ils ne veulent pas aller en Amérique". Factores como el depósito de heridos de América de la Isla de León, con mutilados

miento de la Constitución política de la Monarquía, Madrid, Imprenta de Collado, 1820.

Ramón DE MESONERO ROMANOS: Memorias de un setentón, Madrid, La Librería, 1995, t. I, pp. 200 201.

4 Informe del embajador (11 de enero de 1820), Archive des Affaires Étrangères, Correspondance Politique, Espagne, t. 705, ff. 28-30, [en adelante, A.A.E.E., t. 705] 5 Francisco BROTONS: Rafael del Riego o la España libre, Cádiz, Imprenta de la Sincera Unión del Alcalá Galiano, publicadas por su hijo, Madrid, Imprenta de Enrique Rubiños, 1886, t. II, pp. 3-4. 
que contaban los sangrientos detalles de la guerra, la primera conspiración en 1819 y la epidemia de fiebre amarilla habían desmoralizado a los soldados, que ya habían sido rebeldes dos veces en seis meses, por lo que "c'est une erreur volontaire de la part du Gouvernement de croire que la répugnance à s'embarquer soit le partage d'une faible partie de l'armée. Elle est générale...". En ese sentido, las reticencias al embarque del soldado raso serían aprovechada por los pronunciados en sus diversas proclamas, tanto por Riego el día 1 en Las Cabezas como por Quiroga en San Fernando el día 5, Ilegando su eco a las proclamas gallegas de finales de febrero. Debemos entenderlo por tanto como uno de los catalizadores iniciales del movimiento, particularmente dirigido al soldado. ${ }^{6}$

Desde la reunión de las fuerzas sublevadas en San Fernando el día 7 hasta el 27 de enero la conquista de Cádiz fue el punto esencial en el plan de los pronunciados, buscando con ello un golpe de efecto antes de que las fuerzas absolutistas pudieran organizarse. Sin embargo, todos los intentos resultaron infructuosos. En la noche del 5 se frustró la posibilidad de toma la ciudad gracias a la trama civil de revolucionarios dirigida por Alcalá Galiano por la desconfianza entre militares y civiles de Cádiz, probando, eso sí, la importante participación de civiles en el pronunciamiento gaditano. El ataque a la Cortadura dirigido el 15 de enero por Riego también fracasó y se intensificaron las operaciones de espionaje para intentar apoderarse de Cádiz con un golpe de mano desde dentro, a la vez que se comenzó a fortificar la Isla.7

La situación bélica estaba en punto muerto y era la guerra propagandística mediante proclamas el campo de batalla del momento. Las autoridades gaditanas, además de improvisa una efectiva defensa, consiguieron que el obispo de la diócesis expidiera una pastoral condenando el movimiento revolucionario. Mientras tanto, las fuerzas de infantería fueron retiradas de las cercanías de la Isla para evitar posibles simpatías con los rebeldes. El absolutismo optó por contemporizar mientras reorganizaba sus fuerzas, consciente de su propia debilidad y de la escasa fiabilidad política de sus tropas. Por ello el 9 de enero José O'Donnell, comandante general del Campo de Gibraltar, proclamaba que no quería verse en la obligación de verter sangre española, concediendo la posibilidad de alcanzar el perdón para aquellos que no fueran de los promotores del complot. ${ }^{8}$

El férreo control de la información puesto en práctica por el absolutismo, sin embargo, jugó en su contra incluso entre actores proclives a su política como la embajada francesa de forma que los pronunciados contaron con la ventaja de que su verdadera debilidad fuera considerada una falsedad gubernamental. Para el 20 de enero el gabinete ya había perdido su credibilidad y el embajador no creía sus informaciones pues "on croit que la continuation d'une résistance quelconque prouve à la foi que les insurgés sont encore nombreux et que le gouvernement n'ose pas compter sur les troupes qui semblens lui être demeuré fidèles". El descrédito era tal que el cuerpo diplomático tendía sistemáticamente a creer las noticias contrarias al gobierno, ya que "le système de mystère et de déception du Cabinet, est tellement prouvé à chaque instant que, malgré soi, on est disposé à croire aux nouvelles qui lui sont défavorables". En un contexto de desinformación en el que "il est impossible de prétendre adresser des relations exactes de ce qui se passe en Andalousie [...] entre le silence de la Cour et les exagérations de l'esprit de parti",

6 Ramón SANTILLÁN: Memorias (1808-1856), Madrid, Tecnos, 1996, pp. 99 y 101-102. Marqués de MI-

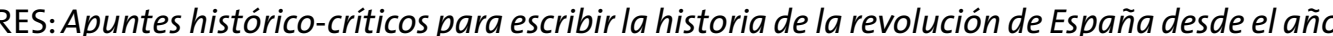
1820 hasta 1823, Londres, Ricardo Taylor, 1834, t. 1, p. 28. Informes del embajador (11 y 17 de enero de 1820), A.A.E.E., t. 705, f. $30 \mathrm{~V}$ y ff. 41V-42. Un buen análisis de las proclamas e ideología de los pronunciados en José CEPEDA GÓMEZ: "El Ejército destinado a Ultramar y la sublevación de 1820 en Andalucía", Anuario de Historia Contemporánea, nº 2-3 (1975-1976), pp. 286-297.

7 Antonio ALCALÁ GALIANO: Memorias..., t. I, pp. 505-512. Francisco BROTONS, Rafael del Riego..., pp. 64-65.

8 lbid pp 48-49 Sobre el papel de la lglesia véase José CÉPEDA CÓMEZ: “La Iglesia de Andalúí

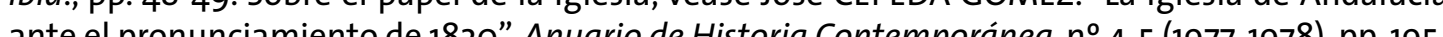
218. “Proclama del Comandante General del Campo de Gibraltar", A.A.E.E., t. 705 , f. 27. uno de los resultados más impactantes eran los cálculos que cifraban la fuerza de los sublevados en diez batallones de infantería de los dieciséis que formaban el Ejército Expedicionario, reunidos además toda la artillería, para un total cercano a los 10,000 hombres. ${ }^{9}$

El impasse militar entre ambos contendientes y la imposibilidad de acciones bélicas decisivas llevó a que tomara cada vez mayor importancia la guerra propagandística de las proclamas, verdadero mecanismo de comunicación y difusión del pronunciamiento para apela a la opinión pública. A la altura del 20 de enero resultaba evidente que el pronunciamiento necesitaba una movilización ciudadana o militar que sumara apoyos para superar la situación de tablas. Ese día los sublevados lanzaban una proclama capital donde, además del restablecimiento de la Constitución, acción que esperaban de Fernando una vez que el Ejército Nacional le había sacado de la "odiosa esclavitud" en que lo tenían los aduladores, mostraban ya un programa político de claro signo liberal y con medidas concretas para ganarse el apoyo de diversos grupos sociales. ${ }^{10}$

La ocupación de Cádiz, sin embargo, seguía atrayendo todas las miradas, puesto que si caía en manos rebeldes, serían dueños de un puerto inatacable y de la flota. El último intento de conquistar la preciada ciudad lo constituyó la fracasada insurrección civil gaditana guiada por el coronel Nicolás Santiago Rotalde, quien había tramado una conspiración para la noche de 24 de enero. Se descartó entonces por completo la posibilidad de tomar Cádiz y se creó el 25 de enero la Gaceta de la Isla en una evidente profundización en la vertiente política del pronunciamiento. El periódico tenía un carácter militar y civil, pero no dejó de ser una institucionalización periodística de la guerra de proclamas en la que, como Alcalá Galiano reconocía, se utilizó con profusión "el arma psicológica de la media verdad y el bulo", particularmente en lo referido a la columna móvil que dos días después abandonaba la plaza."

\section{La columna móvil y el contagio}

A finales de enero, las tropas del general Freyre encargadas de acabar con el pronunciamiento (unos 8.000 soldados y 2.000 caballos) estaban en disposición de poner sitio a San Fernando. Sin embargo, su operatividad era limitada, no habiéndose puesto en movimiento hasta el día 28 de enero según el embajador galo ya que "ses troupes ne lui inspirent aucune confiance, et que le gouvernement lui a recommandé de ne commencer ses opérations qu'après avoir épuisé les moyens de doucer de la séduction". Además, los intentos de los pronunciados para atraer a la opinión pública parecían exitosos, pues la embajada francesa reconocía con pavor el estado de una opinión pública donde "leur partisans sont partout, dans les provinces, dans la capital, parmi les Gardes du Roi. [...] On parle dans tous les lieux de réunions, des opérations des rebeIles; on fait presque publiquement des voueux pour leur succès. On les indique d"avance, et je suis persuadé que, dans plusiers provinces, on n'attend que la prise de Cadix pour se prononcer". La constatación más terrible, sin embargo, era la de la conexión entre los deseos de cambio del sistema político de los pronunciados y el hastío de la opinión pública por el absolutismo, pues "tout le monde n'est pas d'accord, mais tout le mond veut un changement de systême....".

Así pues, a finales de enero el pronunciamiento se encontraba ante un momento decisivo. La imposibilidad de tomar Cádiz ofrecía una perspectiva de inacción a las tropas sublevadas que sería letal en el sitio de San Fernando, pues las fuerzas absolutistas estaban completando su reorganización y podrían atacarles con ventaja. De ahí, según el testimonio de Evaristo San

9 Informe del embajador ( 20 y 24 de enero de 1820), A.A.E.E., t. 705, ff. 48-49, 51 y ff. 52-53.

10 "San Fernando, 20 de enero de 1820", Proclamas (varias) dirigidas al Pueblo, a los Milicianos y al Ejército Español. Biblioteca Nacional de España, MSS. 12942.

11 Francisco BROTONS: Rafael del Riego..., p. 68. José CEPEDA GÓMEZ: El Ejército..., p. 337.

12 Informe del embajador ( 27 y 31 de enero de 1820 , y 7 de febrero de 1820 ), A.A.E.E., t. 705 , ff. $67-68 \mathrm{v}$ ff. $75-76$ y f. 87 
Miguel, la decisión de crear una columna móvil que "esparcieses manifiestos, atrajese al partido algunos cuerpos que se suponían vacilantes, e hiciese ver por último que no era el miedo el que tenia a las tropas encerradas". Se mantenía bajo las órdenes de Quiroga a las tropas menos entusiastas, unos 3.000 hombres, y se apostaba por la difusión y extensión de la revolución con la salida de parte de las tropas de la Isla. La columna estaba compuesta por los batallones de Asturias, Sevilla (salvo la compañía de granaderos), Guías, dos compañías de Valencey y 40 caballos, sumando unos 1.500 hombres. La mayoría habían sido mandados por Riego desde el primer momento del pronunciamiento, habiéndose establecido una importante relación entre soldados y oficiales a lo largo del mes de enero en diversas escaramuzas. Riego hubo de prometer no pasar más allá de Vejer y dejar en garantía las mochilas de sus soldados, aspecto que favorecería notablemente la movilidad de la columna, que partió el 27 de San Fernando. Sólo unos días después, el 1 de febrero, quedaba sitiada la plaza por las fuerzas absolutistas. ${ }^{13}$

La importancia de la columna móvil resultó capital en el desenlace final del pronunciamiento. Su función fue ante todo política y propagandística, no militar, y por ello proclamó la Constitución por diversos pueblos de Andalucía apelando con ello a la movilización nacional que veía con sorpresa el restablecimiento constitucional en el sur del país al paso de la columna rebelde. Su prolongada resistencia ante las superiores fuerzas absolutistas llevó a muchos a pensar que Andalucía era ya constitucional y le ofrecía un apoyo mayor del que realmente tuvo; a ese objetivo tendían las proclamas de Riego y las de San Fernando, mostrando una clara conciencia de la necesidad de establecer el "contagio revolucionario", toda vez que la conspiración y el pronunciamiento ya habían tenido efecto. Por ello, el fracaso o éxito militar de la columna no era tan importante como el conseguir provocar que la opinión pública les apoyase y se manifestase en las insurrecciones urbanas que permitirían a la postre tomar el poder. ${ }^{14}$

La restauración constitucional fue acompañada además de un programa económico liberal que la columna aplicó en los pueblos del tránsito, declarando extinta toda contribución impuesta por el gobierno y la libre introducción de productos extranjeros pagando un derecho del $12 \%$, siendo libre la introducción de comestibles y quedando el tabaco desestancado. El propio embajador francés destacaba con sorpresa este programa y la actuación de la columna, puesto que "aucun excès n'á été commis par les rebelles: ils payent exactemente les rations qu'ils demandent, et leur chef se fait une étude de se rendre populaire au moyen des actes d'administration..."15

En ese sentido, el carácter pacífico del pronunciamiento se manifestó en que a nadie se forzó para que jurase a la Constitución, ofreciendo pasaporte a los soldados que rehusaron. Las devoluciones de prisioneros tomados a los realistas fueron frecuentes desde el 1 de enero, esperando un trato igual, manteniéndose esa medida hasta en las más difíciles circunstancias de la columna móvil puesto que según señaló Riego a un oficial absolutista durante las operaciones, era "esta recíproca en nosotros la prueba más convincente de que somos hermanos y compatriotas, asegurando a V.S. que nada me es tan sensible como tener que hacer uso de las armas, y que evito y evitaré cuanto me sea posible las efusiones de sangre".16

José O'Donnell, gobernador del campo de Gibraltar, fue encargado de la persecución de la co-

13 Evaristo SAN MIGUEL: Memoria sucinta..., p. 3. A. T., Historia de la revolución de España en 1820, Cádiz, Imprenta de Carreño, 1820, pp. 68-71.

14 Sigo esta tipología (conspiración, pronunciamiento, contagio revolucionario y toma del poder) de Irene CASTELLS: La utopía..., pp. 25-26.

15 El Español Constitucional: o Miscelánea de política, ciencias y artes, literatura, \&c. Periódico mensual, Londres, E. Justins, t. III, $n^{\circ} \mathrm{XX}$, abril 1820, pp 273-274. Informe del embajador (14 de febrero de 1820) A.A.E.E., t. 705, f. 94

16 Francisco BROTONS. Rafael del Riego..., p. 31. “Correspondencia seguida con todas las autoridades", Málaga, 19 de febrero, Biblioteca Nacional de España, MSS. 20270. lumna e inicialmente intentó fomentar la deserción como solución pacífica al pronunciamiento. Para el 3 de febrero contaba con 400 caballos y 1.400 infantes, aunque "mal armados y vestidos, con mucha escasez de zapatos y aún de municiones" según su propio testimonio.Varios oficiales y el general en jefe le había recomendado no comprometerse en una acción "cuyo buen resultado no fuese muy probable". Estas circunstancias hicieron que no atacara a Riego en la primera quincena de febrero, hostigando únicamente a su columna buscando la deserción de los soldados. Así, hasta el 14 de febrero, en que se le incorporaron nuevas tropas, evitó "todo encuentro formal con Riego" pues tenía miedo que sus oficiales aprovecharan cualquier contratiempo "para declararse abiertamente y sublevar la tropa contra mí". Para el día 15 ya había reunido unas fuerzas considerables y se decidió a atacarlo, contando con 2.700 infantes y 200 caballos. ${ }^{17}$

Sin embargo, la resistencia de los rebeldes durante 45 días y la primera actitud de O'Donnell generó dudas sobre la actitud de las fuerzas realistas, magnificando el potencial de las fuerzas pronunciadas y el respeto que imponían. La embajada francesa se sorprendía notablemente de que nada se hubiera hecho por acabar con la insurrección, y en esa situación crítica las dudas arreciaban: "je ne vois qu'incertitude dans le gouvernement, et tiédeur dans ses agents qui tous, partagent, jusqu'a un certain point, les doctrines des rebelles". A esto se sumó la sorpresa generada por la inesperada y atrevida salida de la columna, de foma que consumado el bloqueo de la Isla "tout le monde est occupé du sort d'une division de 1.500 hommes"

Pero el foco de interés del pronunciamiento se había trasladado desde San Fernando y Cádiz a las tierras andaluzas por las que se movía una columna que aplicaba la Constitución por donde pasaba. Para el 12 de febrero la columna móvil había restablecido la Constitución en Conil de la Frontera, Vejer y Algeciras y se había batido en una escaramuza con las tropas realistas en los Ilanos del Taibilla. Entonces, visto que el retorno a la Isla estaba cortado por 6.000 soldados de las tropas reales, se decidió a retroceder, según San Miguel, para llamar la atención del enemigo, desgastar a su caballería en terreno poco favorable y esperar un momento adecuado para verificar la reunión. Esta retirada y la actuación constitucional desempeñada constituiría la base del éxito de la columna móvil por las repercusiones que tendría en el resto del país su constante movimiento. A su vez, fue uno de los hechos capitales que cimentaron la imagen de héroe revolucionario en la persona de Rafael del Riego. ${ }^{19}$

17 El Restaurador, 25 de octubre de 1823, suplemento al núm. 106, Apuntes relativos a la campaña de 1820, pp. 2-4 y El Restaurador, 26 de octubre 1823, suplemento al núm. 107, Apuntes..., pp. 5-6. Cabe tomar esta fuente con prevención, tanto por la fecha en que fue escrita como por su carácter justificativo ante las críticas que señalaban que Riego en 1820 "por intrigas de facción, sólo fue perseguido en la apariencia". Es evidente el interés en 1823 por sobrevalorar las fuerzas de los pronunciados, cifrándolas en "más de 2.000 hombres de excelente calidad, bien disciplinados, provistos de todo, e interesados en vencer por el criminal entusiasmo que se les había inspirado".

18 Informe del embajador ( 3 y 7 de febrero de1820), A.A.E.E., t. 705 , f. 82 y ff. 84-84v. 19 Evaristo SAN MIGUEL: Memoria de las operaciones de la columna móvil..., pp. 5-6. La condición móvil so cono primer sublevado el de enero y su destacada actuación al frente de la columna móvil se convirtieron a partir de marzo de 1820 en la base de su imagen como héroe revolucionario. Véase Victor SANCHEZ MARTiN: "Creación, construcción y dudas sobre la imagen del héroe RENO SECO y Juan I MARCUEUO BENEDICTO (eds.): Culturas politicas mas liberal Discursos, representaciones prócticas (1808-1902). Vas politicas monárquicas en la España liberal. Discursos, representaciones y prácticas (1808-1902), Valencia, Publicacions de la Universitat de gran valor simbólico al coincidir con la presidencia del Congreso por 1822 ofreció un contexto de gran valor simbólico al coincidir con la presidencia del Congreso por parte de Riego y la entrega del sable que ceñía el 1 de enero. Véase Víctor SANCHEZ MARTiN: "El héroe revolucionario en el parlamento. La labor códiz y la Historia Parlamentaria, Cádiz, Servicio de Publicaciones Universidad de Cádiz, 2012, p. 5 .

brero, Biblioteca Nacional de España, MSS. 2027 
Una carta de Barcelona fechada el 12 de febrero es un perfecto ejemplo del resultado del silencio informativo y la circulación de rumores contrarios al gabinete. Para entonces, la política informativa absolutista ya había generado todos los efectos negativos posibles a su causa. La misiva señalaba que, pese a las medidas para evitar el conocimiento de las noticias, las proclamas del Ejército Nacional se habían reimpreso en abundancia, con el resultado de "la deserción de bastantes soldados y oficiales, que han partido, para reunirse a la división ambulante del general Riego", de la cual se cifraba de forma más o menos correcta su fuerza originaria en 2.000 hombres. Sin embargo, se aseguraba que tras la reunión de diversas tropas, contaba con 6.500 plazas. El estado de la situación ofrecido mostraba por una parte a Riego recorriendo la costa para animar a los pueblos y "recoger la tropa, que deserta del ejército de Freyre", calculándose que en breve llegaría a Granada y Málaga con más de 9.000 hombres. Por otra, se afirmaba que Quiroga había presentado batalla a Freyre, que no la había aceptado, temeroso de las deserciones. Por último, completaba la ficción el papel de los pueblos ocupados por las tropas realistas, que "no son los que menos contribuyen a la causa de la libertad" y la amenaza del próximo movimiento de otra división constitucional, que marcharía desde la Isla a Badajoz. ${ }^{20}$

En este sentido, lo acaecido con las informaciones sobre la columna de Riego resulta revelador de la importancia de su actuación imaginada. La propia embajada francesa constataba que "le silence du gouvernement a cet égard devient plus obstiné de jour en jour. II reçoit des courriers á chaque instant; comme rien ne transpire, on en conclut très naturellement que les nouvelles sont mauvaises, et l'exagèration, la malveillance se plaient à répandre les bruits les plus allarmants". Se pensaba que los soldados realistas licenciados se habrían unido a Riego, que mandaría ya 5,000 hombres, contrastando "la déplorable inertie du Gouvernement et la hardiesse de Riego". Lo que más daño hacía al absolutismo, sin embargo, era su descrédito: "voilà 35 jours que l'insurrection est connue á Madrid, et tous les jours on nous répète: C'est fini". Si esta era la credibilidad que los afines otorgaban al gobierno, podemos entender perfectamente la composición de la situación que se hacían sus más ardientes enemigos, ejemplificada en la mencionada carta de Barcelona. Pasaban los días y el silencio del gobierno era la peor noticia para sus partidarios, pues "des estafettes arrivent tous les fois, et nous n'apprenons pas que Riego ait été battu ou que ses soldats l'aient abandonné". El gobierno parecía quedarse sin apoyos, y era general entre sus partidarios la idea de que salvo los oficiales superiores "la reste de l'armée est plus disposée a soutenir qu'a renverser les idées des constitutionnels".

Sin embargo, O'Donnell había cambiado de estrategia a mediados de febrero. En las cercanías de Marbella batió la retaguardia de la columna móvil el 17 de febrero, ocasionándole un centenar de bajas y un severo quebranto en la moral de los menos comprometidos. Pero cuando comunicó la victoria, la falta de un estado de muertos y prisioneros llevó al embajador francés, y como él a muchos, a no creerle. Pensaron que la Corte, descontenta con sus retiradas frente a Riego iba a quitarle el mando y O'Donnell, avisado, se decidió a tener un encuentro con la columna, pero sin firmeza y retirándose finalmente permitiendo que escapara. El embajador calificó el suceso de pequeña escaramuza que no indicaba nada, mucho menos que las tropas realistas estuvieran dispuestas a luchar francamente contra las rebeldes. $Y$ es que para los absolutistas era evidente "la même timidité de la part de leurs chefs, tandis que Riego, plus fort que lorqu'i partit de la isla, parcouru le pays, montrant aux habitans l'impunité de la révolte et répandant des doctrines qui seront funestes a l"autorité". Unos días después se confirmaba que "les avantages qu'Odonnell prétendais avoir remportés sur Riego, son faux; que celui ci, au contrarie, continu les troupes royales dans les environs de Marbella, malgré leur supériorité numérique". ${ }^{22}$

20 El Español Constitucional: o Miscelánea de Política..., t. III, $n^{\circ} \mathrm{XIX}$, marzo de 1820, pp. 238-239. 21 Informe del embajador (10 y 14 de febrero de 1820), A.A.E.E., t. 705 , ff. 88-90 y ff. 94 V-95.

22 Informe del embajador (24 y 28 de febrero de 1820), A.A.E.E., t. 705, ff. 114V-115v y f. 118.

Al absolutismo ya ni tan siquiera le valían las victorias sobre la columna para tranquilizar a os suyos. Todo lo que no fuera la eliminación completa e indiscutible del movimiento rebelde corría el riesgo de ser tomado por propaganda gubernamental y no ser creído. A ello contribures de perfil bajo y un continuo goteo de proclamas y gacetas. López Baños y Arco Agüero el 4 de febrero se dirigían a los ejércitos realistas, para demandarles su apoyo, deslizando además el enfrentamiento entre el ejército nobiliario y el nacional heredado de la Guerra de Independencia, igualando a un grupo y a otro y mostrando el papel de los intereses corporativos de ejército a la hora de tomar partido en la insurrección. Por su parte, el 18 de febrero Quiroga interpelaba al pueblo español a luchar por su libertad, dirigiéndose de nuevo a los soldados del ejército y anunciando que "la mayor parte de las tropas nos han buscado como hermanos y las hemos recibido con los brazos abiertos".23

Asi pues, en otras partes del país bien podía pensarse que la rebelión se desarrollaba de un modo que realmente no se correspondía con la realidad, de forma que la evidente resistencia en San Fernando, los muy públicos movimientos de Riego y la información sobre el pronunciamiento permitían imaginar y reinterpretar las proclamas con halagüeñas expectativas, muy distintas a la fría realidad. Y eso es exactamente lo que sucedió. En el momento en que la columna móvil, perseguida ya con dureza por un cada vez más cuestionado O'Donnell, comenzó a sufrir sucesivas derrotas, su misión política ya había sido cumplida con creces y su tenaz resistencia había permitido imaginar su actuación militar de forma muy diferente a como realmente aconteció. El 21 de febrero estallaba la insurrección constitucional en La Coruña y la proclama publicada el 22 en el "segundo alcázar del Patriotismo Español", aludía al "momento venturoso de unir nuestros esfuerzos a las tropas Nacionales". El pueblo de la Coruña, "siguiendo el impulso que ha principado a dar el Ejército expedicionario y que han adoptado ya muchos pueblos de la Andalucía", también declaraba su voluntad constitucional, tomando ejemplo del establecimiento constitucional en los pueblos de Andalucía, que sin embargo, tan sólo existía mientras las fuerzas de la columna permanecían en los pueblos. ${ }^{24}$

Pese a ello, se había establecido el contagio revolucionario, y este condujo a las insurrecciones urbanas, que desequilibraron la situación de impasse abriendo nuevos frentes a un gobierno incrédulo de que se multiplicaran los focos revolucionarios en el resto del país. El día 29 de febrero se publicaba la Constitución en Oviedo, reconociendo el ejemplo seguido: "nuestros heroicos militares han clamado en Andalucía: Cortes, Constitución, Rey Constitucional”. E mismo día estallaban sublevaciones constitucionales en Murcia y poco después en Tarragona. La columna móvil, reducida por la deserción y los combates en Málaga, Antequera, Ronda y Morón, llegó al amanecer del 5 de marzo a Villanueva de San Juan, contando entonces con 400 hombres, el mismo día que se publicaba solemnemente la Constitución en Zaragoza. ${ }^{25}$

El 7 de marzo los restos de la columna móvil, menos de 300 hombres, entraban en Córdoba, donde recibieron la noticia de los sucesos de Galicia. Ese día, en la última proclama conocida de la columna, Riego se hacía eco de la situación "de una de las provincias más considerables y opulentas de la España" con 30,000 hombres "alistados de nuevo en las banderas de la Patria", mostrando tanto su conocimiento de lo que sucedía en el resto del país como la importancia

23 "Cuartel general de San Fernando, 4 de febrero" $y$ "Cuartel General de San Fernando. 18 de febrero de 1820 ". Proclamas (varias) dirigidas al Pueblo, a los Milicianos y al Ejército Español. Biblioteca Nacional de España, MSS. 12942

24 "Soldados... Dado en la Coruña, $2^{\circ}$ Alcázar del Patriotismo Español", Diario Patriótico Constitucional de La Coruña, 22 de febrero de1820.

25 A. T.: Historia de la revolución..., p. 89. El Español Constitucional: o Miscelánea de Política..., t. III, nº XX, abril de 1820, pp. 308-309, y nº XXI, mayo de 1820, pp. 387-388. Evaristo SAN MIGUEL: Memoria sucinta.., pp. 19-20. 
de la propaganda que, de nuevo, acrecentaba de forma amplia los efectivos rebeldes. El mismo día oficiaba al Ayuntamiento de Córdoba, encabezando el documento con el título de "Ejército nacional, Primera División, Columna de Andalucía", en clara referencia a los otros focos de resistencia, pese a sus exiguas fuerzas. ${ }^{26}$

El pronunciamiento se había extendido. Así se habían confirmado las ideas de la embajada francesa que, señalando el hundimiento del absolutismo, indicaba que "tous les moyens de coërcion manquent...", aspecto ejemplificado en la convocatoria de Cortes que el absolutismo fernandino había ofrecido el 6 de marzo. Sin embargo, cuando el conde de La Bisbal se pronunció por la Constitución al mando del ejército que debía acabar definitivamente con el pronunciamiento, el absolutismo se quedó sin opciones. Sería entonces cuando el 7 de marzo Fernando VII se puso al frente de la revolución anunciando su decisión de jurar la Constitución. Sólo unos días después, desconociendo la noticia, Riego y sus oficiales se vieron en la obligación de disolver la columna móvil en Bienvenida, pensando que habían sido derrotados y decididos a continuar la resistencia en Galicia o Cádiz. Era el 11 de marzo, y sólo un día antes, el monarca había jurado marchar francamente el primero por la senda constitucional. ${ }^{27}$

\section{Conclusiones}

Aunque se ha señalado que "era del contagio ideológico previo de donde emergió con fuerza el pronunciamiento de opinión pública de 1820 y no de las operaciones y las proclamas de Riego y de Quiroga", consideramos que, como señalara Gil Novales, "toda España había vivido los tres primeros meses de 1820 imaginando los movimientos de Riego, que la distancia, la incertidumbre y la ilusión agrandaban". Las operaciones y proclamas fueron importantes porque por su carácter y circunstancias, fueron imaginadas, moviendo a la acción política. Cabe preguntarse si, como indica Cepeda "ise hubiera extendido ese movimiento revolucionario si Riego y sus compañeros de armas no hubiesen actuado?". Precisamente considero que las informaciones del embajador francés al respecto de las evoluciones de la columna y la credibilidad del gobierno absolutista aportan mucha luz al respecto del descrédito que supusieron al gabinete, a la par que permitieron creer en una fortaleza de los pronunciados a sus partidarios que no se correspondía con la realidad. Así, la actuación de la columna móvil, aunque fracasada en el plano militar, permitió que se pusieran en marcha otras voluntades, siendo el corolario a la resistencia de los pronunciados sitiados en San Fernando al poner en práctica la Constitución. En otro ámbito quedaría el debate acerca de si la controvertida elección que desde el primer momento hizo Riego, tendente a la restauración de la Constitución de Cádiz pudo favorecer la movilización de la nación en mayor medida que la vaga referencia prevista inicialmente a un nuevo texto constitucional. ${ }^{28}$

En síntesis, parece evidente que la incapacidad del absolutismo para acabar militarmente con la sublevación en el sur permitió la aparición de nuevos focos revolucionarios, alentados por ese ejemplo que llevó a que en otras partes del país cristalizara la oposición al absolutismo con la colaboración entre soldados y civiles, abriendo paso así a la revolución. Oposición que cristalizó, no lo olvidemos, pensando que el sur ya era constitucional en buena medida, aspecto este en el que jugó un papel esencial la política de proclamas y gacetas de los sublevados, la marcha por Andalucía de una mítica e imaginada columna de Riego y una política de silencio informativo absolutista que consiguió desconcertar incluso a sus más favorables partidarios. Así pues, aunque el pronunciamiento fracasó en sus objetivos militares, la conjunción de los

26 Ibid, p. 21. A. T., Historia de la revolución..., pp. 95-96.

27 Informe del embajador (2 de marzo de 1820), A.A.E.E., t. 705, ff. 133-133v

28 Miguel ALONSO BAOUER: El modelo..., p. 69. Alberto GIL NOVALES: El Trienio Liberal, Madrid, Siglo

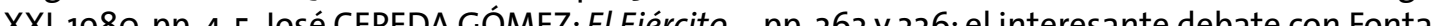

na acerca de si se debió el cambio de régimen en 1820 al pronunciamiento, en p. 336 . tres elementos anteriores permitió el contagio revolucionario, mostrando el éxito en la apelación a la opinión pública. De esta forma, las insurrecciones urbanas en lugares muy alejados de la geografía inicial del pronunciamiento permitieron finalmente que un fracaso militar se convirtiera en una revolución que permitió la restauración de la Constitución de Cádiz. 


\section{EL CONTRABANDO DE ARMAS DURANTE} LA GUERRA DEL RIF, 1921-1927

Julián Paniagua López

En este artículo voy a analizar el contrabando de armas durante al guerra del Rif y la forma en que se trató de combatirlo. El periodo estudiado abarca desde 1921 hasta 1926 cuando el poder de Abd-el-Krim estaba en su momento más álgido y se intentó establecer el Estado del Rif. Se explica el periplo de uno de los contrabandistas principales y aliado de Abd-el-Krim, Charles Gardiner; la creación de la Oficia Mixta, que fue el organismo encargado de perseguir el contrabando de armas; y por último, la estrategia utilizada para tratar de frenar la llegada de suministros por tierra al ejército y zonas ocupadas por Abd-el-Krim. La fuente documental es el A.G.A. fondo de África, I.D.D. dos, tres y trece. Las cajas concretas se mencionan a pie de página.

El contrabando fue uno de los fenómenos más extendidos durante todo el periodo del Protectorado Español de Marruecos. Para hacernos una idea de su importancia no hay más que leer el Acta de Algeciras de 1906. De los seis capítulos que componen el acuerdo, dos de ellos están dedicados al contrabando, uno al de mercancías y otro específicamente al de armas. El contexto político y militar en el que se desarrolló la guerra del Rif no podía ser mejor para este tipo de comercio. En primer lugar estaba muy reciente la guerra entre griegos y turcos; y, en segundo lugar, solo hacía 3 años que había terminado la Primera Guerra Mundial, con lo cual los comerciantes de armas necesitaban deshacerse del material sobrante. La guerra del Rif, por tanto, fue una buena oportunidad para este negocio. No obstante, los rifeños no fueron grandes compradores de armas, ya que la mayor parte de su material bélico fue recogido de los españoles durante el desastre de Annual en julio de 1921 y, posteriormente, en otras batallas. Pero esto no quiere decir que los rifeños no compraran armas; de hecho hasta intentaron comprar una flota de aviones. Las armas llegaron al Rif por dos vías. La primera, de un escaso volumen, fue por mar desde Amberes cruzando el estrecho de Gibraltar. La segunda, con un volumen mucho mayor, fue desde Holanda, por tierra hasta Turquía y después por mar bordeando la costa del norte de África. Esta segunda vía no la voy a analizar en este texto

Desde el inicio del establecimiento oficial del Protectorado, las autoridades militares españolas pusieron todos los medios para evitar el contrabando de armas. Por ejemplo: José Marina Vega, Alto Comisario y Teniente General del ejército, publicó un bando' el 26 de noviembre de 1914 en el que se desarrollaba el artículo 13 del Acta de Algeciras y se prohibía la posesión, compra y venta de armas, municiones y demás efectos de guerra, castigándose con la pena de reclusión temporal y sometiendo a la ley militar a los que participaran en dicho comercio, tanto compradores como vendedores. Este bando se tradujo al árabe, se colocó en todas las plazas que en aquel momento estaban bajo la jurisdicción española, se leyó públicamente en todos los zocos y lugares de concurrencia de los marroquíes y se envió a los representantes extranjeros acreditados para que se lo comunicaran a sus súbditos. Tanto el contenido de este bando, como, sobre todo, la fecha en la que se publicó, da una idea del problema al que se enfrentaron los militares españoles.

Tras el desastre de Annual en julio de 1921, Abd-el-Krim fue consciente de las posibilidades que tenía para organizar el proyecto político de independencia del Rif. No obstante, aunque ganara la guerra, hacía falta un reconocimiento internacional del nuevo Estado. Para ello Abdel-Krim contactó con algunas personas que pretendían mediar en el conflicto. Es lo que Rosa Madariaga ha denominado "la carta inglesa" de la guerra del Rif. Fueron 3 personas en concreto, John Arnall, Gordon Canning y, sobre todo, Charles Alfred Percy Gardiner. No se puede afirmar que los dos primeros se dedicaran al contrabando, aunque la esposa de John Arnall sí ayudó a los rifeños adquiriendo cable telegráfico y permitiendo reuniones en su casa en Tánger a destacados miembros de la rebelión. Sí se dedicó al contrabando el tercero, el capitán Gardiner, con quien Abd-el-Krim estableció un contrato de cesión de servicios y fue nombrado Ministro Plenipotenciario de los Negocios en el Exterior de la República del Rif.

Independientemente de ese contrato, Gardiner introdujo en dos ocasiones armas en el Rif, pero su número fue muy escaso, ya que los barcos que utilizó eran de pequeño calado, un yate de recreo, el Sylvia, y un barco de pesca reconvertido en mercante, el Star of the Orient. Quienes mejor han tratado este episodio de la guerra del Rif hasta ahora han sido Rosa Madariaga Peter Symes y Sueiro Seoane. ${ }^{2}$ No obstante, tras la consulta de los documentos en el archivo hay que señalar que, aún sin decir nada erróneo, en estos trabajos sí hay algunas imprecisiones importantes. ${ }^{3}$ Lo más relevante de la colaboración de Gardiner con Abd-el-Krim no fue ni la entrada de algunas cajas de fusiles compradas en Amberes, ni la estafa que hizo Gardiner, que ya de por sí son importantes estos hechos, sino la entrega de un equipo de radiotelegrafía sin hilos y el equipo suficiente para instalar una red de telégrafo desde Axdir que enlazaba con 4 puntos en el Rif. Con ello el ejército de Abd-el-Krim pudo conocer con antelación toda la estrategia militar del ejército español, tanto de la marina como del ejército de tierra. Esto ocurrió en 1924, justo el año más victorioso del ejército rifeño.

Todos los manejos y negocios que hacía Gardiner, tanto en París como en Londres, eran estrechamente vigilados por los espías españoles contratados en ambas embajadas. Es de destacar el gran trabajo de información que realizó el equipo dirigido por el embajador de España en Londres, Alfonso Merry del Val, quien enviaba puntualmente y con muchísima frecuencia los informes correspondientes de sus agentes. Los militares españoles, tanto en Madrid como en Marruecos, conocían de antemano y con puntualidad el comportamiento de Gardiner, la ruta de ambos barcos, uno desde Marsella y el otro desde Amberes, y su cargamento. A pesar de ello no lograron impedir su llegada a la bahía de Alhucemas. Hay que decirlo con toda rotundidad: el trabajo de los militares españoles en Marruecos en este aspecto fue inoperante $e$ inepto; sencillamente hicieron el ridículo, ante los rifeños y ante la comunidad internacional, sobre todo ante Francia e Inglaterra. Todo el gran y buen trabajo de espionaje que dirigió Merry del Val, se vino a abajo ante la inoperancia de los militares españoles.

La marina española sabía que el barco Sylvia partió de París hasta Marsella atravesando los canales con destino Alhucemas. En el Mediterráneo tuvo incluso una avería del motor en Almería y tuvieron que acercarse a la costa a reparar el barco y, finalmente, alcanzaron la ba-

Rosa MADARIAGA: España y el Rif Crónica de una historia casi olvidada, UNED, Centro Asociado de Melilla, Melilla, tercera edición (2008). Susana SUEIRO SEOANE: España en el Mediterráneo Primo de Rivera y la cuestión marroquí, 1923-1930, UNED, Madrid (1992). Peter SYMES: "The Notes of the Rif Revolt" en International Bank Note Society Journal, Volume $41, \mathrm{n}^{\circ} 3$, (2002).

3 Las cajas consultadas para el análisis de la vigilancia de la red de contrabandistas dirigidas por (a) cajas, hay otra serie de documentos relativos a la vigilancia de Gardiner diseminados en más cajas. 
hía. Hay muchos telegramas en los cuales se informaba de la posición del barco bordeando la costa española, pero ni lo detuvieron ni lo atacaron. Cuando los contrabandistas llegaron a la bahía de Alhucemas, escondieron el barco tras una roca, muy cerca del peñón de Alhucemas, que es territorio español. El barco fue bombardeado por la aviación, pero no lograron acertar. El Sylvia estuvo una semana fondeado en la bahía de Alhucemas. Con respecto al segundo barco, el Star of the Orient, la marina española sabía el día, la hora y la velocidad (12 nudos) cuando salió de Amberes rumbo a Gibraltar y después a Alhucemas. Se desplazaron dos fragatas de guerra a la bahía. Aunque el calado de las fragatas no les permitiera acercarse mucho a la costa, sí tenían la capacidad suficiente para detectarlo. Sin embargo cometieron el error de tener las luces encendidas, con lo cual Gardiner supo por donde acceder a la bahía, desviar su rumbo para evitar las fragatas españolas y descargar el cargamento.

El embajador Merry del Val se quejó amargamente en los despachos que envió, diciendo que cómo era posible que el Sylvia hubiera permanecido una semana oculto tras una roca sin ser molestado, en el primer caso, y cómo cometieron el error de tener las luces encendidas, en el segundo. La cortesía y el lenguaje diplomático impidieron al embajador insultar a sus colegas españoles. El gobernador de Gibraltar también se sorprendió mucho ante el hecho de haber estado el Sylvia anclado una semana en la bahía de Alhucemas y ni la marina ni la aviación española hundieran el barco. Merry del Val hizo las gestiones necesarias ante el gobierno británico para que detuvieran a Gardiner por actividades de contrabando por ser súbdito inglés. Pero tanto el gobernador de Gibraltar, el de Tánger, como el gobierno de Londres afirmaban que no estaba demostrado que se dedicara al contrabando, y en caso de cometer ese delito, no lo había hecho ni en territorio ni en aguas jurisdiccionales británicas, por lo tanto la tarea de detenerlo le correspondía a los españoles y demostrar que se dedicaba al contrabando de armas.

Después del viaje a Alhucemas con el Star of the Orient Gardiner dejó el barco en Gibraltar y regresó a Londres, donde adquirió un tercer barco, el Silver Crescent, pero ya abandonó la colaboración con Abd-el-Krim y obtuvo un encargo del Ministerio de Comercio británico para promocionar productos británicos en las colonias del África subsahariana. Los espías españoles siguieron sus pasos unos años más. La última noticia de Gardiner fue en 1929 que pretendía poner un casino en Málaga. Hay que decir, para desgracia de los españoles y vergüenza de ejército español, que tanto Gardiner como las delegaciones británicas en Tánger y Gibraltar, se burlaron de los españoles. Prueba de ello son los artículos que el mismo Gardiner publicó en un periódico inglés donde contaba sus aventuras en Marruecos y los dos viajes que hizo con sus barcos. ${ }^{4}$ Excepto el tono, muy triunfante y con un punto de arrogancia, el relato del propio Gardiner coincide con los informes, telegramas y documentos de los militares españoles y de los embajadores en París y Londres.

Es verdad que las autoridades del Protectorado siempre intentaron poner remedio al contrabando de armas, pero no fue hasta 1925 cuando se creó el organismo encargado de combatirlo. Fue la Oficina Mixta Hispano-francesa, primero ubicada en Málaga y después trasladada a Tánger en 1929. Antes de esa fecha, en 1916, ya había intención de crearla, pero en Tánger, para conocer y vigilar todo lo que ocurría con "el elemento subversivo y antiespañol". Es decir, no solo se pensaba ya en el contrabando de armas, sino en todo lo referente al orden público. Por ejemplo: hay una carta que le envía el Alto Comisario, Gómez Jordana, al Ministro de Esta-

4 Las andanzas de Gardiner en el Rif fueron contadas no solo por los militares españoles o el servicio secreto francés, sino también por él mismo, por su esposa, por su sobrina e incluso, una parte de los articulos por el capitán McLean, el escocés acompañante de Gardiner en sus viajes. Hay julio de 1925. Alfred CARDINER: “My Escape in Lifeboat from Spanish Bombs", Ilustrated Sunday julio de 1925. Alfred GARDINER: "My Escape in Lifeboat from Spanish Bombs", Illustrated Sunday
Herald, 2 de agosto de 1925. Marie CLAVERT-LINK: "Exploits of a Soldier of Fortune" Illustrated Herald, 2 de agosto de 1925. Marie CLAVERT-LINK: "Exploits of a Soldier of Fortune", Illustrated Sunday Herald, 14 de junio de 1925 . do, don Amalio Gimeno, fechada el 27 de diciembre de 1916, en la que expresa que "esa oficina es necesaria, pero en este momento solo hay 8 personas de total confianza para dedicarse a las labores de información".

El gran error que cometió Abd-el-Krim fue atacar la zona francesa. Realmente si no hubiera sido por la colaboración con Francia, España hubiera perdido la guerra. En 1925 dos delegaciones diplomáticas de España y Francia, asesoradas por militares, se reunieron en Madrid para concertar unos acuerdos de cooperación y unir fuerzas para pacificar definitivamente la zona. Los acuerdos a los que se llegan fueron los siguientes:

Acuerdo hispano-francés de 4 de junio e 1925; Acuerdo relativo a la vigilancia marítima (22 de junio); Acuerdo relativo a la vigilancia terrestre (8 de junio); Acuerdo relativo a las proposiciones de paz (11 de julio); Acuerdo relativo a la protección de Tánger (21 de julio); Acuerdo relativo a la cooperación militar ( 25 de julio); y Acuerdo relativo a la delimitación de las dos Zonas de influencia ( 25 de julio). ${ }^{6}$

Los acuerdos definían la forma de colaboración militar entre ambos países, sobre todo para evitar y reprimir el contrabando de armas y la llegada de suministros a las kabilas rebeldes del Rif. Por mar se estableció un bloqueo ampliando el límite marítimo de tres millas de la costa a seis. Dentro de ese espacio, cualquier barco que se encontrara dentro podía ser abordado, registrado y conducido al puerto más cercano. Las embajadas de ambos países enviaron la notificación oficial informando de la medida. Todos la aceptaron, excepto Estados Unidos, que indicó que lo único que respetaría serían las tres millas oficiales de distancia desde la costa y lo que estuviera legislado en el Acta de Algeciras de 1906. Por tierra se prohibió la circulación de personas y mercancías entre ambas zonas, española y francesa, y perseguirían todas las reuniones o tentativas de incitar a la rebelión. Como consecuencia de esos acuerdos, se creó la Oficina Mixta de Información, que era el organismo encargado de recabar toda la información de las personas o grupos sospechosos de rebelión y de actos de contrabando de armas. Los resultados de esta colaboración política y militar fueron: el desembarco de Alhucemas en septiembre de 1925, aunque ya estaba pensado y planeado antes de esa fecha; un año más tarde la rendición de los rifeños, la entrega de las armas; y finalmente el exilio de su líder Abdel-Krim. Para España significó un éxito de cara a su imagen en Europa, especialmente porque se había establecido una opinión generalizada, sobre todo en los periódicos británicos, respecto a la dificultad o incluso imposibilidad de someter a los rifeños. Aunque Primo de Rivera presentara la rendición de las kabilas como una gran victoria y, años más tarde, la propaganda franquista presumiera de que el desembarco en Alhucemas debería ser considerado como una de las grandes acciones de guerra, casi al mismo nivel que el de Normandía, la realidad fue que teniendo en cuenta los medios de defensa de los rifeños, más bien habría que considerarlo desproporcionado e incluso vergonzante, porque apenas hubo resistencia, no tuvo nada de heroico y, además, en gran parte de la campaña posterior se emplearon armas químicas, iperita, prohibidas ya en ese momento por el Protocolo de Ginebra de 1925.

Por último, quiero explicar el modo por el cual se intentó controlar el tráfico de armas y suministros por tierra a las kabilas del Rif.

Es difícil pensar que los militares españoles destinados en el Protectorado, tuvieran la formación suficiente como para utilizar el análisis de redes sociales y aplicarlo a una estrategia de

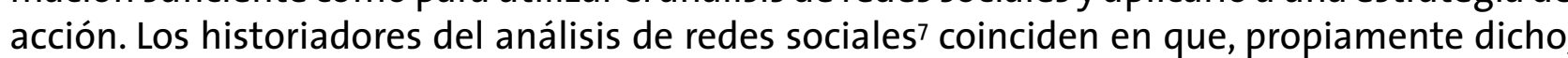

5 Carta de Gómez Jordana a don Amalio Gimeno (27 de diciembre de 1916), AGA, Caja 81/10494.

6 Toda la documentación se encuentra en la caja 81/10012 del AGA. Contiene tanto los acuerdos como todos los documentos preparatorios previos y también los posteriores, cartas, informes, actas, oficios, reacciones, desarrollo de los artículos, instrucciones, etcétera.

7 Linton C. FREEMAN: The Development of Social Network Anaysis. A Study in the Sociology of Science, Vancouver, Empirical Press, 2004 
este método de investigación social comienzó en el año 1934 con la publicación de Jacob Levy Moreno Who Shall Survive? Obviamente, hay precedentes importantes, tales como Durkheim, Tönnies, Henry Morgan y Georg Simmel, por citar solo algunos autores. Pero a pesar de que la obra de Moreno tenía una carencia importante, como es la ausencia de un análisis matemático riguroso y la recogida sistemática de los datos reticulares, sin embargo, lo más relevante fue que Moreno ya utilizaba el término "red" (network) en el mismo sentido en que se emplea actualmente. Pues bien, nueve años antes de la publicación de la obra de Moreno, los militares españoles ya utilizaron la intuición de la red social como método estratégico para aplicarlo en acciones de guerra. Lo que hicieron los militares españoles ni se acerca al trabajo preliminar de Moreno. Es, más bien, un rudimento de lo que es el análisis de redes sociales. Pero teniendo en cuenta la época, el contexto y la falta de formación, es de destacar como captaron la intuición de la red social y la enorme utilidad que posee ese método. ${ }^{8}$

Uno de los asuntos más importantes de toda estrategia militar, es el control y vigilancia de los caminos y los puntos de comunicación. Hay puntos o zonas en el territorio cuyo control proporciona una situación de ventaja sobre el enemigo. Esto no es nuevo. La estrategia de los militares españoles para evitar los suministros al ejército de Abd-el-Krim, en armas, equipamiento y alimentos, no estuvo únicamente en el control de los caminos concretos que había en el territorio, sino en la creación de un modelo abstracto que sirviera para todos los caminos de territorio. Porque una cosa es conocer el terreno, valles, ríos, montañas, vegetación, rocas, y otra muy distinta establecer un sistema de control de puntos y vínculos entre los puntos, independientemente de dónde estuvieran situados realmente esos puntos. Y esta es la clave de todo.

El 13 de mayo de 1925, el coronel Orgaz envió un informe al Alto Comisario en el cual explicaba con un gráfico, la estrategia y el sistema de control de los abastecimientos. Dice así:

"Excmo. Señor:

Por si ello pudiera apreciarse útil y teniendo en cuenta las circunstancias actuales que obligan a poner una máxima atención en cuanto signifique acentuación de nuestro bloqueo de las zonas rebeldes, esta Sección tiene el honor de elevar a V.E. la siguiente propuesta de organización de Intervención y vigilancia de personal y mercancías:

Necesidad imperiosa de vigilar e intervenir la circulación de mercancías y toda clase de vituallas se ha sentido siempre. Ahora en los momentos en que parece que los ánimos de los rebeldes empiezan a vacilar, o que por lo menos están espectantes y en que es precaria su situación económica, es la ocasión más a propósito para que convencidos de la inexpugnabilidad de nuestras organizaciones fiscales tomen impulso en su determinación y se aproximen de modo decidido sin que puedan esperar de componenda alguna, flojedad que les permite aprovisionarse.

Por eso es preciso unificar la intervención del tráfico indígena y también del europeo para que si alguna esperanza ha cabido en el ánimo de los rebeldes la pierdan por completo y se suman otra vez en una imposibilidad absoluta de comercio y aprovisionamiento.

Para que esta vigilancia e intervención de las mercancías se verifique de un modo uniforme y ordenado y además tenga todas las garantías de buen éxito, preciso será que examinemos los distintos casos que pueden presentarse. Todos ellos están incluidos en el adjunto gráfico esquemático:

$1^{\circ}$.- de ciudad a ciudad.

$2^{\circ}$.- de ciudad a zoco.

$3^{\circ}$.- de zoco a ciudad.

$4^{\circ}$.- de zoco a zoco.

8 Para este análisis la caja consultada ha sido la 81/642 del AGA $5^{\circ}$.- de ciudad a poblado amigo.

$6^{\circ}$.- de poblado amigo a ciudad.

$7^{\circ}$.- de poblado amigo a poblado amigo.

$8^{\circ}$.- de zoco a poblado amigo.

$9^{\circ}$.- de poblado amigo a zoco.

$10^{\circ}$.- de cualquiera de estos puntos a poblado enemigo".

Y el esquema que adjuntó al informe fue el siguiente:

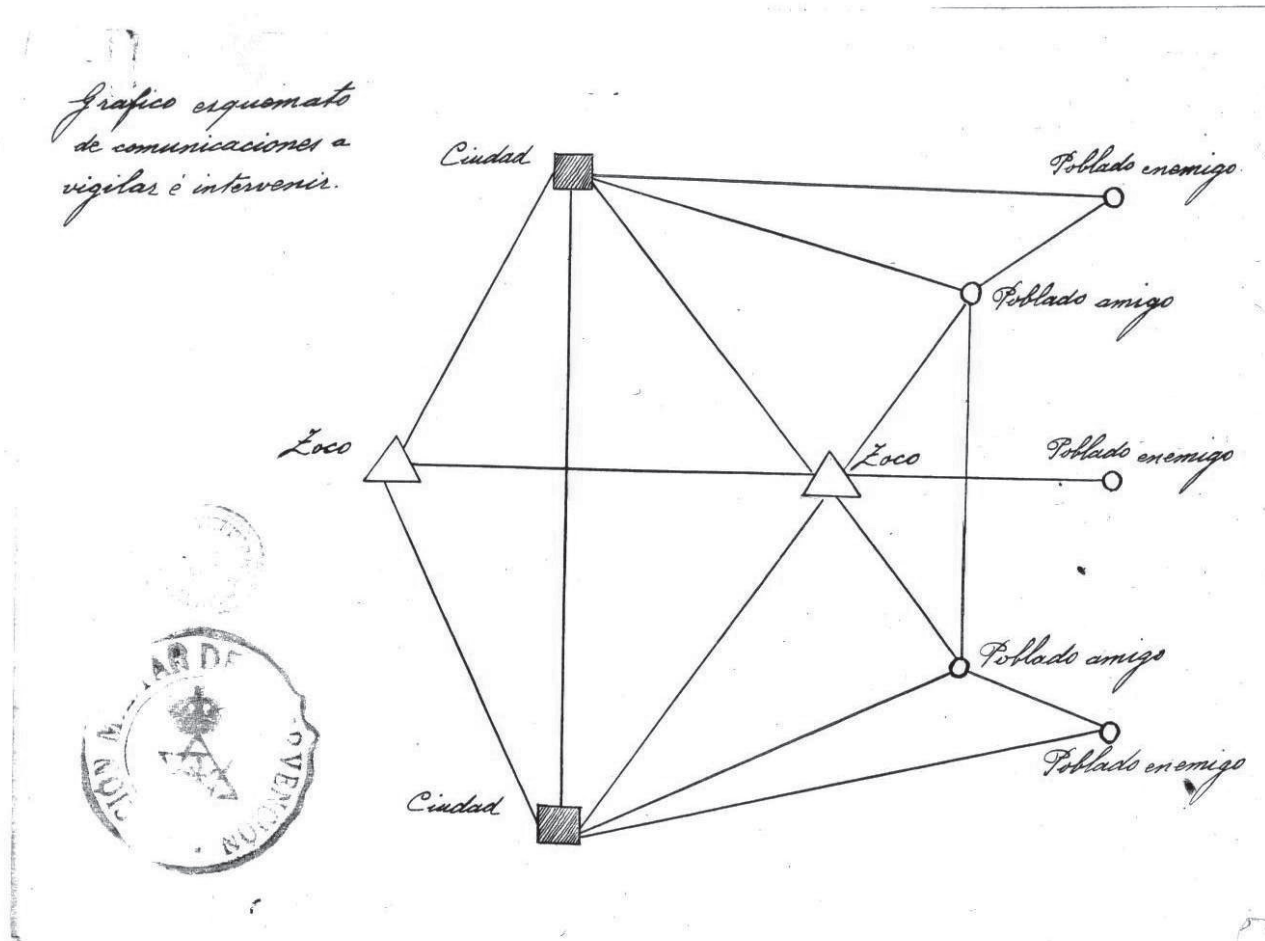

Img. 01 Esquema. (Fuente: Gráfico esquemático de comunicaciones a a vigilar e intervenir, AGA $81 / 642$.)

Como vemos, el coronel Orgaz no presentó al Alto Comisario un mapa del terreno, sino un modelo abstracto de nodos unidos por vínculos con unas determinadas propiedades. En este caso el vínculo representa el transporte de mercancías. Obviamente el desarrollo posterio de esta idea no giró en torno a los conceptos de centralidad, intermediación, cercanía, cliques que el análisis de redes sociales utiliza para sus estudios. 9 Fue mucho más simple, aunque la efectividad no fue la esperada. Las instrucciones fueron aprobadas el 22 de mayo. Transcribo literalmente algunas de ellas, ya que el documento es muy extenso:

\section{"INSTRUCCIONES SOBRE REPRESIÓN DE CONTRABANDO.}

COPIA OUE CITA.

Se restablece lo prevenido en la Orden General de la Comandancia General de 8 de abri de 1923 , con las ampliaciones y aclaraciones siguientes.

A.- DE LA PLAZA DE MELILLA A LOS POBLADOS EUROPEOS, CAMPAMENTOS Y ZOCOS.

9 Stanley WASSERMAN y Katherine FAUST: Social Network Analysis. Methods and Aplications. Cambridge, Cambridge University Press, 1997. 
$1^{\circ}$. PERSONAS. Toda persona no militar estará obligada a proveerse del correspondiente pase para poder circular por el territorio. Este pase no será extendido sino después de una eficaz comprobación de la verdadera personalidad del demandante y concedido será registrado y fijada en el la ruta a seguir, de la que no podrá desviarse el viajero, bajo pena de incurrir en la sanción correspondiente.

Si se careciera de antecedentes respecto al solicitante, deberá exigírsele al menos dos fiadores solventes, quedando estos responsables a las resultas de la conducta del pasaportado. En los puntos de tránsito serán visados los pases por los Interventores, tantos como en la ruta existan, y en el punto de llegada, será visado o recogido el pase y se verificará si el tiempo empleado desde el punto de salida al de llegada es normal, investigando con todo detalle las causas del retraso, hasta que no quepa duda alguna.

Esta misma comprobación será verificada en los puntos de tránsito.

En caso de duda, tanto en los puntos intermedios como en el final, será detenido el pase hasta la completa aclaración del caso.

Estos pases, para las personas no indígenas, deberán ser expedidos por la Comandancia General y por la Oficina Central de Intervención, para los indígenas, llevándose registro.

Los pases de circulación general, tratándose como se trata de un régimen de excepción, solo se darán a personas de garantía absoluta, procurando restringirlas en todo lo posible.

$2^{\circ}$. MERCANCíAS. (a).- Para la salida de artículos de esta plaza con destino al suministro a fuerzas que están en el campo, será preciso guía de circulación de los mismos autorizada por la Comandancia General. Para nutrir cantinas y demás establecimientos de Campamento y posiciones por lo que al elemento civil se refiere, las guías se expedirán por la Junta de Arbitrios con el $V^{\circ}$. $\mathrm{B}^{\circ}$. de la Comandancia General.

Para los primeros se formularán las guías ante la petición hecha por oficio de los Jefes de Unidad y para los segundos por petición escrita del interesado, visada por el Jefe del Campamento o posición o por el Interventor a que corresponda el poblado. Dichos pases guías llevarán consignadas las rutas a seguir, la cual no podrá ser abandonada por los poseedores de aquellas bajo ningún concepto, y serán duplicadas, consignándose los nombres del remitente y del destinatario, y siendo portadores de ellas los conductores de las mercancías.

Al llegar al punto de destino, se presentará la guía al Jefe del Campamento o posición o al Interventor de la kabila, fuera de estos, el cual después de comprobar si procedió con legalidad en la ruta y están conformes las mercancías con lo consignado en la guía, devolverá un ejemplar con la certificación de haberse recibido completa la mercancía, al punto de destino para su confronte y archivo.

En las cantinas y comercios de campamentos y posiciones en que no existan tropas indígenas, no se permitirá la venta ni el transporte por tanto con destino a ellas de los artículos llamados morunos de exclusivo uso de los indígenas, que solo podrán venderse en los zocos o poblados.

(b).- Todo comerciante sea o no indígena que de Melilla pretenda transportar mercancías a poblados europeos o zocos deberá hacer la justificación de su persona ante el interventor de su kabila (o si viviese en Melilla, en la Central de Intervención) quien tomará cuantas medidas de garantía sean precisas, autorizándole por medio de pase q que vaya a la Oficina Central de Intervención, donde se le extenderá el pase guía el que se hará consta la cantidad, clase de mercancías, punto de origen y de destino, así como la ruta a seguir, que no podrá variar de ninguna manera.

El pase autorización de la Oficina Central será registrado con todos los datos que en el figuren a fin de comprobar que el destino de la mercancía es el debido, y deberá ser entregado en el punto de llegada, donde se comprobará por el Interventor, si el número y cantidad son las marcadas y no ha habido por lo tanto desviación alguna, certificando y devolviendo al punto de origen para su archivo, un ejemplar del duplicado de dicha guía, en que se haga constar por lo que se refiere a los zocos si la mercancía se ha vendido en todo o en parte sirviéndole en este caso como guía para su retorno por la misma ruta.

(c).- En todos los puntos de tránsito serán revisados los pases cerciorándose de que lo autorizado marcha en las condiciones que el pase fija. Si fuera notada alguna variación será inmediatamente detenida la mercancía y el portador y se dará cuenta al punto de origen para la determinación que corresponda.

En caso de falta en el punto final, se dará cuenta al de origen, como hemos dicho anteriormente para aclarar, si la hubiera la duda y será detenido el portador de su mercancía hasta que justifique de modo preciso el destino de la merma y si no fuera hecha esta justificación, será embargada la mercancía vendiéndose en pública subasta.

Todos los viajeros y conductores de vehículos, llevarán con el pase guía de ruta, su documentación personal.

Los viajeros que no siguieran la ruta consignada en el pasaporte que lleveren, serán multados y si reincidieren, se les retirará el pase que no se les volverá a expedir más.

\section{PREVENCIONES GENERALES.}

$1^{\mathrm{a}}$.- Las telas, verduras y demás mercancías, serán limitadas por los Interventores.

$2^{\mathrm{a}}$ - - Toda compra de varios artículos del detall que en conjunto constituya una carga, no podrá transportarse sin la correspondiente guía dada por el Oficial.

$3^{\mathrm{a}}$.- Se restringirá todo lo posible las compras al por mayor (excepto la cebada en época de siembra) porque habiendo zocos diarios en el territorio, les basta a los indigenas con las compras al por menor.

$4^{a}$.- Los Interventores señalarán las rutas a seguir por los indígenas que de los distintos aduares vayan a los zocos con productos del país (cereales, frutos, ganados, etc.) los días en que estos se celebren.

$5^{a}$.- Los indigenas que contravinieren lo ordenado en las presentes instrucciones, serán castigados con arreglo a lo preceptuado en el Reglamento de multas.

$6^{\mathrm{a}}$.- Toda persona que se encuentre $\sin$ ir debidamente autorizada podrá ser expulsada del territorio como indeseable, aparte la responsabilidad correspondiente si estuviese comprendido en los artículos de espionaje del Código de Justicia Militar.

$7^{\mathrm{a}}$.- Las mercancías que no vayan con guías en la forma legal establecida, que sean conducidas fuera de la ruta señalada en la guía, o con guía cuyo plazo de validez haya expirado, serán consideradas como contrabando y decomisadas pudiendo además imponerse a 
conductor o dueño una multa graduada según la importancia de la falta, sin perjuicio de las responsabilidades que le corresponda con arreglo al Código de Justicia Militar.

$8^{a}$.- Oueda terminantemente prohibido todo comercio de exportación o importación con la zona no sometida.

$9^{a}$.- Cuando por conveniencias políticas sea preciso autorizar la salida o entrada de alguna mercancía de zona insumisa, la autorización concedida precisamente por la Comandancia General o por la Oficina Central de Intervención, con conocimiento del Comandante General, será expresa y limitada con el pase de duración definido, de manera que no pueda en absoluto ser utilizada más que para el caso marcado.

10a.- Los modelos de pases personales, pases de autorización para compra de mercancía, pases de autorización para transporte, cartilla y pases individuales de compra para los indigenas podrán ajustarse respectivamente a los formularios 1, 2, 3, 4 y 5 .

Melilla 31 de agosto de 1925

La imposición de estas medidas no produjo ningún resultado esperado, ya que por diferentes caminos desde Tánger, la frontera con la zona francesa y Argelia, llegaban suministros al Rif. Sí es de destacar la aplicación de la intuición de la red para combatir el contrabando, pero ahí termina todo. No fue más que un intento.

A modo de conclusión y con la perspectiva del tiempo hay varias reflexiones que se pueden hacer en torno al Protectorado Español de Marruecos, especialmente a partir de los acontecimientos bélicos. No deja de sorprender que un territorio pobre como era el Rif de principios de siglo, con un ejército de unos 15.000 hombres mal equipados, llegara a enfrentarse a una potencia colonial europea con ejército regular, que llegó a desplazar a más de 100.000 soldados. Aunque comparado con los ejércitos europeos de la época el ejército español estaba mal equipado y peor formado, sin embargo no dejaba de ser un ejército profesional financiado por el Estado. En cambio el ejército de los rifeños estaba compuesto por civiles, aunque asesorados por agentes europeos. A pesar de todo, ese ejército rifeño estuvo a punto de vencer al español.

Pero analizadas las investigaciones previas y los documentos históricos consultados, la realidad es que esto no debería sorprender. España no estaba preparada ni política, ni social, ni económica, ni militarmente para afrontar no solo una guerra, sino la colonización del norte de Marruecos. No había conocimientos sobre la sociedad marroquí, ni apenas mapas o estudios geográficos, ni infraestructura, ni organización, y la experiencia colonial que se tenía no servía para Marruecos. España en esa época no era más que una potencia de segundo o incluso tercer ni medios para cumplir los acuerdos internacionales a los que se había comprometido, tanto en el Acta de Algeciras de 1906, como en el acuerdo posterior con Francia en 1912, por el que se establecía la Zona de Influencia de España en Marruecos. Esos acuerdos nunca debieron ser firmados. Pero, aparte de la tragedia humana, por la gran cantidad de muertos que hubo, la otra tragedia política y moral de España es que no podía retirarse del territorio, porque hubiera significado la pérdida total del escaso prestigio internacional que tenía y que deseaba recuperar, aparte del incumplimiento de los acuerdos internacionales a los que se había comprometido. La actuación de España en Marruecos, sobre todo hasta la llegada de la República, se podría definir con las tres des: desconocimiento, desorganización, desastre. A pesar de toda la propaganda que hubo tras el desembarco de Alhucemas en 1925 y la posterior pacificación del Rif, la realidad es que para España, el desastre en el Protectorado abarcó mucho más que el de la batalla de Annual. La ineficacia en la represión del contrabando fue una prueba de ello. Si tan necesaria era la Oficina Mixta de Información ¿por qué no se creó antes de 1925 y por qué no se ubicó en Tánger desde el principio, que era donde debía estar? Si el gobierno británico no iba a mover un solo dedo para detener a su corsario Gardiner, ¿por qué no lo detuvieron en Alhucemas, especialmente cuando poseían toda la información necesaria y con la debida antelación? Si la historia sirve para algo, este es un buen ejemplo en el que se puede aprende de ella. 
